\author{
Universidade de São Paulo \\ Instituto de Física \\ Instituto de Química \\ Instituto de Biociências \\ Faculdade de Educação
}

\title{
Reflexos do Pibid na prática pedagógica de licenciandos em química envolvendo o conteúdo oxirredução
}

Keysy Solange Costa Nogueira

São Paulo - SP

2018 
Keysy Solange Costa Nogueira

\section{Reflexos do Pibid na prática pedagógica de licenciandos em química envolvendo o conteúdo oxirredução}

Tese de doutorado apresentada ao Instituto de Física, ao Instituto de Química, ao Instituto de Biociências e à Faculdade de Educação da Universidade de São Paulo como requisito parcial para a obtenção do título de Doutor em Ensino de Ciências.

Área de concentração: Ensino de Química

ORIENTADORA: Profa. Dra. Carmen Fernandez

CO-ORIENTADORA:Profa. Dra. Elaine Pavini Cintra

São Paulo - SP

2018 
Autorizo a reprodução e divulgação total ou parcial deste trabalho, por qualquer meio convencional ou eletrônico, para fins de estudo e pesquisa, desde que citada a fonte.

FICHA CATALOGRÁFICA

Preparada pelo Serviço de Biblioteca e Informação

do Instituto de Física da Universidade de São Paulo

Nogueira, Keysy Solange Costa

Reflexos do Pibid na prática pedagógica de licenciandos em química envolvendo o conteúdo oxirredução. São Paulo, 2018.

Tese (Doutorado) - Universidade de São Paulo. Faculdade de Educação, Instituto de Física, Instituto de Química e Instituto de Biociências.

Orientador: Profa. Dra. Carmen Fernandez

Área de Concentração: Ensino de Química

Unitermos: 1. Química - Estudo e ensino; 2. Conhecimento;

3. Formação de professores.

USP/IF/SBI-022/2018 


\section{Dedicatória}

Aos meus pais, Dimas e Eliana, por todos os esforços que fizeram na vida para que eu e meus irmãos tivéssemos uma formação pessoal e profissional em um país com tantas desigualdades. Sempre ensinaram a tratar com respeito, simplicidade, honestidade e compaixão o próximo. Agradeço ainda meu pai que, em sua inocência durante esses quatros anos, me ligava todos os dias perguntando a data em que defenderia a tese de doutorado, uma ingenuidade tão doce e propulsora na minha luta diária no desenvolvimento deste estudo.

Ao meu companheiro de vida, Cosme, pelo amor que nos une e por ter sido compreensivo nesses anos todos dedicados à pesquisa. Seu aconchego foi fundamental nesta caminhada.

À minha orientadora, Carmen Fernandez, pelos anos de convivência, por todo aprendizado, congressos, trabalhos escritos, pelas danças e principalmente por ter respondido ao meu e-mail, no qual solicitava gentilmente a sua orientação. Seu gesto mudou a minha vida. Muito obrigada!!

Por fim, dedico este trabalho a um ser muito especial, Lauro de Moura (in memorian), meu querido sogro. O amor entre nós sempre foi imenso!! 


\section{Agradecimentos}

Expresso aqui um pouco da minha gratidão às pessoas que foram fundamentais na minha vida e no desenvolvimento deste estudo.

Inicialmente agradeço aos meus avós, Antônio Costa e Maria do Carmo, que amo tanto, pelo acolhimento e amor com que recebiam a mim e meus primos nas longas férias que passávamos no sítio onde residem. A infância em suas companhias me fizeram aprender a doçura e a garra que temos que ter nesta vida.

Às minhas tias e primos que amo tanto, agradeço os diversos momentos de alegria compartilhados. Nossas festas são inesquecíveis!

Aos meus sobrinhos, sobrinhas e afilhados, agradeço o amor tão especial.

À minha tia Conce, o amor e admiração mutua, e à sua mãe, minha avó Conceição (in memorian), sua doçura, igual eu nunca encontrei.

Ao seu Manuel, pelos ensinamentos sobre botânica.

Ao Mateus, Carla e Kelry, irmãos de quem sinto tanta falta em compartilhar os momentos em família. Carrego vocês na "malinha de mão do meu coração".

Aos meus queridos, Bruno, Elka e Clo, por fazerem parte da minha trajetória na pós-graduação e completarem minha vida com suas fofurezas.

À Luciane, pela acolhida quando cheguei ao PEQuim, pela amizade e companheirismo na vida acadêmica. Que sejamos parceiras sempre!!

Ao Pablo pelas discussões sobre os aspectos quantitativos envolvidos nos estudos de PCK.

A todos que participam do grupo de dança do IQ-USP, em especial ao Jurandir, por compartilharmos a expressão da delicadeza da alma, a dança.

À Rosana, minha queria irmã acadêmica, pelos risos e abraços nos momentos de carência na pós-graduação.

À Juliana Leal, minha irmã acadêmica, de quem sinto tanto orgulho. Obrigada pelo carinho.

À Camila, nossas discussões sobre a vida pessoal e acadêmica. Camila, você é uma profissional que inspira!

À minha co-orientadora Elaine Cintra, por ter possibilitado e incentivado o meu ingresso na pesquisa científica na área de ensino.

Aos professores que participaram da banca de qualificação e defesa Alberto Villani, Leila Inês Follmann Freire,José Guilherme da Silva Lopes, Paulo de Avila Júnior, José Otavio Baldinato e Edenia Maria Ribeiro do Amaral. A contribuição de vocês foi fundamental para o desenvolvimento e conclusão desta investigação.

A todos os pibidianos, coordenadora e supervisora, que amavelmente aceitaram participar deste estudo. Sou imensamente grata a todos vocês! 
A todos aqueles que, embora não citados, me apoiaram, o meu carinhoso muito obrigada!

Por fim agradeço à Fundação de Amparo à Pesquisa do Estado de São Paulo (FAPESP) pelo financiamento deste projeto, processo n 2013/07937-8 e pela bolsa de estudos concedida, processo no 2016/08677-8. 
Por uma deontologia da profissão docente

\#pibidfica 


\section{RESUMO}

NOGUEIRA, K. S. C. Reflexos do Pibid na prática pedagógica de licenciandos em química envolvendo o conteúdo oxirredução. 2018. 358f. Tese (Doutorado) apresentada ao Instituto de Física, Instituto de Química, Instituto de Biociências e Faculdade de Educação, Universidade de São Paulo, 2018.

Nesta pesquisa são apresentados os resultados de uma investigação que teve como objetivo acessar o conhecimento docente de futuros professores de química, no contexto do Programa Institucional de Bolsa de Iniciação à Docência (Pibid). Esta pesquisa figura como um estudo de caso. Os dados se baseiam nas narrativas registradas por meio de gravações audiovisuais de três participantes da pesquisa durante as reuniões do subprojeto Pibid-química, regências e entrevistas semiestruturadas. Além destes, foram analisados relatórios, planos de aula, questionários dos pibidianos e um instrumento de percepção dos alunos da escola conveniada sobre o conhecimento docente dos licenciandos. Investigaram-se ainda os possíveis impactos do Pibid na formação da coordenadora e supervisora que orientaram os pibidianos. Buscou-se, por meio dos diversos documentos, indícios do conhecimento docente dos licenciandos bolsistas Pibid. A análise dos dados qualitativos teve como fundamentação teórica a análise de conteúdo, sendo as categorias provenientes do modelo do conhecimento base em conjunto com o modelo pentagonal. A análise do instrumento de percepção permeou métodos estatísticos. Para analisar as marcas deixadas pelo Pibid na formação da coordenadora e supervisora, adotaram-se as categorias do modelo conhecimento docente e outras emergentes. O pibidiano Antônio apresentou um bom conhecimento de conteúdo, de seus alunos e de suas limitações em relação ao conteúdo redox. Por outro lado, em algumas passagens das aulas, teve dificuldades em organizar a classe e o tempo de sua aula ao conteúdo. Antônio fez uso, em suas sequências didáticas, de diferentes instrumentos avaliativos. As suas estratégias de ensino se baseavam principalmente em práticas experimentais, na leitura, entre outros. A pibidiana Melissa demonstrou não dominar o conteúdo de reações redox, não ter conhecimento de currículo e de estratégias para desenvolver o conceito que ensinava. Grande parte dos conhecimentos docentes que emergiram dos documentos analisados da pibidiana foi reflexo das orientações que recebia das tutoras e também da experiência oportunizada pelo Pibid de como acessar as dificuldades dos alunos com o conteúdo específico, experimentar a gestão de classe e a organização de aulas. As avaliações adotadas pela pibidiana tinham por objetivo coletar dados para o subprojeto. Durante a sua regência não demonstrou uma preocupação com a aprendizagem dos alunos, mas em executar o currículo pretendido e aplicar as avaliações. O pibidiano Mateus demonstrou também limitações com o conteúdo e em selecionar os conceitos necessários para a aprendizagem dos discentes. Apresentou ainda dificuldades com a gestão do tempo e da classe. Por outro lado, passou a conhecer as barreiras conceituais dos discentes com o conteúdo redox, a partir de sua vivência no Pibid. Diversas das decisões sobre o fazer no ensino de ciências eleitas por Mateus foram orientações da supervisora. Pelo mapeamento infere-se que os conhecimentos para a docência acessados pelos pibidianos foram reflexo do Pibid personificado na figura das tutoras e pela experiência em sala. Evidenciou-se ainda que o Pibid vem contribuindo para a formação continuada da coordenadora, por possibilitar que a professora universitária conheça, por exemplo, a realidade da escola da educação básica; e da supervisora, por conceber-se como co-formadora dos licenciandos. Conclui-se que o conhecimento docente acessado por Mateus e Melissa foi influenciado pelas orientações da coordenadora. Acredita-se que o contato com o futuro ambiente profissional e a tutoria pelas docentes experientes oportunizaram aos pibidianos acessar os conhecimentos inerentes ao desenvolvimento do conhecimento base e do PCK.

Palavras chave: Conhecimento base, conhecimento pedagógico de conteúdo, reações redox, Pibid. 


\section{ABSTRACT}

NOGUEIRA, K. S. C. Pibid contributions in the pedagogical practice of chemistry student teachers involving the redox content. 2018. 358f. Thesis (PhD in Science Education - Chemical Education) submitted to the Physics Institute, Chemistry Institute, Biosciences Institute and Faculty of Education, University of São Paulo, 2018.

This study presents the results of a research that aimed to access the teacher knowledge of future chemistry teachers, in the context of the Institutional Program for Scholarships for Initiation in Teaching (Pibid). This is a case study. Data were collected from audiovisual recordings of narratives from three participants during the Pibid-chemistry meetings, from regencies and from semi-structured interviews. In addition, Pibidparticipants' reports, lesson plans and questionnaires were analyzed, and an instrument that assessed the students' perception about the teacher knowledge of the undergraduate students regarding teaching practices. The possible impacts of Pibid on the training of the coordinator and supervisor who guided the Pibid participants were also analyzed. Several documents were analyzed for evidence of the teacher knowledge of the Pibid students. The theoretical background for the analysis of qualitative data was based on content analysis, with categories from the base knowledge and the pentagonal model. The analysis of the students' perception instrument was based on statistical methods. In order to analyze the marks left by Pibid in the training of the coordinator and supervisor, the study adopted the categories of teaching knowledge'model and other emerging ones. Pibid participant Antônio presented consistent content knowledge, students knowledge and students difficulties knowledge in relation to the redox content. On the other hand, in some occasions during classes, he had difficulties organizing the class and the content into the class time. Antônio used, in his didactic sequences, different evaluation instruments. His teaching strategies were based mainly on experimental practices, reading, among others. Pibid-participant Melissa demonstrated not master the redox reactions content, she did not have any knowledge about curricula and so could not develop strategies to work with the subject she taught. Much of the teaching knowledge that emerged from the documents analyzed from Melissa reflects the guidelines that she received from the coordinator and supervisor and from the experience offered by Pibid: how to access students' difficulties with a specific content, how to deal with class management and organizing the classrooms. The assessment instruments adopted by Melissa were aimed at collecting data for the subproject. During her regency, she did not show concern for student learning, but in executing the intended curriculum and applying the assessments. Another Pibid participant, Mateus also seemed to have limited content knowledge and about selecting the necessary concepts for students learning. He also presented difficulties with time and class management. On the other hand, he came to understand the students' conceptual difficulties with the redox content from his experience in Pibid. Several of the decisions that must be made in science education chosen by Mateus were guidelines given by his supervisor. From the mapping, it is inferred that the teaching knowledge accessed by the participants was a reflection of Pibid participation, personified in the figure of the tutor and by the experience in the classroom. It was also evidenced that Pibid contributes to the continued professional developing of the coordinator, by enabling university professors to know, for instance, the reality of basic education schools; and of supervisors, for conceiving themselves as co-teachers of the teaching students. The conclusion drawn is that the teaching knowledge accessed by Mateus and Melissa were influenced mainly by the coordinator's guidelines. It is believed that contact with their future work environment and tutoring by experienced teachers were fundamental for Pibid participants to access the knowledge inherent to the development of basic knowledge and the PCK.

Keywords: Base knowledge, pedagogical content knowledge, redox reactions, Pibid. 


\section{LISTA DE FIGURAS}

Figura 1. Mapa dos campi do Pibid (Fonte: CAPES, 2013, p.85) ................... 36

Figura 2. Modelo de Raciocínio Pedagógico e Ação (MRPA) proposto por Shulman (1987) e adaptado por Salazar (2005). Fonte: FERNANDEZ, 2011.. 46

Figura 3. Modelo da relação entre os domínios do conhecimento do professor proposto por Grossman (1990). Fonte: Fernandez (2011).

Figura 4. Os componentes do conhecimento pedagógico do conteúdo para 0 ensino de ciências (MAGNUSSON; KRAJCIK; BORKO,1999); Fonte: Fernandez (2011)

Figura 5. Modelo pentagonal do Conhecimento Pedagógico de Conteúdo para o Ensino de Ciências (PARK; OLIVER, 2008b). Fonte: FERNANDEZ, 2011 ... 52 Figura 6. Modelo hexagonal do Conhecimento Pedagógico de Conteúdo para 0 Ensino de Ciências (PARK; OLIVER, 2008a). Fonte: FERNANDEZ (2011) .... 53

Figura 7. Etapas de desenvolvimento do Subprojeto Pibid-Química investigado

Figura 8. Categorias do Modelo Base em conjunto com as categorias do modelo pentagonal do PCK, um modelo híbrido. 71

Figura 9. Elementos da estrutura sintática e substantiva do conhecimento do tema a ensinar (BERNAL; VALBUENA, 2011, p.302; tradução nossa) ............ 72 Figura 10. Número total de trabalhos catalogados sobre o conteúdo redox e a relação de trabalhos que contemplavam as dificuldades de seus participantes com esse conteúdo na RASBQ, ENPEC, ENEQ e EPPEQ 103

Figura 11. Padrões a serem seguidos na resolução da atividade (Fonte: MIRALLES; MONTIEL; ODETTI, 2009, p.1836)

Figura 12. Coocorrência das categorias do Conhecimento Docente de Antônio em todos os documentos analisados 121

Figura 13. "Lousa" elaborada por Antônio para aula Pilha de Daniell (Fonte: Relatório anual - Antônio) 124

Figura 14. Exercício proposto por Antônio e Melissa para aula 2 (Fonte: Relatório anual da dupla - Antônio, p.15). 161

Figura 15. Mapa de integração entre os componentes do Conhecimento Docente de Antônio na aula de Sensibilização 167

Figura 16. Mapa de integração entre os componentes do Conhecimento Docente de Antônio na aula de atomística. 168

Figura 17. Mapa de integração entre os componentes do Conhecimento Docente de Antônio na aula Pilha de moedas. 169

Figura 18. Mapa de integração entre os componentes do Conhecimento Docente de Antônio na aula Pilha de Daniell 169

Figura 19. Mapa de integração entre os componentes do Conhecimento Docente de Antônio na aula de Revisão .... 170

Figura 20. Mapa de integração de integração entre os componentes do Conhecimento Docente de Antônio na aula de Contaminação por Chumbo.. 171 Figura 21. Mapa de integração entre os componentes do Conhecimento Docente de Antônio na aula de logística reversa 
Figura 22. Mapa de integração entre os componentes do Conhecimento Docente de Antônio na aula Feedback...................................................... 172

Figura 23. Mapa de integração entre os componentes do Conhecimento Docente de Antônio de todas as aulas ministradas por Antônio na EJA ........ 173

Figura 24. Coocorrência das categorias do Conhecimento Docente de Melissa

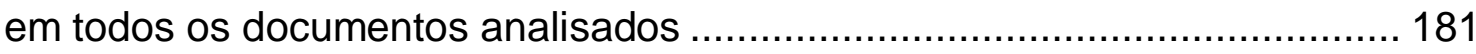

Figura 25. Texto confeccionado por Melissa sobre a bateria de chumbo ...... 193

Figura 26. Exercício proposta na aula de atomística.................................. 227

Figura 27. Exercício da aula de revisão.................................................. 228

Figura 28. Mapa de integração entre os componentes do Conhecimento Docente de Melissa na aula de Sensibilização .......................................... 233

Figura 29. Mapa de integração entre os componentes do Conhecimento Docente de Melissa na aula de atomística ................................................ 234

Figura 30. Mapa de integração entre os componentes do Conhecimento Docente de Melissa na aula de Revisão ..................................................... 235

Figura 31. Mapa de integração entre os componentes do Conhecimento Docente de Melissa na aula de logística reversa ....................................... 235

Figura 32. Mapa de integração entre os componentes do Conhecimento Docente de todas as aulas ministradas por Melissa na EJA ......................... 236

Figura 33. Coocorrência das categorias do Conhecimento Docente de Mateus 245

Figura 34. Lousa estruturada por Mateus para a aula de estrutura atômica e definição de oxidação 249

Figura 35. Roteiro da aula experimental da gota salina (a) e deposição de cobre (b) (Fonte: Relatório individual - Mateus, p.32)........................................ 285 Figura 36. Exercício proposto na aula de estrutura atômica e definição de oxidação... 287

Figura 37. Mapa de integração entre os componentes do Conhecimento Docente de Mateus na aula de Sensibilização 292

Figura 38. Mapa de integração entre os componentes do Conhecimento Docente de Mateus na aula de Estrutura atômica e definição de oxidação a. (arquivo 8) e b. (arquivo 8.1) 292

Figura 39. Mapa de integração entre os componentes do Conhecimento Docente de Mateus na aula de conceitos gerais de eletroquímica ..... 293

Figura 40. Mapa de integração entre os componentes do Conhecimento Docente de Mateus na aula gota salina e deposição de cobre a. (arquivo 10) e b. (arquivo 10.1) 294

Figura 41. Mapa de integração entre os componentes do Conhecimento Docentede Mateus na aula lúdica a. (arquivo 11) e b. (arquivo 11.1) 295

Figura 42. Mapa de integração entre os componentes do Conhecimento Docentede todas as aulas ministradas por Mateus nas turmas de segundo ano 295 


\section{LISTA DE TABELAS}

Tabela 1. Distribuição da carga horária dos Componentes Curriculares da Licenciatura em Química do Instituto Federal de São Paulo............................ 59

Tabela 2. Práticas de ensino como componente curricular (PECC) ................ 59

Tabela 3. Distribuição dos trabalhos por evento no período de 2008 a 2016 .. 79 Tabela 4. Principais dificuldades relacionadas ao ensino e aprendizagem de

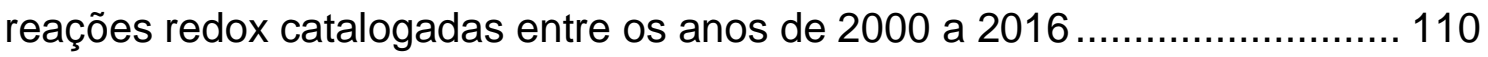

Tabela 5.Relatório gerado no Atlas.ti - Conhecimento Docente de Antônio .. 120 Tabela 6. Resposta de Antônio para Ação Descrever no Ciclo reflexivo ....... 152 Tabela 7. Dados gerados no Atlas.ti - Emersão do Conhecimento Docente nas aulas ministradas por Antônio na EJA.

Tabela 8. Porcentagem de respondentes que assinalaram as subcategorias, que compunham cada categoria, seus respectivos valores mínimos e máximos . 174 Tabela 9. Valores da Média, mediana e desvio padrão de cada questão...... 176 Tabela 10. Alfa de Cronbach para todo instrumento e separado por dimensão, além do alfa na ausência de cada categoria ............................................ 178

Tabela 11. Relatório gerado no Atlas.ti - Conhecimento Docentede Melissa 180 Tabela 12. Resposta concedida por Melissa ao ciclo reflexivo antes de assistir as regências 202

Tabela 13. Resposta concedida a Ação-Reconstruir (ciclo reflexivo) por Melissa antes e depois de assistir as regências. 209

Tabela 14. Resposta de Melissa à ação Confrontar antes de assistir as aulas 218

Tabela 15. Trechos do CoRe adaptado ................................................. 220 Tabela 16. Dados gerados no Atlas.ti - Emersão do Conhecimento Docente nas aulas ministradas por Melissa na EJA 233

Tabela 17. Porcentagem de respondentes que assinalaram as subcategorias e seus respectivos valores mínimos e máximos 237

Tabela 18. Valores da média, mediana e desvio padrão de cada questão .... 238 Tabela 19. Alfa de Cronbach para todo o instrumento e separado por dimensão, além do alfa na ausência de cada categoria 240

Tabela 20. Ordem cronológica de coleta de dados e seus respectivos arquivos Mateus.

Tabela 21. Relatório gerado no Atlas.ti - Conhecimento Docente de Mateus 244 Tabela 22. Resposta concedida a Ação-descrever (ciclo reflexivo) por Mateus antes e depois de assistir as regências. 263

Tabela 23. Resposta concedida a Ação Informar e Reconstruir (ciclo reflexivo) por Mateus antes e depois de assistir as regências 278

Tabela 24. Dados gerados no Atlas.ti - Emersão do Conhecimento Docente nas aulas ministradas por Mateus nas turmas de segundo ano 291

Tabela 25. Porcentagem de respondentes que assinalaram as subcategorias, que compunha cada categoria, e seus respectivos valores mínimos e máximos

Tabela 26. Valores da média, mediana e desvio padrão para cada subcategoria 
Tabela 27. Alfa de Cronbach para todo o instrumento e separado por dimensão, além do alfa na ausência de cada categoria 299

Tabela 28. Relatório gerado no Atlas.ti - Categorias do Conhecimento Docentedas tutoras 300

Tabela 29. Relatório gerado no Atlas.ti - A importância do Pibid na formação da coordenadora Maria 312

Tabela 30. Relatório gerado no Atlas.ti - A importância do Pibid na formação da supervisora Luiza 318 


\section{LISTA DE QUADROS}

Quadro 1. Evolução dos custeios executados ................................................ 36

Quadro 2. Número total de bolsas aprovadas para os projetos Pibid em 2014 por nível de participação

Quadro 3. Objetivos das diferentes orientações para o ensino de ciências e a natureza da instrução.

Quadro 4. A natureza da instrução associada com diferentes orientações para o ensino de ciências 50

Quadro 5. CoRe (Representação do Conteúdo) (LOUGHRAN; MULHALL;

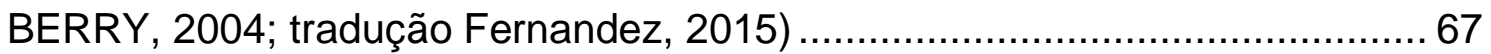

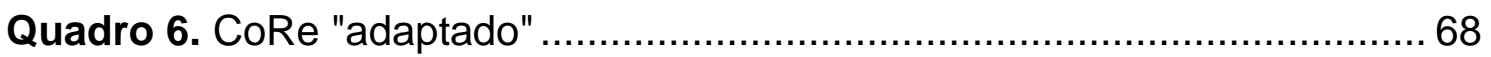

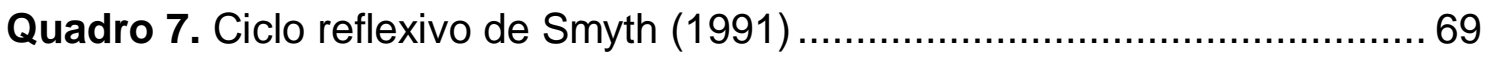

Quadro 8. Descrição dos principais componentes do Atlas.ti.......................... 76

Quadro 9. Organização dos dados para o cálculo do alfa ............................... 78

Quadro 10. Classificação dos valores de Alfa de Cronbach............................ 78

Quadro 11. Ordem de coleta de dados e seus respectivos arquivos - Antônio e

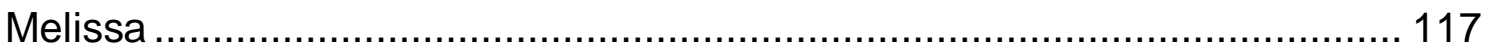

Quadro 12. Blocos de aulas planejadas pelos pibidianos Melissa e Antônio 118 Quadro 13. Questões problemas reelaboradas por Antônio e Melissa (Fonte: adaptado Relatório dupla, 2014, p.7-8) .................................................. 137

Quadro 14. Proposta de avaliação para aula de sensibilização - PNRS ....... 148

Quadro 15. Roteiro da aula experimental - Pilha de moedas (adaptado, Fonte:

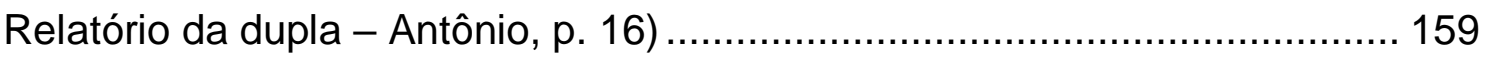

Quadro 16. Trechos do CoRe adaptado.................................................... 160

Quadro 17. Exercício proposto por Antônio para aula Pilha de moedas (Fonte: Relatório da dupla - Antônio, p.19-20) ....................................................... 163

Quadro 18. Lousa confeccionada por Melissa para aula de atomística ........ 182 Quadro 19. Descrição da aula de logística reversa (Fonte: Relatório anual Melissa)..... 207

Quadro 20. Métodos de avaliação e o que avaliar em ciências, que permeavam

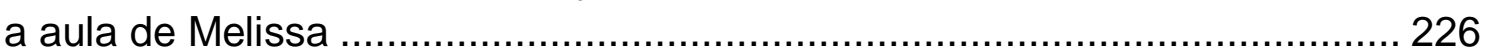

Quadro 21. Blocos de aulas planejadas pelo pibidiano Mateus ................... 242 Quadro 22. Aulas implementadas no segundo semestre e os resultados alcançados 271

Quadro 23. Relação entre o Conhecimento do Currículo e o Conhecimento Pedagógico Geral na aula de estrutura atômica e definição de oxidação...... 280 Quadro 24. Respostas concedidas por Mateus as questões 4 e 5 do CoRe. 281 Quadro 25. Repostas concedidas por Mateus as questões 1, 2 e 8 do CoRe 290 


\section{LISTA DE ABREVIATURAS E SIGLAS}

AACC - Atividades Acadêmico-Científico-Culturais

CAPES - Coordenação de Aperfeiçoamento de Pessoal de Nível Superior CEE - Conselho Estadual de Educação - Governo do Estado de São Paulo CEFAM - Centro Específico de Formação e Aperfeiçoamento do Magistério CNE/CP - Conselho Nacional de Educação/Conselho Pleno CoRe - Representação do Conteúdo (Content Representation) CTS - Ciência, Tecnologia e Sociedade EJA - Educação de Jovens e Adultos ENEQ - Encontro Nacional de Ensino de Química ENPEC - Encontro Nacional de Pesquisa em Educação em Ciências EPPEQ - Encontro Paulista de Pesquisa em Ensino de Química FFCL-USP - Faculdade de Filosofia, Ciências e Letras da Universidade de São Paulo IFSP-SP - Instituto Federal de Educação, Ciência e Tecnologia de São Paulo FNDE - Fundo Nacional de Desenvolvimento da Educação

OEC - Objetivo Educacional e do Contexto RCE - Representação do Conteúdo e Estratégias para seu ensino CCE - Conhecimento das Compreensões dos Estudantes LDBEN - Lei de Diretrizes e Bases da Educação Nacional MEC - Ministério da Educação

MLE - Metodologia da Lembrança Estimulada MRPA - Modelo de Raciocínio Pedagógico e Ação PCK - Conhecimento Pedagógico de Conteúdo (Pedagogical Content Knowledge) PCNEM - Parâmetros Curriculares Nacionais para o Ensino Médio PECC - Práticas de Ensino como Componente Curricular Pibid - Programa Nacional de Bolsas de Iniciação à Docência PNRS - Política Nacional de Resíduos Sólidos PROEJA - Programa Nacional de Integração da Educação Profissional RASBQ - Reunião Anual da Sociedade Brasileira de Química SBQ - Sociedade Brasileira de Química SESU - Secretaria de Educação Superior CT - Conhecimento do Tema TCLE - Termo de Consentimento Livre Esclarecido USP - Universidade de São Paulo 


\section{Sumário}

APRESENTAÇÃO

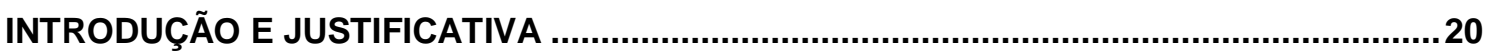

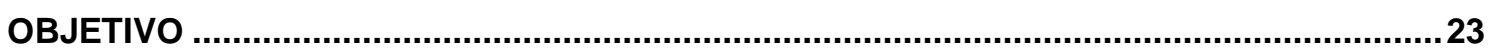

Objetivos específicos........................................................................... 23

CAPÍTULO 1. FORMAÇÃO DE PROFESSORES NO BRASIL E AS POLÍTICAS PÚBLICAS 24

1.1. Passado e presente: um olhar de 1549 aos tempos atuais ...................... 24

1.2. A Formação de professores a partir de 1996 ........................................ 30

1.2.1. O Programa de Iniciação à docência - Pibid ......................................... 33

1.3. A disciplina de química e a formação do professor de química no Brasil.. 39

CAPÍTULO 2. FUNDAMENTAÇÃO TEÓRICA ...................................................................44

2.1. Base de conhecimentos da profissão docente ....................................... 44

2.2. Conhecimento Pedagógico de conteúdo (PCK) .................................... 49

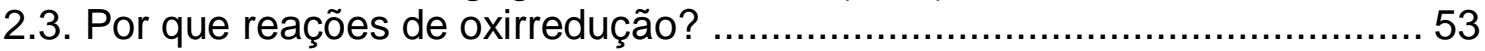

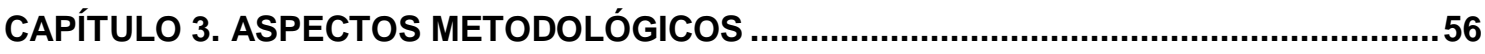

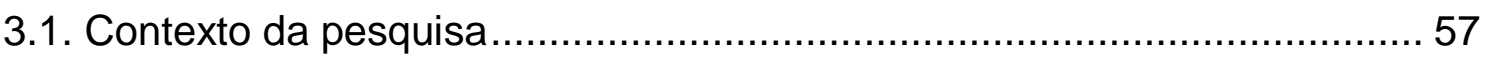

A licenciatura em Química no IFSP ............................................................ 57

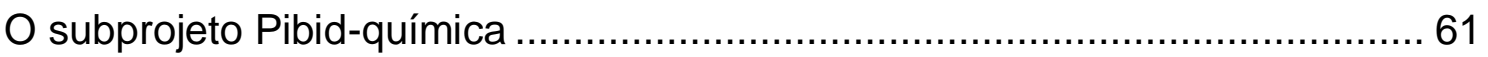

Caracterização da escola conveniada ao Pibid ............................................. 62

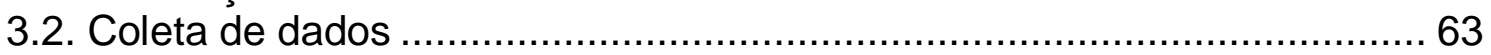

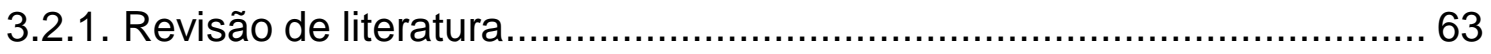

O Pibid e seus impactos no desenvolvimento profissional docente ................. 63

Dificuldades e limitações do conteúdo redox - eventos nacionais e internacionais

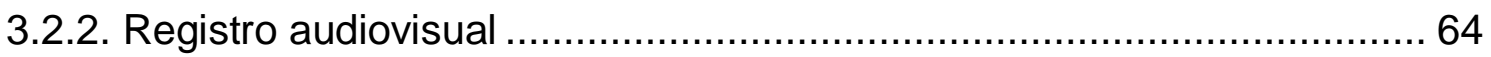

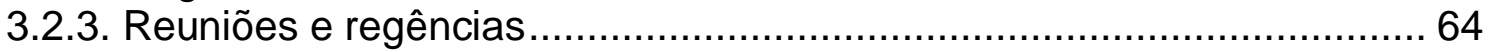

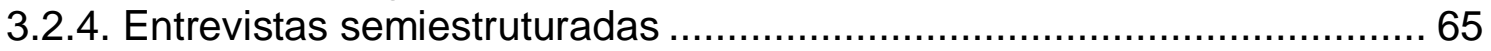

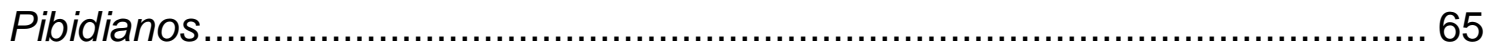

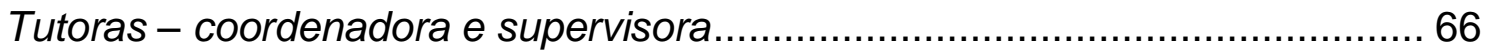

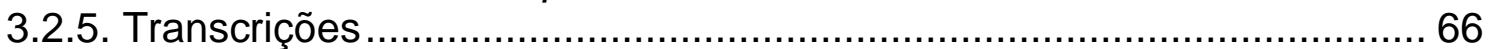

3.2.6. Questionário socioeconômico e cultural .............................................. 66

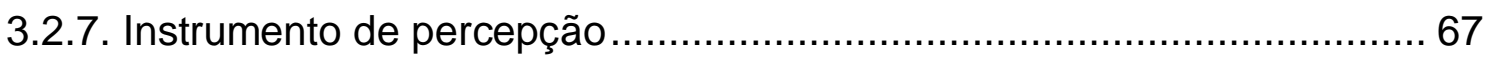

3.2.8. Representação de Conteúdo-CoRe adaptado ..................................... 67

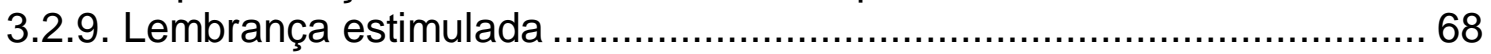

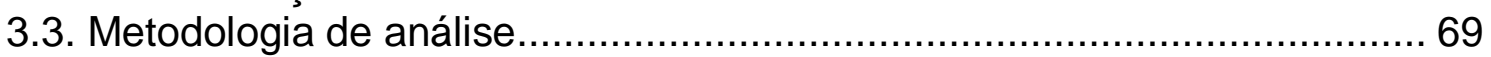

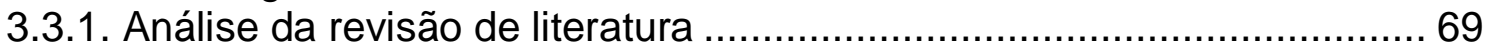

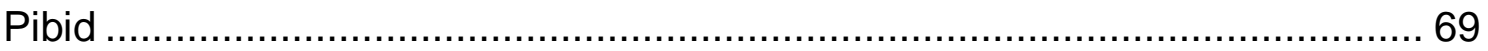

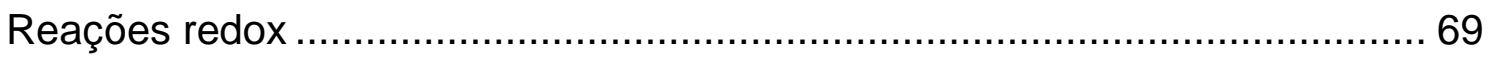

3.3.2. Acesso ao Conhecimento Docente dos pibidianos................................. 69

3.3.3. Análise dos impactos do Pibid na formação das tutoras ....................... 75

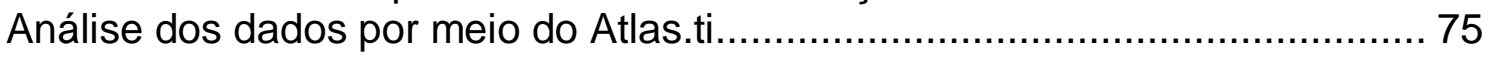

3.3.4. Análise do Instrumento de Percepção................................................. 77

CAPÍTULO 4. RESULTADOS E DISCUSSÕES............................................................

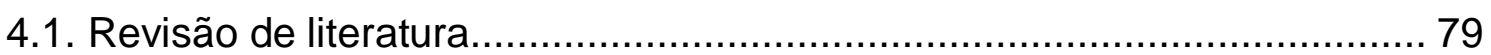

Pibid e o desenvolvimento profissional docente ……….............................. 79

O Pibid nas teses e dissertações ............................................................... 95 
Reações redox nos eventos nacionais e internacionais ............................ 102

Eventos Nacionais...................................................................... 102

Eventos Internacionais ................................................................. 110

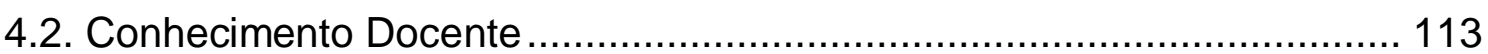

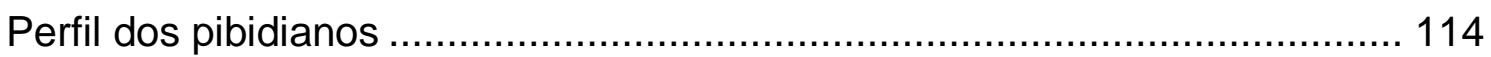

O pibidiano Antônio ........................................................................ 115

A pibidiana Melissa ............................................................................... 116

O pibidiano Mateus ............................................................................ 116

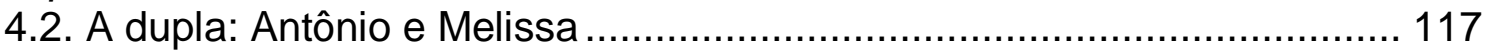

4.2.1. Conhecimento Docente de Antônio ................................................. 119

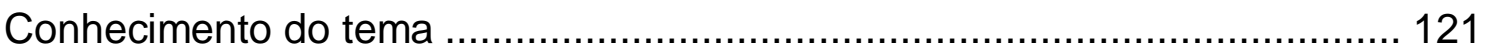

Conhecimento pedagógico geral ............................................................ 129

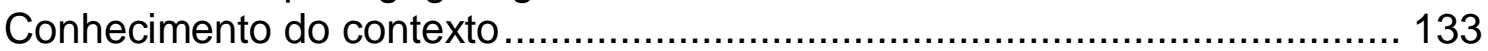

1. Orientações para o ensino de ciências.................................................... 135

2. Conhecimento do currículo em ciências................................................ 142

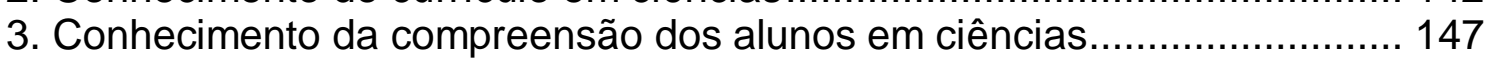

4.Conhecimento das estratégias instrucionais para o ensino de ciências...... 155

5.Conhecimento da avaliação da aprendizagem em ciências ...................... 160

Síntese do Conhecimento Docente de Antônio ......................................... 166

4.2.1.1. Percepções dos alunos da escola conveniada sobre o conhecimento docente de Antônio ................................................................................. 173

4.2.2. Conhecimento Docente de Melissa ................................................ 179

Conhecimento do tema ................................................................... 182

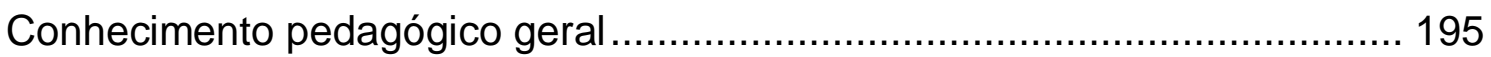

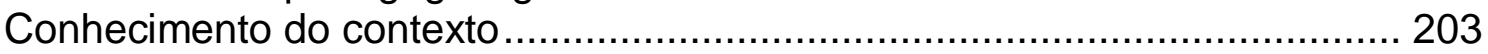

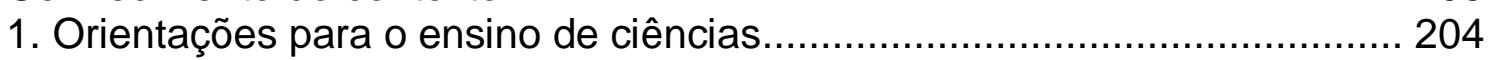

2. Conhecimento do currículo em ciências .............................................. 211

3. Conhecimento da compreensão dos alunos em ciências ....................... 214

4. Conhecimento das estratégias instrucionais para o ensino de ciências..... 221

5. Conhecimento da avaliação da aprendizagem em ciências ....................... 226

Síntese do Conhecimento Docentede Melissa ............................................. 233

4.2.2.1. Percepções dos alunos da escola conveniada sobre o conhecimento docente de Melissa ....................................................................... 236

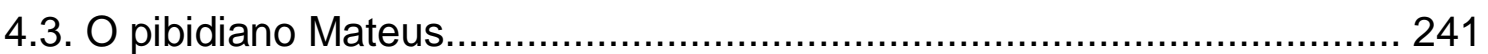

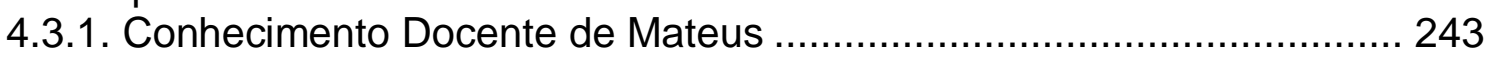

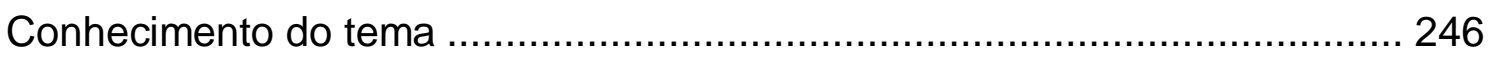

Conhecimento pedagógico geral ..................................................... 259

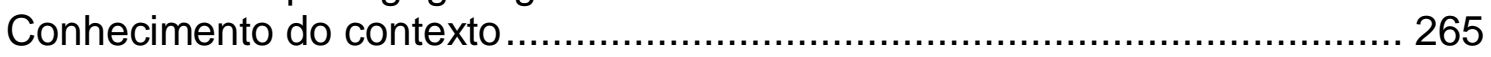

1. Orientações para o ensino de ciências............................................... 267

2. Conhecimento do currículo em ciências................................................ 279

3. Conhecimento da compreensão dos alunos em ciências.......................... 281

4.Conhecimento das estratégias instrucionais para o ensino de ciências...... 284

5. Conhecimento da avaliação da aprendizagem em ciências...................... 286

Síntese do Conhecimento Docente de Mateus ............................................ 291

4.3.1.1. Percepções dos alunos da escola conveniada sobre o conhecimento docente Mateus...................................................................................... 296

4. 4. As tutoras - Maria e Luiza............................................................ 300

4.4.1. Componentes do conhecimento docente ....................................... 300

4.4.2. Os impactos do Pibid na formação continuada ................................ 310

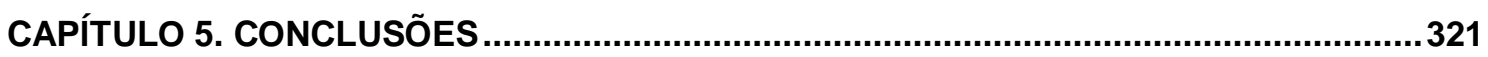

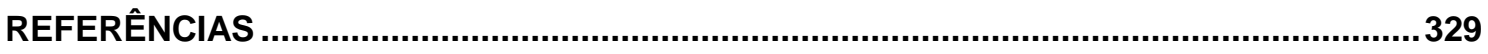


APÊNDICES

Apêndice 1 - Termo de consentimento livre e esclarecido ............................ 351

Apêndice 2 - Roteiro de entrevista semiestruturada - Pibidianos .................. 352

Apêndice 3 - Roteiro de entrevista semiestruturada - coordenadora ............ 353

Apêndice 4 - Roteiro de entrevista semiestruturada - supervisora ................ 354

Apêndice 5 - Questionário socioeconômico e cultural ................................ 355

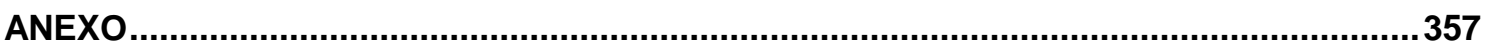

ANEXO 1 - Instrumento de percepção do Conhecimento Docente ................ 357 


\section{APRESENTAÇÃO}

Esta tese de doutorado foi desenvolvida no grupo de Pesquisa em Ensino de Química (PEQuim) que investiga o conhecimento de professores de química, mais especificamente, o Conhecimento Pedagógico de Conteúdo (PCK, Pedagogical Content Knowledge), que diferencia um docente de química de um químico especialista. Diversos trabalhos foram e estão sendo produzidos no grupo nessa temática (SALES, 2010; FERNANDEZ, 2011, 2014, 2015; ELIAS, 2011; MONTENEGRO, 2012; MONTENEGRO; FERNANDEZ, 2015; GIROTTO JÚNIOR, 2012, 2015; OLIVEIRA JÚNIOR, 2012; SILVA, 2012; PEREIRA, FERNANDEZ, 2013; GIROTTO JÚNIOR; FERNANDEZ, 2013; GOES, 2015; GOES et al., 2013; FREIRE; FERNANDEZ, 2014; 2015; FERNANDEZ; GOES, 2014; NOVAIS; FERNANDEZ, 2014; TACOSCHI; FERNANDEZ, 2014; LEAL; NOVAIS; FERNANDEZ, 2015; TACOSHI; FERNANDEZ, 2014). O PCK é específico para cada conteúdo, sendo produzido em ação pelo professor ao levar em conta as dificuldades dos alunos, concepções alternativas, estratégias, analogias, experimentos, entre outros. As pesquisas do grupo buscam documentar e analisar, em diferentes contextos, o PCK de professores de química e possibilidades de seu desenvolvimento. O objetivo central do PEQuim é desenvolver conhecimento teórico sobre o PCK para que posteriormente seja possível utilizar estes resultados para contribuir na proposição de currículos de cursos de formação de professores de química e subsidiar políticas públicas. ${ }^{1}$

Iniciei minha vida acadêmica, cursando licenciatura em química no Instituto Federal de Educação, Ciência e Tecnologia de São Paulo (IFSP-SP), no ano de 2008. $\mathrm{E}$, durante a graduação, atuei como aluna de iniciação científica em alguns projetos. Em um deles, investiguei a concepção de interdisciplinaridade de um grupo de docentes que atuava na licenciatura em química do IFSP-SP; outro estava vinculado à implementação de uma prática interdisciplinar, para alunos do 1ํano do Ensino Médio Integrado do próprio instituto.

Atuei ainda como bolsista do Programa Institucional de Bolsa de Iniciação à Docência (Pibid). A minha participação nesse programa envolvia o desenvolvimento de projetos que buscassem correlacionar os conceitos químicos com o cotidiano dos discentes, mas principalmente iniciar meus primeiros passos como professora de química. No último semestre da licenciatura, comecei a atuar na Rede Estadual de Ensino de São Paulo, na qual lecionei por dois anos.

O desenvolvimento de trabalhos de iniciação científica e a vivência como pibidiana me levaram a querer fazer mestrado. Mas, era apenas um desejo. E no final

${ }_{1}$ PEQuim, disponível em: <http://sites.usp.br/pequim/>. Acesso em 04/03/2018. 
do curso, em 2012, procurei a professora Dra. Carmen Fernandez para ser minha orientadora. Porém, como a professora estava com muitos orientandos, não fiz o processo seletivo de 2013 para ingressar no mestrado, e durante um ano e seis meses frequentei o grupo PEQuim como colaboradora.

Em 2014 ingressei no Programa de Pós-Graduação Interunidades em Ensino de Ciências da Universidade de São Paulo (PIEC-USP) no curso de mestrado, e em meados de março de 2016, a minha transferência para o curso de doutorado direto foi solicitada por minha orientadora e, depois de uma sinalização positiva da banca de qualificação e da avaliação positiva de um parecerista exerno, passei para o doutorado direto. Em meu projeto de doutorado investiguei a construção do Conhecimento Docente de um grupo de licenciandos em química, participantes do Pibid, por meio de suas ações no contexto desse programa. A escolha em investigar alunos bolsistas do programa de iniciação à docência está atrelada à inquietação emergida como pibidiana de compreender como os bolsistas constroem suas sequências didáticas de um conceito considerado difícil de ser ensinado, reações de oxirredução, de modo acessível ao aluno e que este consiga entender a relação do conceito aprendido na química com a sua vida. Além disto, a escolha de investigar o desenvolvimento de sequências didáticas pelos bolsistas do Pibid está relacionada à análise da construção do Conhecimento Docente ainda na formação inicial. 


\section{INTRODUÇÃO E JUSTIFICATIVA}

A palavra docência tem sua origem etimológica no latim - docere, que significa ensinar, instruir, mostrar, indicar, dar a entender, e seu registro em língua portuguesa data de 1916 (ARAÚJO, 2004). Formalmente a docência é o trabalho do professor e, por muitos séculos, a formação desse profissional vem passando por diversas modificações. Na contemporaneidade uma dessas mudanças (BRASIL, 1996, 2002) sinalizam que a formação inicial de professores da educação básica em cursos de nível superior seja desvinculada dos cursos de bacharelado e que as disciplinas pedagógicas devam permear toda a formação do licenciando, o que levaria ao rompimento do hiato existente entre a formação e a prática pedagógica do professor. A nova legislação discorre que " [...] É preciso indicar com clareza para o aluno qual a relação entre o que está aprendendo na licenciatura e o currículo que ensinará no segundo seguimento de ensino fundamental e no ensino médio" (BRASIL, 2002 p.21)

Contudo, quando se investiga a formação de docentes (PEREIRA, 1999; MALDANER, 2003; MESQUITA; SOARES, 2009; GATTI, 2010), conclui-se que a maioria das instituições formadoras ainda não superou o currículo conhecido como três mais um implementado na década de trinta e que apresenta como característica principal o desenvolvimento nos três primeiros anos de conhecimentos de conteúdo e no último ano de disciplinas pedagógicas, que incluem o estágio supervisionado e as práticas de ensino. Esse modelo é concebido na literatura como o da racionalidade técnica. Segundo Pereira (1999), esse modelo de formação apresenta algumas distorções que estão atreladas:

[...] à separação entre teoria e prática na preparação profissional, à prioridade dada à formação teórica em detrimento da formação prática e a concepção da prática como mero espaço de aplicação de conhecimentos teóricos, sem um estatuto epistemológico próprio (p.112).

E, apesar de muitas instituições (GAUCHE et al., 2008; GATTI; BARRETO, 2009; ARANTES, 2013) terem estruturado seus currículos segundo as novas demandas legais (BRASIL, 2002), novos desafios surgem (PEREIRA, 2000) como, por exemplo, os problemas relacionados ao estágio supervisionado, pela ligação frágil entre os centros formadores e as escolas conveniadas. Além disto, problemas diretamente ligados aos docentes formadores dos licenciandos que acabam valorizando os conteúdos sem estabelecer o elo entre o conhecimento químico e pedagógico (SANTOS, 2005). Nesse sentido, Gatti e Nunes (2009) em um estudo sobre a formação de professores para o ensino fundamental, consideram que: 
ideia de oferecimento de formação na área disciplinar específica com alto peso em número de disciplinas e horas-aulas, praticamente sem integração com as disciplinas pedagógicas (p.48).

A partir dessa literatura sugere-se que apenas o domínio do conteúdo específico não é o suficiente para ensinar. Nesse sentido, alguns estudos propuseram um corpo de conhecimentos inerentes ao profissional docente, dentre os quais destaca-se o Conhecimento Pedagógico de Conteúdo (PCK, Pedagogical Content Knowledge).

O PCK é reconhecidamente o conhecimento que distingue um professor de química de um químico especialista, é específico para cada conteúdo e produzido em ação pelo professor levando em conta as dificuldades dos alunos, concepções alternativas, estratégias, analogias, experimentos, etc., que promovem uma melhor aprendizagem daquele conteúdo (SHULMAN, 1986, 1987). É ainda um tipo de conhecimento adquirido na prática de professores em sala de aula (VAN DRIEL et al., 1998). Acredita-se que esse conhecimento possa ser bastante útil para professores em formação inicial, de forma que a pesquisa de PCK com professores experientes pode gerar contribuições importantes para cursos de formação inicial de docentes, fazendo com que a prática de professores bem-sucedidos possa promover uma ampliação de repertórios de experiência pedagógica em licenciandos ainda durante a formação inicial desses professores (FERNANDEZ, 2014, 2015). Por outro lado, pesquisas apontam em direção à perspectiva de que é possível e desejável desenvolver o PCK durante a formação inicial (VAN DRIEL; DE JONG, 2001).

Em uma tentativa de vincular a teoria com a ação didática, o Pibid - Programa Institucional de Bolsa de Iniciação à Docência - promovido pela Capes (Coordenação de Aperfeiçoamento de Pessoal de Nível Superior) é uma iniciativa para o aperfeiçoamento e a valorização da formação de professores para a educação básica (CAPES, 2014) e tem como objetivo principal a formação de docentes em nível superior para a educação básica, promovendo a integração entre esses dois níveis de ensino. $O$ Programa pressupõe a inserção dos licenciandos no cotidiano de escolas da rede pública, proporcionando-lhes oportunidades de criação e participação em experiências metodológicas, tecnológicas e práticas docentes de caráter inovador e interdisciplinar que busquem a superação de problemas identificados no processo de ensinoaprendizagem (CAPES, 2014).

Os projetos devem promover a inserção dos estudantes no contexto das escolas públicas desde o início da sua formação acadêmica para que desenvolvam atividades didático-pedagógicas sob a orientação de um docente da licenciatura e de um professor da escola.

Neste trabalho investigou-se como esse programa institucional vem influenciando na estruturação e construção dos conhecimentos docentes (SHULMAN, Introdução e Justificativa 
1986) de licenciandos em química por meio do desenvolvimento e implementação de sequências didáticas sobre reações redox. A hipótese é que o processo de desenvolvimento das sequências pelos pibidianos, além de outros instrumentos que serão detalhados no decorrer do trabalho, possa levá-los a desenvolver o PCK a respeito de reações redox ainda na formação inicial. O contexto do projeto Pibid é especialmente adequado a essa investigação, pois se tem um sujeito ainda em formação inicial, mas em contato estreito com a prática pedagógica. Além disto, a promoção da elaboração das sequências didáticas de forma assistida, tanto pela universidade como pelo professor da escola conveniada pode resultar numa forma frutífera de desenvolver o PCK de professores em formação inicial.

Diante desses aspectos, as questões de pesquisa que nortearam este estudo foram:

- Quais foram os conhecimentos docentes acessados pelos futuros professores de química durante suas trajetórias como bolsistas?

- Qual a influência das orientações da supervisora e da coordenadora na construção dos conhecimentos docentes dos bolsistas?

- O Pibid tem impactado na formação continuada da supervisora e coordenadora?

- O Pibid vem constituindo-se um terceiro espaço de formação inicial?

O texto está organizado da seguinte forma: nesta primeira parte, Introdução e Justificativa, foram apresentadas algumas problemáticas na formação de professores e o referencial teórico para o conhecimento docente, além do Pibid como contexto da pesquisa. Na sequência apresentam-se os objetivos da investigação. No primeiro capítulo foram delineados os aspectos históricos e contemporâneos relativos à formação de professores, mais especificamente à formação de licenciados em química. No segundo capítulo tem-se a fundamentação teórica sobre a Base de Conhecimentos proposta inicialmente por Shulman e outros referenciais teóricos para o PCK. No terceiro capítulo estão dispostos os aspectos metodológicos e as características que norteiam este estudo. No capítulo seguinte apresentam-se os resultados e discussões. Nesse sentido, apresenta-se inicialmente o levantamento bibliográfico sobre o programa de iniciação à docência e seus impactos na formação da tríade (coordenador, supervisor e pibidianos) e o levantamento bibliográfico sobre as limitações associadas ao ensino de aprendizagem de reações redox. Posteriormente os conhecimentos docentes construídos pelos pibidianos e a percepção dos alunos da educação básica sobre os seus conhecimentos docentes. Na sequência trata-se do impacto do Pibid no desenvolvimento profissional da supervisora e coordenadora. No capítulo cinco as Conclusões. 


\section{OBJETIVO}

O objetivo central desta investigação é analisar o desenvolvimento do conhecimento docente de licenciandos em química, participantes do Pibid.

\section{Objetivos específicos}

Evidenciar o desenvolvimento dos Conhecimentos Base e do Conhecimento Pedagógico de Conteúdo relativo ao tema reações de oxirredução de licenciandos em química, bolsistas de um subprojeto Pibid-Química, durante suas ações neste programa institucional. Elucidar a possível influência das orientações da supervisora e da coordenadora na construção do conhecimento docente dos pibidianos. Revelar aspectos de como o Pibid vem constituindo-se como um terceiro espaço de formação inicial, além da graduação e do estágio supervisionado. 


\section{CAPÍTULO 1. FORMAÇÃO DE PROFESSORES NO BRASIL E AS POLÍTICAS PÚBLICAS}

Neste capítulo objetivou-se pontuar fatos históricos que constituem a formação de professores no Brasil.

\subsection{Passado e presente: um olhar de 1549 aos tempos atuais}

A influência dos jesuítas nas raízes da educação brasileira é inquestionável e a vinda deles ao Brasil, por volta de 1549, marca o início da educação na então colônia de Portugal. Quando os religiosos aportam no Brasil, chegam com a missão de converter o gentio à fé católica (SHIGUNOV NETO; MACIEL, 2008), o que significou que "[...] a sua espantosa atividade missionária, política e educadora se apresentava subordinada às exigências ecumênicas da Igreja e aos supremos interêsses [sic] da religião" (AZEVEDO, 1996, p. 502). Nesse contexto colonial, a educação estabelecida pelos padres da Companhia de Jesus foi marcada por dois períodos de desenvolvimento: o primeiro, o heróico (1549-1570) e o segundo, conhecido como de expansão e consolidação (1570-1759). O período heróico é marcado pela inserção dos religiosos nas aldeias com a função de se apropriarem da cultura indígena e realizarem catequização por convencimento. Contudo, a falta de receptividade levou os jesuítas a sucumbirem à cultura do gentio. E, a partir de então, as crianças indígenas eram conduzidas às instituições denominadas "Casas de Meninos", nas quais aprendiam as doutrinas cristãs, o idioma português, entre outros aspectos. Esses dois períodos marcam o surgimento dos primeiros colégios no Brasil frequentados, principalmente, por filhos de colonos.

A estrutura curricular do colégio dos jesuítas era baseada no documento que data de 1599, o Ratio Studiorum, no qual:

Eram previstos seis anos de studia inferiora [sic], divididos em cinco
cursos (três de gramática, um de humanidades ou de poesia, um de
retórica); um triênio de studia superiora [sic] de filosofia (lógica, física,
ética), um ano de metafísica, matemática superior, psicologia e
fisiologia. Após um repetitio generallis [sic] e um período de prática de
magistério, passava-se ao estudo da teologia, que durava quatro anos
(MANACORDA, 2010, p. 248).

Essa estruturação curricular era o símbolo das práticas pedagógicas implementadas pelos padres jesuítas nos Colégios da Companhia de Jesus e representava a soberania católica no ensino. O currículo de base propedêutica era estruturado em Classes Inferiores, o ginásio e Faculdades Superiores de Filosofia e Teologia. 
No período colonial os jesuítas consideravam aptos ao magistério os que "[...] manifestam talentos, sobretudo talentos raros para a pregação [...]" (ORGANIZAÇÃO E PLANO DE ESTUDOS DA COMPANHIA DE JESUS. REGRAS DO PROVINCIAL, REGRA 11) ${ }^{2}$. Para formar professores os religiosos selecionavam os livros e mantinham o controle dos conteúdos que seriam estudados e lecionados pelos futuros docentes, principalmente os relacionados às questões religiosas e filosóficas.

Após duzentos e dez anos de domínio da educação brasileira, a Companhia de Jesus entra em decadência por ser considerada um obstáculo ao formar o cidadão a serviço da ordem religiosa e não aos interesses da colônia, o que resultou em sua expulsão da colônia pelo Marques de Pombal, em 1759. Esse fato dá início à laicização do ensino por meio da implementação das Aulas Régias, que marcou o surgimento da escola pública e que, segundo Nóvoa (1995), envolveu a substituição dos professores religiosos por professores laicos, mas não envolveu mudanças nas normas e valores referentes à profissão docente, permanecendo este profissional com características de um religioso. Esta mudança ficou conhecida como Reforma Pombalina, que tinha no iluminismo o seu ideário, e no progresso científico e na divulgação do saber, seus objetivos.

A seleção de professores para atuarem nas Aulas Régias ocorria por meio de concurso público, não sendo exigido nenhum diploma ou habilitação para a ocupação do cargo. Os docentes admitidos deveriam instalar as escolas em suas residências, assumindo todas as despesas (CARDOSO, 2004).

Contudo, esta que seria a primeira fase da Reforma Pombalina foi um fracasso, o que levou o governo a instituir um imposto para sustentá-la, medida insuficiente para a remuneração de professores e para continuar a reforma. Ainda ao final do século XVIII o Brasil não a viu estabelecida. Porém, as influências iluministas permaneceram no cenário de formação de professores no então Brasil colônia (MENDONÇA, 2005, 2007).

Em 1820 surgem no Brasil as primeiras escolas de formação de professores, as escolas mútuas. Neste movimento, o decreto de 1ำ de março de 1823 é considerado oficialmente a primeira tentativa na história nacional de implementar uma instituição de formação de professores (BASTOS, 1997; CASTANHA, 2007; SAVIANI, 2009). A escola mútua tinha como fundamentação o método Lancaster, desenvolvido pelos ingleses Andrew Bell e Joseph Lancaster no século XIX (BASTOS, 1997), que preconizava "[...] entre outras coisas, desenvolver principalmente os hábitos disciplinares de hierarquia e ordem, exercendo um controle pela suavidade, uma vigilância sem punição física [...]"

\footnotetext{
${ }^{2}$ Dados extraídos da

página:http://www.histedbr.fe.unicamp.br/acer_fontes/acer_histedu/brcol013.htm. Acesso em 02/11/2014.

Capítulo 1. Formação de Professores no Brasil e as Políticas Públicas
} 
(VILLELA, 2000, p. 107). Além disso, se priorizava a moral e a religião em detrimento do conteúdo e, uma formação de professores pela prática, sem formação teórica.

O surgimento dessas instituições, a priori, instruiria militares e cidadãos comuns. No entanto, em abril do mesmo ano, outro decreto $n^{\circ} 69$ de 29 de abril de 1823, determinou que as províncias deveriam encaminhar às Cortes militares aqueles que tivessem "[...] a necessária e conveniente aptidão, para aprenderem o mencionado método e poderem, voltando à sua Província, dar lições não só aos seus Irmãos de Armas, mas ainda às outras classes de cidadãos" (CASTANHA, 2008, p.18-19).

Um marco histórico para a educação brasileira, a primeira Lei Geral de Ensino no Brasil, instituída em 15 de outubro de 1827 por Dom Pedro I, propôs a criação de escolas primárias, tendo também no método mútuo a sua base pedagógica. Esta lei geral estabeleceu que os professores que pleiteavam uma vaga seriam "[...] examinados publicamente perante os Presidentes em conselho; e estes proverão o que for julgado mais digno e darão parte ao governo para sua legal nomeação" (BRASIL, 1827). Segundo Lopes e colaboradores (2011) a partir desta lei observa-se um processo homogêneo de organização estatal para a formação docente.

No entanto, somente com o Ato Adicional de 1834 e com a transferência de responsabilidade às províncias, para constituir seu corpo docente, ocorreriam efetivamente as primeiras iniciativas para formar professores.

Nesse contexto, o processo de institucionalização da formação docente surge com a implementação das Escolas Normais, que tinham a intenção de "[...] sob sua ação, os mestres miseráveis e pouco instruídos do início do século XIX vão, em algumas décadas, ceder lugar a profissionais formados e preparados para a atividade docente" (NÓVOA, 1992, p. 125). Em consequência, várias escolas são instituídas nas províncias do Rio de Janeiro/Niterói em 1835, na Bahia em 1836, em Minas Gerais em 1835, no Ceará em 1845 e em São Paulo em 1846. Essas instituições surgem em um contexto em que a política educacional almejava o equilíbrio da sociedade (de classes) por meio da instrução (LOPES et al., 2011).

A Escola Normal de Niterói ganha destaque dentre as escolas implementadas, e para ingressar nessa instituição era exigido pela Lei $N^{\circ} 10$ de 1835 que o candidato fosse "[...] cidadão brasileiro, maior de dezoito anos, com boa morigeração (boa educação); e saber ler e escrever" (LOPES et al., 2011, p.106). Para Lopes e colaboradores (2011), a finalidade da Escola Normal era o controle social e não a instrução do povo. A adoção do método Lancaster ocorreu por ser considerado disciplinador.

As disciplinas ministradas nessa instituição seriam regidas por um diretor que seria o único professor que, pelo método Lancaster, deveria ensinar matemática, Capítulo 1. Formação de Professores no Brasil e as Políticas Públicas 
geografia, moralidade cristã e gramática (TANURI, 2000; VILLELA, 2000). Esta simplicidade curricular foi ampliada pela reforma em 1847 que uniu a Escola Normal ao Liceu Provincial e propiciou uma formação com maiores possibilidades a professores de ensino primário e ensino médio. Contudo, o regulamento que objetivava esta junção não foi aprovado pela Assembleia Legislativa e o Liceu Provençal não saiu do papel.

A decisão de que os novos docentes fossem formados pelo sistema alunomestres adotado durante a presidência de Coutinho Ferraz, em 1849, abalou a formação de professores na Escola Normal, pois na prática significava que durante o processo formativo os futuros docentes seriam formados na vivência de sala de aula, atuando como auxiliares de mestres experientes. Esta medida significou o fim da Escola Normal.

Depois de quase uma década de sua extinção a província do Rio de Janeiro reabre pela Lei n.1.127 de 4 de fevereiro de 1859 a Escola Normal, com o objetivo de "[...] habilitar na teoria e na prática, intelectual e moralmente, os cidadãos que se destinarem ao magistério da instrução primária" (PROVÍNCIA do Rio de Janeiro, Regulamento de 1862, p. 64). Nesta nova fase é permitido o ingresso de mulheres, que a frequentariam em dias alternados aos dos homens. Esta nova Escola Normal só iniciaria as suas atividades em 1862 (LOPES et al., 2011).

Durante décadas a Escola Normal passou por diversas reformas, sendo considerada uma das mais importantes a Deliberação de 1880, que instituiu um currículo composto por um maior número de disciplinas científicas. Mas, ao final do primeiro ano de sua implementação tal decreto foi derrubado retornando o currículo mínimo.

No período da República a Escola Normal de São Paulo, sob a gestão de Caetano de Campos, instituiu em 1890 a reforma de instrução pública, considerada um modelo de formação de professores no Brasil. Em sua proposta, Campos ampliou o currículo, instituiu a escola modelo que serviria de "laboratório" para a prática de novas metodologias de ensino. Esta escola modelo era conduzida pelas pedagogas Miss Browne e Maria Guilhermina. Segundo Almeida, essa reforma "[...] alterou significativamente o ideal da formação prática do professor e alicerçou a escola no sistema escolar [...]" (1995, p. 670). No entanto, esta escola idealizada por Campos só seria inaugurada em 1894 com o nome de Escola Normal da Praça, um símbolo da formação de professores no Brasil.

Para alguns autores, as reformas propostas por Caetano de Campos tornaram a formação de professores o eixo central da reforma educacional que estava sendo conduzida, sendo consideradas como o processo de transição entre o ensino normal, durante o império, e o novo ensino normal que estava sendo delineado na República.

Em 1917 a Escola Normal passa por uma nova reforma, a de Afrânio Peixoto, diretor de instrução do Distrito Federal, que resultou na adoção de dois ciclos, a saber: Capítulo 1. Formação de Professores no Brasil e as Políticas Públicas 
o de preparação; e o profissional. Outra reforma, a de Sampaio Dório em 1920 em São Paulo, diminuiu o tempo do curso primário para atender a um número maior de crianças, passando a obrigatoriedade de ingresso ao sistema educacional aos 9 anos e não mais aos 7 anos. Essa reforma refletiu diretamente na formação de professores, aumentando para 3 anos a formação oferecida aos docentes. Porém, outro decreto de 1928 reimplementou o curso normal em dois ciclos, o profissional e o de preparação.

$\mathrm{Na}$ década de 30 do século $\mathrm{XX}$, a política educacional passa a ser orientada pelos objetivos do Estado Novo, no qual os valores da família deveriam ser o alicerce da sociedade. Nesse período, foram criados órgãos federais para a administração do ensino e para o estabelecimento de regras a serem seguidas pelos estados (HILSDORF, 2006).

Nesse novo cenário as Escolas Normais são reformuladas. Em São Paulo, são modificadas as matérias preparatórias, que passam a ter status de estudos secundários e foi instituído ainda, para os diplomados na Escola Normal, o curso de aperfeiçoamento pedagógico. Com essas reformulações, enfim, a Escola Normal se consolida como um espaço de excelência na formação de docentes. Nesse contexto é criada a escola de professores, que anos mais tarde seria incorporada à Universidade de São Paulo. A partir das novas iniciativas para a formação de professores, a Escola Normal perde força, passando a diplomar apenas os profissionais para as séries iniciais, ficando a cargo das instituições de ensino superior a titulação para as séries secundárias.

Em consonância com tal proposição, as Instituições de Ensino Superior do Distrito Federal, implementadas em 1932 por Anísio Teixeira, e de São Paulo propostas por Fernando de Azevedo em 1933, são orientadas pelo ideário da nova Escola Normal. Por meio do Decreto n. 3.801 de 1932, Anísio Teixeira no Distrito Federal, rompe com a tradição de estruturação das escolas normais, ao transformar essas instituições em Escolas de Professores, por meio do delineamento de três cursos: fundamento profissional; específico de conteúdo profissional; e de integração profissional. Nessa nova fase, a estruturação do currículo já no primeiro ano envolvia as disciplinas:

Biologia Educacional, Psicologia Educacional, Sociologia Educacional,
História da Educação, Introdução ao Ensino - Princípios e Técnicas,
Matérias de Ensino (Cálculo, Leitura e Linguagem, Literatura Infantil,
Estudos Sociais, Ciências Naturais) e Prática de Ensino (Observação,
experimentação e participação) (VIDAL, 2001, p. 82).

Em São Paulo, Fernando de Azevedo estabeleceu no Instituto de Educação a Escola de Professores. Nessas instituições, a formação de professores enfim estava sustentada por um modelo pedagógico que no entendimento de Tanuri "[...] oferecia, ao lado de um exíguo currículo profissional, um ensino de humanidades e ciências 
quantitativamente mais significativo" (2000, p.72), permitindo, assim, romper com a tradição dos currículos das Escolas Normais.

Em 1934 é instituída a Universidade de São Paulo e em 1935 a Universidade do Distrito Federal, em oposição ao modelo de formação docente das Escolas Normais. Nas novas instituições surgem as licenciaturas que diplomariam os professores para a educação secundária, enquanto os cursos de pedagogia formariam docentes para a escola normal (SAVIANI, 2005).

O Decreto-Lei n. 1.190 de 1939 organizou a Faculdade Nacional de Filosofia da Universidade do Brasil ao instituir a titulação de "técnicos em educação". Por meio desse decreto instituiu-se o modelo de formação de professores conhecido por três mais um, no qual os três anos iniciais eram destinados às disciplinas específicas e o último ano às pedagógicas. Esse modelo de formação de professores permeou as licenciaturas e os cursos de pedagogia no Brasil inteiro.

O ensino normal passou a seguir as mesmas orientações por meio da Lei Orgânica do Ensino Normal de 1946. Em sua nova estrutura o curso normal em consonância com os cursos secundários foi delineado em dois ciclos: o ginásio, com a função de formar regentes para atuarem no primário, sendo que seu funcionamento ocorreria na Escola Normal, e o colégio do curso secundário que funcionaria em Escolas Normais e nos Institutos de Educação, cujo objetivo era diplomar docentes para o ensino secundário.

Anos mais tarde com a Lei de Diretrizes e Bases da Educação Nacional n. 4.024 de 1961, rompe-se com a tradição de um currículo uniforme das escolas normais. A formação de regentes nas escolas de ginásio sendo mantida não gerou grandes modificações para o ensino normal.

Porém, esse modelo de educação com base na Escola Normal entra em declínio em 1964 no Brasil com o golpe militar. Nesse novo cenário, mudanças na educação são estabelecidas pela Lei n. 5.540/1968 que reestruturou o ensino superior e pela Lei $n$. 5.692/1971 que substituiu as denominações de ensino primário e ensino médio por primeiro grau e segundo grau (SAVIANI, 2005, 2009), substituindo ainda a Escola Normal por uma Habilitação Específica de $2^{\circ}$ Grau para professores que atuariam no $1^{\circ}$ Grau. Além disto, a Habilitação Específica do Magistério (HEM) foi organizada em duas modalidades pelo Parecer n. 349 de 1971, no qual a primeira habilitaria professores para lecionarem até a quarta série por meio de um curso com duração de três anos, enquanto que a segunda diplomaria ao magistério docentes para atuarem do sexto ao primeiro ano, em um curso de quatro anos (SAVIANI, 2009; BORGES et al., 2011). As novas mudanças estabelecidas por esse parecer significaram a substituição do curso 
Normal por uma habilitação de segundo grau, marcada por um currículo mínimo, que representava o núcleo comum estabelecido em todo território nacional.

Contudo, em 1982 o governo brasileiro implementou os Centros Específicos de Formação e Aperfeiçoamento do Magistério (CEFAM) com a proposição de restaurar a Escola Normal. No entanto, segundo Saviani (2009) esse projeto não foi amplamente difundido. Além disto, durante a década de 80 surge no Brasil um movimento que tinha por objetivo a reformulação dos cursos de pedagogia e licenciatura por meio de uma "docência como base da identidade profissional de todos os profissionais da educação" (SILVA, 2003, p. 68-69). Após onze anos da extinção do regime militar os educadores acreditavam que a nova Lei de Diretrizes e Bases da Educação Nacional (LDBEN) de 1996 levaria a formação docente a um novo caminho que deixaria no passado as problemáticas relacionadas à sua diplomação.

\subsection{A Formação de professores a partir de 1996}

A formação de profissionais em nível superior no Brasil teve início em 1808. Contudo, a obrigatoriedade de formar professores em nível superior ocorreria quase dois séculos depois, com a promulgação da Lei n. 9394 de 20 de dezembro de 1996 que estabeleceu a nova Lei de Diretrizes e Bases da Educação (LDBEN). Essa lei propõe como um dos pressupostos para a organização dos cursos de licenciatura o rompimento com o currículo três mais um, surgido no país em 1934 com a implementação das primeiras licenciaturas. Estabelece ainda que a educação seja constituída em dois níveis, o ensino superior e o ensino básico, sinalizando que a formação docente para o ensino básico realizar-se-ia em nível superior.

A LDB trouxe mudanças importantes para a atuação dos profissionais da educação. Nesse sentido:

Os sistemas de ensino promoverão a valorização dos profissionais da educação, assegurando-lhes, inclusive nos termos dos estatutos e dos planos de carreira do magistério público: I - ingresso exclusivamente por concurso público de provas e títulos; II - aperfeiçoamento profissional continuado, inclusive com licenciamento periódico remunerado para esse fim; III - piso salarial profissional; IV progressão funcional baseada na titulação ou habilitação, e na avaliação do desempenho; V - período reservado a estudos, planejamento e avaliação, incluído na carga de trabalho; VI - condições adequadas de trabalho (BRASIL, 1996, p.23).

Por outro lado, as funções do professor devem permear todo o processo de ensino, segundo o artigo 13 da LDBEN:

I - participar da elaboração da proposta pedagógica do estabelecimento de ensino; II - elaborar e cumprir plano de trabalho, segundo a proposta pedagógica do estabelecimento de ensino; III zelar pela aprendizagem dos alunos; IV - estabelecer estratégias de recuperação para os alunos de menor rendimento; $\mathrm{V}$ - ministrar os dias 
letivos e horas-aula estabelecidos, além de participar integralmente dos períodos dedicados ao planejamento, à avaliação e ao desenvolvimento profissional; $\mathrm{VI}$ - colaborar com as atividades de articulação da escola com as famílias e a comunidade (BRASIL, 1996, p.16-17).

Contemporaneamente os cursos de formação de professores para atuarem na educação básica são ofertados por instituições de ensino superior pública ou privada, sendo a sua graduação regida pela Resolução CNE/CP № 1, de 18 de fevereiro de 2002 que sugere em seu artigo 6ำ que as instituições que promovem os cursos de formação de professores para a educação básica deverão permear no projeto pedagógico de seus cursos:

I - as competências referentes ao comprometimento com os valores inspiradores da sociedade democrática;

II - as competências referentes à compreensão do papel social da escola;

III - as competências referentes ao domínio dos conteúdos a serem socializados, aos seus significados em diferentes contextos e sua articulação interdisciplinar;

IV - as competências referentes ao domínio do conhecimento pedagógico;

$\mathrm{V}$ - as competências referentes ao conhecimento de processos de investigação que possibilitem 0 aperfeiçoamento da prática pedagógica;

VI - as competências referentes ao gerenciamento do próprio desenvolvimento profissional (BRASIL, 2002, p.2).

A resolução CNE/CP no 1 de 18 de fevereiro de 2002 teve mais duas deliberações de complementaridade do Estado de São Paulo, a saber: a CEE78/2008 que estabelece as diretrizes para a formação de professores nos cursos de pedagogia, normal superior e licenciaturas "[...] vinculados ao sistema estadual ressalvados a autonomia universitária" (SÃO PAULO, 2008, p.1) e a CEE no 111/2012, que procura complementar essa resolução, mas que entrou em vigor em 2013.

A deliberação CEE 78/2008 discorre que os cursos de formação de professores para atuarem no ciclo dois e no ensino médio deverão contemplar $25 \%$ de sua carga horária para o desenvolvimento de conteúdos curriculares para que seja possível alcançar os respectivos objetivos:

I - desenvolvimento de competências básicas em Língua Portuguesa, estatísticas e indicadores educacionais;

II - análise reflexiva dos conteúdos e diretrizes curriculares das disciplinas que é objeto de sua futura atuação docente nos quatro anos finais do Ensino Fundamental e no Ensino Médio;

III - elaboração de práticas pedagógicas adequadas à transmissão dos conteúdos curriculares dos níveis de ensino e desenvolver nos alunos as competências esperadas, explicitando as formas de transposição 
didática do conhecimento do professor para aqueles a serem adquiridos pelos alunos (SÃO PAULO, 2008, p. 4).

Os cursos de licenciatura deverão ainda contemplar atividades relacionadas aos estudos de psicologia, de métodos de avaliação, de problemas do sistema de ensino e a integração entre as disciplinas. A deliberação CEE 111/2012 com base na deliberação CEE 78/2008 em seu artigo 8 sinaliza que os cursos de formação de professores para os anos finais do ensino fundamental e para o ensino médio deverão contemplar $30 \%$ de sua carga horária para formação didática e pedagógica dos licenciandos, revelando uma tentativa de superar o hiato do currículo três mais um, por meio de disciplinas que contemplem a história da educação, o conhecimento da psicologia, a compreensão do desenvolvimento do sistema educacional brasileiro e sua evolução, entre outros. Além de prever uma carga horária mínima de 400 para o estágio supervisionado, distribuído, segundo seu artigo 10:

I - 200 (duzentas) horas de apoio ao efetivo exercício da docência nos anos finais do ensino fundamental e no ensino médio;

II - 100 (cem) horas dedicadas às atividades de gestão do ensino nelas incluídas, entre outras, as relativas a trabalho pedagógico coletivo, conselho de escola, reunião de pais e mestres, reforço e recuperação escolar nos anos finais do ensino fundamental e no ensino médio.

III - 100 (cem) horas de atividades teórico práticas e de aprofundamento em áreas específicas (SÃO PAULO, 2012, p.3).

O CNE nos últimos anos concentrou suas ações sobre a formação de profissionais para o magistério e, para tanto, constituiu uma comissão permeada por conselheiros das Câmeras de Educação Básica e Superior. Assim, um dos grandes avanços foi a aprovação do Plano Nacional de Educação (2014/2024) que propôs alcançar vinte metas a serem consolidadas, dentre as quais destaca-se a formação de profissionais para o magistério. No desdobramento de seus trabalhos e após reuniões no Congresso Nacional e no Senado Federal, apresentou parecer e resolução que foram aprovados pelo CNE, que por vez resultaram no Parecer CNE/CP no 2/2015 e Resolução CNE/CP no 2/2015 que instituem as novas regras para a formação inicial e continuada de profissionais do magistério da Educação Básica.

A resolução CNE/CP n02 de 09/06/2015 definiu as Diretrizes Curriculares Nacionais para a formação inicial de professores em nível superior (cursos de licenciatura, cursos de formação pedagógica para graduados e cursos de segunda licenciatura) e para a formação continuada (BRASIL, 2015). O prazo para as instituições de ensino adequarem-se era de 2 anos. $O$ artigo 1, inciso 2, apresenta:

As instituições de ensino superior devem conceber a formação inicial e continuada dos profissionais do magistério da educação básica na perspectiva do atendimento às políticas públicas de educação, às Diretrizes Curriculares Nacionais, ao padrão de qualidade e ao Sistema 
Nacional de Avaliação da Educação Superior (Sinaes), manifestando organicidade entre o seu Plano de Desenvolvimento Institucional (PDI), seu Projeto Pedagógico Institucional (PPI) e seu Projeto Pedagógico de Curso (PPC) como expressão de uma política articulada à educação básica, suas políticas e diretrizes (BRASIL, 2015, p.3).

Este parecer propõe cursos de formação de professores para graduados que haviam sido extintos pela LDBEN, e que foram denominados "cursos de formação pedagógica para graduados não licenciados", além de propor uma segunda modalidade "cursos de segunda licenciatura".

Os cursos de formação inicial para os profissionais do magistério para a educação básica, em nível superior, serão constituídos por três tipos de formação: graduação de licenciatura; cursos de formação pedagógica para graduados não licenciados; e cursos de segunda licenciatura.

Os cursos de licenciatura química sofreram uma significativa mudança passando a ter a carga horária mínima de 3.200 horas e tempo mínimo de 4 anos ou 8 semestres. Em relação à modalidade do curso de formação pedagógica para não licenciados "[...] devem ter carga horária mínima variável de 1.000 (mil) a 1.400 (mil e quatrocentas) horas de efetivo trabalho acadêmico, dependendo da equivalência entre o curso de origem e a formação pedagógica pretendida" (BRASIL, 2015, p. 12). Segundo o artigo 15 desta resolução "Os cursos de segunda licenciatura terão carga horária mínima variável de 800 (oitocentas) a 1.200 (mil e duzentas) horas, dependendo da equivalência entre a formação original e a nova licenciatura (BRASIL, 2015, p. 13).

Contudo, é preocupante pensar a formação de profissionais para o magistério e a educação básica por meio de uma carga horária tão reduzida em relação aos cursos de graduação em licenciatura. Além disto, serão as instituições formadoras de graduados sem licenciatura que ficarão responsáveis em verificar a compatibilidade entre a formação do candidato e a habilitação pretendida.

A partir da exposição das leis que regulamentam a formação de professores no Brasil, podemos inferir que há uma busca pela profissionalização docente delineada por aspectos associados ao domínio do conteúdo programático e de conteúdos didáticos, entre outros. Entretanto, a formação inicial de professores é primordial para o estabelecimento da profissão docente e, para tanto, deve ser minuciosamente planejada, estruturada e implementada.

\subsubsection{O Programa de Iniciação à docência - Pibid}

A Política Nacional de Formação de Professores instituída pelo Decreto $n^{\circ}$ 6.755/2009 nasce como mais uma medida de reforma na formação de docentes, iniciada em 1996 com a promulgação da LDBEN. Em seu artigo três, inciso dez, dispõe que deve-se "[...] promover a integração da educação básica com a formação inicial docente 
[...]" (BRASIL, 2009). E na busca da realização desse objetivo é implementado o Programa Institucional de Bolsa a Iniciação à Docência (Pibid), que nasce de uma ação entre o Ministério da Educação (MEC), tendo como intermediário a Secretária de Educação Superior (SESU), a Coordenação de Aperfeiçoamento de Pessoal de Nível Superior (Capes) e o Fundo Nacional de Desenvolvimento da Educação (FNDE). O primeiro edital do programa de iniciação à docência foi lançado em 2007 e buscou atender principalmente as disciplinas do ensino médio de física, química, biologia e matemática, em decorrência da falta de professores nessas áreas. Mais tarde a Portaria n.72 de 9 de abril de 2010 (CAPES, 2010) veio substituir as portarias que anteriormente regulamentavam o Pibid, na qual se delineiam seus objetivos:

I) incentivar a formação de professores para a educação básica, apoiando os estudantes que optam pela carreira docente; valorizar o magistério, contribuindo para a elevação da qualidade da escola pública;

II) elevar a qualidade das ações acadêmicas voltadas à formação inicial de professores nos cursos de licenciatura das instituições de educação superior;

III) inserir os licenciandos no cotidiano de escolas da rede pública de educação, promovendo a integração entre educação superior e educação básica;

IV) proporcionar aos futuros professores participação em experiências metodológicas, tecnológicas e práticas docentes de caráter inovador e interdisciplinar e que busquem a superação de problemas identificados no processo de ensino-aprendizagem, levando em consideração o desempenho da escola em avaliações nacionais, como Provinha Brasil, Prova Brasil, SAEB, ENEM, entre outras;

V) incentivar escolas públicas de educação básica, tornando-as protagonistas nos processos formativos dos estudantes das licenciaturas, mobilizando seus professores como co-formadores dos futuros docentes.

Para Francisco Júnior e Zibetti (2011) resultados promissores nos anos iniciais do Pibid levaram à expansão do programa, que passou a abranger todas as disciplinas da educação básica. O Pibid propõe a inserção de licenciandos no ambiente escolar, como uma forma de aproximar a teoria e a prática, por meio da supervisão de um professor da escola básica e um professor coordenador, da instituição de ensino superior. Assim, possibilita aos licenciandos vivenciarem seu futuro ambiente profissional, tendo como referência os saberes experienciais do professor atuante na escola pública e os saberes metodológicos do professor da instituição de ensino superior, o que pode levar a uma formação contínua dos participantes envolvidos (FARIAS; JARDILINO; SILVESTRE, 2015). 
O programa permite ao futuro docente uma formação na prática, e que este compreenda que "Não há docência sem discência, as duas se explicam e seus sujeitos, apesar das diferenças que os conotam não se reduzem à condição de objeto, um do outro" (FREIRE, 1996, p.26). As palavras de Paulo Freire ressaltam um importante paradigma que precisa ser rompido, a visão de que o aluno é objeto do sujeito que ensina, o professor, para que essa relação passe a ser entendida como de interdependência em que ambos os atores envolvidos devam buscar o conhecimento que desperta a curiosidade, a criticidade e a reflexão. Nessa perspectiva, o Pibid pode proporcionar essas mudanças há tanto tempo requeridas, porque tem sido um ambiente de discussão sobre a conjuntura da educação e os desafios a serem superados (CANAN, 2012).

A vivência no espaço escolar pelo licenciando, geralmente é oportunizada pelo estágio supervisionado. Para Pimenta e Lima (2004).o estágio supervisionado tem o seu desenvolvimento baseado, por vezes, em expor os erros da escola, dos professores, entre outros. Somado a isto, os futuros professores geralmente enfrentam resistência do docente da educação básica em ceder espaços de suas aulas para a implementação das atividades de estágio.

O Pibid é apresentado como um programa que se diferencia do estágio supervisionado:

[...] por ser uma proposta extracurricular, com carga horária maior que a estabelecida pelo Conselho Nacional de Educação - CNE para o estágio e por acolher bolsistas desde o primeiro semestre letivo, se assim definirem as IES em seu projeto. A inserção no cotidiano das escolas deve ser orgânica e não de caráter de observação, como muitas vezes acontece no estágio. A vivência de múltiplos aspectos pedagógicos das escolas é essencial ao bolsista (CAPES, 2013, p.68).

O Pibid possibilita ainda ao licenciando desenvolver suas atividades tendo a orientação de professor-coordenador da instituição na qual está se graduando, e a supervisão de um professor da educação básica, além de promover a troca de experiências entre os participantes envolvidos nesse programa, propiciando o fortalecimento da prática e o desenvolvimento docente (CANAN, 2012).

Apesar dessas diferenças, tanto o estágio supervisionado como o Pibid consideram o ambiente escolar como primordial para formação docente, e contribuem para a valorização das licenciaturas e dos profissionais do ensino. Aos participantes do Pibid são ofertados quatro tipos de bolsas:

I. coordenação institucional, para o professor de licenciatura que coordena o projeto Pibid na IES, no valor de $\mathrm{R} \$ 1.500,00$; II. coordenação de área, para o professor de licenciatura que coordena o subprojeto, no valor de $\mathrm{R} \$ 1.400,00$; III. supervisão, para o professor da escola pública de educação básica, no valor de $\mathrm{R} \$ 765,00$; IV. iniciação à docência, para o estudante de licenciatura, no valor de $\mathrm{R} \$$ 
400,00. Art. 26. A duração das bolsas serão definidas em edital, observando que a participação dos bolsistas de iniciação à docência no programa será de até 12 meses, prorrogáveis por até igual período, mesmo que ingresse em curso de licenciatura ou subprojeto diferente (CAPES, 2016, p.9-10).

Do ano de 2007 até 2013 o custeio desse programa pode ser apresentado no quadro 1.

Quadro 1. Evolução dos custeios executados

\begin{tabular}{|c|c|}
\hline Ano & Valores em reais \\
\hline 2009 & $20.041 .950,00$ \\
\hline 2010 & $80.398 .941,22$ \\
\hline 2011 & $138.597 .928,92$ \\
\hline 2012 & $219.084 .614,74$ \\
\hline 2013 & $287.900 .596,63$ \\
\hline Total & $746.024 .031,51$ \\
\hline
\end{tabular}

(Fonte: CAPES, 2013, p.74)

Os valores estão relacionados ao número de bolsistas que passaram de 3.088 no ano de 2009 para 90.254 bolsistas no ano 2013, sendo que a região brasileira com maior número de bolsas é a região Nordeste com um total de 28.019, seguida da região sudeste com 25.381. Uma situação de contraposição, pois geralmente as regiões Sul e Sudeste sempre apresentam um maior número de participantes em programas educacionais e de financiamentos de bolsas relacionadas à pesquisa. Os bolsistas no ano $2012 / 2013$ eram $69 \%$ do sexo feminino e $31 \%$ do sexo masculino.

Nos anos de 2013/2014 as instituições de ensino superior que participavam do Pibid eram $284^{3}$, que englobavam 855 campi e 2.997 subprojetos. O mapa de campi (figura 1) possibilita uma visão abrangente de seu impacto no território brasileiro.

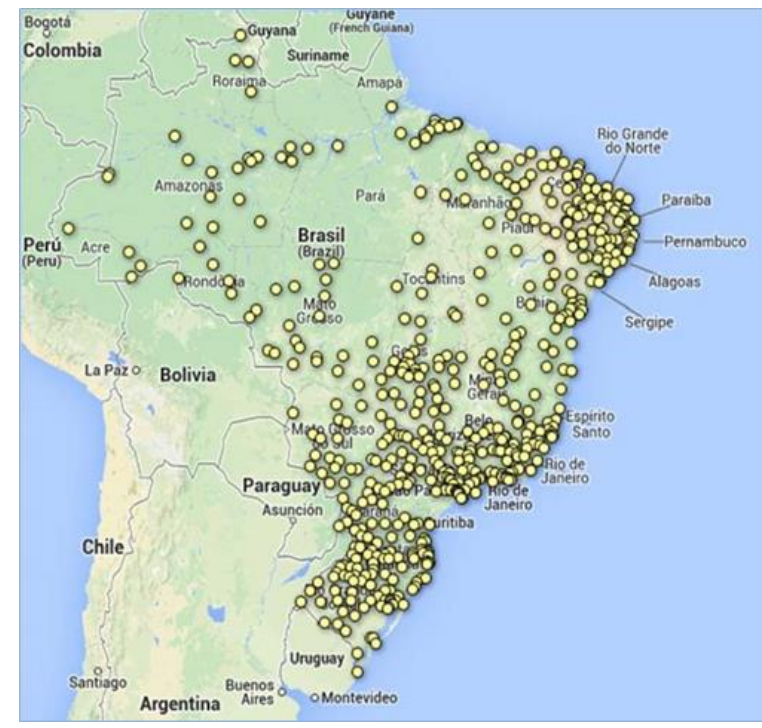

Figura 1. Mapa dos campi do Pibid (Fonte: CAPES, 2013, p.85)

\footnotetext{
${ }^{3}$ Não encontraram-se dados atualizados sobre a distribuição de bolsas do Pibid pelo país. Capítulo 1. Formação de Professores no Brasil e as Políticas Públicas
} 
Dados disponibilizados pela Capes em 2014 revelaram que 53\% das instituições que participam do Pibid são públicas (35\% federal, 13\% estadual e 5\% municipal) e 47\% particulares ( $40 \%$ sem fins lucrativos e $7 \%$ com fins lucrativos). Apesar da região Sudeste concentrar 40\% (114) das instituições que participam do Pibid, como dito anteriormente, a região Nordeste é que apresenta o maior número de bolsistas. No quadro 2 dispõe-se o número de bolsas e suas respectivas distribuições que foram concedidas no ano de 2014.

Quadro 2. Número total de bolsas aprovadas para os projetos Pibid em 2014 por nível de participação

\begin{tabular}{|l|c|c|c|}
\hline \multicolumn{1}{|c|}{ Tipo de Bolsa } & Pibid $^{1}$ & Pibid $^{2}$ & Total \\
\hline Iniciação à Docência & 70.192 & 2.653 & 72.845 \\
\hline Supervisão & 11.354 & 363 & 11.717 \\
\hline Coordenação de Área & 4.790 & 134 & 4.924 \\
\hline Coordenação de Área de Gestão & 440 & 15 & 455 \\
\hline Coordenação Institucional & 284 & 29 & 319 \\
\hline Total & 87.060 & 3.194 & 90.254 \\
\hline
\end{tabular}

1. Edital Capes no 61/2013; 2. Edital Capes no 66/2013 (Fonte: Capes, 2014).

Como podemos observar no quadro 2, o número de bolsas de iniciação à docência, com exceção do Pibid Diversidade, representa $80,6 \%$ do número total de bolsas concedidas.

Os dados referentes aos números de bolsistas em áreas que faltam professores são representados por 5.476 em matemática, 5.146 em biologia e em terceiro lugar 3.923 em química.

Atualmente os dados referentes ao número de bolsas e de bolsistas estão em um processo constante de mudança, em virtude dos cortes que estão sendo realizados.

Segundo os coordenadores que participaram do programa, seus impactos nas escolas estão relacionados principalmente ao uso das bibliotecas, de espaços multimídias e demais ambientes das escolas que antes eram negligenciados como espaços propícios para serem utilizados no processo de ensino-aprendizagem (CAPES, 2013). E ainda, segundo esses coordenadores, os impactos do Pibid refletem diretamente nas licenciaturas, pois possibilita ao futuro professor uma maior articulação entre a teoria e a prática, um envolvimento maior dos formadores com a licenciatura, a diminuição da evasão nos cursos, além de mudanças nos projetos pedagógicos das instituições formadoras (CANAN, 2012).

Segundo dados oficiais, $50 \%$ dos ex-bolsistas recém-formados passaram a atuar em instituições públicas (CAPES, 2013). Na percepção de um bolsista em um subprojeto Pibid-Química este programa: 
[...] trouxe à Instituição de Ensino novas possibilidades de refletir a prática pedagógica, buscando incorporar a esse contexto questões ligadas à importância do preparo do professor; do planejamento de aulas; das formas de condução de uma atividade; etc. De uma forma geral, o Pibid proporcionou à licenciatura uma nova maneira de estabelecer vínculo com a educação básica, de forma reflexiva e planejada (CAPES, 2013, p.105).

O Pibid é um programa que vem possibilitando a valorização do magistério e a inserção do licenciando no contexto escolar no início de sua formação. Estudos apontam que os saberes docentes vão sendo construídos também com o ensinar, o que poderá levar à construção de uma identidade profissional. Nessa perspectiva, para Mello:

Ninguém facilita o desenvolvimento daquilo que não teve oportunidade de aprimorar em si mesmo. Ninguém promove a aprendizagem daquilo que não domina, a constituição de significados que não compreende e nem a autonomia que não pôde construir (2001, p.6).

Assim, o Pibid se constitui um programa que ultrapassa a união entre a teoria e a prática, constituindo-se como um terceiro espaço de formação, conceituado por Zeichner como:

espaços híbridos nos programas de formação inicial de professores que reúnem professores da Educação Básica e do Ensino Superior, e conhecimento prático profissional e acadêmico em novas formas para aprimorar a aprendizagem dos futuros professores (2010, p.487).

Este conceito foi adotado pelo autor Zeichner (2010) ao retratar a formação de professores no contexto estadunidense. Esses novos espaços possibilitariam um equilíbrio entre o conhecimento acadêmico e a prática profissional. Com o intuito de investigar o Pibid como um terceiro espaço de formação, Felício (2014) buscou identificar os significados que os pibidianos atribuem às suas experiências no programa institucional para a sua formação docente. Para a autora, o programa de iniciação à docência constitui-se como um terceiro espaço pois:

- distingue-se do estágio curricular obrigatório na consideração do cenário escolar;

- permite a inserção antecipada do licenciando na escola, que se assume como parceira no processo de formação inicial docente, ao acolhê-lo, por intermédio dos supervisores;

- compreende uma configuração que possibilita a participação de professores da universidade (coordenador de área), responsáveis diretos pelos licenciandos bolsistas, e do professor da escola de Educação Básica (supervisor), responsável pelo licenciando, quando ele se encontra na escola desenvolvendo as atividades de iniciação à docência;

- pressupõe um diálogo constante entre licenciando, coordenador de área e supervisor;

- são previstas ações visando iniciar o licenciando na docência tendo por base experiências reais, advindas do contexto escolar; - assume o movimento de reflexão-ação-reflexão como pressuposto fundamental para o desenvolvimento das atividades; 
- propicia a permanência contínua dos licenciandos no cotidiano escolar, por um período de, pelo menos, dois anos (FELíCIO, 2014, p.423).

Alguns estudos, entretanto, apontam as fragilidades do Pibid. Nessa perspectiva, Silva (2012) identificou que as lacunas deixadas pelo programa de inciação à docência relacionavam-se à buracracia que impede o desenvolvimento das atividades em tempo hábil, à não participação de toda a escola nas iniciativas propostas pelos subprojetos, aos conflitos entre os bolsistas, à falta de embasamento teórico dos pibidianos, ao desenvolvimento e ações pontuais na sala de aula, entre outros. Em um subprojeto do curso de letras os bolsistas pontuaram a falta de recursos tecnológicos, a carga horaria alta que deveriam cumprir levando-os a um conflito de interesse com as disciplinas da graduação, baixo valor da bolsa, entre outros (MATOS, 2015). Outro estudo buscou mapear nas redes sociais a importância do Pibid para a formação dos licenciandos participantes de subprojeto de História, Física, Química, Matemática, Biologia, Pedagogia, Letras e Geografia. Nos aspectos negativos os autores elencaram que as lacunas do programa associavam-se aos fatores: desgastes ocasionados nos pibidianos pelo prazo de entrega dos relatórios, contato com a realidade violenta das escolas e crítica ao trabalho em grupo (RAMOS; ARAÚJO; SANTANA, 2016).

\subsection{A disciplina de química e a formação do professor de química no Brasil}

Como um contraponto com a nova realidade que está sendo construída no interior do Pibid, apresenta-se neste item a disciplina de química e a formação de seus professores no contexto brasileiro.

Os cursos de formação de professores no Brasil foram estruturados correlatos aos de bacharelado e as primeiras licenciaturas em química não trilharam um caminho muito diferente. Em 1810 a instituição da Academia Real Militar marca o início do ensino regular de ciências no Brasil. Segundo Santos e Filgueiras (2011), apesar dessa instituição de ensino ter por objetivo o ensino da ciência bélica, teve um currículo constituído por curso completo de matemática, física, química, mineralogia, etc. As aulas de química eram lecionadas no quinto ano e o professor responsável baseava seu ensino nas obras de grandes estudiosos da área como Vauquelin e Lavoisier. Nesse mesmo ano, foi criada na Academia Real Militar uma cadeira de química ocupada por Daniel Gardner, um médico britânico (SANTOS; FILGUEIRAS, 2011) e dividida com o General Carlos Antônio Napion (1757-1814). O primeiro dedicou parte de sua vida ao estudo da química e da metalurgia, direcionados à aplicação militar, enquanto o segundo já lecionava química no Brasil desde 1809, no seminário de São Joaquim. 0 segundo curso regular de química no Brasil tem seu início no Colégio Médico-cirúrgico de Salvador, tendo como professor o Dr. Sebastião Navarro de Andrade. 
A formação de professores de química só ocorreria a partir de 1930 com a implementação das instituições de ensino superior. Nesse cenário, a discussão em torno do ensino de química segundo Echeverría e colaboradores (2008):

Coube ao Estado a implantação e a integração dos ramos de conhecimento a serem transmitidos ou produzidos, mediante o regime universitário e a expansão das oportunidades educacionais em nível médio e primário, destinadas às camadas mais amplas da população (p. 73).

A reforma Francisco de Campos de 1931, deliberada pelo decreto n. 19.851 de 11 de abril do referido ano (AZEVEDO, 2010) influenciou a organização do ensino secundário e a regularização de professores para atuarem nesse nível de ensino. Porém, para Mesquita e Soares (2011) não houve diretrizes dispostas para a formação e valorização docente. Esse decreto dispõe a obrigatoriedade do ensino de química nos dois anos finais do ensino fundamental e nos dois anos de um curso complementar de "[...] adaptação dos estudantes às futuras especializações profissionais" (AZEVEDO, 2010, p. 710). Em decorrência da obrigatoriedade das disciplinas científicas, a questão da formação de professores nessas áreas se torna uma preocupação, sendo que as primeiras Instituições formadoras foram a Instituição de Educação de São Paulo e o Instituto de Educação do Distrito Federal (MESQUITA; SOARES, 2011).

A Universidade de São Paulo foi criada em 1934 tendo seu corpo docente constituído por docentes de instituições já existentes, dentre elas a Faculdade de Direito, a Escola Politécnica, entre outras. Nessa universidade era prevista a formação de professores no magistério para atuarem no ensino secundário, promulgado pelo decreto de abertura da USP:

Art. $5^{\circ} \mathrm{O}$ Instituto de Educação, antigo "Caetano de Campos", participará da Universidade exclusivamente pela sua Escola de Professores, ficando-lhe, porém, subordinados administrativamente e tecnicamente, como institutos anexos, o Curso Complementar, a Escola Secundária e 0 Jardim de Infância, destinados à experimentação, demonstração e prática de ensino no estágio profissional dos alunos da Escola de Professores [...] §2 $\mathrm{O}$ candidato ao magistério secundário, escolhida a seção de conhecimentos em que pretende especializar-se na Faculdade de Filosofia, Ciências e Letras, poderá fazer simultaneamente, no $3^{\circ}$ ano, o curso de formação pedagógica no Instituto de Educação (UNIVERSIDADE DE SÃO PAULO-NORMAS HISTÓRICAS).

No interior dessa instituição foi nascendo o Instituto de Química que teve seu quadro de professores composto principalmente por cientistas alemães. A primeira turma de química foi formada por quarenta alunos, que em sua grande maioria eram médicos, professores, entre outros. Contudo, ao perceberem que se tratava de um curso de graduação, a turma decaiu a um quarto do original. E, segundo aponta Mesquita e Soares (2011), a estrutura curricular do curso não era muito distinta do currículo três 
mais um. Após três anos o estudante era diplomado licenciado, mas este título à época tinha outro significado, pois "licenciado" significava que o indivíduo possuía uma licença cultural e ou científica. A formação pedagógica poderia ser cursada na Faculdade de Educação com um tempo de duração de um ano, sendo o cursista ao seu término, titulado como professor secundário.

Quase duas décadas após a abertura do curso de química, é que se instituiu um currículo mínimo para formar professores de química na Faculdade de Filosofia, Ciências e Letras da Universidade de São Paulo (FFCL-USP). Porém, faltava ainda uma lei que regulamentasse a profissão docente em âmbito nacional, mas isso só ocorrereria em 1946 com a Lei Orgânica do Ensino Normal, pelo Decreto n. 8.530, que discorria sobre a formação docente para o ensino primário. Dos graduados formados no Instituto de Química de 1937 a 1965, somente 38 se dedicaram ao magistério no ensino secundário, o que representou apenas $12 \%$ dos formados por essa instituição (SCHNETZLER, 2002).

A Universidade do Distrito Federal no Rio de Janeiro ainda na metade da década de 30 também promoveu a formação de professores para o ensino secundário. Contudo, essa universidade foi extinta e incorporada à Universidade do Brasil e pelo decreto $\mathrm{n}$. 1190 de 1939, passou a ter denominação de Faculdade Nacional de Filosofia, e um de seus cursos era a química. Em sua estrutura curricular para formar químicos, mantevese a estrutura três mais um. Mas, somente aos cursistas da didática, o último ano era concedido à licenciatura e aos que não cumpriam esta etapa o diploma de bacharel.

Este modelo permaneceu na USP no curso de química até 2003 em virtude das novas demandas legais (BRASIL, 2002). A partir desse ano a USP abriu a licenciatura noturna e as disciplinas de cunho pedagógico passam a ser desenvolvidas ainda no terceiro período.

Uma conquista importante nesse período foi o parecer do Conselho Federal de Educação 292 de 1962, que tornou obrigatório que 1/8 dos currículos dos cursos de formação de professores fossem permeados por disciplinas pedagógicas. E, apesar da obrigatoriedade, as licenciaturas continuaram a ofertar as disciplinas pedagógicas no último ano (TERRAZAN et al., 2008)

Em um salto de 1930 a 1965 o Brasil tinha além de São Paulo e Rio de Janeiro, mais onze instituições que ofereciam cursos de formação de professores de química, a saber: Universidade Católica de Pernambuco (1943), Universidade Federal de Minas Gerais (1943), Universidade Federal da Bahia (1943), Universidade Federal do Rio Grande do Sul (1944). Universidade Federal do Ceará (1958), Universidade Federal de Sergipe (1950), Universidade Estadual Paulista Júlio de Mesquita Filho (1961), Universidade de Uberaba (1961), Fundação Universidade de Brasília (1962), Capítulo 1. Formação de Professores no Brasil e as Políticas Públicas 
Universidade Federal do Amazonas (1963), Faculdade de Filosofia, Ciências e Letras de Ribeirão Preto-USP (1964). Dentre as instituições, a Universidade Católica de Pernambuco e a Universidade de Uberaba são universidades privadas, o que revela que nesse contexto, o valor do diploma em instituições públicas e privadas, passou a ser "igual". Feito este "conquistado" principalmente pela instituição da Lei de Diretrizes e Bases da Educação Nacional em 1961. Mais tarde, a Lei 5.540 de 1968 estabelece reformas na educação superior, com o propósito de socorrer a educação básica, em decorrência da obrigatoriedade da educação a partir dos oito anos, em seu artigo 30 apresenta algumas das diretrizes:

A formação de professores para o ensino de segundo grau, de disciplinas gerais ou técnicas, bem como o preparo de especialistas destinados ao trabalho de planejamento, supervisão, administração, inspeção e orientação no âmbito de escolas e sistemas escolares, farse-á em nível superior. ${ }^{4}$

Depois de décadas o governo brasileiro em uma tentativa de formar professores não somente de química, propõe a formação por meio das licenciaturas curtas e dos esquemas I e II. O Esquema I era destinado aos participantes com cursos superiores e o Esquema II, para profissionais de ensino médio. Para indivíduos com formação em nível superior a habilitação em docência poderia ser obtida com uma formação complementar de 600 horas. No Esquema II o tempo de diplomação variava entre 1080 a 1480 horas.

Na década de setenta, o governo instituiu as licenciaturas curtas para formar professores para o ginásio. Nesse cenário surge a imagem do professor polivalente. Outra resolução 74/30 fixava um currículo mínimo para as licenciaturas que promoviam a formação nas áreas de ciências, entre elas a química, estruturada em duas etapas: a primeira referente ao $1^{\circ} \mathrm{grau}$; e a segunda, ao $2^{\circ} \mathrm{grau}$, com habilitação específica. Contudo, em 1975, outra resolução extingue a formação específica em área e estabelece a formação de professores polivalentes, um retrocesso aos poucos avanços conquistados até então. A comunidade científica reagiu a tal resolução e o Ministério da Educação recuou e implementou um comitê para reavaliá-la. O término das atividades do comitê culminou em uma proposta maquiada da resolução de 1974. Apesar de ter sido implementada, os interesses divergentes entre MEC e as instituições formadoras promoveram a continuidade da licenciatura por estas últimas, e a formação em curto prazo pelo MEC.

A década de oitenta marca a formação de professores de química pela inserção de um grupo de pesquisadores de ensino na Sociedade Brasileira de Química (SBQ) e

\footnotetext{
${ }^{4}$ Planalto. http://www.planalto.gov.br/ccivil_03/Leis/L5540.htm. Acesso em 28/10/2014. Capítulo 1. Formação de Professores no Brasil e as Políticas Públicas
} 
pelo significativo aumento de mestres e doutores na área de ensino de química. $\mathrm{Na}$ vanguarda, a Universidade de Minas Gerais implementa nessa década nos cursos de licenciatura em química as disciplinas de história da química, instrumentação para o ensino de ciências, entre outras. Contudo, as diretrizes para a formação de professores só viriam a ser promulgadas em 1996 (SAVIANI, 2009).

Os passos históricos retratados revelam os entraves e lutas para se estabelecer os cursos de formação de professores e consequentemente de docentes de química no Brasil, além dos problemas envolvidos nessa formação. Um passado tão contemporâneo que, por vezes, parece que está sendo retratado o momento atual, refletindo não somente os aspectos relacionados à formação inicial, mas no déficit de professores com formação específica nessa área. Segundo dados do relatório publicado pelo Tribunal de Contas da União (2013), o número de docentes sem formação em química para atuarem na educação básica chega a mais de 4.800 no país. 


\section{CAPÍTULO 2. FUNDAMENTAÇÃO TEÓRICA}

\subsection{Base de conhecimentos da profissão docente}

Na década de 1980 nos Estados Unidos e Canadá um movimento reformista reivindicava a condição de profissionais aos professores, por acreditarem que havia uma base de conhecimento inerente à profissão docente (ALMEIDA; BIAJANE, 2001). E diversos pesquisadores buscaram elucidar os saberes/conhecimentos próprios dessa profissão. Alguns desses estudiosos (TARDIF, 2010; GAUTHIER et al., 1998) adotam a denominação saber docente, por fundamentarem seus estudos no pensamento do professor - Schön, enquanto Shulman emprega a expressão conhecimento de professores, pois "o conhecimento é a especialização do saber, ou seja, o conhecimento passa pela reflexão do saber fazer, elevando a prática a um nível de consciência, reflexão, análise, sistematização e intenção" (FERNANDEZ, 2015, p. 504). Pelo fato de provirem de linhas teóricas distintas, os conceitos de saberes e conhecimentos não são sinônimos, apesar de por vezes serem tratados como tais. Em consonância com nossos objetivos de pesquisa apoiaremos nossa investigação em autores dedicados a desvelar o conhecimento docente.

Shulman durante uma apresentação de título "paradigma perdido na pesquisa sobre ensino" na Conferência Nacional da Universidade do Texas em 1983, discorreu aos presentes que o paradigma perdido era o conteúdo específico, e a inexistência de estudos que buscassem compreender como alguém que domina o conteúdo o ensina para quem não o sabe (FERNANDEZ, 2014). Na percepção do autor, existe um corpo de conhecimentos que caracteriza o trabalho docente como profissão, pois "chamar algo de profissão é assumir que há uma base de conhecimentos amplamente construídos na academia" (SHULMAN, 2004, p.13)

A priori, Shulman (1986) propôs três níveis de conhecimento do conteúdo para professores: a) o conhecimento do conteúdo específico; b) o conhecimento pedagógico do conteúdo; c) o conhecimento do currículo.

Para Shulman (1987) o conhecimento do conteúdo específico está vinculado ao conhecimento específico de uma área, como o da química. Para o autor este conhecimento tem duas estruturas fundamentais: a substantiva e a sintática. A primeira estaria relacionada às estruturas conceituais reconhecidas em uma área do saber, e que servem de orientação nas investigações, enquanto que as estruturas sintáticas remetem aos padrões estabelecidos por uma área, que orientam as pesquisas, e que fundamentam a validação de novos conhecimentos pela comunidade científica.

Em relação à segunda categoria do conhecimento do conteúdo proposta por Shulman, o conhecimento pedagógico de conteúdo seria a forma como um determinado Capítulo 2. Fundamentação Teórica 
conceito é apresentado, e que possibilitaria ao professor perceber as dificuldades do aluno em entendê-lo. Por fim, a última categoria, o conhecimento curricular, repousaria na relação existente entre os conteúdos e os seus objetivos de ensino, em conhecer os programas curriculares desenvolvidos e os temas que permeiam um determinado nível de ensino. Esse conhecimento abrange dois níveis: o currículo horizontal e currículo vertical, sendo que o currículo horizontal está atrelado aos conteúdos e conceitos que estão associados com conteúdos de outras disciplinas, enquanto o currículo vertical está relacionado à habilidade do professor conhecer o que vem antes e depois de um determinado conteúdo, de modo a fazer adaptações e ou substituições.

Posteriormente à proposição dos três níveis de conhecimento do conteúdo para professores, Shulman concluiu que o PCK fazia parte do conhecimento do professor e não somente do conteúdo, o que o levou a propor este como um conhecimento base para o docente. Segundo Shulman (1987) são sete os conhecimentos do professor: i.) conhecimento do conteúdo específico; ii.) conhecimento de contextos educativos; iii.) conhecimento de valores educativos e de seus objetivos; iv.) conhecimento pedagógico geral; v.) conhecimento curricular; vi.) conhecimento pedagógico do conteúdo e; vii.) conhecimento das características, da cognição, entre outras, dos discentes.

Para Shulman, o PCK representa a interação entre a pedagogia e o conteúdo. Nas palavras do autor esta interação conteria "[...] os tópicos mais regularmente ensinados em sua área de estudo, as formas mais úteis de representação dessas ideias, as analogias mais poderosas, ilustrações, exemplos, explicações e demonstrações" (1986, p. 9). Além disto, este conhecimento seria característico do professor e não de um especialista da área, não apenas pelo seu conhecimento da matéria, mas pelo modo como a organiza para ser ensinada.

Atualmente o PCK é considerado um dos pilares do conhecimento dos professores (ROLLNICK et al., 2008). Pode-se dizer que o conhecimento pedagógico do conteúdo inclui todo o conhecimento que um professor precisa para ensinar um assunto de forma eficaz. A aquisição do PCK é, portanto, uma tarefa central para aprender a ensinar (SHULMAN, 1987; MAGNUSSON et al.,1999). Shulman (1987) buscou destacar ainda a importância do papel da experiência no desenvolvimento profissional de docentes, além dos sete conhecimentos base, por meio da proposição do Modelo de Raciocínio Pedagógico e Ação (MRPA, figura 2). 


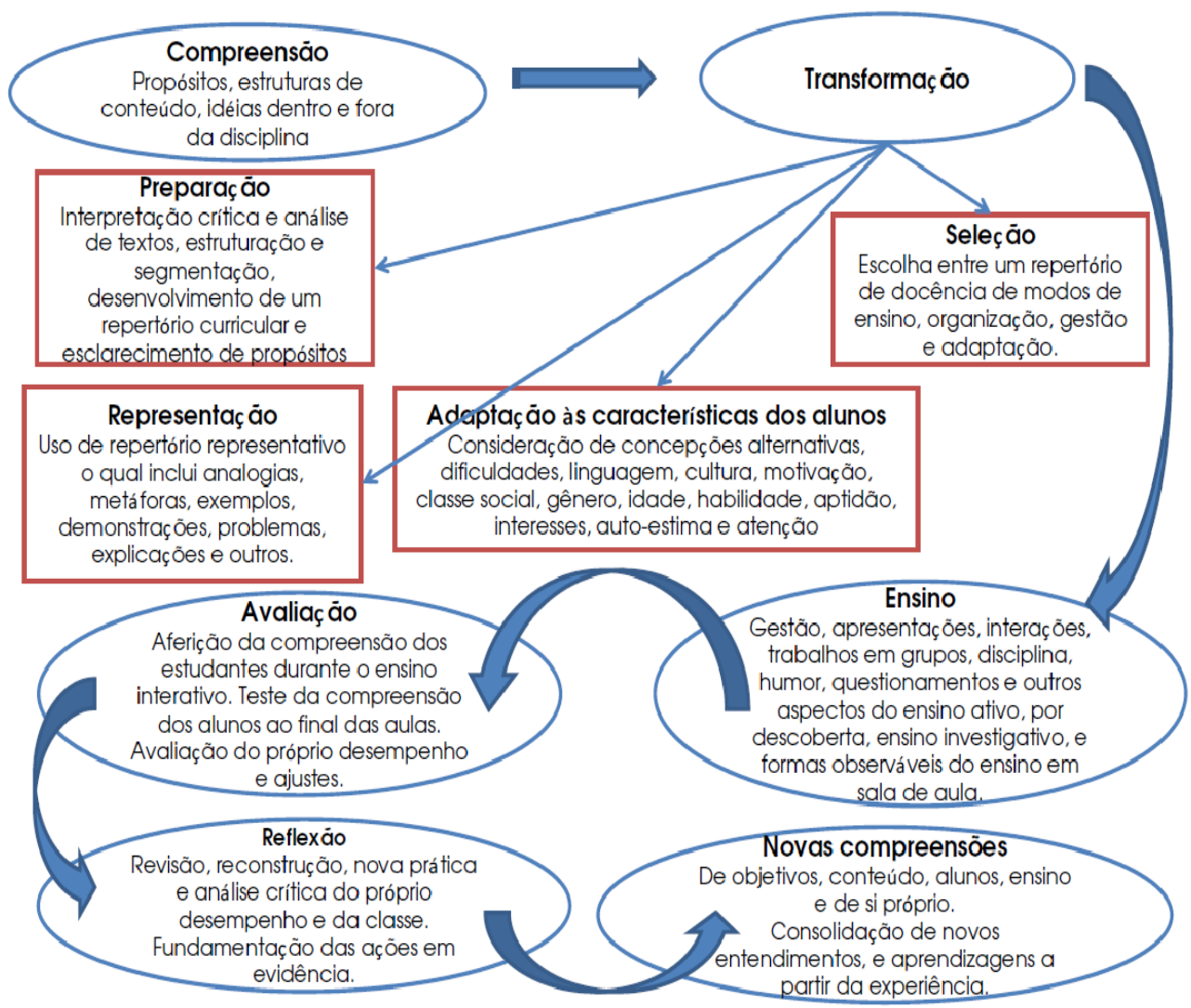

Figura 2. Modelo de Raciocínio Pedagógico e Ação (MRPA) proposto por Shulman (1987) e adaptado por Salazar (2005). Fonte: FERNANDEZ, 2011

Nesse modelo o autor procurou representar como o professor compreende um determinado tema e como ele o transforma de maneira a ensiná-lo, atingindo assim novas compreensões sobre o mesmo. O que significa que este modelo permite destacar a importância da experiência no desenvolvimento profissional durante a ação docente.

O modelo engloba os conhecimentos que o professor possui sobre o conteúdo e sobre as abordagens metodológicas que desenvolve sobre um determinado tema. Em cada etapa (SHULMAN, 1987, p.16-17) uma série de conhecimentos e habilidades é necessária, como descrito a seguir:

- Compreensão: possibilita identificar os propósitos e estrutura do conteúdo fora e no interior da disciplina. O que significa que os docentes necessitam de uma compreensão além da matéria que ensinam, para que possam implementar espaços favoráveis de aprendizagem para a maioria de seus discentes.

- Transformação: está relacionada à transformação de temas para serem ensinados, que possibilitariam uma compreensão pessoal do docente, que leve a uma aprendizagem daqueles que ensinam. Essa transformação permeia cinco subcategorias: a) Preparação- relaciona-se aos critérios de escolha dos materiais didáticos, de modo a desenvolver um repertório curricular e uma percepção clara sobre os seus propósitos de ensino; b) Representação- refere- 
se ao repertório que podem incluir "[...] analogias, ilustrações, metáforas, exemplos, experimentações, simulações, dramatizações, músicas, filmes, casos de ensino, demonstrações, diferentes tipos de mídia etc." (MIZUKAMI, 2004, p. 6); c) Seleção - permeia a utilização não somente dos métodos tradicionais de ensino, mas também "[...]uma variedade de formas de aprendizagem cooperativa, ensino recíproco, maiêutica socrática, aprendizagem por descoberta, método de projetos, aprendizagem fora do ambiente de sala de aula." (Ibidem, p.6); d) Adaptação -são todas as modificações possíveis de serem implementadas na prática pedagógica visando a tornar 0 assunto acessível aos alunos, independentemente de quais sejam suas experiências ou concepções anteriores, níveis de conhecimento, interesses e habilidades; e) Adaptações "conjuntas"- o desafio é não apenas levar em conta as características e particularidades de cada um dos alunos, mas analisá-las de forma coletiva e integrada, percebendo as diferentes individualidades que estruturam o perfil social daquele grupo.

- Ensino: está relacionado com a abordagem para determinado conteúdo, trabalhos em grupo, disciplina, formulação de perguntas, o ensino por investigação e outras formas observáveis de ensino em sala de aula.

- Avaliação: está relacionada a verificar a compreensão dos alunos durante o ensino interativo, avaliar a compreensão dos alunos ao finalizar as lições, avaliar o próprio desempenho e adaptar-se às experiências.

- Reflexão: está relacionada à revisão, construção, representação e análise crítica do próprio desempenho e do da classe.

- Novas Compreensões: estão relacionadas às novas compreensões dos objetivos, da matéria, dos alunos, do ensino e de si mesmo e a consolidação de novas maneiras de compreender e aprender através da experiência.

Devido à sua natureza processual o Modelo de Raciocínio Pedagógico e Ação requer processos de raciocínio do professor sobre o conteúdo para o ensino que estão em reestruturação contínua. Sua dinâmica vai sendo enriquecida pelo contexto em que se sucede, como resultado das interações sociais que a atividade educativa implica e os momentos distintos que caracterizam a prática docente. O modelo de Raciocínio Pedagógico e Ação é assim, um modelo dinâmico e cíclico de reflexão e ação docente (FERNANDEZ, 2011).

Grossman (1990) agrupou as sete categorias de conhecimentos de professores, propostas inicialmente por Shulman em quatro: i.) conhecimento pedagógico geral; ii.) conhecimento do tema; iii.) conhecimento pedagógico do conteúdo e, iv.) conhecimento 
do contexto. O modelo proposto pela autora (figura 3) apresenta a relação entre os domínios dos principais conhecimentos do professor.

As caixas na figura designam os principais domínios de conhecimento para o ensino, ou seja, o conhecimento do conteúdo específico, o conhecimento pedagógico geral e o conhecimento do contexto. Para Grossman, o PCK é o resultado da transformação de outros domínios do conhecimento e as linhas que ligam os domínios de conhecimento ilustram a relação entre o PCK e os outros domínios do conhecimento para o ensino. No modelo de Grossman, o PCK é orientado pela concepção dos propósitos para ensinar um conteúdo específico e é constituído pelo conhecimento das compreensões dos estudantes, pelo conhecimento do currículo e pelo conhecimento das estratégias instrucionais. As setas duplas no modelo indicam uma relação de reciprocidade entre os domínios. O montante se destina a retratar que o PCK é o resultado de uma transformação do conhecimento do tema, pedagogia e contexto, mas que o conhecimento resultante pode estimular o desenvolvimento dos domínios da base de conhecimento. (FERNANDEZ, 2011, 2014, 2015)

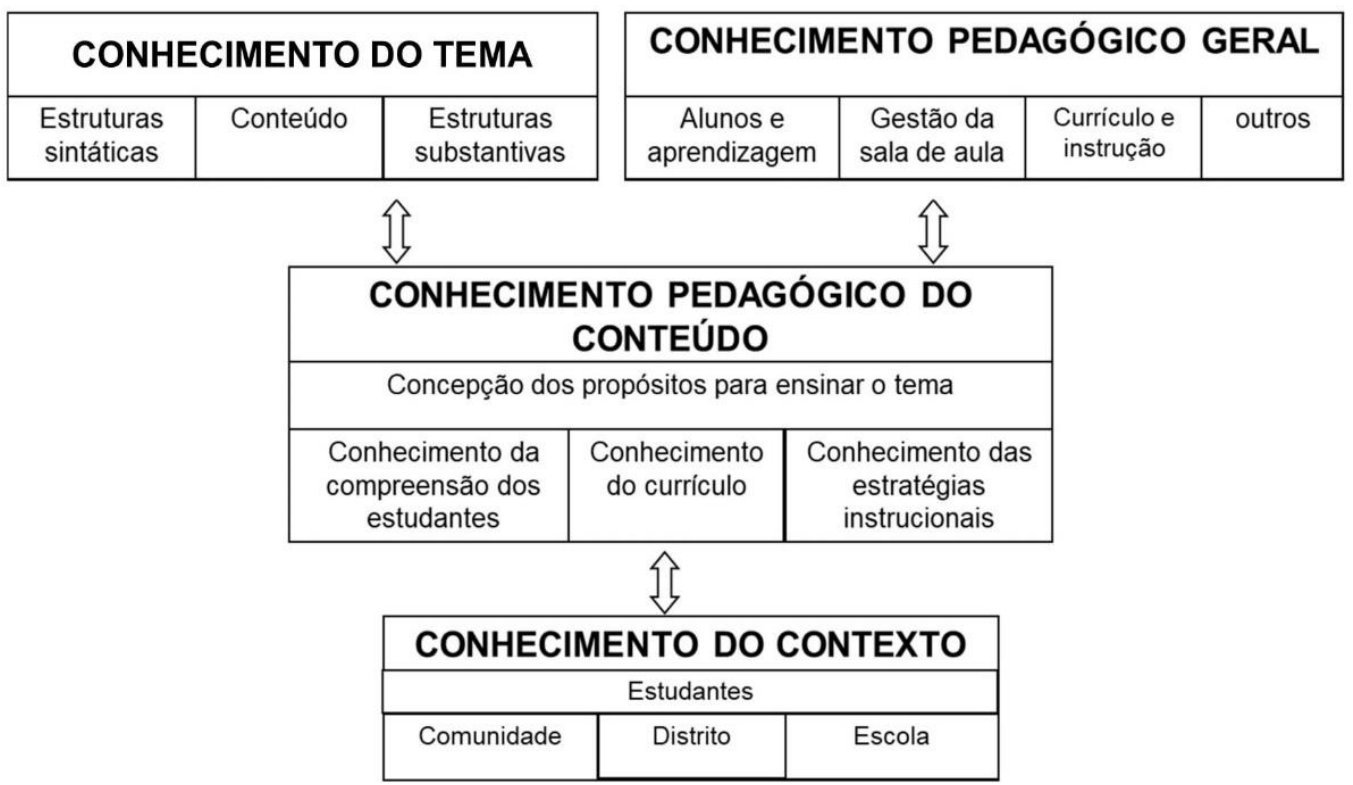

Figura 3. Modelo da relação entre os domínios do conhecimento do professor proposto por Grossman (1990). Fonte: Fernandez (2011)

O modelo apresentado acima refere-se ao modelo de conhecimentos de professores que incluem o PCK como um conhecimento base. Contudo, serão apresentados também outros modelos propostos para o PCK (FERNANDEZ, 2014a, b, 2015; FERNANDEZ, GOES, 2014), pois dentre esses conhecimentos o foco desse estudo foi o Conhecimento Pedagógico de Conteúdo, que pode revelar como ocorre o processo de transformação do sujeito conhecedor do tema, reações de oxirredução, em um futuro professor da disciplina. 


\subsection{Conhecimento Pedagógico de conteúdo (PCK)}

Magnusson e colaboradores (1999) com base no trabalho de Grossman propôs que o PCK para o ensino de ciências é constituído por cinco componentes: (a) Orientações para o ensino de ciências, (b) Conhecimentos e crenças sobre o currículo de ciências, (c) Conhecimentos e crenças a respeito da compreensão dos alunos sobre temas específicos de ciências, (d) Conhecimentos e crenças sobre a avaliação em ciências, e (e) Conhecimentos e crenças sobre estratégias instrucionais para o ensino das ciências. Estes componentes são transformados para o ensino (figura 4).

A partir do modelo de Grossman que conceitua que o PCK é orientado pela concepção dos propósitos para ensinar um conteúdo específico e é constituído pelo conhecimento das compreensões dos estudantes, pelo conhecimento do currículo e pelo conhecimento das estratégias instrucionais, Magnusson e colaboradores (1999) incluem um item relacionado à avaliação ao Conhecimento Pedagógico do Conteúdo para o ensino de ciências (figura 4).

O componente hierarquicamente superior nesse modelo "Orientações para o Ensino de Ciências" refere-se aos conhecimentos e crenças dos professores sobre as finalidades e objetivos para o ensino de ciências. Grossman designou este componente como concepções dos propósitos para ensinar um conteúdo específico (FERNANDEZ, 2014a, 2014b, 2015). Para Magnusson e colaboradores (1999), as orientações representam uma forma geral de ver ou conceituar o ensino de ciências.

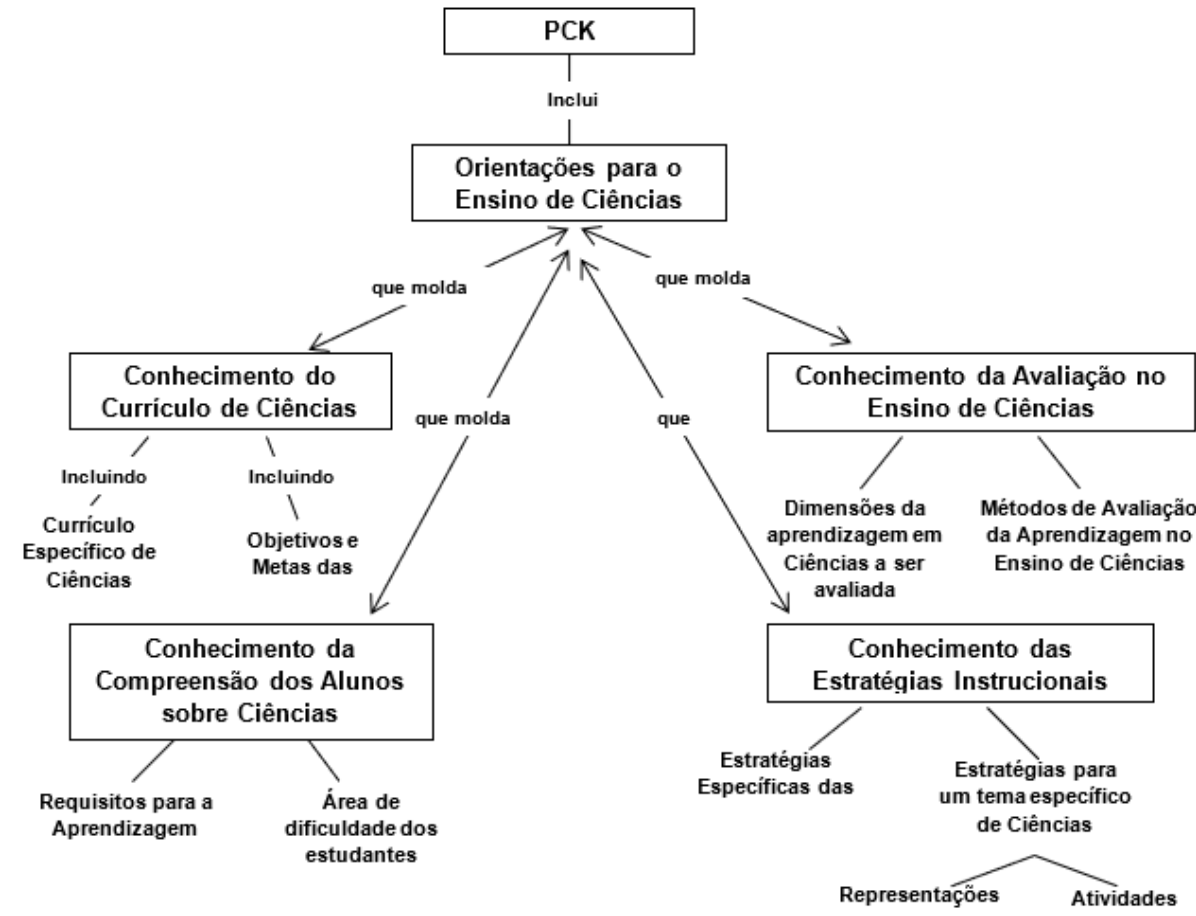

Figura 4. Os componentes do conhecimento pedagógico do conteúdo para o ensino de ciências (MAGNUSSON; KRAJCIK; BORKO,1999); Fonte: Fernandez (2011) 
Magnusson colaboradores (1999) propuseram nove diferentes orientações para o ensino de ciências: processo, rigor acadêmico, didática, mudança conceitual, atividade dirigida, descoberta, ciência baseada em projetos; investigação e investigação dirigida. As orientações são geralmente organizadas de acordo com a ênfase da instrução, desde um tipo-processo ou tipo-conteúdo até aquelas que enfatizam ambos, mais do tipo-investigação. Cada orientação foi descrita com relação a dois elementos úteis na sua definição e diferenciação: os objetivos do ensino de ciências que um professor com uma orientação particular deve possuir e as características típicas da instrução que deveriam ser conduzidas por um professor com uma dada orientação. Esses objetivos e as características das nove orientações são apresentadas nos quadros 3 e 4 , respectivamente.

Quadro 3. Objetivos das diferentes orientações para o ensino de ciências e a natureza da instrução

\begin{tabular}{|c|c|}
\hline Orientação & Objetivos para o ensino de ciências \\
\hline Processo & $\begin{array}{l}\text { Ajudar os estudantes a desenvolver as "habilidades para o processo da } \\
\text { ciência". }\end{array}$ \\
\hline Rigor acadêmico & Representar um determinado corpo de conhecimentos (ex. química). \\
\hline Didática & Transmitir os fatos da ciência. \\
\hline Mudançc & $\begin{array}{l}\text { Facilitar o desenvolvimento do conhecimento científico através do } \\
\text { confronto dos estudantes com contextos explicativos que desafiam suas } \\
\text { concepções ingênuas. }\end{array}$ \\
\hline Atividade dirigida & $\begin{array}{l}\text { Permitir que os estudantes sejam ativos com o uso de materiais, } \\
\text { experimentos do tipo "mão-na-massa". }\end{array}$ \\
\hline Descoberta & $\begin{array}{l}\text { Fornecer oportunidades aos estudantes para que descubram sozinhos } \\
\text { alguns conceitos científicos alvo. }\end{array}$ \\
\hline $\begin{array}{l}\text { Ciência baseada em } \\
\text { projetos }\end{array}$ & Envolver os estudantes na investigação de soluções para problemas reais. \\
\hline Investigação & Representar a ciência como uma pesquisa, investigação. \\
\hline $\begin{array}{l}\text { Investigação } \\
\text { orientada }\end{array}$ & $\begin{array}{l}\text { Constituir uma comunidade de aprendizes, cujos membros partilham a } \\
\text { responsabilidade de compreender o mundo físico, especialmente no que } \\
\text { diz respeito ao uso das ferramentas da ciência. }\end{array}$ \\
\hline
\end{tabular}

Fonte: Magnusson, Krajcik e Borko (1999, p.100). Fonte: Fernandez (2014b).

Quadro 4. A natureza da instrução associada com diferentes orientações para o ensino de ciências

\begin{tabular}{|l|l|}
\hline \multicolumn{1}{|c|}{ Orientação } & \multicolumn{1}{c|}{ Características das instruções } \\
\hline Processo & $\begin{array}{l}\text { Professor apresenta aos alunos o processo de raciocínio empregado pelos } \\
\text { cientistas para adquirir novos conhecimentos. Os alunos participam em } \\
\text { atividades que desenvolvem o processo de pensamento e habilidades de } \\
\text { pensamento integradas. }\end{array}$ \\
\hline Rigor acadêmico & $\begin{array}{l}\text { Os alunos são desafiados com problemas e atividades difíceis. Trabalhos de } \\
\text { laboratório e demonstrações são utilizados para verificar os conceitos } \\
\text { científicos demonstrando a relação entre determinados conceitos e } \\
\text { fenômenos. }\end{array}$ \\
\hline Didática & $\begin{array}{l}\text { O professor apresenta a informação, geralmente através de exposição ou } \\
\text { discussão, e as perguntas direcionadas aos alunos têm propósito de fornecer } \\
\text { um suporte justificável para o conhecimento dos fatos produzidos pela ciência. }\end{array}$ \\
\hline
\end{tabular}




\begin{tabular}{|l|l|}
\hline $\begin{array}{l}\text { Mudança } \\
\text { conceitual }\end{array}$ & $\begin{array}{l}\text { Estudantes são pressionados a respeito de sua visão sobre o mundo e levados } \\
\text { a considerar a adequação das explicações alternativas. O professor facilita a } \\
\text { discussão e o debate necessário para estabelecer as asserções de } \\
\text { conhecimento validado. }\end{array}$ \\
\hline Atividade dirigida & $\begin{array}{l}\text { Os estudantes participam em atividades do tipo "mão-na-massa" utilizadas } \\
\text { para verificação ou descoberta. As atividades escolhidas podem não ser } \\
\text { conceitualmente coerentes se os professores não entendem o propósito de } \\
\text { atividades específicas e, consequentemente, omitem ou modificam } \\
\text { inapropriadamente aspectos críticos delas. }\end{array}$ \\
\hline Descoberta & $\begin{array}{l}\text { Centrada no aluno. Os alunos exploram o mundo natural seguindo seus } \\
\text { propósitos interesses e descobrem padrões de como o mundo funciona } \\
\text { durante suas explorações. }\end{array}$ \\
\hline em projetos & $\begin{array}{l}\text { Centrada no projeto. A atividade de professores e estudantes é centrada numa } \\
\text { questão direcionadora que organiza os conceitos e os princípios e direciona } \\
\text { as atividades dentro de um tópico de estudo. Através da investigação, os } \\
\text { alunos desenvolvem uma série de artefatos (produtos) que refletem as } \\
\text { compreensões emergentes deles. }\end{array}$ \\
\hline Investigação & $\begin{array}{l}\text { Centrada na investigação. O professor apoia os alunos na definição e } \\
\text { investigação dos problemas, no esboço das conclusões e na avaliação da } \\
\text { validade do conhecimento a partir de suas conclusões. }\end{array}$ \\
\hline $\begin{array}{l}\text { Investigação } \\
\text { orientada }\end{array}$ & $\begin{array}{l}\text { Centrada na comunidade de aprendizagem. O professor e os estudantes } \\
\text { participam na definição e investigação dos problemas, na determinação dos } \\
\text { padrões, inventando e testando explicações e avaliando a utilidade e validade } \\
\text { de seus dados e a adequação de suas conclusões. O professor apoia os } \\
\text { esforços dos alunos em utilizar os materiais e as ferramentas intelectuais da } \\
\text { ciência com vistas ao uso independente das mesmas. }\end{array}$ \\
\hline
\end{tabular}

Fonte: Magnusson, Krajcik e Borko (1999, p.101). Fonte: Fernandez (2014b).

Uma comparação das características das instruções que segue uma determinada orientação revela que algumas estratégias de ensino, por exemplo, o uso de investigação, são características de mais de uma orientação. Magnusson e colaboradores (1999) concluem que, de fato, não é o uso de uma determinada estratégia, mas o propósito de empregá-la que distingue a orientação de um professor frente ao ensino de ciências (ELIAS, 2011).

Os modelos propostos por Magnusson e colaboradores (1999) e Grossman (1990) têm uma semelhança com o modelo de Shulman, pois discorrem que o conhecimento do tema (CT) é externo ao PCK. Contudo, tanto Grossman (1990) como Magnusson e colaboradores (1999) ao proporem a inserção das concepções e propósitos para o ensino de um determinado conteúdo, orientações para o ensino de ciências, o conhecimento do currículo, além do conhecimento da avaliação, como componentes do PCK, fizeram esses autores diferenciarem seus modelos do proposto inicialmente por Shulman (FERNANDEZ, 2014, 2015). A composição do modelo de Magnusson e colaboradores (1999) possibilita fazer inferências sobre os conhecimentos dos docentes, por meio da observação de suas práticas.

Os autores Park e Oliver (2008b) propuseram o modelo pentagonal, emergido de um estudo de revisão bibliográfica dos trabalhos de Grossman (1990), Tamir (1988) 
e Magnusson e colaboradores (1999) (PARK; CHEN, 2012). Esse modelo é constituído pelos cinco componentes do modelo de Magnusson colaboradores (1999) apresentado na figura 4.

Embora Magnusson e colaboradores tenham reconhecido a interação entre os cinco componentes, estruturaram o seu modelo de forma linear. Em contrapartida, o modelo pentagonal enfatiza essa inter-relação entre os componentes, como apresenta a figura 5 .
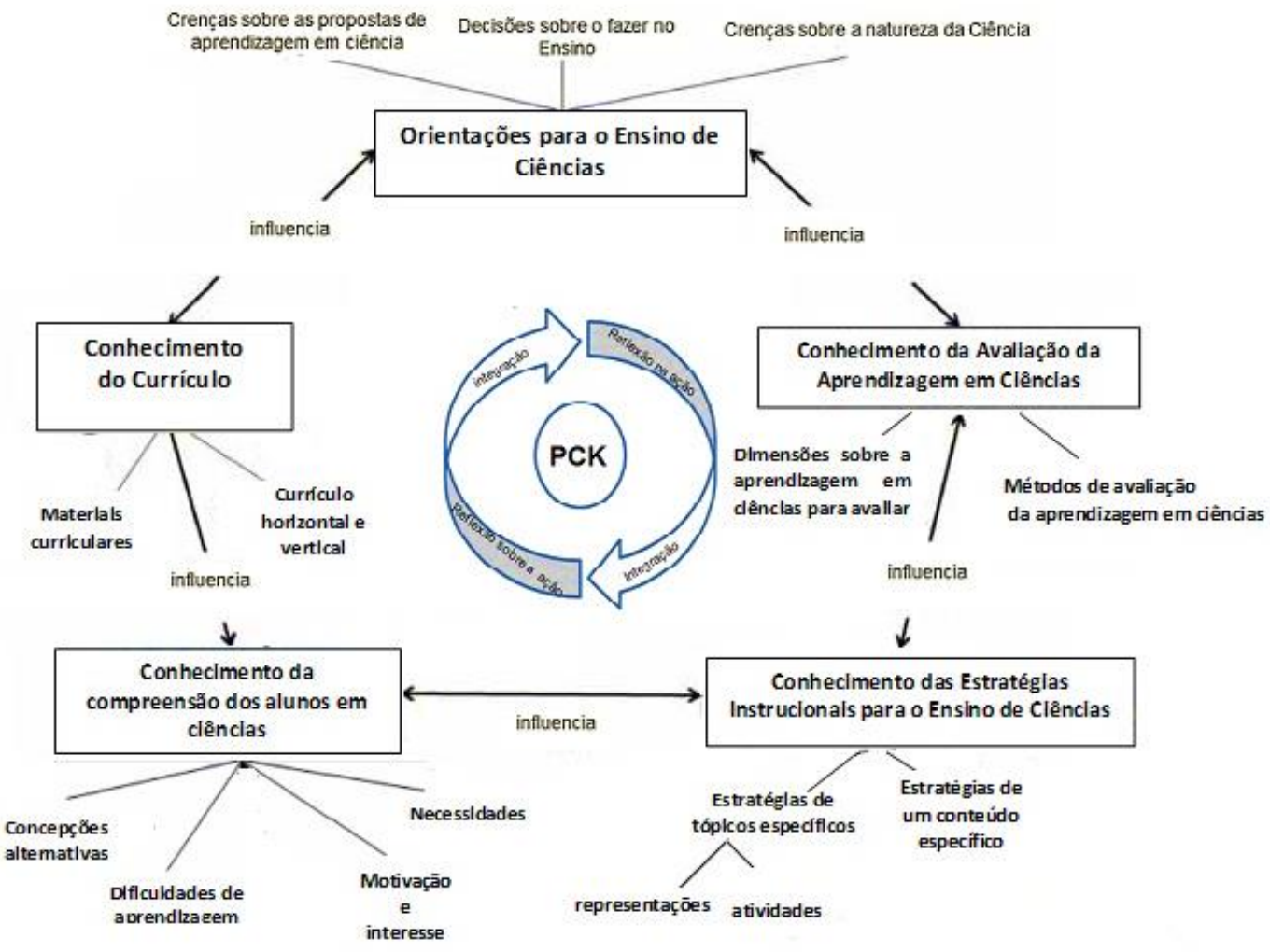

Figura 5. Modelo pentagonal do Conhecimento Pedagógico de Conteúdo para o Ensino de Ciências (PARK; OLIVER, 2008b). Fonte: FERNANDEZ, 2011

Nesse modelo o PCK está no centro e a integração entre os componentes reforça a coerência e o reajuste contínuo, motivados pela reflexão-na-ação e reflexãosobre-ação (PARK; OLIVER, 2008b).

Em virtude dos dados empíricos emergidos em uma investigação, Park e Oliver (2008a) acrescentaram a eficácia como um domínio do PCK, resultando em um modelo denominado hexagonal (figura 6). 


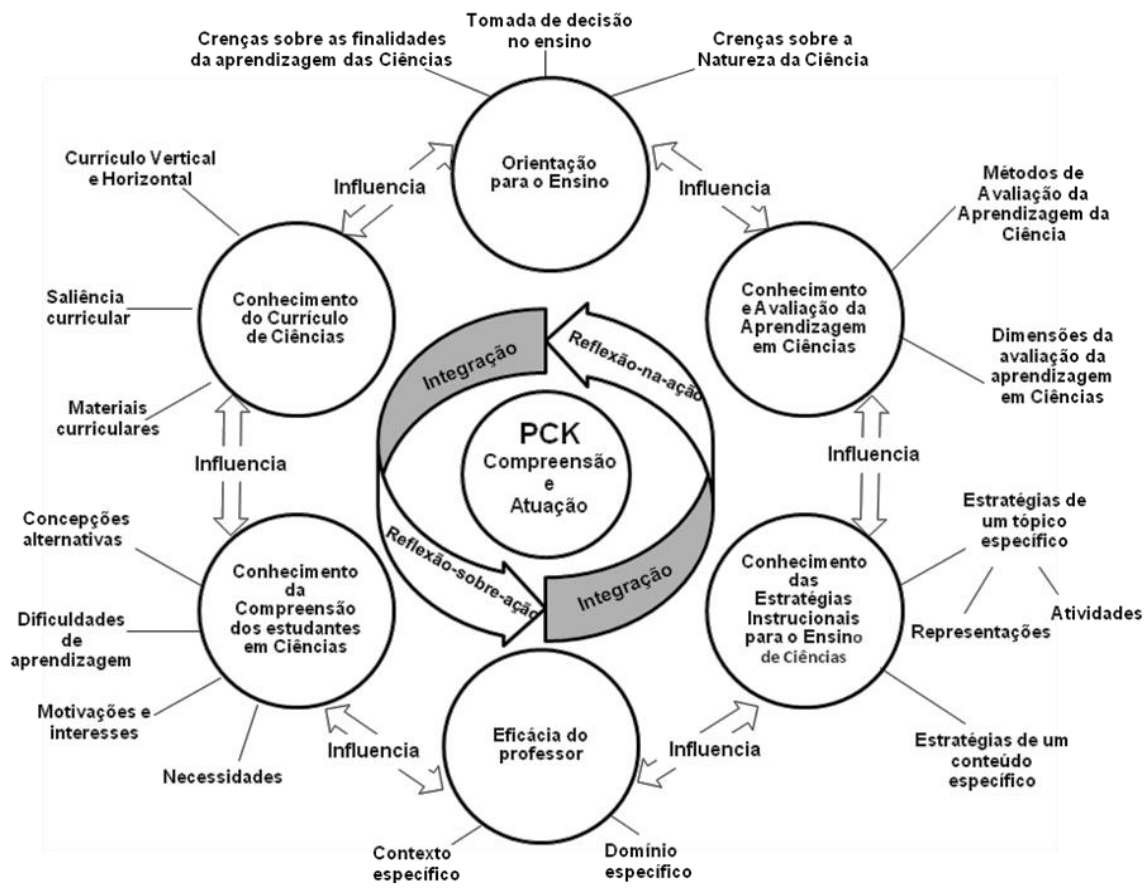

Figura 6. Modelo hexagonal do Conhecimento Pedagógico de Conteúdo para o Ensino de Ciências (PARK; OLIVER, 2008a). Fonte: FERNANDEZ (2011)

Na perspectiva de Montenegro e Fernandez "A integração desses componentes é realizada através de reajustes a partir tanto da reflexão na ação como da reflexão sobre a ação" (2015, p. 260), o que significa que nesse modelo os seis componentes influenciam uns aos outros continuamente.

\subsection{Por que reações de oxirredução?}

O ensino de reações redox tem sido apontado na literatura como um dos conteúdos mais difíceis de serem ensinados e aprendidos. A investigação de Soudani e colaboradores (2000) revelou que estudantes têm problemas em associar o conceito de reações de oxirredução com a sua vivência diária. Nessa perspectiva, muitos autores investigaram as dificuldades dos alunos com o tema oxirredução (GARNETT; TREAGUST, 1992a, 1992b, 1999; SANGER; GREENBOWE, 1997a, 1997b; DE JONG; TREAGUST, 2002). Segundo Garnett e Treagust (1992a) alunos de ensino médio têm dificuldade em identificar o ânodo e cátodo e suas respectivas funções. Os autores argumentam ainda que os discentes não compreendem o sentido da corrente elétrica em células eletroquímicas. Esse trabalho foi replicado por Sanger e Greenbowe (1997a) que objetivaram também estudar as concepções alternativas dos estudantes sobre células galvânica, eletrolítica e de concentração. Os resultados dos autores foram semelhantes aos identificados por Garnett e Treagust. Entretanto, nesse novo ensaio seus investigadores desconsideraram os potenciais eletroquímicos como um conceito de acesso às concepções alternativas dos alunos. 
Em outro trabalho Sanger e Greenbowe (1997b) propuseram trabalhar com as concepções alternativas dos discentes relacionados ao sentido do fluxo de elétrons por meio da adoção de uma animação computacional como recurso didático. Nessa mesma perspectiva Hudle e colaboradores (1999) adotaram um modelo computacional que pudesse propiciar a substituição das concepções alternativas dos discentes em relação ao fluxo de corrente elétrica em eletroquímica. O modelo adota uma membrana semipermeável em substituição a ponte salina para completar o circuito. Para os autores essa ferramenta possibilitou a compreensão dos conceitos pelos alunos de diferentes níveis de ensino.

Para Ogude e Bradley (1996) as limitações conceituais dos alunos relacionadas ao conteúdo redox resulta no estabelecimento de dois cenários: o primeiro em que grande parte dos estudantes consegue resolver questões quantitativas sobre 0 conteúdo redox; e o segundo, em que um número limitado de estudantes respondem a questões qualitativas por requererem um conhecimento mais amplo e profundo do conteúdo.

Em uma pesquisa sobre o conteúdo eletroquímica em livros de ensino superior os autores Sanger e Greenbowe (1999) concluíram que este material pode ser uma fonte de erros conceituais, que pode levar a concepções alternativas, principalmente em relação aos conceitos de ponte salina e o fluxo de elétrons em soluções eletrolíticas.

Em sua dissertação, Pereira (2014) analisou a "Webquest - Eletroquímica: um grande choque", como uma possível metodologia que propiciasse a construção do conhecimento pelos discentes, tendo como referencial teórico na análise dessa aprendizagem Vygotsky. Segundo Pereira, desenvolver o conteúdo eletroquímica estava relacionado às suas leituras de referenciais que retratavam as dificuldades de aprendizagem de alunos acerca de conceitos básicos de eletroquímica, levando-o a estruturar a Webquest permeando os conceitos: definição de anodo, cátodo, reação espontânea e não-espontânea, agente oxidante e redutor, além da definição e constituição de pilha e bateria e os impactos ambientais ocasionados pelo descarte inadequado desses materiais. As maiores dificuldades vivenciadas durante a implementação do projeto foi a falta de conhecimento dos alunos de $2^{\circ}$ ano do ensino médio sobre a eletroquímica. Por outro lado, para o autor a estruturação da Webquest associada ao empenho dos alunos no desenvolvimento das atividades propiciaram a aprendizagem do conteúdo.

Além das dificuldades dos discentes, alguns professores por considerarem o tema difícil de ensinar, não preparam planos de aula (AHTEE; ASUNTA; PALM, 2002). Sanjuan e colaboradores (2009) apontam para o fato de muitos professores deixarem este conteúdo para o final do ano letivo, já sabendo que não haverá tempo hábil para Capítulo 2. Fundamentação Teórica 
trabalhá-lo por terem dificuldades com tal assunto. Segundo Bucat (2004) os docentes têm dificuldades relacionadas principalmente em explicar a simbologia, as definições e os modelos do conteúdo redox.Na literatura, são raros os estudos sobre as concepções de professores a respeito de reações de oxirredução (ÖZKAYA, 2002, 2003). Em relação ao $\mathrm{PCK}$, nenhum dos trabalhos analisados buscou investigar na formação continuada e ou inicial de professor como este conteúdo vem sendo desenvolvido em sala de aula, mas as limitações dos professores em relação a este conteúdo (ROLLNICK; MAVHUNGA, 2014; YILMAZ; BAYRAKÇEKEN, 2015).

Assim, esse fato justifica ainda mais o nosso interesse em pesquisar como futuros docentes trabalham este conteúdo em sala de aula e de que forma o Pibid pode contribuir para o desenvolvimento do PCK desse tema em licenciandos em Química. 


\section{CAPÍTULO 3. ASPECTOS METODOLÓGICOS}

Em consonância com os objetivos traçados, esta pesquisa figura-se como do tipo qualitativa. Entretanto, com um objetivo mais específico de analisar a percepção dos alunos da escola conveniada ao Pibid sobre o conhecimento docente dos pibidianos, adotou-se um instrumento acessório de caráter quantitativo. Para alguns autores esta pesquisa figuraria como do tipo mista de incorporação, em virtude da adoção da ferramenta quantitativa, porém os dados coletados que corroboram para responder as questões de pesquisa são de caráter qualitativo, refletindo em uma investigação não mista (CRESWLL; CLARK, 2013).

A pesquisa qualitativa, segundo Bogdan e Biklen, (2003) apresenta cinco características, a saber: o ambiente natural; os dados são em grande parte descritivos; o processo tem mais importância que o produto; preocupação com o significado; e a tendência indutiva do processo de análise dos dados.

Nessa investigação grande parte dos dados foi coletada em contextos reais de sala de aula, um ambiente natural. Na literatura são descritas diversas formas de pesquisa qualitativa, mas duas se destacam no campo da educação, a do tipo etnográfica e o estudo de caso. Nesta pesquisa o estudo de caso mostrou-se mais adequado, já que é a investigação de um caso (LUDKE; ANDRÉ, 1986), em um contexto específico em que os investigadores buscam o entendimento de uma situação problema, assim como, "[...] retenham as características holísticas e significativas dos eventos da vida real - como ciclos individuais de vida, o comportamento dos pequenos grupos [...]" (YIN, 2010, p.24). O estudo de caso apresenta características fundamentais:

1. Os estudos de caso visam à descoberta.

2. Os estudos de caso enfatizam a "interpretação em contexto".

3. Os estudos de caso buscam retratar a realidade de forma completa e profunda.

4. Os estudos de caso usam uma variedade de fontes de informação.

5. Os estudos de caso revelam experiência vicária e permitem generalizações naturalísticas.

6. Estudos de caso procuram representar os diferentes e, às vezes, conflitantes pontos de vista presentes numa situação social.

7. Os relatos de estudo de caso utilizam uma linguagem e uma forma mais acessível do que os outros relatórios de pesquisa (LÜDKE; ANDRÉ, 1986, p.18-20).

Estes aspectos revelam uma busca em retratar um contexto particular, complexo em sua essência, o que leva o pesquisador a coletar uma variedade de dados, advindos de diferentes fontes, colhidas durante toda a pesquisa.

Em contrapartida, as pesquisas quantitativas possibilitam a mensuração de um instrumento adotado em específico, que pode levar a associação entre as variáveis. Entre outras características, esse tipo de investigação é orientada pela produção de 
resultados generalizáveis, e que adotam métodos estatísticos de comprovação (SERRANO, 2004). Para Diehl (2004) a pesquisa quantitativa evita possíveis "[...] distorções de análise e interpretação, possibilitando uma maior margem de segurança" (p.13).

A partir das características descritas considera-se o estudo de caso um aporte teórico condizente para investigar os componentes do Conhecimento Docente por meio da observação da estruturação e implementação das aulas pelos pibidianos de forma tutorada pela coordenadora e supervisora. Considera-se este caso como de tipo único, pois a investigação buscou retratar uma realidade particular - subprojeto-Pibid química e os participantes (pibidianos, supervisora e coordenadora) que participam deste ambiente.

Esta pesquisa foi constituída pela triangulação dos dados coletados por meio dos instrumentos: a) entrevista semiestruturada; b) registro audiovisual da elaboração e implementação de sequências de ensino-aprendizagem pelos pibidianos; c) questionário sociocultural; d) questionário de percepção sobre os bolsistas com afirmações em escala Likert e uma questão aberta; e) lembrança estimulada; f) análise documental das sequências de ensino, relatórios e demais materiais produzidos pelos pibidianos; g) instrumento de acesso ao PCK - CoRe adaptado; h) análise do Plano Pedagógico da Licenciatura (PPC); i) transcrição das aulas e reuniões nas quais os participantes dessa investigação eram orientados sobre suas ações no programa de iniciação à docência.

\subsection{Contexto da pesquisa}

Os participantes desta pesquisa foram três discentes da licenciatura em química do Instituto Federal de São Paulo (Campus São Paulo) inseridos no Pibid. Apesar de os pibidianos estarem em formação inicial, apresentam um vínculo com a sala de aula em virtude de sua participação nesse programa. Este contexto é particularmente interessante, pois o PCK se desenvolve em contato com a prática da sala de aula e com a experiência, o que nos possibilita investigar o desenvolvimento do Conhecimento Docente ainda na formação inicial.

\section{A licenciatura em Química no IFSP}

No ano de 2007 o Conselho Diretor do Instituto Federal de São Paulo (campus São Paulo) aprovou a implementação do Curso de Licenciatura em Ciências da Natureza, por meio da Resolução 251/07, tendo suas atividades iniciadas no ano de 2008. Contudo, nesse mesmo ano o curso passou por uma reestruturação que resultou na abertura em 2009 da Licenciatura em Química, com o propósito de atender a demanda por profissionais com formação específica nesta área, pois a única instituição Capítulo 3. Aspectos metodológicos 
pública que graduava estes profissionais na capital paulista era a Universidade de São Paulo (TEIXEIRA et al., 2008).

Teixeira e colaboradores (2008) estruturaram o Projeto do Curso, segundo as novas demandas do MEC do Brasil:

Incentivar projetos curriculares voltados para a educação científica e mudanças curriculares que incorporem abordagens práticas e problematizadoras das Ciências.

Ampliar e melhorar a formação inicial de professores de Ciências, mediante incentivo com bolsas de licenciatura e abertura de campos de estágio orientado.

Promover a formação continuada de professores de Ciências, mediante cooperação institucional, coordenada pela CAPEMP Coordenação de Aperfeiçoamento de Professores do Ensino Médio (a ser instituída) e com apoio da CAPES - Fundação Coordenação de Aperfeiçoamento de Pessoal de Nível Superior, do CNPq - Conselho Nacional de Desenvolvimento Científico e Tecnológico e de outros órgãos de fomento.

Implantar as Oficinas de Ciências, Cultura e Arte em instituições de ensino e científicas, como espaços de ensino aprendizagem e de formação inicial e continuada de professores; Promover a pósgraduação de professores de Ciências, incentivando-se tomar sua prática pedagógica como objeto de investigação.

Promover a colaboração institucional, para formação inicial e continuada de professores, bem como para o apoio aos sistemas públicos de ensino.

Implantar programas de produção e distribuição de livros e materiais didáticos de Ciências (MINISTÉRIO DA EDUCAÇÃO, apud, TEIXEIRA et al. 2000, p.16).

O projeto político pedagógico foi delineado atendendo ainda a Resolução CNE/CP 2 de 19 de fevereiro de 2002 (BRASIL, 2002) do Conselho de Educação, que designa que todos os cursos de formação de professores para a educação básica em nível superior devem ter uma carga mínima de 2800 (duas mil e oitocentas horas). Nesse cenário, a instituição de ensino implementou uma licenciatura, segundo as novas demandas para a educação brasileira, sendo que seus componentes curriculares estão distribuídos em oito semestres, em uma carga horária total de 2.994 horas, organizadas, a saber:

[...] 1966,5 horas para o desenvolvimento dos conteúdos curriculares de formação específica, presencial, em sala de aula; 427,5 horas de prática como componente curricular, articulado aos componentes curriculares ao longo de todo o curso; 400 horas de estágio supervisionado, articulado aos componentes curriculares do curso, com 200 horas no ensino de ciências do ensino fundamental e 200 horas no ensino de química do ensino médio; 200 horas de atividades acadêmico científico culturais (TEIXEIRA et al. 2008, p.23). 
$\mathrm{Na}$ tabela 1 apresenta-se a distribuição dos componentes curriculares da instituição de ensino investigada.

Tabela 1. Distribuição da carga horária dos Componentes Curriculares da Licenciatura em Química do Instituto Federal de São Paulo

\section{Disciplinas Carga horária}

\begin{tabular}{cc}
\hline Química teórica* $^{*}$ & 687,5 \\
\hline Experimentais de química $^{*}$ & 456 \\
\hline Física teórica e experimental $^{*}$ & 171 \\
\hline Matemática* $^{*}$ & 171 \\
\hline Educação $^{*}$ & 192,5 \\
\hline Interface química e educação* $^{*}$ & 806,5 \\
\hline Biologia teórica* $^{*}$ & 256,5 \\
\hline Experimentais de biologia $^{*}$ & 142,5 \\
\hline Geologia $^{*}$ & 28,5 \\
\hline Outras $^{*}$ & 82 \\
\hline Total $^{*}$ & 2994
\end{tabular}

*Não foram subtraídas as cargas horárias das atividades PECC, AACC e Estágio, dos conteúdos específicos (TEIXEIRA et al., 2008).

A primeira análise que se faz na grade curricular é que a Instituição de Ensino investigada apresenta em sua estrutura curricular disciplinas envolvidas com as ciências da natureza, como física, matemática, química, biologia e geologia. Outro componente curricular que devemos destacar são as disciplinas de interface química e educação, que correspondem a 806,5 horas $(27 \%)$ da carga horária do curso. Em relação às 400 (quatrocentas) horas de práticas de ensino como componente curricular (PECC), estão distribuídas nas disciplinas apresentadas na tabela 2.

Tabela 2. Práticas de ensino como componente curricular (PECC)

\begin{tabular}{cc}
\hline Disciplinas & Carga horária \\
\hline Química teórica/Experimentais de química & 142,5 \\
\hline Educação & 28,5 \\
\hline Interface química e educação & 199,5 \\
\hline Biologia teórica/Experimentais de biologia & 57 \\
\hline Total & 427,5 \\
\hline
\end{tabular}

As práticas de ensino estão no interior das disciplinas e/ou em aulas de laboratório, porém as PECC são desenvolvidas de acordo com o perfil do professor responsável pela disciplina na qual estão inseridas, pois esta pode ser direcionada nas aulas práticas referentes aos conteúdos teóricos, como também para o desenvolvimento de projetos que permeiam a educação, mas atende às 400 horas determinadas pelo Conselho de Educação, atendendo também a carga horária para estágio (400 horas) e atividades acadêmico-científico-culturais (200 horas).

A análise do projeto pedagógico do curso de Licenciatura na instituição investigada revelou ainda que o conteúdo de reações redox começa a ser desenvolvido no sexto semestre nas disciplinas, a saber: 
- Química Inorgânica I - Aplicações de reações redox- Diagrama de Latimer e de Frost.

- Química Analítica Qualitativa - Reações redox.

- Química Orgânica II - Reações de oxirredução.

No sétimo semestre aparecem conceitos eletroquímicos nas disciplinas:

- Físico-Química II - Propriedades termodinâmicas das células eletroquímicas, potenciais de eletrodo, mecanismos das reações de eletrodo, eletrólise, eletrodeposição de metais, baterias, corrosão, células a combustível.

- Química Analítica Quantitativa -Titulometria de oxirredução.

A estrutura curricular do curso revela-se inovadora, com forte abordagem experimental e problematizadora, permeada por componentes curriculares na área de ciências e biologia que leva a uma interface dessas áreas com a química (TEIXEIRA et al., 2008). Tal fato revela que o objetivo principal é formar professores capazes de desenvolver no Ensino Médio uma educação que desperte no aluno o interesse pelo desenvolvimento científico e tecnológico e que este entenda os fenômenos da natureza de modo integrado.

Com relação à sua localização, o Instituto Federal de São Paulo (campus São Paulo) tem sua sede na região norte da capital paulistana. A estrutura física desse centro de ensino conta com 3 auditórios, 53 salas de aulas, 5 salas de projeção, 1 biblioteca, 16 laboratórios de informática, 7 salas de desenho, 2 laboratórios de química, 2 laboratórios física, 2 laboratórios de biologia, 1 pista de atletismo, 1 campo de futebol, 4 quadras poliesportivas, 16 banheiros. Seu prédio apresenta alguns problemas decorrentes de infiltrações. Por outro lado, conta com excelente área verde que cerca o entorno do prédio e um bosque.

Além da licenciatura em química, a instituição oferece cursos de formação de professores para educação básica, nas áreas de concentração, a saber: biologia, física, geografia, matemática e letras.

O curso de química conta com dezesseis docentes com mestrado e/ou doutorado em diferentes áreas. A professora coordenadora do Pibid atua nesta licenciatura desde 2008, além de ministrar aulas no ensino médio integrado e mestrado nas áreas de mecânica e ensino de ciências. Tem graduação em química, mestrado em química e doutorado em físico-química. Suas experiências profissionais vão além da sala de aula, pois atua como coordenadora da área de química e na organização de eventos da licenciatura. Suas pesquisas têm como temas de estudos: formação de professores, avaliações em larga escala, ensino de química (eletroquímica) e desenvolvimento de projetos de caráter interdisciplinar com abordagem CTS. 
A coordenadora tem em seu currículo um número representativo de orientações de trabalhos de iniciação científica, iniciação à docência, trabalhos de conclusão de curso (TCC) e dissertações de mestrado. Participou de diversos eventos científicos nacionais e internacionais e de bancas julgadores de mestrado, doutorado e TCC.

\section{O subprojeto Pibid-química}

No ano de sua abertura, 2009, a Licenciatura em Química passou a integrar o projeto institucional de iniciação à docência promovido pela Capes em conjunto com o Pibid-Institucional, que incluía todas as licenciaturas dessa instituição no Estado de São Paulo. O subprojeto Pibid-química está sendo desenvolvido, por uma professora coordenadora da área.

No subprojeto os trabalhos estruturados pelos bolsistas são elaborados por meio de duas abordagens: CTS (Ciência, Tecnologia e Sociedade) e a experimentação investigativa, tendo como questão motivadora a Política Nacional de Resíduos Sólidos - PNRS (BRASIL, 2010), uma lei que propõe o avanço nacional relacionado ao destino inadequado de resíduos sólidos. Sua execução ocorre por meio de reuniões entre a coordenadora de área e os pibidianos, nas quais são definidas metas, estudos, referenciais, orientações sobre o desenvolvimento de atividades, programação de ações nas escolas conveniadas, etc. Na figura abaixo tem-se a representação das etapas que norteiam as atividades desenvolvidas no interior do subprojeto Pibid-Química.

\section{1}

\section{Formação dos grupos e escolha das temáticas}

- São constituídos os grupos de pibidianos.

Permeia o estudo de temas pertinentes ao desenvolvimento das propostas de ensino.

\section{Planejamento das propostas de ensino e vivência pedagógica}

- Mediada pela coordenadora, os pibidianos e a supervisora participavam de reuniões, em que são apresentadas as propostas de ensino.

- Observação de campo, análise da infraestrutura da escola conveniada e a prática docente (professor supervisor).

\section{3}

Implementação das regências e reuniões

- Aplicação das aulas na escola conveniada e reuniões nas quais são discutidos os resultados das intervenções.

- Elaboração das demais intervenções que irão compor o plano de ensino.

\section{4}

Avaliação do desenvolvimento dos projetos

Apresentação dos resultados pelos bolsistas sobre os projetos desenvolvidos.

- Escrita dos relatórios pelos bolsistas e confecção de resumos para congressos.

Figura 7. Etapas de desenvolvimento do Subprojeto Pibid-Química investigado

Nessas reuniões também ocorriam a formação de grupos de bolsistas para atuarem em uma das duas escolas estaduais, conveniadas ao subprojeto.

A estrutura do Pibid-química investigado tinha como componentes um coordenador do quadro de docentes da licenciatura em química, dois supervisores em 
exercício em escolas públicas e doze licenciandos em química. As funções de cada um dos participantes no programa institucional são estabelecidas em edital publicado pela instituição de ensino superior (2014). O coordenador tem como uma das funções selecionar os supervisores e os bolsistas de iniciação à docência. O supervisor viabiliza as atividades dos pibidianos na escola e os alunos bolsistas disponibilizam formalmente os resultados parciais e finais de seu trabalho na escola, divulgando-os na instituição em que estudam em eventos de iniciação à docência promovidos pela instituição e em ambiente virtual do Pibid organizado pela Capes (2014).

No Pibid os licenciandos são organizados em duplas ou trios para desenvolverem seus projetos na escola campo, que neste estudo foi uma escola de Ensino Médio regular e de Educação de Jovens e Adultos (EJA), que recebeu seis bolsistas, sendo que um dos pibidianos desligou-se do programa no início do segundo semestre de 2014. Na outra escola, com sede na região norte da cidade de São Paulo ficaram alocados os outros bolsistas.

Os licenciandos são tutorados pela docente da instituição de nível superior a desenvolverem as sequências didáticas sobre o conteúdo de reações de oxirredução. Vale ressaltar que na fase inicial de coleta de dados outra docente (Rebeca) da instituição de ensino superior participava dessa tutoria, mas desligou-se do grupo do subprojeto no início do segundo semestre.

\section{Caracterização da escola conveniada ao Pibid}

A escola onde os licenciandos desenvolviam seus projetos está localizada na região sul da cidade de São Paulo. E, segundo dados do censo escolar (2014), a instituição atende a 834 alunos do Ensino Médio regular (EM), 641 alunos do Ensino Fundamental (EF-II) e 184 alunos da Educação de Jovens e Adultos (EJA), sendo a quantidade média de alunos por sala: EF (35), EM (30) e EJA (20).

A instituição de ensino tem seu espaço físico constituído por 53 salas de aula, 1 biblioteca, 6 banheiros, 1 sala de coordenação, 1 sala de leitura, 1 laboratório de ciências, 1 laboratório de informática, 1 sala de professores, 1 cantina, 1 refeitório, 2 bebedouros, 2 quadras de esporte, 1 sala de secretaria, 1 auditório, 1 sala multimídia, 1 pátio e 1 sala de almoxarifado. Conta com equipamentos de TV, DVD, antena parabólica, copiadora, retroprojetor, impressora, aparelho de som, projetor multimídia, fax e câmera fotográfica/filmadora. O prédio tem um bom estado de conservação, com boa limpeza e iluminação. Possui ainda, recursos didáticos e paradidáticos, que ficam acessíveis aos docentes. O laboratório de ciências é um espaço de destaque na instituição, pois está suprido de materiais e equipamentos para realização de aulas 
experimentais. A escola conta com apenas três professores de química de um total de 116 funcionários.

A professora de química supervisora do Pibid tem graduação em licenciatura e bacharelado em química, mestrado em ensino de ciências e especialização em química e meio ambiente. A docente tem ampla experiência profissional tanto em nível médio como superior, além de atuar como revisora de materiais didáticos, na orientação de trabalhos de conclusão de curso técnico e na estruturação e implementação de cursos de formação continuada para professores de ciências. Participou de vários eventos na área de ensino de ciências. Na escola conveniada ao Subprojeto Pibid-Química a supervisora atuava há mais dez anos.

\subsection{Coleta de dados}

\subsubsection{Revisão de literatura}

O Pibid e seus impactos no desenvolvimento profissional docente

Para analisar os possíveis impactos do Pibid na formação inicial e continuada de professores, mapeou-se entre os anos de 2008 a 2016 trabalhos publicados em anais de eventos científicos nacionais: Reunião Anual da Sociedade Brasileira de Química (RASBQ)/Divisão de Ensino; Encontro Nacional de Pesquisa em Educação em Ciências (ENPEC); Encontro Paulista de Pesquisa em Ensino de Química (EPPEQ); Encontro Nacional de Ensino de Química (ENEQ); e no Banco de Dissertações e Teses da Capes. A análise envolveu apenas as investigações que propuseram evidenciar as contribuições desse programa na formação da tríade: licenciando (pibidiano), professor da educação básica (supervisor) e professor formador (coordenador).

\section{internacionais}

Dificuldades e limitações do conteúdo redox - eventos nacionais e

Grande parte dos artigos retratam as problemáticas relacionadas ao ensino e aprendizagem desse conteúdo fora do contexto brasileiro. Desejando-se entender a realidade em âmbito nacional foi feito um mapeamento entre os anos de 2000 a 2016 de investigações que tiveram como objeto de estudo reações redox. Para tanto, analisou-se nos principais eventos científicos nacionais na área de ensino as dificuldades relatadas pelos autores para o ensino e aprendizagem de reações redox a partir de suas experiências. Esses eventos foram: Reunião Anual da Sociedade Brasileira de Química (RASBQ)/Divisão de Ensino; Encontro Nacional de Pesquisa em Educação em Ciências (ENPEC); Encontro Paulista de Pesquisa em Ensino de Química (EPPEQ); e no Encontro Nacional de Ensino de Química (ENEQ). E com o objetivo de contrapor essas possíveis limitações ao ensino e aprendizagem desse conteúdo nos eventos nacionais, também foi realizado a catalogação no mesmo período, em três 
grandes eventos internacionais: European Science Education Research Association (ESERA); Congreso Internacional sobre Investigación en la Didáctica de las Ciencias (Enseñanza de las Ciencias); e Conferência da National Association for Research in Science Teaching (NARST).

\subsubsection{Registro audiovisual}

O registro audiovisual foi adotado como metodologia de coleta de dados, pois as observações de campo ocorreram de forma sistemática (NOVAIS; LEAL; FERNANDEZ, 2011). Nessa perspectiva, o autor Loizos (2008) argumenta que este tipo de registro deve ser utilizado "sempre que algum conjunto de ações humanas é complexo e difícil de ser descrito compreensivamente por um único observador, enquanto este se desenrola" (p.149). Na visão de alguns pesquisadores (GARCEZ; DUARTE; EISENBERG, 2011) a adoção de registro audiovisual possibilita o registro ainda de expressões corporais, a reação de participantes frente à proposição de uma atividade, contradições na fala, entre outras, difíceis de serem captados com outros recursos metodológicos. Utilizou-se este recurso no registro das aulas, reuniões e entrevistas semiestruturadas. Porém, antes da realização das gravações, os participantes da pesquisa, assinaram o Termo de Consentimento Livre Esclarecido (TCLE), de acordo com as proposições do Comitê de Ética na Pesquisa em Educação da USP (apêndice 1) aceitando participar do estudo.

\subsubsection{Reuniões e regências}

Durante os passos iniciais para o desenvolvimento desta pesquisa, realizou-se o registro audiovisual das reuniões gerais do subprojeto Pibid-Química, na qual eram discutidos os temas a serem desenvolvidos por cada equipe formada pelos pibidianos. Os registros audiovisuais em um primeiro momento ocorreram na instituição formadora e, numa segunda fase foram realizados na escola estadual conveniada ao Pibid. Foram realizadas gravações com todos os grupos de alunos bolsistas. Os primeiros registros audiovisuais ocorreram na reunião geral com todos os pibidianos, na qual foram discutidos os temas a serem escolhidos pelos bolsistas, os possíveis conceitos químicos a serem trabalhados, a divisão dos grupos, a produção de trabalhos para congressos e revistas científicas, entre outras. Essa reunião foi realizada em uma das escolas estaduais localizada na região norte da cidade de São Paulo. Posteriormente foi realizado o registro de reuniões nas quais cada grupo apresentava sua proposta de trabalho, mas sem a participação dos demais grupos. Nessas reuniões os bolsistas recebiam a orientação da coordenadora acerca da escolha do conteúdo químico sobre a preparação de aulas de sensibilização e aulas experimentais/teóricas. Nesses 
encontros eram finalizadas as intervenções a serem aplicadas pelos pibidianos na escola conveniada.

Após os planos de aula terem sido concluídos, foram realizados os registros audiovisuais das regências dos pibidianos e, posteriormente, as reuniões que ocorriam com a professora-coordenadora para discutirem os resultados obtidos e os próximos passos de ação dos pibidianos. Os últimos registros envolveram as reuniões destinadas à discussão das ações promovidas pelos pibidianos durante o ano de 2014 e a orientação para a confecção do relatório final pelos bolsistas sobre suas atuações neste programa de iniciação à docência, durante os dois semestres do referido ano.

\subsubsection{Entrevistas semiestruturadas}

Em pesquisas qualitativas o uso de entrevistas semiestruturadas é uma ferramenta recorrente (DUARTE, 2004). Esse instrumento é caracterizado pela sua estruturação em perguntas consideradas essenciais para o entendimento do assunto investigado e pelo surgimento de novas questões em decorrência do ambiente estabelecido no decorrer da entrevista (MANZINI, 1991). Segundo Triviños a entrevista semiestruturada:

[...] mantém a presença consciente e atuante do Pesquisador e, ao mesmo tempo permite a relevância na situação do ator. Este traço da entrevista semi-estruturada (sic), segundo modo de pensar, favorece não só a descrição dos fenômenos sociais, mas, também sua explicação e a compreensão de sua totalidade, tanto dentro de sua situação específica como de situações de dimensões maiores. De toda maneira, diante dessas últimas situações, é necessário lembrar que os instrumentos de coleta de dados não são outra que a teoria em ação, que apoia a visão do pesquisado (TRIVIÑOS, 1987, p. 146).

A entrevista semiestruturada permite ainda que o entrevistado utilize de narrativas próprias sobre a temática investigada.

\section{Pibidianos}

Com propósito de coletar dados que possibilitassem a triangulação com os outros instrumentos, iniciou-se a construção do roteiro da entrevista semiestruturada, norteada por questões que envolviam a vivência do licenciando no Pibid, as escolhas profissionais e as influências deste programa em sua formação. Após a finalização do roteiro, foram realizadas entrevistas piloto (TRIVIÑOS, 1987; MANZINI, 2003; REA; PARKER, 2000) com três pibidianos. Contudo, ao seu término considerou-se pertinente readequar o roteiro original, retirando algumas questões que não foram bem assimiladas pelos entrevistados e incluir novas questões. Esse processo resultou em um roteiro final (apêndice 2) com questões que permeavam o universo do pibidiano, a saber: o processo de elaboração das aulas; o papel do coordenador e supervisor no Pibid; o interesse em ensinar; as estratégias de ensino adotadas, entre outras. As entrevistas 
semiestruturadas foram realizadas individualmente com cada um dos três bolsistas participantes desse estudo. As entrevistas ocorreram tanto no campus da Instituição de ensino superior, próximo ao final das atividades desenvolvidas na escola conveniada, de acordo com a escolha do entrevistado, tendo cada entrevista tempo médio de duração de vinte minutos.

\section{Tutoras - coordenadora e supervisora}

Em virtude das atribuições dentro do Pibid serem diferentes para cada uma das tutoras, considerou-se pertinente a construção de dois roteiros: o primeiro (apêndice 3) teve por objetivo guiar a entrevista com a coordenadora e o segundo (apêndice 4) a entrevista com a supervisora. As questões que permeiam o instrumento tiveram por finalidade fazer emergir relatos sobre a escolha pela carreira docente, a possível influência de disciplinas pedagógicas nas orientações, como avaliam o desenvolvimento profissional dos pibidianos, como o Pibid contribuiu para a formação continuada, entre outras. As entrevistas foram realizadas individualmente quando as atividades desenvolvidas no subprojeto foram encerradas.

\subsubsection{Transcrições}

Com o intuito de interpretar as falas e as ações dos pibidianos durante as reuniões, as regências, e as entrevistas semiestruturadas registradas em áudio e vídeo, a transcrição torna-se fundamental (CARVALHO, 2006). Nessa perspectiva, realizou-se as transcrições dos materiais coletados em sua totalidade, de modo a manter-se a fidedignidade das falas dos participantes. $\mathrm{Na}$ literatura são apresentadas diversas regras que ajudam a transcrever as entonações, pausas, humor, entre outras, presentes nas falas dos participantes (CARVALHO, 2006). Durante as transcrições organizaramse as falas em turnos, que correspondem à fala iniciada e concluída por um participante. Essa organização facilita a localização no contexto da qual foi extraída e subsidia as análises do pesquisador e as suas possíveis conclusões.

\subsubsection{Questionário socioeconômico e cultural}

No intuito de caracterizar os aspectos econômicos, sociais e culturais dos bolsistas do programa de iniciação à docência do subprojeto investigado, elaborou-se um questionário socioeconômico e cultural (apêndice 5), constituído por questões sobre o nível de escolaridade dos pais, faixa etária, exercício de atividade remunerada, fluências nas línguas inglesa e espanhola, tempo de estudo, instituição de ensino de conclusão do Ensino Médio, entre outras. Para garantir a participação de todos os alunos bolsistas, aplicou-se o questionário durante os encontros em que ocorriam as entrevistas semiestruturadas. 


\subsubsection{Instrumento de percepção}

Ao término das atividades desenvolvidas pelos pibidianos na escola conveniada aplicou-se um instrumento (anexo 1) a quarenta alunos, pertencentes ao $2^{\circ}$ ano do ensino regular e ao $3^{\circ}$ ano da EJA (Educação de Jovens e Adultos) dessa instituição de ensino, com o objetivo de reconhecer e registrar suas percepções sobre a atuação de cada bolsista do Pibid durante o desenvolvimento de suas regências.

O teste adotado neste estudo foi desenvolvido por Jang, Guan e Hsieh (2009) e traduzido por Girotto Júnior (2015). O instrumento era constituído por quatro categorias: conhecimento do tema (CT); representação do conteúdo e estratégias para seu ensino (RCE); objetivo educacional e do contexto (OEC); e conhecimento das compreensões dos estudantes (CCE) (GIROTTO JÚNIOR, 2015). As categorias eram compostas por seis diferentes questões Likert que variavam, a saber: 0 (Não me recordo / Não sei) 1 (Se nunca ocorreu na prática de ensino), 2 (Se ocorreu raramente na prática de ensino), 3 (Se ocorreu às vezes na prática de ensino), 4 (Se ocorreu frequentemente na prática de ensino) e 5 (Se sempre ocorreu na prática de ensino). O instrumento tinha ainda uma questão aberta para que os discentes pudessem descrever possíveis dificuldades de aprendizagem ou realizar um comentário que julgassem pertinente sobre os pibidianos. O teste original não tinha a escala 0 (Não me recordo / Não sei), incluída neste estudo. O instrumento adaptado e usado neste estudo é constituído por 28 questões e seis escalas.

\subsubsection{Representação de Conteúdo-CoRe adaptado}

No percurso desta pesquisa utilizou-se ainda como instrumento de coleta de dados o instrumento Representação de Conteúdo - CoRe (quadro 5).

Quadro 5. CoRe (Representação do Conteúdo) (LOUGHRAN; MULHALL; BERRY, 2004; tradução Fernandez, 2015)

\begin{tabular}{|l|l|l|l|}
\hline \multicolumn{2}{|c|}{ Questões } & \multicolumn{2}{|c|}{$\begin{array}{c}\text { Ideias centrais vinculadas a } \\
\text { esse conteúdo }\end{array}$} \\
\cline { 2 - 4 } & $\begin{array}{c}\text { Grande } \\
\text { Ideia 1 }\end{array}$ & $\begin{array}{c}\text { Grande } \\
\text { Ideia 2 }\end{array}$ & $\begin{array}{l}\text { Grande } \\
\text { Ideia n }\end{array}$ \\
\hline $\begin{array}{l}\text { 1. O que você pretende que os estudantes aprendam com } \\
\text { esta ideia? }\end{array}$ & & & \\
\hline $\begin{array}{l}\text { 2. Por que é importante para os estudantes saberem esta } \\
\text { ideia? }\end{array}$ & & & \\
\hline 3. O que mais você sabe sobre esta ideia? & & & \\
\hline $\begin{array}{l}\text { 4. Quais são as dificuldades e limitações conectadas ao } \\
\text { ensino desta ideia? }\end{array}$ & & & \\
\hline $\begin{array}{l}\text { 5. Que conhecimento sobre o pensamento dos estudantes } \\
\text { influi em seu ensino desta ideia? }\end{array}$ & & & \\
\hline 6. Quais os fatores influem no ensino desta ideia? & & & \\
\hline $\begin{array}{l}\text { 7. Que procedimentos você utilizaria para que os alunos se } \\
\text { comprometam com esta ideia? }\end{array}$ & & & \\
\hline $\begin{array}{l}\text { 8. Que maneiras específicas você utilizaria para acompanhar } \\
\text { o entendimento ou confusão dos alunos sobre a ideia? }\end{array}$ & & & \\
\hline
\end{tabular}

Capítulo 3. Aspectos metodológicos 
O CoRe é uma ferramenta de acesso ao PCK constituída por oito perguntas, que possibilita a manifestação das ideias centrais dos participantes envolvidos na pesquisa a partir de suas reflexões acerca das ideias principais de um conteúdo específico, em particular neste estudo, reações redox.

Em virtude de uma solicitação dos pibidianos em acrescentar uma temática e excluir os números de ideias, foi proposto um CoRe "adaptado" segundo os seus anseios (quadro 6). Nesse sentido, preservou-se da estrutura do CoRe a escolha por um conteúdo específico e as perguntas, excluindo as grandes ideias.

Quadro 6. CoRe "adaptado"

Conteúdo específico: Reações redox

\section{Tema gerador:}

1. O que você pretende que seus alunos aprendam sobre este conteúdo?

2. Porque é importante para os alunos saberem este conteúdo?

3. O que você mais você sabe sobre este conteúdo?

4. Quais são as dificuldades e limitações conectadas ao ensino deste conteúdo?

5. Que conhecimento sobre o pensamento dos estudantes influi em seu ensino deste conteúdo?

6. Que outros fatores influem no ensino deste conteúdo?

7. Que procedimentos você utilizaria para que os alunos compreendam esse conteúdo?

8. Que maneiras específicas você utilizaria para acompanhar o entendimento ou confusão dos alunos sobre este conteúdo?

Na aplicação do CoRe adaptado os licenciandos responderam em dupla, Antônio e Melissa, e em trio, Mateus, Elder e Clara (nomes fictícios). O pibidiano Mateus respondeu ao CoRe individualmente.

\subsubsection{Lembrança estimulada}

Objetivando fazer emergir o pensamento dos bolsistas sobre suas tomadas de decisão em sala de aula, adotou-se a Metodologia da Lembrança Estimulada (MLE) (FALCÃO; GILBERTO, 2005). Nesse sentido, os bolsistas foram convidados a assistir trechos das suas próprias aulas sobre o conteúdo redox. Durante a exibição foram aguçados a comentarem os aspectos: ação didática, linguagem empregada, relação pibidiano-aluno/supervisora/pibidiano, entre outros. A escolha pela MLE está pautada na possibilidade desse método propiciar a reflexão sobre a ação de cada pibidiano.

Em complementariedade à MLE solicitou-se que os pibidianos respondessem ao ciclo reflexivo de Smyth (MONTENEGRO; FERNANDEZ, 2015) em dois momentos: o primeiro antes de visualizarem suas regências, sendo os pibidianos orientados a recorrer às suas lembranças sobre as aulas do conteúdo reações redox; e o segundo depois de assistirem aos episódios das aulas referentes ao mesmo conteúdo (quadro 7). 
Quadro 7. Ciclo reflexivo de Smyth (1991)

\begin{tabular}{|c|l|}
\hline Ação & \multicolumn{1}{c|}{ Questão } \\
\hline Descrever & O que faço? \\
\hline Informar & Qual o significado das minhas ações? \\
\hline Confrontar & $\begin{array}{l}\text { Quem tem poder em minha sala de aula? A que interesse minha } \\
\text { prática está servindo? } \\
\text { Acredito nesses interesses ou apenas estou reproduzindo? }\end{array}$ \\
\hline Reconstruir & Como posso agir de forma diferente? \\
\hline
\end{tabular}

$\mathrm{Na}$ primeira ação, Descrever, os pibidianos descreviam os procedimentos adotados na sala de aula quando implementaram sua regência. Nessa etapa poderiam ser retomadas as lembranças relacionadas ao planejamento e à execução da aula, os objetivos delineados com cada atividade e as estratégias adotadas. Na sequência, em Informar, os pibidianos refletiam e situavam como eram realizadas as atividades, o motivo de suas escolhas, entre outros. Em Confrontar, os bolsistas refletiam se as ações implementadas ocorreram da forma planejada: as relações estabelecidas com os alunos, possíveis evidências de aprendizagem ou dificuldades. Na última etapa, Reconstruir, os bolsistas apontavam o reconhecimento dos pontos altos ou baixos da aula, considerando as ações anteriores propostas no ciclo, de modo a englobar possíveis melhorias em sua ação pedagógica.

\subsection{Metodologia de análise}

\subsubsection{Análise da revisão de literatura}

Pibid

A catalogação envolveu apenas as investigações que propuseram evidenciar entre os participantes (coordenadores, pibidianos e supervisores) os pertencentes a subprojetos da área de química. Na sequência, procedeu-se com a leitura na íntegra dos trabalhos inventariados segundo as proposições de Severino (2016). Essa leitura objetivou identificar os aspectos gerais dos estudos. Na sequência, procedeu-se a segunda leitura dos trabalhos, de modo a identificar as contribuições para o desenvolvimento profissional docente de pibidianos, supervisores e coordeandores.

\section{Reações redox}

Os trabalhos catalogados foram lidos na íntegra com o objetivo de analisar-se as dificuldades identificadas às limitações associadas ao ensino e aprendizagem de temas envolvendo oxirredução.

\subsubsection{Acesso ao Conhecimento Docente dos pibidianos}

Nesta investigação os dados coletados sobre os participantes do estudo ocorreu por meio de diferentes instrumentos, sugerindo uma gama considerável de possíveis dados, e para analisá-los adotou-se a análise de conteúdo como ferramenta. A análise 
de conteúdo surgiu no final da década de quarenta, mas seu conceito de maior impacto no ensino de ciências foi proposto na década de setenta por Bardin (2011, p.48):

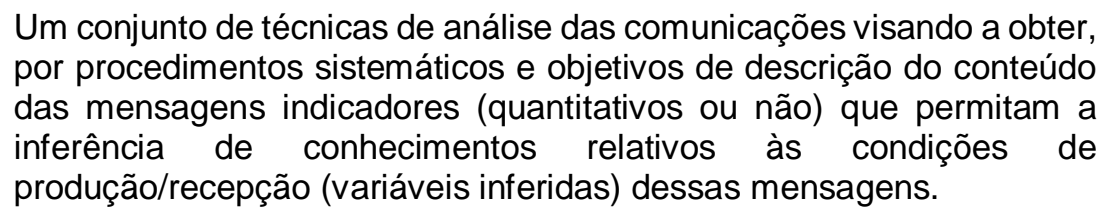

A conceituação apresentada pela autora revela que a análise de conteúdo é um conjunto de técnicas de análise que permite ao investigador romper com as incertezas, por meio de uma leitura aprofundada dos materiais coletados. O processo de esmiuçar os dados envolve algumas etapas que permitem ao pesquisador inferir significados aos mesmos. São inúmeras terminologias utilizadas para designar as etapas que constituem a análise de conteúdo (TRIVIÑOS, 1987), apesar de suas semelhanças. Contudo, optamos por adotar as etapas sugeridas por Moraes (1999) em pesquisas de ensino de ciências: 1. Preparação das informações; 2. Unitarização/transformação do conteúdo em unidades; 3. Categorização/classificação das unidades em categorias; 4. Descrição; 5. Interpretação. Segundo o autor apesar dessas etapas envolverem a análise qualitativa pode ser adotada em estudos quantitativos.

Posteriormente à transcrição dos registros audiovisuais e da organização de todos os materiais coletados durante a pesquisa, foi realizada a análise de conteúdo, adotando-se as categorias do modelo de Base de Conhecimentos Docente (GROSSMAN, 1990) em conjunto com as Categorias do modelo pentagonal (PARK; OLIVER, 2008b), transformando-o em um modelo híbrido como apresentado na figura 8. 


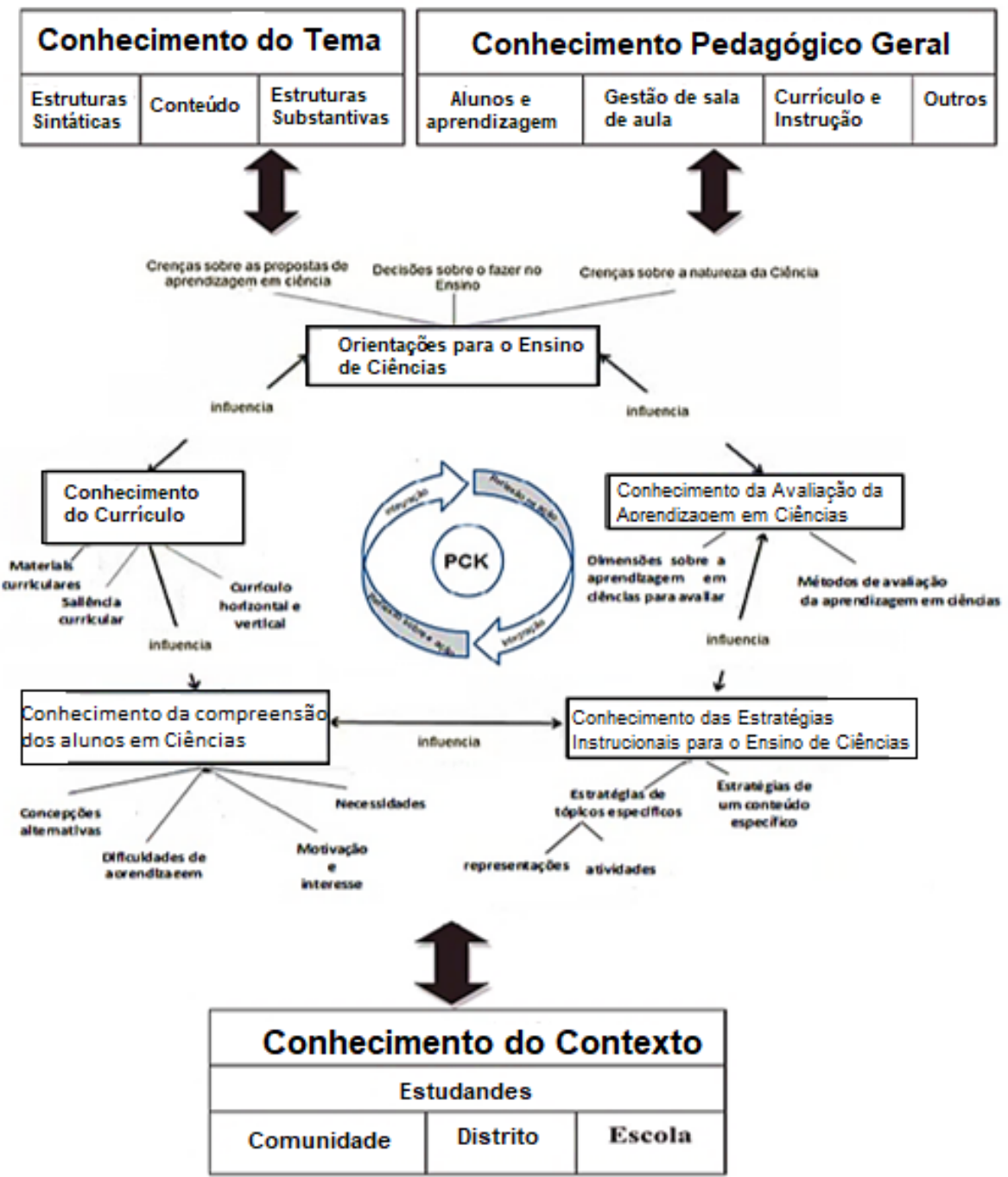

Figura 8. Categorias do Modelo Base em conjunto com as categorias do modelo pentagonal do PCK, um modelo híbrido

$\mathrm{Na}$ figura fica explícito que a categoria Conhecimento Pedagógico de conteúdo do Modelo Base, cedeu lugar ao Modelo Pentagonal de PCK de Park e Oliver (2008b). Nesse modelo no componente Conhecimento do Currículo acrescentou-se a saliência curricular, proposta no modelo hexagonal (PARK, OLIVER, 2008a). Segundo as autoras, Freire e Fernandez, (2014) os conhecimentos base não dependem de um conteúdo específico para emergir e independem da área de formação do professor. Por outro lado, o PCK emerge quando o docente ensina um conteúdo específico de uma disciplina. Nesse modelo híbrido acredita-se que a base de conhecimentos docentes, incluindo o PCK como um de seus componentes, irá sobressair-se principalmente na prática docente.

Na literatura sobre análise de conteúdo considera-se que seja fundamental que as categorias sejam excludentes, mas "[...] pode pôr-se em causa esta regra, com a condição de se adaptar o código de maneira a que não existam ambiguidades no momento dos cálculos (multicodificação)" (BARDIN, 2011, p. 149-150). Além disto, a Capítulo 3. Aspectos metodológicos 
pertinência das categorias deve refletir os objetivos das questões de investigação. Nesse sentido, considerou-se a sobreposição das categorias de análise adotadas como importantes para revelar a integração entre os componentes do Conhecimento Docente dos pibidianos. Para cada uma das categorias de análise descreve-se na sequência os aspectos que as delineiam.

Conhecimento do tema: engloba o conhecimento do conteúdo, os conhecimentos das estruturas substantiva e sintática (SCHWAB, 1964). A primeira contempla as estruturas conceituais reconhecidas em uma área do saber que orientam as investigações e fundamentam as disciplinas, a segunda representa os padrões estabelecidos por uma área, que orientam as pesquisas, permeando os aspectos epistemológicos adotados em uma área que validam novos conhecimentos. Essa distinção tênue na definição das estruturas talvez seja reflexo da pouca atenção dada por Grossman a esses conceitos. Os autores Bernal e Valbuena (2011) propuseram um esquema (figura 9) com os aspectos mais importantes das estruturas sintáticas e substantivas para o ensino de um conteúdo.

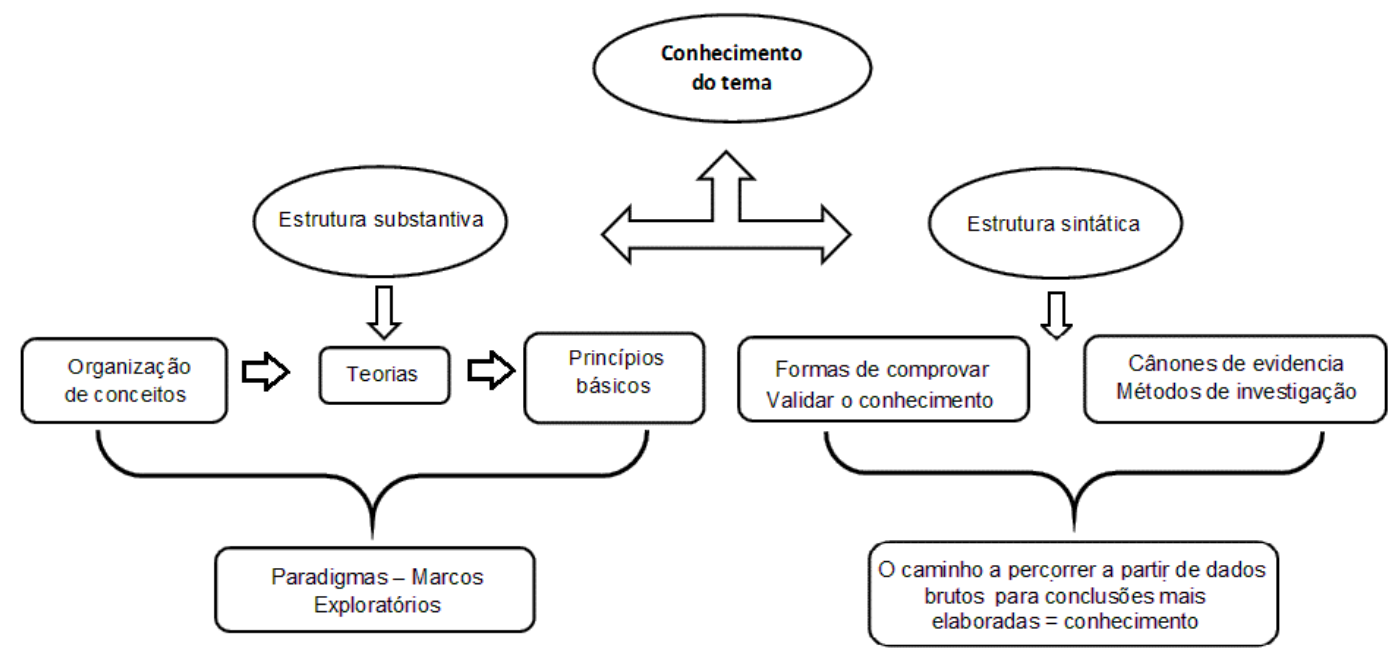

Figura 9. Elementos da estrutura sintática e substantiva do conhecimento do tema a ensinar (BERNAL; VALBUENA, 2011, p.302; tradução nossa)

$\mathrm{Na}$ figura 9 foi delineado que as estruturas substantivas e sintáticas representariam o conhecimento do professor sobre os referenciais epistemológicos que formalizam o conhecimento (BERNAL; VALBUENA, 2011). Desse modo, a estrutura substantiva configuraria os marcos epistemológicos que fundamentam a organização da disciplina influenciando as escolhas curriculares dos professores. Por outro lado, a estrutura sintática repousaria em saber como novos conhecimentos são incorporados à disciplina. A sua ausência limitaria a busca do professor por novos conceitos em sua área. Para Rozo (2012) a estrutura sintática, por meio do seu conjunto de regras, regeria as relações entre os elementos da estrutura substantiva pois, "Pressupõe, portanto, a 
especificidade de uma disciplina sobre a definição do que para ela é uma descoberta ou uma verificação, quais os critérios utilizados para medir a qualidade dos seus dados [...]" (p.32, tradução nossa).

Para tornar mais palpável esses conceitos evoca-se a definição de estrutura sintática e substantiva, proposta por Lozano para química verde:

Segundo o exposto, o pu (professor universitário) deve se perguntar ao planejar e ensinar a qv (química verde)/qa (química ambiental)/qs (química sustentável), o que ele sabe sobre isso: Para o substantivo, se conhece os princípios da qv, o que seria a química ambiental, ou a química sustentável ou uma educação ambiental, e como seria ensinada nos programas de lq (licenciatura em química), que conceitos e teorias estão envolvidos? Para o sintático, que procedimentos e métodos são mais adequados para abordar e alcançar os princípios da qv, como têm sido sua construção, que comunidades aceitam hoje a qv/qa/qs? O que quer que seus alunos da licenciatura aprendam e por que é importante que seus alunos saibam isso, o que pensa ele como professor que the faltaria saber para ensinar, quais dificuldades e limitações pensa ter como professor para ensiná-los (2015, p.173).

Para Grossman (1990) o domínio desse conhecimento influencia o professor em suas escolhas metodológicas e no seu desenvolvimento profissional. Em consonância, trabalhos relatados na literatura apontam que docentes tendem a ensinar o conteúdo que dominam (GROSSMAN; WILSON; SHULMAN, 1989).

Conhecimento pedagógico geral: representa o modo como o professor adota suas estratégias pedagógicas, organiza a gestão de sala de aula, o seu conhecimento do currículo e instrução, para que alcance os objetivos relacionados à aprendizagem de seus alunos. Seria um conhecimento que transcende os limites de uma disciplina específica.

Conhecimento do contexto: para Grossman (1990) esse conhecimento representaria a adaptação de um conteúdo às particularidades de um determinado contexto. Essa categoria é composta por quatro componentes: 1. Estudante, 2. Comunidade, 3. Distrito, e 4. Escola.

O componente estudante engloba o conhecimento do professor sobre seus alunos relacionados ao nível de escolaridade, suas características sociais, culturais e psicológicas. Em relação à Comunidade permeia os aspectos culturais e econômicos, nos quais a escola e a sua comunidade estão inseridas. Na sequência tem-se o Distrito, compreendido como o "[...] conhecimento do bairro no qual os professores trabalham, incluindo as oportunidades e as restrições impostas pelo bairro [...]" (GROSSMAN, 1990, p.9). O último componente Escola está relacionado com o conhecimento do professor sobre a cultura da escola, suas normas, o funcionamento administrativo e outros aspectos que influenciam diretamente a sua ação didática. 
Orientações para o ensino de ciências: nesta categoria temos as crenças do professor sobre as propostas e objetivos para ensinar ciências. Este domínio do conhecimento é formado pelas subcategorias:

- Crenças sobre as propostas de aprendizagem em ciências: permeia as orientações para o ensino de ciências (quadro 3 e 4);

- Decisões sobre fazer no ensino: englobam os caminhos escolhidos pelo professor durante suas ações didáticas no ensino de um conteúdo específico;

- Crenças sobre a natureza da ciência: como o docente concebe o desenvolvimento da ciência, como se apropria dos métodos de desenvolvimento científico para validar novos conhecimentos.

Esse conhecimento influencia não apenas o PCK, mas também o conhecimento base (FERNANDEZ, 2015).

Conhecimento do currículo em ciências: permeia o conhecimento do professor sobre materiais curriculares, delineia também o entendimento docente sobre a importância de um tópico específico em relação ao currículo. Esta categoria é constituída por três subcategorias:

- Materiais curriculares: o conhecimento sobre materiais e a sua adoção na construção das aulas como, por exemplo, vídeos, artigos e livros didáticos.

- Saliência curricular: denota os conceitos que o professor prioriza em relação ao conteúdo que está ministrando.

- Currículo horizontal e vertical: o horizontal está fundamentado na relação que o professor estabelece entre um conteúdo que está ministrando em uma disciplina, com conceitos que comporão outras regências ou ainda que podem ser objeto de ensino de outras disciplinas, enquanto o vertical estabelece a relação entre os conteúdos que serão objeto de ensino ao longo de um ano ou de um semestre para outro.

Conhecimento da compreensão dos alunos em ciências: representa o conhecimento do professor sobre os componentes:

- Concepções alternativas: permeia o conhecimento de concepções alternativas em relação ao conteúdo ensinado, que podem refletir na aprendizagem.

- Dificuldades de aprendizagem: delineia o conhecimento do professor acerca das concepções prévias dos discentes sobre um conteúdo, além do conhecimento dos conceitos não compreendidos pelos alunos.

- Motivação e interesse: delineia os conhecimentos que o docente têm sobre o que motiva e interessa os discentes.

Capítulo 3. Aspectos metodológicos 
- Necessidade: relacionadas às necessidades individuais ou coletivas de aprendizagem.

Conhecimento da avaliação da aprendizagem em Ciências: permeia o que o professor considera importante avaliar, inclui o conhecimento de métodos que podem aferir a aprendizagem (TACOSHI, FERNANDEZ, 2014). Esta categoria é constituída por duas subcategorias:

- Dimensões sobre a aprendizagem em ciências para avaliar: envolve o processo de verificação da aprendizagem do aluno em relação a certos conceitos que o docente considera importantes de serem avaliados, em relação a um conteúdo como um todo. Isso implica "[...] que as dimensões a serem avaliadas devem ser claras e previamente estabelecidas pelo professor, de modo que esta avaliação se mostre significativa" (LEAL; NOVAIS; FERNANDEZ, 2015, p. 734).

- Métodos de avaliação da aprendizagem em ciências: permeia os métodos de avaliação conhecidos pelo professor.

Conhecimento das Estratégias instrucionais para o ensino de ciências: engloba as estratégias adotadas pelo docente em suas aulas, que refletem seus objetivos educacionais para o ensino de ciências (MONTENEGRO; FERNANDEZ, 2015).

- Estratégias de um conteúdo específico: está relacionado ao conhecimento de estratégias para ensinar um conteúdo específico, denotando as estratégias gerais, que exprimem os objetivos educacionais

- Estratégias de tópicos: está relacionada às estratégias para ensinar um tópico específico, que compõe um domínio da ciência.

\subsubsection{Análise dos impactos do Pibid na formação das tutoras}

Adotou-se as categorias do Conhecimento Docente para mapear os conhecimentos para a docência que integravam as narrativas da coordenadora e supervisora destinadas à orientação dos pibidianos. Para analisar os possíveis impactos do Pibid foram eleitas categorias emergentes.

\section{Análise dos dados por meio do Atlas.ti}

Para analisar a construção do conhecimento docente dos pibidianos em suas trajetórias no Pibid, considerou-se pertinente analisar em que contextos (reuniões com as tutoras, sala de aula, entrevista, entre outros) emergiam as categorias do Conhecimento Docente. De modo semelhante procedeu-se a análise dos impactos do Pibid na formação da coordenadora e supervisora. Para tanto, adotou-se como recurso 
o Atlas.ti, que é um software de análise qualitativa para grandes volumes de dados fotográficos, vídeos, áudios e textos que permite estabelecer relações entre os documentos coletados e as categorias de análise (KLÜBER, 2014).

A primeira versão do programa foi lançada comercialmente em 1993, sendo usado principalmente naquela época, por estudiosos da Grounded Theory (KLÜBER, 2014). Ao longo dos anos pesquisadores que fundamentam seus estudos na análise de conteúdo passaram a adotar o programa. Desde o seu lançamento foram diversas as versões lançadas. Neste estudo a versão utilizada foi o Atlas.ti 8.0 (licença estudante). Nesses lançamentos são mantidos seus componentes principais, descritos no quadro 8.

Quadro 8. Descrição dos principais componentes do Atlas.ti

\begin{tabular}{|c|c|}
\hline Componentes & Descrição \\
\hline Unidade Hermenêutica & $\begin{array}{l}\text { São os projetos desenvolvidos pelo pesquisador e que } \\
\text { podem ou não estar associados ao nome do documento } \\
\text { analisado. Nessa unidade estão todos os demais } \\
\text { componentes do programa (primary documents, codes, } \\
\text { quotations, memos, etc.) e os resultados das análises } \\
\text { que podem gerar os relatórios. }\end{array}$ \\
\hline $\begin{array}{l}\text { Documentos primários (primary } \\
\text { documents) }\end{array}$ & $\begin{array}{l}\text { Representam os documentos coletados pelo } \\
\text { pesquisador e que podem ser inseridos no programa. } \\
\text { Esses documentos podem estar em diferentes formados } \\
\text { (pdf, jpg, doc, etc.). }\end{array}$ \\
\hline Codificando (Codes/Coding) & Representação das categorias de análise \\
\hline Citações (Quotations) & $\begin{array}{l}\text { São os códigos de análise. Representam as } \\
\text { classificações dos trechos selecionados na análise e que } \\
\text { o pesquisador considerou importante. }\end{array}$ \\
\hline Anotações (Memos) & $\begin{array}{l}\text { Referem-se às anotações do pesquisador sobre as } \\
\text { análises realizadas. Essas anotações geralmente são } \\
\text { anotações de campo, associações entre os dados e as } \\
\text { categorias, possíveis lembranças do pesquisador sobre } \\
\text { referenciais e que podem contribuir na fundamentação } \\
\text { de sua análise, possíveis conclusões, entre outros } \\
\text { aspectos. }\end{array}$ \\
\hline Famílias (Families) & $\begin{array}{l}\text { As famílias podem ser compreendidas como o } \\
\text { agrupamento dos demais itens (códigos, documentos, } \\
\text { anotações, etc.). Por exemplo, ao realizarmos o registro } \\
\text { audiovisual de aulas dos grupos pibidianos e professores } \\
\text { experientes, seria possível separar os participantes em } \\
\text { duas famílias: professores experientes e professores em } \\
\text { formação. }\end{array}$ \\
\hline Redes (Networks) & $\begin{array}{l}\text { As redes são as associações gráficas entre os } \\
\text { componentes de análise, que facilitam a visualização das } \\
\text { relações entre as categorias. }\end{array}$ \\
\hline
\end{tabular}

Para análise dos documentos, inicialmente foi criada a Unidade Hermenêutica, para cada participante da pesquisa. Nessa unidade, foram inseridos os documentos coletados (documentos primários) na pesquisa e, na sequência foram criadas as categorias (codes) que fundamentam a análise. Ao serem inseridos os documentos primários, o software os enumera automaticamente. Para classificar os trechos 
selecionados (quotations), arrasta-se a categoria ao período selecionado. Um mesmo trecho pode ser classificado em diferentes codes, o que permite analisar a integração entre os componentes do Conhecimento Docente. Nos codes, o pesquisador pode unilos em famílias ou subcategorias. Não foi realizada a etapa Redes no software, preferiuse criá-las manualmente em outro programa. Posteriormente, foi gerado no Atlas.ti os relatórios das análises feitas pelo pesquisador relacionados:

- Ao número total de categorias do conhecimento docente presentes em cada documento analisado.

- Ao número de coocorrências entre as categorias do Conhecimento Docente.

- À emersão do Conhecimento Docente no contexto de sala de aula.

Por meio dos relatórios gerados pelo programa pode-se realizar inferências sobre a construção do conhecimento docente dos pibidianos ao longo de suas experiências no programa institucional de iniciação à docência e sobre a influência das tutoras nessa construção.

\subsubsection{Análise do Instrumento de Percepção}

Com relação ao instrumento de percepção dos alunos acerca do conhecimento docente dos pibidianos, realizou-se a sua análise por um viés quantitativo e qualitativo. O método quantitativo permeou a análise estatística do tipo exploratória (média, mediana, variância e desvio padrão) e do Alfa de Cronbach.

$O$ alfa possibilita inferir o grau de confiança nos dados obtidos pelo instrumento adotado (VIEIRA, 2009). A confiabilidade é compreendida como a análise dos resultados obtidos e como essa reflete a realidade (HAYES, 2008). Neste estudo adotou-se o Alfa de Cronbach para análise da confiabilidade do questionário (BLACKER; ENDICOTT, 2002). Essa ferramenta possibilita também inferir, a partir dos valores obtidos, o grau de correlação entre as questões que compõem o questionário (STREINER, 2003). O coeficiente a é dado por:

$$
\alpha=\frac{k}{k-1}\left[\frac{\sigma_{\tau}^{2}-\sum_{i=1}^{k} \sigma_{i}^{2}}{\sigma_{\tau}^{2}}\right]
$$

A variância de cada coluna de $X$ é representada por $\sigma_{\ell}^{2}$, enquanto que a variância da soma de cada linha de $\mathrm{X}$ por $\sigma_{\tau}^{2}$. O valor de $k$ deve ser maior do que 1 para que 0 denominador seja diferente de zero e $n$ deve ser maior do que 1 , a fim de ser diferente de zero no denominador do cálculo $\sigma_{\ell}^{2}$ e a $\sigma_{\tau}^{2}$. Caso haja consistência nas respostas $\sigma_{\tau}^{2}$ será grande e $\alpha$ tenderá a 1 . Por outro lado, caso as respostas sejam aleatórias 0 $\sigma_{\tau}^{2}$ seria comparável com a soma dos desvios individuais $\left(\sigma_{\ell}^{2}\right)$, o que levaria o $\alpha$ a tender a zero (LEONTITSIS; PAGGE, 2007). 
Para transformar as respostas concedidas no instrumento em dados quantitativos, esses foram organizados em consonância com a proposta dos autores Cronbach e Shavelson (2004) para calcular o alfa. Desse modo, no quadro 9 está ilustrado a organização dos dados, em que cada coluna indica um respondente e a sua resposta para cada item.

Quadro 9. Organização dos dados para o cálculo do alfa

\begin{tabular}{|c|c|c|c|c|c|c|c|c|c|c|c|c|c|c|c|c|c|c|c|c|c|c|c|c|c|c|c|c|c|}
\hline Aluno & \multicolumn{7}{|c|}{$\mathrm{CT}$} & \multicolumn{7}{|c|}{ RCE } & \multicolumn{7}{|c|}{ OEC } & \multicolumn{7}{|c|}{ CCE } & \multirow[t]{2}{*}{ Soma } \\
\hline & 1 & 2 & 3 & & & 6 & 7 & 1 & \begin{tabular}{|l|}
2 \\
\end{tabular} & 3 & \begin{tabular}{l|l|}
4 \\
\end{tabular} & 5 & 6 & 7 & 1 & 2 & 3 & & & \begin{tabular}{|c|}
6 \\
\end{tabular} & 7 & \begin{tabular}{|l|}
1 \\
\end{tabular} & 2 & \begin{tabular}{|l|}
3 \\
\end{tabular} & 4 & & & 7 & \\
\hline 1 & 5 & 4 & 5 & 5 & 4 & 5 & 5 & 5 & 5 & 5 & 5 & 5 & 4 & 5 & 5 & 5 & 5 & 5 & 5 & 5 & 5 & 5 & 4 & 5 & 5 & 5 & 5 & 5 & 136 \\
\hline 2 & 5 & 4 & 5 & 4 & 5 & 0 & 5 & 5 & 1 & 5 & 5 & 4 & 4 & 0 & 5 & 5 & 4 & 3 & 5 & 0 & 5 & 3 & 3 & 0 & 0 & 5 & 0 & 5 & 95 \\
\hline 3 & 4 & 4 & 3 & 5 & 5 & 4 & 4 & 5 & 4 & 5 & 5 & 4 & 4 & 4 & 4 & 5 & 5 & 4 & 5 & 5 & 5 & 4 & 4 & 4 & 5 & 5 & 4 & 5 & 124 \\
\hline 4 & 5 & 3 & 4 & 0 & 3 & 2 & 2 & 3 & 5 & 3 & 2 & 3 & 3 & 2 & 4 & 3 & 3 & 3 & 2 & 2 & 1 & 5 & 4 & 3 & 3 & 2 & 2 & 2 & 79 \\
\hline 5 & 5 & 5 & 5 & 4 & 5 & 3 & 4 & 5 & 4 & 5 & 5 & 5 & 4 & 4 & 5 & 4 & 5 & 3 & 2 & 4 & 5 & 3 & 2 & 3 & 4 & 4 & 5 & 2 & 114 \\
\hline 6 & 3 & 3 & 3 & 4 & 3 & 4 & 4 & 4 & 4 & 4 & 4 & 4 & 4 & 4 & 3 & 4 & 4 & 4 & 4 & 4 & 4 & 4 & 3 & 4 & 3 & 4 & 4 & 4 & 105 \\
\hline 7 & 4 & 3 & 3 & 4 & 4 & 3 & 5 & 5 & 4 & 4 & 5 & 2 & 4 & 5 & 5 & 5 & 2 & 2 & 3 & 3 & 4 & 2 & 2 & 3 & 3 & 4 & 3 & 3 & 99 \\
\hline 8 & 4 & 3 & 4 & 5 & 4 & 4 & 4 & 5 & 5 & 4 & 5 & 5 & 3 & 3 & 4 & 5 & 4 & 4 & 5 & 4 & 5 & 4 & 3 & 4 & 4 & 4 & 4 & 4 & 116 \\
\hline 9 & 5 & 3 & 4 & 4 & 4 & 5 & 4 & 4 & 3 & 3 & 5 & 4 & 4 & 2 & 4 & 5 & 4 & 4 & 3 & 4 & 4 & \begin{tabular}{|l|}
5 \\
\end{tabular} & 4 & 4 & 3 & 3 & 4 & 5 & 110 \\
\hline 10 & 4 & 4 & 3 & 4 & 4 & 3 & 4 & 4 & 4 & 3 & 3 & 3 & 3 & 2 & 3 & 4 & 4 & 4 & 4 & 4 & 3 & 3 & 3 & 3 & 3 & 4 & \begin{tabular}{|l|l|}
3 \\
\end{tabular} & 4 & 97 \\
\hline 11 & 3 & 3 & 3 & 4 & 3 & 4 & 4 & 3 & 2 & 2 & 3 & 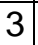 & 3 & 2 & 4 & 5 & 2 & 3 & 4 & 3 & 4 & 2 & 1 & 1 & 1 & 4 & 3 & 3 & 82 \\
\hline 12 & 4 & 5 & 5 & 5 & 4 & 5 & 5 & 4 & 4 & 4 & 5 & 5 & 3 & 3 & 5 & 5 & 5 & 4 & 3 & 4 & 5 & 5 & 4 & 4 & 5 & 5 & 5 & 5 & 125 \\
\hline 13 & 5 & 5 & 5 & 4 & 4 & 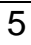 & 5 & 4 & 4 & 3 & 5 & 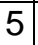 & $\mathbf{T}$ & 4 & 4 & 5 & 3 & $v$ & 5 & 5 & 5 & \begin{tabular}{|l|}
3 \\
\end{tabular} & 3 & 4 & 4 & 4 & 4 & 4 & 118 \\
\hline
\end{tabular}

Conhecimento do tema (CT), Representação do conteúdo e estratégias para seu ensino (RCE), Objetivo educacional e do contexto (OEC) e Conhecimento das compreensões dos estudantes (CCE)

$\mathrm{Na}$ sequência, adotou-se a fórmula descrita anteriormente para calcular o alfa, em que o valor da variância de cada item ( $\sigma_{l}^{2}$ - linha vertical) e a soma das respostas de cada participante $\left(\sigma_{\tau}^{2}\right.$ - horizontal), determinam o seu valor, como podemos observar abaixo:

$$
\propto=\frac{28}{28-1} \llbracket \frac{285,73-32,28}{285,73} \rrbracket
$$

$$
\propto=0,92
$$

$\mathrm{Na}$ literatura não há uma concordância acerca do valor do alfa na análise da confiabilidade de um questionário. Nesse sentido, o limite inferior a 0,7 é aceito e outros estudos consideram 0,6 para pesquisas exploratórias (HAIR JUNIOR et al., 2005; SANTOS, 1999; HAIR, 2005; LANDIS; KOCH, 1977; VIEIRA, 2009). Os autores (MALHOTRA, 2011; FREITAS; RODRIGUES, 2005) sugerem uma classificação para os valores de alfa, apresentados no quadro 10.

Quadro 10. Classificação dos valores de Alfa de Cronbach

\begin{tabular}{|c|c|c|c|c|c|}
\hline Confiabilidade & Muito baixa & Baixa & Moderada & Alta & Muito alta \\
\hline Valor de Alfa & $\alpha<0,30$ & $0,30 \leq \alpha<$ & $0,60 \leq \alpha<$ & $0,75 \leq \alpha<$ & $0,90 \leq \alpha$ \\
de Cronbach & & 0,60 & 0,75 & 0,90 & \\
\hline
\end{tabular}

A descrição do cálculo de Alfa Cronbach foi realizada, pois considerou-se pertinente ilustrar a transformação das respostas concedidas pelos estudantes da educação básica em valores quantitativos. Os cálculos foram realizados usando 0 programa Excel® como ferramenta. 


\section{CAPÍTULO 4. RESULTADOS E DISCUSSÕES}

Inicialmentte dispõe-se a revisão de literatura acerca do Pibid e seus impactos na formação de professores e das limitações associadas ao ensino redox mapeados nos eventos científicos nacionais e internacionais. Posteriormente, apresenta-se os resultados sobre o Conhecimento Docente de Antônio, Melissa e Mateus.

\subsection{Revisão de literatura}

Pibid e o desenvolvimento profissional docente

Os trabalhos foram mapeados por meio da busca de estudos que permeassem as palavras-chave: Pibid, bolsista de iniciação à docência (ID) e/ou iniciação à docência, nos campos: título, resumo, palavras-chave e agradecimentos. Foram catalogados 57 trabalhos (12 RASBQ, 5 EPPEQ $^{5}, 34$ ENEQ e 6 ENPEC). Na tabela a seguir estão distribuídas as investigações ao longo dos anos analisados.

Tabela 3. Distribuição dos trabalhos por evento no período de 2008 a 2016

\begin{tabular}{cccccc}
\hline Ano & RASBQ & ENPEC & EPPEQ & ENEQ & Total \\
\hline 2008 & 0 & - & - & 0 & 0 \\
\hline 2009 & 0 & 0 & 0 & - & 0 \\
\hline 2010 & 0 & - & - & 0 & 0 \\
\hline 2011 & 5 & 1 & 2 & - & 8 \\
\hline 2012 & 1 & - & - & 10 & 11 \\
\hline 2013 & 1 & 4 & 3 & - & 8 \\
\hline 2014 & 1 & - & - & 12 & 13 \\
\hline 2015 & 3 & 1 & - & - & 4 \\
\hline 2016 & 1 & - & - & 12 & 13 \\
\hline
\end{tabular}

Como é possível observar o evento com maior número de pesquisas que analisaram o impacto do Pibid na formação do pibidiano, coordenador e supervisor foi o ENEQ. Nas duas últimas edições do evento houve recorde de trabalhos inscritos e aceitos, o que talvez tenha refletido em um número maior de pesquisas relacionadas à temática. Nos trechos a seguir apresentaremos os impactos do Pibid na formação da tríade relatados pelos pesquisadores.

Lima (2011) objetivou analisar a percepção dos pibidianos sobre a colaboração entre a universidade e a educação básica. Para tanto, aplicou um questionário a um grupo de bolsistas. Os resultados denotam que os licenciandos reconhecem o programa como um espaço que os possibilita compreender o futuro ambiente profissional e desenvolver o senso crítico e autonomia, pois “[...] a vida numa sala de aula exige muita dinâmica, concentração, domínio do conteúdo e que devem saber preparar atividades capazes de gerar aprendizagem efetivas" (LIMA, 2011, p.1).

\footnotetext{
${ }^{5}$ Não foi possível acessar os anais do ano de 2015. 
Afonso e colaboradores (2011) investigaram a influência do supervisor na formação de licenciandos bolsistas do Pibid. Os instrumentos de coleta de dados foram: questionário, entrevistas com os pibidianos e reuniões com a professora da escola e os bolsistas. $\mathrm{Na}$ análise do material coletado evidenciou-se que o contato com a supervisora levou os pibidianos a refletirem sobre a prática, e proporcionou uma maturidade em lecionar.

Oliveira e colaboradores (2011) relataram as contribuições do Pibid na formação inicial de licenciandos por meio da análise das atividades desenvolvidas em um subprojeto. Nesse sentido, seus autores acompanharam todas as atividades desenvolvidas em um subprojeto. Os resultados apontam que o programa institucional figurou como um espaço de vivência, no qual o licenciando tem a oportunidade de vivenciar o espaço escolar durante a sua formação, orientado por professores experientes. Além disto, o licenciando bolsista pode refletir sobre a sua ação didática e sua profissionalização ainda na graduação.

Matos, Chagas e Takata (2011) analisaram os impactos dos primeiros meses do projeto de iniciação à docência da UniCentro na formação de licenciandos em química. Foram realizadas entrevistas semiestruturadas com ex-pibidianos e futuros bolsistas. Nas entrevistas os ex-bolsistas argumentaram que o Pibid tem oportunizado a sua vivência no espaço escolar e estimulado a criatividade no planejamento das aulas. Em relação aos futuros bolsistas, indicam que o programa de iniciação à docência possibilita que professores em formação auxiliem os professores da educação básica nas aulas. Em um dos relatos um ex-bolsista argumenta: "Após esses meses de projeto, consigo ter outra visão quando for preparar minha aula" (MATOS; CHAGAS; TAKATA, 2011, p.1).

Santos e Lorenzo (2011) investigaram a contribuição do Pibid na formação de licenciandos em química. Para tanto, aplicaram um questionário aos pibidianos. $\mathrm{Na}$ percepção dos bolsistas as contribuições do Pibid estavam embutidas em uma maior participação dos bolsistas em eventos científicos. Quando os pibidianos foram questionados "Você recomenda a participação dos colegas no Pibid? Resultado: 79\% recomendam esse programa" (SANTOS, LORENZO, 2011, p.1). O autor não traz no texto muitos dados que permitam esmiuçar os objetivos de sua investigação. Por fim, os autores concluem que a principal contribuição do subprojeto foi na formação acadêmica dos bolsistas. Nesse sentido, Silva e colaboradores (2012) analisaram as contribuições das atividades desenvolvidas no interior de um subprojeto para a formação profissional de seus bolsistas. Os autores apresentam em suas discussões que os bolsistas têm nota final nas disciplinas pedagógicas da licenciatura $20 \%$ maior que a média da turma, reflexo da união da teoria e prática, proporcionada pelo Pibid. A Capítulo 4. Resultados e Discussões 
frequência nas aulas de graduação dos bolsistas aumentou, quando comparado com os anos anteriores em que não estavam vinculados ao programa. Além do que, o desempenho nas disciplinas ditas "exatas" também tem melhorado.

Fadigas (2013) desenvolveu um estudo sobre a importância do Pibid para os discentes do curso de Licenciatura em Química de um Centro de Formação de Professores situado no Recôncavo da Bahia. Foi aplicado um questionário a todos os bolsistas do subprojeto de química do Pibid/2009. Desse subprojeto participavam 09 bolsistas, 02 professores supervisores e 03 escolas estaduais de Ensino Médio. Segundo os bolsistas, o programa auxiliou na formação acadêmica em virtude da participação em eventos acadêmicos e na construção de suas identidades de professor.

Souza e colaboradores (2014) analisaram a formação dos bolsistas em dois ambientes: a sala de aula e em uma oficina didática. Segundo os autores:

A falta de experiência dos bolsistas no manejo da sala de aula os levava, no confronto da experiência obtida com os dois ambientes de prática pedagógica, a considerar a sala de aula como o lugar da mera transmissão de conhecimentos e as oficinas didáticas como o lugar da mediação do conhecimento para os alunos, a qual envolvia a leitura de textos e a experimentação [...] (SOUZA et al., 2014, p.1).

Os pibidianos argumentam que a vivência no Pibid ampliou o repertório de saberes docentes (SOUZA et al., 2014).

Vogel e Rezende (2015) mapearam as marcas deixadas pelas atividades de formação no contexto do Pibid. Nesse sentido, os autores buscaram apresentar a distribuição de termos mais importantes das árvores máximas de similitude de dois grupos (63 bolsistas do Pibid-QUÍMICA e 56 não bolsistas). Na árvore de similitude a experimentação aparece como palavra com maior conectividade, denotando que a experimentação era a base de sustentação dos projetos desenvolvidos no subprojeto Pibid-Química. Por outro lado, a palavra "paciente" foi a que apresentou maior conectividade na árvore dos não bolsistas, sugerindo que os participantes percebiam a profissão professor como um dom. Para os autores o Pibid tem possibilitado que seus bolsistas reestruturem suas concepções do que é ser professor.

Herber e colaboradores (2015) acompanharam e analisaram a possível contribuição das atividades desenvolvidas em um subprojeto na formação docente dos licenciandos. Para coleta de dados, foram observadas as reuniões de grupo registradas em diário de campo, realizadas entrevistas semiestruturadas e aplicados questionários. Para os bolsistas a participação no Pibid tem propiciado experiência profissional e o convívio com os alunos, que seria possível somente no estágio supervisionado. Segundo os pibidianos a participação no programa tem influenciado na escolha 
profissional, no contato com diversas metodologias de ensino e na percepção que os conteúdos químicos devem ser adequados ao contexto escolar.

Paganini, Gomes e Ponzoni (2015) avaliaram o impacto de um subprojeto na vida acadêmica e profissional de pibidianos e ex-pibidianos. Os autores adotaram um questionário enviado por meio eletrônico e respondido por 23 participantes. Desse total

[...] $78,3 \%$ apontaram a obtenção de experiência docente como principal motivo para ingressar no projeto, $8,7 \%$ para melhoria do currículo, $8,7 \%$ para confirmar a escolha profissional e 4,3\% pelo auxílio financeiro; a principal colaboração do Pibid na sua formação para $65,3 \%$ dos entrevistados foi o conhecimento do cotidiano das escolas, principalmente o contato com alunos do Ensino Básico [...] Quanto à influência na escolha profissional, $87 \%$ dos bolsistas afirmam que o Pibid ajudou nessa escolha (PAGANINI; GOMES; PONZONI, 2015, p.1).

Beltrame e colaboradores (2016) analisaram a motivação dos pibidianos ao ingressarem no Pibid. Em consonância, foi aplicado um questionário a bolsistas e exbolsistas. Nas respostas, grande parte dos pibidianos argumentou que o Pibid é um espaço de aperfeiçoamento profissional. Outro participante discorreu que "Pelo fato de estar em um curso de licenciatura para me formar e seguir carreira como professor, uma melhor formação e melhora curricular devem ser constantes, me fazendo assim aderir ao projeto" (BELTRAME et al., 2016, p.1). Outros aspectos apontados estão relacionados à aproximação com a produção acadêmica e a experiência profissional.

Fernandes, Mendonça e Gomes (2011) apesar de terem como objetivo principal investigarem a evolução das ideias sobre experimentação, também analisaram as contribuições do Pibid na formação de seus bolsistas. Nessa perspectiva, coletaram seus dados por meio de questionário, entrevista semiestruturada, relatórios e carta. Em relação ao segundo objetivo, os dados revelaram que o Pibid estimulou à docência e à permanência na licenciatura.

Massena (2013) realizou um estado da arte entre os anos de 2009 a 2012 sobre o Pibid em dois encontros nacionais: Encontro Nacional de Pesquisa de Educação em Ciências (ENPEC, 2009 e 2011) e Encontro Nacional de Didática e Prática de Ensino (ENDIPE, 2010 e 2012). As categorias de análise foram:

1) a Formação de professores; e o 2) Desenvolvimento profissional. Dessas duas categorias, emergiram subcategorias a partir das análises dos textos. No caso da Formação de professores foram identificadas quatro (4) subcategorias: a) Formação inicial: a influência do Programa na formação dos licenciandos; b) Formação continuada: a influência do Programa no desenvolvimento dos professores da escola; c) Estágio: compreender a relação entre o estágio e o Pibid e como o primeiro influencia na formação inicial, após a experiência no Programa; e d) Políticas: como o Programa vem funcionando enquanto política educacional (MASSENA, 2013, p.5). 
As pesquisas retratavam principalmente os impactos do Pibid na formação inicial por influenciar os bolsistas a seguirem a carreira docente e a melhoria de suas ações didáticas. Os trabalhos desses encontros também buscaram elucidar as contribuições do programa na formação continuada dos supervisores, que estavam associadas principalmente ao subsídio que recebiam dos licenciandos na sua prática docente. Não há menção à formação continuada dos coordenadores.

Sandri e Terrazzan (2013) caracterizaram a prática de supervisão no Pibid. Para tanto, os autores realizaram entrevistas com supervisoras. Os dados foram analisados por meio das categorias: Orientação no Planejamento e Avaliação das Atividades; Estabelecimento de um trabalho de integração; Incentivo para a docência; Estabelecimento de um bom clima afetivo-relacional; e Auxílio na resolução de problemas. Algumas ações figuram como práticas colaborativas. Segundo os autores, a partir dos dados analisados, o supervisor tem o papel de co-formador do licenciando ao facilitar o desenvolvimento e a aprendizagem do pibidiano.

Siqueira, Massena e Brito (2013) analisaram as contribuições do Pibid na construção da identidade e saberes docentes de pibidianos dos cursos de biologia, química e física. Para a coleta de dados os pibidianos responderam um questionário com questões abertas, para que os bolsistas pudessem refletir sobre suas experiências no programa de iniciação à docência. Os pibidianos reconheciam o valor da profissão professor, ao romperem com uma percepção rasa do ensino:

Sim, o Pibid me mostrou um lado escolar que eu não conhecia, pois
muito se fala de uma escola desatualizada e devastada e o Pibid vem
para romper com esse paradigma, mostrando que é capaz de existir
uma escola de qualidade" (Q16); [...] existem pessoas necessitando de
um professor que esteja orientando, educando e passando
conhecimento, para que no futuro ele [o aluno] possa se tornar um
excelente profissional (B15) (SIQUEIRA; MASSENA; BRITO, 2013,
p.5).

Para mais, demonstram um amadurecimento na graduação, pois segundo um bolsista "[...] antes eu não tinha a visão da necessidade dos textos pedagógicos, achava chatos e cansativos. Hoje entendo a importância de tais textos para a docência, pois cada um tem uma essência que nos ajuda e muito na prática docente" (SIQUEIRA; MASSENA; BRITO, 2013, p.6). Em outros momentos relatam que o Pibid influenciou na sua permanência na licenciatura.

Outros autores (CAMARGO; SILVA; OLIVEIRA, 2013) buscaram analisar as contribuições de um subprojeto na construção dos saberes necessários à prática educativa tendo como referencial teórico Paulo Freire. Para tanto, foram analisados os relatórios semestrais de 12 bolsistas. Os resultados apontam que: 
[...] os licenciandos já conseguem identificar uma parcela significativa dos saberes necessários para a formação docente em termos quantitativos. Em termos qualitativos a análise revela [...] a carência da percepção dos licenciandos indicando uma compreensão parcial do trabalho docente [...] (CAMARGO; SILVA; OLIVEIRA, 2013, p.4).

Em outro trecho um bolsista relata as contribuições do programa para a sua formação:

O projeto possibilita um contato com uma realidade que só se pode conhecer atuando diretamente dentro dela. As peculiaridades pertencentes à escola em questão, à realidade do ensino médio público, os sujeitos envolvidos nessa trama, as relações existentes, os bastidores (sala de professores, diretoria). No tocante à evolução pedagógica pessoal, ela acontece no contato com os alunos, na exposição a situações inéditas e com a reflexão póstuma sobre a atitude adotada neste momento (CAMARGO; SILVA; OLIVEIRA, 2013, p.5).

Para outro pibidiano o Pibid é um espaço que tem possibilitado a formação de professores comprometidos com a aprendizagem dos educandos.

Silva Júnior e Prado (2015) avaliaram possíveis indícios do Pibid na prática docente de egressos dos cursos de licenciatura em química e biologia. Foram realizadas entrevistas com os licenciandos e informações compartilhadas por coordenadores de cada subprojeto. No estudo foi possível evidenciar que o Pibid influencia na escolha dos ex-bolsistas por atuarem na educação básica. Ademais, os pibidianos apontam que o programa possibilitou a vivência no espaço escolar não oportunizado pelo estágio.

Afonso e colaboradores (2011) analisaram relatos confeccionados por bolsistas do programa de iniciação à docência, com o objetivo de compreender as experiências desses licenciados em dois cenários: o estágio supervisionado e o Pibid. Na percepção dos pibidianos, apesar do estágio ser uma etapa importante na sua formação, geralmente as atividades desenvolvidas permeiam principalmente a observação de aulas e consequentemente não conseguem conhecer o espaço escolar. Por outro lado, o Pibid tem proporcionado o trabalho colaborativo com professores, criando oportunidades de troca de experiências entre todos os envolvidos.

Nakanishi e Altarugio (2011) realizaram uma entrevista com uma professora supervisora. Segundo as autoras:

A partir do depoimento da professora tentamos levantar possíveis fatores que têm contribuído para o aparente sucesso da parceria estabelecida entre ela e o grupo de alunos e seus reflexos sobre sua própria aprendizagem, dos bolsistas e dos alunos da escola [...] (p. 132).

Nos resultados a supervisora relata que o Pibid contribuiu para a sua formação em virtude de proporcionar novas experiências metodologia e repensar a sua prática, como denota o trecho abaixo: 
Acaba a mesmice. Em uma das atividades que você [a coordenadora] chamou a atenção deles [dos bolsistas] porque a atividade que eles estavam aplicando era a mesma do ano passado, aquilo foi um puxão de orelha pra mim também. Realmente, acabei pensando: às vezes a gente já tem aquela atividade pronta e não se dá o trabalho de mexer em nada. O conteúdo pode ser o mesmo, mas a forma tem que mudar (NAKANISHI; ALTARUGIO, 2011, p.133).

Infere-se que a questão da "mesmice" que reflete na aplicação da mesma aula, seja talvez reflexo do número de horas aulas que o docente trabalho, que o impossibilita ter espaço no para desenvolver um plano de ensino em consonância com o contexto em que trabalha.

Para a supervisora a sua orientação tem contribuído na formação dos licenciandos em virtude de sua preocupação com a educação e as atividades desenvolvidas pelos bolsistas. Para a docente a inserção de licenciandos no Pibid contribui para um melhor enfrentamento da realidade escolar e acerca da própria profissão (NAKANISHI; ALTARUGIO, 2011).

Outro resumo traz a reflexão de uma bolsista sobre o trabalho integrado e quais as contribuições do Pibid para a sua formação (CAMPOS et al., 2013). Nos resultados os autores discorrem que a oportunidade de vivenciar duas formas de organização curricular (interdisciplinar e disciplinar) possibilita aos bolsistas compreenderem as potencialidades para a sua formação ao estruturarem aulas interdisciplinares.

Santos e Arroio (2013) investigaram as contribuições do Pibid na formação de seus bolsistas em relação à sua formação, à aprendizagem na prática em sala de aula e ao trabalho em grupo. Para tanto, foram realizadas entrevistas com os bolsistas. Os pibidianos argumentam que no contexto do Pibid colocam em prática o que aprenderam na licenciatura e também no interior do subprojeto. E que o desenvolvimento das aulas em grupo possibilita a troca de experiências. Os pibidianos ao argumentarem sobre as possíveis lacunas na formação preenchidas pelo Pibid discorrem:

[...] eu estou dentro de uma escola pública, conhecendo uma realidade que era super distante pra mim (...) entender que eles já passaram por outras experiências e que não estão tão abertos ao ensino, ao conhecimento, como a licenciatura diz, mas que você tem que conquistar isso neles, tem que seduzir eles ao conhecimento.

Esse projeto mostra a prática, mostra que a prática é difícil, mas ela é possível e tem como dar uma saída pela tangente, conseguir fazer o que a gente tem que fazer: fazer o aluno participar e ao mesmo tempo você pegar o conhecimento e entender o que é para fazer.

O projeto dá a parte prática né, acho que é o que falta no curso de licenciatura, acho que tem muita teoria e mesmo nos estágios que tem, acaba focando em uma coisa só sabe, uma coisa meio limitada, você não tem muita liberdade de como atuar (SANTOS; ARROIO, 2013, p.1). 
Os autores concluem que o Pibid tem sido um espaço em que os licenciandos passam a ter uma consciência acerca das limitações e possibilidades para as suas aulas (SANTOS; ARROIO, 2013).

Lima, Andrade e Sussuchi (2013) apresentam as reflexões construídas por bolsistas acerca da contribuição do Pibid para a sua formação e para a construção de sua identidade docente, ao responderem um questionário com questões abertas e fechadas. As contribuições do Pibid para a formação do licenciando estão relacionadas principalmente ao aperfeiçoamento da relação teoria-prática e do ensino interativo de química. Salienta-se que este espaço possibilita aprendizagem de novos métodos de ensino e que os resultados das intervenções no contexto do Pibid ao serem compartilhados em congressos os aproximam da pesquisa em ensino.

Martins e colaboradores (2012) investigaram o processo de aprendizagem para a docência no contexto do Pibid. Para tanto, buscaram responder a questão: "Que olhares sobre a iniciação à docência e ao ensino de Ciências podem ser identificados a partir das vivências e reflexões de bolsistas de licenciatura em Química?" (MARTINS et al., 2012, p.1). Segundo relato de dois bolsistas, a escrita dos diários de campo e portfólio, posteriormente discutidos com a coordenadora, possibilitaram espaços de discussões que permeavam aspectos inerentes à profissão docente. Nesse sentido, as principais aprendizagens sobre a iniciação à docência, que marcaram os pibidianos foi compreender que as diferentes abordagens de ensino influenciam o interesse do aluno pela disciplina e a importância em realizar o levantamento dos conhecimentos prévios dos discentes como etapa que antecede o planejamento das aulas. Além disto, compreenderam que dificuldades em outras disciplinas influenciam o ensino de conceitos químicos e que a discussão teórica no subprojeto contribuiu para uma formação extracurricular.

Menezes e colaboradores (2012) realizaram uma entrevista com 16 pibidianos buscando correlacionar a experiência no Pibid e a sua relação com a vida acadêmica. Os autores estruturaram as questões:

\begin{abstract}
A licenciatura era sua primeira opção de curso quando prestou vestibular? Se não, qual era? 2. Sua opinião a respeito da licenciatura mudou depois que entrou para o Pibid? 3- De que maneira o Pibid interferiu em sua opinião? 4- Sua dedicação ao curso (licenciatura) aumentou depois que entrou no Pibid? 5- Você nota alguma diferença no rendimento dos alunos na escola em que atua? 6- Em algum momento do curso pensou abandonar? Se sim, o Pibid influenciou a sua opinião de alguma forma? (MENEZES et al., 2012, p.1).
\end{abstract}

Para $78 \%$ dos entrevistados o Pibid reconstruiu suas percepções sobre a licenciatura, interferindo positivamente na formação, o mesmo percentual de pibidianos respondeu que a participação no programa melhorou o desempenho acadêmico. Outros 
$29 \%$ não abandonaram o curso por conta do Pibid. Segundo os autores a inserção precoce dos licenciandos na escola os estimulou a continuarem na licenciatura e que o Pibid tem possibilitado aos participantes da investigação a desconstrução do imaginário social em relação à profissão professor.

Pereira e colaboradores (2012) analisaram as percepções iniciais dos bolsistas sobre a elaboração de suas primeiras aulas, também buscaram elencar as marcas do Pibid na formação inicial dos pibidianos. Nesse sentido, ao responderem um questionário, a maioria dos bolsistas "Dos que cursaram a disciplina de estágio (45\%), todos afirmaram que vêem diferenças entre o Pibid e o estágio supervisionado: acreditam que o Pibid permite uma maior vivência do ambiente escolar" (PEREIRA et al., 2012, p.1). Para os participantes o programa oferece mais recursos e tempo livre para o desenvolvimento de metodologias diversificadas. Acreditam que a atuação como pibidiano "Com minhas aulas espero ser mediadora de conhecimento e que o aluno possa ser sujeito ativo na construção de seu conhecimento" (PEREIRA et al., 2012, p.1).

Dantas e Mello (20102) analisaram as contribuições do Pibid para a formação de licenciandos, mais especificamente para o domínio curricular e de conteúdo. Os dados foram coletados por meio da análise dos relatórios pedagógicos do coordenador institucional e de área e de entrevistas semiestruturadas realizadas com o coordenador de área. Nos resultados ao discorrer sobre as ações dos bolsistas o coordenador:

\begin{abstract}
relata que durante as atividades propostas para o subprojeto procurou dar ênfase às necessidades formativas dos bolsistas, principalmente no que concerne a participação em ambiência real de ensino (observação, monitoria e regência), visto que na antiga estrutura curricular de 1997 do curso de Licenciatura em Química, as atividades escolares em ambiência real de ensino só iniciavam no $6^{\circ}$ semestre [...] (DANTAS; MELLO, 20102, p.6).
\end{abstract}

Ferreira e colaboradores (2012) analisaram as contribuições de um subprojeto para escolas da rede de ensino e também na formação de seus pibidianos, por meio de um questionário. Com relação aos bolsistas, quando questionados qual seria a contribuição do programa para sua formação, oito licenciandos responderam que foi a vivência escolar, e dois a preparação de atividades. Por outro lado, todos os bolsistas foram unânimes em afirmar que se sentem mais preparados para exercer a profissão docente em virtude de suas vivências no Pibid. Os autores discutem ainda que a participação em reuniões pedagógicas, no conselho de classe, monitoria, auxílio na elaboração/correção de avaliações, contribuem para o aprendizado desses futuros professores.

Martins e colaboradores (2012) investigaram os relatos escritos por bolsistas do Pibid durante sua vivência no programa. Nas descrições, os bolsistas argumentam que o programa influenciou nas suas formações acadêmicas, nesse sentido, um pibidiano 
expõe que "O Programa além de promover a minha formação profissional com a iniciação à docência, refletiu na minha formação acadêmica e na minha vida pessoal, pois ver um ambiente profissional na área de saúde se interligar com a Química é muito interessante" (MARTINS et al., 2012, p.1).

Nascimento e colaboradores (2012) pesquisaram as contribuições do Pibid para a formação de seus bolsistas. Os autores adotaram um questionário estruturado com questões abertas e fechadas, respondido por seis pibidianos. Nos resultados $67 \%$ argumentaram que participaram do programa buscando uma formação reflexiva sobre a prática. Para outros $37 \%$ ao participarem do programa tiveram contato com novas metodologias de ensino. Para 56\% o Pibid contribui para a sua formação em virtude do entrelaçamento da educação básica e ensino superior, oportunizando dessa forma experiência profissional.

Em outro resumo (MATOS et al., 2012) os autores buscaram analisar a influência do Pibid na vida acadêmica e na formação inicial de seus bolsistas. Inicialmente os pibidianos argumentam que o Pibid ajudou a mudarem a percepção sobre a profissão professor, pois inicialmente não sabiam como funcionava uma escola, consideravam a profissão árdua e não tinham noção da importância dessa profissão na formação de cidadãos críticos. A vivência escolar tem sido decisiva na escolha pela carreira docente. A convivência com discente da educação básica tem refletido no comprometimento do pibidiano com o ensino, tornando o programa como um espaço de amadurecimento dos conteúdos químicos e pedagógicos aprendidos ao longo do curso.

Afonso, Marques e Marques (2012) objetivaram analisar o processo de interação bolsista-supervisor. Para tanto, realizaram entrevistas semiestruturadas com cinco pibidianos. Segundo os bolsistas o acompanhamento da supervisora na elaboração das atividades planejadas contribuiu no desenvolvimento mais eficiente. A presença da docente ajudou na segurança dos bolsistas durante a implementação das aulas. Por fim, que o contato com o professor experiente suscitou reflexões sobre suas práticas, que geralmente não acontece na universidade.

Pinho (2012) apresenta suas reflexões como coordenadora no Pibid em um subprojeto de química que tem o propósito de esmiuçar a interface entre os saberes das áreas da Educação, da Química e da Psicologia, e suas implicações na formação de licenciandos em química. Na percepção da coordenadora, o licenciando é estimulado a estruturar aulas práticas e teóricas para que os discentes da educação básica possam articular o conhecimento químico com a sua realidade. Dessa forma, o bolsista é incentivado a construir roteiros de aulas por meio de novas estratégias. Durante as reuniões do subprojeto a coordenadora reconhece um amadurecimento do pibidiano ao ter um olhar mais sensível para a escola e com o professor da educação básica. $\mathrm{Na}$ Capítulo 4. Resultados e Discussões 
percepção da coordenadora há um crescimento do bolsista em relação à sua capacidade de expressão verbal e na estruturação de textos. Por fim, argumenta que o Pibid possibilita ao licenciando um aprofundamento de seus conhecimentos pedagógicos de conteúdo por meio de sua vivência como aluno de iniciação à docência.

Dias, Silva e Mattos (2014) realizaram entrevistas semiestruturadas com bolsistas e supervisoras, para investigar as contribuições do Pibid para a sua formação inicial e continuada. Para os bolsistas, com a implementação de aulas foi possível atrelar a teoria à prática. Tiveram ainda a oportunidade de preencher lacunas da formação na licenciatura:

O principal conhecimento que eu acredito ter desenvolvido com a participação no Pibid foi sobre atividades com abordagem CTS. O Pibid me possibilitou enxergar a possibilidade de realizar o ensino por temas, em que o conteúdo aparece contextualizado a aspectos sociais, tecnológicos e ambientais. Mais do que isso, no Pibid eu comecei a aprender como fazer essas atividades com caráter CTS" (B2) (DIAS; SILVA; MATTOS, 2014, p. 5).

Também aprendi a importância de um bom planejamento para o trabalho com grandes e pequenos projetos. A escola possui dificuldades imprevisíveis que, por vezes, nos fizeram ter de reorganizar várias vezes nosso planejamento". (B1) "Durante este período, também pude me familiarizar com os contratempos que podem ocorrer eventualmente na escola, e, para isso, é importante que tenhamos conhecimento de outras formas de abordagens dos conteúdos para que não prejudique o bom andamento das aulas (B3) (DIAS; SILVA; MATTOS, 2014, p.5-6).

Em relação à formação continuada, os resultados apontam para a atuação do supervisor como um co-formador do pibidiano e a sua aproximação com a universidade. Segundo uma das supervisoras a presença dos pibidianos contribui para a sua reflexão sobre a sua prática, refletindo nas mudanças de suas aulas, por meio de novas abordagens de ensino:

Todas as escolas deveriam ter essa experiência enriquecedora, pois a partir da presença deles na escola eu mudei o modo de agir em relação a muitas práticas do dia a dia, que às vezes passa despercebida por nós. Eles trazem novos ânimos e novas atitudes para o nosso trabalho (DIAS; SILVA; MATTOS, 2014, p.7).

Prado e Silva Júnior (2014) apesar de investigarem a influência do Pibid na escolha pela carreira docente, traz elementos da contribuição desse programa na formação inicial de licenciandos. Em consonância, todos os bolsistas argumentaram que o Pibid foi uma vivência que definiu sua carreira no magistério pois, ao vivenciarem a escola por mais horas e tendo o acompanhamento do supervisor, conseguiam ter uma real noção da profissão professor.

Carvalho e Ribeiro (2014) investigaram as contribuições do Pibid para a formação docente. Para tanto, entrevistaram um grupo de professoras supervisoras. As 
entrevistas foram analisadas pelas questões norteadoras: "Importância do Pibid para a formação docente; Características adquiridas pelos Licenciandos-Bolsistas no decorrer de suas atuações no projeto; Benefícios trazidos à escola; e Benefícios trazidos ao Professor Supervisor" (CARVALHO; RIBEIRO, 2014, p.3). Para um dos entrevistados o Pibid contribuiu para a formação docente:

O que a gente percebe: a inserção do aluno durante a sua formação na escola, é que, junto com o professor, é possível a gente fazer a discussão dos problemas que a escola vive com base nas teorias que eles estão estudando aqui. Eu faço questão de estar sempre discutindo com eles, verificando o que eles estão estudando, e tentando fazer esse vínculo de uma coisa com a outra (PROFESSOR A) (CARVALHO; RIBEIRO, 2014, p.3).

Para outro supervisor tem questões que permeiam a profissão docente que são aprendidas no contexto escolar, e o pibidiano ao ser inserido nesse ambiente tem possibilidade de aprender a lidar com a indisciplina, em adequar uma aula experimental e a organizar o quadro negro.

Rizzatti e colaboradores (2014) analisaram as contribuições do Pibid como formação complementar na formação de licenciandos em química. Como instrumento de coleta de dados os autores adotaram um questionário respondido por licenciandos participantes e não participantes do programa de iniciação à docência e observações das ações desenvolvidas no contexto do subprojeto. Em uma das questões que permeava o instrumento "Para os acadêmicos perguntou-se se eles conheciam o Pibid, se este programa contribui para a formação docente em química, se as ações do Pibid o motivavam a seguir a carreira docente, entre outras" (RIZZATTI et al., 2014, p.3). As respostas concedidas pelos acadêmicos revelaram que todos consideram que o Pibid contribuiu na sua formação por oportunizar a experiência na carreira docente e melhorar o conhecimento teórico. Relatam ainda que o Pibid incentivou a permanência na licenciatura, pois segundo os autores "Para eles é gratificante ensinar aos alunos os conteúdos já estudados durante o curso de graduação em química e ver o quanto eles se interessam e tiram suas dúvidas nas aulas de experimentos" (RIZZATTI et al., 2014, p. 5). Quando questionados sobre o estímulo em participar do programa os bolsistas citaram a oportunidade de lecionar, melhorar o ensino e participar de pesquisas.

Machado e colaboradores (2014) apresentam reflexões dos pibidianos sobre as contribuições do Pibid para a sua formação, por meio da análise dos diários de seis bolsistas e de uma supervisora. Nos trechos a seguir são apresentadas algumas dessas reflexões:

[...] minhas experiências estão sendo adquiridas por estar inserida no ambiente escolar e por compartilhar minhas ideias [...] 
[...] O Pibid tem me proporcionado analisar criticamente o papel do professor, acredito que ser professor é estar inserido nos desenvolvimentos formativos dos educandos [...]

[...] durante minha graduação apenas estudos didáticos foram abordados e o contato com o ambiente escolar muitas vezes baseiase somente nos estágios supervisionados. Entretanto, através deste programa verifica-se uma maior aproximação do licenciando com os educandos [...] (MACHADO et al., 2014, p.1).

Santos, Adorni e Silva Júnior (2014) apresentam as contribuições do Pibid para a formação docente. No texto, os autores disponibilizam o relato de um bolsista que descreveu que no programa de iniciação à docência pôde relacionar a teoria e a prática, adotando diferentes metodologias de ensino que propiciaram uma melhor aprendizagem dos discentes. A experiência suscitou um novo olhar sobre a escola e para as realidades dos estudantes, diminuindo a distância entre a universidade e a educação básica.

Oliveira, Siqueira e Suart (2014) avaliaram a contribuição do Pibid na formação de licenciandos em química. Analisaram as reflexões escritas antes e após a implementação do projeto. Posteriormente, esmiuçaram o material produzido por duas licenciandas. Para a formação inicial as bolsistas relatam que o programa permitiu que se sentissem professoras, ampliassem a formação de maneira crítica e reflexiva, além de salientarem que os estudos dirigidos para a estruturação das unidades de ensino também influenciam a sua formação.

Silva, Silveira e Kiouranis (2014) investigaram por meio dos diários produzidos pelos pibidianos a influência do Pibid para a construção de saberes necessários à prática docente. Ficou evidente nos relatos que a experiência propiciada pelo programa leva a reflexões sobre as aulas implementadas, tendo como consequência a reelaboração das propostas de ensino. Em outro trecho, os bolsistas compartilham a importância do Pibid na constituição dos saberes necessários à prática docente:

A.5 - Acredito que, com a continuação deste (Pibid), proporcionará ainda mais contribuições e aprendizagens, pois garante um contato maior com o nosso ambiente de trabalho, proporciona aprendizagens sobre como elaborar atividades diferenciadas, como empregar metodologias distintas conforme o objetivo estabelecido, as adversidades que podemos encontrar e como superá-las, além de habilidades e competências que são exigidas e desenvolvidas no projeto como, disciplina, organização, responsabilidade, trabalho em grupo e outras.

A.13 - (Pibid) proporciona uma melhor visão sobre a área da licenciatura e também como é a escola pública, suas dificuldades e realidades, para que nós, como futuros professores possamos estar a par do funcionamento de uma escola e também para termos um maior entrosamento com os alunos num geral, poder desenvolver a prática da docência, métodos alternativos de ensino, postura e autoconfiança (SILVA; SILVEIRA; KIOURANIS, 2014, p. 6). 
Outro bolsista discorre sobre a importância da leitura de artigos e dissertações proporcionada pelo subprojeto na aprendizagem de novas teorias de ensino.

Sá e colaboradores (2014) analisaram as contribuições do Pibid na constituição das identidades docentes. Nos resultados as formas identitárias assumidas eram distintas: monitores, professores da Educação Básica, professores investigadores e professores reflexivos. A constituição dessas identidades múltiplas foram marcadas pelas identidades individuais. O Pibid tem contribuído na construção dessas formas identitárias, pela antecipação do pibidiano na escola. Para os autores o programa não pode por si dar conta da complexidade das problemáticas relacionadas à educação no Brasil.

Passos e Salgado (2014) investigaram as contribuições de ações formativas do subprojeto química para o desenvolvimento profissional. Os resultados apontam que as atividades na escola e na academia favorecem o desenvolvimento de competências e saberes docentes, além de tornar os professores supervisores co-formadores dos licenciandos.

Duarte, Botelho e Quadros (2014) buscaram mapear a atenção que o supervisor tem recebido no Pibid. Para tanto, os autores realizaram um mapeamento em periódicos da área e nos bancos de teses e dissertações do Brasil. Foram catalogados nove trabalhos que direta e indiretamente retratavam estes participantes. Os resultados denotam que pouca atenção tem sido dada ao supervisor e, consequentemente, a sua formação continuada tem ficado em segundo plano.

Pinto, Andrade e Lima (2014) elencam as contribuições de um subprojeto química na formação de pibidianos. Os autores concluem que o subprojeto tem um potencial ao promover a consolidação de um espaço de formação em que os conhecimentos profissionais estão sendo construídos em virtude da vivência da profissão docente na formação inicial.

Rosa, Mendes e Locatelli (2016) investigaram a construção da identidade docente e a epistemologia da prática na formação inicial de pibidianos. Segundo os autores:

\begin{abstract}
A análise das ações pedagógicas desenvolvidas pelos licenciandos e refletidas por meio do debate e discussão dos resultados obtidos agregam saberes profissionais que se fundamentam a partir da dinâmica que ocorre no dia a dia escolar (ROSA; MENDES; LOCATELLI, 2016, p.7).
\end{abstract}

$\mathrm{Na}$ discussão dos resultados as autoras apresentam os argumentos dos pibidianos relacionados à importância do programa institucional de iniciação à docência para a sua formação, nesse sentido apontam que o Pibid os possibilitou aprenderem novas estratégias de ensino, desenvolver trabalhos submetidos a congressos, a 
compreender a profissão docente, entre outros. Para Rosa, Mendes e Locatelli (2016) os licenciandos em química no Pibid puderam vivenciar saberes que foram construídos a partir no agir pedagógico.

Silveira e colaboradores (2016) evidenciaram a contribuição do Pibid para as escolas campi e na formação continuada de supervisores a partir do olhar do professor supervisor. Para os autores o programa de iniciação à docência contribui para a melhoria da escola pública, na qual o subprojeto era vinculado, pois geralmente esse estabelecimento não possui espaço adequado, verba e materiais para a realização de novas abordagens de ensino. A contribuição para a formação continuada está em:

[...] proporciona um ambiente de conhecimento, discussão, proposição e execução de formas diferenciadas de abordagem dos conteúdos químicos, com o objetivo de desenvolver e melhorar a aprendizagem pelos alunos da escola de ensino médio. Além disso, apresenta o diferencial de que os docentes podem participar de todo processo, desde a preparação à aplicação das abordagens propostas, abordagens estas, em muitos casos, não realizadas nem mesmo durante suas formações iniciais (SILVEIRA et al., 2016, p.1).

Gomes e Gomes (2016) analisaram as contribuições do Pibid na formação de bolsistas atuantes e ex-bolsistas egressos. Para tanto, realizaram entrevistas semiestruturadas. Os resultados apontam que para os bolsistas atuantes no programa, a vivência no espaço escolar e no desenvolvimento de práticas de ensino possibilita que construam suas identidades profissionais. Enquanto para os ex-bolsistas egressos, o Pibid propiciou uma segurança em lecionar, o compromisso com a profissão e um domínio melhor na sala de aula (GOMES; GOMES, 2016).

Rocha, Lima e Pinho (2016) analisaram as contribuições do Pibid na formação continuada do supervisor. Segundo os autores a participação do supervisor possibilita o seu conhecimento acerca das diretrizes do programa, reconhece as dificuldades relacionadas a recursos, monitoram os licenciandos e propicia uma reflexão sobre suas práticas.

Nesse mesmo sentido, SILVA e colaboradores (2016), investigaram o papel do programa institucional na formação continuada de supervisores. Os resultados suscitam que o processo formativo está traduzido na reflexão dos professores sobre suas práticas e na sua inserção na pesquisa.

Herber, Severo Filho e Pino (2016) ao realizarem a avaliação de um subprojeto entre os anos de 2014 e 2016 por meio dos relatórios produzidos pelos pibidianos, evidenciaram que o programa tem possibilitado uma qualificação dos licenciandos em virtude do desenvolvimento de conhecimentos inerentes à profissão docente, associados à realização da reflexão-ação-reflexão de suas práticas pedagógicas. 
Dantas, Soares e Mello (2016) investigaram a contribuição do Pibid para a formação inicial de seus bolsistas. Para tanto, aplicaram um questionário aos pibidianos, supervisores e coordenadores. Na análise dos resultados sinalizam que o programa de iniciação à docência tem contribuído para formar professores-pesquisadores, que são críticos em relação à sua prática e buscam realizar a reflexão-ação-reflexão.

Melo, Santos e Santos (2016) analisaram como as diferentes escolas, estruturas e alunos influenciam na atuação dos licenciandos bolsistas do programa de iniciação à docência. Em consonância, os autores analisaram os relatórios anuais dos pibidianos. Nos resultados, explanou-se que os planos de aulas tiveram que ser readequados em virtude dos diferentes perfis das instituições de ensino, de suas estruturas físicas e de seus discentes. Nas ações, os pibidianos puderam implementar diversas metodologias de ensino, o que proporciona uma maior experiência profissional.

Silva, Pinheiro e Felício (2016) buscaram evidenciar as percepções de bolsistas do Pibid sobre os impactos desse programa para sua formação docente. $O$ instrumento de coleta de dados foi um questionário aberto com oito perguntas. Para $90 \%$ dos pibidianos o programa combate à evasão na licenciatura em química. Para os pibidianos, ao desenvolverem suas atividades como bolsistas, passam a ter uma nova visão sobre o exercício da profissão professor em virtude da conexão entre a prática pedagógica e a pesquisa.

Ao realizarem um relato de experiência que tinha por objetivo analisar as contribuições do Pibid para a formação de licenciandos em química os autores Silva, Prado e Jesus (2016), destacam:

[...] que, através do Pibid, o licenciando abre mais uma vertente de aprendizado ao obter contato e vivência com a Educação Básica, compreendendo as dificuldades da Escola e da sala de aula, verificando quais atividades são proveitosas ao aprendizado, analisando os planejamentos, fazendo discussões relevantes sobre 0 processo de ensino-aprendizagem e, dentre outras vivências, vai paulatinamente qualificando a sua formação inicial (p.1).

Obara e colaboradores (2016) investigaram a contribuição do programa de iniciação na aprendizagem docente. A coleta de dados envolveu entrevistas semiestruturadas com ex-bolsistas, egressos da licenciatura em química e atuantes na docência. Os ex-pibidianos discorreram que suas práticas são fundamentadas em seus saberes experienciais constituídos em suas vivências no Pibid.

Longhin e colaboradores (2016) apresentaram uma reflexão sobre a contribuição do Pibid para a formação inicial. Para tanto, buscaram traçar um paralelo entre a articulação da ação dos pibidianos com os licenciandos que estavam no estágio supervisionado. Para os autores: 
Por meio do Pibid, é oportunizado aos alunos a partir do $2^{\circ}$ Período da LQ vivenciar a realidade do Ensino Médio (EM) e desenvolverem atividades na área da docência de forma que compreendam as contribuições dessas para a sua formação bem como para aprendizagem de Química dos alunos EM, sempre com apoio de um professor Supervisor na escola parceira e do Coordenador na universidade. A possibilidade de trabalho conjunto entre um aluno ID do $2^{\circ}$ Período e de um do ES cursando o 6ํㅜㄹodo foi possibilitada na escola parceira [...]. As atividades pedagógicas de intervenção/mediação realizadas em colaboração permitiram que os ID (iniciação docente) e alunos ES (estágio supervisionado) se inserissem no ambiente escolar, adquirindo experiências docentes com 0 professor de Química da escola e o supervisor do Pibid, tanto nas abordagens dos conteúdos, quanto nas dificuldades e nos desafios da prática docente, mostrando um aspecto positivo na formação dos licenciados (LONGHIN et al., p.1, 2016).

\section{O Pibid nas teses e dissertações}

No banco de teses e dissertações da Capes foram mapeadas a priori 315 teses e dissertações por meio da busca da palavra-chave Pibid no campo de busca. Foram catalogadas apenas as pesquisas que trouxessem nos resumos ou título que os participantes investigados envolviam de algum modo pibidianos, supervisores ou coordenadores pertencentes à química. Nessa acepção, foram selecionadas 18 pesquisas que objetivaram analisar os impactos do Pibid na formação inicial e continuada de seus atores. Em consonância, Dantas (2013) investigou em seu mestrado os impactos do Pibid na formação inicial de licenciandos participantes do subprojeto de Química da Universidade Federal de Mato Grosso (UFMT). Para tanto, realizou entrevistas semiestruturadas, análise documental (relatórios institucionais e documentos oficiais) e aplicou questionários. Os participantes foram onze ex-bolsistas, duas supervisoras e um coordenador de área. Os ex-bolsistas discorreram que o programa os influenciou em querer atuar na rede pública de ensino e a cursarem a pósgraduação. Um dos pibidianos argumentou que "Com o Pibid eu descobri o que é licenciar, o que é ser professor, por que tinha coisas que eu não sabia. Tinha autores que eu nem sabia que existiam. Ex-bolsista 10" (DANTAS, 2013, p.128). Na percepção de uma supervisora, o programa propiciou aos licenciandos compreenderem o lado bom da educação ao serem inseridos no espaço escolar ainda na graduação. Outro expibidiano aponta diferenças na formação de um professor em início de carreira participante do Pibid dos outros docentes também em início de carreira que não participaram do programa, como denota o trecho abaixo:

Se não fosse o Pibid eu não teria essa visão ampla da docência, pois só na graduação isso não é possível. O Pibid contribuiu e muito no meu crescimento e em todo o processo de iniciação profissional, desde como montar uma aula, qual a melhor maneira de expor essa aula, a maneira de se apresentar, de conversar com o aluno, de conversar com o seu professor, com o coordenador. As ações que eu tenho hoje em sala de aula não seria possível só com a graduação. O tempo da 
graduação não é suficiente para ampliar e inovar os conhecimentos da docência como, por exemplo, contextualizar as aulas, tanto é que em nossas aulas da graduação nem tinha muita contextualização. No Pibid a gente sempre tinha esse cuidado de pensar na aula, de pensar em como motivar nossos alunos. O Pibid contribui em todo esse processo de motivação e inovação. Ex-bolsista 10 (DANTAS, 2013, p. 131).

Outros aspectos positivos associados ao Pibid apresentado na pesquisa foram: o Pibid possibilitar o retorno do professor da educação básica à universidade, transformando-o em um co-formador; a melhoria nas condições das escolas, entre outros. Por fim, o Pibid é apontado como um espaço diferente do estágio supervisionado, por proporcionar a inserção do licenciando na escola de forma mais articulada, em virtude da orientação do professor da educação básica. De modo semelhante, Stanzani (2012) investigou o papel do Pibid na formação inicial de professores. Para tanto, acompanhou o processo de elaboração e implementação de aulas e realizou entrevistas com os pibidianos. A autora também entrevistou os coordenadores de área e os supervisores. Os resultados denotam que o programa possibilita uma formação que induz a reflexão e problematização sobre a prática, por meio do desenvolvimento de práticas de ensino e pesquisa. Segundo os bolsistas a participação no programa os influenciou em seguir a carreira docente e o interesse pela área de ensino. Um bolsista relatou que o Pibid o possibilitou construir outra visão sobre o profissional professor:

B3: Se você não partir para um estágio, para um projeto como esse, você fica com aquela visão de professor de universidade e você acaba criando uma espécie de bloqueio, você acha que se você for professor, você vai agir como o professor da universidade, então, realmente muda muita coisa, desde que a gente entra até agora, fazendo o projeto, essa visão do que é ser professor já passou por vários caminhos na minha cabeça, uma visão que eu tinha dos meus professores de Ensino Médio, uma visão dos meus professores da universidade e, agora, das minhas experiências no Pibid (STANZANI, 2012, p. 59).

Possibilita ainda o contato com estratégias de ensino e de novas metodologias mas, principalmente a articulação do ensino superior e da educação básica, de modo a propiciar ao licenciando ensinar em contextos reais de sala de aula. Em relação à aula a ser desenvolvida um bolsista aponta:

B5: Tem que dominar muito o assunto, não é só chegar lá na frente e falar hoje eu tenho que dar uma aula de termoquímica e passar o que está lá no livro e pronto, então tem que preparar aula antes, tem que desenvolver tudo antes, tem que ter um desenvolvimento com os alunos também, como você vai agir com eles, tem que ser calmo, porque é bem diferente, porque antes eu achava que era tudo ao contrário, vou pegar um livro, vou chegar lá e olha hoje a aula é disso e hoje eu vejo que não é nada disso, que isso não existe (STANZANI, 2012, p. 62). 
Por fim, o autor descreve que as relações estabelecidas entre a tríade (pibidiano, coordenador e supervisor) propicia o acesso dos futuros professores com referenciais da área de ensino de química.

Carmo (2015) investigou os saberes construídos em virtude da participação de licenciandos de química, física e biologia no Pibid. Para tanto, foram entrevistados sete pibidianos. Com relação aos pibidianos de química, em um dos trechos do texto o bolsista discorre sobre a importância do Pibid na desconstrução do senso comum relacionado ao processo de ensino:

Houve disciplinas que me ajudaram, pois tive disciplinas que me ajudaram a fazer planos de aula, então quando eu ia para a reunião do Pibid e a professora falava eu já tinha noção do que era. E disciplinas como a de Psicologia da Educação que discute como você não julgar os alunos, por exemplo, em relação à inteligência, porque nessa disciplina você estuda que existem tipos de inteligência, aptidões diferentes. [...] Então eu tinha esse cuidado de perceber nesses alunos mais agitados essa relação com sua vida pessoal (SÔNIA - QUI-2011) (CARMO, 2015, p.70).

Esse trecho revela o entrelaçamento dos conhecimentos aprendidos nas disciplinas da licenciatura e qual conhecimento era necessário construir ao vivenciar a prática de ensino. A aproximação do licenciando com o supervisor possibilita a construção do saber experiencial. Nas considerações finais a autora discorre:

Tendo como referência os saberes docentes definidos a partir da epistemologia da prática profissional de Tardif (2014), pudemos analisar como as vivências escolares marcam e ressignificam saberes advindos do contexto universitário (saberes da formação profissional e disciplinares), assim como permitem aos licenciandos constituírem saberes próprios da docência que são constituídos no encontro com o contexto escolar (curricular e experiencial) (CARMO, 2015, p. 99).

Teste (2015) investigou os impactos do Pibid como uma ação política na formação de professores de química de uma instituição de ensino no Estado de São Paulo. Para a realização de sua dissertação acompanhou as reuniões no interior de um subprojeto, aplicou questionários semiabertos a doze pibidianos e realizou entrevistas semiestruturadas com uma coordenadora, com duas supervisoras e com os licenciandos participantes do programa. Os resultados apontam que o programa institucional possibilita uma formação contextualizada, a reflexão do pibidiano sobre a ação, outra visão dos experimentos e incute no bolsista o interesse pela pesquisa em ensino de química, tendo como consequência o ingresso dos pibidianos na pósgraduação. Além disto, os pibidianos passam a ser referência nas disciplinas pedagógicas da graduação, em virtude da experiência em sala de aula, do conhecimento sobre os alunos e o contexto escolar, entre outros. A partir de seu estudo, o autor evidenciou que grande parte dos bolsistas pretende lecionar na educação básica. Somadas as contribuições na formação inicial o programa promove a formação Capítulo 4. Resultados e Discussões 
continuada de professores da educação básica ao incorporarem novas estratégias de ensino em suas ações didáticas e por atuarem como supervisores, compreendem que são co-formadores dos futuros professores. Por outro lado, Teste (2015) evidenciou algumas problemáticas relacionadas à falta de preparo dos supervisores e delimitação das funções dos bolsistas para que estes não exerçam na escola funções que são dos supervisores.

Em outra dissertação Silva (2015) investigou os significados atribuídos pelos pibidianos ao Pibid. O autor realizou entrevistas com oito pibidianos. A análise dos dados permeou a Análise Textual Discursiva por meio de cinco categorias: i. Desenvolvimento do Trabalho Colaborativo, com a subcategoria Relações Interpessoais no Desenvolvimento de Projetos na Escola; ii. Articulação teoria-prática, com a subcategoria Desenvolvimento de Experiências Metodológicas e Instrumentos Didáticos; iii. Ambientação com o Pibid; iv. Articulação IF-S - Escola: O Papel dos Sujeitos no Processo Formativo e v. Importância do Programa na Ótica dos Licenciandos: Conhecer o Futuro e Valorizar o Presente. Os resultados apontam para aspectos positivos e negativos do Pibid na formação dos licenciandos. Os aspectos positivos estão associados ao trabalho colaborativo e à experiência como sendo mais significativa do que no estágio (regência/observação), por adquirirem autoconfiança no exercício da profissão professor. Em relação às limitações, são elencados os aspectos: conflitos com os supervisores e com a coordenação/direção das escolas, a adaptação ao Programa/subprojeto no início dos trabalhos; a desinformação dos responsáveis institucionais sobre objetivos e o papel do Pibid no processo formativo dos licenciandos. Além do mais, a bolsa ofertada para os pibidianos possibilita a permanência dos licenciandos nos cursos de graduação.

Lima (2015) analisou a contribuição do programa institucional na formação inicial dos bolsistas. A autora aplicou questionários, realizou entrevistas com oito egressas do curso de Química (ex-pibidianas), dois coordenadores de área e duas supervisoras do Pibid/Química e por fim realizou análise documental. Os dados revelaram que o programa é um desenraizado da racionalidade técnica presente no curso da licenciatura em que está sediado o subprojeto, por possibilitar uma articulação entre a teoria e a prática, mobilizar saberes experiências nos pibidianos em virtude da vivência no ambiente escolar e com professores experientes (coordenador e supervisor), o desenvolvimento de projetos por meio da formação de grupos, entre outros. Em contrapartida, algumas limitações emergem não haver prazo para a continuidade do programa e os poucos espaços de reconstrução dos saberes docentes promovidos pelo programa que não são socializados a todos os bolsistas. 
Almeida (2015) propôs compreender e analisar os percursos formativos, profissionais e as práticas dos docentes formadores que atuam como coordenadores de área de conhecimento participantes do Pibid. Os participantes, coordenadores de área, pertenciam a subprojetos das áreas da química, física, matemática e biologia. O autor realizou entrevistas semiestruturadas e questionários que permitissem ao entrevistado narrar a sua trajetória profissional e os processos formativos dos docentes formadores que faziam parte do Programa. Nas narrativas "[...] os docentes foram unânimes em afirmar que não ensinam propriamente, mas sim incentivam e facilitam a aprendizagem dos estudantes, despertando neles o interesse em aprender e estimulando a busca por conhecimentos [...]" (ALMEIDA, 2015, p.76). Acreditam que os licenciandos estão sendo formados pela reflexão, e que a partir desse exercício constroem seus saberes docentes. Segundo os coordenadores o Pibid contribuiu para a sua formação ao possibilitar ter uma compreensão da escola e de suas demandas educacionais.

Em sua tese Deimling (2014) pesquisou as contribuições e as limitações do Pibid da Universidade Tecnológica Federal do Paraná (UTFPR) para a formação dos bolsistas de iniciação à docência e para a formação e atuação docente dos supervisores da educação básica, professores colaboradores e dos coordenadores institucional, de gestão de processos educacionais e de área do Programa. Nesse sentido, participaram da pesquisa um coordenador institucional, dois coordenadores de área de gestão de processos educacionais, quatro coordenadores de área, sete professores supervisores, quatro professores colaboradores e quarenta e oito alunos bolsistas de quatro subprojetos (Física, Letras-Inglês, Matemática e Química). Os resultados suscitam que o Pibid influencia na permanência do licenciando na carreira docente, principalmente por adentrarem no espaço escolar com a supervisão e coordenação de professores experientes que os levam a refletir sobre seus saberes docentes ainda na graduação e a compreenderem o contexto educacional. Uma limitação apontada no interior dos subprojetos relaciona-se à falta de discussão do conteúdo em relação a seus aspectos conceituais e pedagógicos. Para alguns docentes o Pibid é um espaço formativo que contribui para a formação e desenvolvimento profissional do licenciando, contudo para outros não, e consideram os pibidianos como auxiliares da escola e professores substitutos. Além disto, existem problemáticas relacionadas à formação e entendimento do supervisor sobre o seu papel de co-formador do licenciando. Outra crítica feita por coordenadores institucionais e coordenadores de gestão é que os coordenadores de área precisam compreender que os objetivos da iniciação à docência são diferentes de uma iniciação científica que tem por meta a produção e publicação de trabalhos científicos (DEIMLING, 2014). 
Tobaldini (2013) em sua dissertação analisou os saberes docentes construídos pelos pibidianos durante suas vivências no programa de iniciação à docência. Como referenciais teóricos o autor adotou Carvalho e Gil Pérez (2001), Gauthier e colaboradores (2006) e Tardif (2010). Os dados foram coletados por meio dos diários de pesquisa e entrevistas, no qual eram retratadas as experiências vivenciadas pelos bolsistas e as atividades realizadas no Subprojeto no espaço da universidade. $\mathrm{Na}$ análise do material foi possível identificar a construção de quatro saberes: Saber Fazer Docente, Saber de Formação, Saber Relacionar-se e Saber Pessoal. Os três primeiros saberes manifestam-se nos dois grupos de bolsistas e o Saber Pessoal, no grupo de bolsistas sem experiência. Na percepção da autora, por mais que os dois grupos tenham acessado três saberes docentes iguais, estes foram sendo constituídos de maneiras distintas, em virtude de ter ou não experiência.

Sena (2015) em seu trabalho de mestrado analisou o processo de formação continuada de professores da educação básica participantes do Pibid. Para tanto, foram realizadas entrevistas semiestruturadas, analisadas por meio da Análise Textual Discursiva. A participação dos supervisores no subprojeto de Química estudado permitiu contato com diferentes metodologias e estratégias de ensino, muitas vezes pouco utilizadas no cotidiano de suas práticas de ensino. O subprojeto oportunizou aos supervisores recursos materiais e humanos que subsidiaram suas práticas pedagógicas, enriquecendo suas aulas e proporcionando vivências diferentes em sala de aula. O Pibid possibilitou ainda a aproximação com a academia, tornando os supervisores co-formadores dos licenciandos. Por outro lado, as barreiras vivenciadas estão associadas à função do supervisor como intermediador da escola com a universidade, à dedicação que devem ter para orientarem os pibidianos, entre outros.

Santos (2016) apresenta os desdobramentos de sua dissertação, que objetivou analisar os impactos do Pibid na formação de pibidianos, em dois subprojetos da área da química pertencentes a instituições públicas distintas. Como instrumentos de coleta de dados a priori a autora realizou o estudo dos subprojetos das duas instituições, avaliações de sondagem e entrevistas semiestruturadas. Os resultados apontaram que os participantes da investigação concordam que o programa possibilita uma vivência escolar maior que a proporcionada pelo estágio supervisionado. Além disso, em suas ações devem propor novas abordagens e matérias didáticas. De modo, geral a autora argumenta que o Pibid promove a autonomia do futuro professor, em relação ao entrelaçamento do conhecimento científico e pedagógico.

Martins (2016) investigou as contribuições do Pibid na formação inicial de licenciandos em química e física de uma instituição de ensino. Em consonância, foram realizadas entrevistas semiestruturadas e aplicado um questionário a pibidianos da Capítulo 4. Resultados e Discussões 
Física e Química e uma entrevista semiestruturada realizada com os concluintes do curso de Física e Química que participaram do Pibid e hoje atuam como docentes. Concluiu-se que as principais contribuições do programa de iniciação à docência para a formação inicial estão nas vivências dos licenciandos no ambiente escolar e na diversidade de atividades desenvolvidas que envolvem o ensino, a pesquisa e a comunidade.

Silva (2016) analisou como um subprojeto Pibid/Química tem contribuído no desenvolvimento de saberes docentes. Os dados foram coletados por meio dos diários reflexivos. $\mathrm{Na}$ análise do material buscou-se identificar os aspectos relacionados à construção/reconstrução de conhecimentos científicos e pedagógicos, além do entrelaçamento entre a teoria e a prática profissional. Os resultados denotam que 0 processo contínuo de reflexão sobre a prática, se traduziram na construção de conhecimentos químicos e pedagógicos, e consequentemente na consolidação de saberes necessários ao exercício da profissão docente.

Rosa (2016) investigou os saberes sistematizados por licenciandos bolsistas do Pibid que influenciam na construção de sua identidade docente. Os resultados revelam que os saberes experienciais, saberes da ação pedagógica, produção de saberes na relação interinstitucional e saberes publicizados envolvidos na formação inicial de professores de Química participantes do programa de iniciação à docência influenciaram na estruturação de suas identidades docentes. As práticas didáticas oportunizadas pelo programa reestruturam os saberes a cada ação docente.

Afonso (2013) investigou o papel dos professores colaboradores e coformadores de uma escola pública estadual, ao atuarem com bolsistas de iniciação à docência de Química. Para o desenvolvimento do estudo a pesquisadora atuou como orientadora desses bolsistas. Além dos bolsistas, também participaram da investigação: três supervisores; a professora de Química da escola estadual, que também é uma das supervisoras; o coordenador pedagógico do Ensino Médio e duas bolsistas coordenadoras das áreas de Letras e de Química. Como instrumento de coleta de dados foram utilizados: o diário de campo da pesquisadora, o portfólio e entrevistas semiestruturadas. Para análise do material foram criadas categorias a priori a partir do objetivo da pesquisa. Os resultados sugerem que o acompanhamento por um professor experiente se torna fundamental para que os bolsistas percebam o papel do professor em sala de aula. Em relação a essa vivência ainda como um licenciando, o pibidiano argumenta que as limitações à sua ação na escola estão associadas principalmente à indisciplina e ao número reduzido de aulas de química. Por outro lado, o acompanhamento das supervisoras e professoras colaboradoras tem oportunizado ao 
pibidiano construir confiança nas atividades propostas e no seu desenvolvimento profissional.

Teixeira Junior (2014) analisou as contribuições do Pibid para a formação de licenciandos em química norteado pelos objetivos, a saber:

Os alunos dos cursos de licenciatura em Química, que participam do PIBID em diferentes instituições superiores, percebem as contribuições deste programa? E, os objetivos do Pibid podem ser (ou são) alcançados em outras instâncias do curso, como nas disciplinas específicas, pedagógicas e/ou nos estágios supervisionados?" (TEIXEIRA JUNIOR, 2014, p. 19).

Em consonância com os objetivos traçados, o autor desenvolveu sua pesquisa em duas partes: na primeira, traçou o perfil socioeconômico dos bolsistas, e buscou elucidar se o Pibid tem alcançado seus objetivos. Na segunda etapa, organizou as categorias: a. incentivo à docência; b. valorização do magistério; c. integração universidade-escola; d. criação/participação em práticas de caráter inovador; e. papel do supervisor e, f. articulação teoria e prática. Nos resultados o autor aponta que o Pibid incentiva a docência e a valorização do magistério, ao oportunizar aos professores em formação inicial participarem de práticas pedagógicas em seu futuro ambiente profissional, tornando a escola de educação básica um lócus de formação, tendo como co-formador o professor supervisor, melhorando assim, a sua formação.

Castro (2016) analisou as contribuições do Pibid da Universidade Federal do ABC (UFABC), subprojeto Química, para a construção/manifestação da base de conhecimentos inerentes à profissão professor. Para tanto, o pesquisador acompanhou as atividades desenvolvidas no subprojeto. Essas atividades envolveram atividades lúdicas e unidades de medida. Os dados coletados foram analisados por meio das categorias do modelo proposto por Rollnick e colaboradores (2008). Na primeira atividade os dados suscitam que os pibidianos não tinham domínio do conhecimento do tema, denotando um fraco PCK. Entretanto, no segundo momento (unidades de medida) os bolsistas concentraram suas atenções no conhecimento do tema, resultando em um entrelaçamento dos demais domínios com o PCK. Para o autor o Pibid vem constituindose como um espaço que promove a reflexão de temas associados à construção do conhecimento base.

\section{Reações redox nos eventos nacionais e internacionais}

\section{Eventos Nacionais}

Foram catalogados 138 resumos na revisão de literatura. Grande parte das investigações propuserem, como estratégia de ensino para o conteúdo redox, práticas experimentais por meio da abordagem por investigação, por demonstração, entre outros. Os temas centrais eram pilhas, baterias e corrosão. Nesses experimentos muitos 
autores propunham desenvolver práticas de baixo custo. Nesse sentido, Neves e colaboradores argumentam que o objetivo da proposta de ensino "[...] incluem a montagem de um gerador de ozônio de baixo custo para uso em laboratório de ensino a partir de componentes simples" (2004, p.1). Apesar do emprego de diferentes estratégias de ensino, apenas 42 estudos dos 138 catalogados, discutiam as dificuldades vivenciadas por seus autores ao investigarem o processo de ensino e aprendizagem do conteúdo redox. Na figura abaixo apresentamos o total de trabalhos catalogados ao longo dos 17 anos e a relação entre as pesquisas que contemplaram e não contemplaram as dificuldades relacionadas ao ensino de reações redox por seus autores.

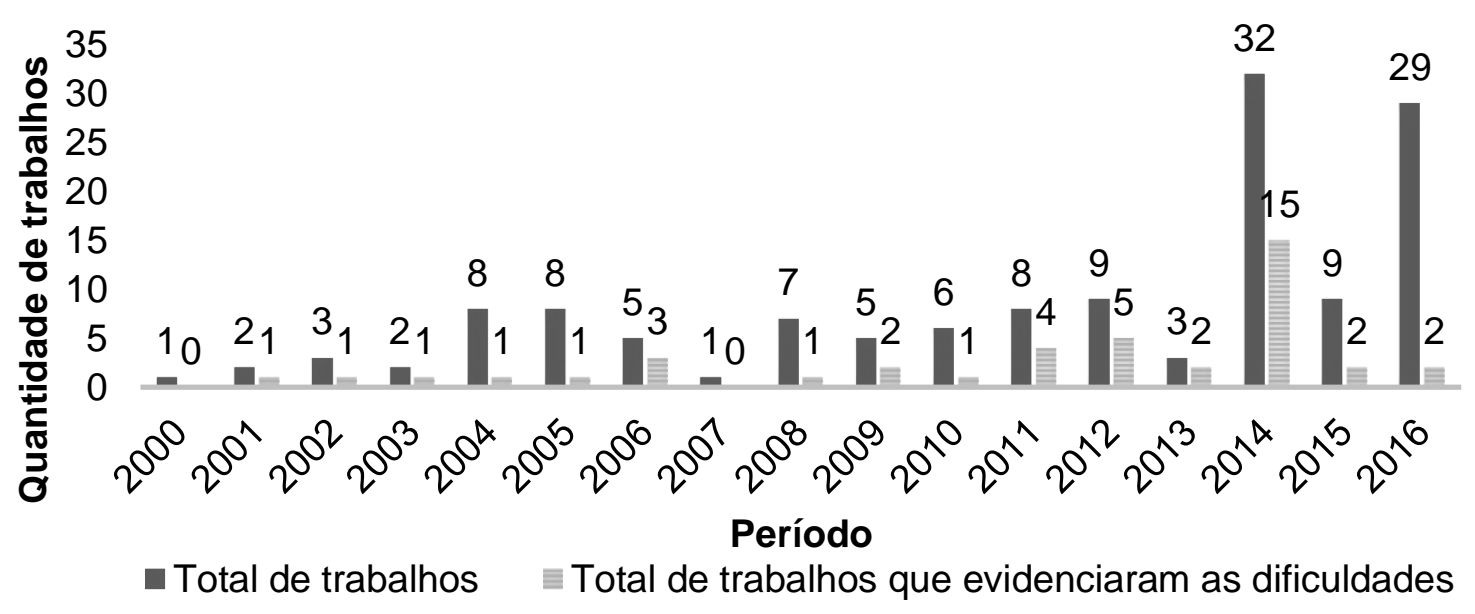

Figura 10. Número total de trabalhos catalogados sobre o conteúdo redox e a relação de trabalhos que contemplavam as dificuldades de seus participantes com esse conteúdo na RASBQ, ENPEC, ENEQ e EPPEQ

O público alvo das investigações, em ordem decrescente foi: alunos do ensino médio (23) > professores da educação básica (9) > licenciandos em química (7) e professores da educação básica e pós-graduandos (1). Nesse sentido, a seguir serão delineadas as principais limitações apresentadas nas pesquisas com a respectiva estratégia de ensino adotada.

Propondo identificar as limitações sobre reações redox de professores novatos por meio de práticas experimentais, Cruz e colaboradores (2006) denotaram em sua pesquisa que os docentes participantes não compreendiam a simultaneidade do processo de oxirredução. Outro projeto desenvolveu experimentos de eletroquímica em uma turma da Proeja (Programa Nacional de Integração da Educação Profissional). Os participantes demonstraram limitações em explicar o porquê o led vermelho acendia com maior intensidade que os demais leds adotados na prática experimental e em compreender que a reação química produz corrente elétrica (SOUZA; REIS; LINHARES, 
2009). Nessa mesma linha experimental, no experimento envolvendo a reação entre a palha de aço e a solução de hipoclorito de sódio $(\mathrm{NaClO})$ os alunos tiveram limitações em aferir os produtos da reação, em identificar os agentes oxidante e redutor, o número de oxidação das espécies envolvidas, e balancear a reação química (BENIGNO; OLIVEIRA; FRANCISCO JUNIOR, 2012). Outros autores apontaram que alunos não previam o acontecimento das reações redox ao compararem os potenciais de redução das espécies químicas envolvidas, além de conceberem equivocadamente que os elétrons atravessavam a solução salina (BOCANEGRA; GAZOLA, 2011). Igualmente, Gomes e colaboradores (2014) identificaram durante um experimento com biossensor para dosagem de triglicerídeos em caldos culinários que graduandos dos cursos de bacharelado e licenciatura em química, não relacionavam o potencial eletroquímico detectado com as reações redox ocorridas (GOMES et al., 2014). Além disso, discentes conceituam erroneamente a reação redox (ALMEIDA et al., 2014) e a eletrólise (BARRETO et al., 2014). Por outro lado, em um experimento envolvendo o processo de inibição da oxidação da maçã pelo suco de limão, os alunos não conseguiam descrever a ação antioxidante do limão (MENDES; BATINGA; CAMPOS, 2014). Outra problemática apontada por Moura e colaboradores (2014) foi a dificuldade dos discentes reconhecerem que no cátodo ocorre a redução enquanto que no ânodo a oxidação (MOURA et al., 2014).

Outro estudo que adotou um questionário como instrumento de coleta de dados evidenciou que alunos não conseguiam escrever a reação redox entre o cobre e o zinco, na pilha de Daniell (NASCIMENTO; MELO; REGIANI, 2014). Para Soares, Müchen e Adaime "Os estudantes poderiam ter conhecimento teórico, mas não conseguiram representá-lo através da linguagem química, o que contemplaria dificuldades no aspecto representacional" (2014, p.1616).

Melo, Sousa e Cintra (2015) realizaram a análise estatística e pedagógica dos itens envolvendo a eletroquímica nas provas do ENEM (Exame Nacional do Ensino médio) de 2009 a 2013. Na parte pedagógica, alunos do ensino médio demonstraram dificuldades em compreender o termo "força redutora" e reconhecerem as espécies químicas que sofrem oxidação e redução. Ao adotarem também um questionário para investigar a concepção de professores (NOVAIS et al., 2014; SILVA; RIBEIRO; CHAVES, 2009), professores e pós-graduandos em ensino de ciências (OLIVEIRA; TORRES, 2015) e de alunos (SANTOS; COSTA; CHAVES, 2013) sobre radicais livres e antioxidantes, pesquisadores expuseram em seus resultados que os participantes tinham conhecimentos limitados sobre a temática, refletindo em construções conceituais baseadas no senso comum. Goes e colaboradores (2016) ao analisaram um questionário aplicado antes e após o desenvolvimento do curso de formação Capítulo 4. Resultados e Discussões 
continuada, evidenciaram que os docentes apresentaram limitações em relação aos conceitos de célula galvânica, célula eletrolítica, força eletromotriz e corrente elétrica. De modo semelhante, Goes, Fernandez e Agostinho (2016) ao avaliarem um questionário respondido por professores, constataram que os docentes demonstraram dificuldades em compreender o conceito de força eletromotriz e assimilaram erroneamente que as reações redox ocorrem somente com a participação do oxigênio.

Em outra investigação para identificar as concepções sobre reações redox de um grupo de bolsistas de um subprojeto Pibid-Química, pesquisadores solicitaram que os pibidianos indicassem os principais conceitos relacionados ao tema e respondessem ao questionamento "Baseando-se nas suas concepções sobre o tema, formule o conceito de oxidação e redução procurando mencionar no seu texto os conceitos de perda e ganho de elétrons além de número de oxidação" (SKEIKA et al., 2014, p.1). Nas respostas, os licenciandos apresentaram os conceitos de número de oxidação (NOX) (60\% das vezes), redução e oxidação, contudo de modo fragmentado sem estabelecer relações claras entre um conceito e outro, sugerindo uma falta de conhecimento sobre a temática.

Os autores Fontes, Lourenço e Messeder (2012), desenvolveram uma pesquisa sobre o tema pilha de Daniell, norteados por dois objetivos: identificar a concepção de alunos e analisar livros didáticos para identificar as possíveis ilustrações errôneas acerca deste tema. Para tanto, aplicaram um questionário a um grupo de alunos do terceiro ano do ensino médio. Os dados suscitam que os discentes não compreendem o funcionamento da pilha de Daniell e, consequentemente, as reações químicas responsáveis pelo acendimento da lâmpada. Em relação aos livros didáticos, os autores argumentam que:

[...] a pilha de Daniell apresentada nos livros didáticos não representa fielmente a maneira como ele a construiu, até por que, quando John $\mathrm{F}$. Daniell projetou sua pilha em 1836 a lâmpada ainda não existia, pois somente seria inventada em 1879 pelo americano Thomas Alva Edison (1847-1931) (FONTES; LOURENÇO; MESSEDER, p.10, 2012).

Outro grupo de pesquisadores aplicou um questionário a alunos do ensino médio com o intuito de compreender seus conceitos sobre pilhas. Nas respostas os discentes expuseram limitações sobre o funcionamento das pilhas, apesar do tema ter sido objeto de estudo em aulas anteriores (ZITTEL; MILARÉ; FREIRE, 2011). Nesse mesmo sentido, bolsistas do programa de iniciação à docência, argumentam que os alunos do ensino médio memorizam as representações químicas, sem compreender o processo redox, principalmente por não assimilarem as nomenclaturas, representações e simbologias químicas. Segundo os pibidianos, $14,29 \%$ dos discentes participantes da investigação deixaram em branco a questão que solicitava o cálculo do número de 
oxidação dos constituintes do íon permanganato $\left(\mathrm{MnO}_{4}^{-}\right)$. As dificuldades conceituais saltaram ainda mais quando nenhum aluno soube balancear a reação: $\mathrm{Cl}_{2}+\mathrm{H}_{2} \mathrm{O}_{2} \rightarrow$ $2 \mathrm{HCl}+\mathrm{O}_{2}$. Outras surgiram quando os alunos não identificaram o agente oxidante e redutor, além de não compreenderem o sinal positivo atribuído a quem perde elétrons e negativo a quem ganha (SILVA; MARTINS; TEIXEIRA JÚNIOR, 2014). Demonstraram outra incoerência conceitual ao reconhecerem a semi-reação $\mathrm{Zn}_{(\mathrm{s})} \rightarrow \mathrm{Zn}^{2+}{ }_{(\mathrm{aq})}+2 \mathrm{e}^{-}$como a que sofre redução, e a semi-reação $\mathrm{Cu}^{2+}{ }_{(\mathrm{aq})}+2 \mathrm{e}^{-} \rightarrow \mathrm{Cu}_{(\mathrm{s})}$ como a que sofre oxidação. Menos de $8 \%$ dos alunos identificam o cátodo, ânodo e os agentes oxidante e redutor, de forma correta (LIMA; TEIXEIRA JÚNIOR, 2014).

Igne e colaboradores (2006) ao investigarem a concepção de alunos sobre reações redox identificaram que apesar dos discentes reconhecerem a tendência de um metal reduzir ou oxidar, não compreendem a causa do fenômeno, assimilando erroneamente que, quanto maior o valor do potencial de redução, maior seria a tendência de o átomo perder elétrons, e que a espécie oxidante sofre oxidação. Em outra questão expuseram não relacionar a somatória das semirreações ocorridas na pilha com a somatória dos potencias de redução e oxidação, evidenciando a falta de conexão entre os aspectos qualitativo e quantitativo, problemática apontada pelos autores Ogude e Bradley (1996). Por fim, tinham a concepção que os elétrons fluíam através da ponte salina independentemente da espécie química correspondente. Segundo Carvalho e colaboradores (2006) ao investigarem o desenvolvimento do conteúdo redox no ensino médio por seis professores, por meio de questionário, a maioria dos professores adotam a experimentação como principal estratégia de ensino, e consideram difícil ensinar eletrólise, "força" oxidante e redutora e balanceamento das reações.

Outros investigadores adotaram sequências de ensino para o desenvolvimento da eletroquímica. Nessa perspectiva, ao propor uma sequência de ensino, Nunes e colaboradores (2013) trabalharam com dois grupos: o primeiro formado por estudantes ( $n=58)$ que participaram da aplicação da sequência, denominado de Grupo de Intervenção (Gl) e outros alunos $(n=58)$ provenientes do ensino convencional, denominado Grupo Padrão (GP). Mediante a análise dos resultados do GI, apenas 4 alunos descreveram que água conduzia corrente elétrica na presença de íons. $\mathrm{Na}$ percepção dos pesquisadores as dificuldades dos participantes podem ser resultado da inapropriação dos conceitos de íons e condutibilidade elétrica. A dificuldade de enxergar o protagonismo dos íons em solução aquosa já foi tema de investigação (CÁSSIO et al., 2012). Em outro momento da intervenção, os discentes (43 do grupo Gl e 51 do grupo GP) não responderem à questão que solicitava a escrita da reação química do processo de eletrólise ígnea do Cloreto de Sódio ( $\mathrm{NaCl})$. Apenas quatro e cinco estudantes do $\mathrm{Gl}$ Capítulo 4. Resultados e Discussões 
e GP, respectivamente, fizeram uso de equações químicas de forma correta (NUNES et al., 2013). Em outro resumo o autor propôs o planejamento e implementação de uma unidade de aprendizagem sobre corrosão e suas reações de oxirredução, tendo como temática a maresia. Neste trabalho as principais limitações vencidas pelos docentes foram conseguir "[...] compreender a relação que existe entre os aspectos macroscópicos, microscópicos e simbólicos no processo de elaboração conceitual que sempre líamos a respeito, ouvíamos falar, mas nunca tínhamos conseguido compreender" (MAIA et al., 2008, p.7).

Freitas e colaboradores (2012) propuseram, em virtude do baixo rendimento dos discentes em uma prova de eletroquímica, uma sequência de seis aulas fundamentadas na história da eletroquímica e no experimento da Pilha de Volta e de Daniell. Segundo os autores, os discentes não conseguiram estruturar as reações redox, representar a pilha e indicar a direção que os elétrons fluíam na célula eletroquímica $\mathrm{Mg} / \mathrm{Fe}$. De modo semelhante, outra investigação objetivou aplicar uma intervenção didática que possibilitasse a reestruturação de conceitos equivocados por meio das etapas: 1. Leitura e interpretação do texto: História e Perspectiva dos Veículos Elétricos, 2. Resolução do questionário em grupo, 3. Socialização das hipóteses elaboradas e 4. Na estrutura do resumo seus autores expuseram que a etapa 4, tinha como objetivo reestruturar conceitos equivocados sobre eletroquímica permeados na aula 3. Nesse sentido os alunos participantes sugeriram que os conceitos que haviam tido dificuldade foram: a natureza dos compostos iônicos e covalentes; eletronegatividade e polaridade; variação no número de oxidação, energia elétrica e térmica associada às transformações químicas; semi-reação de oxidação e redução; reações redox; e agente oxidante e redutor (SILVA; SILVA; SOUZA, 2014).

Durante um curso para professores da educação básica, os docentes vivenciaram situações concretas de ensino tendo como conteúdo a eletroquímica por meio da experimentação e planejamento de sequências didáticas a serem aplicadas por eles em contextos reais de sala de aula. No desenvolvimento do curso foi possível identificar concepções alternativas dos professores ligadas a corrente elétrica, condutibilidade em soluções, conceito de redução e oxidação, além das limitações na representação das reações químicas (LIMA; AGOSTINHO; MARCONDES, 2004). Outros pesquisadores investigaram as dificuldades de aprendizagem de um grupo de licenciandos em química sobre a eletroquímica, no "[...] contexto de um minicurso realizado como parte do Programa de Formação Complementar" (FREIRE; SILVA JÚNIOR; SILVA, 2011, p.4). Durante a sua implementação foram propostas algumas atividades a serem desenvolvidas pelos pibidianos, dentre elas a realização de uma prova em que uma das questões solicitava a identificação dos processos redox nas Capítulo 4. Resultados e Discussões 
semicélulas de cada sistema. Contudo, 34\% dos participantes responderam erroneamente por desconhecerem o termo semicélula e pelo não reconhecimento da influência da concentração das soluções no funcionamento das pilhas. Outros licenciandos tinham limitações em descrever o sentido do fluxo de elétrons nas pilhas e a função da ponte salina que seria, segundo os graduandos, deslocar elétrons.

Bianchini e Zuliani (2010) evidenciaram durante um curso ministrado por licenciandos em química, que os discentes do ensino médio tinham limitações em explicar a oxidação de um metal sem a presença de oxigênio, e como o processo de galvanização protege os metais.

Em uma das publicações catalogadas, seus autores analisaram como uma proposta CTS (Ciência, Tecnologia e Sociedade) poderia aguçar a curiosidade dos discentes. Para tanto, propuseram uma oficina de eletroquímica, articulando o conhecimento científico e tecnológico ao contexto socioambiental. Contudo, apesar dos discentes terem estudado os conceitos de eletroquímica apresentaram dificuldades em articulá-lo com a temática ambiental, além de não compreenderem os aspectos quantitativos da eletroquímica (SILVA; FERNANDES; SOUZA, 2014).

Gomes e Pereira (2014) estruturaram um Estudo de Caso para identificar as concepções de uma turma do curso técnico em química integrado ao Ensino Médio sobre pilhas. Os dados expuseram que, apesar dos alunos saberem os conceitos de oxidação e redução, cátodo e ânodo, não estruturaram respostas sobre o conceito geral de pilhas, além de não empregarem em seus argumentos a palavra "elétron". Estabelecem tenuamente o processo de oxidação e redução aos íons, além de não relacionarem a energia produzida na pilha com o potencial medido em volts e, consequentemente, que a ddp está condicionada às espécies químicas participantes das semirreações.

Em outro resumo, seus autores objetivavam "[...] verificar como os alunos do curso de Licenciatura em Química (...) estabelecem relações entre conceitos, através da construção de mapas, e como aplicá-los na avaliação do conhecimento sobre reações de oxirredução" (MASSON et al., 2002, p.1). Nos mapas construídos os graduandos expunham limitações na escrita das semirreações de oxidação e redução e na semântica: entre oxidante e oxidado, redutor e reduzido. Outro trabalho com mapas conceituais apontou que os docentes não diferenciavam conceitos microscópicos e macroscópicos, e buscavam detalhar os conceitos de atomística, em detrimento das reações químicas (LIMA; AKAHOSHI; MARCONDES, 2005).

Por meio da resolução de exercícios constituídos por questões de vestibulares, outros autores propuseram investigar as dificuldades dos discentes em relação à eletroquímica. Os dados obtidos sinalizam dificuldades relacionadas à escrita de Capítulo 4. Resultados e Discussões 
reações redox envolvendo espécies iônicas e o cálculo do número de oxidação. Nessa mesma linha de intervenção, Barros, Silva e Ribeiro (2003) aplicaram a um grupo de alunos do terceiro ano uma questão de vestibular da UFMG com alto índice de erro. Entretanto, os discentes tiveram um índice elevado de acerto nos três itens que compunham o exercício sendo estes respectivamente, $71 \%$, 93\% e 79\%. Contudo, no item $129 \%$ dos alunos escreveram equivocadamente as reações químicas em virtude da leitura errada dos potenciais de redução fornecidos, que denotavam que a reação química não poderia acontecer (BARROS; SILVA; RIBEIRO, 2003).

Por meio da adoção de um jogo denominado "Super redox", um grupo de investigadores pretendia desenvolver o conceito de semirreações, balanceamento de reações, entre outros. Mas, antes aplicaram um pré-teste a discentes do ensino médio e mais de $80 \%$ da classe não percebia a diferença entre receber e doar elétrons e tinham dificuldades com a estequiometria nas reações redox e na diferenciação entre pilha e eletrólise (SILVA; LOPES, 2012). Por outro lado, outros investigadores empregaram a estratégia metavisual para ajudar alunos do ensino médio a compreenderem a diferença de dimensões entre átomos e íons em uma reação eletroquímica. Para tanto, a priori, propuseram que os discentes observassem um experimento, e na sequência, em dupla, elaborassem a representação submicroscópica da reação. Em outra etapa foram disponibilizados desenhos para que os alunos comparassem com os seus, e pudessem reconstruí-los. Nessa intervenção as principais limitações dos discentes foram interpretar o nível submicroscópico, pois não conseguiam perceber a diferença de tamanho entre o cátion e o átomo (LOCATELLI; ARROIO, 2014).

Dois outros trabalhos adotaram a FlexQuest como estratégia de ensino, entretanto, ambos pertenciam aos mesmos autores (SANTOS; LEÃO, 2011, 2012). Nessas pesquisas os docentes da educação básica estruturaram a FlexQuest, no entanto, expuseram dificuldades em abordar a eletroquímica em temáticas diferentes de pilhas e baterias por não conseguirem transpor os conceitos redox para outros temas como evidencia o trecho a seguir: "[...] como impedir a oxidação da pele? O envelhecimento em si. No caso, seria o isolar, limitar, a ação dos radicais livres. Não é isso? Bom, mas aí eu acho difícil amarrar isso com Eletroquímica... né? Eu acho a proposta boa, cotidiana, dá pra puxar a atenção dos meninos, só não saquei a correlação com o eixo central [...]" (SANTOS; LEÃO, 2012, p.6-7).

As análises dos trabalhos catalogados suscitam que seus autores estavam pautando seus estudos na proposição de diferentes estratégias, como um possível meio para superar as dificuldades no ensino e na aprendizagem de redox. Como descrito anteriormente, apenas $38 \%$ das pesquisas descrevem as dificuldades dos investigados 
em relação ao conteúdo redox e não apenas enumeram as limitações apontadas, principalmente, na literatura internacional.

$\mathrm{Na}$ tabela 4 agrupou-se sucintamente as principais limitações associadas ao ensino redox catalogadas nesses trabalhos.

Tabela 4. Principais dificuldades relacionadas ao ensino e aprendizagem de reações redox catalogadas entre os anos de 2000 a 2016

\section{Limitações}

\begin{tabular}{|c|c|}
\hline $\begin{array}{l}\text { Compreender a simultaneidade das reações } \\
\text { redox }\end{array}$ & Aferir os produtos das reações redox. \\
\hline $\begin{array}{l}\text { Assimilar a transformação de energia química } \\
\text { em energia elétrica }\end{array}$ & Identificar os agentes oxidante e redutor \\
\hline Diferenciar pilha de eletrólise & Balancear as reações redox \\
\hline $\begin{array}{l}\text { Prever a reação química por meio da } \\
\text { comparação dos potenciais de redução das } \\
\text { espécies químicas }\end{array}$ & $\begin{array}{l}\text { Reconhecer que no cátodo ocorre a redução e } \\
\text { no ânodo a oxidação }\end{array}$ \\
\hline Conceituar reações redox & Conceituar eletrólise \\
\hline Compreender a ação antioxidante de alimentos & Conceituar radicais livres e antioxidantes \\
\hline $\begin{array}{l}\text { Não estabelecem relações entre os conceitos } \\
\text { redox }\end{array}$ & $\begin{array}{l}\text { Livros didáticos representam erroneamente a } \\
\text { pilha de Daniell }\end{array}$ \\
\hline $\begin{array}{l}\text { Não assimilam as nomenclaturas, } \\
\text { representações e simbologias químicas }\end{array}$ & Não conseguem conceituar Pilha de Daniell \\
\hline $\begin{array}{l}\text { Limitações em explicar a oxidação de um metal } \\
\text { sem a presença de oxigênio, e como o processo } \\
\text { de galvanização protege os metais }\end{array}$ & $\begin{array}{l}\text { A concepção que os elétrons fluem através da } \\
\text { ponte salina independentemente da espécie } \\
\text { química correspondente }\end{array}$ \\
\hline $\begin{array}{l}\text { Assimilavam erroneamente que quanto maior o } \\
\text { valor do potencial de redução, maior seria a } \\
\text { tendência de o átomo perder elétrons, e que a } \\
\text { espécie oxidante sofre oxidação }\end{array}$ & $\begin{array}{l}\text { Natureza dos compostos iônicos e covalentes, } \\
\text { eletronegatividade e polaridade, energia } \\
\text { elétrica e térmica associada às } \\
\text { transformações químicas }\end{array}$ \\
\hline $\begin{array}{l}\text { Falta de conexão entre os aspectos qualitativo e } \\
\text { quantitativo }\end{array}$ & $\begin{array}{l}\text { Inapropriação de conceito de íons e } \\
\text { condutibilidade elétrica }\end{array}$ \\
\hline $\begin{array}{l}\text { Compreender a relação que existe entre os } \\
\text { aspectos macroscópicos, microscópicos e } \\
\text { simbólicos no processo }\end{array}$ & $\begin{array}{l}\text { Não compreendem o sinal positivo atribuído a } \\
\text { quem perde e negativo a quem ganha elétrons }\end{array}$ \\
\hline $\begin{array}{l}\text { Não reconhecer a influência da concentração } \\
\text { das soluções no funcionamento das pilhas }\end{array}$ & $\begin{array}{l}\text { Não empregarem em seus argumentos a } \\
\text { palavra "elétron" }\end{array}$ \\
\hline $\begin{array}{l}\text { Detalham os conceitos de atomística, em } \\
\text { detrimento das reações redox }\end{array}$ & $\begin{array}{l}\text { Transpor os conceitos redox para outros } \\
\text { temas }\end{array}$ \\
\hline Calcular o número de oxidaç & Diferenc \\
\hline
\end{tabular}

Grande parte das pesquisas teve como público alvo alunos do ensino superior, o que sugere que a longo prazo isso pode ser refletido no ensino básico, pois grande parte desses graduandos eram de cursos de licenciatura.

\section{Eventos Internacionais}

Apesar de muitos trabalhos catalogados proporem metodologias para superar as dificuldades em ensinar reações redox e também analisar as concepções alternativas de alunos e professores, poucos pesquisadores expõem as limitações dos participantes de seus estudos. Em consonância, apesar do mapeamento de 25 trabalhos (7 ESERA $<9$ NARST < 10 ENSEÑANZA), apenas 7 (3 ESERA < ENSEÑANZA 4) retratavam as 
dificuldades relacionadas a reações redox. Os participantes das pesquisas eram, em ordem decrescente: alunos do ensino médio (3), licenciandos em química (3) > professores da educação básica (1). Lima e Marcondes (2005) propuseram um curso de formação continuada sobre o tema de eletroquímica, no qual os participantes pudessem analisar criticamente propostas experimentais sobre o tema e expusessem suas possíveis limitações conceituais. Segundo os autores, no final do curso os professores superaram algumas limitações conceituais, entretanto, demonstraram dificuldades "[...] em relação a: resistividade, condutância, condutibilidade elétrica, polarização, descarga, dipolos [...]" (LIMA; MARCONDES, 2005, p.2).

Outro estudo (MIRALLES; MONTIEL; ODETTI, p.1836, 2009) propôs um curso de inorgânica para dois grupos. O primeiro grupo era composto por 30 alunos recém ingressantes na graduação (grupo controle), enquanto o segundo grupo por 30 graduandos não participantes do curso, ambos os grupos deveriam responder a um questionário sobre reações redox envolvendo o diagrama de Latimer. Os cursistas deveriam seguir o protocolo para responder o questionário disposto na figura 11.

\footnotetext{
1.- Retome el fundamento teórico del tema Diagramas de Latimer desarrollado en la Unidad II y complemente con la lectura de las páginas 165 a 167 del Capitulo 9, del libro "Química Inorgánica Descriptiva" del autor Geof Rayner - Canham (se adjunta archivo con las páginas escaneadas, además está disponible en biblioteca).

2.- Afiance lo aprendido interpretando los diagramas presentados, por grupo de elemento y en soluciones ácida y básica, en el apéndice 3, páginas 545 a 554 del libro "Química Inorgánica Descriptiva" del autor Geof Rayner - Canham.

3.- Las dudas que surjan puede aclararlas haciendo uso del correo electrónico de la Asignatura.

4.- Resuelva la Serie $N^{\circ}$ 8: Diagramas de fem. Potenciales de hemireacciones.

5-Envie la serie resuelta a la dirección de mail: quimicainorganicafacena@ayahoo.com ar

Contraseña: abcdef

Si no tiene acceso al correo, entregue personalmente en el laboratorio 32 .

Fecha de entrega: 31 de octubre hasta las $16 \mathrm{hs}$.

6.- Para fijación del contenido desarrollado resuelva los ejercicios complementarios de la serie 8.
}

Figura 11. Padrões a serem seguidos na resolução da atividade (Fonte: MIRALLES; MONTIEL; ODETTI, 2009, p.1836)

Segundo os autores os diagramas de Latimer foram escolhidos por possibilitar a integração de certos conceitos, a saber: balanceamento de equações redox, critérios de espontaneidade, potencial, entre outros. Nos resultados os discentes demonstraram incoerência conceitual, pois não conseguiam calcular o número de elétrons, por não identificarem os estados de oxidação das espécies químicas envolvidas, além de interpretarem equivocadamente os potenciais de redução.

Valencia e colaboradores (2013) propuseram e implementaram uma sequência de ensino sobre a eletroquímica, permeando aspectos históricos da eletroquímica e embasada em modelos que permitissem explicar os fenômenos científicos observados. Nos resultados os discentes explicam por meio de representações (desenhos) como ocorria a condução elétrica, nas ilustrações observou-se que os alunos têm o Capítulo 4. Resultados e Discussões 
entendimento que a condução elétrica ocorre em virtude da diferença de cargas entre as partículas, contudo não relacionam o fluxo da corrente elétrica com o movimento dos elétrons. Ao representarem uma bateria, confundem átomo com elétron, além de não compreenderem como ocorre o processo de carregamento de uma bateria. Entendem que as reações redox ocorrem somente na presença de oxigênio. Os autores, ao perguntarem aos alunos porque os barcos de uma empresa ficam oxidados depois de um tempo, receberam explicações baseadas em aspectos macroscópicos, como umidade, sol, chuva. Os discentes não mencionam que as causas estão relacionadas a reações com elétrons.

Silva e Cintra (2013) investigaram as contribuições da simulação e aulas experimentais no ensino das reações redox. $\mathrm{Na}$ etapa que os discentes realizaram as representações submicroscópicas para as reações entre $\mathrm{AgNO}_{3(\mathrm{aq})}+\mathrm{Cu}_{(\mathrm{s})}$ e $\mathrm{Fe}(\mathrm{s})+$ $\mathrm{CuSO}_{4(\mathrm{aq})}$, os discentes não diferenciaram o tamanho do átomo e do íon, além de disporem elétrons "nadando" na solução. Para as autoras, as aulas experimentais propiciam uma melhor compreensão das representações macroscópicas dos conceitos estudados e discutem que a adoção da simulação abre espaço para a discussão dos modelos propostos, que influencia diretamente nas representações submicroscópicas sobre o fenômeno estudado pelos discentes.

Ekiz e colaboradores (2011) realizaram um estudo que investigou a compreensão e as possíveis dificuldades de futuros professores de química sobre células eletrolíticas. Os licenciandos responderam a sete questões subjetivas relacionadas à temática. Os resultados revelaram que os licenciandos não diferenciavam células eletrolíticas de células galvânicas, não identificam os eletrodos como ânodo e cátodo, e consequentemente não previam o produto da eletrólise.

Bouni e colaboradores (2011) analisaram o papel da simulação na aprendizagem dos alunos, sobre células eletroquímicas e circuito fechado. Para tanto, alunos de ensino secundário responderam a um questionário pré-teste antes de visualizarem as simulações. Posteriormente, os discentes responderam o questionário acompanhado de uma entrevista em que deveriam delinear suas percepções acerca da simulação. No pré-teste $40 \%$ dos alunos demonstraram limitações em compreender o fluxo de elétrons e íons, respectivamente nos condutores ôhmicos e nos condutores eletrolíticos da célula. Ao analisar o questionário no pós-teste, $80 \%$ dos discentes parecem ter compreendido o fluxo de elétrons e íons.

Goes e Fernandez (2015) ao analisarem o CoRe respondido por licenciandos em química, evidenciaram que os participantes têm a compreensão de que as limitações dos discentes sobre o conteúdo redox, são reflexos do não entendimento da simultaneidade das reações redox, por assimilarem que a oxidação está associada ao Capítulo 4. Resultados e Discussões 
ganho de oxigênio e por não compreenderem os termos agente oxidante e redutor. Nesse trabalho, apesar de as autoras não evidenciaram as dificuldades dos professores em formação, consideramos pertinente analisar o que os futuros docentes sabem sobre as limitações dos estudantes sobre este conteúdo.

Dentre a literatura analisada, tanto em âmbito nacional como internacional, são raros os estudos sobre as concepções de professores a respeito de reações de oxirredução (ÖZKAYA, 2002, 2003). Em relação ao PCK, nenhum dos trabalhos analisados buscou investigar na formação continuada e ou inicial de professor como este conteúdo vem sendo desenvolvido em sala de aula, mas as limitações dos professores em relação a este conteúdo (ROLLNICK; MAVHUNGA, 2014; YILMAZ; BAYRAKÇEKEN, 2015).

Assim, esse fato justifica ainda mais o nosso interesse em pesquisar como futuros docentes trabalham este conteúdo em sala de aula e de que forma o Pibid pode contribuir para o desenvolvimento do Conhecimento Docente desses licenciandos em Química.

\subsection{Conhecimento Docente}

Como descrito anteriormente, este trabalho buscou evidenciar as contribuições do Pibid na construção do Conhecimento Docente de bolsistas desse programa institucional. Para tanto, foram selecionados e coletados materiais referentes às ações dos bolsistas durante suas atividades nesse subprojeto. Contudo, durante a coleta de dados foi observado que nem todos os bolsistas estavam caminhando com a finalidade de trabalhar o conteúdo redox, o que nos levou a selecionar apenas os bolsistas que trabalharam com este conteúdo programático. Nesse sentido, foram coletados os dados referentes a três pibidianos, que por razões éticas receberam nomes fictícios, a saber: Melissa, Antônio e Mateus. Os bolsistas atuaram em uma escola estadual na região sul da cidade de São Paulo sob a supervisão de Luiza e coordenação de Maria. Suas ações no Pibid foram executadas em dupla, Melissa e Antônio, e em trio, Mateus, Elder e Clara. Desses pibidianos analisou-se o Conhecimento Docente de Melissa, Antônio e Mateus, por serem os bolsistas que estavam no subprojeto desde o início da coleta de dados, e por terem estruturado as aulas que implementaram.

Para identificar o possível reflexo do Pibid na construção do Conhecimento Docente dos pibidianos, buscou-se entrelaçar momentos temporais que levem a vislumbrar essa influência. Posteriormente, foi descrito os resultados relacionados aos possíveis impactos do Pibid na formação das tutoras Maria e Luiza.

Partindo-se do pressuposto que a prática oportunizada pelo Pibid e as orientações recebidas das professoras tutoras poderiam refletir no Conhecimento 
Docente dos pibidianos, buscou-se desvelar os reflexos do Pibid na prática pedagógica dos licenciando em química participantes deste estudo. Em consonância com os objetivos de pesquisa traçados, apresentam-se como resultados inicialmente a análise do perfil socioeconômico e cultural dos bolsistas atuantes na escola sede da região sul da cidade de São Paulo e o perfil individual dos pibidianos. Na sequência, foi esquematizado o resumo das aulas desenvolvidas pela dupla Antônio e Melissa, seguido das análises de seus respectivos conhecimentos docentes. Subsequentemente, delineia-se as aulas implementadas por Mateus, e o seu Conhecimento Docente de Mateus.

\section{Perfil dos pibidianos}

No intuito de traçar os perfis individuais dos três bolsistas investigados, as respostas obtidas ao instrumento (apêndice 5) foram tabuladas segundo a variação percentual.

O grupo de pibidianos era constituído por uma discente do sexo feminino tinha 18 anos. Outros dois bolsistas eram do sexo masculino, sendo que dois deles tinham idade entre 16 a 20 anos, solteiros, e o terceiro com idade entre 21 a 24 anos, casado.

Os bolsistas ao concluírem o ensino médio, ingressaram no ensino superior. Nesse grupo de pibidianos, dois concluíram a educação básica em escolas públicas e apenas um em instituição privada. Dentre os bolsistas, dois cursaram o ensino médio concomitantemente com o técnico em química.Em relação ao número de vestibulares prestados para ingressar na licenciatura os três pibidianos responderam que fizeram três processos seletivos diferentes.

Quanto à escolaridade dos pais dos bolsistas, foi observada uma variação no nível de formação das mães, onde duas tinham formação em nível superior e outra era analfabeta. Em relação ao grau de escolaridade dos pais, dois tinham formação em nível superior e um o ensino fundamental incompleto.

Todos os pibidianos revelaram que a atividade remunerada que exerciam era o Pibid e contribuíam parcialmente na renda familiar.

Outras duas questões tratavam sobre o conhecimento em língua inglesa e espanhola. O conhecimento era nulo em língua estrangeira por dois pibidianos, um em inglês e outro em espanhol. Por outro lado, dois pibidianos sinalizaram que lêem, mas não escrevem e nem falam, espanhol e inglês.

Segundo alguns referenciais teóricos (VALLE, 2003; PRIMl et al., 2000; BOTTI; MEZZAROBA, 2007) são diversos os fatores que influenciam na escolha profissional, dentre eles a experiência de vida, a família, os professores, entre outros. Nesse sentido, para um dos pibidianos a escolha pela carreira docente foi influenciada pela baixa 
relação candidato e vaga. Quanto à certeza de escolha pela licenciatura em química, dois dos pibidianos estavam absolutamente decididos, e os demais tinham dúvida. Talvez a indecisão de um dos pibidianos seja reflexo de suas idades, entre 18 e 20 anos, pois a decisão precoce por uma profissão logo ao término do ensino médio leva muitos jovens a optarem por uma carreira como se a fossem exercer para a vida toda, não os levando a escolhas racionais (BRAGA et al.,1997; VELOSO; ALMEIDA, 2001; ARAÚJO et al., 2007; BOUDAN, 1997; JESUS; VIANNA, 2014). Essa incerteza em cursar licenciatura por um dos três pibidianos é um dado preocupante, em virtude da grande evasão nas licenciaturas, e por não ser a primeira opção dos candidatos em nível superior (TARTUCE; CARDEAL, 1997; CUNHA; TUNES; SILVA, 2001; ALMEIDA, 2010). Segundo dois bolsistas, o tempo destinado aos estudos está em torno de quatro horas e para outro, em oito horas, sugerindo que os pibidianos mantêm uma rotina dedicada aos estudos. Os graduandos residem em diferentes regiões da cidade de São Paulo, sendo um na zona leste e dois na sul. $O$ tempo de translado de suas residências à Instituição de Ensino varia de 30 a 90 minutos. Os principais meios de transporte utilizados são o metrô e ônibus.

A seguir, apresenta-se o perfil dos três pibidianos Antônio, Melissa e Mateus, delineado pelas narrativas construídas ao longo da entrevista semiestruturada (apêndice 2).

\section{O pibidiano Antônio}

Antônio nasceu em 1992 no estado do Rio de Janeiro. Cursou o ensino médio em escola pública e fez curso técnico em química. Seu ingresso em nível superior foi no ano de 2012 no Instituto Federal de Educação, Ciência e Tecnologia do Rio de Janeiro (IFRJ). A sua primeira opção era a Engenharia Química, contudo a alta concorrência no curso desejado o levou a prestar o vestibular para licenciatura.

O bolsista revelou que ao iniciar a graduação "[...] pretendia no futuro continuar fazendo vestibular, e eliminar matéria da Engenharia Química. Com o tempo eu fui gostando da licenciatura, e decidi terminar o curso" (Entrevista semiestruturada, Antônio - turno 10). Apesar de estar decidido a concluir a licenciatura em química e considerar que ensinar é prazeroso, tem dúvidas se atuará ou não como professor.

A motivação inicial de Antônio em participar do Pibid "[...] foi a possibilidade de receber uma bolsa, depois eu fui vendo que é um trabalho sério, e que podia me agregar algum tipo de capacitação" (Entrevista semiestruturada, Antônio - turno 24). Na fala de Antônio é importante perceber a valorização que passa a atribuir ao Pibid para a sua formação como futuro professor. Apesar de na entrevista não ter deixado claro a necessidade de receber uma bolsa, durante as conversas com a pesquisadora ao longo 
do processo de coleta de dados, Antônio revela que em virtude de sua mudança do Rio de Janeiro para São Paulo sua esposa era a única provedora das despesas familiares. Em outros trechos, argumenta que a sua atuação no programa contribuiu para o estudo de metodologias de ensino, além de propiciar a elaboração e aplicação dos planos de ensino (Entrevista semiestruturada - Antônio).

Antônio no ano da coleta de dados (2014) estava cursando o sexto semestre e algumas disciplinas do sétimo. Esse ano foi o ano de seu ingresso no Pibid. É um aluno sem reprovações e uma vida acadêmica como graduando marcada pelo desenvolvimento de pesquisas como aluno de iniciação científica e iniciação à docência.

\section{A pibidiana Melissa}

A pibidiana Melissa nasceu em 1997 no estado de São Paulo. Sua formação na educação básica foi realizada em instituição particular. Seu ingresso na licenciatura ocorreu no ano de 2014 aos 17 anos e a carreira docente sempre foi seu desejo. Segundo a bolsista, no ensino médio habitualmente ajudava os seus amigos de classe que tinham dificuldades com conceitos químicos, pois era a disciplina que mais gostava (Entrevista semiestruturada, Melissa).

As motivações de Melissa em participar do Pibid podem ser compreendidas no trecho: "Na verdade, eu tive uma intimação para trabalhar no Pibid, e falaram pra mim: 'Ah, é bom, vai lá, né? Você vai gostar' E eu vim meio que de paraquedas, eu não fazia muita ideia do que ia acontecer, ah, vai lá que é bom" (Entrevista semiestruturada, Melissa - turno 19). Em sua fala, sugere que não conhecia o programa institucional, mas mesmo assim decidiu fazer a sua inscrição na seleção de bolsistas.

Melissa ingressou no Pibid no mesmo ano de seu ingresso na licenciatura, isto pode ter sido um fator limitante para o desenvolvimento de suas aulas em decorrência da pouca familiaridade com disciplinas pedagógicas e de conteúdo específico. Até o momento da entrevista não teve reprovações na graduação, sendo considerada pelos docentes da licenciatura uma graduanda comprometida com a sua formação.

\section{O pibidiano Mateus}

Mateus nasceu na cidade de São Paulo em 1996. No ensino médio cursou concomitantemente o curso técnico em química, em instituições públicas. Aos dezessete anos, ingressou na licenciatura em química, e assim como Antônio, a licenciatura não era a sua primeira opção, uma vez que seu grande desejo era ser matemático. Contudo, por influência de uma professora de química, amiga de sua mãe, decidiu optar pela licenciatura e pelo curso técnico em química. Segundo Mateus seu principal desejo em ensinar tinha por motivação "[...] formar um cidadão que seja crítico, 
um cidadão que consiga formar as suas decisões conscientemente, né" (Entrevista semiestruturada, Mateus - turno 20).

Segundo o bolsista a possibilidade de ter experiência em sala de aula e ser tutorado por professores experientes o motivaram a participar do Pibid.

No ano de 2014 o pibidiano estava no quarto semestre do curso e em seu segundo ano como bolsista do Pibid.

\subsection{A dupla: Antônio e Melissa}

As ações dos pibidianos eram realizadas em dupla. Para tanto, inicialmente será descrito o perfil do par em relação aos aspectos relacionados à elaboração das aulas e à escolha de sua temática. Posteriormente, apresenta-se a análise realizada acerca do conhecimento para a docência de Antônio e Melissa, e na sequência a percepção dos alunos da escola conveniada sobre o conhecimento docente dos bolsistas. Melissa e Antônio propuseram blocos de aulas, de acordo com os pressupostos da educação CTS e como temática $O$ descarte inadequado de baterias automotivas.

Os pibidianos argumentaram que a escolha do tema foi realizada em dupla e que a estruturação das aulas passava por reuniões semanais com a coordenadora e, por vezes, com a participação da supervisora. Para compreender a dinâmica do processo de desenvolvimento das aulas, organizou-se na sequência (quadro 11) as atividades acompanhadas e os documentos gerados em cada atividade observada pela pesquisadora.

Quadro 11. Ordem de coleta de dados e seus respectivos arquivos - Antônio e Melissa

\begin{tabular}{|l|c|}
\hline \multicolumn{1}{|c|}{ Atividade } & Arquivo \\
\hline Reunião geral & 1 \\
\hline Reunião geral & 2 \\
\hline Apresentação da proposta de trabalho & 3 \\
\hline Aula de sensibilização & 4 \\
\hline Reunião para saber o andamento & 5 \\
\hline Reunião Geral & 6 \\
\hline Reunião para saber o andamento & 7 \\
\hline Reunião para saber o andamento & 8 \\
\hline Reunião para saber o andamento & 9 \\
\hline Aula de sensibilização & 10 \\
\hline Aula de atomística & 11 \\
\hline Aula de Pilha de moedas & 12 \\
\hline Aula de Pilha de Daniell & 13 \\
\hline Reunião para saber o andamento & 14 \\
\hline Aula de revisão & 15 \\
\hline Aula de contaminação por chumbo & 16 \\
\hline Aula para saber o andamento & 17 \\
\hline Aula de logística reversa & 18 \\
\hline Entrevista semiestruturada - Antônio & 19 \\
\hline Aula feedback & 20 \\
\hline Apresentação dos resultados & 21 \\
\hline Reunião geral & 22 \\
\hline Reunião com a dupla & 23 \\
\hline
\end{tabular}




\begin{tabular}{|l|r|}
\hline Entrevista semiestruturada - Melissa & 24 \\
\hline Lembrança estimulada & 25 \\
\hline
\end{tabular}

Apesar das reuniões e da implementação de uma aula de sensibilização no primeiro semestre, os blocos de aulas (quadro 12) sobre o conteúdo redox foram sendo planejados e executados somente no segundo semestre na turma do terceiro ano da EJA.

Quadro 12. Blocos de aulas planejadas pelos pibidianos Melissa e Antônio

\begin{tabular}{|c|c|c|}
\hline Aula & Objetivos & Atividades \\
\hline 1-Sensibilização & $\begin{array}{llr}\begin{array}{l}\text { Conhecer } \\
\text { criticamente }\end{array} & \text { e } & \text { analisar } \\
\text { Nacional } & \text { a } & \text { Política } \\
\text { Sólidos } & & \text { Resíduos }\end{array}$ & $\begin{array}{l}\text { Apresentar aos alunos a PNRS por } \\
\text { meio de situações-problema. } \\
\text { Atividade escrita em grupo com a } \\
\text { proposição de soluções para as } \\
\text { problemáticas. }\end{array}$ \\
\hline $\begin{array}{l}\text { 2-2.1.Revisão } \\
\text { 2.2.Experimento } \\
\text { demonstrativo }\end{array}$ & \begin{tabular}{lr} 
Revisar & conteúdos \\
necessários para a \\
compreensão dos conceitos \\
\multicolumn{2}{l}{ de eletroquímica } \\
\end{tabular} & $\begin{array}{l}\text { 2.1. Retomar os conceitos de } \\
\text { atomística e íons. Exercícios } \\
\text { 2.2. Oxidação da palha de aço em } \\
\text { solução de sulfato de cobre }\end{array}$ \\
\hline 3-Pilha de moedas & $\begin{array}{l}\text { Desenvolver um experimento } \\
\text { para o aluno identificar os } \\
\text { componentes da pilha }\end{array}$ & $\begin{array}{l}\text { Pilha de Volta (pilha de moedas) e } \\
\text { leitura de texto }\end{array}$ \\
\hline 4-Pilha de Daniell & $\begin{array}{l}\begin{array}{l}\text { Conhecer } \\
\text { da pilha. }\end{array} \\
\end{array}$ & Aula expositiva. \\
\hline $\begin{array}{l}\text { 5- } \\
\text { 5.1. Revisão: } \\
\text { pilhas em série e bateria } \\
\text { automotiva Experimento } \\
5.2 \text {. E demonstrativo } \\
\text { d }\end{array}$ & $\begin{array}{l}\text { Diferenciar uma pilha de uma } \\
\text { bateria. Estudar } \quad 0 \\
\text { funcionamento de uma } \\
\text { bateria automotiva }\end{array}$ & $\begin{array}{l}\text { 5.1. Aula expositiva e exercício } \\
\text { sobre pilha. Leitura de um texto } \\
\text { sobre a bateria de carro. } \\
\text { 5.2. Demonstrar a confecção de } \\
\text { uma bateria }\end{array}$ \\
\hline $\begin{array}{l}\text { 6-Contaminação por } \\
\text { chumbo }\end{array}$ & $\begin{array}{l}\text { Discutir as consequências do } \\
\text { descarte inadequado de } \\
\text { materiais com presença de } \\
\text { chumbo }\end{array}$ & $\begin{array}{l}\text { Realizar um debate por meio da } \\
\text { exibição de reportagens que tratam } \\
\text { dos impactos ambientais } \\
\text { ocasionados pelo descarte } \\
\text { inadequado de baterias } \\
\text { automotivas. Atividade escrita }\end{array}$ \\
\hline $\begin{array}{l}\text { 7-Como destinar } \\
\text { corretamente o chumbo? } \\
\text { Logística Reversa e o } \\
\text { papel do aluno como } \\
\text { consumidor }\end{array}$ & $\begin{array}{l}\text { Estudar os pressupostos da } \\
\text { logística reversa para } \\
\text { resíduos de chumbo }\end{array}$ & $\begin{array}{l}\text { Explicar o processo de reciclagem } \\
\text { da bateria automotiva por meio da } \\
\text { logística reversa. Produção de } \\
\text { textos/desenhos pelos alunos, que } \\
\text { alertem para o descarte adequado } \\
\text { do chumbo }\end{array}$ \\
\hline 8-Finalização/feedback & $\begin{array}{l}\text { Realizar uma discussão das } \\
\text { etapas desenvolvidas ao ao } \\
\text { longo do projeto. }\end{array}$ & $\begin{array}{l}\text { Disponibilizar para comunidade } \\
\text { escolar um banner estruturado com } \\
\text { os textos e desenhos da aula } 7\end{array}$ \\
\hline
\end{tabular}

(Fonte: adaptado, Relatório Pedagógico - Melissa e Antônio (2014, p.4-5).

Embora os bolsistas tenham elaborado as duas primeiras aulas em conjunto, as demais foram sendo estruturadas individualmente, contudo um auxiliava o outro na implementação das regências. No decorrer da análise apresenta-se ainda elementos das aulas e reuniões que antecederam a organização do bloco de aulas apresentadas no quadro11, para vislumbrar a influência do Pibid na estruturação do conhecimento docente, e que refletiram na construção das aulas implementadas no segundo semestre. 


\subsubsection{Conhecimento Docente de Antônio}

Por meio da análise das reuniões em grupo do CoRe adaptado, das regências, da entrevista semiestruturada, dos relatórios anuais da dupla e individual, da lembrança estimulada, dos diários de bordo e do Ciclo reflexivo de Smyth, emergiu-se os possíveis reflexos do Pibid na construção do Conhecimento Docente de Antônio. Nesse sentido, apresenta-se na tabela 5, o resultado do mapeamento do conhecimento docente nos documentos supracitados. Os dados foram gerados, por meio do programa Atlas.ti. 
Tabela 5.Relatório gerado no Atlas.ti - Conhecimento Docente de Antônio

\begin{tabular}{|c|c|c|c|c|c|c|c|c|c|}
\hline \multirow{2}{*}{ Documento } & \multicolumn{9}{|c|}{ Categorias do Conhecimento Docente } \\
\hline & $\mathbf{A}$ & B & C & 1 & 2 & 3 & 4 & 5 & Total \\
\hline Reunião Geral (arquivo 2) & 0 & 0 & 0 & 0 & 0 & 0 & 0 & 0 & 0 \\
\hline Apresentação da proposta de trabalho (arquivo 3) & 0 & 17 & 2 & 0 & 0 & 0 & 0 & 0 & 19 \\
\hline Aula de sensibilização (arquivo 4) & 1 & 19 & 0 & 0 & 0 & 0 & 0 & 0 & 20 \\
\hline Reunião para saber o andamento (arquivo 5) & 0 & 2 & 5 & 13 & 5 & 1 & 4 & 2 & 32 \\
\hline Reunião Geral (arquivo 6) & 0 & 0 & 0 & 1 & 0 & 0 & 0 & 0 & 1 \\
\hline Reunião para saber o andamento (arquivo 7) & 0 & 10 & 2 & 3 & 3 & 1 & 5 & 1 & 25 \\
\hline Reunião para saber o andamento (arquivo 8) & 0 & 25 & 1 & 2 & 5 & 0 & 3 & 0 & 36 \\
\hline Reunião para saber o andamento (arquivo 9) & 4 & 18 & 3 & 15 & 16 & 10 & 15 & 4 & 85 \\
\hline Aula de sensibilização (arquivo 10) & 0 & 11 & 0 & 2 & 0 & 0 & 0 & 0 & 13 \\
\hline Aula de atomística (arquivo 11) & 11 & 2 & 0 & 9 & 10 & 0 & 2 & 0 & 34 \\
\hline Aula Pilha de moedas (arquivo 12) & 28 & 7 & 3 & 77 & 19 & 6 & 30 & 2 & 172 \\
\hline Aula Pilha de Daniell (arquivo 13) & 25 & 8 & 1 & 38 & 26 & 5 & 19 & 1 & 123 \\
\hline Reunião para saber o andamento (arquivo 14) & 0 & 9 & 2 & 14 & 12 & 2 & 9 & 3 & 51 \\
\hline Aula de revisão (arquivo 15) & 15 & 3 & 0 & 23 & 4 & 7 & 8 & 0 & 60 \\
\hline Aula de contaminação por chumbo (arquivo 16) & 0 & 2 & 0 & 23 & 3 & 0 & 7 & 3 & 38 \\
\hline Reunião para saber o andamento (arquivo 17) & 0 & 4 & 1 & 7 & 1 & 1 & 2 & 3 & 19 \\
\hline Aula de logística (arquivo 18) & 1 & 1 & 1 & 3 & 0 & 0 & 1 & 1 & 8 \\
\hline Entrevista semiestruturada (arquivo 19) & 0 & 28 & 6 & 7 & 4 & 2 & 1 & 1 & 49 \\
\hline Aula feedback (arquivo 20) & 2 & 1 & 0 & 8 & 0 & 5 & 1 & 5 & 22 \\
\hline Apresentação dos resultados (arquivo 21) & 0 & 11 & 3 & 8 & 4 & 5 & 7 & 4 & 42 \\
\hline Reunião Geral (arquivo 22) & 0 & 0 & 0 & 4 & 0 & 0 & 0 & 0 & 4 \\
\hline Reunião com a dupla (arquivo 23) & 0 & 7 & 0 & 12 & 6 & 2 & 12 & 5 & 44 \\
\hline Lembrança estimulada (arquivo 25) & 2 & 26 & 1 & 10 & 10 & 7 & 9 & 6 & 71 \\
\hline Ciclo de Smyth - Antes & 0 & 0 & 1 & 3 & 0 & 0 & 2 & 0 & 6 \\
\hline Ciclo de Smyth - Depois & 0 & 2 & 0 & 3 & 0 & 1 & 2 & 0 & 8 \\
\hline CoRe adaptado & 1 & 0 & 0 & 2 & 1 & 4 & 1 & 1 & 10 \\
\hline Relatório da dupla & 6 & 3 & 0 & 10 & 5 & 6 & 11 & 5 & 46 \\
\hline Relatório individual - Antônio & 2 & 15 & 3 & 14 & 7 & 1 & 8 & 7 & 57 \\
\hline Diário da aula de atomística & 1 & 0 & 0 & 0 & 1 & 0 & 1 & 0 & 3 \\
\hline Diário de bordo da aula de Pilha de moedas & 0 & 1 & 0 & 0 & 0 & 1 & 0 & 0 & 2 \\
\hline Diário de bordo da aula de sensibilização & 0 & 1 & 0 & 0 & 0 & 1 & 0 & 0 & 2 \\
\hline Total & 99 & 233 & 35 & 311 & 142 & 68 & 160 & 54 & 1102 \\
\hline
\end{tabular}

bordo da aula de sensibilização

233

$311 \quad 142$

68

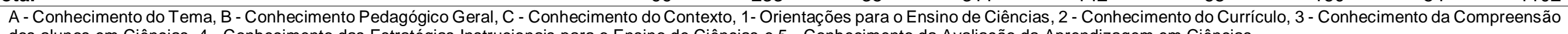
dos alunos em Ciências, 4 - Conhecimento das Estratégias Instrucionais para o Ensino de Ciências e 5 - Conhecimento da Avaliação da Aprendizagem em Ciências 
Ao todo foram selecionados 726 trechos dos documentos analisados, contudo em virtude das sobreposições entre as categorias nos extratos selecionados resultou em um número maior de categorias 1102. Como pode-se observar, no primeiro documento não foi selecionado nenhum trecho, isso ocorreu em virtude de Antônio ter permanecido como um observador na reunião. Os conhecimentos docentes emergem principalmente na aula de pilha de moedas (arquivo 12) e pilha de Daniell (arquivo 13), com respectivamente 172 e 123, trechos selecionados. Na figura 12 dispõe-se a coocorrência entre as categorias do Conhecimento Docente.

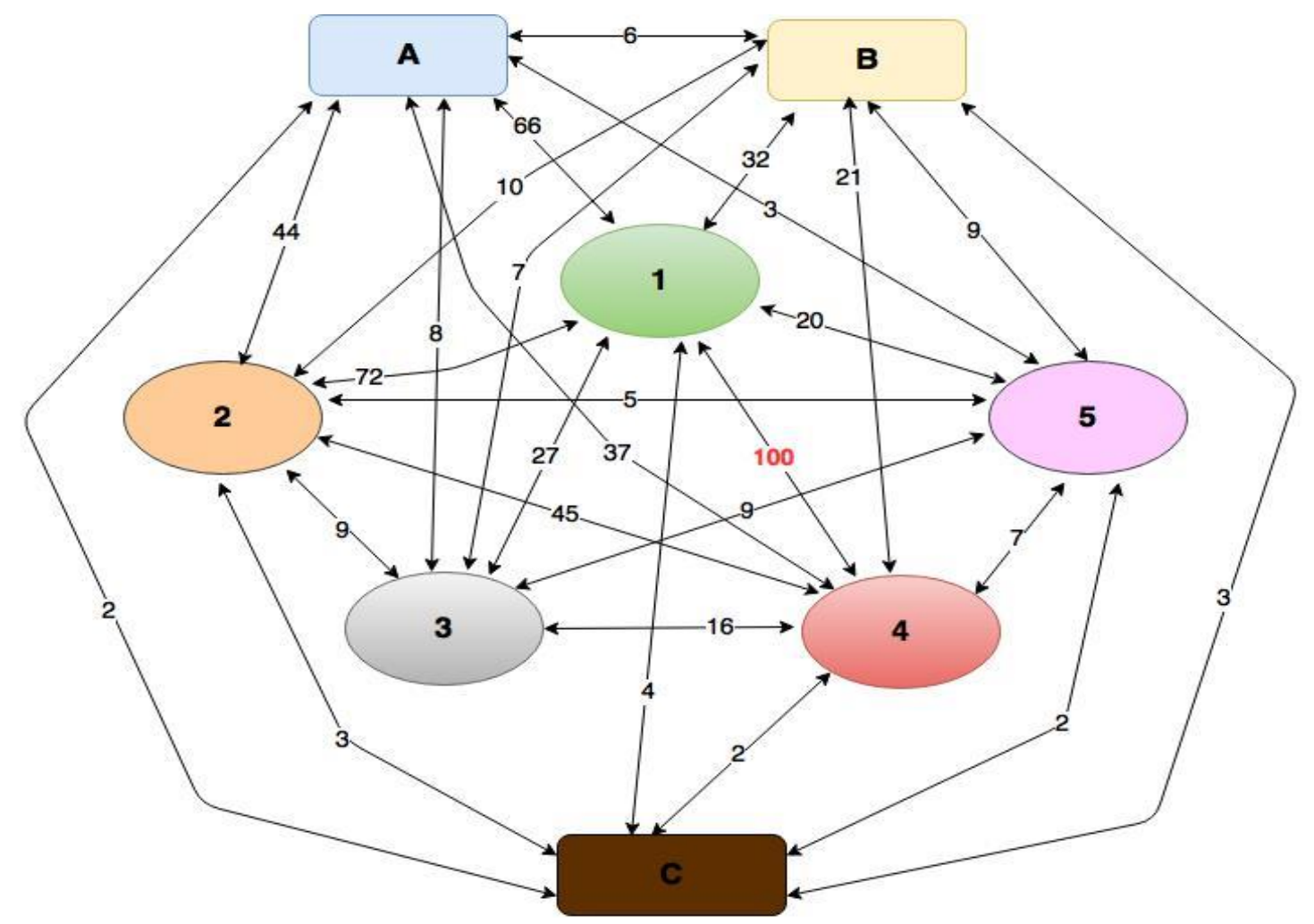

Figura 12. Coocorrência das categorias do Conhecimento Docente de Antônio em todos os documentos analisados ${ }^{6}$

Para compreender os contextos nos quais emergiram os conhecimentos docentes do licenciando e suas coocorrências serão esmiuçados a seguir cada componente do modelo docente adotado.

\section{Conhecimento do tema}

Nesta categoria tem-se o conhecimento acerca do conteúdo redox, diretamente relacionado com os conhecimentos específicos que se pretende ensinar. Para discorrer sobre o conhecimento do tema de Antônio, buscou-se ao longo dessa categoria trazer

\footnotetext{
${ }^{6} \mathrm{~A}=$ Conhecimento do Tema, $\mathrm{B}=$ Conhecimento Pedagógico Geral, $\mathrm{C}=$ Conhecimento do Contexto - Orientações para o Ensino de Ciências, 2 - Conhecimento do Currículo, 3 - Conhecimento da Compreensão dos alunos em Ciências, 4 - Conhecimento das Estratégias Instrucionais para o Ensino de Ciências e 5 - Conhecimento da Avaliação da Aprendizagem em Ciências 
elementos dos documentos coletados, e fundamentou-se a análise à luz do aporte teórico.

O licenciando ministrou aulas sobre o conteúdo redox que permeavam a experimentação e a história da química, denotando indícios da estrutura sintática. Quando apresenta-se os elementos estruturantes das aulas experimentais, ganha destaque a leitura de dois textos produzidos pelo pibidiano sobre o histórico dos experimentos de pilhas e seus cientistas, Alessandro Volta e John Frederic Daniell. Para Mizukami (2004) é esperado que o licenciando busque o aprofundamento do conteúdo por meio da sua origem e essência. Para desenvolver o conteúdo redox, durante o planejamento da primeira parte da aula 1 a coordenadora discorreu sobre a importância de iniciar a regência pelo conceito de atomística e íons, pois eram os conceitos base para iniciar o desenvolvimento do conteúdo. Embora inicialmente não concordasse com a orientação da coordenadora (Reunião para saber o andamento, arquivo 8), Antônio readequou seu planejamento e incluiu a definição de íons (cátions e ânions) e a tendência de certos elementos em perder ou ganhar elétrons (Reunião para saber o andamento, arquivo 9). No entanto, quem ministrou a primeira parte da regência 1 foi Melissa. Antônio foi responsável por realizar o segundo momento da aula, no qual abordou a definição de reações redox por meio de um experimento demonstrativo de oxidação da palha de aço em solução de sulfato de cobre. Durante a regência, Antônio permeou o conceito de dissociação iônica para que seus discentes pudessem correlacionar os fenômenos estudados com o nível macroscópico e o fenomenológico, além de contrapor com o representacional por meio da representação em lousa das semirreações e reações globais envolvendo ainda a variação do número de oxidação.

Durante sua trajetória inicial, as discussões nas reuniões com a dupla eram pautadas principalmente sobre CTS, como descrevemos na categoria Orientações para o Ensino de Ciências. A primeira reunião em que surge discussão sobre o conteúdo específico é na reunião para saber o andamento (arquivo 7). Durante um debate entre Antônio e a coordenadora sobre abrir ou não uma pilha, o pibidiano discorreu que abriria a pilha para o aluno compreender a sua constituição, mas não apresentou um encaminhamento de como esta atividade estaria relacionada ao desenvolvimento do conteúdo reações redox, o que levou a coordenadora a não concordar com a sua implementação.

Ao retornar para a reunião com a dupla (Reunião para saber o andamento, arquivo 9) em que os pibidianos apresentam a proposta da aula Pilha de moedas (Pilha de Volta), as tutoras orientaram o pibidiano a revisar os conteúdos ministrados na aula anterior. Antônio segue a orientação iniciando a aula relembrando a definição de reações redox, potencial de redução, eletrólito, ânodo, cátodo, e acrescentando os Capítulo 4. Resultados e Discussões 
conceitos sobre o sentido de migração dos elétrons e a influência da concentração da solução na duração e funcionamento das pilhas (Aula Pilha de moedas, arquivo 12). Durante o experimento abordou ainda os conceitos de NOX, reações redox, polos positivo e negativo, semirreações e reação global, transferência de elétrons, diferença de potencial, definição de pilha e o contexto histórico do desenvolvimento da Pilha de Volta e a importância desse cientista para o desenvolvimento da pilha. Ao final do experimento, Antônio buscou correlacionar o conceito que estava trabalhando com as pilhas comerciais, mesmo que de modo incipiente, conforme o trecho:

Antônio - Pode acender a luz, professora ((Luiza)), não vai dar pra fazer a discussão como eu queria com vocês, mas o importante é que vocês percebam que o conceito que a gente ensina de símbolo, ah, deu elétrons, recebeu elétron, isso tem uma importância, e isso determina o funcionamento da pilha que vocês usam em casa, pra usar no controle remoto, entendeu? (Aula Pilha de moedas, arquivo 12, turno 206-208).

Os conceitos emergidos na aula da pilha de moedas, foi uma orientação da coordenadora Maria durante a reunião para a sua estruturação, denotando que seriam esses os conceitos a serem abordados por Antônio em sua aula

Maria - É o que tá fazendo aqui, exatamente. Isso aqui é fácil? Não é, mas a gente tá construindo conhecimento. Aí ele vai falar: "Isso aqui como que é mesmo turma?" "Isso aqui oxidou" "Isso daqui reduziu". Muito bem, alguém perdeu elétron, alguém recebeu elétron. Porque nós temos fazer a reação global, faz a reação global. Porque que tem que passar por isso? Se a gente quer trabalhar com pilha, como é que a gente explica uma pilha sem mostrar as reações? Não mostra, não é pilha, é qualquer coisa, mandrágora de novo. Aí sim, aí vem aquela coisa bonita: "Olha, em 1900 e nada, 1800 alguma coisa, como é que é" (reunião para saber o andamento, arquivo 9, turno, 415).

$\mathrm{Na}$ figura 13 dispõe-se a "lousa" elaborada por Antônio, que o guiou na implementação da aula teórica da Pilha de Daniell. Vale relembrar que a confecção da "lousa" era uma orientação da coordenadora Maria. 


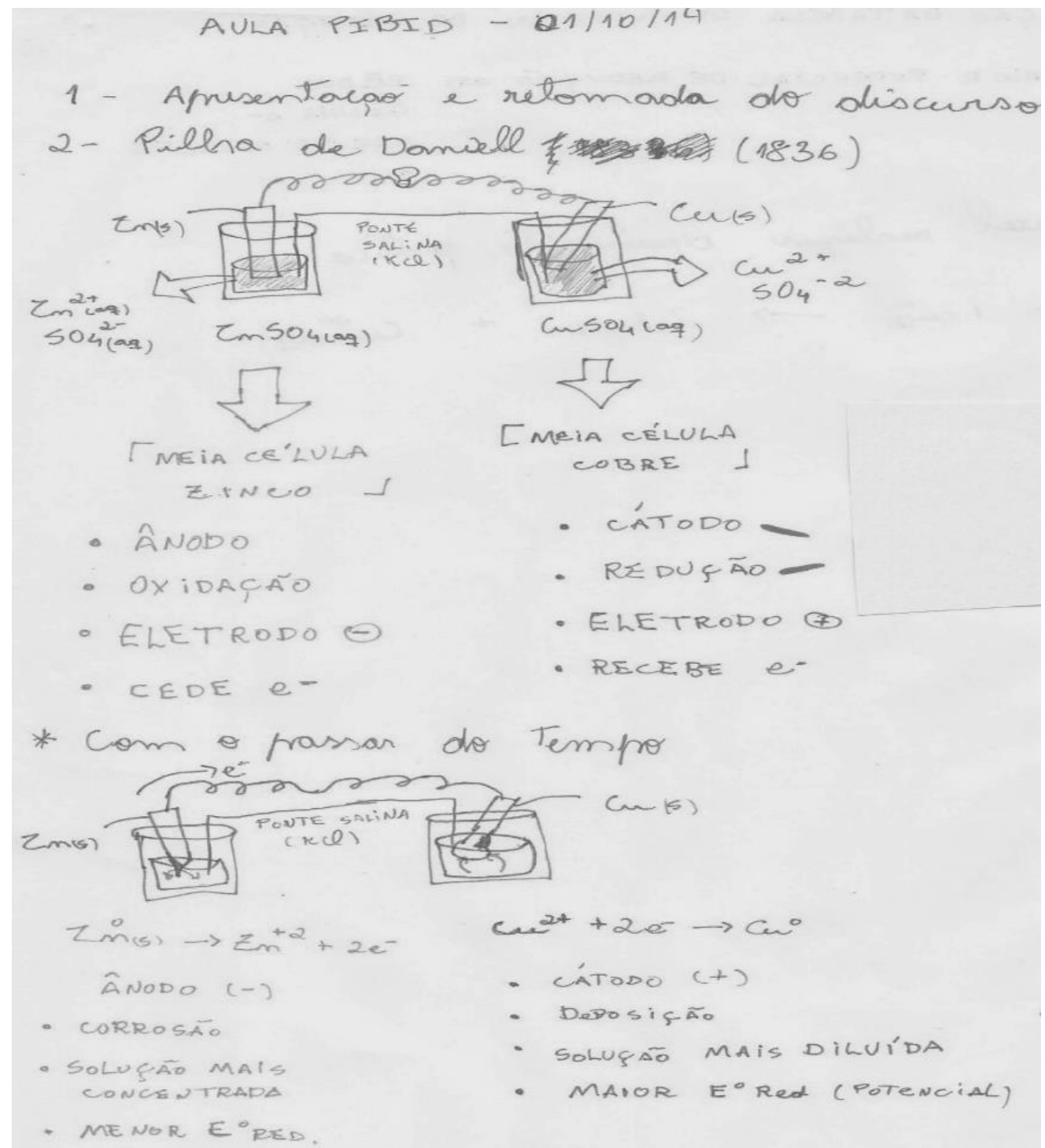

Figura 13. "Lousa" elaborada por Antônio para aula Pilha de Daniell (Fonte: Relatório anual - Antônio)

Apesar de retomar a definição de íons, solução iônica, definição de redox e a tendência de certos átomos em perder ou ganhar elétrons, Antônio explorou principalmente o funcionamento da pilha de Daniell como denotam os turnos:

Antônio - Bom pessoal, então, a pilha de Daniell funciona assim: ele coloca um béquer, a gente chama béquer aquele frasco transparente (Ininteligível 00:04:26), béquer é o nome que a gente dá pra vidraria acrílica, ah tá me zuando né ((refere-se a um aluno da classe)). Então, é uma vidraria. Aí ele coloca uma solução de sulfato de zinco, a gente sabe que esse tipo de composto quando tá em meio aquoso ele dissocia, né, aí a professora falou assim: "Ah, isso é sulfato de cobre, se colocar corrente elétrica, ele tá em forma de íons, e até representei aqui em forma de íons, esse composto ele pode (Ininteligível 00:04:56) assim, mas no meio aquoso ele fica assim, separado, a água vai e solvata ele, entendeu". E do outro lado ele coloca uma solução de sulfato de cobre, entendeu, e emergido nessas duas soluções ele coloca uma placa, isso aqui é uma plaquinha metálica, de cobre metálico, aqui tem uma plaquinha dessa, a gente pode até fazer esses experimentos. 
Aluno - Quando a gente voltar da aula ((do recesso que teve)).

Antônio - A ponte salina, essa ponte salina aqui é pra trabalhar com equilíbrio de cargas, os dois...Os dois frascos, né?

Aluno - Essa ponte salina é tipo um fio.

Antônio - É uma solução eletrolítica, lembra que a gente falou de solução eletrolítica? É que com o tempo a gente vai ver que os elétrons ficam migrando desse lado, pra esse lado da solução entendeu? Vai gerar uma corrente elétrica, você pode até acender um led, acender alguma coisa de baixa tensão, né. E, só que aí, pra essa pilha durar mais, não acabar tão rápido igual àquela que a gente fez de pilha de moedas, ele coloca uma ponte salina, é uma solução igual essa daqui, só que geralmente se usa a solução $\mathrm{KCl}$ (Aula Pilha de Daniell, arquivo 13, turno 34-39).

Em outros trechos da aula continua a explicação sobre o funcionamento da Pilha de Daniell:

\begin{abstract}
Antônio - Então, retomando, o potássio vai pro lado do cobre, e o cloreto vai pro lado do zinco, eu vou explicar porque ele vai pro lado e pro outro, realmente pra equilibrar a carga, porque, a gente vai ver que esse zinco, ele vai ceder elétrons pro cobre, é igual, a gente fez no experimento, vai ter esses elétrons, e aí a gente representa da mesma forma, que é assim, a gente até aprendeu a representar isso ((referese a aula de Melissa)). Uma reação, uma semi-reação de oxidação, é onde o zinco metálico tá na forma de cátion liberando dois elétrons, foi isso que a gente aprendeu, e por isso que o $\mathrm{Cl}$ ele vai migrar pro lado do zinco, entendeu, porque vai tá formando esse tipo de cátion aqui.
\end{abstract}

Aluno - Digamos que ele vai devolver.

Antônio - Ele vai fazer um equilíbrio de cargas né, e a ponte salina é isso que a gente comentou aqui. Então, basicamente esse é o experimento de pilha de Daniell, e eu coloquei aqui uma lâmpada, mas você pode procurar no livro didático ou qualquer outro livro de vestibular, pode ser um interruptor, qualquer coisa, é só pra fechar o circuito (Aula Pilha de Daniell, arquivo 13, turno 78-80).

Nessa regência evidenciou-se que Antônio apesar de não ter um repertório rico de analogias, demonstrou bom conhecimento sobre reações redox e de outros conceitos químicos como, por exemplo, concentração iônica e equilíbrio químico para que os alunos compreendessem o porquê a pilha para de funcionar.

Em relação ao seu conhecimento de nível superior sobre outros conceitos químicos, Antônio o evocou de forma confusa quando um aluno o questionou se os elétrons de um determinado elemento químico apresentariam propriedades magnéticas que justificaria a sua tendência em ganhar os elétrons ao invés de perdê-los, como pode ser constatado no trecho: "Envolve o elétron, é que envolve substância paramagnética e diamagnética, entendeu, é um conceito bem diferente. É, química quântica, pra entender porque um material ele é atraído, é algo semelhante [...]" (Aula Pilha de moedas, arquivo 12, turno 181). A partir dessa fala infere-se que o pibidiano tentou desviar a dúvida do aluno ao invés de esclarecê-la. Entretanto, a literatura aponta que para que o professor ensine não basta dominar o conteúdo, mas associar a sua ação 
pedagógica ao seu conhecimento do contexto, de outras áreas, do aluno e do currículo (WILSON; SHULMAN; RICEHERT, 1987).

No CoRe adaptado, o bolsista apresenta como temática central a Pilha de Volta. Os principais conceitos emergidos foram o de polos positivo e negativo, a transferência de elétrons, o potencial de redução e os fenômenos de corrosão observados no cotidiano. Na entrevista semiestruturada não aparecem menções ao conteúdo.

As aulas de Antônio envolveram a experimentação em conjunto com o histórico da Pilha de Volta e Daniell. Os experimentos eram implementados tendo a função de comprovar o conteúdo ministrado, como revela o trecho a seguir:

Antônio - Química é fascinante. (Falas sobrepostas 00:22:4400:23:02). Tem corrente elétrica aí cara (Falas sobrepostas 00:23:0300:23:23). Vamos organizar ((a sala)) Tá aqui a prova de que tá acontecendo algum efeito, porque tá produzindo corrente elétrica, isso daí é um fato, porque tá acendendo o led, entendeu, então aquela simbologia que a gente fez no quadro ali (Falas sobreposta 00:23:38$00: 23: 55)$. Só que agora vocês eu queria que vocês mudassem o eletrólito, eu queria que vocês usassem água de torneira, e usasse a mesma quantidade de moedas. Eu queria que você fizesse agora com a mesma quantidade de moedas, entendeu? (Falas sobrepostas 00:24:25-00:25:10). É isso é um outro assunto que eu queria comentar com vocês. ((Um aluno faz uma pergunta inaudível)) (Aula Pilha de moedas, arquivo 12, turno 120).

O trabalho desenvolvido por Lôbo (2012) que investigou as concepções de professores e futuros docentes de química acerca da adoção da atividade experimental como recurso didático revelou que a principal função concebida pelos docentes e licenciandos foi que o experimento tinha a função de comprovar uma teoria, como segue o trecho a seguir:

Antônio - Mas se cada um vim aqui ver, vai ver que o led tá aceso. E alguns grupos aqui, semana passada a gente fez o experimento, também viu que...

Aluno - Menos o meu led né.

Antônio - É verdade, mas a gente vai fazer vários experimentos e o seu led vai dar certo, você pode ficar tranquilo.

Aluno - Não é nada, ela é incapaz, mesmo.

Antônio - Não, não é ((quer dizer que a aluna é capaz)), desconsidera o colega aqui ((o aluno que falou que a aluna era incapaz)). Eu vou retornar vocês com a Melissa, mas só pra ver que tudo que a gente tá conversando ali de quantidade de elétrons passando pro outro elemento químico, de fato acontece, o interessante é que a gente usa esse tipo de equações químicas pra representar a migração do elétron, é só pra representar o que tá acontecendo aqui, se eu usar só uma pilha aqui, vai dar 0,8 volts, para meu led acender preciso de 1,4 ou 1,3 , por isso que eu coloquei uma bateria, que é uma sequência de pilhas (Aula de revisão, arquivo 15, turnos 434-438).

Essa visão vai ao encontro da percepção de Antônio, que apesar de não ter ficado explícito em seu plano de aula, foi enfatizado em suas falas nas aulas 
experimentais, o que reforça a sua visão epistemológica de que o conhecimento científico é verdadeiro e inquestionável, e consequentemente reflete no componente Orientações para o ensino de ciências - Crenças sobre a natureza da ciência. Em outro trecho Antônio demonstrou confusão conceitual em relação à função da ponte salina:

Antônio - É uma solução eletrolítica, lembra que a gente falou de solução eletrolítica? É que com o tempo a gente vai ver que os elétrons ficam migrando desse lado, pra esse lado da solução entendeu? Vai gerar uma corrente elétrica, você pode até acender um led, acender alguma coisa de baixa tensão, né. E, só que aí, pra essa pilha durar mais, não acabar tão rápido igual àquela que a gente fez de pilha de moedas, ele coloca uma ponte salina, é uma solução igual essa daqui, só que geralmente se usa a solução $\mathrm{KCl}$ (Aula pilha de Daniell, arquivo 13, turno 40).

Entretanto, a função da ponte salina é fechar o circuito e propiciar equilíbrio de cargas nas soluções. Na sequência, Luiza interrompe a explicação de Antônio questionando:

Luiza - Como é que é Antônio? O que você falou aí? Não, repete o que você falou aí da ponte salina?

Antônio - Pra equilibrar o equilíbrio de cargas.

Luiza - Tá, mas pra quê serve a ponte salina?

Antônio - Pra equilibrar o equilíbrio de cargas pra pilha durar mais.

Luiza - Pra quê?

Antônio - Pra pilha durar mais. Não? Ah, então...

Luiza - Não senhor, não é pra pilha durar mais não, se você não colocar isso aí, você não fecha o circuito, tá.

Antônio - Ah, Também.

Luiza - Também não, se você tirar a ponte salina, a pilha não funciona, ok? Então assim, é... se a gente faz a ponte salina com ágar-ágar, sabe o que é ágar-ágar? É uma gelatina de alga, tá? Então você usa cloreto de potássio, $\mathrm{KCl}$, mas em vez de fazer liquido você faz ela em gelatina, ela fica meio durinha, tá, aí dá pra você tirar e por a ponte salina, tá? Quando você tira a ponte salina, que é um tubo em $U$, a pilha para de funcionar, porque o circuito abriu.

Antônio - Não, você tá certa.

Luiza - Desculpa, é conceito, conceito tem que tá certo, eu tô aqui.

Antônio - Mas também equilibra as cargas também, né?

Luiza - Sem dúvida.

Antônio - As duas coisas tá.

Luiza - Sem dúvida, porém a principal função da ponte salina, primeiro é fechar o circuito tá, e segundo é o que você tá falando, equilibrar as cargas, mas como é que se equilibram, né, que você vai explicar agora.

Luiza - Não, gente, ele ((Antônio)) é aluno, ele tá aprendendo, então, eu tô aqui ligada porque ele tá ensinando vocês, eu tô ensinando ele (Aula pilha de Daniell, arquivo 13, turno 41-65). 
Talvez a intenção de Luiza fosse ajudar Antônio a não cometer equívocos conceituais pois, na sua percepção o pibidiano estava em sala de aula também para aprender e não apenas ensinar. Contudo, para Antônio

Ah, eu acho que eu não fiz nenhum erro científico ali, pelo menos eu não vi o erro científico, e eu acho que ela podia ir direto ao ponto, ela não precisava ter me destruído dessa maneira, eu não sei se às vezes ela... ela não queria só interromper, às vezes nem ela mesmo sabia onde estava meu erro, eu não sei, às vezes ela queria dar uma outra expressão, o que mais? O que mais? E eu estou falando e às vezes ela podia ter ido direto ao ponto (Lembrança estimulada, arquivo 25 , turno 438).

No trecho subsequente da lembrança estimulada, o pibidiano argumenta que estava iniciando a sua explicação sobre a ponte salina e que a supervisora não o deixou continuar.

É, na minha opinião, pra falar só isso? Fechar o circuito? E não foi um erro científico, foi só falar uma palavra, que talvez eu poderia ter falado durante a minha explicação, e o entendimento pros alunos não ia mudar em nada, entendimento pros alunos, nem na área da química não ia mudar em nada, não ia ter acréscimos que valesse a pena ela me corrigir, acréscimos ou que eu falei seria um equívoco pros alunos. E o engraçado é que essa intervenção mostra muito aquilo que eu estava percebendo em todas as aulas anteriores que demonstra que 0 aluno, perdi a credibilidade com o aluno, que depois acho que em um outro momento alguém faz uma pergunta pra mim, acho que até o aluno que faz e eles não tem mais paciência comigo, que eu explique né (Lembrança estimulada, turno 444).

Para Côrrea e Batista (2013) o supervisor atua como um mediador da ação didática do pibidiano, de modo a propiciar a manutenção e/ou modificação de suas aulas para garantir o desenvolvimento profissional do licenciando. Contudo, pelo relato do bolsista, a intervenção da tutora não o levou a reconhecer a necessidade de um estudo mais fundamentado do conteúdo ministrado. Além disto, a tutora tirou a autoridade do pibidiano frente aos alunos, o que fez com que o pibidiano ficasse inseguro.

Pelos dados analisados sobre o Conhecimento do Tema, Antônio demonstrou ter conhecimento sobre reações redox, mas não é possível inferir que seja reflexo apenas do Pibid. Nas reuniões com a tutora e nas aulas implementadas demonstrava segurança em discutir os aspectos conceituais de sua aula. Foi possível emergir o conhecimento do conteúdo, mas as estruturas sintáticas e substantivas não foram identificadas em nossa análise. Apesar de Antônio buscar trabalhar com o histórico da eletroquímica, não figura como estrutura substantiva, por não explorar em suas aulas marcos teóricos e os aspectos epistemológicos de uma área que validam o conhecimento. 


\section{Conhecimento pedagógico geral}

Nessa categoria, a análise dos diferentes documentos revela a percepção de Antônio acerca das abordagens de ensino, dos alunos, do processo de ensinoaprendizagem e da relação professor-aluno.

$\mathrm{Na}$ organização da classe Antônio considerava importante a formação de grupos, pois, para o bolsista "O que eu acho legal, acho que seria a turma toda discutindo. É, porque vai explanar o assunto, mas todo mundo vai poder participar da discussão (Reunião para saber o andamento, arquivo 8 - turno 170). Antônio concebia a sua atuação como a de um mediador no processo de aprendizagem:

Pesquisadora - E durante as suas atividades que você propõe em sala de aula, se o aluno tá tendo... se você tem o hábito de olhar, pra saber se alguém tá precisando de ajuda, ou se alguém não entendeu, você fica atento a essas circunstâncias?

Antônio - Fico, mas eu não procuro de imediato ajudar, eu entendo que eu tenho que deixar ele, não é quebrar a cabeça, mas ele construir o conhecimento (Entrevista semiestruturada, Antônio, turnos 83-84).

Em outro momento trata essa atuação por um viés em que busca enaltecer o aluno em relação à sua produção: "E depois a gente vai mostrar pra eles, essa frase é sua, esse texto foi tu que elaborou, entendeu, a gente vai pegar os melhores argumentos pra fazer um único folheto" (Reunião para saber o andamento, arquivo 7, turno 52). Em relação à organização do conteúdo ao tempo de aula, Antônio foi orientado a repensar a relação conteúdo e tempo:

Maria - Posso dar uma sugestão pro grupo, vejam o que vocês acham, vocês não querem repensar essa aula mesmo? Porque a gente discutiu tanta coisa antes que realmente não tá encaixando, assim gente eu acho que precisa é... eu acho que tem muita coisa, em quarenta e cinco minutos a gente tem que colocar o aluno na sala de aula, chamar atenção, eu acho que é muita coisa pra quarenta e cinco minutos sabe, tem que ficar mais sucinto [...] (Reunião para saber o andamento, arquivo 7, turno 187).

Para que a aula não fosse carregada de conceitos e promovesse a participação dos alunos, o pibidiano considerava fundamental ensinar reações redox na EJA por um víeis conceitual. Nesse sentido, durante a reunião em que apresentou a readequação dos blocos de aulas a serem implementados no segundo semestre, Antônio discorreu:

Antônio - É, a gente fez um plano de aula, né, e seriam quatro aulas.

Rebeca - É, essa sequência né?

Antônio - Já não é mais, já mudou.

Rebeca - Então é melhor vocês falarem, a gente vai...

Antônio - Seria uma aula sobre... Teve quatro aulas no cronograma, a primeira seria de PRNS, Política Nacional de Resíduos Sólidos, a gente pensar em resíduos sólidos, (ininteligível 00:00:40) o assunto vai ser esse, a segunda aula... Depois a gente vai argumentar, a segunda aula seria sobre oxirredução, mas seria um conteúdo bem assim, 
conceitual pra turma do EJA, e a terceira aula seria sobre experimento de pilha de moedas, o que foi aprendido com elas, a quarta e última aula seria a produção de um panfleto, da seguinte maneira, não, vou contar depois, deixa que a Melissa fale da PNRS, depois eu comento (Reunião para saber o andamento, arquivo 9, turnos 2-6).

Na percepção de Antônio os discentes da EJA não precisavam aprender o nível representacional conforme denotam os trechos:

Não sei por que, mas na minha impressão como aluno, é muito mais fácil, ele responder assim, perdeu elétron, ganhou elétron do que representar isso aqui, quimicamente.

É porque assim, pra mim parece que um aluno do EJA ele não precisa aprender isso assim, ele precisa entender como é que a química tá no dia a dia dele (Reunião para saber o andamento, arquivo 9, turno 306 e 314).

Com relação à organização do tempo o pibidiano dividia a aula num momento destinado à explicação e à resolução de exercícios. Mas, sempre nos momentos iniciais de sua prática de ensino explicava os objetivos da aula e do subprojeto, o que revela a importância dada por Antônio em direcionar a classe acerca dos conteúdos que seriam ministrados ao longo do semestre.

Permeando os elementos que figuram a gestão da classe, Antônio argumentou que na aula de Pilha de moedas teve algumas dificuldades em "[...] controlar a turma, foi todo mundo quase ao mesmo tempo, todo mundo muito alvoraçado, tive dificuldade de controlar a turma nesse sentido, e eu também não consegui dar atenção pra esse grupo [...]" (Reunião com a dupla, arquivo 23, turno 67).

Ao fazer refletir sobre suas aulas o pibidiano retoma o episódio conturbado da aula da Pilha:

Antônio - Ah, sobre as minhas aulas assim, eu pude ver assim, confirmar aquilo que eu já estava meio que, na minha reflexão já há bastante tempo sobre organização da sala, sobre o apagar a luz, sobre o tempo, eu acho, a não ser essa aula aí que eu fiz ela lenta e consegui, mas aulas igual àquela da pilha de moedas, o aluno não tinha como seguir roteiro, o roteiro estava muito grande pra duas aulas, era impossível seguir os roteiros, e como não seguiu roteiro, fez aquele caos de aula, mas assistir o vídeo foi bom porque assim, vai fazer eu refletir mais ainda quando for à próxima aula. Vai ficar mais na memória assim, uma reflexão antes do vídeo, depois do vídeo, de avaliar assim o que podia ter sido feito diferente (Lembrança estimulada, arquivo 25, turno 530).

Essa reflexão de Antônio sobre suas aulas apresenta elementos atrelados a readequação do roteiro, que está associada ao componente Conhecimento das Estratégias instrucionais para o ensino de ciências - estratégias de um tópico específico e as Orientações para o ensino de Ciências - Decisões sobre o fazer no ensino, já que revela o desejo de adequar o roteiro e certos caminhos escolhidos em sua ação didática. 
Outra limitação associada à sua ação didática era a baixa frequência dos discentes que ocasionava a quebra da proposta de ensino. Por outro lado, reconhecia que uma turma com um número reduzido de alunos facilitava o desenvolvimento das aulas, assim como ter lecionado na EJA, pois os alunos dessa modalidade eram mais participativos e comprometidos com o ensino. Nesse sentido, apresenta-se o trecho a seguir:

Antônio - Então, o projeto desenvolveu também na turma $3^{\circ} \mathrm{A}$ do colégio, tem uma foto da turma, a gente teve uma opinião que eles são muito participativos, e parece que, não sei se todos eles são assim, mas esse EJA, todas as atividades que a gente propunha eles faziam com maior empenho, entendeu, e não tinha um que falava assim: "Ah, não quero fazer" Colocou ali, muito aplicado nas tarefas, e a turma não era muito grande. Ah, falando deles ainda, eles, em média é 20 alunos, mas eles têm uma baixa frequência, vai um dia, falta no outro, e isso aí atrapalha um pouquinho o projeto, porque não deu pra dar continuidade, porque você às vezes você fazendo um projeto que devia ter uma sequência e não tem, porque a pessoa faltou (Apresentação dos resultados, arquivo 21, turno 6).

Ao retornar para as primeiras percepções de Antônio sobre os alunos da escola conveniada, logo após implementar a sua primeira regência (Aula sensibilização Ilha das flores) como bolsista, ao ser indagado pela coordenadora como havia sido a aula argumentou:

Eu digo que o EJA é um lugar que eu quero dar aula, agora essa turma do $3 \mathrm{~F}$ eu reclamei até no meu diário de bordo, a questão do horário, toda vez que a gente chegava lá era um horário diferente, eles nunca deixavam um horário certo, nesse dia que a gente aplicou a sensibilização no 3F a gente começou a dar aula pra eles era 10:10 ((da noite)), né (Reunião para saber o andamento, arquivo 5, turno 25).

A oportunidade de vivenciar essas situações ainda na formação inicial transforma o Pibid em um ambiente propício ao crescimento profissional, pois "pensando criticamente a prática de hoje ou de ontem é que se pode melhorar a próxima prática" (FREIRE, 1996, p.43). Dessa forma, se propicia a contribuição dos conhecimentos aprendidos na licenciatura com os aprendidos no espaço escolar.

Mas, qual seria a percepção de um bom professor para Antônio? O pibidiano entende que um bom professor conversa com cada aluno de forma diferente, uma vez que os indivíduos apresentam características distintas (Reunião para saber o andamento, arquivo 8). Na visão de Freire o diálogo

[...] é uma exigência existencial. $E$, se ele é o encontro em que se solidarizam o refletir e o agir de seus sujeitos endereçados ao mundo a ser transformado e humanizado, não pode reduzir-se a um ato de depositar ideias de um sujeito no outro, nem tampouco tornar-se simples troca de ideias a serem consumidas pelos permutantes (FREIRE, 1987, p. 79). 
O autor discorre que o conhecimento é um processo de mediação entre docentes e alunos. Nesse sentido, a sensibilidade do pibidiano em enxergar o diálogo como relevante à prática docente, na verdade é um componente do Conhecimento Pedagógico Geral importante de ser acessado ainda em sua formação inicial e, consequentemente, para o seu desenvolvimento profissional. Apesar de nosso sujeito não ter mencionado nenhum documento oficial durante os encontros em que eram discutidas as estruturações das aulas e nos demais documentos analisados, o diálogo é visto nas diretrizes dos documentos oficiais para o ensino da EJA como sendo necessário para "[...] criar oportunidades de ouvir e falar, reelaborar argumentos a partir de novas informações construir conceitos" (BRASIL, 1997, p. 53). O que na prática significa que por meio do diálogo Antônio conquistou possivelmente um espaço mais sólido com seus discentes, no qual estes se sentiram mais seguros em realizar questionamentos, esclarecer dúvidas e opinar sobre a qualidade de sua explicação.

A relação professor-aluno é vista por meio da afetividade, pois segundo o pibidiano:

Como professor assim, o ato marcante foi a ideia que o professor ali se colocando no mesmo nível faz uma amizade, achei que foi bem interessante fazer amizade com eles, a ideia foi, se eu faltasse eles sentiam falta, se eles faltassem eu sentia falta deles também, não sei se todo professor se apaixona, mas essa ideia [...] (Apresentação dos resultados, arquivo 21 , tuno 71 ).

A aprendizagem carrega consigo a afetividade, que se revela por meio da emoção (WALLON, 2007). Na perspectiva de Freire "A afetividade é o território dos sentimentos, das paixões, das emoções, por onde transitam os medos, sofrimentos, interesses, alegrias" (1997, p.170). Na literatura há percepções de que os sujeitos nascem extremamente imaturos, no contexto desse estudo esse sujeito é o professor em formação inicial, e sua sobrevivência está condicionada pelo outro (na nossa perspectiva o aluno), e essa necessidade se traduz em sentimento. $O$ importante a destacar na fala do pibidiano é o seu reconhecimento que a construção do conhecimento é permeada pelo aspecto afetivo. A descrição da afetividade evocada por Antônio não teve por objetivo aprofundar-se nessa área, mas sinalizar que a sua fala está carregada de alegria pelo convívio com seus alunos. Alguns autores defendem que a relação no âmbito profissional não esteja dissociada do sujeito (NÓVOA, 1995).

Retomando o processo de estruturação das regências, Antônio buscou na aula experimental de Pilha de Volta fundamentar por meio da prática investigativa:

[...] o roteiro era investigativo, porque no verso do roteiro, ele tinha etapas que sinalizar os resultados que ele estava obtendo, dele fazer uma troca de um reagente com outro, então da forma, ele conseguiu indicar que se ele acrescentasse mais eletrólito o potencial não aumentava (Apresentação dos resultados, arquivo 21, turno 18). 
Esse trecho revela uma tentativa de Antônio de tornar o aluno protagonista do processo de aprendizagem, figurando como uma tendência empírico-ativista, na qual o professor é o mediador no processo de ensino-aprendizagem (LIBÂNEO, 1985). Por outro lado, apesar da perspectiva empírico-ativista ir na contramão da racionalidade, as aulas de Antônio integraram também a racionalidade técnica por meio da aplicação de aulas de conteúdos e exercícios de fixação.

Vislumbra-se que Antônio, por meio de seus princípios educacionais ancorados em seu conhecimento sobre os alunos e aprendizagem, dos encaminhamentos das situações de ensino e das orientações das tutoras, acessou essa categoria de conhecimento do modelo base e principalmente os objetivos propostos em suas aulas, em que o domínio apenas do conteúdo não garantiria (MIZUKAMI, 2004).

\section{Conhecimento do contexto}

Esta categoria engloba o conhecimento do licenciando sobre o estudante, a comunidade e suas características sociais e culturais, o distrito/bairro e a escola.

Em um dos encontros do grupo de Antônio com a coordenadora, ao discorrer sobre a adoção de uma situação problema relacionada à questão do lixo, cujo objetivo era suscitar uma discussão na classe, o pibidiano argumenta que esse tipo de dinâmica possibilita um conhecimento do contexto dos discentes, como denota o trecho:

Antônio - É legal que tipo assim, o contexto de cada aluno, né, e tipo assim, eu acho que o debate é muito bom nesse tipo de situação, porque você consegue que a pessoa exporte assim informação.

Maria - É, então o questionário tem o sócio econômico, porque aí você sabe se ele mora próximo.

Antônio - É e aí você vai relacionar, né (Apresentação da proposta de trabalho, arquivo 3, turno 80-82).

A narrativa de Antônio revela que o pibidiano buscou conhecer o contexto inicialmente pela aplicação do questionário sócio econômico e cultural, que era uma orientação da coordenadora. Desse modo, ao aplicar o questionário na turma da EJA, os dados suscitaram que grande parte dos alunos morava em bairros próximos à escola.

Para adequar o conteúdo, buscou observar nos seus passos iniciais na escola as possíveis limitações dos alunos em relação a seus conhecimentos básicos em química (Reunião para saber o andamento, arquivo 8). Sobre a escola, o pibidiano contava com o apoio de funcionários para trazerem instrumentos e equipamentos audiovisuais quando necessário (Aula Pilha de moedas, arquivo 12). Nesse sentido, discorreu que a estrutura da escola era muito boa, e que apesar de algumas vezes ter sido necessário a substituição de um reagente por outro em aulas experimentais, essa mudança não configurou como um problema para a implementação das aulas. Ainda sobre o espaço escolar, o licenciando descreve que "A escola possui salas de vídeo, Capítulo 4. Resultados e Discussões 
laboratório, informática com acesso à internet, apresentando ótima conservação e estrutura e muitos funcionários para organização escolar" (Relatório anual, Antônio). Por outro lado, em seus passos iniciais na implementação das regências no primeiro semestre Antônio argumenta sobre as limitações: "É notado que isso aconteceu num dia, na próxima aula a outra professora utilizou em sala pra passar um vídeo, aí depois eu acho que foi situação de greve, sei que foi só acumulando" (Reunião para saber o andamento arquivo 5, turno 5). Esse relato revela um processo de ambientação do espaço escolar e outras problemáticas vivenciadas pelo pibidiano em virtude dos problemas políticos que marcaram o país.

Segundo o pibidiano, o espaço da escola conveniada era constituído por "[...] vários cartazes de feiras de ciências, de artes e leituras de livro, mostrando ser uma escola com ótimas estruturas e empenhada na formação de cidadãos" (Relatório Anual, Antônio). O conhecimento do contexto o levou expor as atividades dos discentes na escola, "A ideia é o que, que uma pessoa chegue aqui na escola, pô, a turma do $3^{\circ} \mathrm{A}$ do ano passado, é um projeto que eles fizeram..., falando sobre o descarte inadequado de chumbo" (Aula logística reversa, arquivo 18, turno 63). Acreditava que assim estaria valorizando seus alunos. Em nenhum dos documentos analisados o pibidiano sinaliza que a estrutura da escola estadual comprometeu de alguma forma as suas ações durante a implementação das regências. No CoRe adaptado não há menção ao conhecimento do contexto.

Para o bolsista a localização da escola nas imediações de uma estação de metrô facilitava o acesso dos alunos ao estabelecimento de ensino. Relata ainda que essa localização influenciou no desenvolvimento da temática sobre a contaminação por baterias, pois no bairro da escola existe uma grande concentração de lojas de baterias e oficinas mecânicas. Nessa perspectiva, o pibidiano argumenta "[...] a gente fez uma visita na região, em volta ali do colégio, e a gente constatou que tem muita oficina mecânica, lojas de peças de automóveis e até umas duas desmanche [sic] de carro" (Apresentação dos resultados, arquivo 21, turno 8). Em conformidade com esse aspecto, ao analisar-se os registros iniciais das reuniões entre Antônio e a coordenadora emergem elementos que apontam que parte do conhecimento acerca do distrito/bairro que Antônio construiu também foi proporcionado pelas narrativas da supervisora, como pelo relato da coordenadora "[...] lembra que a professora ((supervisora)) falou que aquela região ali há um tempo trás, a não sei quantos anos atrás era uma região de descarte dessas baterias?" (Apresentação da proposta de trabalho, arquivo 3, turno 14).

Por meio das representações de Antônio, um bom professor além de dominar o conteúdo, deve conhecer bem o contexto escolar, do bairro, da própria cidade e a 
origem social de seus alunos, pois assim estaria mais envolvido e preparado para atuar em sala de aula (Entrevista semiestruturada, Antônio).

\section{Orientações para o ensino de ciências}

Ao analisar o CoRe adaptado, os elementos dessa categoria emergem quando Antônio responde ao questionamento: Por que é importante para os estudantes aprenderem sobre esta ideia?

[...] os alunos poderão utilizar esses conceitos em algum momento da sua vida para decidir suas escolhas cotidianas, como, por exemplo, a substância que o portão é constituído para prevenir a corrosão, a importância da escolha do material para pintura do mesmo (CoRe adaptado, Antônio).

A colocação de Antônio revela uma orientação para o ensino de ciências do tipo Rigor Acadêmico, contudo essa orientação perpassa ainda a Orientação didática. As decisões do que fazer no ensino de ciências está relacionado aos encaminhamentos práticos que o bolsista realiza na sala de aula ao implementar suas propostas de ensino, levando em consideração nessas ações possíveis conhecimentos que carrega consigo acerca da prática de outros professores que traz para a sua aula o interesse pela profissão, as influências do ambiente escolar e a organização de sua prática pedagógica, as escolhas metodológicas, entre outros aspectos que influenciam o seu fazer no ensino.

A trajetória de Antônio no contexto do Pibid revela que suas aulas eram também desenvolvidas por projetos, tendo como abordagem CTS. Em relação às suas impressões em trabalhar com esta metodologia em suas aulas de química, vislumbra que a:

[...] aula com CTS é melhor, mas não que CTS seria uma ferramenta fundamental pra uma boa aula, mas ela tem alguns conceitos que fazem um ensino inovador, eu poderia utilizar outra ferramenta sem ser CTS, mas que também priorizasse aulas contextualizadas, aulas que é... que o aluno faça uma prática e produza algo, eu acho nesse sentido entendeu? Não tô dizendo que tem que ser CTS. Mas tem que ter... (Entrevista semiestruturada, Antônio- turno 56).

Suas colocações sobre as atividades preparadas sinalizam que buscou trabalhar com a abordagem CTS (Ciência, Tecnologia e Sociedade) para aproximar-se do cotidiano dos alunos e por ser "espinha dorsal" do subprojeto do qual participava. Outro dado importante emergido por Antônio sobre o desenvolvimento de suas aulas estava em sua percepção de que a elaboração das mesmas estava mais fundamentada nos anseios do coordenador e supervisor. Nesse sentido, apresenta-se um trecho de umas das reuniões em que foi discutido a estruturação das aulas do segundo semestre em que Antônio desabafa sobre o conflito na elaboração das aulas: 
Então, eu não sei, mas quando a gente explicou, conversa com ela ((Luiza)), eu falei com ela: "Olha", você ((Luiza)) quer tirar CTS, e a Maria quer colocar CTS, você ((Luiza)) quer colocar química, tem que achar um ajuste entre vocês, foi o que eu argumentei com ela assim, porque senão eu vou ficar assim, quicando dos dois lados, eu não consigo me direcionar, por isso uma vez eu te mandei o e-mail: "Professora precisa ajustar com ela, porque eu não tô entendendo mais, uma quer CTS, uma quer..." (Reunião para saber o andamento, arquivo 8, turno 47).

O pibidiano expôs suas limitações em compreender como deveria estruturar suas aulas em virtude das perspectivas divergentes entre a coordenadora e a supervisora com relação ao enfoque do projeto. Contudo, em uma reunião anterior no trecho no qual Maria chamava atenção do grupo de Antônio pela quantidade de atividades propostas, a coordenadora argumentou:

Tem muita coisa. Sabe por quê? Deixa eu falar uma coisa...a hora é... uma outra coisa que eu tô falando pros outros grupos, é o seguinte, a hora que espremer o trabalho de vocês tem que sair duas coisas, tem que sair CTS e tem que sair química (Reunião para saber o andamento, arquivo 6 , turno 68).

Com relação à organização das aulas que comporiam o projeto, pelo trecho acima, é notável a orientação de Maria para que fossem encurtadas o número de aulas a serem planejadas, que reflete diretamente na sua Orientação para o ensino de ciências baseada em projetos - Crenças sobre as propostas de aprendizagem em ciência. Ainda sobre esse aspecto, o bolsista ressalta que "[...] todo mundo sabe que o professor gosta de aplicar aquilo que ele participa na criação né, de modo que ele vai entrar com mais gosto em sala de aula sabendo que ele elaborou aquilo ali, né" (Entrevista semiestruturada, Antônio, turno 164). Acredita que dessa forma teria possibilidade de errar e de ter uma experiência de crescimento profissional. Nesse trecho tem elementos ainda do Conhecimento Pedagógico Geral, em virtude de Antônio salientar que todo professor gosta de aplicar o que elaborou.

Por outro lado, em uma das primeiras reuniões com o grupo, Maria buscou orientar os pibidianos acerca dos objetivos do ensino CTS. Nesse sentido, segue o turno:

De repente se vocês fizessem um levantamento prévio, fizessem um estudo daquela região ou de informações a respeito daquela região para trazer isso para colocar na sensibilização, porque daí sim eu acho que acaba envolvendo um pouco mais o aluno, né, inclusive esse tipo de abordagem de pegar o problema que o aluno tá enfrentando que é a base do CTS, o CTS implica nisso, em que o aluno tenha efetivamente, que ele esteja vivendo vamos dizer assim, que faça parte da rotina dele, faça parte do universo dele esse problema [...] (Apresentação da proposta de trabalho, arquivo 3, turno 14).

$\mathrm{Na}$ fala da coordenadora, além dos objetivos a serem desenvolvidos nos alunos em virtude da estruturação das regências pelo viés CTS, observa-se orientações 
relacionadas ao Conhecimento Pedagógico Geral e o Conhecimento do Contexto. Antônio descreve as questões problema que norteariam a aula, mas a supervisora argumenta que a proposição de Antônio não figurava como uma problemática, como revelam os trechos a seguir:

Antônio - (Ininteligível 00:11:51) ((Antônio começa a ler uma situação problema)) "Um consumidor chamado Manuel foi comprar uma nova bateria automotiva, foi orientado pelo comerciante da loja a trazer de sua casa a bateria esgotada. Diante dessa orientação o consumidor Manuel se revoltou, argumentando que o responsável pelo ciclo de vida da bateria automotiva é somente do fabricante da bateria automotiva, portanto cabe a ele ir em sua casa buscar a bateria esgotada, você concorda com o senhor Manuel? [...]

Luiza - Mas aí, desculpa Antônio, isso não é uma situação problema. Digamos que você coloca aí, você concorda, ou discorda com essa posição? Tá você não tá (Ininteligível 00:13:14) entendeu? A proposição do problema seria você, como..., sei lá, não colocar concorda ou não concorda, mas sim o problema real, então assim, ou, sei lá, o cara não quer entregar a bateria, ou como solucionar...entendeu... (Reunião para saber o andamento, arquivo 9, turno 47-48).

As orientações da tutora levam Antônio a reestruturar (quadro 13) a sua abordagem de ensino, e a propor uma situação problema para o desenvolvimento da temática da contaminação.

Quadro 13. Questões problemas reelaboradas por Antônio e Melissa (Fonte: adaptado Relatório dupla, 2014, p.7-8)

Um consumidor chamado Manoel, ao comprar uma nova bateria automotiva, foi orientado pelo comerciante da loja a trazer de sua casa a bateria esgotada. Diante desta orientação o consumidor Manoel, se revoltou, argumentando que a responsabilidade de cuidar do ciclo de vida das baterias automotivas é somente da fabricante, portanto não voltaria a sua casa para Ihe trazer a bateria esgotada.

De quem e a responsabilidade sobre a bateria?

Como você resolveria essa situação?

Duas empresas de uma determinada região, preocupadas com o destino final das pilhas produzidas por elas após o consumo, tiveram iniciativas diferentes para solucionar o problema do descarte inadequado. Uma delas confeccionou embalagens que informavam para o consumidor não jogar as pilhas usadas no lixo comum. Já a outra colocou recipientes de coleta de suas pilhas em metade das lojas para as quais ela vendia seu produto.

A preocupação no descarte dos resíduos de pilhas apresentada pelas empresas é pertinente?

Outros setores da sociedade também possuem responsabilidade no gerenciamento dos resíduos gerados pela população?

É importante destacar que o processo de estruturação dos blocos de aulas, era negociado entre os pibidianos e a coordenadora. Em consonância em uma das 
reuniões, Antônio demonstra seu descontentamento ao estruturar as aulas e nunca serem aceitas:

Antônio - Que eu faço aí ((está referindo-se que estrutura aulas, mas nunca são aceitas)).

Maria - Eu sei, mas é que... Calma, a gente vai chegar num consenso. Até se vocês forem agora pra aula, fica matutando isso na cabeça, de repente na hora que vocês saírem da aula dá uma passada aqui, eu vou tá aqui, fala a ideia, entendeu? Vai trocando o WhatsApp entre vocês (Reunião para saber o andamento, arquivo 8, turno 319-320).

As ações de nosso participante acerca de suas decisões sobre fazer no ensino de ciências pela experimentação talvez seja reflexo de sua escolha profissional, pois ao ser questionado por um aluno da escola conveniada sobre por que escolheu licenciatura em química, Antônio explica que "Foi por conta dos experimentos, os experimentos começaram a me falar ((pensar)) assim: "isso não é mágica, tem um conceito por trás disso", e isso me emocionou" (Aula Pilha de moedas, arquivo 12, turno 297). Para Maldaner (1999) muitos indivíduos permanecem na universidade pelo gosto pela química, pela pesquisa em uma área da química, mas não necessariamente pela docência em química. Outro trecho que corrobora com esse referencial surge quando o pibidiano retrata os resultados de suas aulas durante uma apresentação realizada no interior do subprojeto, em que argumenta "o químico pode trabalhar em cima disso sim, o químico, a função do químico é exatamente isso, criar novas substâncias, criar novos compostos que tenham as mesmas funcionalidades que outros, ou até melhores, entendeu?" (Aula de contaminação por chumbo, arquivo 16, turno105).

As Orientações para o Ensino de Ciências englobam as crenças sobre a natureza da ciência. As percepções do bolsista acerca da natureza da ciência se revelam durante uma das reuniões com a supervisora e coordenadora do subprojeto quando Antônio é questionado sobre que conceitos redox trabalharia com a turma da EJA. O pibidiano argumenta que abordaria definição de reações redox, e assinala às tutoras que:

[...] eu ia falar sobre isso pra ele conseguir enxergar: "Olha, a química, a ciência ainda existe porque ela estuda fenômenos pelo seu portão, a sua chave que enferrujou, ela existe porque ela está estudando esse fenômeno, pra explicar esse fenômeno" (Reunião para saber o andamento, arquivo 9, turno 285).

Na visão de Reiss (2009) a natureza da ciência é reduzida à noção de como a ciência é constituída e como os cientistas a desenvolvem, resultando em uma concepção limitada acerca da natureza, que reflete em práticas de ensino, como a proposta por Antônio, que buscam reproduzir em sala de aula experimentos com a função de comprovar o conteúdo trabalhado (GIL-PERÉZ et al., 2001; 2008). Por outro lado, o pibidiano buscou trabalhar com os discentes durante suas regências a ideia que 
a ciência evolui por meio da história da ciência: "1800, um cara bonito, inteligente, descobriu, tá vendo esse elétron aqui que saiu? Ele pode ser utilizado pra realizar trabalho, que aí é o princípio da pilha [...]" (Reunião para saber o andamento, arquivo 9, turno 416).

Em uma aula experimental demonstrativa envolvendo a oxidação da palha de aço em solução de sulfato de cobre, ao discutir o que havia ocorrido, Antônio chama a atenção dos alunos para os aspectos visíveis:

É meio esverdeada, né? E aconteceu alguma coisa aqui, que tá diferente daqui, a forma como tá arranjada esses átomos tá diferente, é isso que os químicos gostam de representar daquela maneira ali, é a forma do químico olhar praquilo ali e falar assim: "Opa, é uma reação de oxirredução" entendeu, ele consegue olhar pra aquela equação ali, e imaginar isso um nível submicroscópico e num nível macroscópico também, entendeu, representar isso. Interessante notar, é que realmente acontece uma reação de oxirredução e vai ficar nesse estado ali tá pessoal (Aula atomística, arquivo 11, turno 224).

No argumento do pibidiano há uma tentativa de convencer os alunos que a oxidação e a redução realmente acontecem. Para tanto, busca relacionar os diferentes níveis: macro, micro e simbólico. Nesse trecho a percepção acerca da natureza da ciência de Antônio repousa em compreender que o método científico é definitivo e inquestionável, uma visão bastante compartilhada por docentes e futuros professores (FERNÁNDEZ et al., 2002; GIL-PÉREZ et al., 2001) revelando uma concepção empírico-indutivista, em que a experimentação em suas aulas tem função de comprovar os conceitos científicos e ser fonte de conhecimento (ROSA; ROSA, 2010). Essa visão da ciência permeia todas as aulas experimentais regidas pelo pibidiano.

Em outra prática experimental, a Pilha de Volta, propôs o experimento das moedas, sua intenção era desenvolver uma prática investigativa, como denota o trecho "[...] e aí no experimento a gente vai verificar isso, a gente vai inverter os papéis ((a ordem)), e a gente vai verificar: "Porque o led não acendeu?" E aí você vai saber, porque um tem o potencial de redução [...]" (Aula Pilha de moedas, arquivo 12, turno 29). Para Antônio a prática investigativa potencializaria a aprendizagem e o papel do aluno na aprendizagem. Sua fala estava baseada nos referenciais teóricos que adotou na elaboração do relatório (SUART; MARCONDES, 2009; DOMIN, 1999; HODSON, 2005) (Relatório Anual, Aula 3 - Antônio). Entretanto, a aula foi conduzida tradicionalmente, pois não permeou as características da prática investigativa que deveria possibilitar espaços aos alunos para refletirem, discutirem e explicarem (AZEVEDO, 2004). Segundo a autora a prática investigativa deveria proporcionar mudanças tanto no aluno como no professor, por meio do desenvolvimento de habilidades e de raciocínio que não foram atingidos em sua totalidade por Antônio (Relatório anual da dupla, aula 3 Antônio). O roteiro da prática experimental foi construído de modo investigativo em Capitulo 4. Resultados e Discussões 
virtude da orientação de Luiza na reunião que antecedeu a implementação da Pilha de Volta a ser implementada, Luiza o orienta a elaborar um roteiro experimental investigativo:

Luiza - Que tal se você fala em botar a pilha com um papelzinho seco, e observar o que ocorre, depois papelinho molhado na água e observar o que ocorre.

Antônio - E eu peguei (Ininteligível 00:23:36)

Luiza - Depois molhar o papelzinho lá na água e sal, observar o que ocorre. Então você vai de uma maneira, né, a gente espera que você leve o aluno a concluir, que há uma necessidade de um meio que conduza elétrons pra ver essa função da corrente elétrica e a lâmpada acender, o led acender (Reunião para saber o desenvolvimento, arquivo 9, turno 371-373).

Antônio seguiu as orientações da tutora em buscar desenvolver uma prática experimental com características investigativas e que refletem tanto em suas orientações para o ensino de ciências, em estratégias e na motivação e interesse do aluno pelo conteúdo. Vale ressaltar que o pibidiano demonstrou uma certa resistência em reestruturar o roteiro, que segundo as tutoras havia sido planejado para o ensino médio regular, apesar de Antônio argumentar que contemplava tanto o ensino médio regular, como a EJA. Sobre esse episódio tem-se ainda o relato de Luiza para que Antônio desenvolvesse uma aula de caráter investigativo:

Luiza - É, então eu compartilhei, o Felipe compartilhou com vocês, não compartilhou? O Felipe copiou dois vídeos, um da Sociedade Brasileira de Química, um que é da Rita Estwart que dá algumas dicas de como... bem pra o professor como trabalhar em sala de aula determinadas questões, visando o experimento investigativo, né, também, que eu acho que é uma das coisas que a gente tem que se preocupar, então não fazer uma experiência pela experiência, mas que aquilo tem que sair alguma coisa, e aí assim, até depois eu conversei com o carioca ((Antônio)), só deixando vocês a par, de um experimento lá, como que ele poderia transformar aquele experimento em investigativo? Então eu falei assim: olha, por exemplo, se você coloca aqui em vez de dar a montagem já pronta pros alunos, que vai acender a lâmpada que é uma pilha, o que você não faz? Bota pra eles montarem com o papelzinho seco, não vai acontecer nada, tá, observe o que aconteceu, faz uma pergunta, aí molha o papelzinho na água, o que aconteceu? Aconteceu alguma coisa? Mudou alguma coisa? Molha o papelzinho na água com sal, mudou alguma coisa? O que você consegue concluir disso? Então você vai levando o aluno a pensar, e a refletir no caminho daquilo que você quer, que é que ele compreenda que pra haver corrente elétrica é necessário a presença de íons. Então, agora, então assim, a dificuldade que eu senti neles, era assim, no começo do semestre passado estava todo mundo perdido, inclusive eu, porque eu também não sabia muito direito o que era, o que ia dar, aonde a gente ia desembocar, então praticamente, eu acho que no semestre passado, o que eles, exceto o grupo de vocês que fez a experiência (Reunião para saber o andamento - Grupo Mateus, arquivo 6, turno 14).

No início de seu discurso Luiza apresenta alguns Materiais Curriculares Conhecimento do Currículo, em que Antônio estava sendo orientado a pesquisar. Além 
disto, a supervisora ainda orienta o pibidiano a desenvolver sua aula por meio da prática experimental de caráter investigativo que influencia suas orientações para o ensino de ciências e, consequentemente, figura como uma estratégia de ensino para o desenvolvimento de um tópico específico - Conhecimento das Estratégias Instrucionais para o Ensino de Ciências.

Analisando-se ainda a aula de pilha de moedas, Antônio traz um texto sobre o inventor da Pilha e faz uma discussão com os alunos de como foi evoluindo as pesquisas que deram origem à pilha comercial, além de propor uma comparação entre a pilha montada em sala e as comerciais (Relatório Anual da dupla, aula 3 - Antônio). Porém, durante as aulas videogravadas não observamos essa discussão. O importante é que Antônio buscou trabalhar em sala de aula com o contexto histórico, em uma tentativa de fazer seus alunos perceberem que a ciência evoluiu ao longo dos séculos (Crenças sobre a natureza da ciência), quando, por exemplo, iniciou a sua aula da Pilha de Daniell "Então esse é o tema da nossa aula, pilha de Daniell, que aconteceu em 1836 a invenção dele, que claro, ele utilizou de alguns conceitos que o próprio Alessandro Volta construiu, né, sobre pilhas [...]" (Aula Pilha de Daniell, arquivo 13, turno 20).

Ao término das etapas de implementação das aulas, durante uma reunião geral, Antônio em suas reflexões que as aulas planejadas e implementadas deveriam ter uma sequência: "Você quer fazer poucas alterações, você obriga o aluno ((pibidiano)) a ir em tempos distantes um do outro pra fazer intervenções, e faz o aluno ((da educação básica)) esquecer até do seu nome" (Reunião geral, arquivo 22, turno 52). Na percepção do pibidiano as aulas deveriam estar prontas para que houvesse reuniões com a tutora para discuti-las logo após a sua execução, para que assim o discente tivesse um ensino progressivo. Maria argumenta que esse problema seria sanado quando fosse associado o planejamento do Pibid com o da professora supervisora. Por outro lado, em um diálogo com a coordenadora:

Maria - Não terminou o trabalho do Pibid, continua, aí quando nós voltarmos aí a gente avalia, provavelmente pessoas vão entrar, tem bastante gente, provavelmente pessoas vão sair, e a vida é assim, Pibid é uma fase, tem uma fase que a gente passa pelo Pibid, e no caso de vocês, se vocês quiserem continuar eu acho extremamente bacana, gostei de vocês da dupla, o grupo de vocês foi autossuficiente vamos dizer assim, nós fizemos intervenções porque tem umas que são necessárias, e vocês foram crescendo com o passar do tempo, não sei se vocês perceberam isso.

Antônio - Eu fui entendendo a ideia do que era, no começo eu não entendi muito bem, mas eu fui... ah é isso. Entendi. Meu amadurecimento foi assim na de ideia de que era uma sequência didática (Reunião com a dupla, arquivo 23, turno 229-230).

A forma que conduziu suas regências sobre o conteúdo redox estava fortemente influenciada por suas crenças sobre a natureza da ciência, além do seu entendimento 
sobre as propostas e objetivos relacionados ao ensino. Porém, não se pode ignorar que Antônio estava inserido no Pibid, no qual seu subprojeto apresentava certas diretrizes que deveria seguir e que estavam pautados em: elaborar aulas de sensibilização sobre a PNRS; coletar dados para o subprojeto; readequar atividades em função das orientações da coordenadora; propor aulas que contemplassem atividades em grupo; elaborar atividades que incentivassem a resolução de problemas; propor práticas experimentais; trabalhar mais com conteúdo específicos em virtude das exigências da supervisora, entre outras. Essas nuances que deveriam ser incorporadas pelo pibidiano em suas propostas de ensino podem ter influenciado em suas Orientações para o ensino de ciências.

\section{Conhecimento do currículo em ciências}

Nessa categoria tem-se o conhecimento de Antônio sobre os materiais curriculares, os conteúdos que prioriza, além das conexões que realiza entre os conteúdos ministrados em momentos distintos de suas regências.

No planejamento das aulas discutido em reunião com a coordenadora, a intenção de Antônio era iniciar o conteúdo redox com o conceito de NOX: "Essa aula seria realmente química, ia começar com o conceito de variação de NOX [...]" (Reunião para saber o andamento, arquivo 8, turno 254). Contudo, a coordenadora salientou que o pibidiano estava trabalhando com uma turma da EJA e que, portanto, era necessário iniciar a aula pela estrutura atômica, conceito de íons, para então apresentar a definição de reações redox. Na visão de Antônio iria "[...] ficar um pouco desconexo assim, você ensinar o que é átomo, o que é eletrosfera, não vai ter nada a ver com pilhas assim, a questão [...]" (Reunião para saber o andamento, arquivo 8, turno 294). Esse trecho revela o entrelaçamento do currículo vertical no seu planejamento, mas também em compreender como esse conteúdo químico aparece nos documentos oficiais, Currículo do Estado de São Paulo e PCN, denotando que a organização do conteúdo foi reflexo do conhecimento de currículo de suas tutoras.

Ainda em relação ao currículo horizontal e vertical, nas reuniões do subprojeto Antônio buscou relacionar a tabela periódica e a localização dos átomos em determinadas famílias que os caracterizavam com certo número de oxidação (Reunião para saber o andamento, arquivo 9). Além de entrelaçar os conceitos desenvolvidos em diferentes aulas, em outras regências "aí tipo: não percam, semana que vem vai fazer uma pilha, e a gente vai estudar o conceito que a gente está estudando agora, e..." (Reunião para saber o andamento, arquivo 9, turno 242).

No decorrer da Reunião para saber o andamento (arquivo 8), Antônio inicia a estruturação dos conceitos que iria trabalhar e desenvolver. Segundo o bolsista a ideia 
era ensinar o conteúdo redox, por meio do equilíbrio entre o conteúdo químico e a abordagem CTS, mas sempre tendendo para o conteúdo (Entrevista semiestruturada, Antônio).

Ao discutir a adoção do experimento da Pilha de moedas com as tutoras, Antônio - como apresentou-se na Categoria Orientações para o Ensino de Ciências, pretendia levar o discente a testar diferentes eletrólitos no experimento, para tanto buscou na regência desenvolver o conceito de eletrólito:

[...] a gente deixou aqui 4 soluções, porque todas elas são eletrólitos, minto, uma não é, uma não é eletrólito, ela tem um pouco eletrólito porque é água da torneira, água da torneira ela vem com alguns sais, mas se fosse água destilada ela não teria um cátion então ela não seria uma solução eletrolítica, solução eletrolítica é uma solução que consegue conduzir corrente elétrica, entendeu, essa se dissocia no sal. Eu acho que pra introduzir é isso, mas a gente vai começar a fazer o experimento, e vou começar trabalhar com vocês alguns conceitos pra recuperar, entendeu? (Aula Pilha de moedas, arquivo 12, turno 14).

Essa passagem revela ainda a estratégia de Antônio em inicialmente relembrar os conceitos desenvolvidos na aula anterior e conceitos que contribuiriam para o aluno compreender os fenômenos da prática experimental. Por outro lado, contradiz a intenção do pibidiano de implementar uma prática experimental investigativa.

Olhando-se para a trajetória de Antônio no Pibid, durante uma aula ministrada por outra pibidiana, o pibidiano apresenta o conceito de isótopos para que os alunos compreendessem que a denominação é dada, quando os átomos têm o mesmo número atômico. E continuou o raciocínio com a turma:

[...] então a regra que ela falou que o mesmo número de nêutrons tem que ser igual o número de prótons e essa soma dá a massa atômica, não é uma regra, que assim, existe exceções, que são os isótopos que a professora falou que são átomos que tem mais nêutrons do que prótons, entendeu, e aí dá essa diferença de [...] (Aula atomística, arquivo 11 , turno 51 ).

No contexto dessa aula fez uma explanação sobre o estado metálico, ao explicar o significado do zero na representação do átomo, entre outros.

Retornando à primeira aula ministrada por Antônio sobre redox, por meio de um experimento demonstrativo explicou o conceito de dissociação iônica ao diluir sulfato de cobre em água. Em outra aula, pilha de Daniell, o pibidiano correlacionou o conceito de orbital molecular, e como a localização do elétron na camada mais externa poderia influenciar no ganho ou perda de elétrons (Aula Pilha de Daniell, arquivo 13). Essa aula foi permeada por uma gama de conteúdos químicos, considerando que Antônio estava ministrando aulas numa turma da EJA. Entretanto, para o pibidiano os discentes da EJA tinham um interesse pela química, que pode ser evidenciado em sua fala quando realiza o encerramento das atividades: 
[...] fiz uma discussão de encerramento avaliando como é que foi ao longo do projeto na escola, e aí eu recebi deles um relato positivo sobre as aulas, as aulas de experimentação, as de vídeo foi bem legal, alguns alunos não foram nessa aula, mas durante os períodos gostavam de aula de química, se interessavam pela área de química, e teve um agradecimento da turma pela participação do projeto com a gente [...] (Apresentação dos resultados, arquivo 21, turno 69).

Essa postura dos alunos possibilitou o pibidiano avançar com o conteúdo. Uma realidade que vai na contramão do ensino nessa modalidade, pois estudos apontam que alunos da EJA têm dificuldades com o conteúdo, impossibilitando o professor avançar, o que torna o ensino de conceitos químicos fragilizado (NASCIMENTO, 2012). Essa vivência em sala de aula levou Antônio a considerar que seja importante o professor transitar nos diferentes conceitos da química para estudar um determinado conteúdo, assim como identificar conhecimentos de outras áreas para melhorar o processo de ensino-aprendizagem de seus alunos quando os conhecimentos de sua área específica não dão conta (Entrevista semiestruturada, Antônio), revelando uma perspectiva multidisciplinar do ensino. Ainda nessa perspectiva da multidisciplinaridade, em outra regência, sobre contaminação de chumbo procurou integrar conhecimento de outras disciplinas para explicar os efeitos de chumbo no organismo, além de trazer para a sua explicação, mesmo que de modo limitado, os casos de contaminações sofridas por artistas como Candido Portinari e Aleijadinho, por utilizarem tintas com excesso de chumbo (Aula contaminação por chumbo, arquivo 16).

Todos os documentos analisados revelaram o conteúdo específico priorizado por Antônio. No CoRe adaptado a saliência curricular permeia o conceito de pilha, potencial de redução, ferrugem e noção de polo positivo e negativo (o sentido de migração dos elétrons). Na primeira aula ministrada por Antônio sobre redox os principais conceitos emergidos sobre o tema foram definição de reações redox, semi-reação e reação global. $\mathrm{Na}$ segunda regência apresentou novamente a definição de reação redox, porém aparecem mais o conceito de pilha, tabela de potencial de redução, definição de solução eletrolítica e eletrólito e equilíbrio de cargas. O conceito de eletrólito emerge em consequência da orientação dada por Luiza na elaboração do roteiro da aula experimental da Pilha de moedas, que discutimos na categoria Orientações para 0 ensino de ciências. Além disto, Maria pontua:

[...] Que o elétron não foi utilizado pra realizar o trabalho, que é o princípio da pilha, porque eu tenho mecanismo, aí entra o que a Luiza tava falando sobre a necessidade do eletrólito porque que o elétron tem que ter um caminho, porque que eu tenho os fios ali, porque na minha pilha eu tenho o condutor, porque que eu tenho aquele, como é que chama aquele troço lá de carbono lá dentro, de carvão? Não é? É um eletrodo, porque que o elétron não sabe nadar, é verdade. Então, tratar de como funciona uma pilha, tem tanta coisinha, é por isso que quando a gente fala: "Ah, agora eu vou ensinar pilha" ensina pilha a gente 
precisa de muitas aulas, entendeu, muitas [...] (Reunião para saber o andamento, arquivo 9, turno 399).

Com relação aos materiais curriculares adotados na elaboração das aulas, Antônio demonstrou um conhecimento básico de livros didáticos de ensino médio, por outro lado, um conhecimento rico em reportagens, vídeos, música e artigos, que além de serem citados foram utilizados em suas regências. (Entrevista semiestruturada, Antônio; Aula sensibilização, arquivo 10; Aula atomística, arquivo 11; Aula pilha de moedas, arquivo 12; Aula Pilha de Daniell, arquivo 13). O livro didático adotado na fundamentação das aulas foi de Química Geral do autor Ricardo Feltre, que traz uma abordagem tradicional do conteúdo. Uma situação recorrente nas aulas do licenciando era o seu discurso de que os conteúdos retratados em classe estavam presentes nos livros didáticos "[...] você ((aluno)) pode procurar no livro didático ou qualquer outro livro de vestibular, pode ser um interruptor, qualquer coisa, é só pra fechar o circuito" (Aula Pilha de Daniell, arquivo 13, turno 80). Nesse trecho o pibidiano estava desenvolvendo a função da ponte salina na pilha de Daniell, o que demonstra ter analisado os livros para entender como esses trazem a definição de ponte salina. Em outra passagem quando definia o conceito de pilha de Daniell argumenta que:

[...] no livro didático que você vai olhar, Olha: "o Antônio falou isso aqui pra mim na sala de aula, a pilha de Daniell, um experimento que mostra, uma solução, o sulfato de zinco, a gente sabe que em meio aquoso não fica assim bonitinho, fica em forma de íons né, a mesma coisa acontece com sulfato de cobre, em forma de íons né, na solução (Aula Pilha de Daniell, arquivo 13, turno 124).

Afirmou ainda que a representação da pilha que dispôs na lousa está em todos os livros didáticos, pois é o princípio para o entendimento das pilhas contemporâneas (Aula Pilha de Daniell, arquivo 13). Os conceitos emergidos nessa aula foram "ganho e perda de elétrons, ânodo e cátodo, oxidação e redução, agentes oxidantes e redutores, solução mais concentrada e mais diluída e diferença de potencial de redução entre metais" (Relatório anual, Aula 4 -Antônio). Suas explicações sobre as reações redox também denotam ser advindas de livros didáticos, pois ao fazer a representação das semirreações argumenta com a turma que está nesse material da mesma forma como representou na lousa. Em outros momentos, mais especificamente em uma aula de contaminação de chumbo, discorreu que a sua fala "[...] tava toda baseada em cima daquele artigo com o que o vídeo relacionava com o artigo também" (Reunião com a dupla, arquivo 23, turno 146).

Com relação ao material curricular, Antônio também confeccionou dois textos sobre o histórico das pilhas, além de estruturar e fundamentar uma de suas aulas tendo como abordagem a prática investigativa, além da fenomenologia, macroscópica e simbólica, na qual adotou referências de renome como Mortimer (2000), além de Suart 
e Marcondes (2009); Domin (1999); Hodson (2005), revelando que o pibidiano não adotava um único referencial teórico na elaboração de suas regências.

Antônio demonstrou ter um excelente conhecimento dos reagentes, vidrarias e equipamentos necessários às aulas experimentais (Aula atomística, arquivo 11; Aula Pilha de moedas, arquivo 12; Aula Pilha de Daniell, arquivo13). Sobre o laboratório da escola conveniada, argumentou que tinha os reagentes e materiais necessários às suas aulas, o que demonstra que explorou esse espaço para reconhecer suas condições para o desenvolvimento de suas regências. Contudo, quando a montagem de um experimento não deu certo, fez adaptações utilizando os reagentes e materiais disponíveis: "[...] eu fiz uma sequência lá, vindo do zinco, indo passando pro cobre, aí na sequência da pilha [...]" (Aula de revisão, arquivo 15, turno 424). Antônio, nesse trecho, estava preparando uma bateria em substituição a um experimento de pilha de Daniell, em que a ponte salina feita de papel embebido em solução eletrolítica não funcionou, fez uma adaptação a partir de seu conhecimento sobre materiais e reagentes que tinha à sua disposição. Salienta-se que esse experimento foi adotado por Antônio em virtude da orientação de Maria na reunião para saber o andamento (arquivo 14). Nessa mesma aula, Antônio realiza o experimento de oxidação de cobre em nitrato de bário, pois não tinha nitrato de prata, revelando mais uma vez o seu conhecimento dos reagentes disponíveis no laboratório e o seu conhecimento químico.

$\mathrm{Na}$ percepção de Antônio ao finalizar suas regências, compreendeu a necessidade de melhorar as atividades para que tivessem "[...] um caráter mais científico por causa de melhor fundamentação teórica" (Relatório anual, Antônio). Assim, as aulas deveriam envolver um ensino progressivo (Reunião geral, arquivo 22). Segundo Moraes e colaboradores (2007) a implementação de aulas inovadoras requer revisões.

De modo geral as aulas do pibidiano foram estruturadas seguindo os objetivos do subprojeto, mas o que não significa que Antônio não as tenha estruturado seguindo alguns de seus anseios que perpassava principalmente a estruturação de aulas experimentais (Entrevista semiestruturada, Antônio).

Para um licenciando infere-se que por meio dos diferentes documentos analisados, Antônio demonstrou ter um bom conhecimento dos materiais curriculares e dos conteúdos que permeiam o ensino do conteúdo redox. Por outro lado, não demonstrou ter um conhecimento de como este conteúdo aparece nos documentos oficiais (PCN) e no currículo do Estado de São Paulo, evidenciando que estruturou suas aulas pelo conhecimento sobre o currículo de suas tutoras. 


\section{Conhecimento da compreensão dos alunos em ciências}

A constituição dessa categoria do conhecimento docente está entrelaçada pelo conhecimento dos professores sobre seus alunos com relação às suas concepções alternativas e prévias, somadas às suas dificuldades de aprendizagem, o que os motiva e os interessa, além do conhecimento das necessidades individuais e coletivas que são fundamentais para a aprendizagem.

$\mathrm{Na}$ análise da entrevista semiestruturada surgem os primeiros elementos dessa categoria, relacionados aos conhecimentos prévios dos discentes. Nesse viés, o pibidiano refletiu que "De fato não tem feito levantamento prévio né, mas durante o percurso do Pibid ficou muito...isso tem que tá mais evidente durante as aulas" (Entrevista semiestruturada, turno - 44, Antônio). Existe ainda, em sua percepção limitações ao ensino desse conteúdo relacionadas à falta de conhecimento dos alunos sobre ferrugem, o esgotamento de pilhas e baterias, que na sua visão possibilitaria a contextualização desse conceito (CoRe adaptado, Antônio).

Para o pibidiano suas aulas foram fundamentadas tendo como um dos objetivos que seus estudantes desenvolvessem a habilidade de executar atividades fundamentadas nas teorias científicas (Entrevista semiestruturada, Antônio). Ainda com relação ao conhecimento a ser desenvolvido pelos discentes, na aula de pilha pretendia que os alunos compreendessem "Como a pilha funciona, a função específica de cada componente e como representar simbolicamente aquele fenômeno" (CoRe adaptado, Antônio). Esse trecho revela as habilidades pretendidas a serem desenvolvidas no processo de ensino. Contudo, quando se revisita as primeiras reuniões, o bolsista não considerava pertinente propor atividades nas quais os alunos deveriam representar as reações químicas envolvendo o conteúdo, mas apenas as que requeressem a parte conceitual (Reunião para saber o andamento, arquivo 9), revelando uma mudança em suas percepções acerca das dificuldades dos discentes, um novo olhar, propiciado pela sua imersão na turma da EJA e, consequentemente, reflexo das orientações de suas tutoras.

Em uma das reuniões em que os diálogos estão mais direcionados para o conteúdo específico, Maria sugere que a diferença entre pilha e bateria seja abordada na explicação de Antônio, denotando que Maria percebia a dificuldade do discente em fazer essa distinção. Em consonância, Antônio na aula de revisão abordou esse conceito por meio de um experimento demonstrativo. Em uma reunião anterior no qual Antônio apresenta a proposta de aula sobre atomística como discorre-se na Categoria Conhecimento do Tema, delineia como seria a dinâmica da regência: " $E$ aí eu já ia entrar, falar um pouquinho do átomo, explicar essa capacidade do elemento químico perder elétrons entendeu, elétrons mais afastados do núcleo e o chumbo que tem essa Capitulo 4. Resultados e Discussões 
capacidade" (Reunião para saber o andamento, arquivo 9, turno 229). A estrutura da aula foi reflexo da orientação da supervisora, suscitando indícios de sua influência no conhecimento docente de Antônio relacionado ao Conhecimento do Currículo Currículo horizontal e vertical, do Conhecimento da Compreensão dos alunos em ciências/necessidades. Ao fim da apresentação a coordenadora argumenta que do modo como a aula foi estruturada os discentes compreenderiam:

[...] o que é um átomo neutro, o que é um íon, o que é um Cátion, e o mais importante, perceber que se mudar essa configuração eletrônica dele vai mudar as propriedades, e aí a gente tá andando pra trabalhar com o que a gente quiser, pra trabalhar bateria, pra trabalhar contaminação de íons, de elementos diferentes, aí a ideia... (Reunião para saber o andamento, turno 264).

Esse trecho revela o modo como a coordenadora considerou as dificuldades dos alunos ao orientar Antônio na construção da aula.

Em relação às estratégias adotadas para ajudar seus alunos com dificuldades de aprendizagem, Antônio salienta que procurou relembrar os conceitos trabalhados e evidenciar suas concepções errôneas emergidas nas atividades avaliativas (Entrevista semiestruturada, Antônio).

Em virtude da fragilidade dos discentes com a escrita, Maria sugere que fosse proposta a produção textual como atividade para os discentes da EJA na aula sobre PNRS:

Que dessa aula aqui, sabe o que também poderia surgir pra não perder esse contexto? Que os grupos depois da discussão elaborassem o consenso que eles chegaram, tendo em consideração o problema e o que diz na legislação. Então, a contribuição dessa aula aqui, o produto final, seria exatamente esse relato do grupo entendeu, essa discussão por escrito (Reunião para saber o andamento, arquivo 8, turno 149).

Essas orientações foram seguidas por Antônio, resultando na implementação da avaliação apresentada no quadro 14.

Quadro 14. Proposta de avaliação para aula de sensibilização - PNRS

Duas empresas de uma determinada região, preocupadas com o destino final das pilhas produzidas por elas após o consumo, tiveram iniciativas diferentes para solucionar o problema do descarte inadequado. Uma delas confeccionou embalagens que informavam para o consumidor não jogar as pilhas usadas no lixo comum. Já a outra colocou recipientes de coleta de suas pilhas em metade das lojas para as quais ela vendia seu produto.

A preocupação no descarte dos resíduos de pilhas apresentada pelas empresas é pertinente?

Outros setores da sociedade também possuem responsabilidade no gerenciamento dos resíduos gerados pela população? 
Apesar de compreendermos que o PCK é específico para um conteúdo, consideramos pertinentes trazer atividades avaliativas adotadas na aula de problematização, por fazer parte do projeto desenvolvido por Antônio.

Ao apresentar os conteúdos que seriam ministrados Antônio argumenta com a coordenadora que iniciaria pelo conceito de NOX, Maria discorda argumentado:

Maria - Gente, pro EJA, tá pro EJA.

Maciel - Uma introdução.

Maria - Gente, já deu o horário.

Antônio - Deixa pra próxima então pra gente discutir ou se a senhora quiser ficar com o slide pra ver.

Maria - Não, eu preciso conversar com vocês, não tem jeito de só ver os slides porque eu não vou entender nada. Não gente, assim essa, olha, tá muito bom, mas assim pra EJA, eu já dei aula pra EJA, e vocês também já viram a turma da EJA, não faz sentido trabalhar NOX com eles. Nossa ferrou tudo, passar NOX pra EJA, porque pra regular isso aqui tá... (Reunião para saber o desenvolvimento, arquivo 8, turno 265269).

Maria discorre sobre as limitações relacionadas ao ensino do conteúdo redox. Essas problemáticas apontadas por Maria estão associadas a falta de Conhecimento das dificuldades conceituais dos alunos com reações de oxirredução. Ao refletir sobre essa aula, Antônio reconhece que "[...] a segunda aula seria uma aula de revisão química, seria uma aula de... A gente ia conhecer os conhecimentos prévios deles sobre a atomística, sobre ionização, e até baseado nessa aula preparar uma próxima aula, pras próximas etapas" (Apresentação dos resultados, arquivo 21, turno 12). O discurso do pibidiano salienta um reconhecimento sobre a importância de perceber as possíveis dificuldades dos discentes da EJA com a química e, consequentemente, com o conteúdo redox. Nesse sentido, para Antônio as dificuldades e limitações conectadas ao ensino de reações redox estavam interligadas ao entendimento sobre o potencial de redução e à compreensão dos alunos do fenômeno da oxidação no nível submicroscópico. Outro aspecto apontado pelo pibidiano relaciona-se às concepções alternativas, estavam associadas a "[...] concepção de carga elétrica ser positiva e os elétrons saem do positivo para o negativo em um circuito, concepção alternativa possivelmente da experiência com instalação elétrica residencial" (CoRe adaptado, Antônio). Esse trecho corrobora com a afirmação de Antônio, geralmente os estudantes têm tendência a considerarem que o sentido do fluxo de elétrons vai do polo positivo para o polo negativo por desconhecerem as convenções na pilha, de que os elétrons migram do polo negativo para o positivo, e ainda confundirem com o fluxo da corrente elétrica que tem o sentido contrário do percurso dos elétrons nas pilhas. Segundo 
Caramel e Pacca (2011) essa concepção percebida por Antônio é uma das principais concepções alternativas associada ao conceito de pilha.

Quando se analisa a aula de Pilha de moedas, em um dos trechos surgiu a influência da supervisora na subcategoria Dificuldades de aprendizagem ao chamar atenção de Antônio para o questionamento de um aluno, como demonstra o trecho:

Luiza - Antônio você ouviu a pergunta?

Antônio - Ele falou se eu tô com o led dele, e eu falei que não.

Luiza - Não, não. A pergunta: se aumentar o tamanho da moeda, se aumenta a voltagem da pilha?

Antônio - Sim.

Aluno - Sim?!

Antônio - Não, o tamanho da moeda, como assim, a largura da moeda?

Antônio - Não, não vai acontecer isso. ((Aumentar a voltagem da pilha))

Luiza - Porque não?

Luiza - Vai influenciar ou não vai influenciar? Eu não entendi.

Antônio - Vamos lá. Deixa eu te explicar o porquê não, é porque essa diferença de potencial que tem do cobre pro alumínio é a mesma, entendeu, independente da largura da moeda, entendeu, a pressão, vou dizer assim, a pressão elétrica que o cobre faz encima do alumínio faz pra puxar esse elétron do alumínio é o mesmo, então o tamanho não vai influenciar a pilha, eu posso até falar assim: "Vai influenciar sim, mas muito pouco".

Antônio - É por que...

Aluno - Ficou em cima do muro

Antônio - Não é porque assim, porque...

Luiza - Se mudar a moeda por uma, sei lá, uma plaquinha de cobre, tá.

Antônio - Eu acho que é desprezível o que vai acontecer, é desprezível porque a tendência do cobre puxar o alumínio é a mesma, entendeu, o que vai fazer é uma coisa, melhorar a luminosidade no seu led, é botar mais uma pilha em cima. Porque aí vai somar ((ddp)).

Aluno - Não interessa o tamanho, né?

Luiza - Então, o que muda, é a quantidade de pilhas que você tá fazendo tá. Então, a bateria do carro você tem várias selinhas né, são várias pilhas, ok?

Antônio - É, porque no caso fazia até sentido a gente fazer sempre aquelas baterias de carros grandes, né. Mas não tem essa utilidade. ((A largura da moeda e dos materiais não influencia no aumento da voltagem da pilha)) (Aula pilha de moedas, arquivo 12, turno 139-157).

Nesse trecho Antônio buscou usar uma analogia de ddp com pressão elétrica.

Em outro momento da aula o pibidiano se apoia na ideia de força para explicar o equilíbrio de cargas, pois na narrativa de Antônio a bateria construída no experimento tinha "[...] uma durabilidade não muito longa, igual à pilha que você compra no mercado. 
O efeito é o mesmo. Tem um momento que acontece um equilíbrio, tem um momento que o elétron já não tem mais força pra conseguir caminhar até o outro lado, entendeu (Aula Pilha de moedas, arquivo 12, turno 122). Contudo, a analogia resultou no surgimento de uma concepção equivocada pelos discentes da EJA descrita pelo pibidiano na apresentação dos resultados para o grupo do subprojeto e na reunião com a dupla (Apresentação dos resultados, arquivo 21; Reunião com a dupla, arquivo 23). Nesse sentido, durante suas reflexões sobre as dificuldades dos discentes com 0 conteúdo, Antônio salientou que os mesmos apresentaram concepções equivocadas ao justificarem o fim da vida útil da pilha em virtude da diminuição da força dos elétrons (Relatório anual dupla, aula 3 - Antônio). Nessa aula, Antônio recorreu à ideia de força nove vezes, como uma analogia. Porém, para o pibidiano esse erro estava associado a expressões usadas no cotidiano, por exemplo, "Acabou a força”, para descrever o corte de fornecimento de energia elétrica.

Considerando-se ainda o contexto da aula de Pilha de moedas, no início da regência Antônio fez uma pequena revisão sobre os conceitos desenvolvidos na aula de atomística, contudo ao terminar a sua explicação Luiza argumenta ao pibidiano que muitos alunos haviam faltado na aula anterior e, consequentemente, não sabiam o que o pibidiano estava ensinando:

Luiza - Eu já tenho um monte de dúvidas que precisam ser resolvidas, tem gente que não estava na aula passada, então essas pessoas que não estavam aula passada, não sabem o que é oxidação, não sabem o que é redução, você falou em potencial de redução, vocês entenderam esse potencial de redução? Porque eu olhei pra cara de vocês e vi um monte de cara de "ué"?

Aluno - Nem sei o que tá falando ((sobre o que tá falando, o conteúdo ministrado por Antônio)), né professora?

Luiza - Porém, ninguém abriu a boca, né? Então eu estou abrindo a boca por eles, porque parece que o bicho comeu a boca deles, né, a língua, porque tá tendo algum problema aí e eles ficaram sem língua pra pergunta.

Aluno - No meio da semana né professora? (Ininteligível 00:05:01) ((Risos na turma))

Antônio - Toda vez que um elemento químico ele perde elétrons para outro elemento químico que está forçando essa perda de elétrons, a gente chama de oxidação, o elemento oxidou. Toda vez que um elemento químico ganha esse elétron do outro elemento químico, a gente chama de redução, ele ganhou esse elétron, entendeu, temos mais conceitos que a gente pode explorar daqui pra frente, mas eu vou explorar junto com um experimento, entendeu, o importante saber que vai ter uma troca de elétrons aqui, alguém vai dar elétrons pro outro, e esse outro vai receber esse elétron, entendeu? Essa troca depende muito..., e aí no experimento a gente vai verificar isso, a gente vai inverter os papéis ((a ordem)), e a gente vai verificar: "Porque o led não acendeu?" E aí você vai saber, porque um tem o potencial de redução, que é uma tabela que os químicos adoram e físicos também, todo físico e químico adoram constante tabela, né, que ele consegue medir 
padronizando com o hidrogênio, como são hidrogênio zero, consegue ver quem é que tem o maior caráter de atrair esse elétron pra ele, entendeu, e é isso que a gente vai ver. Eu sei que é difícil compreender no início, mas eu espero que no experimento a gente vai pelo menos entender que estudar química tem o seu lado bom, ainda mais pra sociedade, entendeu, e eu acho que a gente pode começar agora. Gente, eu tô com medo do tempo, então... (Aula de Pilha de moedas, arquivo 12, turno 25-29).

A supervisora, em virtude de seu conhecimento sobre as dificuldades dos alunos e suas necessidades, inferiu que o pibidiano deveria retomar a definição de reações redox para que toda a turma pudesse acompanhar os conceitos redox, e compreender o experimento.

$\mathrm{Na}$ aula de pilha de moedas, Antônio concluiu que os discentes "[...] foram participativos, curiosos e ativos, demonstrando interesse em conhecer o fenômeno de produção de energia elétrica através de reações químicas" (Relatório aula dupla, aula 3 - Antônio). Nesse mesmo sentido, ao responder o ciclo reflexivo de Smyth (1991) antes e depois de assistir as regências, identifica-se que Antônio inicialmente tinha uma percepção de sua prática distinta da que teve depois de assistir as aulas, em consonância apresenta-se na tabela 6 os trechos do instrumento referente a Ação Descrever, nos dois momentos em que Antônio o respondeu.

Tabela 6. Resposta de Antônio para Ação Descrever no Ciclo reflexivo

\begin{tabular}{|c|c|c|c|}
\hline Ação & Questão & $\begin{array}{l}\text { Descrição - Antes de assistir } \\
\text { as regências }\end{array}$ & $\begin{array}{l}\text { Descrição - Depois de } \\
\text { assistir as regências }\end{array}$ \\
\hline Descrever & O que faço? & $\begin{array}{l}\text { Início a aula preparando uma } \\
\text { introdução do tema, em } \\
\text { seguida compartilho os } \\
\text { objetivos da aula. A próxima } \\
\text { etapa pode variar, se for } \\
\text { experimental, entrego o roteiro } \\
\text { e permito a independência do } \\
\text { aluno, quanto as questões do } \\
\text { roteiro. Em geral é um } \\
\text { momento do aluno construir } \\
\text { seu conhecimento. Termino } \\
\text { com uma síntese da aula. }\end{array}$ & $\begin{array}{l}\text { Eu início com um diálogo com } \\
\text { a turma sobre o tema, depois } \\
\text { abro um espaço para a } \\
\text { participação do aluno, no } \\
\text { entanto, percebi após o vídeo } \\
\text { que os alunos não foram } \\
\text { totalmente independentes. } \\
\text { No final das aulas procuro } \\
\text { fazer conexão entre os temas } \\
\text { abordados em sala e realizar } \\
\text { um resumo do aprendizado. }\end{array}$ \\
\hline
\end{tabular}

Como observa-se na tabela apresentada acima para Antônio inicialmente os discentes demonstravam uma certa dependência com o roteiro da aula experimental, contudo ao assistir a aula reconhece a dificuldade dos alunos e como deveria proceder na atividade experimental. Esse trecho também revela suas reflexões acerca de suas Decisões para o ensino de ciências - Orientações para o ensino de ciências. Em outro momento do ciclo em que responde as questões: Confrontar - Quem tem poder em minha sala de aula? A que interesse minha prática está servindo? Acredito nesses interesses ou apenas estou reproduzindo?" Antônio antes de assistir as aulas reconhece que "Embora a aula sendo preparada por mim independente do aluno, ela visa o aprendizado do aluno." Por outro lado, ao término da exibição de suas regências quando 
volta a responder o questionário, argumenta para o mesmo questionamento: "No geral a minha prática em sala de aula está direcionada ao aluno, porém visualizei um momento que utilizo recursos que não apontam para um aluno, mas um químico formado."

$\mathrm{Na}$ aula de Pilha de Daniell Antônio foi orientado a explicar o sentido do elétron na pilha, pois segundo Luiza por "[...] convenção dos físicos, em 1900 e nada, tá, a corrente ela está no sentido inverso do caminho do elétron, certo, isso aí dá nó na cabecinha de químico, quem dirá na de.... Mas, então assim, é importante a gente mostrar pra eles isso [...]" (Reunião para saber o andamento, arquivo 9, turno 419). Nesse sentido, durante a implementação da Regência a supervisora questiona Antônio se havia explicado o sentido do fluxo de elétrons e Antônio responde que brevemente, entretanto, o pibidiano apenas explicou, então Luiza explica aos discentes a convenção adotada na física, e a diferença da química (Aula Pilha de Daniell, arquivo 13).

$\mathrm{Na}$ aula feedback demonstrou conhecimento relativo às necessidades dos discentes relacionadas à aprendizagem, que envolveram a ação do pibidiano por meio de elogios aos discentes por apresentarem um crescente desenvolvimento cognitivo e pela importância de cada aluno no trabalho final (cartaz) (Relatório anual dupla, aula 8 - Antônio). Durante a apresentação dos resultados, Antônio discorre que os alunos "[...] se interessaram por saber mais sobre os fenômenos da tecnologia, falaram da pilha de níquel de celular, começaram a relacionar pilha alcalina de controle remoto, relacionaram que a reação redox estava envolvida todas elas da mesma forma" (Apresentação dos resultados, arquivo 21, turno 28). Por outro lado, em sua última regência, quando realizou o feedback das atividades desenvolvidas, discorreu à turma sobre a sua avaliação acerca do rendimento dos alunos nas atividades desenvolvidas, apresentando certa inquietação pelo erro conceitual apresentado por alguns discentes. (Aula Feedback, arquivo 16).

Nas primeiras regências de Antônio, Luiza solicitou ao pibidiano que nas atividades avaliativas trouxesse questões de vestibular, contudo na percepção da coordenadora essas questões eram complexas. Então, Antônio numa tentativa de atender aos anseios da supervisora e motivar os discentes, argumentou em uma aula que o conteúdo ensinado era recorrente no vestibular:

Então, os que vocês têm que ter em mente que vai cair no vestibular, ou que no livro didático que você vai olhar, Olha: "o Antônio falou isso aqui pra mim na sala de aula, a pilha de Daniell, um experimento que mostra, uma solução, o sulfato de zinco, a gente sabe que em meio aquoso não fica assim bonitinho, fica em forma de íons né, a mesma coisa acontece com sulfato de cobre, em forma de íons [...] 
[...] É que isso aqui cai muito em vestibular, isso aqui cai muito em qualquer provinha, cai isso aqui, é de praxe isso aqui (Aula Pilha de Daniell, arquivo 13, turno 124 e 189).

Tendo o propósito de incutir a Motivação e Interesse nos discentes, Antônio propõe a adoção da tabela de potencial "Nessa tabela periódica tem uma tabela aqui de potencial de redução. Eu só queria que vocês olhassem que ela colocou ali zinco e níquel, como é que o Antônio ou a Melissa saberia dizer que pra que lado o elétron tá indo? Ele decorou isso?" (Aula de revisão, arquivo 15, turno 524).

Sobre esse episódio, Antônio foi questionado se considerou inadequado adotar a tabela de potencial em uma aula para turma da EJA:

Antônio - Porque, tá, mas como é que o Antônio sabe? É essa questão que vai expandir o horizonte deles, tá, como é que eu vou saber se eu usar outro experimento?

Pesquisadora - Além de só observar né.

Antônio - É, tipo assim, eu não estou negando entendeu, eu decorei, mas pra você expandir seu conhecimento a gente vai trazer a tabela, e eu achei legal a tabela ficar no final mesmo por causa assim, vamos expandir mais, claro, eu não vou fazer todos os exemplos da tabela, eu tinha que ter uma aula assim sobre a tabela.

Pesquisadora - Porque não era coerente pela carga de conteúdo, que é um conteúdo difícil, vocês ensinarem tabela de potencial de redução.

Antônio - Porque no fundo, ensinar eu teria gastado uma aula pra ela, e fazer exemplos, avaliações e a gente não queria perder nenhuma aula pra isso, porque isso não estava, resíduos sólidos, isso estava numa área mais assim...(Lembrança estimulada, arquivo 25, turno 329 333).

Ao término da aula de Pilha de moedas (arquivo 12), Antônio, ao retornar para sua casa, resolveu gravar as suas reflexões sobre as aulas, nesse sentido, apresentase, o pequeno relato feito pelo pibidiano:

Continuando o diário de bordo...gostaria de refletir sobre a intervenção da professora na minha aula. No momento em que os alunos estavam discutindo a diferença entre pilhas e baterias, um aluno afirmou que pilhas e baterias são as $m$... são a mesma coisa. Eu prontamente intervi na conversa, re... referindo a eles que pilhas e baterias são coisas diferentes, no entanto, a professora Luiza, supervisora do projeto, na escola, me rebateu, dizendo que depende, e que...e disse que depende e não afirmou, muita coisa além disso. Fiz uma reflexão minha após a aula de que, durante as minhas apresentações no (ininteligível em 00:01:05), seria necessário a professora não inter... não intervir nas nossas aulas, porque tira o controle nosso sobre a turma, e mostra uma fragilidade nossa. Seria interessante conversar com ela, para, ao final da aula ((aumentou o tom de voz)) corrigir os nossos erros e não durante, em frente aos alunos. Tal procedimento também já foi orientado pela disciplina estágio, em que o orientador, pediu para que, quando fosse aplicar uma regência, pedi que o professor saia... que o professor da turma saia da sala de aula ou senão, não se pronuncie, medi... mediante qualquer forma (Diário de bordo, aula pilha de moedas). 
Sobre essa aula Antônio argumenta que os discentes apresentaram dificuldades em entender a tabela de potencial padrão de redução em virtude de não assimilarem que - 0,26 é maior que - 0,76. Essa limitação era apontada por Maria durante as reuniões sobre o conteúdo específico. Para o pibidiano os discentes não compreenderam a tabela de potencial "Eles conheceram, não entenderam, mas conhecer eles conheceram" (Lembrança estimulada, arquivo 25, turno 355).

De modo geral, Antônio procurou motivar o aluno incentivando-o a participar das aulas. Buscou ainda suprir as limitações relacionadas à dificuldade com a escrita e leitura da turma da EJA por meio da proposição de atividades que desenvolvessem essas duas habilidades. Com relação às necessidades coletivas e individuais, estas eram também trabalhadas sempre que possível de acordo com o contexto da aula, como revela o trecho "Pode, pode pegar. Eu não ligo assim de vocês compartilharem a ideia, não, vou te passar a ideia, mas não copia igual entendeu, pra mim, que eu quero saber o individual" (Aula Contaminação por chumbo, arquivo 16, turno 169).

\section{Conhecimento das estratégias instrucionais para o ensino de ciências}

Neste componente estão incluídas as estratégias de ensino que compõem o repertório do licenciando para ensinar um conteúdo e um tópico específico.

As estratégias adotadas pelo licenciando constituem seu modo de desenvolver o ensino (ENNIS, 1994). Assim, no CoRe adaptado, o pibidiano sugere a experimentação como abordagem para desenvolver o conceito de pilha. Nos demais documentos analisados suas regências envolveram as respectivas estratégias de ensino: feedback; experimento investigativo/demonstrativo; revisão do conteúdo; roteiros experimentais; produção e leitura de texto; explicação teórica; adoção de música e reportagens; discussão em classe, lousa, ilustrações e analogias. Essas estratégias estavam diretamente influenciadas pelos objetivos do subprojeto que priorizava a abordagem CTS. Por meio dessa abordagem Antônio buscou entrelaçar em suas aulas o contexto vivenciado por seus discentes, por meio de exemplos pelos quais os alunos pudessem interligar com seu conhecimento de mundo. Um exemplo surge quando o pibidiano realiza a definição de eletrólitos:

[...] não deve ser utilizado sem os devidos equipamentos de segurança, por ser um produto corrosivo (...) porque o vinagre na verdade que a gente bota na salada é o ácido acético diluído em água, por isso que você pode comer entendeu, mas o vinagre ele corrói da mesma forma que o ácido sulfúrico (Aula Pilha de moedas, arquivo 12, turno 31).

Busca ainda correlacionar o conteúdo químico com o cotidiano dos discentes. $\mathrm{Na}$ aula de pilha de moedas argumentou que o princípio usado nesse experimento é o mesmo das pilhas usadas em casa pelos alunos, chegou a sugerir durante a regência, caso a pilha acabasse na casa dos alunos, que estes poderiam confeccioná-la. 
Ainda no primeiro semestre durante uma reunião com a coordenadora (Apresentação da proposta de trabalho, arquivo 3), Antônio apresentou a seus pares a dinâmica da aula de sensibilização, tendo como estratégia a exibição do documentário Ilha das Flores para desenvolver o conceito de lixo, contudo a tutora questiona:

Maria - Sabe o que eu senti fata aí? Vocês não falaram especificamente das baterias.

Antônio - É porque a primeira aula, a primeira sensibilização que a gente vai fazer é sobre o llha das Flores ele não fala sobre bateria (Apresentação da proposta de trabalho, arquivo 3, turno 37-38).

Em continuidade a coordenadora argumenta

Maria - Porque assim o que eu gostaria de sugerir para vocês, que estivesse amarrado coisas importantes que são sustentação do trabalho, Política Nacional de Resíduos Sólidos que ela cai muito bem ali, que vocês estão querendo fazer esse raciocínio, essa reflexão a respeito do lixo, pra onde é que ele vai, porque ele vai para lá e porque não toma outro rumo, e as baterias, então as baterias nesse momento não entrou, vamos dizer assim, então eu acho que de repente é uma sugestão de não fazer os dois artigos ((sensibilização)) no mesmo dia então.

Antônio - Entendi, o que você falou.

Maria - Só faz a llha das Flores e aí faz num outro dia pra gente falar especificamente das baterias e de repente vocês vão trazer até dados da região.

Antônio - Na verdade, é assim, as baterias seriam um resgate mesmo, porque como você agora eu também pensei "pô, mas a gente não tá falando de bateria", né, e aí foi uma forma de tentar resgatar só um início (Ininteligível 00:11:07)

Maria - Claro, mas eu acho que é pertinente Antônio se você pensar em introduzir a Política Nacional de Resíduos Sólidos, entendeu, de trazer essa legislação que acaba norteando todo o nosso trabalho, que o lixo existe, entretanto ele precisar ser direcionado, ele vai ser tratado de forma adequada que é o que a gente não faz hoje.

Antônio - Sim, eu concordo com você, só achei que na primeira aula eu queria agradar eles, não colocar eles... (Apresentação da proposta de trabalho, arquivo $3,44-49$ ).

Apesar dessa regência ter sido implementada em uma turma do ensino médio regular, considerou-se pertinente esmiuçar a reunião no sentido de emergir a influência das orientações da coordenadora em sua estruturação, pois esses direcionamentos iniciais influenciaram Antônio na proposição da aula de sensibilização sobre a PNRS, que permeou o descarte inadequado de baterias automotivas como estratégia para o ensino de reações redox. Durante a reunião Maria os orienta a abordar a lei de modo que o discente se sinta inserido na problemática. Esse trecho da reunião revela ainda a influência das categorias Conhecimento do Contexto e Pedagógico Geral, na escolha pelas estratégias de ensino. 
Um episódio de destaque evocado na categoria Conhecimento do Tema foi a discussão para adotar-se a abertura de uma pilha como uma estratégia para iniciar o ensino do conteúdo redox, pois Antônio, apesar de ter o objetivo de ensinar pilha, não sabia a sua constituição:

Maria - É a coisa mais besta do planeta, tem um monte de pó preto que suja a mão, bagunça tudo, é alcalino pra caramba.

Antônio - E o pó preto é um tóxico?

Maria - Não, é óxido de manganês, aquilo lá, o problema é que é um metal alcalino, tem alguma coisa ou tem hidróxido de amônio ou de hidróxido lítio, de sódio

Antônio - Não, é porque às vezes ele vai falar assim "eu posso jogar na lixeira, porque tá bem guardado, tá bem guardado" (Reunião para saber o andamento, arquivo 7, turno 190-193).

Nessa discussão se observa elementos das categorias Conhecimento das estratégias instrucionais para o Ensino de Ciências, e ausência do conhecimento do tema. Essa estratégia não foi usada por Antônio em suas aulas, em decorrência da coordenadora deixar claro que não basta apenas propor uma atividade que não tenha objetivos.

Outra estratégia de destaque foi propor o contexto histórico das pilhas para despertar o interesse dos discentes para o conteúdo redox, assim como as práticas experimentais. Segundo Antônio, esse material foi produzido em virtude da identificação pessoal pela história da química e o desejo de ingressar em um mestrado em história da ciência (Aula Pilha de moedas arquivo 12), além do desenvolvimento das atividades em grupo, que propiciou a participação e a relação dos alunos entre si e com o pibidiano. (Entrevista semiestruturada, Antônio). Os textos produzidos foram lidos em conjunto com a turma como um modo de chamar a atenção para o conteúdo histórico envolvendo pilhas, além de solicitar que outros alunos lessem também o roteiro do experimento investigativo, pois na sua visão estava envolvendo a classe em sua aula (Aula pilha de moedas arquivo 12).

Uma das analogias adotadas na aula de pilhas de moedas envolveu 0 conhecimento de Antônio em física:

Também, por isso que as pilhas acabam, chegam um momento que elas chegam num equilíbrio, eu queria falar nessa explicação aqui que é igual à pressão atmosférica, se a gente colocar um tubo em forma de U, uma quantidade de água, e...o tubo vai querer sempre ficar no mesmo nível, né, porque quer ficar em equilíbrio, e se por algum motivo eu fizer uma pressão com o pistão pra baixo, quando eu soltar o pistão a pressão atmosférica vai voltar ao mesmo equilíbrio entendeu? (Aula Pilha de moedas, arquivo 12, turno 248).

A analogia de força para explicar a tendência de um elemento em atrair ou perder elétrons foi mal interpretada por alguns alunos, levando-os a apresentarem concepções 
equivocadas sobre o conteúdo redox, que foram exploradas na categoria Conhecimento da compreensão dos alunos em ciências. Na adoção dessa analogia, Mateus desconsidera a conservação da matéria.

$\mathrm{Na}$ aula seguinte à Pilha de Daniell, Antônio, para explicar a simultaneidade da reação redox, evoca a analogia "Não adianta se você ganhou gordura é porque você pegou do leite da vaca, e a vaca perdeu, então nada se cria, tudo se transforma, entendeu, então assim, então essa solução ficou mais concentrada" (Aula Pilha de Daniell, arquivo 13, turno 162). Outra estratégia adotada nessa aula foi relembrar o experimento demonstrativo de oxidação da palha de aço em solução de sulfato de cobre para ensinar o conceito de bateria. Antônio adotou esta prática experimental, como discorrido na categoria Conhecimento do Currículo, em função da tutoria concedida por Maria:

E como funciona uma bateria. Se vocês quiserem levar as coisinhas pra montar uma bateria de Daniell, só pra relembrar conceitos, fazer um paralelo, olha aqui também os elétrons, pra fazer analogias, pra fazer comparativa entre a bateria de Daniell e a bateria de chumbo, tem material aqui, se vocês acharam que não é necessário, sem problemas (Reunião para saber andamento, arquivo 14, turno 238).

A experimentação influencia as orientações para o ensino de ciências de Antônio e, consequentemente, a sua estratégia para ensinar um tópico especifico. Nessa perspectiva, a coordenadora orienta o pibidiano:

Sabe o que dá pra fazer aqui? Só, isso aqui vai tomar três minutinhos da aula, pede ajuda pra turma: "Então me ajuda a escrever o que aconteceu nessa reação, porque a reação aconteceu?" Vamos considerar que bombril é ferro, tá, aí vocês vão provar, "Porque que é ferro zero?" Olha está em estado sólido, tá novinho o bombril, tá comprido, né. Então isso é importante trabalhando com o aluno, mas..."É cobre, é, todo mundo sabe que é cobre, mas qual cobre que é?" Aí leva um pedaço de cobre "É esse cobre? Cobre zero?" "Não" Então aí vocês vão gastar 15 minutos da aula pra montar essa reação aqui, montou essa reação, taca o pau, já tá na hora de fazer a química, aí já tá naquele subsídio, né. Então aí vocês vão dizer: "Ah o ferro aqui, ele perdeu dois elétrons, foi pra ferro $2+$ ah tá, o cobre estava em solução+ dois elétrons", e eles aprenderam a fazer isso aqui na aula anterior, vocês vão fazer esse exerciciozinho aqui entendeu? Já tá recuperando, vai dar o cobre zero "Ah, que legal" Aí vocês vão dar uma de mandrágora "Vamos somar tudo isso, saiu daqui, entrou aqui. Então aqui oxidou, aqui reduziu" Tudo que veio da aula passada (Reunião para saber o andamento, arquivo 9, turno 405).

Antônio argumenta que seria difícil para o aluno, mas Maria mostra que o conceito está sendo ensinado de modo gradual. Essa estratégia foi implementada na EJA, em consonância com as orientações das tutoras:

Antônio - Olha, eu tenho aqui solução, que é sulfato de cobre. É interessante notar que em meio aquoso, todo sulfato que é o $\mathrm{SO}_{4}^{-}$, e o cobre eles não estão associados, eles não estão mais juntos. Então aqui, na verdade, eu tenho um cobre dois mais $\left(\mathrm{Cu}^{2+}\right)$, logo esse cobre 
que ela representou aqui, porque ele está dissociado em meio aquoso. E aí eu vou colocar, a gente chama isso de bombril, isso aqui palha de ferro, isso aqui é ferro metálico, provavelmente emite isso né. Como ela falou ali, eu vou colocar o ferro metálico no sulfato de cobre, porque eu quero que solte cobre dois mais $\left(\mathrm{Cu}^{2+}\right)$, que vai reagir com ferro metálico, é só aguardar um tempinho, que a gente vai fazer um fenômeno macroscópico. Eu tinha feito anteriormente, tá vendo a solução é azul, essa solução já não é mais azul, quer dizer aconteceu alguma coisa que... (Aula atomística, arquivo 11, turno 222).

Em outra aula Maria sugere novamente que Antônio adote como estratégia no final da regência (Aula de revisão) o experimento de oxidação da palha de aço em solução de sulfato de cobre:

Sabe o que ele dá pra fazer também? Se vocês acharem que tem muito tempo, vai sobrar tempo, que eu acho que não vai, fala pilha, da bateria, é...retoma, se quiser leva até o material pra fazer a pilha de Daniell, só pra retomar, só pra lembrar, e tenta fazer um paralelo, na pilha de Daniell, quem é oxidado (Reunião para saber o andamento, arquivo 14, turno 214 ).

Para a coordenadora, desse modo Antônio poderia chegar na definição de bateria.

No processo de construção das aulas, mais especificamente da aula experimental da Pilha de moedas, Antônio é orientado a construir um roteiro que possibilitasse ao aluno observar os fenômenos que permeariam a prática experimental

Luiza - É, eu acho que assim, quando a gente fala no experimento, e olhando e falando o roteiro, não é um roteiro, receita de bolo, entendeu? É um roteiro pra que o aluno tenha um encadeamento lógico de pensamento, e leve alguma conclusão, quer dizer, ele esteja naquele momento investigando alguma coisa, o que está acontecendo, porque, tentando chegar em alguma conclusão, o que aconteceu, porque aconteceu (Reunião para saber o andamento, arquivo 9, turno 495).

Sugerindo uma estratégia para o desenvolvimento do conceito de pilha, esta orientação foi incorporada por Antônio em algumas das questões que compunham o roteiro do experimento, dispostas no quadro 15.

Quadro 15. Roteiro da aula experimental - Pilha de moedas (adaptado, Fonte: Relatório da dupla - Antônio, p. 16)

8.Verifique se sua pilha de moedas funciona com o papel de filtro seco.

9.Agora inverta a posição da sequência papel alumínio, papel filtro embebido e moeda de cinco centavos. A pilha funcionou?

10. Verifique se a pilha de moedas funciona sem o papel de filtro entre o papel alumínio e a moeda.

11.Considerando os conhecimentos envolvidos no experimento, quais as condições necessárias para o funcionamento de uma pilha.

Resumindo, o repertório de estratégias de Antônio, foi sendo construído, principalmente pelos direcionamentos concedidos pela coordenadora e supervisora. Nessa perspectiva, durante as reuniões o pibidiano era orientado a revisar o conteúdo, a produzir texto, a adequar suas estratégias à turma da EJA, etc. Alguns desses Capítulo 4. Resultados e Discussões 
aspectos se dispõem nas categorias Conhecimento do Tema e Conhecimento Pedagógico Geral.

A experimentação emergiu como principal ferramenta didática adotada nas aulas de Antônio, talvez pela influência de sua formação inicial em técnico em química. Contudo, os contextos em que seriam implementados foram sendo delineados nas reuniões entre as tutoras e o bolsista. Nesse sentido, essa estratégia surgiu nas regências em que Antônio iniciou o conceito de reações redox e na aula de revisão de eletroquímica, denotando indícios da influência do Pibid na construção desse componente do conhecimento docente.

\section{Conhecimento da avaliação da aprendizagem em ciências}

Para alguns autores a avaliação no ensino é vista como uma questão complexa, pois tem sido tratada como a principal forma de verificar a aprendizagem e conduzir as práticas pedagógicas (HOFFMANN, 2009; CHUEIRI, 2008; TACOSHI; FERNANDEZ, 2014). E para entender a visão do pibidiano sobre processos avaliativos analisou-se nos diferentes documentos a imersão do seu conhecimento sobre o que considerava inerente a ser avaliado com relação ao conteúdo redox e as ferramentas que adotou nesse processo avaliativo, além do seu conhecimento de métodos específicos de avaliação.

No CoRe adaptado as questões 1, 7 e 8 revelam algumas das compreensões de Antônio sobre o conteúdo a avaliar, e formas de avaliação, como se pode observar no quadro 16.

Quadro 16. Trechos do CoRe adaptado

\begin{tabular}{|l|l|}
\hline Questões & $\begin{array}{l}\text { Conteúdo específico: Reações redox } \\
\text { Tema gerador: Pilha de Volta }\end{array}$ \\
\hline $\begin{array}{l}\text { 1.O que você pretende que os } \\
\text { estudantes aprendam com esta } \\
\text { ideia? }\end{array}$ & $\begin{array}{l}\text { Como a pilha funciona, a função específica de cada } \\
\text { componente e como representar simbolicamente aquele } \\
\text { fenômeno. }\end{array}$ \\
\hline $\begin{array}{l}\text { 7.Que procedimentos você } \\
\text { utilizaria para que os alunos se } \\
\text { comprometam com esta ideia? }\end{array}$ & $\begin{array}{l}\text { Entregaria um roteiro experimental para produção de pilhas } \\
\text { químicas, dentro do roteiro abriria um espaço para os } \\
\text { alunos adicionarem anotações de percepções, desenhos } \\
\text { explicativos dos fenômenos e representação simbólica do } \\
\text { fenômeno a partir de definição de símbolos científicos. }\end{array}$ \\
\hline $\begin{array}{l}\text { 8. Que maneiras específicas } \\
\text { você utilizaria para acompanhar } \\
\text { o entendimento ou confusão } \\
\text { dos alunos sobre este } \\
\text { conteúdo? }\end{array}$ & $\begin{array}{l}\text { Distribuiria uma atividade escrita que possuísse um caráter } \\
\text { de avaliação individual, na atividade constariam espaços } \\
\text { para desenhos de modelos de pilhas pedindo a indicação } \\
\text { da orientação da transferência de elétrons, a prévia do } \\
\text { resultado final da pilha do modelo desenhado e a } \\
\text { representação química da transferência de elétron entre as } \\
\text { espécies envolvidas no desenho. }\end{array}$ \\
\hline
\end{tabular}

(Fonte: adaptado de CoRe adaptado, Antônio)

O conceito de pilhas foi considerado mais importante para avaliar, segundo a percepção de Antônio. Sobre esse conceito, o pibidiano considerava que seus discentes deveriam aprender o nível representacional e o sentido do fluxo de elétrons, e para Capítulo 4. Resultados e Discussões 
tanto, propôs a adoção de atividade escrita associada à representação simbólica. Em consonância, os documentos oficiais sinalizam que a escrita pode ser uma porta de comunicação em que o aluno pode expressar e representar, levando ao domínio da linguagem científica por meio de uma aprendizagem significativa acerca dos conteúdos desenvolvidos nas disciplinas das áreas da ciência da natureza e suas tecnologias (BRASIL, 2006).

$\mathrm{Na}$ primeira orientação para a estruturação dos exercícios implementadas na EJA, Maria sugere que as atividades avaliativas contemplem:

[...] eu teria exercícios aqui dessa etapa que seja então um exercício, dois exercício, de repente aquilo que a gente estava discutindo ontem das demandas cognitivas né, das habilidades, de repente escolher uma habilidade, escolher, no primeiro dia faz uma demanda de lembrar, por exemplo, aquilo que aplicou que acabou de fazer na aula será que eles conseguiram lembrar, será que eles conseguem reconhecer a partir daquilo, ou uma segunda demanda só entender, por exemplo, interpretar, então bem simplesinho, então escolher em cada um desses dias, não fazer, por exemplo, três folhas de exercícios para eles resolver, por que não vai ter jeito, então fazer menos atividades, mas que sejam atividades representativas [...] (Reunião para saber 0 andamento, arquivo 5, turno 40).

O trecho descrito acima foi apresentado na categoria Orientações para o Ensino de Ciências e refletiram diretamente na estruturação dos exercícios propostos por Antônio e Melissa na aula, conforme denota a figura 14.

Exercício

1) Complete a tabela:

\begin{tabular}{|c|c|c|c|c|}
\hline $\begin{array}{c}\text { Substância } \\
\text { eletricamente } \\
\text { neutra }\end{array}$ & Íon & $\begin{array}{c}\text { Cátion ou } \\
\text { ânion? }\end{array}$ & $\begin{array}{c}\text { O átomo } \\
\text { ganhou ou } \\
\text { perdeu } \\
\text { elétrons? }\end{array}$ & $\begin{array}{c}\text { Ocorreu } \\
\text { redução ou } \\
\text { oxidação? }\end{array}$ \\
\hline $\mathrm{Na}_{(\mathrm{s})}$ & & & Perdeu 1e & \\
\hline $\mathrm{Cu}_{(\mathrm{s})}$ & $\mathrm{Cu}^{2+}$ & Cátion & & \\
\hline $\mathrm{Cl}_{2(\mathrm{~g})}$ & & & Recebeu 1e & Redução \\
\hline $\mathrm{F}_{2(\mathrm{~g})}$ & $\mathrm{F}^{-}$ & & & \\
\hline $\mathrm{Pb}_{(\mathrm{s})}$ & & Cátion bivalente & & Oxidação \\
\hline $\mathrm{Ca}_{(\mathrm{s})}$ & & & & \\
\hline $\mathrm{O}_{2(\mathrm{~g})}$ & $\mathrm{O}^{2-}$ & & & \\
\hline
\end{tabular}

2) Complete corretamente as representações:

$\mathrm{Li}_{(\mathrm{s})} \rightarrow \square+\mathrm{e}^{-}$

$\mathrm{Cu}_{(\mathrm{s})} \rightarrow \square+2 \mathrm{e}^{-}$

$\mathrm{Al}_{(\mathrm{s})} \rightarrow \square+3 \mathrm{e}$

$\mathrm{F}_{2(\mathrm{~g})}+2 \mathrm{e}^{-} \rightarrow \square$

$\mathrm{Cl}_{2(\mathrm{~g})}+\square \rightarrow 2 \mathrm{Cl}^{-}$

Figura 14. Exercício proposto por Antônio e Melissa para aula 2 (Fonte: Relatório anual da dupla - Antônio, p.15) 
Considerando-se o exercício exposto na figura acima, em outra reunião Maria orienta os pibidianos sobre como deveriam abordar o conceito, e assemelha-se muito a proposta de exercício:

Rebeca - De repente você explicar o exemplo do magnésio, do óxido e do magnésio e fazer aquela, por exemplo, outros elementos químicos destas famílias também tem esse mesmo comportamento e aí propor uma atividade só de fixação mesmo desse conteúdo.

Maria - Exatamente, é ele pensar nisso daqui olha, esse daqui é zero. Aí vocês montam, aqui aparece mais elétrons e aqui não aparece ninguém, fica em branco aqui. Então o que é isso aqui? É o processo, esse processo aqui formou o quê? Aí coloca pra ele completar, formou um cátion, muito bem, aí essa reação aqui você pode até falar ser reação, essa reação, essa semi-reação aqui, e uma semi-reação de oxidação (Reunião para saber o andamento, arquivo 9, turno 304-305).

Nas reuniões do subprojeto os principais conceitos a serem avaliados estavam diretamente ligados à conceituação de reações redox e a sua representação simbólica (Reunião para saber o andamento, arquivo 9). A esse respeito, em uma das reuniões iniciais, a coordenadora Maria discorreu para outro pibidiano que não importava o número de alunos que respondessem os exercícios, mas que ao menos uma parcela da classe o realizasse:

De quarenta, cinco, dez, quinze, vinte, estiverem participando e os outros não, em algum momento eles vão permear o trabalho, em algum momento eles vão participar, tá certo, faz parte a gente lidar com essa expectativa de que faz parte né, a gente não pode guiar o nosso trabalho por aqueles que não vão fazer (Reunião para saber 0 andamento, arquivo 7, turno 124).

Contrapondo a fala da coordenadora, Antônio aponta que "[...] talvez não fique um pouco... você não consegue às vezes tomar essa postura, porque você fica sem diagnosticar se a proposta foi muito pesada mesmo, entendeu, tipo assim você consegue ver se realmente eu peguei pesado com a turma [...]" (Reunião para saber o andamento, arquivo 7, turno 125). Para Antônio a avaliação teria que ser adequada ao nível de conhecimento dos alunos e ao perfil da classe. Por outro lado, Maria traz elementos de sua vivência como docente para mostrar ao bolsista que o mesmo não deve se preocupar caso os alunos, em sua totalidade, não resolvessem a atividade.

$\mathrm{Na}$ confecção da aula experimental da pilha de moedas a atividade avaliativa estava pautada na habilidade do discente em propor explicações para os fenômenos observados no experimento. Para Antônio era importante que seus alunos assimilassem as condições necessárias para que a pilha funcionasse. Nesse sentido, a coordenadora o orienta:

[...] Então, a produção do aluno nessa aula vai ser uma produção, que a gente vai valorizar a observação do fenômeno, a gente vai valorizar as evidências, porque pro aluno poder discutir depois, pra ele poder compreender ele tem que ter esse senso de observar as evidências. 
Entendeu? Então, montar aqui as pessoas que vão nortear a aula, vocês vão falar "Ah..." De repente pode ser até no final da aula que eles vão responder ou pode ser durante coisas bem assim de observação, eu estou vendo isso, lá no final se vocês tiverem alguma coisa motivadora como a professora colocou, porque que toma choque ou porque... Entendeu? Pode até colocar, mas agora eu não saberia dizer, mas eu presumo nessa aula aqui, a produção do aluno, uma coisa assim bem de valorizar o experimento, valorizar a observação, o que eu estou vendo, o que eu consigo destrinchar, entendeu? Então eu acho assim, não viaja muito não, não coloca muita coisa não, coloca 10 questões não, coloca pouca coisa, um a, b, c, pra ser o básico ou então deixa uma coisa: $O$ que você observou que justifica esse fenômeno? Qual a evidência? Porque que surge a voltagem? Ele "Ah, não sei professora" Uai, vai usar com você lá. Se eu mudar, por exemplo, os componentes que não for uma bateria de cobre com zinco, se for uma bateria com chumbo vai mudar a voltagem, será? São coisas que eles sabem, a identidade do elemento vai ser muito importante, não sejam muito ambiciosos não, tá? Façam coisas bem básicas que justifiquem que eles entenderam o funcionamento básico. O que vocês acham? (Reunião para saber o andamento, arquivo 9, turno 425).

A orientação de Maria reflete na organização e aplicação do exercício. Nesse sentido apresenta-se no quadro 17 a atividade avaliativa estruturada por Antônio.

Quadro 17. Exercício proposto por Antônio para aula Pilha de moedas (Fonte: Relatório da dupla - Antônio, p.19-20)

\section{Atividade escrita - Experimento: pilha de moedas}

Turma:

$\mathrm{N}^{\circ}$

1.Em cada um dos itens abaixo descreva sua importância no funcionamento de nossa pilha química de moedas:

a) Moedas de 5 centavos (Cobre):

b) Papel alumínio:

c) Papel toalha ou filtro:

d) Solução eletrolítica $(\mathrm{NaClO})$ ou $(\mathrm{NaCl})$.

3. O que você observou medindo com o voltímetro, quando mediu a voltagem da pilha de moedas com o passar do tempo? Como pode explicar este fenômeno?

4. Neste experimento acontecem fenômenos químicos e físicos. Para explicar o fenômeno físico de acender uma lâmpada de LED, a ciência moderna utiliza conhecimentos químicos. Mediante essa introdução, comente sobre a importância dos conhecimentos químicos para a sociedade moderna?

Essa proposta de atividade procurou, segundo o pibidiano, incutir no sujeito respondente a reflexão e o desenvolvimento de hipóteses baseadas no seu conhecimento e na sua observação dos acontecimentos. Esse tipo de avaliação mediadora está desvinculado de uma resposta correta/errônea, mas caminha em direção a adoção das respostas obtidas pelo professor em um processo de discussão com a classe sobre os conceitos que constituiam a atividade (HOFFMANN, 2009). Para o bolsista, durante a dinâmica em sala de aula foi possível realizar uma avaliação informal dos alunos e ter a percepção "[...] que os alunos conseguiram ter uma participação significativa na discussão acerca dos conteúdos de oxidação e redução, e 
da função de cada componente da pilha; o que é um resultado positivo" (Relatório anual dupla, aula 3 - Antônio).

A estrutura da avaliação apresentada no quadro 15 desempenhava duas funções: a primeira, em ter a sua nota adotada pela supervisora do Pibid em suas próprias avaliações, e a segunda, um instrumento de coleta de dados para o subprojeto. As questões elaboradas pelo pibidiano suscitam os conceitos redox que considera importantes avaliar: o tempo de funcionamento da pilha; os fatores que influenciam seu funcionamento; e a função da solução eletrolítica.

Para Antônio a aplicação de exercícios em todas as aulas era reflexo da orientação de Maria, como denota o diálogo a seguir:

Antônio - A questão de exercício pra mim está acarretado a professora Maria, porque ela pediu que toda aula tivesse uma produção do aluno.

Pesquisadora - Pra vocês terem como um dado.

Antônio - É, não que eu e ela concordasse em dar exercício todas as aulas.

Pesquisadora - Vocês acham que não eram necessário?

Antônio - Eu não sei a opinião dela ((Melissa)), mas na minha opinião não era necessário.

Pesquisadora - Não, de vocês enquanto professores ali em sala de aula.

Antônio - Na minha opinião, tinha momentos que queria valorizar algum conhecimento, e não podia porque não tinha horário, e tinha que se reservar horário pra exercícios (Lembrança estimulada, arquivo 25, turno 232-238).

Antônio buscou ainda desenvolver atividades avaliativas não formais por meio do diálogo com a classe:

Os resultados foram, os alunos corresponderam a expectativa das perguntas da turma, tudo que eu perguntava sobre oxidação vinha uma resposta positiva, eles conseguiram classificar cada componente da pilha de Daniell, e eu pude até estender um pouco [...] (Apresentação dos resultados, arquivo 21, turno 28).

Para o pibidiano os alunos participaram da discussão e responderam aos conceitos, pois os assimilaram (Relatório anual dupla, Aula 4 - Antônio). Em consonância, pode-se destacar que, a priori, Antônio tem uma percepção diferente sobre avaliação de suas tutoras, pela avaliação em sala de aula ter propiciado a reflexão de seus discentes, revelando que essa avaliação em específico, por meio do diálogo, estava carregada de intencionalidades que revelam "quem é o educador quando interpreta os eventos da cena pedagógica" (SORDI, 2001, p. 173). Na perspectiva avaliativa, durante as regências o bolsista usava o questionamento como forma de avaliar a aprendizagem dos alunos sobre o conteúdo redox, e seu objetivo não era pautado na simples repetição, pois no contexto da sala de aula criado pelo pibidiano 
ficou claro seu desejo em acompanhar o processo de aprendizagem dos discentes. Contudo, ao passar a avaliação final, suas convicções anteriores são "rompidas" pelo entendimento do que havia passado em classe e permeava as respostas da atividade:

A maioria que estão aqui eu trabalhei com vocês, vou ler a pergunta. "Em cada um dos itens abaixo escreva a sua função em nossa pilha química de moedas." Eu falei aqui no início, e falei no fim a função da moeda, do papel embebido no eletrólito, e o alumínio, eu falei aqui, entendeu. $\mathrm{E}$ número dois: "O que você observou medindo com o voltímetro" Eu sei que nem todos mediram, é claro, a diferença de potencial, a voltagem da pilha de moedas com o passar do tempo, mas eu comentei aqui na frente, com o tempo alguma coisa acontece com a nossa pilha, né? [...] (Aula Pilha de moedas, arquivo 12, turno 291).

A avaliação que Antônio propôs seguia as exigências do subprojeto e as orientações da coordenadora, o que o levou a oscilar entre um discurso que corrobora com uma percepção de avaliação pela mera reprodução do conceito ensinado em sala, e uma visão de que a atividade didática é um processo que "[...] deve acompanhar passo a passo o processo de ensino e aprendizagem" (LIBÂNEO, 1994, p.195) para que sejam observados os avanços dos alunos e possíveis adequações em suas Decisões sobre fazer o Ensino (Orientações para o Ensino de Ciências) e na escolha de seus Métodos de avaliação da Aprendizagem em Ciências.

Em outra aula, o pibidiano buscou estruturar suas atividades avaliativas por meio de questões baseadas em vídeos que usou indicando o uso de um instrumento específico que fazia parte de seu conhecimento sobre métodos avaliativos (Aula Contaminação de Chumbo, arquivo 16).

No feedback das atividades desenvolvidas pelos alunos da escola conveniada, Antônio afirmou que "[...] foram entregues todas as atividades escritas dos alunos com a correção e comentadas algumas respostas que possuíam erros conceituais baseados em concepções alternativas; e também as repostas que foram bem elaboradas [...]" (Relatório anual da dupla, Aula 8 - Antônio). Durante a discussão dos resultados sobre essas atividades com a coordenadora, Antônio passou a valorizar o erro em detrimento dos acertos. Por outro lado, reconheceu que respostas errôneas emergidas podem ser reflexo de sua explicação durante as regências, o que vai ao encontro com a proposição de Perrenoud (2007) de que avaliação não pode ser um processo para detectar o sucesso ou insucesso dos estudantes, mas possibilitar o diagnóstico de suas limitações, levando o professor a buscar novas atividades que contribuam para o seu rompimento.

Antônio ao discorrer sobre suas percepções de uma aula que havia estruturado e quais eram suas expectativas antes de implementá-la, traz elementos do Conhecimento das estratégias instrucionais para o ensino de ciências, Orientações para o Ensino de Ciências, Conhecimento da avaliação da aprendizagem em Ciências e Conhecimento da Compreensão dos alunos em ciências, como denota o trecho abaixo: Capítulo 4. Resultados e Discussões 


\begin{abstract}
Antônio - E também assim, a próxima aula eu fui na ideia assim, "ah, vou ter, a gente vai pensando: Ah, vou ter que reensinar aquilo tudo de novo, e eu cheguei lá e eu me deparei com outra situação", parecia assim: "De novo isso? Já sei, isso aí nós estamos craque" e aí ficou um pouco esse caráter, eu falei: "Olha, a última aula foi legal." Houve uma tendência geral pra explicar a diminuição..., ah, nessa atividade aí, uma questão, tinha uma pergunta falando sobre o que ele estava observando com o tempo a pilha, e a ideia era ele perceber que chega um momento que a pilha acaba porque está chegando um elemento químico né, só que por algum motivo eles não assimilaram essa ideia, e talvez uma percepção alternativa deles de voltar pra força, e achar que tá perdendo a força, e aí não sei se foi um erro da explicação, ou se foi uma concepção alternativa, eu sou levado a achar que foi uma concepção alternativa, até porque, até mesmo na conversão com outros professores eu tenho percebido que existe a ideia de que quedas de energia elétrica, quedas de força também, na linguagem comum. Também, força? (Apresentação dos resultados, arquivo 21, turno 24).
\end{abstract}

No desenvolvimento do projeto pelo licenciando, a avaliação final envolveu a elaboração de um panfleto no qual os alunos da escola conveniada expressariam suas percepções sobre a contaminação de chumbo, incluindo questões de biologia e química (reações redox) (Relatório anual da dupla, Aula 7.2 - Antônio). Segundo o bolsista, por meio desse instrumento "Os alunos fizeram discursos de percepção da química como uma ciência importante para a sociedade porque a partir dela podem ser criados materiais para usos tecnológicos menos tóxicos ou menos impactantes na natureza" (Relatório anual da dupla, Aula 7.2 - Antônio).

Evidenciou-se nas narrativas de Antônio que os principais conceitos avaliados em suas práticas de ensino e os diferentes métodos de avaliação englobaram a produção de texto, exercícios sobre redox, questionamentos no contexto real de sala de aula, entre outros. Como se apontou anteriormente, as atividades avaliativas eram requeridas tanto para a tabulação de notas para a professora supervisora como para o pibidiano identificar as limitações de seus alunos e, também, para a coleta de dados acerca da aprendizagem dos discentes para o subprojeto do Pibid.

Esse cenário revela que durante a trajetória no programa o bolsista pôde experienciar diferentes métodos avaliativos, o que nos leva a acreditar que a iniciação à docência é um ambiente de aprendizagem dos conhecimentos da profissão professor que possibilitou a Antônio repensar sua prática avaliativa a partir dos elementos que elencamos no interior dessa categoria do PCK, e iniciar seus contatos com métodos e processos avaliativos.

\title{
Síntese do Conhecimento Docente de Antônio
}

A análise envolvendo apenas as aulas ministradas por Antônio na EJA permite vislumbrar o conhecimento docente do pibidiano no contexto de sala de aula. Na tabela 7 dispõe-se uma fotografia geral de suas aulas. 
Tabela 7. Dados gerados no Atlas.ti - Emersão do Conhecimento Docente nas aulas ministradas por Antônio na EJA

\begin{tabular}{lccccccccc}
\multicolumn{1}{c}{ Aula } & \multicolumn{1}{c}{ Categorias do Conhecimento Docente } & Total \\
\cline { 2 - 9 } & $\mathbf{A}$ & $\mathbf{B}$ & $\mathbf{C}$ & $\mathbf{1}$ & $\mathbf{2}$ & $\mathbf{3}$ & $\mathbf{4}$ & $\mathbf{5}$ & \\
\hline Sensibilização (arquivo 10) & 0 & 11 & 0 & 2 & 0 & 0 & 0 & 0 & 13 \\
\hline Atomística (arquivo 11) & 11 & 2 & 0 & 9 & 10 & 0 & 2 & 0 & 34 \\
\hline Pilha de moedas (arquivo12) & 28 & 7 & 3 & 77 & 19 & 6 & 30 & 2 & 172 \\
\hline Pilha de Daniell (arquivo 13) & 25 & 8 & 1 & 38 & 26 & 5 & 19 & 1 & 123 \\
\hline Revisão (arquivo 15) & 15 & 3 & 0 & 23 & 4 & 7 & 8 & 0 & 60 \\
\hline Contaminação por chumbo (arquivo & 0 & 2 & 0 & 23 & 3 & 0 & 7 & 3 & 38 \\
16) & 1 & 1 & 1 & 3 & 0 & 0 & 1 & 1 & 8 \\
\hline Logística reversa (arquivo 18) & 2 & 1 & 0 & 8 & 0 & 5 & 1 & 5 & 22 \\
\hline Feedback (arquivo 20) & 82 & 35 & 5 & 183 & 62 & 23 & 68 & 12 & 470 \\
\hline Total & & & & & & & & &
\end{tabular}

A - Conhecimento do Tema, B - Conhecimento Pedagógico Geral, C - Conhecimento do Contexto, 1- Orientações para o Ensino de Ciências, 2 - Conhecimento do Currículo, 3 - Conhecimento da Compreensão dos alunos em Ciências, 4 Conhecimento das Estratégias Instrucionais para o Ensino de Ciências e 5 - Conhecimento da Avaliação da Aprendizagem em Ciências

$\mathrm{Na}$ análise mais detalhada para cada aula, construiu-se mapas que ilustram a coocorrência das categorias do Conhecimento Docente.

$\mathrm{Na}$ aula de Sensibilização a integração do componente Orientações para o Ensino de Ciências (1) e o Conhecimento Pedagógico (B), talvez seja reflexo do projeto do pibidiano ser estruturado por meio de projetos, o que norteou o modo como Antônio conduziu os alunos e suas aprendizagens, as estratégias de ensino para abordar a questão da problemática por contaminação por chumbo e os modos de avaliação, por meio da resolução de problemas. Dispoe-se na figura 15 o mapa de integração entre esses dois componentes.

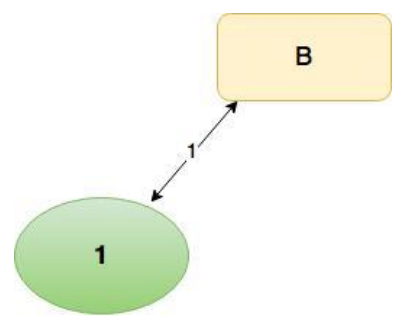

Figura 15. Mapa de integração entre os componentes do Conhecimento Docente de Antônio na aula de Sensibilização

$\mathrm{Na}$ aula de Atomística o tempo foi dividido em uma parte téorica (revisão) implementada por Melissa e outra parte experimental conduzida por Antônio. Na sua regência o pibidiano demonstrou ter um bom conhecimento acerca de materiais de laboratório (2) e sobre o tema (A) que influenciam e são influenciados pela sua Orientação para o Ensino de Ciências (1). Em virtude de suas Crenças sobre a Natureza da Ciência e suas Crenças sobre as Propostas de Aprendizagem a experimentação é empregada para comprovar a teoria. Essas crenças influenciaram também suas escolhas e seus Conhecimentos das Estratégias Instrucionais para o Ensino de Ciências (4). Em relação ao conhecimento de currículo (2), temos a imersão do currículo vertical 
em virtude das orientações das tutoras em revisar o conteúdo de atomística antes de iniciar o conceito de reações redox, resultando em uma coocorrência mais expressiva entre o Conhecimento do Tema (A) e o Conhecimento do Currículo (2). Na figura 16 tem-se o mapa de integração entre os componentes do conhecimento docente na aula de atomística.

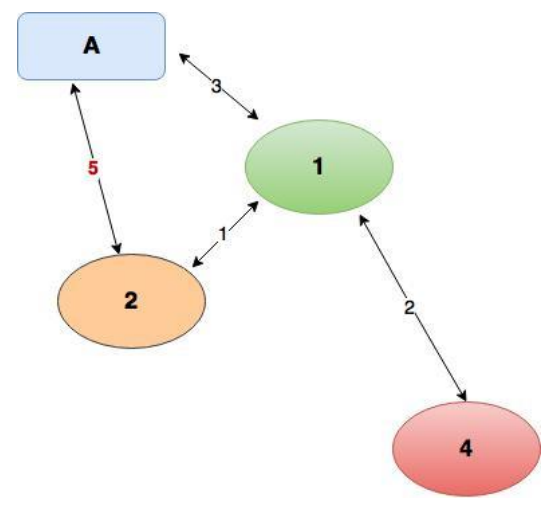

Figura 16. Mapa de integração entre os componentes do Conhecimento Docente de Antônio na aula de atomística

A aula Pilha de moedas foi fundamentada na experimentação em virtude de suas Orientações para o Ensino de Ciências. Nesse sentido, apresenta-se na figura 17 a imersão das integrações do Conhecimento do Tema (A) com os componentes Conhecimento das estratégias instrucionais (4), com o Conhecimento do Contexto (C), Conhecimento do Currículo (2). Na organização do plano de ensino para essa regência, Antônio teve pequenos direcionamentos para implementar a aula experimental relacionada à abordagem investigativa. A maior integração desse componente do conhecimento base ocorreu com as Orientações para o Ensino de Ciências (1), reflexo das crenças sobre a natureza da ciência e das orientações para o ensino de ciências do pibidiano. A segunda maior integração ocorreu entre o Conhecimento das Estratégias Instrucionais (4) e as Orientações para o Ensino de Ciências (1). Por outro lado, o Conhecimento da Avaliação da Aprendizagem (5) e o Conhecimento da compreensão dos alunos em ciências (3) se conectam apenas a um dos componentes do conhecimento docente. 


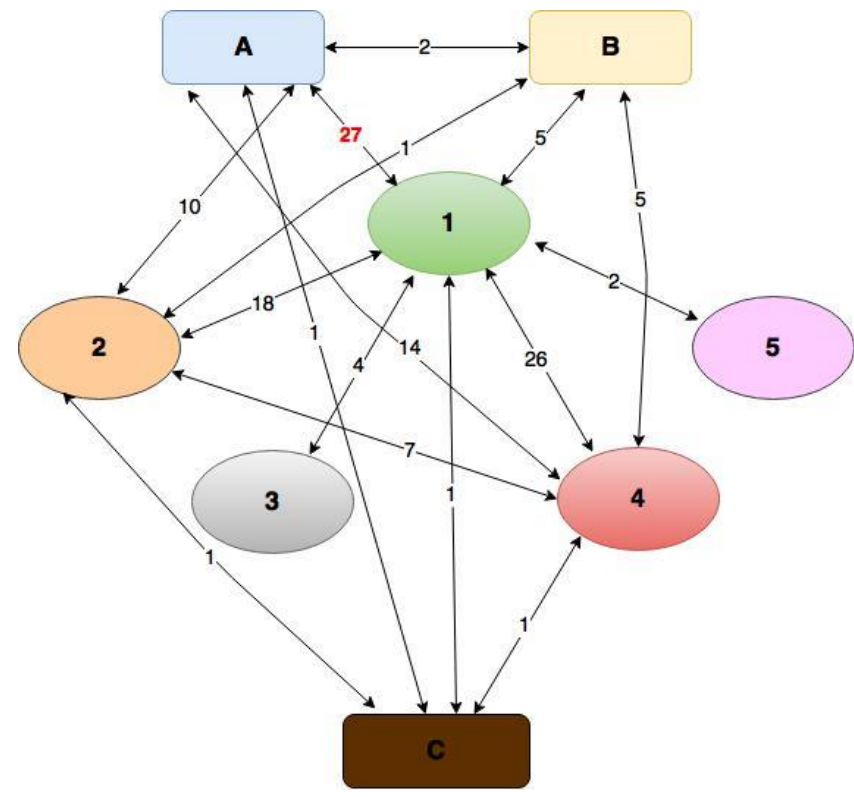

Figura 17. Mapa de integração entre os componentes do Conhecimento Docente de Antônio na aula Pilha de moedas

$\mathrm{Na}$ aula de Pilha de Daniell foi sugerido pelas tutoras que a aula fosse estruturada por um viés teórico e que envolvesse a revisão dos conteúdos ministrados anteriormente, em virtude dos discentes terem ficado um período sem aula. A coocorrência, como denota-se na figura 18, entre os componentes é maior entre os Conhecimento do currículo (2) e Orientações para o Ensino de Ciências (1). A segunda maior integração ocorreu entre as Orientações para o Ensino de Ciências (1) e o Conhecimento do Tema (A). No Conhecimento do Tema (A) a sua segunda maior integração está no componente Conhecimento do Currículo (2) - Saliência curricular (conceitos de ganho e perda de elétrons, ânodo e cátodo, oxidação e redução, agentes oxidantes e redutores, solução mais concentrada e mais diluída e diferença de potencial de redução entre metais).

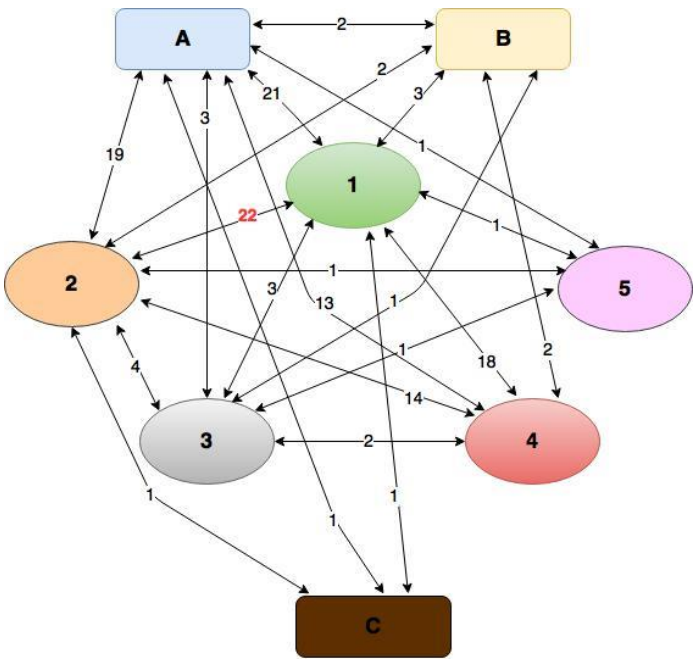

Figura 18. Mapa de integração entre os componentes do Conhecimento Docente de Antônio na aula Pilha de Daniell 
$\mathrm{Na}$ aula de revisão o pibidiano demonstrou ter um bom conhecimento do tema e, apesar de aplicar os experimentos como forma de comprovar a teoria, escolheu essa estratégia por orientação de sua tutora. Nessa aula, Antônio pôde perceber, durante a explicação da outra pibidiana, as dificuldades que os discentes tinham com o conteúdo específico, o que resultou em novos direcionamentos durante a aula e, consequentemente, em suas Decisões sobre o fazer no Ensino, tendo como consequência quatro coocorrências entre as Orientações para o ensino de ciências (1) e o Conhecimento da compreensão dos estudantes em ciências (3). A maior conexão ocorreu entre os componentes Conhecimento do Tema $(A)$ e Orientações para o Ensino de Ciências (1), e a segunda, entre as Orientações para o Ensino de Ciência (1) e Conhecimento das estratégias instrucionais para o ensino de ciências (4), e desta, com o Conhecimento do tema (A). No mapa de integração apresentado na figura 19 se tem a conexão entre os componentes do conhecimento para a docência de Antônio:

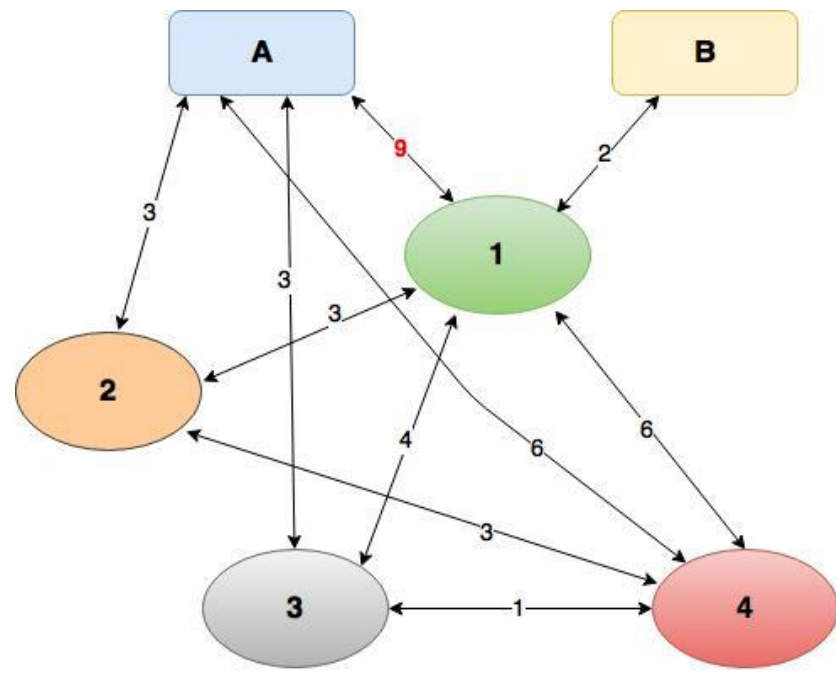

Figura 19. Mapa de integração entre os componentes do Conhecimento Docente de Antônio na aula de Revisão

Em uma das últimas regências Antônio trabalhou com a problemática de contaminação por chumbo. Nessa aula ficou explícito a influência do subprojeto baseado em projetos na estruturação da aula. Não foi observado nessa aula a influência das crenças sobre a natureza da ciência de Antônio. Na formulação do plano de ensino e na sua implementação o pibidiano adotou como estratégia de ensino o uso de vídeos reportagens e videoclipes para discutir a problemática. Não emerge na aula o conhecimento do conteúdo redox. A maior relação está entre os componentes Conhecimento das estratégias instrucionais para o Ensino de Ciências (4) e as Orientações para o ensino de Ciências (1), como denota a figura abaixo. 


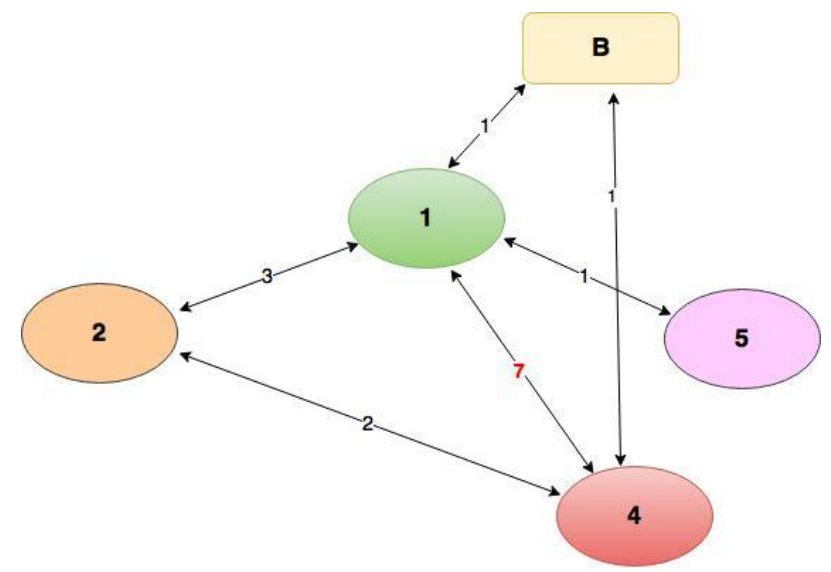

Figura 20. Mapa de integração de integração entre os componentes do Conhecimento Docente de Antônio na aula de Contaminação por Chumbo

Nos direcionamentos concedidos aos alunos durante a aula de logística reversa, Antônio explorou a estruturação de cartazes e orientou os discentes a contemplarem nessa produção os conceitos redox desenvolvidos durante o segundo semestre, de modo a correlacioná-los com as problemáticas de contaminação por chumbo. O cartaz foi adotado como instrumento de avaliação pelo pibidiano, e a relação entre o Conhecimento do contexto (C) e o Conhecimento da avaliação da aprendizagem em ciência (5) aparecem de forma bem tímida em virtude de o pibidiano não ter explorado muito as problemáticas do entorno escolar com a possível contaminação de chumbo pelo descarte inadequado de baterias automotivas. Nessa aula, de modo geral, não há uma exploração do conteúdo específico, e as poucas coocorrências entre os componentes do conhecimento docente ocorreram em virtude da forma como a aula foi desenvolvida pelo par de Antônio, pelo seu pouco preparo conceitual com o conceito de logística reversa do chumbo. Na figura 21 dispõe-se a correlação entre os componentes do conhecimento docente emergidos por Antônio.

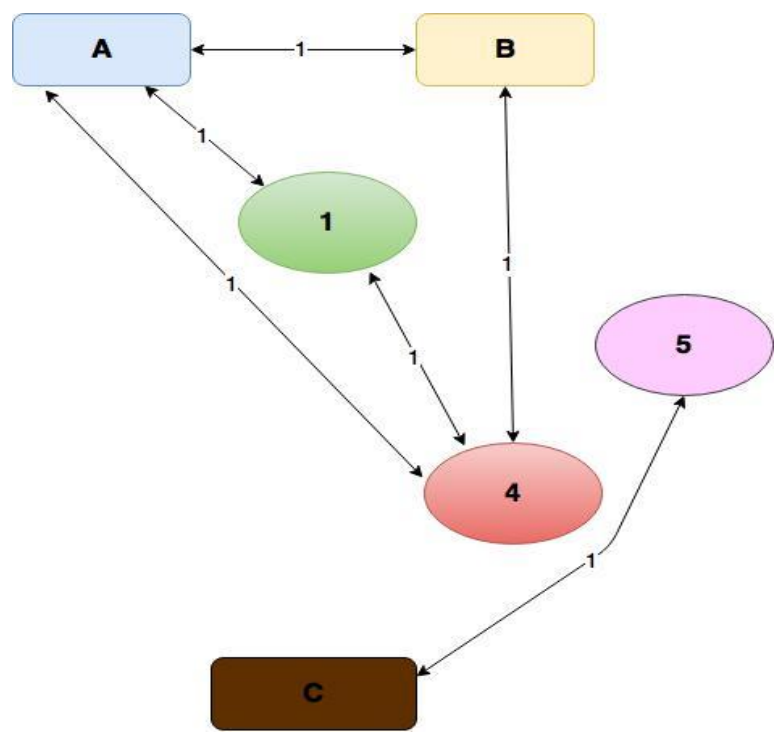

Figura 21. Mapa de integração entre os componentes do Conhecimento Docente de Antônio na aula de logística reversa 
A aula feedback tinha por objetivo dispor à classe todas as atividades avaliativas desenvolvidas pelos alunos e discutir os aspectos conceituais que os discentes haviam tido mais dificuldade. Durante a aula Antônio expressou, pela primeira vez, compreender as concepções alternativas dos alunos com o conteúdo redox, o que influenciou diretamente a maneira como conduziu sua aula e, consequentemente, em uma maior correlação entre o componente Conhecimento da Compreensão dos Estudantes (3) e Orientações para o Ensino de Ciências (1). Esse último componente também apresentou a mesma integração com o Conhecimento da Avaliação e da aprendizagem em ciências (5) - Dimensões sobre a aprendizagem em ciências para avaliar, pois foi nessa aula que Antônio mais discutiu sobre o processo de avaliação que constituíram suas regências. Acredita-se que a vivência no Pibid proporcionou que o pibidiano começasse a construir os conhecimentos dos alunos e suas dificuldades relacionadas ao conteúdo específico, além de suas necessidades. Na figura 22 dispõe-se o mapa de conexão entre os conhecimentos para a docência emergidos na feedback.

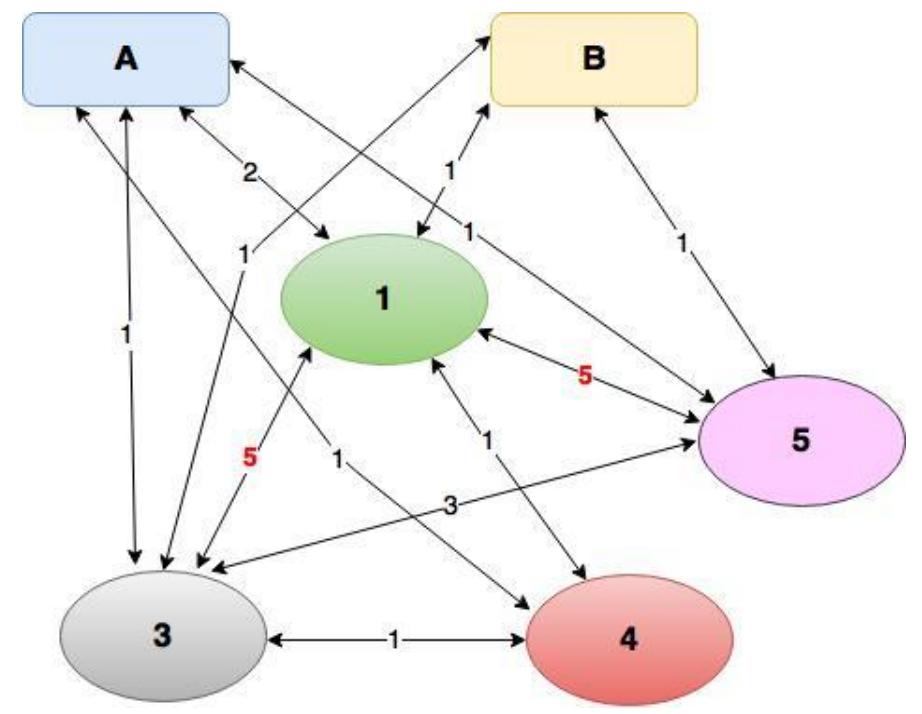

Figura 22. Mapa de integração entre os componentes do Conhecimento Docente de Antônio na aula Feedback

$\mathrm{Na}$ figura 23 estruturou-se o mapa de conexão entre os componentes do Conhecimento Docente emergidos em todas as aulas ministradas por Antônio na EJA. A maior integração (63) nas aulas ministradas por Antônio ocorreu entre os componentes Conhecimento do Tema (A) e Orientações para o Ensino de Ciências (1). Essas intersecções são resultantes da estrutura do subprojeto baseada em projetos e das Crenças sobre a natureza da ciência do pibidiano. Essas crenças também refletiram diretamente nas escolhas das estratégias Instrucionais para o Ensino de Ciências, adotadas por Antônio nas regências. 


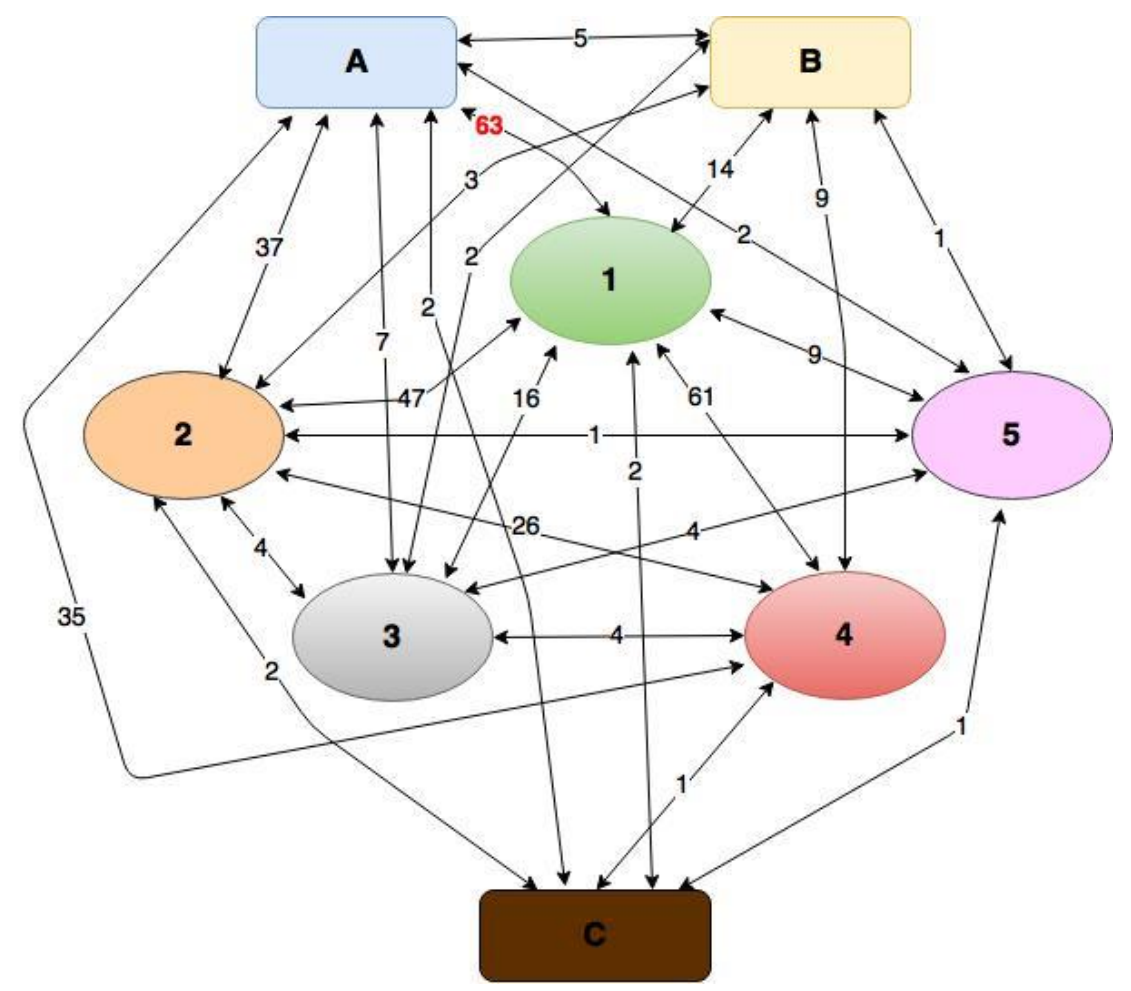

Figura 23. Mapa de integração entre os componentes do Conhecimento Docente de Antônio de todas as aulas ministradas por Antônio na EJA

O esmiuçamento dos mapas de Integração entre os componentes do Conhecimento Docente denotam que as prinicipais coocorrências estão presentes entre: O conhecimento do Tema (A) e as Orientações para o Ensino de Ciências (1); as Orientações para o Ensino de Ciências (1) e o Conhecimento das estratégias Instrucionais para o Ensino de Ciências (4); e a terceira maior integração é estabelecida entre Conhecimento do Currículo (2) (oportunizado principalmente pela experiencia e conhecimento das tutoras) e Orientações para o Ensino de Ciências (1).

No final de sua vivência no Pibid é que surgem seus conhecimentos sobre o Conhecimento da Compreensão dos alunos em ciências (3), que emergiu principalmente na aula feedback. O conhecimento do contexto tinha uma conexão mais limitada com os outros componentes do conhecimento docente.

\subsubsection{Percepções dos alunos da escola conveniada sobre 0 conhecimento docente de Antônio}

A adoção do instrumento quantitativo não teve por objetivo contrapor os resultados obtidos qualitativamente, mas investigar o olhar dos alunos da escola da educação básica para a prática pedagógica do pibidiano. A turma na qual Antônio implementava suas regências era da EJA e tinha em torno de 25 alunos matriculados, contudo os que frequentavam eram apenas 13, o que significa que esse número corresponde ao total de alunos que responderam ao teste, denotando a população de conveniência. Em consonância, a análise permeou o procedimento exploratório e não 
de inferência, pois não se usou um conjunto de dados oriundos de uma amostra para generalizar uma população, apesar de entender-se que quanto maior o número da amostra, maior será a sua variância (BLAND; ALTMAN, 1997).

Os dados foram organizados (tabela 8), a priori, catalogando o percentual de participantes que assinalaram as subcategorias/itens que formavam as categorias Conhecimento do tema (CT), Representação do conteúdo e estratégias para seu ensino (RCE), Objetivo educacional e do contexto (OEC) e Conhecimento das compreensões dos estudantes (CCE), além dos valores máximos e mínimos.

Tabela 8. Porcentagem de respondentes que assinalaram as subcategorias, que compunham cada categoria, seus respectivos valores mínimos e máximos

\begin{tabular}{ccccccccc}
\hline Categoria & \multicolumn{6}{c}{ Respostas assinaladas (\%) } & \multicolumn{2}{c}{ Valores } \\
\cline { 2 - 9 } & $\mathbf{0}$ & $\mathbf{1}$ & $\mathbf{2}$ & $\mathbf{3}$ & $\mathbf{4}$ & $\mathbf{5}$ & Mínimo & Máximo \\
\hline CT1 & 0 & 0 & 0 & 15 & 38 & 46 & 3 & 5 \\
\hline CT 2 & 0 & 0 & 0 & 46 & 31 & 23 & 3 & 5 \\
\hline CT 3 & 0 & 0 & 0 & 38 & 23 & 38 & 3 & 5 \\
\hline CT 4 & 8 & 0 & 0 & 0 & 62 & 31 & 0 & 5 \\
\hline CT 5 & 0 & 0 & 0 & 23 & 54 & 23 & 3 & 5 \\
\hline CT 6 & 8 & 0 & 8 & 23 & 31 & 31 & 0 & 5 \\
\hline CT 7 & 0 & 0 & 8 & 0 & 54 & 38 & 2 & 5 \\
\hline RCE 1 & 0 & 0 & 0 & 15 & 38 & 46 & 3 & 5 \\
\hline RCE 2 & 0 & 8 & 8 & 8 & 54 & 23 & 1 & 5 \\
\hline RCE 3 & 0 & 0 & 8 & 31 & 31 & 31 & 2 & 5 \\
\hline RCE 4 & 0 & 0 & 8 & 15 & 8 & 69 & 2 & 5 \\
\hline RCE 5 & 0 & 0 & 8 & 23 & 31 & 38 & 2 & 5 \\
\hline RCE 6 & 0 & 0 & 0 & 38 & 62 & 0 & 3 & 4 \\
\hline RCE 7 & 8 & 0 & 31 & 15 & 31 & 15 & 0 & 5 \\
\hline OEC 1 & 0 & 0 & 0 & 15 & 46 & 38 & 3 & 5 \\
\hline OEC 2 & 0 & 0 & 0 & 8 & 23 & 69 & 3 & 5 \\
\hline OEC 3 & 0 & 0 & 15 & 15 & 38 & 31 & 2 & 5 \\
\hline OEC 4 & 0 & 0 & 8 & 38 & 46 & 8 & 2 & 5 \\
\hline OEC 5 & 0 & 0 & 15 & 23 & 23 & 38 & 2 & 5 \\
\hline OEC 6 & 8 & 0 & 8 & 15 & 46 & 23 & 0 & 5 \\
\hline OEC 7 & 0 & 8 & 0 & 8 & 31 & 54 & 1 & 5 \\
\hline CCE 1 & 0 & 0 & 15 & 31 & 23 & 31 & 2 & 5 \\
\hline CCE 2 & 0 & 8 & 15 & 38 & 38 & 0 & 1 & 4 \\
\hline CCE 3 & 8 & 8 & 0 & 31 & 46 & 8 & 0 & 5 \\
\hline CCE 4 & 8 & 8 & 0 & 38 & 23 & 23 & 0 & 5 \\
\hline CCE 5 & 0 & 0 & 8 & 8 & 54 & 31 & 2 & 5 \\
\hline CCE 6 & 8 & 0 & 8 & 23 & 38 & 23 & 0 & 5 \\
\hline CCE 7 & 0 & 0 & 15 & 15 & 31 & 38 & 2 & 5 \\
\hline & 0 & 23 \\
\hline
\end{tabular}

Os dados tabulados na tabela acima revelam alguns aspectos. Nesse sentido, na categoria CT 1 quando os discentes foram questionados "Meu professor sabe 0 conteúdo que ele está ensinando", mais de $46 \%$ assinalaram que o licenciando sempre sabe o conteúdo, e para $31 \%$ o pibidiano frequentemente explicava o impacto desse 
conteúdo na sociedade (CT 6), o que sugere que a estruturação de suas aulas, tendo como problemática a contaminação por chumbo, foi assimilada pela turma em conjunto com o conteúdo químico. Na categoria RCE 6 "Meu professor usa uma variedade de abordagens de ensino para transformar o conteúdo específico em uma forma de conhecimento compreensível para os alunos", para $62 \%$ dos alunos frequentemente Antônio adotava diferentes abordagens de ensino, o que pode ser evidenciado na própria organização dos blocos de suas aulas e na implementação de suas regências. Ainda nessa categoria, para $38 \%$ da classe Antônio às vezes oferecia espaço para que os discentes pudessem expressar seus pontos de vistas. Para $31 \%$ dos alunos, no item RCE 7 "Meu professor usa mídias ou tecnologias para expressar os conceitos", Antônio raramente usava como estratégias para desenvolver os conceitos, por outro lado, o mesmo percentual de alunos considerou que frequentemente Antônio fez uso desses recursos. Em consonância, nas aulas Antônio as mídias e tecnologias estruturaram parte do repertório das aulas ministradas pelo pibidiano, por exemplo, quando trouxe a canção de Caetano Veloso e Maria Bethânia, sobre a contaminação de chumbo que acometeu moradores da cidade de Santo Amaro na Bahia, além de reportagens, para alguns discentes talvez os instrumentos usados não fossem significativos.

Em relação à categoria OEC 2 "Meu professor interage adequadamente com os alunos e proporciona um bom ambiente de convívio", para $69 \%$ da classe sempre Antônio propiciava a interação com os alunos e, consequentemente, tornava a sala de aula um espaço propício ao convívio social. Ao contrapormos esse percentual com outra questão similar da categoria RCE 4 "Meu professor oferece oportunidade para eu expressar meus pontos de vista durante a aula", observamos no parágrafo acima que obtivemos o mesmo percentual de alunos que responderam como sendo sempre a existência desse ambiente nas aulas do pibidiano, indicando que os itens que compõem as questões apresentam correlações. Porém, quando questionados, OEC 6 "Meu professor lida com o contexto da nossa sala de aula adequadamente" para $23 \%$ isso ocorre sempre, enquanto que para $46 \%$ frequentemente. Talvez seja reflexo das percepções dos alunos sobre os momentos das aulas experimentais em que Antônio não tenha conseguido instruí-los adequadamente e acabou perdido o direcionamento da classe, episódio este descrito na categoria Conhecimento pedagógico geral, acessada por Antônio. Na OEC 5 "Meu professor prepara materiais didáticos adicionais para as aulas", na percepção de $38 \%$ dos alunos sempre, o licenciando preparava esses recursos adicionais, por outro lado, para $23 \%$ isso ocorria às vezes, e para o mesmo número percentual frequentemente. Talvez seja difícil os alunos compreenderam a dimensão das atividades desenvolvidas por Antônio antes de adentrar na sala de aula e, consequentemente, compreenderam que um dos produtos Capítulo 4. Resultados e Discussões 
desses afazeres seja o material didático, mesmo tendo nas aulas o pibidiano discorrido que havia confeccionado os textos e o roteiro do experimento.

$\mathrm{Na}$ subcategoria CCE 1 "Meu professor averigua o conhecimento prévio dos estudantes antes de começar a ensinar um novo assunto", para $31 \%$ dos estudantes sempre Antônio tinha essa procedência, enquanto que para $24 \%$ frequentemente, $31 \%$ às vezes e $15 \%$ raramente. É instigante a percepção dos alunos sobre esse item, pois como o pibidiano argumentou durante a entrevista semiestruturada, realizava o levantamento dos conhecimentos prévios durante as aulas. Com relação a CCE 6 "As escolhas metodológicas do meu professor facilitam minha compreensão sobre 0 conteúdo", na visão de $38 \%$ da classe frequentemente a adoção de determinada metodologia facilitava para a compreensão do conteúdo, enquanto que para $23 \%$ ocorria sempre, em oposição, na perspectiva de $8 \%$ raramente era observado, e outros $8 \%$ não sabiam opinar. Quando olha-se para as diferentes ferramentas avaliativas trazidas para a sala de aula, durante sua trajetória como pibidiano nessa turma da EJA pode-se inferir que Antônio adotou diferentes instrumentos avaliativos, que na perspectiva de mais de $51 \%$ ( $38 \%$ frequentemente $+23 \%$ sempre) foram concebidos como métodos que possibilitaram a compreensão dos conteúdos.

$\mathrm{Na}$ sessão aberta do instrumento destinada às percepções gerais dos alunos, sobre Antônio, apenas três discentes deixaram suas impressões:

\footnotetext{
Está de parabéns que a gente da noite tem um pouco de dificuldade, mais (sic) estão todos de parabéns (A1)

Ouvi ((houveram)) (sic) algumas dificuldades, mas foram bem esclarecidas, após os experimentos e as explicações (A9)

Nada a declarar (A10)
}

Como pode-se observar na escrita dos discentes, esses trazem elementos gerais sobre as aulas ministradas pelo pibidiano.

No agrupamento dos dados apresenta-se o seu tratamento ainda em uma perspectiva da análise estatística exploratória, para tanto, dispõe-se na tabela 9 os valores da média, mediana e o desvio padrão.

Tabela 9. Valores da Média, mediana e desvio padrão de cada questão

\begin{tabular}{cccc}
\hline Questões & Média & Mediana & Desvio Padrão \\
\hline CT1 & 4,31 & 4 & 0,75 \\
\hline CT 2 & 3,77 & 4 & 0,83 \\
CT 3 & 4,00 & 4 & 0,91 \\
\hline CT 4 & 4,00 & 4 & 1,29 \\
\hline CT 5 & 4,00 & 4 & 0,71 \\
CT 6 & 3,62 & 4 & 1,45 \\
\hline CT 7 & 4,23 & 4 & 0,83 \\
\hline RCE 1 & 4,31 & 4 & 0,75 \\
\hline RCE 2 & 3,77 & 4 & 1,17 \\
\hline RCE 3 & 3,85 & 4 & 0,99 \\
\hline RCE 4 & 4,38 & 5 & 1,04
\end{tabular}

Capítulo 4. Resultados e Discussões 


\begin{tabular}{cccc}
\hline RCE 5 & 4,00 & 4 & 1,00 \\
\hline RCE 6 & 3,62 & 4 & 0,51 \\
\hline RCE 7 & 3,08 & 3 & 1,44 \\
\hline OEC 1 & 4,23 & 4 & 0,73 \\
OEC 2 & 4,62 & 5 & 0,65 \\
\hline OEC 3 & 3,85 & 4 & 1,07 \\
\hline OEC 4 & 3,54 & 4 & 0,78 \\
\hline OEC 5 & 3,85 & 4 & 1,14 \\
\hline OEC 6 & 3,62 & 4 & 1,39 \\
\hline OEC 7 & 4,23 & 5 & 1,17 \\
\hline CCE 1 & 3,69 & 4 & 1,11 \\
\hline CCE 2 & 3,08 & 3 & 0,95 \\
\hline CCE 3 & 3,23 & 4 & 1,36 \\
\hline CCE 4 & 3,31 & 3 & 1,49 \\
\hline CCE 5 & 4,08 & 4 & 0,86 \\
\hline CCE 6 & 3,54 & 4 & 1,39 \\
\hline CCE 7 & 3,92 & 4 & 1,12 \\
\hline
\end{tabular}

Conhecimento do tema (CT), Representação do conteúdo e estratégias para seu ensino (RCE), Objetivo educacional e do contexto (OEC) e Conhecimento das compreensões dos estudantes (CCE).

Os dados agrupados sinalizam que a média total para o instrumento foi de 3,84. Ao observar-se detalhadamente as respostas, tem-se que OEC 2 foi a questão de maior média (4,62, com mediana de 5 e desvio padrão de 0,65$)$. Por outro lado, as questões RCE 7 e CCE 2 foram as que apresentaram as menores médias e medianas, com os respectivos valores 3,08 e 3, e o desvio padrão de 1,44 e 0,95. Em relação à maior dispersão, CCE 4 foi a questão com o maior desvio padrão $(1,49)$ e RCE 6 com o menor $(0,51)$. Os valores do desvio padrão indicam a homogeneidade no conjunto de respostas de um grupo. Nesse estudo o valor alto de desvio padrão na CCE 4 indica heterogeneidade nas escalas assinaladas. Por outro lado, o desvio padrão baixo na RCE 6 sinaliza que houve homogeneidade entre as respostas dos estudantes. Dentre as subcategorias que representaram valores de desvio padrão acima de 1 (CT 4 e 4; RCE 2, 4, 5 E 7; OEC 3, 5, 6 E 7; CCE 1, 3, 4, 6 E 7) enquanto as demais apresentarem valores abaixo de 1 (CT 1, 2, 3, 5 e7; RCE 13; OEC 1, 2 E 4; E CCE 2 E 5).

Os valores da média para cada categoria foi de 3,98 para CT, 3,85 para RCE, 3,98 para OEC e 3,54 para CCE. O desvio padrão para cada categoria foi de 0,98 CT, 1,06 RCE, 1,04 OEC e 1,21 CCE. Os valores para mediana de todas as categorias foi 4. Por meio dos valores calculados para mediana e média para todo instrumento e por dimensão, inferiu-se que na percepção dos alunos Antônio tem um bom Conhecimento Docente, reflexo talvez do entendimento desses alunos que o pibidiano tenha competência ao exercer a profissão professor, pois o principal valor da escala assinalado foi 4 .

$\mathrm{Na}$ tabela 10 apresenta-se o agrupamento dos valores de Alfa de Cronbach separado por dimensão e pela ausência de cada categoria, além de as subcategorias/itens que a compunha. 
Tabela 10. Alfa de Cronbach para todo instrumento e separado por dimensão, além do alfa na ausência de cada categoria

Categorias

Alfa de Cronbach na ausência da variável

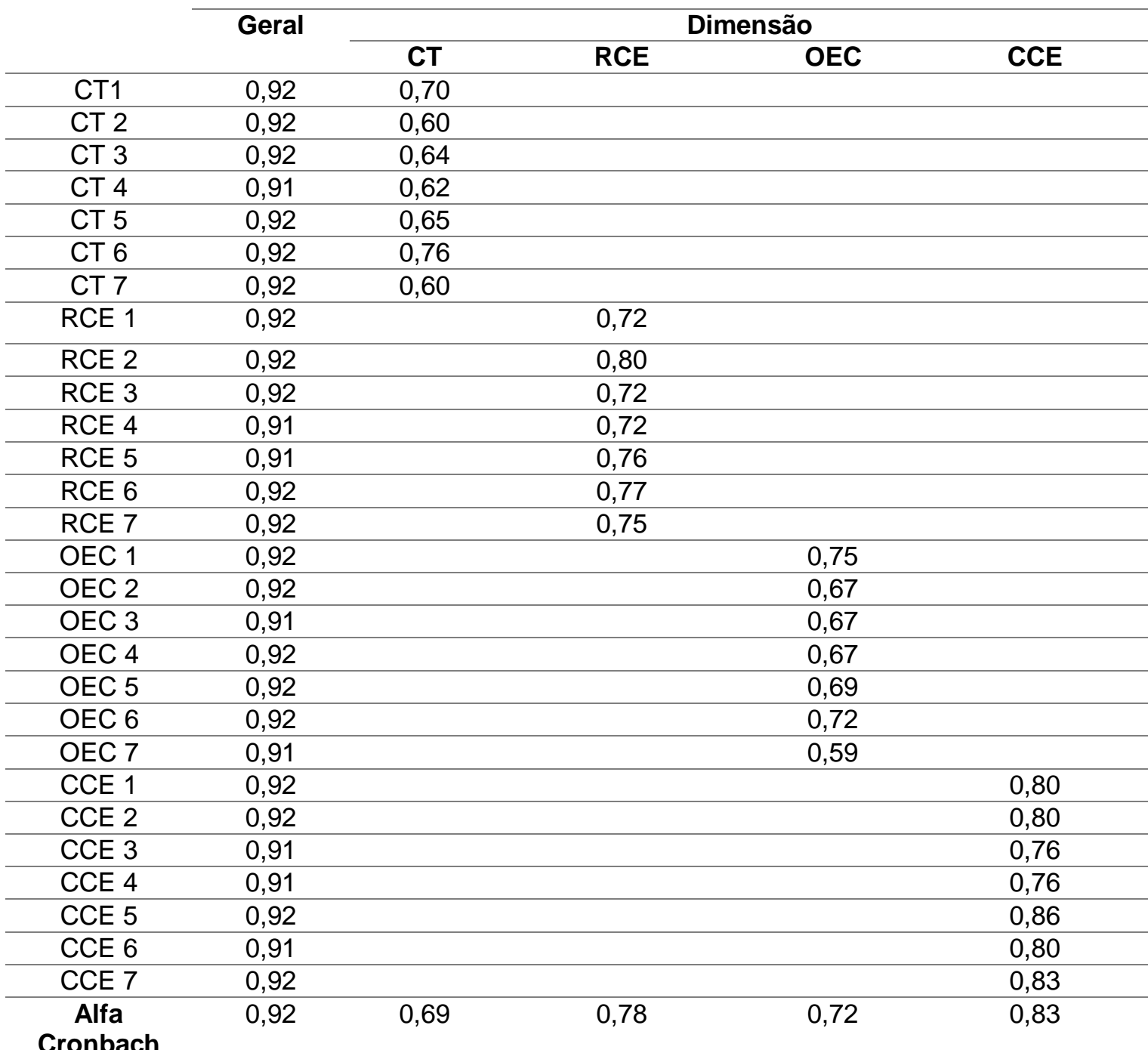

Conhecimento do tema (CT), Representação do conteúdo e estratégias para seu ensino (RCE), Objetivo educacional e do contexto (OEC) e Conhecimento das compreensões dos estudantes (CCE).

O valor de alfa de 0,92 revela que o conjunto de respostas que se obteve com o instrumento utilizado apresentou valores confiáveis e, consequentemente, uma consistência muito boa. Apesar de a literatura apontar que a confiabilidade de um instrumento pode apresentar uma consistência muito boa em relação ao contexto, podese inferir que o grau de correlação entre as perguntas que compunham cada questão apresentava uma boa correlação (STREINER, 2003) em decorrência do valor de alfa, pois o número de itens que compunha o instrumento podia resultar em um aumento na consistência da escala adotada (KRUS; HELMSTADTER, 1993). Nessa perspectiva, realizou também os cálculos para o alfa para cada uma das dimensões, assim como para todo o instrumento. O resultado do Alfa de Cronbach para todo instrumento foi de 0,92, figurando como excelente. Avaliando-se o Alfa de Cronbach por dimensão (CT, RCE, OEC e CCE), os valores calculados foram todos acima de 0,6 , sendo $0,69,0,78$, 
0,72 e 0,83, respectivamente para Conhecimento do tema (CT), Representação do conteúdo e estratégias para seu ensino (RCE), Objetivo educacional e do contexto (OEC) e Conhecimento das compreensões dos estudantes (CCE). Nessa perspectiva, Vieira (2009) argumenta que quando o alfa é calculado item a item, como procedeu-se, revela uma piora ou melhora da consistência geral, sugerindo que um determinado item é importante ou não para a composição geral do instrumento.

Com esses valores de Alfa de Cronbach conclui-se que o instrumento aplicado é confiável e produz mensurações estáveis e consistentes (HAIR, 2005), ou seja, que as conclusões realizadas ao longo desse item sobre a percepção dos alunos da escola conveniada ao Pibid acerca do bom Conhecimento Docente de Antônio são confiáveis.

\subsubsection{Conhecimento Docente de Melissa}

Para identificar o conhecimento docente de Melissa analisaram-se 27 documentos de diferentes fontes, a saber: entrevista semiestruturada; reuniões em grupo; aulas; a lousa produzida para guiar a pibidiana em sua aula; os relatórios confeccionados individualmente e em dupla; o CoRe adaptado; a lembrança estimulada; e o ciclo reflexivo de Smyth. A pibidiana não participou de três reuniões gerais que geraram os arquivos 1, 2 e 6, da Aula Pilha de Daniell (arquivo 13) e Aula feedback (arquivo 20), e que, portanto, não compuseram a análise. O mapeamento do conhecimento docente de Melissa gerado no Atlas.ti, foi agrupado na tabela 11. 
Tabela 11. Relatório gerado no Atlas.ti - Conhecimento Docentede Melissa

\section{Documento}

Apresentação da proposta de trabalho (arquivo 3)

Aula de sensibilização (arquivo 4)

Reunião para saber o andamento (arquivo 5)

Reunião para saber o andamento (arquivo 7 )

Reunião para saber o andamento (arquivo 8 )

Reunião para saber o andamento (arquivo 9)

Aula de sensibilização (arquivo 10)

Aula de atomística (arquivo 11)

Aula Pilha de moedas (arquivo 12)

Reunião para saber o andamento (arquivo 14)

Aula de revisão (arquivo 15)

Aula de contaminação por chumbo (arquivo 16)

Reunião para saber o andamento (arquivo 17)

Aula de logística (arquivo 18)

Apresentação dos resultados (arquivo 21)

Reunião Geral (arquivo 22)

Reunião com a dupla (arquivo 23)

Entrevista semiestruturada (arquivo 24)

Lembrança estimulada (arquivo 25)

CoRe adaptado

Exercício

Lousa

Ciclo de Smyth - Antes

Ciclo de Smyth - Depois

Texto sobre bateria

Aula de atomística - slides

Relatório da dupla

Relatório individual - Melissa

\section{Total}

$\begin{array}{cc}\text { A } & \text { Categ } \\ 0 & 0 \\ 0 & 14 \\ 0 & 3 \\ 0 & 2 \\ 0 & 10 \\ 0 & 5 \\ 0 & 13 \\ 25 & 58\end{array}$

$25 \quad 58$

$\begin{array}{ll}0 & 1 \\ 0 & 2\end{array}$

$\begin{array}{ccc}0 & 2 & 0 \\ 18 & 42 & 0\end{array}$

$\begin{array}{cccc}18 & 42 & 0 & 38 \\ 0 & 4 & 0 & 0\end{array}$

$\begin{array}{lll}0 & 4 \\ 0 & 6\end{array}$

5

6

0

14

12

14

$\begin{array}{ll}1 & 0 \\ 0 & 0\end{array}$

0

4

0

3

$\begin{array}{ll}0 & 0 \\ 0 & 2\end{array}$

\section{Conhecimento Docente}

Total

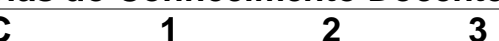

$\begin{array}{ll}0 & 0 \\ 0 & 0\end{array}$

$\begin{array}{ll}0 & 0 \\ 0 & 0\end{array}$

$\begin{array}{lll}1 & 2 & 3 \\ 0 & 0 & 0 \\ 0 & 0 & 0 \\ 0 & 0 & 0 \\ 0 & 0 & 0 \\ 2 & 0 & 0 \\ 1 & 0 & 0\end{array}$

0

12

18

$\begin{array}{ll}0 & 2 \\ 1 & 2\end{array}$

0

$\begin{array}{ll}0 & 3 \\ 1 & 0\end{array}$

0
0

0

2

8

$\begin{array}{ccccc} & 3 & \mathbf{4} & 5 & \\ 0 & 0 & 0 & 0 \\ 0 & 0 & 0 & 14 \\ 0 & 0 & 0 & 3 \\ 0 & 0 & 0 & 2 \\ 0 & 0 & 0 & 12 \\ 0 & 0 & 2 & 8 \\ 0 & 0 & 0 & 0 & 14 \\ & 0 & 4 & 3 & 121\end{array}$

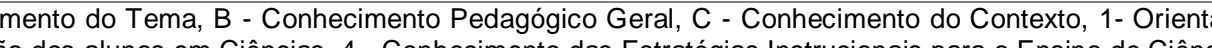

0

$\begin{array}{ll}0 \\ 0 & 0\end{array}$

\begin{tabular}{ll}
1 & 0 \\
1 & 0 \\
0 & 6 \\
0 & 3 \\
\hline
\end{tabular}

$\begin{array}{lll}0 & 0 \\ 0 & \\ 0 & 3 \\ 1 & 5 \\ 5 & 82\end{array}$

$\begin{array}{ll}0 & 0 \\ 0 & 0 \\ 0 & 0 \\ 0 & 1 \\ 3 & \\ 5 & 0 \\ 82 & 44\end{array}$

\begin{tabular}{l}
0 \\
1 \\
8 \\
0 \\
0 \\
0 \\
\hline 3 \\
0 \\
4 \\
4 \\
1 \\
1 \\
\hline 0 \\
\hline 1 \\
0 \\
0 \\
0 \\
\hline 1 \\
\hline 2 \\
0 \\
44 \\
\hline
\end{tabular}

$\begin{array}{ll}3 & 4 \\ 0 & 0 \\ 0 & 0 \\ 0 & 0 \\ 0 & 0 \\ 0 & 0 \\ 0 & 0 \\ 0 & 0 \\ 1 & 4 \\ 0 & \end{array}$

$\begin{array}{lll}0 & 0 & 1 \\ 1 & 1 & 8\end{array}$

$\begin{array}{cccc}0 & 1 & 1 & 8 \\ 1 & 7 & 13 & 127\end{array}$

$\begin{array}{ccc}0 & 1 & 5 \\ 0 & 0 & 10\end{array}$

$\begin{array}{lll}0 & 0 & 10 \\ 0 & 1 & 8\end{array}$

$\begin{array}{cccc}0 & 0 & 1 & 8 \\ 4 & 4 & 6 & 28\end{array}$

$\begin{array}{cccc}4 & 4 & 6 & 28 \\ 0 & 0 & 0 & 0\end{array}$

$\begin{array}{cccc}5 & 0 & 0 & 0 \\ 0 & 3 & 3 & 31\end{array}$

$\begin{array}{llll}5 & 3 & 3 & 31 \\ 0 & 0 & 0 & 19 \\ 7 & 2 & 4 & 33\end{array}$

\begin{tabular}{cccc}
7 & 2 & 4 & 33 \\
\hline & 0 & 2 & 8
\end{tabular}

em Ciências, 4 - Conhecimento das Estratégias Instrucionais para o Ensino de Ciências e 5 - Conhecimento da Avaliação da Aprendizagem em Ciências

Capítulo 4. Resultados e Discussões 
Nos documentos descritos acima selecionaram-se 377 trechos, mas em virtude das sobreposições de algumas categorias resultou em um total de 510 categorias. No primeiro documento (arquivo 3) não emerge nenhum componente do conhecimento docente de Melissa. $\mathrm{Na}$ aula de atomística (arquivo 11) e de revisão (arquivo 15), evidencia-se o maior número de categorias do Conhecimento Docente de Melissa com o total 121 e 127 trechos selecionados.

A maior coocorrência entre as categorias de análise envolveu o Conhecimento do Tema e as Orientações para o Ensino de Ciências. Nesse sentido, apresenta-se na figura 24 o mapa de coocorrência entre as categorias do Conhecimento Docente.

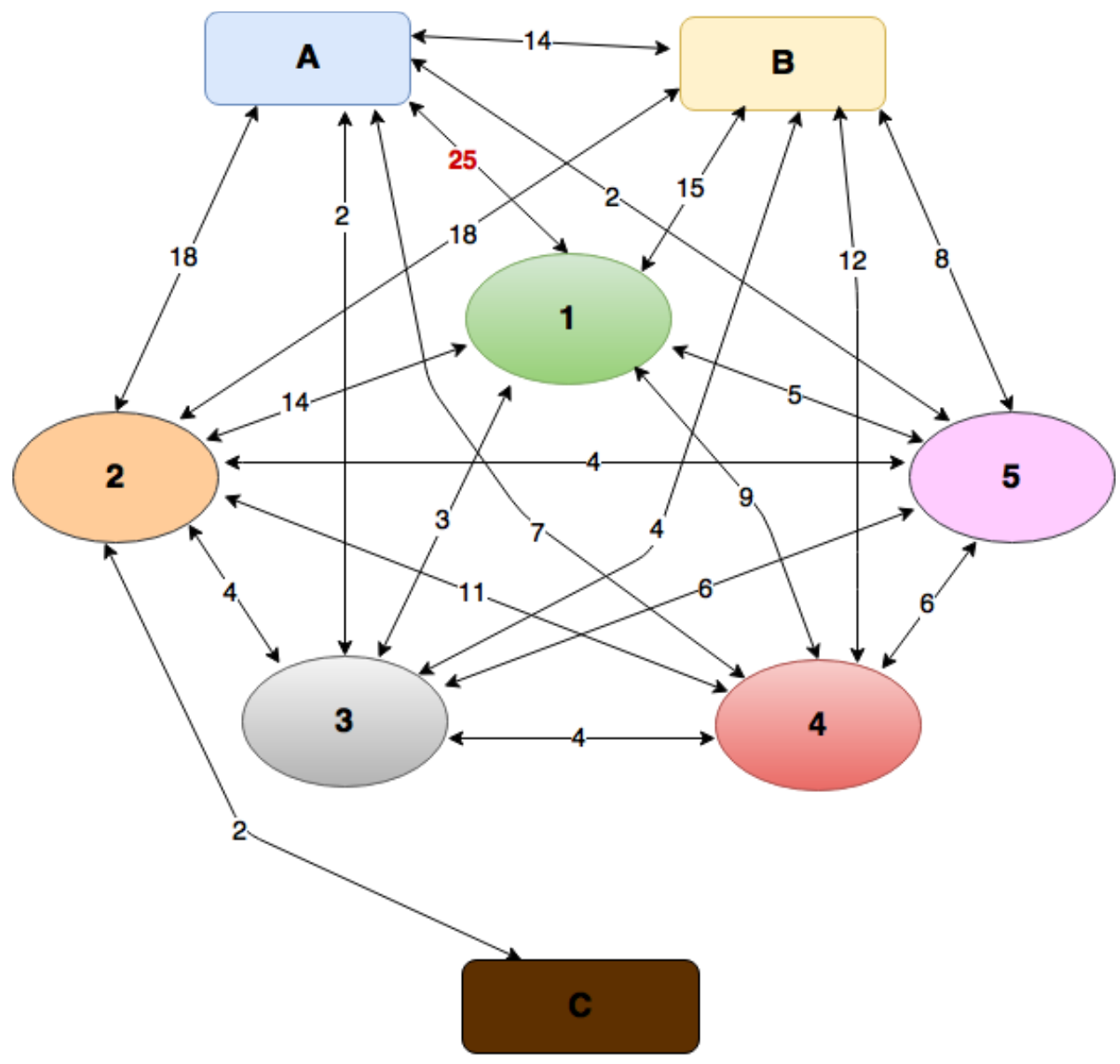

Figura 24. Coocorrência das categorias do Conhecimento Docente de Melissa em todos os documentos analisados ${ }^{7}$

Os contextos em que Melissa inicia a construção de seu conhecimento docente e a integração desses componentes detalha-se nos tópicos a seguir.

\footnotetext{
${ }^{7} \mathrm{~A}$ = Conhecimento do Tema, B = Conhecimento Pedagógico Geral, C = Conhecimento do Contexto - Orientações para o Ensino de Ciências, 2 - Conhecimento do Currículo, 3 - Conhecimento da Compreensão dos alunos em Ciências, 4 Conhecimento das Estratégias Instrucionais para o Ensino de Ciências e 5 - Conhecimento da Avaliação da Aprendizagem em Ciências 


\section{Conhecimento do tema}

$\mathrm{Na}$ descrição desse componente do Conhecimento Base pretende-se emergir narrativas em que sugiram os reflexos das orientações das tutoras no conhecimento do tema de Melissa.

Nas reuniões com a coordenadora sobre a estruturação das aulas era Antônio quem discutia com Maria a organização das regências (Reunião para saber o andamento, arquivo 8 e 9), geralmente Melissa só observava. Nessa primeira regência sobre atomística, Melissa desenvolveu o conceito de estrutura atômica - número de nêutrons, prótons, elétrons número atômico, massa atômica e a definição de reações redox. Para se preparar para lecionar a aula a pibidiana seguiu a orientação da coordenadora e confeccionou a lousa (quadro 18) que orientaria a sua ação didática.

Quadro 18. Lousa confeccionada por Melissa para aula de atomística

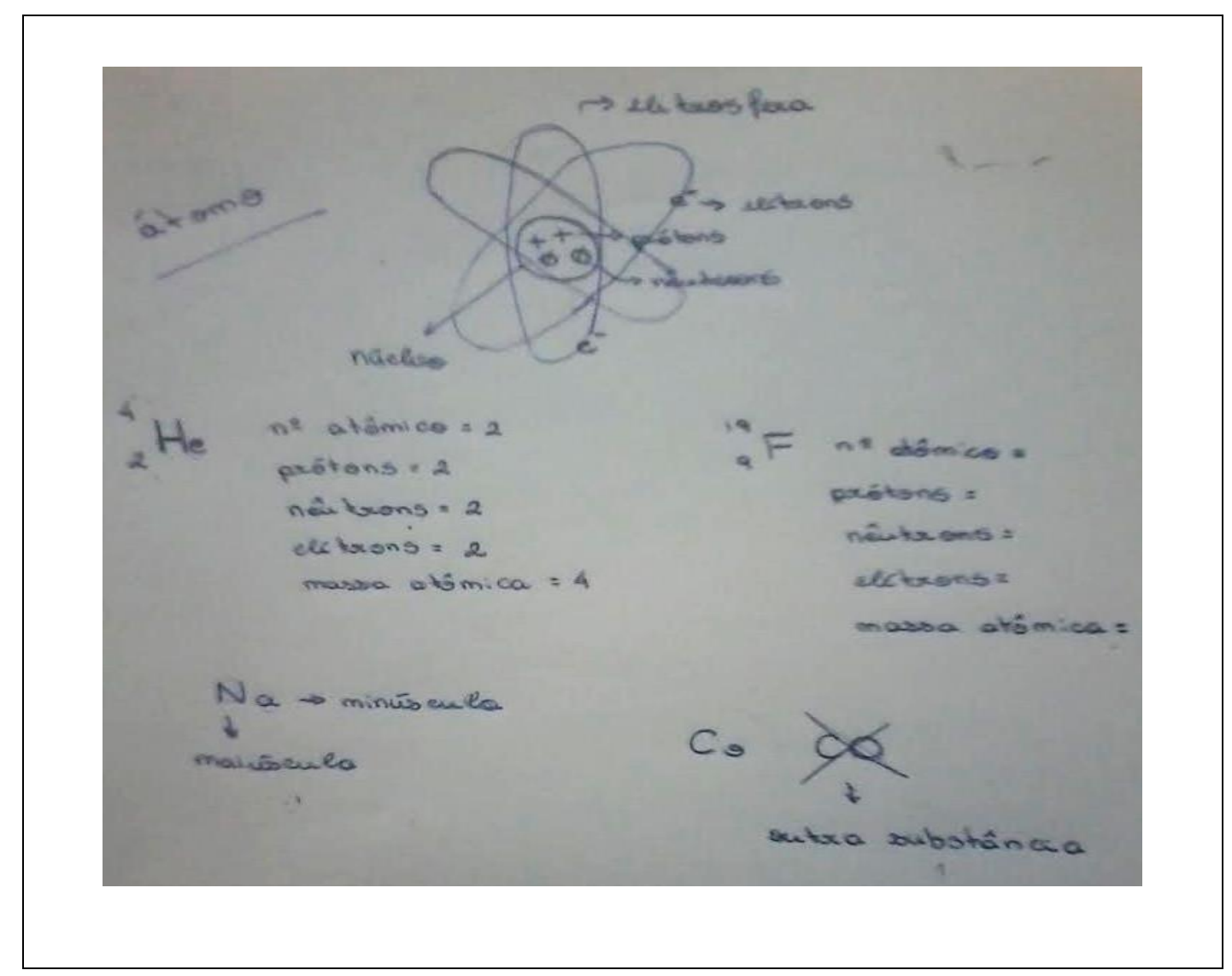



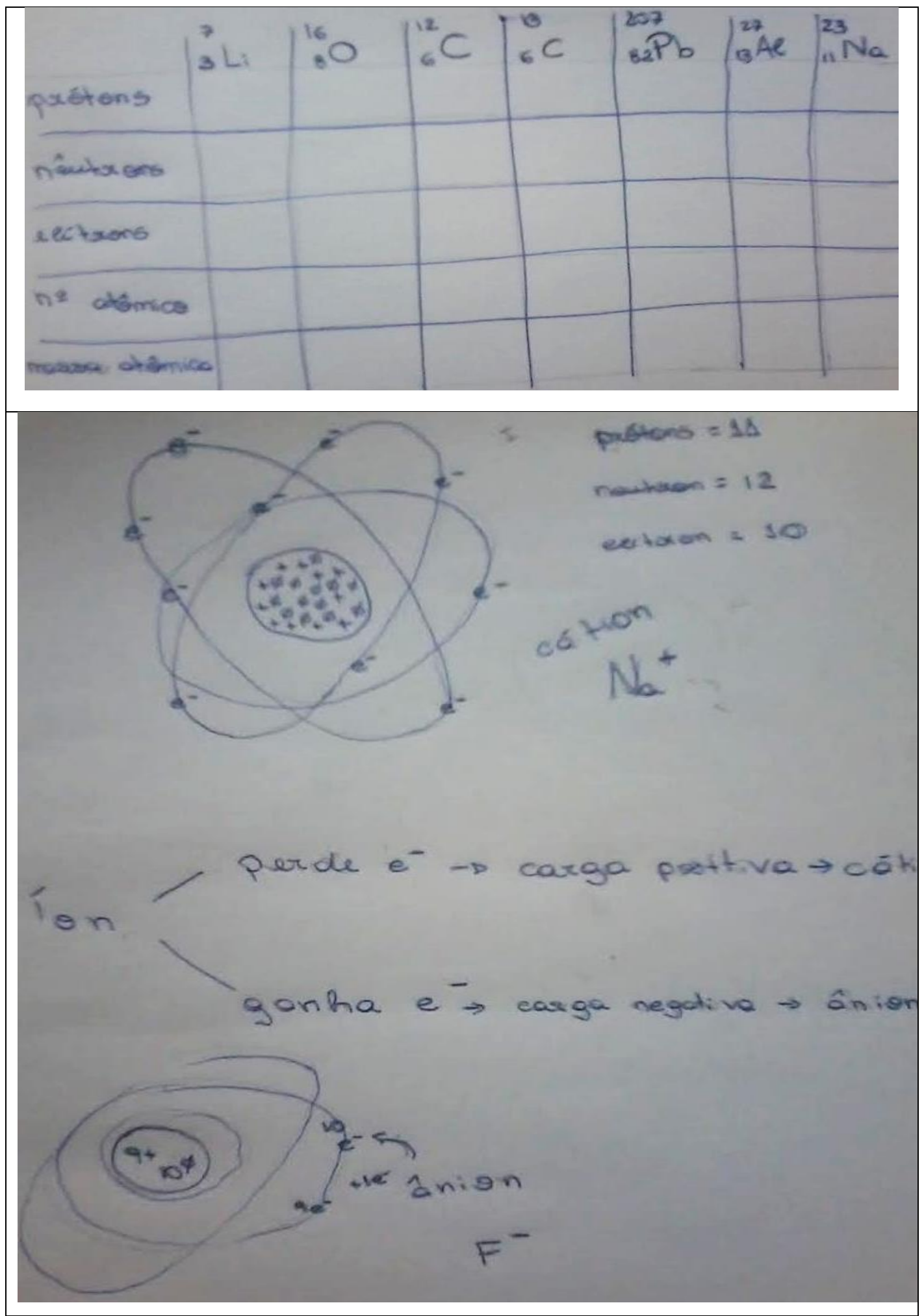

Melissa dividiu a aula em três momentos. No primeiro, realizou uma revisão de atomística e representação dos átomos por meio da projeção de slides, para tanto, elegeu o chumbo como elemento que nortearia sua explicação:

Melissa - Tá na sua forma pura, chumbo metálico, e a gente tem um chumbo em forma de íons, que é um chumbo que a gente tem na pilha e na bateria, ok até aí? Aqui são algumas ampliações que a gente tem no chumbo da indústria, então a gente tem inseticida, a gente tem 
partícula de plástico, borracha, tinta pra impressão, fotografias, explosivo, baterias, tinta, verniz, ok? Aqui a gente vai falar um pouquinho depois disso, da contaminação que o chumbo tem, e aqui a gente vai mostrar o chumbo na tabela periódica. Chumbo é um metal, tá aqui (Aula atomística, arquivo 11, turno 12).

No trecho acima Melissa lista certos conceitos químicos como, por exemplo, o chumbo na forma de íons e na forma metálica, mas não deixa claro suas diferenças químicas. Luiza percebendo que os discentes da EJA não estavam compreendendo a explicação da pibidiana, solicitou a palavra:

Luiza - Posso fazer só um comentário? Volta ali na tabela periódica só um instantinho? Porque ele acabou de olhar pra cá, né, se vocês olharem essa tabela periódica aqui, essa e aquela. Com esses elementos azuis, que ali não tem, essa tabela ainda vocês ainda vão encontrar na internet, mas essa tabela tá desatualizada, ok, tá, essa escadinha que tá aqui que tem o boro, silício, germânio e arsênio e polônio, que vocês vão encontrar pela internet da vida como semimetais, a Sociedade Brasileira de Química, né, que aceita uma outra sociedade que é internacional que é chamada IUPAC, eliminou esse negócio dos semimetais. Então, se vocês olharem ali, a divisão tá em outro lugar, tá certo? Só pra, que eu vi que ele virou pra olhar aquela tabela, então é bom que a gente pontue que as tabelas são diferentes, tá bom? Então, se você olhar, o boro é considerado não metal agora, o silício é não metal, mas o germânio é considerado metal, o arsênio não metal, o antimônio metal, tudo bem? O telúrio não metal e o polônio já virou metal por essa nova divisão, tá bom? Tá, só essa intervenção, de repente você acha que todas as tabelas são iguais, mas não são, ok? Desculpa aí, pode mandar brasa (Aula atomística, arquivo11, turno 13).

Ao término da intervenção da supervisora, Melissa realiza uma representação do átomo na lousa e inicia a explicação de massa atômica, contudo, interrompe a explicação e decide apontar primeiramente a importância dos discentes aprenderem os conceitos que iria ministrar, para que pudessem compreender o conceito pretendido, a definição de reações redox. Nesse sentido, dispõe-se o trecho:

Melissa - Não tudo bem. É... Chumbo. Vocês lembram o que é massa atômica? Ficou difícil, hein, vamos lá, pra isso que ela serve, nas próximas aulas a gente vai começar a trabalhar um pouco com algumas reações, pelo menos essa é a ideia, então pra gente conseguir trabalhar elas, essa aula aqui vai servir pra gente fazer revisão de alguns conceitos químicos que talvez vocês tenham esquecido, mas tenho certeza que vocês já viram. Vocês lembram como é que a gente representa o átomo? Aquele desenho de criança que não é um átomo de verdade, mas é o jeito que a gente sistematiza aqui, desenhinho. Vamos, uma bolinha que é o núcleo, aí rola uns negócios assim que é? (Aula atomística, arquivo 11, turno 14).

Nesse início a pibidiana estabelece uma ação baseada no tipo pergunta e resposta. Não busca revisar o conteúdo, mas inquerir os discentes sobre os conceitos que se propôs ensinar:

Melissa - Vamos lá, o hélio ele tem dois prótons, dois nêutrons, e dois elétrons, vamos lá. Número atômico é igual ao número de prótons de 
um átomo, então qual que é o número atômico do hélio? (Aula atomística, arquivo 11, turno 39).

Na sequência, talvez pela sua reflexão na ação, tenha percebido a importância de definir o que estava ensinando, então apresenta a definição de átomos:

[...] O átomo ele tem que ser... pra ele ser um átomo ele tem que ser neutro, ou seja, ele não pode nem ter carga positiva nem ter carga negativa, então mesmo número de prótons que eu tenho que ter é o mesmo número de elétrons que eu tenho que ter, então se o átomo tem 11 prótons ele vai ter que ter 11 elétrons, se ele tiver 52 prótons ele vai ter que ter 52 elétrons, e assim serve pra todos os átomos, ele vai ter que ser um átomo, beleza? Vamos fazer com outro? (Aula atomística, arquivo 11, turno 43).

Melissa ao invés de buscar a linearidade em sua revisão, a deixa truncada, não há uma sequência que permita ao aluno vislumbrar como os conceitos estão relacionados. Nesse cenário, ao invés de continuar a explicação sobre átomos e íons, inicia a representação do número de massa e número atômico, como denota o diálogo:

Melissa - 19, gente, na tabela periódica, a cada tabela coloca a massa atômica e o número atômico onde bem entende, quando a gente escreve no caderno, ou em qualquer outro lugar, a gente representa dessa forma, essa forma como é que é? O número atômico fica em baixo, e a massa atômica fica em cima, beleza?

Luiza - Não, o de cima, 18, 996, tá, porque é 18, 996? A gente pode ter 0,8 prótons? Ou 0,8 nêutrons? Não, esse número ele chegou como? É a média ponderada do número de massa dos isótopos existentes daquele elemento, então por exemplo, tá, se eu tenho um flúor com número de massa 19 , e tem $90 \%$ na natureza desse flúor, e o outro número de massa é 20 , tem $10 \%$ do outro, tá, essa média ponderada levando em consideração a quantidade de cada isótopo que tem, vai me dar à massa atômica, ok? Aí não é massa atômica, aí é número de massa tá, são coisas distintas. Outra coisa que é importante distinguir, que a gente tá falando em átomo e elemento, átomo e elemento. Bom, átomo é a menor porção que a gente tem de um determinado, né..., de uma determinada coisa, bom, que coisa é essa, bom, todos os átomos que têm mesmo número de prótons, fazem conjuntos de um elemento químico, tá, e aí esse conjunto se dá um nome e se atribui um símbolo, tá? Vamos distinguir, porque se não fica uma confusão, a gente tá falando de elemento químico ou tá falando de átomo? Né, a gente tá falando de átomo e de um determinado elemento químico, né, que é no caso o flúor, tá certo?

Melissa - Eu vou repetir o que eu falei, um átomo, como ele tem que ser neutro, ele tem que ter o mesmo número de prótons e de elétrons, próton carga positiva, elétron carga negativa. Nêutron, é outra história (Aula atomística, arquivo 11, turno 49, 50 e 55).

No trecho acima Melissa retoma a explicação sobre o conceito que desejava deixar claro para o discente, entretanto, demonstra não reconhecer que Luiza estava explicando como se chegava na massa atômica e não na definição de átomo. A explicação de Luiza não contribuiu para que os discentes compreendessem o que Melissa estava buscando explicar, o episódio revela o desejo da supervisora demonstrar o seu conhecimento. 
A pibidiana ao explicar o número de prótons, massa e nêutrons, demonstra não compreender o por que o número atômico seria igual ao número de prótons:

Aluno - Então quer dizer que átomo... número atômico e prótons são na mesma quantidade?

Melissa - Então... a gente.... professora ((Luiza)), me ajuda? Qual que é a diferença entre o número atômico e os prótons. Porque, que a gente dá nomes diferentes?

Luiza - Não tem diferença (Aula atomística, arquivo 11, turno 68-70).

Para a representação do átomo, Antônio sugere que Melissa explique a adoção de letras maiúsculas e minúsculas:

Melissa - Porque a primeira letra..., por quê? Porque, por exemplo, eu vou escrever pra vocês o cobalto, que é Co, se eu colocar o ' $\underline{\text { ' }}$ maiúsculo, sabe o que vai acontecer? Isso aqui é um composto, isso aqui não é cobalto, isso é aqui é monóxido de carbono, então eu não posso com letra maiúscula por quê? Porque corro o risco de eu confundir com outro elemento, eu não posso fazer isso, eu tenho sempre que deixar a primeira maiúscula, a segunda minúscula, beleza? (Aula atomística, arquivo 11, turno 102).

Ao retomar a explicação do conceito de íons, Melissa estabelece a relação conteúdo-aluno-professor por meio de perguntas que tinham por objetivo obter respostas, e não mediar a aprendizagem dos discentes, como observa-se no trecho abaixo:

[...] Pessoal, vocês já ouviram falar sobre tendência a receber elétrons ou tendência a doar elétrons? Já?

Já, aí que bom! Pessoal, vocês sabiam que a tabela periódica é dividida em famílias? Cada coluninha é uma família? A família $1 \mathrm{~A}$ tem tendência a doar ou receber elétrons? O pessoalzinho da família $1 \mathrm{~A}$, esse aqui, eles dão elétrons ou eles recebem elétrons?

Dão. E da família 17, eles dão ou recebem? Recebem. Então olha, tudo que for, tudo que for eu acho, é tudo que for metal, né, tudo que for metal, tem tendência a dar elétrons, e tudo que for gás tem tendência a receber elétrons. Pergunta: Família 18, doa ou recebe elétron? (Aula atomística, arquivo 11, turno 104, 106 e 108).

Nas narrativas dispostas acima evidencia-se que Melissa tenta induzir, a partir das respostas dos discentes, que estes compreendem os conceitos de atomística. $\mathrm{Na}$ sequência, ao iniciar a construção do conceito de reações redox:

Melissa - O pessoal da família 18 é o que a gente chama de gás nobre, porque, o átomozinho, ele tem, cada átomo tem o seu número de voltinha específico, cada átomo, os que tão ali, desculpa, e cada orbitalzinho aqui tem um número $X$ de elétrons, aqueles caras eles têm o que um átomo precisa pra ficar quietinho, são 8 elétrons na última camada, todos esses outros eles não tem 8 elétrons na última camada, é por isso que eles fazem reações ou ganham e doam elétron, e por aí vai, aqueles cara ali eles estão quietinhos com seus 8 elétrons na última camada, por isso eles são chamados de gás nobre, e eles ficam lá na deles, beleza? Pessoal, aqui, meu apagador. Pessoal, meu 
apaga...eu preciso parar de perder meu apagador (aula de atomística, arquivo 11, turno 111).

Definir íon como sendo:

Melissa - Não. Ele tá com uma carga positiva a mais certo? O nome que a gente dá pra quando o elementozinho não tá neutro, íon. Vocês lembram disso? Vocês já viram isso alguma vez na vida de vocês?

Aluno - Não.

Melissa - É no primeiro ano que a gente vê íons, os íons eles podem ser de dois tipos, eles podem ter cargas positivas a mais, né, eles podem ter mais cargas positivas, tipo o caso desse sódio, e quando eles têm carga positiva eles recebem o nome de cátions. Alguém sabe qual que é o nome que eles ganham quando eles têm carga negativa? Tá com cara de que é nerd.

Aluno - Ânion.

Melissa - Ânions. Então, carga positiva, gente, a minha letra tá muito feia? Pode falar, se eu tiver tento dar uma melhorada viu. Carga negativa. E... Posso dificultar mais?

Aluno - Pode.

Melissa - Vocês vão conseguir se eu dificultar mais?

Aluno - A gente tenta.

Melissa - Posso adiantar mais? Pessoal, agora eu vou entrar com um conceito que eu acredito que seja novo pra todo mundo, o átomo..., pois eu vou falar pra vocês, na próxima aula a gente aprofunda mais, hoje eu vou só apresentar pra vocês. Existem dois fenômenos que acontecem com substâncias quando a gente mexe nela, uma a gente vai chamar se oxidação e a outra a gente vai chamar de alguém sabe o contrário de oxidação? Redução. Esse aqui eu deixo vocês não saberem por que eu aprendi isso aqui só na graduação. Oxidação é o ato de você perder elétrons, se você perder elétrons você tá com carga positiva ou negativa? Positiva. Oxidação, perde elétrons, eu vou representar o elétron só pra facilitar, não ter que escrever elétron. Redução é o ato de você ganhar elétrons, e você tá com carga negativa. Tudo bem até aí? Então, então vamos lá, vocês têm que prestar atenção agora. Elétron e uma carga, se um átomozinho vai lá e perde elétrons, perde pra onde? Existe simplesmente um átomo ir lá e perder elétron assim? Perdi? Do nada? Isso existe? Sempre que algum elemento oxidar, outro tem que reduzir, sempre, porque senão... (Aula atomística, arquivo 11, turno 119-127).

Por não compreender o que era redução, a pibidiana compartilha na lembrança estimulada que "Eu falei perdi em todas as vezes, eu não queria que ninguém ganhasse elétrons, então..." (Lembrança estimulada, arquivo 25, turno 107), sugerindo que não dominava o conteúdo que estava ensinando. Nesse mesmo sentido, na aula de atomística ao discorrer sobre o equilíbrio de cargas, sugere ao aluno esquecer o conceito de redução, como evidencia o diálogo:

Aluno - Então tem que ficar em equilíbrio?

Melissa - Sim, na natureza as coisas têm que ficar equilibradas, certo? Então sempre que eu tiver uma reação química, se um elemento oxida, o outro tem que reduzir obrigatoriamente, ok? Como que eu vou representar com vocês o que acontece, só com elemento que oxida, 
esquece a redução, vamos pensar só na oxidação agora, a gente vai fazer o que a gente chama de semireação. Então eu tenho aqui por exemplo átomo de lítio, a gente tá em qual família? Na primeira, então ele tem tendência a perder ou ganhar elétron? A perder? Perdeu elétron.

Aluno - Perde.

Melissa - É um metal, ele perde elétrons, quantos? Família 1, perde quantos elétrons?

Aluno - 1?

Melissa - 1 . Se ele perde um elétron a gente vai deixar ele assim olha, porque ele recebeu esse maiszinho aqui em cima?

Aluno - Porque ele perdeu.

Melissa - Porque ele perdeu? Alguém dá mais? Ele recebe esse maiszinho porque a carga dele tá positiva, ele perdeu um elétron, tá com a carga positiva, ok? E se eu fizer diferente, ai meu Deus, o oxigênio, oxigênio, vou deixar ele aqui bonitinho. Oxigênio, não. Deixa eu pegar um mais fácil (Aula atomística, arquivo 11, turno 128-136).

Melissa nesses turnos definiu reações redox. Tentou construir o conceito do nível microscópico para o representacional, ou seja, partindo de estrutura atômica caminhando em direção a definição de íons, para, em seguida, apresentar o conceito que permearia a sua aula e a de seu par durante o semestre. Essa sequência foi uma orientação de suas tutoras e, consequentemente, representam suas visões de currículo. Entretanto, Melissa demonstrou despreparo com o conteúdo. O diálogo a seguir corrobora com as limitações conceituais da pibidiana evidenciadas nas narrativas de Melissa:

\author{
Luiza - Posso te ajudar? \\ Melissa - Pode professora. \\ Melissa - Fazer processo ao contrário ((redução)). \\ Luiza - Coloca ferro dois mais, mais dois elétrons, vira ferro zero. \\ Melissa - Eu precisava deixar o sinal de menos no íon. \\ Antônio - Ah, põe gás cloro. \\ Luiza - Há, põe gás cloro, cloreto.
}

Melissa - Vou por cloro. Tem $\circ \mathrm{Cl}_{2}$, alguém sabe por que eu tenho que fazer $\mathrm{Cl}$ dois? E não só $\mathrm{Cl}$ ?

Luiza - Não... então pera aí, é $\mathrm{Cl}_{2}$ mais 2 elétrons é isso? (Aula atomística, arquivo 11, turno 137-146).

Nessa aula que, a priori, tinha o objetivo de partir de atomística para chegar na definição de reações redox, Melissa explica o balanceamento da reação do íon cloro ganhando elétrons:

Melissa - Ele ganhou um elétron, tava com uma carga positiva, ele ganhou um eletronzinho, ficou com carga zero. Pera aí. Só um demonstrativo pra vocês. Pessoal, vocês já ouviram falar num negócio chamado balanceamento? 
Aluno - Sim.

Melissa - Sim, aí que bom! Então vamos lá. Tá balanceada? Não. Têm quantos cloros aqui?

Aluno - Dois.

Melissa - E aqui?

Aluno - Um.

Melissa - Um. O que eu tenho que fazer? O que eu tenho que fazer? Fala, você sabe ((aluna da classe), fala. Tenho que colocar o dois em algum lugar não tenho?

Aluno - Tem que colocar mais uma carga em algum lugar aí.

Melissa - Eu tenho dois cloros, aqui eu tenho um cloro, o que tá faltando aqui? Mais um cloro certo? Então só tinha um eu coloco 2. Tá balanceado agora?

Aluno - Tá.
Melissa - Não.
Aluno - Não?
Aluno - Por causa do menos...

Melissa - Por que não. Eu tenho dois cloros, ok, então são dois cloros que estão com carga negativa, mas aqui nessa reação só mostra o número de um elétron. O que eu tenho que fazer? Ganhar mais um. Beleza? Vamos tentar fazer com flúor? Flúor 2+... Quantos flúor eu tenho aqui? (Aula atomística, arquivo 11, turno 168-181).

Nos trechos acima evidência-se que Melissa não estruturou o conteúdo de forma que o conclua, mas parte para outro conceito que envolve a eletroquímica, sem estabelecer suas conexões. A pibidiana não vislumbrou a relação aluno e conteúdo e, consequentemente, não encaminhou os discentes com explicações que seriam necessárias para que pudessem entender o balanceamento das reações químicas. Melissa reconhece que não consegue explicar o porquê de o cloro ganhar dois elétrons "[...] porque eram dois cloros, cada um ganha um, não expliquei, precisava ter explicado isso" (Lembrança estimulada, arquivo 25, turno 116).

Na aula de atomística Melissa abordou a definição de ânodo e cátodo. E sobre essa definição, em dado momento, a supervisora, na aula de Pilha de moedas (arquivo 12) o retoma:

Luiza - Tá. Bom, então o ânodo é o polo negativo, tá. Pra onde tá chegando os elétrons? Uaí, não tá chegando no cobre? Então o cobre é o ponto positivo, tá? Bom, se a gente lembrar da aula passada que a Melissa explicou, cátodo lembra o quê? Lembra cátion, não é? Cátion não é carga positiva?

Aluno - Sim.

Luiza - E anodo lembra o quê? Lembra anodo, não é? E carga negativa? Certo? Então o catodo é positivo, e anodo é o polo negativo da pilha

Aluno - Nossa, se tivesse falado isso na outra aula tinha ficado mais fácil pra responder àquelas perguntas. 
Melissa - Sério que ficava mais fácil? Isso confunde minha cabeça até hoje (Aula pilha de moedas, arquivo 12, turno 286-289).

A fala da pibidiana representa a dificuldade com o conteúdo, denotando uma necessidade de estudar os conceitos a serem ensinados. Além disto, aponta para a necessidade de uma orientação das tutoras acerca do estudo do conteúdo pelos pibidianos, e não apenas a discussão das estratégias de ensino e das orientações voltadas ao planejamento das aulas, afinal o trabalho do professor está condicionado também pelo domínio do conteúdo.

A pibidiana ao assistir a primeira aula, atomística, reconheceu suas limitações conceituais, sucitando que "[...] não tinha tido isso ((reações redox)), eu não sabia muito bem como explicar isso pra eles, eu fiquei perdida mesmo na hora de passar, eu estava perdida (Lembrança estimulada, arquivo 25, turno 79).

A falta de domínio do conteúdo específico reflete em suas aulas, na qual a postura da pibidiana era inquerir os discentes sobre os conceitos abordados na aula. Melissa discorre que considerou:

[...] que eles já sabiam, ou que a hora que eu começasse a puxar eles iam relembrar que eram conteúdo que teoricamente eles já tinham tido, então eu fui fazendo a aula até um certo ponto partindo de um pressuposto que eles já sabiam, por isso que eu fui lançando perguntas né, mas de repente valesse mais a pena eu não fazer dessa forma de pergunta, apesar de partir do pressuposto que eles já sabiam, fazer de uma forma mais...(Lembrança estimulada, arquivo 25, turno 46).

$\mathrm{Na}$ aula de Revisão (arquivo 15) Melissa deveria retomar a definição de bateria, ânodo, cátodo, pólo positivo e negativo, semi-reação, reação global, fluxo de elétrons, ponte salina, eletrodo, entretanto, o que fez foi apenas elencá-los.

Nos encaminhamentos práticos Melissa volta a demonstrar dificuldades com 0 conteúdo a ser ensinado, que pode ser vislumbrado no trecho:

Melissa - Positivo e negativo. Um polo positivo e um polo negativo. É... Pilha tem aquele negocinho ((refere-se a ponte salina)) lá de ter o fluxo de elétrons, que aí faz a energia. Os elétrons vão da onde pra onde? (Aula de revisão, arquivo 15, turno 25).

As limitações conceituais refletem em uma aula carregada de truncamentos. Um contraponto em sua regência foi no momento que questiona os discentes sobre 0 sentido do fluxo de elétrons:

Melissa - Então a parte positiva atrai elétrons.

Aluno - E a negativa doa elétrons.

Melissa - Isso. Aqui atrai elétrons e aqui emite, emite, doa, o que vocês quiserem.

Aluno - Ou faz a corrosão? Não? 
Melissa - Não, aqui tá bom, tudo bem. Agora vamos lembrar da pilha que o Antônio passou pra vocês na semana passada, aquela longínqua semana lá, que faz tempo já (Aula de revisão, arquivo 15, turno 27-31).

Sobre a afirmação que o elétron é emitido, Melissa diz: "Eu acho que estava no livro que eu li, porque essa palavra não é muito comum no meu vocabulário, então acho que foi do livro, devia estar escrito assim no livro" (Lembrança estimulada, arquivo 25, turno 224). Nos trechos acima Melissa demonstra insegurança com o conteúdo, pois no momento em que o aluno afirmou que o elétron perdido gera uma corrosão, a pibidiana poderia ter explicado o conceito de corrosão. Para o discente sempre que um elemento químico se oxida, ele sofre corrosão, contudo, não estava errado, pois com exceção do $\mathrm{Au}$ e Pt, todos os metais sofreram uma corrosão em menor ou maior intensidade (MAIA et al., 2014). O aluno faz uma afirmação importante. Mas, Melissa, por insegurança ao conteúdo, ignora. Segundo a literatura, a corrosão "[...] é a deterioração de metais, usualmente com perda de material metálico para uma solução, provocada por uma reação redox espontânea" (KOTZ; JÚNIOR, 2002, p.189). Em outro momento da aula o conceito de corrosão e ferrugem voltam à tona quando Melissa estava explicando o funcionamento da Pilha de Daniell, por meio de uma representação, entretanto, mais uma vez ignora a dificuldade conceitual demonstrada pelo aluno, por não entender o que seria corrosão e ferrugem, como pode ser observado nos turnos a seguir:

Melissa - É...A tendência é acontecer o que com essa plaquinha?

Aluno - Ela oxidar.

Melissa - Não, tudo bem, ela oxida, mas visualmente assim?

Aluno - Ela enferruja.

Aluno - Ela vai ficar meio azulada.

Melissa - O que você tinha falado antes.

Aluno - Diminuir.

Aluno - Vai dar uma enxadinha, vai cobrir ela assim.

Melissa - Certo?

Aluno - Vai fazer uma camada de cobre.

Melissa - Isso, vai fazer uma camadinha aí. Certo, muito bem. Tudo bem até aí? (Aula de revisão, arquivo 15, turno 169-179).

A falta de objetividade em suas perguntas impossibilita os discentes compreenderam seus questionamentos. Além disto, Melissa não discute com o aluno a diferença entre corrosão e ferrugem, afinal em dois momentos de sua aula essa confusão conceitual surgiu.

A construção do conceito para os discentes não é realizada por Melissa. A pibidiana segue a aula resolvendo a equação global sem deixar claro para o aluno como 
chegou nesse resultado. Nas aulas, Melissa não relembra o que os alunos deveriam compreender, e relembrar era o objetivo da aula.

$\mathrm{Na}$ passagem a seguir Melissa cita os possíveis estados de oxidação que o chumbo assume, entretanto, não explica seus significados, somente afirma que o 2+ é o mais comum:

Melissa - Agora vou mudar os... Eu vou mudar os eletrodos, eu não quero mais com zinco e cobre, vocês já sabem fazer zinco e cobre. Eu vou colocar aqui o chumbo, ok? E aqui eu vou colocar alumínio. Quando o chumbo tá na forma de íon, a carga dele, a mais comum é qual, vocês sabem?

Aluno - A carga dele?

Melissa - É, o estado mais comum dele, $+2,+3,+4$, mais quanto? Vocês sabem?

Aluno - É do que mesmo?

Melissa - Do chumbo.

Aluno - Eu acho que é...

Aluno - +2

Melissa - +2? É isso mesmo.

Aluno - É, isso aí que eu ia falar (Aula de revisão, arquivo 15, turno 286-294).

Segundo a literatura, o estado de oxidação +2 é o mais estável para o chumbo, pois a configuração dos elétrons mais externos do chumbo é $6 s^{2}$ e $6 p^{6}$, tendendo a perder os elétrons do $6 \mathrm{p}$, para formar $\mathrm{Pb}^{2+}$. Compreende-se que a pibidiana atuava em uma turma da EJA, e o mais coerente era explorar outro exemplo ou apenas discorrer que alguns elementos químicos apresentam diferentes estados de oxidação.

Nessa aula (revisão, arquivo 15) Melissa reconhece que não explicou o balanceamento da reação redox:

Melissa - Eu não expliquei, eu falei que eu ia explicar, aí a menina respondeu eu não expliquei, agora tô escutando.

Pesquisadora - Você ia explicar o porquê, é porque o Alessandro perguntou: "Mas porque corta?" aí você falou: "Ah, é porque o que eu tenho no meu produto eu tenho no meu reagente" aí você pergunta "E o que mais?" A Edna responde "Cobre" e aí... quer voltar?

Melissa - Não, eu acho que não precisa, é porque eu não respondi de imediato, eu falei que eu ia responder, aí a Edna falou, continuou falando a reação global, e antes de eu explicar pra ele eu fui colocando o resto da reação, mas eu expliquei depois (Lembrança estimulada, arquivo 25, turno 266-268).

No final da aula Melissa recorre ao texto que produziu para explicar a bateria automotiva. O texto está disposto na figura 25. 


\section{BATERIA DE CHUMBO}

A bateria de $12 \mathrm{~V}$ usada nos automóveis, também chamada de acumulador de Planté, consiste na associação de seis pilhas ligadas em série, cada uma fornecendo aproximadamente 2V. Sua invenção é atribuída ao francês Raymond Gaston Planté, em 1859.

$\mathrm{O}$ ânodo dessa bateria (polo negativo) é constituído por um grupo de placas de chumbo. $\mathrm{Pb}$, e o cátodo, por uma série de placas de óxido de chumbo IV, $\mathrm{PbO}_{2}$.

A equação da semi-reação do ânodo é:

$\mathrm{Pb}_{(\mathrm{s})}+\mathrm{SO}_{4}{ }^{2-}{ }_{(\mathrm{aq})} \longrightarrow \mathrm{PbSO}_{4}{ }^{2-}{ }_{(\mathrm{aq})}+2 \mathrm{e}^{-}$

A semi-reação do cátodo é:

$\mathrm{PbO}_{2}+4 \mathrm{H}^{+}{ }_{(\mathrm{aq})}+\mathrm{SO}_{4}{ }^{2-}(\mathrm{aq})+2 \mathrm{e}^{-} \rightarrow \mathrm{PbSO}_{4}(\mathrm{~s})+2 \mathrm{H}_{2} \mathrm{O}_{(\mathrm{l})}$

Somando as duas, obtemos a equação da reação global: $\mathrm{Pb}_{(\mathrm{s})}+\mathrm{PbO}_{2(\mathrm{~s})}+4 \mathrm{H}^{+}{ }_{(\mathrm{aq})}+2 \mathrm{SO}_{4}{ }_{(\mathrm{aq})} \longrightarrow 2 \mathrm{PbSO}_{4(\mathrm{~s})}+\mathrm{H}_{2} \mathrm{O}_{(\mathrm{L})}$

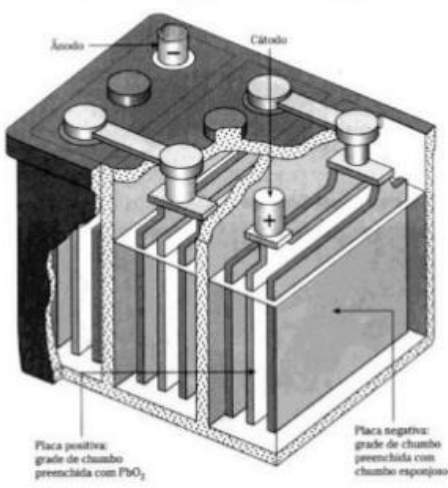

Depósitos de $\mathrm{PbSO}_{4}$ sólido acumulam-se lentamente nas placas. A medida que a produção de corrente prossegue, a bateria vai se descarregando e a solução de ácido sulfúrico (o eletrólito) fica mais diluída. Observando a equeção global, constata-se que, para cada $1 \mathrm{~mol}$ de $\mathrm{Pb}$ que

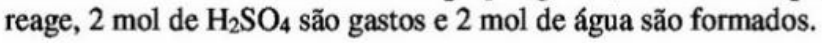

Como saber se uma bateria está gasta? $\mathrm{O}$ teste, que pode ser feito rapidamente em uma auto-elétrica, emprega um densímetro para medir a densidade da solução. Quando a bateria está com carga plena, a densidade está entre 1,25 e $1,30 \mathrm{~g} / \mathrm{cm}^{3}$. Caso a densidade esteja abaixo de $1,20 \mathrm{~g} / \mathrm{cm}^{3}$, a concentração do ácido está baixa e a bateria se concentra parcialmente descarregada.

Figura 25. Texto confeccionado por Melissa sobre a bateria de chumbo

Ao construir a sua narrativa para explicar a bateria automotiva, Melissa discorre que há "[...] formação do sulfato de chumbo e água. É que nessa representação aqui não tá com água nos dois, mas nos dois lados eu tenho formação de água [...]" (Aula de revisão, arquivo 15, turno 15). Entretanto, na oxidação tem-se a formação do hidrônio, enquanto que na redução tem-se a formação de água (KOTZ; TREICHEL, 2002, p.187).

Nas aulas ministradas Melissa não deixa evidente para os discentes a simultaneidade das reações redox (Lembrança estimulada, arquivo 25). Outra problemática no desenvolvimento evidenciada nas aulas, na percepção de Melissa, era que "[...] não estava conseguindo interligar as coisas, parecia que estava duas coisas isoladas era aqui é o esquema, aqui a equação, como se não tivesse ligação, eu estava tentando ver se eu conseguia fazer uma ligação maior entre as duas coisas" (Lembrança estimulada, arquivo 25, turno 256). 
No CoRe adaptado, ao responder ao questionamento $O$ que mais você sabe sobre esta ideia?, a pibidiana descreve "Que as pilhas e baterias funcionam graças a reação redox entre os polos positivos e negativos." A partir da descrição infere-se que Melissa não dominava o conteúdo, pois as pilhas e baterias funcionam a partir do sistema eletroquímico: eletrodos e eletrólito. A diferença de potencial de redução entre os eletrodos ocasiona a reação de oxidação e redução (transformação de energia química em energia elétrica), enquanto o eletrólito viabiliza a condução iônica.

Para preparar-se para lecionar o conteúdo redox, Melissa argumenta que estudou pelo caderno da licenciatura "[...] porque eu não tive nenhum livro no colegial que tivesse esse conteúdo, então eu não tinha, em um primeiro momento eu não tinha pensado nisso de pegar na biblioteca da faculdade nem nada, nem passou isso pela minha cabeça" (Lembrança estimulada, arquivo 25, turno 69).

O conhecimento do tema de Melissa sobre redox era incipiente, apesar de ser 0 objetivo central desse estudo. Considerou-se pertinente explorar o episódio em que Melissa lecionou o conceito de logística reversa, pois não o dominava, demonstrando um despreparo associado aos conceitos que pretendia ensinar. Ao relembrar esse episódio da aula de logística reversa reconhece que não havia estudado o processo de reciclagem de chumbo antes de ensiná-lo:

Melissa - Na verdade foi um pedido dos próprios alunos mesmo, na aula que a gente deu dos vídeos, eles ficaram com essa indagação: "Mas como que recicla o chumbo?" Aí eu fui atrás, porque na hora eu não sabia, que boba tô falando de reciclagem de chumbo, e não sei (Reunião com a dupla, arquivo 23, turno 171).

Para Shulman (1999), o professor deve ter um bom conhecimento do conteúdo para que possa criar representações e situações para o ensinar. Contudo, as aulas de Melissa caminharam em uma direção contrária a proposição do autor, pois a pibidiana demonstrou não ter conhecimento sobre reações de oxirredução, refletindo em uma não compreensão do que Shulman (1987) denominou em seu modelo de Raciocínio Pedagógico e Ação (MRPA), Compreensão, que envolveria o entendimento do professor acerca dos propósitos, estruturas de conteúdo, ideias dentro e fora da disciplina.

De modo geral, a lacuna com relação ao domínio do conteúdo redox, refletiu em uma participação tímida nas reuniões com a coordenadora e em aulas caracterizadas pelo truncamento didático. As construções conceituais da pibidiana eram baseadas no caderno da graduação e, posteriormente, em alguns livros didáticos do ensino médio. Para Carvalho e Gil-Pérez (1995), as pesquisas sugerem que os professores têm limitações com o conhecimento da disciplina que ensinam, tornando-se reprodutores de conteúdos comumente ensinados nos cursos superiores. Além disto, não se observou 
na estruturação desse componente do conhecimento docente de Melissa a influência das tutoras sobre reações redox, exceto quando a ex-coordenadora a sugeriu estudar por livros didáticos do ensino médio. Não emergiram nos documentos evidências sobre os conhecimentos de estruturas sintáticas e substantivas.

\section{Conhecimento pedagógico geral}

Professores em formação geralmente carregam consigo as experiências vivenciadas durante a vida escolar que influenciam suas percepções sobre o que é ser professor, o que seria uma boa aula, entre outros aspectos. Essas lembranças podem compor inicialmente a base de conhecimento desses futuros profissionais. Em consonância, acredita-se que o modo como Melissa manifestou seu Conhecimento Pedagógico Geral esteja relacionado a sua vida escolar na educação básica e na sua curta vivência na licenciatura.

As aulas implementadas por Melissa eram regidas no laboratório da escola, pois segundo a pibidiana permitia "[...] brincar com a demonstração" (Lembrança estimulada, arquivo 25, turno 108) e a formação de grupos. Entretanto, Melissa não propôs nenhuma aula experimental. Em relação à gestão do tempo, a pibidiana dividia a aula na explicação dos conceitos e na resolução de exemplos na lousa.

Em sua trajetória Melissa demonstrou saber gerir a turma nas atividades desenvolvidas. Em outros momentos durante suas regências a pibidiana teve dificuldades com a gestão do tempo, da organização dos conteúdos e atividades, como ocorreu na Aula de revisão:

[...] a gente perdeu tempo demais nos exercícios, aí na hora que chegou pra falar da bateria eu tive que falar em três segundos. Eu só li o texto com eles, esquematizar muito rápido, aí acabou a aula, (Ininteligível 00:22:18) aí a gente passou pra outra aula (Reunião com a dupla, arquivo 23 , turno 134).

Outra situação recorrente que se pode salientar do trecho acima é a dificuldade com a gestão do tempo e as atividades a serem desenvolvidas, o que ocasionou uma preocupação em concluir o planejamento e prosseguir para uma nova fase.

Ao adentrar-se na primeira aula na EJA, Melissa, ao iniciar a regência, apresenta os objetivos do projeto:

Meu nome é Melissa, esse aqui é o Antônio, a gente é do instituto ((nome da instituição)) e a gente tá desenvolvendo um projeto em parceria com a escola chamado Pilha. Nesse projeto nós vamos trabalhar algumas aulas com vocês de uma forma diferenciada. E pra começar a nossa aula, eu quero que vocês se apresentem. Ver se vocês topam falar um pouquinho de vocês só pra saber (Aula de sensibilização, arquivo 10, turno 1).

No trecho acima se observa a preocupação de Melissa em informar aos discentes sobre as aulas que iria ministrar, bem como estabelecer uma relação de Capítulo 4. Resultados e Discussões 
proximidade com os mesmos, demonstrando seu passo inicial com relação a gestão de classe. Na sequência, um aluno solicita à pibidiana que explique a atividade. Melissa, então, orienta os discentes: "Nesse papel que vocês tão recebendo, tem uma situação, e vocês vão em grupo ler essa situação, e discutir juntos a partir das perguntas que vem dessa situação" (Aula de sensibilização, arquivo 10, turno 1). Posteriormente, cada grupo apresentou os argumentos construídos para cada situação problema. O modo como organizou a dinâmica em grupo foi por influência de outro pibidiano que participou de seu grupo, e também por orientação da coordenadora. Nesse sentido, apresenta-se o diálogo:

Maria - Então a gente só poderia fazer um pit stop antes de chegar nesse ponto aí, porque não faz sentido reunir em grupo, entendeu, já que todo mundo vai discutir, só pra ler, lê todo mundo junto então.

Melissa - É uma questão de...

Maria - Agora, o que dá pra fazer é o seguinte, deixa esse grupo pensar um pouco, deixar esse aqui pensar um pouco, esse aqui pensar um pouco, certo, nenhum problema. Aí o que dá pra fazer? Aí eu acho que aí sim poderia ser a leitura em voz alta, porque daí eles falam o artigo, aí: "Ah, esse aqui resolve meu problema" E ele tem que identificar, que aquela... entendeu? (Reunião para saber o andamento, arquivo 8, turno 174-176).

No decorrer da aula de sensibilização Melissa enaltece os discentes sobre as propostas apresentadas para as situações problemas, e posteriormente apresenta 0 objeto de estudo da aula a PNRS:

Vocês estão de parabéns, assim, eu achei que as saídas de vocês foram saídas muito boas, foram muito assim, muito inteligentes, inovadoras, né...E... Assim, porque a gente pediu pra vocês discutirem essas questões nesse início de aula? Porque a gente vai apresentar hoje pra vocês uma política que existe no nosso país desde 2010, que é a Política Nacional dos Resíduos Sólidos, é toda uma política que regulamenta o destino dos resíduos que a gente produz, e a gente veio mostrar pra vocês hoje algumas partezinhas dessa lei, dessa política [...] (Aula de sensibilização arquivo 10, turno 95).

No encerramento da aula a pibidiana explica aos alunos como seriam as próximas regências e retoma os objetivos do projeto a ser desenvolvido:

A partir do nosso próximo encontro, a gente vai começar a entender um pouco da química nos resíduos, aonde que tá a química nos resíduos e aonde que tá o problema no ambiente dessa química. Por isso que foi importante vocês saberem que existe essa lei, porque a partir dessa lei a gente vai começar a entender a química. Ok? Gente, obrigada pela aula (Aula de sensibilização arquivo 10, turno 107).

Nesse componente, ao refletir sobre a aprendizagem dos alunos da EJA na aula de PNRS, Melissa suscitou que buscou analisar as atividades considerando a Taxonomia de Bloom, pois ao analisar o exercício pela taxonomia:

Melissa - [...] a gente já foi logo nas 3 , já foi logo pra criar na primeira aula, e deu certo, eles produziram bastante coisa legal, eu achei até 
que... apesar que é uma avaliação minha, que depois que a gente entregou a lei, não teve tanta diferença na resposta, acho que eles ficaram tão, acho que eles gostaram tanto do que eles inventaram que eles praticamente mantiveram o que já tinham escrito.

Maria - Na realidade acho que a lei colaborou praquilo que eles estavam pensando, eles acabaram achando, encontrando uma resposta legal pra uma solução que eles estavam procurando, que eram soluções bem práticas, eu me lembro que eles falaram de coisas que eram bem acessíveis até se a gente for pensar, se realmente a gente tem um gestor que quer valorizar a relação, que quer colocar em prática aquela ação das baterias, alguma coisa, o que eles estavam pensando eram coisas muito pertinentes, e plausíveis, não era uma coisa do outro mundo, quem recuperar vai ganhar $100 \ldots$.., vai ganhar nada, tá ganhando um desconto... eu lembro que tinha IPTU, que é coisas bem plausíveis. Mas tem outra coisa bacana que surgiu nessa atividade foi a parte deles escreverem, de elaborar texto, não só de discussão, na realidade foram muitas coisas, discussão.

Melissa - É, teve discussão em grupo que dos 4 grupos só teve um que a gente sentiu que eles não se empenharam na discussão, os outros três, a gente viu que tava até frenético, à gente teve que falar: "Gente, chega", vamos passar pra próxima parte, eles estavam super entusiasmados ali (Reunião com a dupla, arquivo 23, turno 26- 28).

Outro aspecto a ser destacado no trecho acima relaciona-se à discussão que Melissa tem com a coordenadora sobre a sua prática de ensino, o que geralmente não é oportunizado nos cursos de licenciatura. Esse espaço de reflexão no subprojeto pode ser vislumbrado como condutor do acesso, construção e reconstrução de conhecimentos docentes, oportunizado desde o início da formação. Entretanto, essa formação diferenciada de fato se processará e refletirá na prática e na formação desses futuros professores, caso tenham uma visão além de reflexiva, crítica sobre sua prática (PERRENOUD, 2002). A propósito, ao refletir sobre a sua participação no Pibid e relatar a sua percepção sobre a sua formação no contexto do subprojeto, Melissa constrói a narrativa:

É, o Pibid é o início, né? Eu sinto muitas vezes..., tem relatos de: "Ah, saí da faculdade e fui meio jogada na sala de aula." Então o Pibid eu acho ele essencial, no sentido que ele é um apoio, porque você não é jogada na sala de aula, você tem durante todo o tempo no mínimo três pessoas, que é o seu grupo, o coordenador e o supervisor, você não tá sozinho ali, então se você se desesperar, tem no mínimo duas pessoas ali com você, e eu acho que isso ah, é a coisa especial do Pibid, então você não tá desamparado na sala de aula (Entrevista semiestruturada, Melissa, turno, 95).

Na regência de atomística Melissa apresenta novamente à turma os objetivos do projeto e da aula que iria ministrar, pois uma das problemáticas vivenciadas na escola conveniada, segundo Melissa, era a irregularidade dos discentes nas aulas "A contagem é de 8 alunos que estavam em toda as aulas, o restante iria uma vez, não ia mais" (Apresentação dos resultados, arquivo 21, turno 7). Nessa aula Melissa demonstrou 
dificuldades em organizar a lousa, e Luiza ao perceber, foi em direção a pibidiana e começou a orientá-la como deveria proceder:

Luiza - Isso, então, por exemplo, acho que facilita, então se você colocar aqui número atômico, tá, é representado pela letra $Z$, tá, é igual número de prótons, é igual a 9 , tá? Então, 9 é um número atômico que é um número de prótons, beleza? Bom, prótons mais nêutrons vai te dá o número de massa, tá certo? Bom, então o número de massa é 19 se eu tenho 9 prótons, eu preciso de 10 nêutrons [...] (Aula de atomística, arquivo 11, turno 80).

$\mathrm{Na}$ sequência, Melissa tenta seguir as orientações da supervisora e busca estruturar a lousa e a sua explicação de modo mais linear. Contudo, a regência continua baseada no estímulo e resposta. Poucos são os momentos que a pibidiana dedica a explicação do conteúdo e a promover a interação dos discentes. Reflexo das limitações com o conteúdo reações redox. No meio da regência Antônio realizou a demonstração do experimento de oxidação da palha de aço em solução de sulfato de cobre, e Melissa, ao retomar a fala, não correlaciona os conceitos que estava desenvolvendo com o experimento, e inicia a explicação do exercício mesmo tendo apenas dez minutos para os discentes o resolverem, como denota os turnos a seguir:

Melissa - Pessoal, vocês conseguem responder esses exercícios rapidinho pra gente? Vocês têm 10 minutos pra fazer.

Antônio - Vamos deixar pra outra aula Melissa?

Melissa - Mas tem 10 minutos, dá pra fazer.

Aluno - A gente vai tentar.

Melissa - Se vocês tiverem dúvida, vocês chamam viu (Aula de atomística, arquivo 11, turno 257-261).

Após o sinal tocar, os discentes insistem em permanecer na sala para finalizarem o exercício "Aluno - Ah, professora ((Luiza)), queremos terminar o exercício" (Aula atomística, arquivo 11, turno 63). O professor de outra disciplina que assumiria a classe concede um tempo para os discentes finalizarem o exercício.

$\mathrm{Na}$ aula de Revisão (arquivo 15) Melissa passa a instruir os discentes: "Eu aconselharia vocês a fazerem anotações do que eu vou passar na lousa, porque vocês vão precisar disso mais pra frente (Aula de revisão, arquivo 15, turno 19). Esse direcionamento não foi realizado na primeira regência. Sobre essa questão, a pibidiana comenta que não havia "[...] parado pra pensar nisso, acho que seria interessante eu ter avisado pra eles, é que como eu fui acostumada a fazer isso (...) nem passou pela minha cabeça de avisar isso: 'Gente, vai lá e anota'. Mas eu podia ter avisado” (Lembrança estimulada, turno 42).

Os questionamentos adotados por Melissa em suas regências parecem ser direcionados a quem pertence a área de química, além disto, não apresentam as definições relacionadas aos tópicos revisados. Talvez o não domínio dos conceitos Capítulo 4. Resultados e Discussões 
químicos tenha refletido em uma aula na qual o aluno se tornou responsável em entrelaçar os tópicos e dominá-los antes mesmo de a revisão realizada por Melissa. Ademais, em diversos momentos a pibidiana demonstra que os discentes deveriam responder a seus questionamentos quando os indagassem:

Melissa - Você tá respondendo antes de eu perguntar criatura, vocês são espertos demais.

Aluno - Oh, muito obrigado, eu me sinto lisonjeado (Aula de revisão, arquivo 15, turno 158-159).

Diferentemente da aula de atomística em que Antônio também fez um experimento demonstrativo, Melissa retoma a aula de revisão (arquivo 15) relacionandoa com a parte experimental:

[...] Porque eu precisei passar tudo isso aqui pra vocês? Nada mais justo do que entender como funciona a bateria de chumbo antes de eu começar a falar sobre ela, certo? A bateria de chumbo acontece exatamente, exatamente não, mais ou menos o que acontece com a pilha de Daniell, com aquela pilha que a gente fez ali, com aquelas pilhas que eu mostrei no quadro, o processo é igualzinho pra qualquer pilha existente na face da terra. Qual que é a da bateria? Baterias são pilhas em série como Antônio já bem disse, aquilo ali a gente pode considerar como uma bateria porque são duas pilhas em série. A bateria de carro é exatamente isso, só que uma voltagem de (Aula de revisão, arquivo 15 , turno 523 ).

$\mathrm{Na}$ percepção da pibidiana, na aula de atomística, apesar de vislumbrar a possibilidade de fazer essa relação com a parte experimental, não havia conseguido, como sugere a narrativa abaixo:

Isso é uma coisa até que eu percebi que às vezes por mais que eu tivesse com o esquema do lado, que eu tivesse com a conta, com a conta não, com a equação, e que o Antônio tivesse feito o experimento demonstrativo, eu estava sentindo que eu não estava conseguindo interligar as coisas [...] (Lembrança estimulada, turno 256, arquivo 25).

No final da aula, não havendo mais tempo para que os discentes resolvessem os exercícios, a pibidiana os orienta "Esse aqui vocês me entregam do jeito que tá e a aula que vem eu deixo vocês terminarem, tá? Devolve só esse" (Aula de revisão, arquivo 15, turno 567). Em consonância, na aula de contaminação por chumbo (arquivo 16) Melissa solicita que os discentes entreguem a atividade da aula passada. No final dessa regência, apesar de Antônio a ter lecionado, Melissa é quem instrui os discentes na entrega da atividade avaliativa que em virtude da falta de tempo os deixa entregar na aula seguinte. Contudo, na reunião com a coordenadora:

Maria - Como foram as produções, eles conseguiram fazer ((aula contaminação por chumbo))?

Melissa - Então, esse é o problema, não deu tempo.

Maria - Gente, eu vou esganar vocês, eu falei para fazer.

Antônio - Ai meu Deus.

Capítulo 4. Resultados e Discussões 
Melissa - Ah meninos, eu falei.

Antônio - Eu vou falar, deixa ela se defender e eu vou falar.

Melissa - Na outra aula, que eu tinha passado da pilha de Daniell, tinha lá as oito perguntinhas, eles não conseguiram terminar naquela aula, então nessa aula eu perdi quase 15 minutos, para terminarem essa e aí eles se empolgaram com a discussão, a gente foi discutindo, eles foram se empolgando, a Luiza se empolgou também.

Antônio - A Luiza tomou muito tempo nosso, nossa.

Melissa - Muito. Então não deu tempo, então a gente pensou que eles poderiam fazer em casa, a gente está rezando para eles trazerem nessa quarta-feira (Reunião para saber o andamento, arquivo 17, turno 7-15).

Pelas vivências anteriores com a gestão do tempo, Melissa demonstra compreender que as atividades devem ser organizadas com base na distribuição do tempo disponível:

Eu acho que a gente podia fazer isso na sala, a gente explicar como vai ser o panfleto, dividir os grupos e falar... e usar sei lá 10 minutos para eles discutirem o que eles acham o que é importante por, pra na aula seguinte fazer a questão do manual, pra eles começarem a digitar (Reunião para saber o andamento, arquivo 17, turno 56).

Melissa em sua última aula, logística reversa, demonstra um domínio maior acerca das instruções a serem concedidas aos discentes "Ah, vai copiando conforme eu vou falando, não tem pressa, tem a aula inteira ainda" (Aula logística reversa, arquivo 18, turno 1).

Posteriormente à sua experiência na EJA, Melissa, ao refletir sobre a sua prática, aponta os aspectos que mudaria em suas aulas:

É, por exemplo, se fosse um, se eu tivesse liberdade total pra dar aula, talvez eu tentasse fazer assim, reservar uma aula e aí eu faço a aula inteira de exercício pra gente resolver junto, porque eu acho legal e interessante a coisa de fazer exercício em sala, em grupo, porque eu acho que o aluno pensa melhor quando ele está pensando junto com outro, mas não toda aula, toda aula eu acho que come tempo, come tempo de discussão, por exemplo, a aula que a gente fez dos vídeos, que a gente precisou ficar naquela, quando que para? Para a discussão pra dar o exercício, se vai com a discussão até o final e passa o exercício em casa (Lembrança estimulada, arquivo 25, turno 240).

Nesse trecho se observa que a experiência oportunizada pelo Pibid levou a licencianda a rever sua prática e suas escolhas relacionadas à gestão do tempo.

Ao final de sua trajetória no Pibid Melissa reconhece a importância do programa para a sua formação em virtude de a experiência na prática e de a tutoria que recebeu dos professores experientes no preparo das aulas e na seleção dos conceitos a serem abordados:

Bom! Eu acho o Pibid nesse sentido...Primeiro a questão da montagem das aulas né? Que toda aula que a gente monta, ela tem que ser 
avaliada, tanto pelo supervisor, quanto pelo coordenador né? é raro uma aula que a gente chega aqui sem nenhum dos dois terem visto, então tem essa coisa do crescimento, de a gente ver, e falar: "olha isso aqui não tá bom, isso aqui tá sem nexo, isso aqui tá grande demais'. Então sempre tem essa ajuda. E acho que é isso (Entrevista semiestruturada - Melissa, turno 67).

A importância do Pibid para a sua formação como futura docente compõe diversos trechos das narrativas de Melissa, bem como de seu relatório anual individual. Em consonância, apresenta-se trechos que denotam a importância do subprojeto para o planejamento das regências e para a sua formação docente:

Eu acho que o papel, a importância, pelo menos que eu vejo, a importância do Pibid é justamente a gente não ser jogado na sala de aula, então o supervisor está ali, justamente pra cumprir esse papel de não deixar a gente simplesmente jogado ali, dar uma apoio, então se ver sei lá viu a gente se desesperou, que a gente esqueceu alguma coisa, os professores estão ali pra somar, e acho que pra dar um feedback depois pra gente, que a gente só tem como, no nosso caso a gente está tendo você que gravou nossas aulas, mas e se a gente não tivesse? Quem tem que dar o feedback pra gente se a aula deu certo se não deu é o supervisor, até porque o coordenador ele monta as aulas, as atividades com a gente, mas ela não tem como ver o que a gente está fazendo na sala de aula, quem vê é o supervisor né. (Lembrança estimulada, arquivo 25, turno 373 ).

Aplicar as aulas no Pibid ajudou na minha formação, pois a cada aula uma atividade precisava ser feita para poder ser aplicada para os alunos. Cada atividade precisava ter um objetivo, e a todo o momento era necessária uma reflexão acerca das atividades, pois elas não poderiam fugir do tema que precisava ser exposto (Relatório anual individual - Melissa).

Em relação aos desafios no interior do Pibid a pibidiana ressalta a dificuldade do trabalho em grupo, pois apesar da boa interação entre os membros e na divisão das tarefas

[...] de forma que ambos fizeram a mesma quantidade de atividades. Porém não houve uma quantidade razoável de reflexões, discussões e montagem de atividades em grupo. A maioria as atividades foram montadas individualmente; talvez montagens em grupo possibilitassem atividades mais ricas (Relatório anual individual - Melissa).

Ao responder o ciclo reflexivo antes de assistir a suas regências, Melissa constrói suas percepções sobre a ação Descrever e Confrontar, dispostas na tabela 12. 
Tabela 12. Resposta concedida por Melissa ao ciclo reflexivo antes de assistir as regências

\begin{tabular}{|c|c|c|}
\hline Ação & Questão & Descrição \\
\hline Descrever & O que faço? & $\begin{array}{l}\text { Os alunos ficam divididos em bancadas, ou seja, } \\
\text { estão em grupo. Eu utilizo a lousa para trabalhar } \\
\text { o conteúdo. }\end{array}$ \\
\hline Confrontar & $\begin{array}{l}\text { Quem tem poder em minha } \\
\text { sala de aula? A que } \\
\text { interesse minha prática esta } \\
\text { servindo? Acredito nesses } \\
\text { interesses ou apenas estou } \\
\text { reproduzindo? }\end{array}$ & $\begin{array}{l}\text { O poder na sala de aula é mútuo, professor e } \\
\text { aluno conversam, evito situações em que apenas } \\
\text { eu falo. O grupo procurou instigar os alunos a } \\
\text { pensar em situações do cotidiano, para que os } \\
\text { conteúdos fizessem sentido. } \\
\text { Acredito nos interesses dessas aulas, apesar de } \\
\text { reconhecer que nem todos os conteúdos serão } \\
\text { ensinados, } 1^{\circ} \text { para o maior entendimento do } \\
\text { fenômeno e } 2^{\circ} \text { para que o aluno possa ter } \\
\text { contato com a linguagem científica. }\end{array}$ \\
\hline
\end{tabular}

A narrativa de Melissa sobre sua escolha profissional, é um contraponto em relação aos dados disponibilizados em pesquisas, como denota os turnos abaixo:

Bom, licenciatura, porque eu já tinha ideia de dar aula já fazia um tempo, e química, porque eu descobri que a matéria que eu gostava, dentre as matérias possíveis, era química.

Sempre, não sabia do que, mas que ia ser professora, eu sabia.

((risos antes de responder)) Não sei, pra mim é... Eu gosto de ensinar, sempre que tinha alguma oportunidade na escola mesmo de eu poder ajudar alguém, explicando alguma coisa, eu sempre gostei, e pra mim é uma coisa que é desde pequena, não sei muito bem o porquê (Entrevista semiestruturada - Melissa, turno 10, 12, 15).

Geralmente a licenciatura não é a primeira opção dos candidatos a um curso superior, e quando o futuro graduando opta pela licenciatura em química é consequência do seu desejo em seguir uma carreira que envolva conhecimento químico (SÁ; SANTOS, 2016). Com relação aos conhecimentos que seriam essenciais para a profissão docente, Melissa considera a linguagem, pois

[...] tem professor que sabe muito bem explicar, mas é pobre em conteúdo, e tem o contrário, professor que sabe muito, que você vê que é muito inteligente, mas que ele sabe só pra ele, tem professor que ele tem um conhecimento, tem um conteúdo, e ao mesmo tempo sabe expor o conteúdo (Entrevista semiestruturada - Melissa, turno 73).

Melissa demonstrou no início de sua vivência no Pibid uma preocupação com a gestão do tempo e da classe. Ao longo de sua trajetória conseguia manter a gestão da classe, apesar de sua aula ser baseada no estímulo-resposta. O espaço do programa de iniciação à docência oportunizou à pibidiana vivenciar a gestão de classe, seja por meio da instrução das atividades a serem desenvolvidas pelos discentes, como pela solicitação que os alunos mantivessem a disciplina e ordem para que as atividades fossem realizadas. Por outro lado, não demonstrou preocupação com o entendimento dos discentes sobre os conceitos lecionados, mas apenas em aplicar os exercícios. 


\section{Conhecimento do contexto}

O conhecimento relacionado aos estudantes, à comunidade, ao bairro e à escola, pouco emergiu nas narrativas de Melissa. Esse conhecimento aparece timidamente, pincipalmente, na entrevista semiestruturada e no relatório anual individual. No relatório anual que produziu, Melissa argumenta:

A escola conveniada dispunha de material e espaço que eram necessários para a realização das atividades, e não houve resistência por parte da coordenação para que os bolsistas usassem esses materiais (como, por exemplo, o projetor). A escola também está localizada em um local que é muito propício para a discussão do assunto, uma vez que está em uma região que por muito tempo foi usada para descartar baterias, e hoje ainda dispõem de várias mecânicas, oficinas, auto elétricas e lojas voltadas para as baterias automotivas (Relatório anual individual - Melissa).

Os conhecimentos de Melissa sobre o contexto, a priori, tinham como fonte de informação os relatos da supervisora:

Luiza - E por exemplo, ali na Salvador Simões, tem uma casa lá que há 30 anos atrás, ali no alto do Ipiranga pertinho do metrô, na Salvador Simões, tem uma casa que só vende somente bateria, aliás eu já comprei bateria para o outro carro lá, entendeu, que o dono da oficina, a filha dele foi minha aluna (Reunião para saber o andamento, arquivo 9, turno 87).

O conhecimento do contexto demonstrado por Luiza influencia diretamente o que Melissa sabia sobre a região da escola conveniada: "Bom, a região também é superinteressante pro nosso projeto, nosso projeto falava de pilhas e baterias, e essa é uma região que tem muita loja voltada pra isso, muita loja que trabalha com auto elétrico" (Apresentação dos resultados, arquivo 21, turno 5). Apesar de a discussão dos resultados com as tutoras sobre como a temática da contaminação de chumbo permeava o universo da instituição da educação básica, pouco dessa problemática da região foi pesquisado e, consequentemente, pouquíssimo discutido nas aulas.

Por meio da participação no Pibid, ao término de sua vivência na turma da EJA Melissa reconheceu a importância de "[...] ter o conhecimento do público que ele tem, né? Porque você adequa o jeito que você está passando, pelo seu público, de todos os jeitos: idade, tribo, lugar que mora... tudo isso influencia no jeito que você pode tá passando uma mensagem" (Entrevista semiestruturada - Melissa, turno 77).

$A$ vivência no futuro ambiente profissional possibilitou à Melissa reconhecer que os discentes da EJA tinham um diferencial dos alunos do ensino médio regular, pois "[...] no supletivo (EJA) eu vi que eles estão mais interessados, mas no regular eu percebi um descaso muito grande com o que tá sendo passado (ensinado), e... então bateu com o que eu já tava imaginando" (Entrevista semiestruturada, Melissa, turno 83). 
A trajetória de Melissa no Pibid suscitou um repertório básico sobre 0 conhecimento da instituição escolar e do bairro. Entretanto, nenhum elemento referente ao conhecimento sobre os alunos e suas origens estruturam as suas narrativas.

\section{Orientações para o ensino de ciências}

Esse componente do PCK é constituído pelas Crenças sobre as propostas de aprendizagem em Ciência e Decisões sobre o fazer no Ensino, além das Crenças sobre a natureza da Ciência que emerge em apenas um dos documentos apreciados. Com relação às Decisões sobre o fazer no ensino, observou-se nas aulas que grande parte dos encaminhamentos práticos era na verdade o Conhecimento Pedagógico Geral de Melissa, pois infere-se que por não ter um conhecimento do conteúdo redox, estruturou e conduziu parte de suas aulas, independente do conteúdo específico. Entretanto, em alguns episódios das aulas, inicia de modo tímido a construção de suas Decisões sobre o fazer no Ensino para ensinar conceitos envolvendo redox. Na estruturação e escolha dos conceitos químicos a serem desenvolvidos nas aulas, sempre recorreu às orientações das tutoras. Para clarificar esses apontamentos iniciais se adentrou em trechos dos documentos que revelaram as propostas de aprendizagem e o início da construção das decisões sobre o fazer no ensino de Melissa.

Os caminhos trilhados por Melissa na confecção do projeto de ensino apresenta as influências da coordenadora no processo de planejamento e na eleição dos encaminhamentos práticos da pibidiana. Nesse sentido, dispõe-se no trecho a seguir a primeira reunião em que os pibidianos apresentaram às tutoras as propostas de aulas a serem implementadas na EJA:

Melissa - Então o que você ((Maria)) acha que tá precisando mudar é a sensibilização?

Maria - Então Melissa agora a gente vai pra uma outra etapa que seria a etapa da gente conversar o que vocês produziram, de repente agora a gente consegue arranjar, rearranjar e moldar pra fazer essa sequência, o importante que a gente tenha assim, a nossa alma seja nesse envolvimento do CTS, do cidadão, do problema, do aluno envolvido, então isso é muito importante porque daí norteia as outras etapas, ok, entenderam? (Reunião para saber o andamento, arquivo 7 , turno 129-130).

As orientações da coordenadora eram constantemente requeridas pela pibidiana. Melissa considerava as diretrizes propostas por Maria "[...] essencial no quesito deixar a aula boa, né? Muitas vezes a gente monta uma aula, mas como a gente está iniciando esse processo, ainda acaba ficando alguma coisa pingada, uns negócios meios sem nexo, então, a Maria no nosso caso [...]" (Entrevista semiestruturada Melissa, turno 47). Nessa mesma perspectiva, Melissa apesar de vislumbrar possíveis 
estratégias, conteúdos, avaliações, entre outros, recorria à orientação de Maria para decidir os encaminhamentos para as próximas regências:

Melissa - E de qualquer forma faltou muita gente, e eu tava pensando se vale a pena a gente começar com algum outro ou já começar essa semana com a realização do projeto ou se vale mais a pena a gente usar essa aula para eles terminarem essas questões.

Maria - Ah, eu acho que vale a pena, senão vocês vão perder essa vaga.

Melissa - E aí usar, porque eu queria falar um pouquinho de logística reversa [...]. Seria uma aula rápida, só para falar de logística universa e aí eles terminam esse texto, se bem que os que fizeram vão ficar putos com a gente, mas...

Maria - O que a gente pode fazer, é fazer o fechamento dessas atividades, porque eles vão responder aquelas perguntas e retomar essa pergunta, retomar, de fechar, de discutir mesmo (Reunião para saber o andamento, arquivo 17, turno 21-24).

$\mathrm{Na}$ reunião com a coordenadora, Melissa expôs as Decisões sobre o fazer no ensino, pensadas para a aula de logística reversa:

Eu acho que a gente podia fazer isso na sala, a gente explicar como vai ser o panfleto, dividir os grupos e falar... e usar sei lá 10 minutos para eles discutirem o que eles acham o que é importante por, pra na aula seguinte fazer a questão do manual, pra eles começarem a digitar (Reunião para saber o andamento, arquivo 17, turno 56).

Ao refletir sobre os encaminhamentos implementados nessa regência (logística reversa), Melissa reconstrói para a coordenadora como a aula foi conduzida:

Bom, essa aula a gente dividiu em duas partes, a primeira parte da aula eu fiz dois esquemas na lousa, um dos esquemas era explicando como que poderia acontecer o processo de logística reversa pra bateria automotiva, que foi baseado em como que a empresa Moura que é de bateria automotiva faz a parte de logística reversa dela, então eu fiz um esquema no quadro que vai desde a produção, da matéria prima, até chegar no consumidor, como que faz a volta, como que vai parar na revenda, e fiz um outro esquema que era de como funcionava a reciclagem da bateria, foi muito legal porque eles estavam interessados, não ficou aquela coisa tipo, não estou entendendo nada, como é que tá funcionando, eles perguntavam, eles se interessavam, surgiu até umas perguntas assim, não esperava que eles fossem fazer, e eles fizeram, mostrou o interesse deles que eles estavam entendendo o que eu estava falando, porque se eles não tivessem entendendo não teria surgido o tipo de pergunta que eles fizeram. E aí a segunda parte a aula a gente pediu pra eles fazerem o panfleto, eu dividi eles em vários grupos, mas eles acabaram por questão de amizade dividiram ali, e ficaram 4 grupos, e eles fizeram à mão mesmo o cartaz, e ficou bem legal, eles exploraram a parte artística, foram criativos, e foi interessante pra gente que esses panfletos, eles foram diagnósticos, porque deixou claro o que foi que ficou neles, de informação, então a parte que a gente queria que eles entendessem que era como funcionava a logística reversa, a importância do consumidor estar participando, qual o papel dele, as doenças, tudo eles colocaram no cartaz, então ficou bem legal [...] (Apresentação dos resultados, arquivo 21 , turno 48 ). 
Como mencionou-se no componente Conhecimento do tema, Melissa não dominava os conceitos relacionados ao conteúdo de química e a problemática da logística reversa, que por vez permeou a reciclagem do chumbo, e mesmo acreditando que para exercer a profissão seria fundamental o professor dominar o conteúdo específico e os pedagógicos, não reconheceu em sua ação didática que não dominava conceitualmente o que propunha ensinar. Além disto, Melissa não buscou estruturar suas decisões sobre o ensino, refletindo em uma ação didática que independe do conteúdo.

Ao responder ao CoRe 2. Por que é importante para os estudantes saberem esta ideia? Descreve: "Pois as pilhas e baterias estão muito presentes no cotidiano das pessoas, portanto conhecer seu funcionamento tanto físico quanto químico auxilia as pessoas a usarem esses materiais com mais consciência. Esse conteúdo também permite discussões acerca do descarte inadequado desses materiais e as consequências para o meio ambiente." Suas percepções revelam um ensino orientado pelo rigor acadêmico.

Ao término das atividades desenvolvidas pelos membros do subprojeto, Melissa descreve no relatório que os processos formativos, personificados na figura da coordenadora Maria, supervisora Luiza, e as experiências na escola, são fundamentais para a sua formação docente:

O subprojeto contribui para a formação como educador, primeiramente,
porque demanda estudo sobre educação. A metodologia CTS foi um
desafio a ser vencido durante todo o desenvolvimento das atividades,
o que demandou reflexão, discussão, debate, troca de ideias e
experiências entre bolsistas, coordenadores e supervisores. Acredito
que essa troca seja uma peça fundamental na formação para uma
carreira como docente [...] A convivência na escola para um professor
em formação é de extrema importância uma vez que forma um
professor mais experiente e preparado; e com a vantagem de que
durante o processo do Pibid o bolsista não está sozinho. Todas as
orientações que são dadas na montagem de cada atividade ajudam
tanto no aperfeçoamento do subprojeto quanto para formar um
professor com uma visão de aulas diferenciada, o que pode ser um
destaque para a carreira docente (Relatório anual individual - Melissa).

Como os projetos desenvolvidos pelos pibidianos permeavam a CTS, Melissa argumenta que buscou o equilíbrio entre o conteúdo químico e os conceitos da logística reversa "devido à realidade dos alunos, a gente busca a química, mas no sentido muito mais social, assim, menos números, menos fórmulas, menos equações, e mais coisas relacionadas à vida deles, né?" (Entrevista semiestruturada - Melissa, turno 49).

Em relação à organização do conteúdo a ser lecionado, ao ser questionada pela Pesquisadora, Melissa argumenta que "[...] foi orientado pra gente que provavelmente eles teriam uma base ruim, e que se a gente entrasse no conteúdo de eletroquímica de 
uma vez eles não iam entender nada do que a gente estava falando [...]" (Lembrança estimulada, arquivo 25, turno 34).

O não domínio do conteúdo redox por Melissa refletiu diretamente em suas Decisões sobre o fazer o ensino de ciências, pois ela exime-se da responsabilidade de revisar os conceitos, o que a leva a acessar seu Conhecimento Pedagógico Geral em praticamente todos os episódios que ensinou o conteúdo especifico. A insegurança demonstrada pela pibdiana nas regências era "[...] porque justamente por eu não, primeiro porque o conteúdo era novo, segundo porque eu não tinha tido isso, eu não sabia muito bem como explicar isso pra eles, eu fiquei perdida mesmo na hora de passar, eu estava perdida" (Lembrança estimulada, arquivo 25, turno 79).

Na última aula ministrada sobre logística reversa, Melissa no relatório final realiza a descrição da aula, como observa-se no quadro 19.

Quadro 19. Descrição da aula de logística reversa (Fonte: Relatório anual - Melissa) Primeiramente foi feita uma explicação na lousa sobre as etapas envolvidas na logística
reversa. Para isso utilizou-se uma pesquisa realizada sobre a empresa de baterias
automotivas Moura, sobre como ela aplica a logística reversa. No quadro foi escrito um
diagrama com o processo desde a matéria prima até a fabricação do material reciclado:

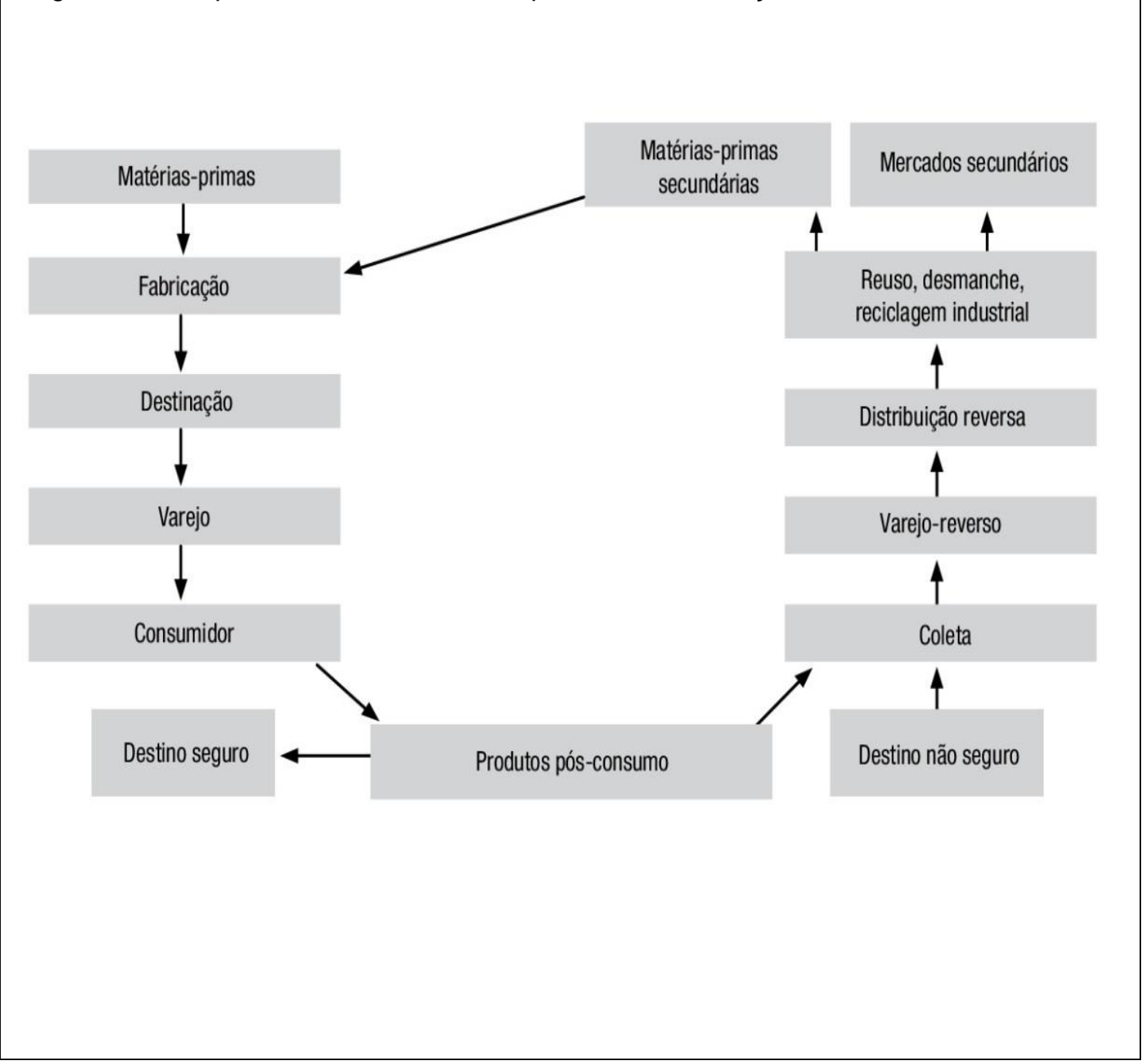




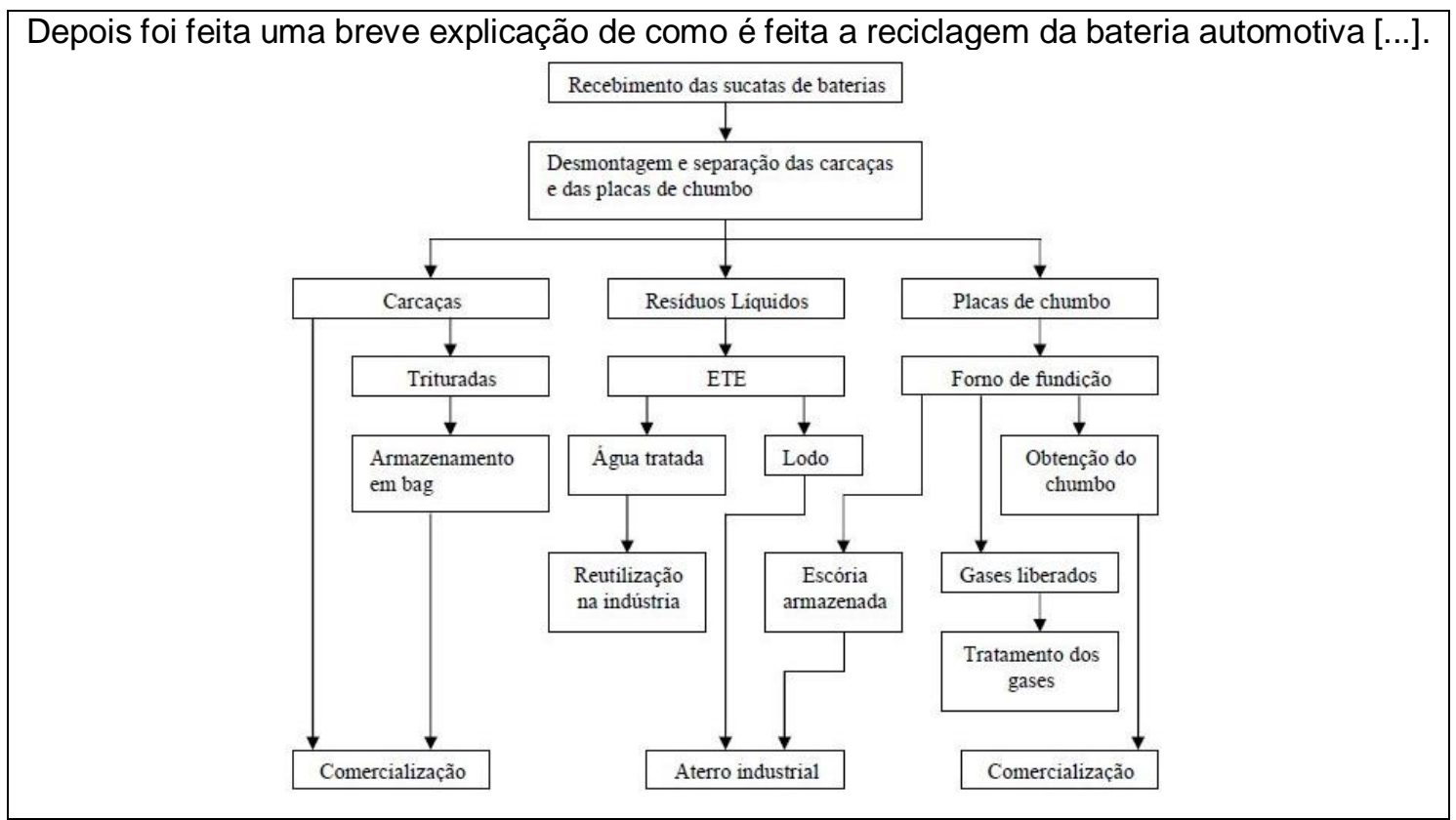

Retomando-se a análise da aula de revisão (arquivo 15) essa refletiu as orientações das tutoras a Melissa, como suscita o diálogo:

Melissa - Mas e aí, o que a gente faria nessa aula, agora dia 22?

Maria - Explicar, fazer link entre...vocês discutirão o que era uma pilha.

Luiza - Retomar os conceitos que vocês trabalharam na aula anterior, tá, então vocês não trabalharam com a pilha de Volta?

Melissa - Sim.

Luiza - Então, e aí você retoma esses conceitos, quer dizer, a questão do eletrólito, da necessidade do eletrólito.

Maria - Quem é o cátodo.204

Luiza - Quem é o cátodo, quem é o ânodo.

Antônio - A Melissa não foi na última aula, mas eu retomei esses conceitos na última aula.

Maria - Teoria não foi?

Antônio - É, foi só teoria, e eu usei a pilha de Daniell pra explicar.

Luiza - Aí você explicou a pilha de Daniell, aí eles ficaram duas semanas sem aula, você acha que esses caras lembram alguma coisa? Pelo que você conhece eles? (Reunião para saber o andamento, arquivo 14, turno 199-2009).

$\mathrm{Na}$ aula de revisão Melissa abordou os estados de oxidação, adotando como exemplo o chumbo, como havia sido acordado com a coordenadora (arquivo 14). Durante a aula discorreu que o alumínio poderia assumir dois estados de oxidação diferente, mas não explica qual seria o mais estável e a diferença entre ambos. No trecho abaixo, apresenta-se o diálogo que retrata o momento que Melissa aborda o Nox:

$$
\begin{aligned}
& \text { Aluno - É do que mesmo? } \\
& \text { Melissa - Do chumbo. } \\
& \text { Aluno - Eu acho que é... }
\end{aligned}
$$


Aluno - +2

Melissa - +2? É isso mesmo.

Aluno - É, isso aí que eu ia falar.

Melissa - E a do alumínio?

Aluno - Do alumínio eu acho que é...

Melissa - A do alumínio tem duas que é muito comum, né, nessa daqui a gente vai usar.

Aluno - +4 não é não?

Melissa - Não. +3 tá bom? Esse trequinho esponjoso vai ser a nossa ponte salina dessa vez, ok? A informação que o exercício dá pra gente, único exclusivamente é o seguinte: aqui acontece corrosão, eu preciso terminar de escrever as palavras, e aqui acúmulo, aqui tem acúmulo e aqui tem corrosão. Vamos fazer a mesma coisa que a gente fez do outro, dessa vez mais rápido já que vocês estão manjando, vocês já sabem. O elétron tá indo de onde pra onde? (Aula de revisão, arquivo 15, turno 290-300).

No diálogo acima Melissa questiona os discentes sobre qual o Nox do chumbo e do alumínio, e apesar de um dos alunos responder corretamente para o chumbo, não compreende qual o Nox era mais estável do alumínio. Talvez pela carência de conceitos que permearam as explicações de Melissa, que mais uma vez demonstra ter limitações com o conteúdo, suas decisões sobre o fazer no ensino estão associadas a falta de um domínio de conceitos químicos e ao seu Conhecimento Pedagógico Geral.

Na percepção de Luiza, as aulas ministradas (atomística, pilha de moedas e pilha de Daniell) por Melissa e Antônio necessitavam de um fechamento do conteúdo, pois os pibidianos mudavam de "[...] assunto sem fechar, entendeu? Eu acho que fica muito... parece uma peça de teatro que eu assisti no sábado (...) apagava a luz e mudava de assunto totalmente, não tinha nada a ver o assunto de antes, parece que ficava totalmente perdido" (Reunião para saber o andamento, arquivo 14, turno 10).

No ciclo reflexivo emergem elementos sobre os caminhos escolhidos na ação didática de Melissa. Nesse sentido, dispõe-se na tabela 13 as respostas concedidas pela pibidiana ao instrumento.

Tabela 13. Resposta concedida a Ação-Reconstruir (ciclo reflexivo) por Melissa antes e depois de assistir as regências.

\begin{tabular}{lll}
\hline \multicolumn{1}{c}{ Ação } & \multicolumn{1}{c}{ Antes } & \multicolumn{1}{c}{ Depois } \\
\hline Reconstruir - Como & Acho que os experimentos poderiam ter & Dando mais subsídios para \\
posso agir de forma & sido mais "mastigados" tentando que eles possam responder \\
diferente & $\begin{array}{l}\text { trabalhar fenômeno e teoria as questões [...] } \\
\text { simultaneamente, e não em aulas } \\
\text { diferentes }\end{array}$ & \\
\end{tabular}

A descrição de Melissa no ciclo reflexivo, revela que a pibidiana não percebia um entrelaçamento entre as aulas teóricas e experimentais, mesmo as que Antônio desenvolveu de modo demonstrativo ao término das aulas teóricas desenvolvidas pela 
pibidiana. Talvez esse hiato esteja fundamentado na problemática relacionada ao trabalho em grupo que influenciou nas propostas de ensino:

[...] A dupla teve uma boa interação e as tarefas foram divididas de forma que ambos fizeram a mesma quantidade de atividades. Porém não houve uma quantidade razoável de reflexões, discussões e montagem de atividades em grupo. A maioria das atividades foram montadas individualmente; talvez montagens em grupo possibilitassem atividades mais ricas (Relatório anual individual - Melissa).

Para a coordenadora o processo de elaboração das aulas pelos pibidianos foi construído em um complexo ambiente de negociação entre os seus anseios, o da supervisora e dos pibidianos. Para Maria esse espaço tem oportunizado a aprendizagem de todos os participantes do Pibid. Nesse sentido, no trecho a seguir Melissa foi orientada por Maria a confeccionar o relatório final englobando os aspectos:

[...] Qual foi...como foi conduzido o trabalho, porque no fundo a gente pode depois compartilhar essa experiência com outras pessoas, porque fazer todo esse caminho que vocês percorreram, foi um caminho bastante árduo se a gente for pensar, imagina todas as vezes que a gente sentou pra gente discutir uma intervenção, como seria, qual era o objetivo, adequar o que cada um de nós... porque no fundo nós tínhamos vocês dois fazendo propostas, lembra o tanto de propostas que vocês fizeram? Aí batia aqui, aí a gente discutia num primeiro momento, aí passava para o segundo momento, terceiro momento, primeiro momento de vocês, segundo momento nosso, terceiro momento com a Luiza, lembra? Foi um negócio bastante árduo, então tudo que foi feito aqui foi algo muito pensado, muito discutido, então eu acho que essa experiência a gente tem que ser criterioso na hora de colocar no papel e enriquecê-la bastante, porque é uma experiência bastante produtiva se a gente for pensar, é difícil o momento que você tem de discutir com tantas pessoas, e pessoas com visões tão diferentes, porque vocês tem um universo de reflexão, aí chegaram comigo, que eu também tenho outro universo, a gente incorporava, tirava coisas, e aí a gente levava pra um outro universo que é o universo da Luiza, que é o universo da escola conveniada. Então, tudo que foi feito aqui passou por diferentes discussões, diferentes crivos, e eu não sei se na vida de vocês, nas próximas experiências de vocês, vocês vão ter tantas oportunidades assim, pelo menos de tratar um assunto, de ter tantas visões, de ter tanta gente interferindo, de ter tanta gente discutindo...o olhar de tantas pessoas, acho que isso é bacana pra gente captar, e também é difícil lembra? O tanto de coisa que vocês fizeram? (Ininteligível 00:18:36) Mas eu acho que é bacana (Reunião com a dupla, arquivo 23, turno 92).

Melissa compunha um subprojeto em que as aulas eram estruturadas por meio de uma abordagem CTS, denotando que as propostas de ensino eram fundamentadas na Ciência baseada em projetos e rigor científico - apesar das limitações com o conteúdo. Suas decisões sobre o fazer no ensino, por vezes tiveram como inspiração um professor da licenciatura que ministrava as aulas de fundamentos da química em virtude de ensinar os conteúdos do mesmo modo que tinha aprendido no primeiro ano de graduação. Suas aulas eram conduzidas por meio de perguntas e respostas "Diversas vezes eu fazia perguntas partindo do pressuposto que eles já sabiam o 
conteúdo, então não dava elementos necessários para as respostas" (Ciclo reflexivo depois, Melissa). Nesse sentido, compreende-se que os caminhos escolhidos para o desenvolvimento de suas aulas figuraram como uma abordagem comunicativa de autoridade ao considerar apenas o que os discentes sabiam sobre o conteúdo específico. Suas intervenções tinham por objetivo sempre formular perguntas direcionadas aos alunos que resultassem em uma resposta confirmatória do conceito redox.

As crenças de Melissa sobre a natureza da ciência emergem em apenas uma de suas narrativas:

Não tudo bem. É... Chumbo. Vocês lembram o que é massa atômica? Ficou difícil, hein, vamos lá, pra isso que ela serve, nas próximas aulas a gente vai começar a trabalhar um pouco com algumas reações, pelo menos essa é a ideia, então pra gente conseguir trabalhar elas, essa aula aqui vai servir pra gente fazer revisão de alguns conceitos químicos que talvez vocês tenham esquecido, mas tenho certeza que vocês já viram. Vocês lembram como é que a gente representa o átomo? Aquele desenho de criança que não é um átomo de verdade, mas é o jeito que a gente sistematiza aqui, desenhinho. Vamos, uma bolinha que é o núcleo, aí enrola uns negócios assim que é? (Aula de atomística, arquivo 11, turno 14).

A partir do delineamento desse componente do PCK, infere-se que o processo de encadeamento das aulas a serem propostas e implementadas por Melissa dependiam fortemente das orientações das tutoras, em especial da coordenadora, reflexo das limitações apresentadas por Melissa com o conteúdo redox e também pela inexperiência com o preparo de aulas, pois não se pode ignorar que a pibidiana estava em seu primeiro ano de graduação e não havia cursado as disciplinas integradoras, além de as específicas. Assim, denota-se que as Crenças sobre as propostas de aprendizagem em ciências foram condicionadas pelo acompanhamento e orientação das tutoras e as Decisões sobre o fazer no Ensino foram marcados pela sua dificuldade com o conhecimento do tema.

$\mathrm{Na}$ entrevista semiestruturada não emergem indícios desse componente.

\section{Conhecimento do currículo em ciências}

Nesse componente do PCK temos o conhecimento de Melissa acerca dos materiais curriculares, o seu entendimento sobre a importância de um tópico com relação a um conteúdo e a sua visão do currículo (horizontal/vertical) de modo a realizar conexões do conteúdo trabalhado em uma aula com conceitos a serem desenvolvidos em outros momentos (horizontal) e ou com outras disciplinas..

Melissa em sua trajetória inicial não demonstra ter um conhecimento do currículo, pois em nenhuma de suas narrativas menciona o currículo do Estado de São Paulo e os documentos oficiais que norteiam o ensino no Brasil. A seleção dos Capítulo 4. Resultados e Discussões 
conteúdos ficou principalmente a cargo das tutoras. Nesse sentido, Melissa argumenta que "Tinha a visão da coordenadora, e tinha conversa nossa também, tanto que a tabela de redução de potencial foi uma discussão que a gente teve, e aí passa ou não passa, por que... (Lembrança estimulada, arquivo 25, turno 340-341). No discurso da pibidiana se evidencia que Melissa não tinha o entendimento do que seria o currículo, apenas cita um episódio em que os pibidianos decidiram trabalhar com a tabela de potencial padrão de redução. Ressalta-se que a coordenadora não concordava em trabalhar com essa tabela, por considerar um instrumento muito difícil para ser desenvolvido na EJA.

A vivência no Pibid possibilitou que Melissa começasse a estabelecer a relação entre o currículo e o que estava sendo lecionado, por ter a possibilidade de assistir as aulas de Luiza:

[...] teve uma aula que eu assisti, que foi em setembro, que no cronograma do terceiro ano, normalmente você passa química orgânica, você taria acabando química orgânica em setembro ou outubro. E era setembro e a professora ainda tava em fragmentos [...] (Entrevista semiestrutura - Melissa, turno 85).

A pibidiana, apesar de descrever no seu relatório a adoção de vídeos, músicas, artigos e experimentos, esses recursos fizeram parte das escolhas metodológicas de Antônio. Os livros didáticos adotados por Melissa inicialmente na construção das aulas de química foram:

Melissa - Bom, as aulas de conteúdo químico é no..., são os próprios livros de química mesmo.

Pesquisadora - Do ensino superior...

Melissa - Eu faço pesquisa nos dois, tem tanto de nível superior quanto no nível médio, porque a vantagem do livro de médio é você entender qual linguagem você tem que usar, né? Normalmente no nível superior ele é mais... acho que pra quem está anotando a aula, não é? No sentido de você entender o que o professor tá pondo no quadro, mas na hora de você selecionar qual a linguagem você vai usar, eu acho o livro de médio muito mais proveitoso, sem dúvida.

Pesquisadora - Você lembra do nome de algum deles ou não?

Melissa - Não. Assim, de médio não, de superior eu usei o, até agora eu usei o Atkins, e o (Ininteligível 00:06:35), de médio eu não lembro o nome (Entrevista semiestruturada - Melissa, turno 37-41).

Nos trechos acima, Melissa identifica nos livros da educação básica um possível direcionamento a ser seguido em suas aulas relacionados à linguagem em que o livro é estruturado, que difere na sua percepção do livro superior. Nesse sentido, Stadler e Barbosa (2012) analisaram se a linguagem adotada pelo professor de química tinha reflexo do livro didático. Os resultados indicam que o professor incorpora na prática pedagógica a linguagem dos livros didáticos como conhecimento químico. Em consonância, infere-se que Melissa, por não ter um conhecimento sobre reações redox, considerava o conhecimento químico presente nesse material como sendo Capítulo 4. Resultados e Discussões 
inquestionável e verdadeiro. Por outro lado, a vivência no contexto do Pibid possibilitou à licencianda refletir sobre a sua aprendizagem e a proposta de ensino, pois, segundo Melissa, para a segunda aula de conceitos químicos (Aula de visão, arquivo 15) estava mais confiante em desenvolver o conteúdo redox por ter estudado, como observa-se nos trechos abaixo:

Melissa - Nela eu estava, nela eu tava até porque eu tinha conseguido mais material pra estudar, a professora Rebeca me emprestou um livro que era dela, que era pra colegial.

Melissa - Isso, era pra colegial, e aí a linguagem era bem simples, então fui pegando a questão do como eu deveria ensinar, ou pelo menos baseada no livro (Lembrança estimulada, arquivo 25, turno 212 e 216).

Melissa, orientada pela ex-coordenadora Rebeca, estudou pelos livros didáticos da educação básica. Nesse material vislumbrou novas possibilidades de ensinar Decisões sobre o fazer no ensino. O reconhecimento de que necessitava estudar e compreender o conteúdo que estava ensinando na formação inicial é de extrema relevância, talvez um indício que Melissa refletiu sobre a sua prática ao buscar superar suas próprias limitações conceituais. Essa percepção contrapõe com o seu preparo para lecionar a aula de atomística, por ter sido pensada, tendo como material de apoio o caderno da graduação, denotando uma falta de conhecimento de materiais curriculares:

Eu estudei..., na verdade eu estudei pelo meu caderno mesmo de química, até porque eu não tive nenhum livro no colegial que tivesse esse conteúdo, então eu não tinha, em um primeiro momento eu não tinha pensado nisso de pegar na biblioteca da faculdade nem nada, nem passou isso pela minha cabeça (Lembrança estimulada, arquivo 25, turno 69).

O olhar vertical do currículo de Melissa traduzido nas aulas de atomística representam o conhecimento das tutoras sobre o currículo, pois Melissa não demonstrou ter esse conhecimento de conectar os conteúdos de series anteriores com reações redox. Como descreveu-se na categoria Conhecimento do Tema, Melissa não participava nas reuniões das discussões relacionadas à seleção dos conteúdos, geralmente concordava com o posicionamento da coordenadora. Apesar dessa participação mais como observadora, o fato de vivenciar esses espaços de discussões em que são eleitos os tópicos a serem ensinados e sua relação com o que se pretende ensinar transformam o espaço do subprojeto em um ambiente de formação que influenciam na construção do PCK.

Os conceitos priorizados por Melissa foram eleitos pelas tutoras e ganharam destaque nas aulas da pibidiana: definição de reações redox, polo positivo e negativo, Nox, semi-reação, cátodo, ânodo, reação global e eletrólito. Em outra reunião (arquivo 15) Melissa foi orientada por Luiza a revisar os conceitos abordados por Antônio na aula 
da Pilha de Daniell (arquivo 13) "Bom, a gente representa a parte de bateria, cátodo, ânodo, qual o polo positivo, qual é negativo, eletrólito" (Reunião para saber o andamento, arquivo 14, turno 237).

Nas reflexões sobre as aulas implementadas Melissa expõe os conceitos priorizados em sua aula, as dificuldades de aprendizagem dos discentes Conhecimento da compreensão dos alunos em ciências, seus métodos de avaliação e as dimensões que avaliar - Conhecimento da Avaliação da Aprendizagem em ciências:

[...] a gente pode até considerar que o objetivo principal da aula foi alcançado, que eles conseguiram entender os artigos das leis, conseguiram ler, conseguiram assimilar, e alguns, não todos, mas alguns grupos conseguiram reestruturar suas respostas à luz da lei. Então a segunda aula foi aula de revisão, introdução das reações redox, então a gente, a partir do chumbo, que é o elemento químico norteador do nosso projeto, a gente falou um pouquinho de estados né da matéria, estado que os elementos poderiam estar, a gente falou um pouquinho da onde os elementos se colocam na tabela periódica e porque daquilo, e aí a gente começou a falar da composição do átomo, das partículas subatômicas, a gente falou de número de massa, número atômico, e a gente passou pra íons, cátion, ânion, e aí a gente introduziu mas de forma bem superficial o que seria oxirredução, perdeu elétron é oxidação, ganhou elétron é redução, mas ficou por enquanto nessa problemática superficial, e aí a gente deu uma atividade escrita pra eles fazerem, e o primeiro exercício ele cobrava parte teórica, e o segundo exercício cobrava parte simbólica, e aí foi interessante da aula, que a gente percebeu que a parte teórica eles entenderam, e a parte simbólica não, a dificuldade deles foi muito grande em fazer a parte simbólica, então a todo tempo eles requisitaram a nossa ajuda, então a gente passou a maior parte da aula sentado do lado deles pra resolver o exercício junto com eles, isso aí foi um resultado interessante que a gente chegou (Apresentação dos resultados, arquivo 21 , turno 17 ).

O conhecimento de Melissa sobre materiais curriculares, saliência curricular e currículo horizontal e vertical, revelou-se incipiente. O acesso de Melissa a esse componente foi sendo possível em virtude de participação no Pibid, e pelas orientações das tutoras. Contudo, não se pode inferir que Melissa tinha consciência, enquanto futura professora, de que esses conhecimentos eram importantes no desenvolvimento das regências e na sua formação docente.

\section{Conhecimento da compreensão dos alunos em ciências}

Os conhecimentos acerca das dificuldades de aprendizagem dos alunos não foram objeto de análise de Melissa ao adentrar no espaço escolar. Essas limitações foram inicialmente apresentadas à pibidiana pelo olhar de Luiza sobre seus alunos, pela experiência da coordenadora como docente e com o tema. As ações da pibidiana estavam mais voltadas ao preparo das regências. Esse cenário fundamenta 0 planejamento da aula de atomística. No dizer de Melissa, selecionou-se "[...] os 
conteúdos que a gente achava mais pertinente pra conseguir conduzir o raciocínio deles, por isso a importância dessa aula" (Lembrança estimulada, arquivo 25, turno 34).

Inicialmente tem-se uma licencianda que não buscou levantar as possíveis dificuldades dos discentes com o conteúdo. Entretanto, com o andamento da sua imersão na sala de aula, inicia-se a sua percepção sobre as dificuldades que os discentes da EJA tinham, pois na visão da pibidiana:

Com essa aula foi possível perceber que esses alunos vieram com muitas defasagens, pois uma aula que deveria ser de revisão, para muitos, parecia que o conteúdo estava sendo visto pela primeira vez.

Durante a resolução dos exercícios os alunos pediram auxílio diversas vezes, e poucas foram as vezes que eles entenderam as explicações (Relatório anual dupla - Melissa).

Considerando-se ainda o aspecto dos conhecimentos prévios, Melissa ao discorrer como os acessava, argumenta:

Hum... A gente não fez isso fazendo questionário mesmo do que eles sabiam antes da aula, a gente geralmente acaba fazendo isso direto na sala de aula mesmo, "Já aprenderam isso?" "Já viram isso na vida de vocês?" A gente vai lançando essas perguntas pra saber por onde a gente tem que começar, né? Mas isso daí é feito na própria aula (Entrevista semiestruturada - Melissa, turno 43).

$\mathrm{Na}$ visão da pibidiana a supervisora foi fundamental para a sua compreensão das limitações dos alunos da EJA e para vislumbrar o perfil dos alunos, pois considerou que o tempo para o desenvolvimento das atividades no Pibid eram limitados, dificultando a realização do reconhecimento desses aspectos, como denota o trecho:

Eu acho o supervisor importante pra... porque o supervisor dá um suporte no que o aluno dele sabe, o que o aluno dele não sabe, qual é o perfil do aluno dele, porque querendo ou não a gente tem pouco tempo, nosso tempo é apertado, então é difícil a gente ter aquela coisa de vir conhecer a turma, saber quem são os alunos, então o supervisor, no caso da Luiza deu muito suporte pra gente no sentido de tanto nessa turma que a gente está ministrando agora, quanto nas duas no semestre passado, que a gente passou, de a gente saber mais ou menos qual é o perfil dos alunos a gente vai trabalhar que dá pra poder juntar algo em cima disso, tipo: "ah pode ir mais rápido, não pode." Nesse sentido (Entrevista semiestruturada - Melissa, turno 45).

Outras dificuldades dos discentes estavam relacionadas à parte simbólica. Para a pibidiana, os discentes compreendiam a definição de oxidação e redução, mas não conseguiam resolver questões que envolviam a semirreação e a reação global. Em um dos episódios de sua aula de atomística, que permeou a resolução de exercícios, percebeu que "Diante do quadro que se apresentava a atividade não poderia mais servir como uma prova, pois se assim fosse, todos os alunos iriam mal. Viu-se a necessidade de resolver os exercícios junto com os alunos, quando era solicitado" (Relatório anual dupla - Melissa). Nesse trecho se observa a reflexão de Melissa sobre a ação, levandoa a optar por atender as Necessidades dos discentes com relação às dificuldades de Capítulo 4. Resultados e Discussões 
aprendizagem. A associação entre a reflexão sobre a ação e os conhecimentos sobre as dificuldades de aprendizagem dos discentes de Melissa, emergidos em sua prática didática, resultam na estruturação da aula de revisão (arquivo 15) por meio do objetivo, a saber:

A meta, no primeiro momento, foi aproximar os alunos com a parte simbólica da eletroquímica. Para isso foram feitos na lousa três exercícios sobre pilhas, em que foi solicitado o reconhecimento do cátodo, ânodo, polos da pilha, espécie oxidada e reduzida, etc. (Relatório anual dupla - Melissa).

Durante a resolução dos exercícios (Aula de revisão, arquivo 15) na lousa, por um aluno, Melissa concluiu:

\begin{abstract}
Bom, a aula seguinte foi uma aula que a gente partiu pro símbolo, então eu usei o mesmo esquema da pilha Daniell, só mudei, só fui mudando os metais, e eu fiz acho que 3 exercícios na lousa com eles, só que aí fui trabalhando a parte de reação mesmo, semi-reação anódica, catódica, global (3), e aí eu ia pedindo pra eles resolverem junto comigo, aí eu colocava na lousa e falava: "E agora? Ele perde quantos? Quem ganha?" Só que assim, justamente porque eles estavam com muita dificuldade na parte simbólica, o negócio que era pra durar assim um terço da aula durou praticamente a aula inteira, que foi os exercícios com eles, eles estavam muito inseguros, eu perguntava, eles demoravam pra responder, alguns respondiam baixinho respondiam inseguros, eles estavam com muita dificuldade nessa parte simbólica mesmo (Apresentação dos resultados, arquivo 21, turno 29).
\end{abstract}

As limitações dos discentes da EJA com o conteúdo coincidem com um dos resultados apontados em nosso levantamento bibliográfico sobre reações redox de que os discentes geralmente conseguem assimilar a parte conceitual, mas não a representacional e simbólica. Ao descrever os resultados dessa regência em seu relatório, Melissa expôs:

[...] O aluno escreveu algo completamente diferente do esperado, e quando foi pedido que ele explicasse o seu raciocínio, ele não conseguiu. Essa dificuldade fez necessária uma alteração no andamento da aula, pois a atividade estava prevista para acontecer em meia hora no máximo, mas demorou uma hora para ser finalizada

Com a devolutiva dos alunos foi possível refletir sobre a dificuldade em relação ao aspecto representacional da química. Essa dificuldade, que já havia sido detectada na segunda aula, foi apresentada novamente; uma vez que os alunos, de modo geral, conseguiram responder as perguntas de caráter mais teórico, mas em sua maioria não responderam as questões que solicitavam que eles equacionassem as reações (Relatório anual dupla - Melissa).

No trecho acima a pibidiana afirma que o discente, ao ir na lousa, estava completamente equivocado sobre o conteúdo. Ao relembrar essa passagem de sua aula, Melissa constrói algumas reflexões:

Tem até um momento, não sei se você pegou esse trecho, que eu pedi, acho que foi pro Anderson que eu pedi pra ele fazer um exercício na lousa, ele ficava olhando, não sabia o que escrever, escreveu um 
negócio completamente diferente do que era esperado, e eu acabei tirando ele da lousa, depois eu achei que eu fiz até errado eu acho que o certo seria eu ficar com ele ali na lousa (Lembrança estimulada, arquivo 25, turno 246).

De acordo com a reflexão construída pela pibidiana e pela dinâmica de suas aulas, acredita-se que a dificuldade do discente foi reflexo da falta de Conhecimento do Tema de Melissa que resultaram em uma Decisão sobre o fazer no Ensino de Ciências, em que poucos elementos conceituais eram explicados em sala de aula e, consequentemente, o discente não conseguia compreender o que Melissa solicitava, pois na aula a pibidiana não explicou o balanceamento de reações redox. Essa Decisão sobre o fazer no Ensino está fortemente influenciado pela Conhecimento Pedagógico Geral de Melissa.

Melissa reconhecia que a linguagem era fundamental para ajudar na aprendizagem dos discentes. Nesse perspectiva, apresenta-se o diálogo abaixo:

Pesquisadora - O que você faz na sala de aula, enquanto pibidiano para ajudar seus alunos no processo de ensino-aprendizagem deles?

Melissa - O que eu faço para ajudar eles no processo de ensinoaprendizagem...

Pesquisadora - É para que eles aprendam aquele conteúdo que você está tentando ministrar.

Melissa: Bom, vou voltar de novo naquela questão da linguagem, eu tento deixar o mais próximo deles possível (Entrevista semiestruturada, Melissa, turno 68-71).

Tendo conhecimento das Necessidades dos discentes associadas à leitura e à escrita, Melissa e seu par propuseram como atividade avaliativa final a produção de um panfleto. Para a pibidiana o instrumento seria "[...] uma via de comunicação, porque se ele fizer um texto, por exemplo, uma redação, lógico que ele vai ter a informação dele, tá sendo aprimorada, ele tem desenvolvendo a leitura, a escrita" (Reunião para saber o andamento arquivo 14, turno 76). Na aula de sensibilização proposta pela dupla, os pibidianos solicitaram que os alunos da EJA propusessem resoluções de situações problemas que também objetivavam promover o desenvolvimento dessas duas habilidades. Melissa percebeu, durante o contexto de sua formação inicial, oportunidades de desenvolver a leitura em sala de aula. Para Silva (2008), independentemente da área de formação, os docentes deveriam desenvolver a leitura, já que "[...] a organização discursiva dos conteúdos das diversas disciplinas é diferente, exigindo o domínio e a aplicação de habilidades diferentes de leitura - não se lê um texto poético da mesma forma que um problema matemático" (SILVA, 1998, p. 124). Por outro lado, um aluno argumenta:

Aluno - Nossa, é muitos termos complexos gente. 
Melissa - Não deem nomes enquanto eu não pedir. Porque eu também não gosto dos nomes. Eu não preciso que vocês me deem nomes. Bom, tudo bem, parte mais fácil tá feita, vamos pra parte difícil? (Aula revisão, arquivo 15, turno 345-346).

O aluno, nesse diálogo, identifica a complexidade do conteúdo e sinaliza à Melissa uma dificuldade que está tendo, pois a aula da pibidiana é baseada em perguntas sobre os conceitos que permeiam reação redox e, consequentemente, sobre suas terminologias. Entretanto, Melissa demonstra incoerência com o encaminhamento de sua prática de ensino e, ao mesmo tempo, ignora as próprias recomendações que os PCN sinalizam a respeito da comunicação e representação que permeiam o ensino de química:

Descrever as transformações químicas em linguagens discursivas.

Compreender os códigos e símbolos próprios da Química atual. Traduzir a linguagem discursiva em linguagem simbólica da Química e vice-versa. Utilizar a representação simbólica das transformações químicas e reconhecer suas modificações ao longo do tempo.

Traduzir a linguagem discursiva em outras linguagens usadas em Química: gráficos, tabelas e relações matemáticas.

Identificar fontes de informação e formas de obter informações relevantes para o conhecimento da Química (livro, computador, jornais, manuais etc.) (PCNEM, p.39).

Permeando ainda o aspecto da linguagem, a pibidiana descreveu no ciclo reflexivo de Smyth (1991) que os discentes deveriam incorporar a linguagem científica. Organizou-se a resposta concedida por Melissa para ação confrontar na tabela 14.

Tabela 14. Resposta de Melissa à ação Confrontar antes de assistir as aulas

\begin{tabular}{|c|c|c|}
\hline Ação & Questão & Descrição \\
\hline Confrontar & $\begin{array}{l}\text { Quem tem poder em minha sala de } \\
\text { aula? A que interesse a minha } \\
\text { prática está servindo? } \\
\text { Acredito nesses interesses ou } \\
\text { apenas estou reproduzindo? }\end{array}$ & $\begin{array}{l}\text { [...] Acredito nos interesses dessas } \\
\text { aulas, apesar de reconhecer que nem } \\
\text { todos os conteúdos serão usados pelos } \\
\text { alunos, acredito que são importantes de } \\
\text { serem ensinados, primeiro para o maior } \\
\text { entendimento do fenômeno e segundo } \\
\text { para que o aluno tenha contato com a } \\
\text { linguagem científica. }\end{array}$ \\
\hline
\end{tabular}

Em poucos momentos Melissa reconhece as Necessidades dos alunos em relação ao conteúdo específico em sua prática didática. Entretanto, na aula de revisão (arquivo 15), tem-se um indício de que Melissa percebe essa Necessidade, o que a leva a construir uma explicação - Conhecimento das estratégias instrucionais para o ensino de ciências, sobre o conteúdo para que o discente compreendesse os conceitos:

Olha, deixa eu terminar de responder aqui antes dele mostrar. Percebe que eu tenho tanto sólido quanto íons nas duas partes, só que quando eu estabeleço a ligação e vai acontecer a redox, um vai perder os seus elétrons, e o outro vai ganhar, por isso, o que acontece? A tendência desse daqui é o zinco passar do estado metálico pro íon, esse aqui a tendência do íon virar metálico, mas eu tenho dos dois nos dois, dá pra entender? (Aula de revisão, arquivo 15, turno 252). 
Em outro momento da regência os discentes começam a expressar suas percepções sobre a explicação da pibidiana:

Aluno - Professora, você vai complicar a gente.

Melissa - Olha, presta atenção, nem sempre no sistema eu vou estar indo da esquerda pra direita, eu posso arrumar do jeito que eu bem entender, então tipo, os dois béquer que estão ali na bancada, eu posso virar eles ao contrário, vai acontecer a reação do mesmo jeito, não necessariamente eu tô indo da esquerda pra direita, ok, tem que prestar muita atenção nisso, pra ter as informações pra eu não ir naquele convencional esquerda pra direita e vocês vão acabar errando. Ok? Então catodo, esse aqui é o...? (Aula de revisão, arquivo 15, turno 330-331).

No diálogo acima, Melissa, percebendo que era necessário explicar com mais clareza o conceito aos discentes, reformula o modo como estava explicando o conceito, por meio de questionamentos aos discentes, o que a fez construir um pensamento que pudesse levar o discente a uma compreensão. Refletindo em suas decisões sobre o fazer no ensino - Orientações para o ensino de Ciências e expressão seu conhecimento sobre o tema.

Para incentivar os discentes a aprenderem o conteúdo que estava ensinando, Melissa argumenta que buscava elogiar os alunos, como denota o trecho abaixo:

E nessa hora eu vi que eu, na hora que eu vi ele fazendo qualquer outra coisa eu entrei em pânico, meu Deus, ele não sabe de nada, eu entrei meio em pânico hora que eu vi que ele não estava conseguindo fazer, e aí eu: "Bom, eu vou ter que ajudar" e essa que falou que ela é inteligente foi pra incentivar mesmo (Lembrança estimulada, arquivo 25 , turno 308).

Na reunião com a coordenadora em que foram expostos os resultados das aulas implementadas, surgem mais indícios das dificuldades conceituais identificadas por Melissa durante sua vivência no programa de iniciação à docência:

Melissa - [...] eles tiveram muita dificuldade, assim, na primeira parte que fala da tabela, a parte conceitual, tipo ah, perdeu o elétron é oxidação, eles entenderam, agora, quando a gente...esse exercício 2 a maioria ou eu tive que sentar do lado, explicar 3 vezes, a mesma coisa, ou teve gente que desistiu, ou teve gente que escreveu qualquer outra coisa, nossa, eles não conseguiram, os que estão certos foi porque eu e o Antônio sentou do lado, foi fazendo junto e foi explicando passo a passo duas, três vezes a mesma coisa, e mesmo assim teve uns 4 que escreveu aqui pedindo pra falar o que tinha que escrever. Ou seja, parte simbólica eles não conseguem fazer.

Maria - Matemática você fala representar?

Melissa - Isso, fazer...

Melissa - Alguns conseguiram fazer, mas foi que tipo, tinha anotado a minha...que eu escrevi na lousa e anotou e copiou no caderno, só mudou o elemento, ainda teve muita gente que inverteu porque na questão eu passei acho que foi primeiro oxidação, depois redução, e no caderno tinha passado ao contrário, então teve muita gente que escreveu o processo certo, o número de elétron certo, mas invertido. 
Maria - Invertido.

Melissa - Então a parte simbólica não... (Reunião com a dupla, arquivo 23, turno 44-49).

Na percepção de Melissa, as dificuldades dos discentes da EJA talvez fossem reflexo de sua aula, ao passo que constrói a reflexão "É que eu acho que assim, talvez por falha minha porque teve muita coisa que eu pulei, mas o que eu vi que o que a gente ia pondo de matemática eles iam se perdendo [...]" (Lembrança estimulada, arquivo 25, turno 144). Em outro momento acredita que faltou se colocar no lugar do aluno para compreender como seria o seu processo de aprendizagem (Lembrança estimulada, arquivo 25). Entretanto, infere-se que a falta de domínio do conteúdo e do exercício em pensar sobre cada momento da aula antes de ser implementada influenciaram fortemente sua ação didática e na dificuldade dos discentes em compreenderem os questionamentos que a pibidiana realizava nas intervenções.

As barreiras de aprendizagem dos discentes foram sendo identificadas por Melissa durante a sua ação didática e refletiram diretamente sobre as suas reflexões. Nessa perspectiva, a pibidiana reconhece "Que a parte macroscópica a gente põe no esquema eles sabiam, chegava na parte matemática não" (Lembrança estimulada, arquivo 25, turno 244). Talvez esse reconhecimento das limitações dos discentes na simbologia química possa influenciar no seu planejamento sobre o conteúdo redox e de outros conteúdos químicos. Dessa forma, a vivência no programa de iniciação à docência possibilitou Melissa a iniciar a construção de um repertório acerca das dificuldades dos discentes que foram descritas no CoRe "adaptado", organizado na tabela 15.

Tabela 15. Trechos do CoRe adaptado

Questões Respostas

4. Quais são as dificuldades e Os alunos normalmente têm dificuldade de limitações conectadas ao ensino compreender, por exemplo, porque em uma pilha de Daniell uma solução fica mais saturada e a outra menos saturada com o passar do tempo

5.Que conhecimento sobre o Sabe-se que os alunos têm dificuldade de entender o pensamento dos estudantes influi conceito de equilíbrio químico, pensando que as pilhas em seu ensino desta ideia? param de funcionar porque elas perdem a força.

6.Quais os fatores influem no ensino Conhecimento básico de eletroquímica, ou seja, saber desta ideia? reconhecer os polos de uma pilha e reconhecer, em uma reação, qual substância está oxidando e qual está reduzindo.

$\mathrm{Na}$ descrição de Melissa para as limitações associadas ao ensino de pilhas, o que aponta como concepções alternativas foram emergidas nas aulas em que a pibidiana ministrou com Antônio.

$\mathrm{Na}$ aula de revisão (arquivo 15) um dos discentes da EJA estava com dificuldade em compreender o que era eletrólito. Melissa, então, retoma os conceitos relacionados à dissociação iônica: 
Aluno - Eu colocar tipo assim, 250 miligramas no zinco, e 300... nossa miligramas? Mililitros. Vai interferir alguma coisa?

Melissa - Não.

Aluno - A água é só o condutor no caso?

Melissa - Não é água, lembra que é o sal, se você enfiar só água aqui.

Aluno - Sim, água com sal, certo, ele é o condutor.

Melissa - Isso. Se eu só colocar os dois metais aqui e não tiver água não vai acontecer nada, eu preciso do eletrólito.

Aluno - Eu consigo fazer isso?

Melissa - Sim. O eletrólito é qualquer solução que eu consigo estabelecer passagem de elétrons, não precisa necessariamente ser desse jeito aqui, eu ter dois béqueres e ter um com o zinco e ter um com o cobre, não precisa necessariamente, tanto que aquela experiência que a gente fez aqui, que a gente fez com as moedas, não era desse jeito, era eletrólitos diferentes, com outras coisas, e acendeu do mesmo jeito lá o led. Lembram disso? (Aula de revisão, arquivo 15, turno 257-264).

Nesses trechos temos a conexão dos componentes do conhecimento do tema, Conhecimento das estratégias instrucionais - ao relembrar os conceitos desenvolvidos e do reconhecimento da dificuldade de aprendizagem do discente em compreender o que era eletrólito.

$\mathrm{Na}$ trajetória de Melissa, observa-se, a priori, que a pibidiana não compreendia quais eram as limitações dos discentes com relação a reações redox, além de suas Concepções Alternativas e o que os Motivava e Interessava. No Pibid Melissa estava imersa em um processo de identificação, construção, desconstrução e reconstrução dos conhecimentos relacionados a este componente do PCK. Acredita-se que esse terceiro espaço de formação propiciou que Melissa começasse a compreender as limitações associadas a esse conteúdo, que são descritas na literatura e que são fundamentais para os docentes considerarem em seus planejamentos e contextos escolares. Talvez esses conhecimentos possam ser acessados e considerados por Melissa em suas próximas aulas.

\section{Conhecimento das estratégias instrucionais para o ensino de ciências}

As principais estratégias de ensino adotadas nas aulas da pibidiana foram: discussão em grupo; resolução de exercícios nas aulas; revisão do conteúdo; produção e leitura de texto; e exposição teórica do conteúdo. Em nenhum dos documentos surgem indícios do uso de analogias por Melissa. As estratégias instrucionais foram fortemente influenciadas pela sua insegurança com os conceitos que envolviam reações redox.

Antes de adentrar nas estratégias para o desenvolvimento das aulas de conteúdo específico, considerou-se pertinente apontar que na aula de sensibilização a estratégia adotada foi a resolução de situações problemas por meio do trabalho em 
grupo, como descreve no componente Conhecimento Pedagógico Geral. Afinal, Melissa participou de um subprojeto fundamentado na CTS e na PNRS.

Na primeira aula do conteúdo redox Melissa adota como estratégia inicial a revisão do conteúdo de atomística - em virtude das orientações das tutoras-, para então, caminhar na direção de definir reações redox. No início da aula Melissa questiona os discentes sobre o que haviam estudado na regência de sensibilização (arquivo 10), como uma forma de aproximar a temática da contaminação pelo descarte inadequado de baterias automotivas com os conceitos químicos que pretendia lecionar, e também retoma o que foi desenvolvido na aula anterior em virtude da ausência de alguns discentes, conforme sugere o diálogo:

Melissa - Boa noite pessoal, alguém não tava aqui semana passada? Então só pra te situar, a gente é do Instituto ((nome da instituição superior)), a gente tá fazendo um projeto aqui com vocês, que a gente vai ensinar química pra vocês, só que de uma forma um pouco diferenciada, aula passada, quem pode contar pra ela o que a gente viu semana passada? Lembram o que a gente viu semana passada? Você lembra o que a gente fez na semana passada?
Aluno - (Ininteligível 00:40:00). Esse aí.
Luiza - Ele tá falando direitinho lá o que era?
Aluno - Resíduos sólidos.

Melissa - Isso, a gente aprendeu sobre Política Nacional dos Resíduos Sólidos, que é uma lei que existe do Brasil desde 2010, que fala sobre todo o destino que os resíduos têm que ter, seria o certo, então nessa aula, eu prometi para vocês que a gente ia entender a química do negócio, né, e nessa aula a gente vai, o nosso projeto ele vai falar principalmente de um tipo específico de resíduo, que são as pilhas e baterias, então, nada mais justo a gente entender primeiro qual que é a química que existe nas pilhas e baterias antes de falar da questão ambiental delas, e antes disso, a gente vai ver o que tem dentro, que tem essencial dentro de uma bateria pra fazer elas funcionarem, e o que existe dentro de uma bateria é o chumbo, o elemento chumbo (Aula de atomística, arquivo 11, turno 2-6).

Outra estratégia adotada pela pibidiana nessa aula foi eleger o chumbo como elemento norteador para a revisão, apresentando suas características químicas, sua aplicação industrial e, posteriormente, os conceitos de atomística, outra orientação das tutoras. Durante a aula Melissa realiza esquemas na lousa e resolve exemplos, tenta promover a participação dos discentes na sua aula como, por exemplo, ao solicitar que estes localizassem na tabela periódica o número atômico e de massa atômica de elementos que elegeu para exemplificar. Contudo, parte da aula de Melissa foi conduzida por meio de perguntas aos discentes sobre o conteúdo. A pibidiana concebia que dessa forma estava promovendo a participação dos alunos. Nessa primeira experiência a pibidiana teve oportunidade de vivenciar e experimentar estratégias de ensino, e vislumbrar as adequadas às suas aulas. Desse modo, na aula de atomística 
a pibidiana percebeu "que as informações na lousa são mais válidas do que quando eu estou só falando" (Lembrança estimulada, arquivo 25, turno 48).

$\mathrm{Na}$ reunião com as tutoras ficou acordado que Melissa ministraria a sua segunda regência, pouco mais de um mês, após a aula de revisão. Para demonstrar que havia concordado com a orientação, Melissa afirma: "Bom, então tudo bem, então, essa quarta feira agora a gente faz o resumo, retoma os conteúdos [...]" (Reunião para saber o andamento, arquivo 14, turno 260). Nesse trecho, tem-se a influência de Maria e Luiza sobre o componente Orientações para o Ensino de Ciências.

Ao iniciar a aula de revisão (arquivo 15), instiga os discentes a relembrarem os conceitos abordados por Antônio nas aulas Pilha de Moedas (arquivo, 12) e Pilha de Daniell (arquivo 13). Entretanto, na sequência, ao implementar os caminhos escolhidos para a revisão - Decisões para o ensino de Ciências, Melissa discorre:

Melissa - Bom, se vocês já fizeram, eu acho que se eu colocar na lousa e falar que eu vou fazer junto vocês vão saber fazer né?

Aluno - Não. É que fala..., por causa do recesso né, eu esqueci.

Melissa - Eu pensei nisso.

Aluno - Não tem nada a ver com o recesso, eu não lembro o que eu fiz ontem direito.

Melissa - Tudo bem, não tem problema. Eu aconselharia vocês a fazerem anotações do que eu vou passar na lousa, porque vocês vão precisar disso mais pra frente.

Aluno - Deixa eu só pegar meu caderno ali dentro da bolsa. Mostra pra professora ((as anotações))

Melissa - Posso?

Aluno - Mostra pra ela a folha separada. Mostra para ela, por favor. Aí professora, ele achou.

Melissa - Ahã, supondo que mal e porcamente o senhor precisa de uma pilha, mal e porcamente mesmo. Toda a pilha tem dois polos, né?

Aluno - Negativo e positivo.

Melissa - Positivo e negativo. Um polo positivo e um polo negativo. É... Pilha tem aquele negocinho ((refere-se a ponte salina)) lá de ter o fluxo de elétrons, que aí faz a energia. Os elétrons vão da onde pra onde? (Aula de revisão, arquivo 15, turnos 15-25).

Nos trechos acima, talvez por estar mais segura em lecionar o conteúdo, passa a formular melhor seus questionamentos de modo que os discentes compreendessem o que estava perguntando. Por outro lado, em alguns episódios demonstrou não dominar o nome dos conceitos que estava ensinando, o que levava sua aula a oscilar em momentos que conseguia formular questões direcionadas a classe de forma clara e coesa, e outros em que realizava perguntas confusas que não permitiam a participação do aluno. Nesse sentido, apresenta-se o diálogo abaixo: 
Melissa - O liquidozinho ganha o nome de? O líquido, qual é o nome do liquido?

Aluno - O líquido...

Melissa - O nome genérico de qualquer líquido que faz isso aqui acontecer?

Aluno - Água.

Melissa - Não. É genérico, podia ser água, mas não é... É genérico.

Luiza - Ele... ((soletrou o início da resposta para ver se os alunos conseguiam chegar a resposta))
Aluno -...trodo
Aluno - Eletrófase.
Aluno - Eletrodo.
Melissa - Eletrodo.
Aluno - Eletrocardiograma.
Aluno - Eletrólito.
Melissa - É tipo isso.
Aluno - Líquido elétrico. Eletro...
Aluno - Eletrólito?

Melissa - Eletrólito. Então a gente tem os eletrólitos, e esses aqui são os...? (Aula de revisão, arquivo, turnos 121-136).

No término das atividades desenvolvidas no Pibid, Melissa reconheceu que "Diversas vezes eu fazia perguntas partindo do pressuposto de que eles já sabiam o conteúdo, então não dava elementos necessários para as respostas" - Orientações para o ensino de ciências (Ciclo reflexivo de Smyth, Ação informar, depois de assistir às suas regenciais). Em outro episódio, um discente estava com dificuldades para compreender a função do eletrólito, Melissa define eletrólito como sendo:

[...] qualquer solução que eu consigo estabelecer passagem de elétrons, não precisa necessariamente ser desse jeito aqui, eu ter dois béqueres e ter um com o zinco e ter um com o cobre, não precisa necessariamente, tanto que aquela experiência que a gente fez aqui, que a gente fez com as moedas, não era desse jeito, era eletrólitos diferentes, com outras coisas, e acendeu do mesmo jeito lá o led. Lembram disso? (Aula de revisão, arquivo 15, turno 264).

Nesse trecho, Melissa, com o objetivo de resolver o conflito conceitual do discente, relembra os experimentos desenvolvidos por Antônio. Na parte final da aula Melissa usa como estratégia para o fechamento do conceito de bateria um texto que estruturou sobre o funcionamento das baterias automotivas. Nas suas reflexões sobre a adoção da estratégia de relembrar os conceitos desenvolvidos por Antônio e o texto, Melissa considera que:

[...] foi importante, mesmo que nem todos tenham prestado atenção da forma dela ter chamado ((Refere-se a aula de revisão. E que quando a supervisora não estava por perto tinha a oportunidade de "errar")) não foi a mais ideal, quando eu fui falar do texto da pilha que eu fui explicar 
a bateria de carro, a bateria é um conjunto de pilhas eu consegui fazer referência com uma coisa que eles já conheciam que era 0 experimento, vocês lembram do experimento que é um monte de pilha em série? A bateria funciona mais ou menos assim. E aí eu consegui fazer uma ligação com uma aula que eles já conheciam que era o experimento, talvez se eu tivesse falado isso sem eles terem visto, ia ficar tipo "Tá, parabéns" (lembrança estimulada, arquivo 25, turno 325).

Na percepção de Melissa a aula de revisão teve por função o aluno "[...] fixar o conteúdo químico, achei que essa aula foi importante, mas falar que ela era superimportante pro nosso projeto de modo geral, não" (Lembrança estimulada, arquivo 25, turno 210). Compreende que a revisão era uma Necessidade - Conhecimento da compreensão dos alunos em ciência, para que os discentes entendessem o conteúdo ministrado. Destaca-se que aula de revisão foi uma orientação da coordenadora e supervisora.

Para a pibidiana a adoção de estratégias instrucionais para desenvolver o conteúdo específico associadas ao diálogo e à linguagem em sala de aula são ferramentas poderosas, pois argumenta que se:

eu puder estar conversando com eles, eu tô tentando fazer isso, tanto nas aulas que são mais ambientais, quanto nas aulas que são mais "químiques" mesmo, eu procuro sempre conversar com eles, e aproximar a linguagem o máximo possível, porque às vezes eu acho, não importa que seja simples, mas o simples é entendível, então o mais simples que eu puder deixar, e conversar com eles o tempo todo, eu acho chato aquela aula que fica sempre o professor falando e todo mundo te olhando, quanto mais eu puder estar conversando com eles, melhor (Entrevista semiestruturada - Melissa, turno 53).

A narrativa de Melissa está influenciada pela estrutura do projeto, fundamentada na CTS. No CoRe, ao responder a questão "7. Que procedimentos você utilizaria para que os alunos se comprometam com esta ideia?", evoca como estratégia "Uma aula teórica sobre reações redox, uma aula teórica sobre eletroquímica e por fim uma aula experimental com a pilha de Daniell em que os alunos seriam instigados a relacionar os conteúdos das aulas anteriores".

Ao recorrer aos episódios de suas aulas, emergem elementos das estratégias que permeavam a sua ação didática por meio das respostas concedidas à algumas ações do Ciclo reflexivo de Smyth:

[...]. Normalmente as atividades passadas são feitas em sala, podendo ser feitas em grupo e com o auxílio do professor [...] eu passo entre as carteiras oferecendo ajuda para a realização dos exercícios - Ação: descrever, antes de assistir as regências.

[...] costumo também fazer anotações, mas de forma resumida, sem muito texto, dando preferências aos desenhos (esquema da pilha, por exemplo) Ação - informar, antes de assistir as regências).

O Conhecimento das estratégias instrucionais de Melissa estava fortemente influenciado pela orientação das tutoras. Por outro lado, infere-se que as regências 
implementadas por meio da explicação dos conteúdos na lousa e questionamentos aos alunos foram inspiradas em lembranças das ações didáticas de professores que a pibidiana conviveu na educação básica e ensino superior. Em sua participação no Pibid Melissa experimenta e tem contato com novas estratégias como a de adotar os exercícios para resolver em conjunto com os discentes, e avaliar como estavam aprendendo - Conhecimento da compreensão dos alunos.

\section{Conhecimento da avaliação da aprendizagem em ciências}

As escolhas de Melissa relacionadas a métodos de avaliação e o que avaliar em suas aulas estavam alinhavadas com as propostas sugeridas pelas tutoras. De modo sucinto, apresenta-se no quadro 20 as atividades avaliativas implementadas por Melissa e as dimensões do conteúdo que objetivou avaliar.

Quadro 20. Métodos de avaliação e o que avaliar em ciências, que permeavam a aula de Melissa

\begin{tabular}{|c|c|c|c|}
\hline Aula & Exercício & Resultados & Comentários \\
\hline Atomística & $\begin{array}{l}\text { Atividade escrita } \\
\text { com exercícios } \\
\text { sobre íons. }\end{array}$ & $\begin{array}{l}\text { Verificou-se qual era o } \\
\text { conhecimento prévio dos } \\
\text { alunos sobre os conteúdos } \\
\text { de química abordados. }\end{array}$ & $\begin{array}{l}\text { Percebeu-se que os alunos têm } \\
\text { facilidade de entender os } \\
\text { conceitos, mas tem dificuldade } \\
\text { com a simbologia. Várias vezes } \\
\text { eles solicitaram o auxílio dos } \\
\text { bolsistas para realizar os } \\
\text { exercícios. }\end{array}$ \\
\hline Revisão & $\begin{array}{l}\text { Atividade escrita } \\
\text { com um exercício } \\
\text { sobre pilha. Leitura } \\
\text { de um texto sobre } \\
\text { como é uma } \\
\text { bateria de carro. }\end{array}$ & $\begin{array}{l}\text { Foram feitos exercícios na } \\
\text { lousa em que os alunos } \\
\text { contribuíram na resolução, } \\
\text { dessa forma eles } \\
\text { conseguiram entender os } \\
\text { conteúdos envolvidos. }\end{array}$ & $\begin{array}{l}\text { Mais uma vez houve facilidade } \\
\text { com a parte teórica, mas } \\
\text { dificuldade com a simbologia. } \\
\text { Muitos alunos deixaram as } \\
\text { questões que exigiam a escrita } \\
\text { das reações em branco. }\end{array}$ \\
\hline
\end{tabular}

(Fonte: adaptado do Relatório individual, Melissa)

$\mathrm{Na}$ aula de atomística e revisão Melissa não apresenta nos resultados quais foram suas percepções sobre a aprendizagem dos discentes em relação ao conteúdo específico, denotando mais seu Conhecimento Pedagógico Geral. Por outro lado, nos comentários realizados sobre as aulas, a pibidiana demonstra identificar posteriormente as aulas, as limitações dos discentes associadas à parte simbólica e teórica Dificuldades de aprendizagem (Conhecimento da compreensão dos estudantes).

Para compreender os contextos desses métodos de avaliação nas aulas de conteúdo específico, dispõe-se nos próximos parágrafos os cenários em que foram implementados. A propósito, na aula de atomística Melissa elaborou com seu par, por sugestão de Maria, o exercício disposto na figura 26. 


\section{Exercício}

1) Complete a tabela:

\begin{tabular}{|c|c|c|c|c|}
\hline $\begin{array}{c}\text { Substância } \\
\text { eletricamente } \\
\text { neutra }\end{array}$ & Íon & $\begin{array}{c}\text { Cátion ou } \\
\text { ânion? }\end{array}$ & $\begin{array}{c}\text { O átomo } \\
\text { ganhou ou } \\
\text { perdeu } \\
\text { elétrons? }\end{array}$ & $\begin{array}{c}\text { Ocorreu } \\
\text { redução ou } \\
\text { oxidação? }\end{array}$ \\
\hline $\mathrm{Na}_{(\mathrm{s})}$ & & & Perdeu 1e & \\
\hline $\mathrm{Cu}_{(\mathrm{s})}$ & $\mathrm{Cu}^{2+}$ & Cátion & & \\
\hline $\mathrm{Cl}_{2(\mathrm{~g})}$ & & & Recebeu 1e & Redução \\
\hline $\mathrm{F}_{2(\mathrm{~g})}$ & $\mathrm{F}^{-}$ & & & \\
\hline $\mathrm{Pb}_{(\mathrm{s})}$ & & Cátion bivalente & & Oxidação \\
\hline $\mathrm{Ca}_{(\mathrm{s})}$ & & & & \\
\hline $\mathrm{O}_{2(\mathrm{~g})}$ & $\mathrm{O}^{2-}$ & & & \\
\hline
\end{tabular}

2) Complete corretamente as representações:

$$
\begin{aligned}
& \mathrm{Li}_{(\mathrm{s})} \rightarrow \square+\mathrm{e}^{-} \\
& \mathrm{Cu}_{(\mathrm{s})} \rightarrow \square+2 \mathrm{e}^{-} \\
& \mathrm{Al}_{(\mathrm{s})} \rightarrow \square+3 \mathrm{e}^{-} \\
& \mathrm{F}_{2(\mathrm{~g})}+2 \mathrm{e}^{-} \rightarrow \square \\
& \mathrm{Cl}_{2(\mathrm{~g})}+\square \rightarrow 2 \mathrm{Cl}^{-}
\end{aligned}
$$

Figura 26. Exercício proposta na aula de atomística.

Como foi apresentado na análise desse componente do conhecimento docente para Antônio, Maria sugeriu que nessa primeira atividade avaliativa os pibidianos construíssem questões que

[...] eu teria exercícios aqui dessa etapa que seja então um exercício, dois exercícios, de repente aquilo que a gente estava discutindo ontem das demandas cognitivas né, das habilidades, de repente escolher uma habilidade, escolher, no primeiro dia faz uma demanda de lembrar, por exemplo, aquilo que aplicou que acabou de fazer na aula será que eles conseguiram lembrar, será que eles conseguem reconhecer a partir daquilo [...] (Reunião para saber o andamento, arquivo 5, turno 40).

Nos exercícios, Melissa segue essas sugestões denotando que as questões do questionário estavam pautadas no aluno relembrar os conceitos que havia desenvolvido na aula. Entretanto, como descreveu-se no componente Conhecimento da compreensão dos alunos em ciências, Melissa acaba adotando o instrumento não mais como avaliação da aprendizagem dos estudantes em virtude de as dificuldades dos discentes da EJA em responde-lo. Na segunda aula sobre o conteúdo específico, Melissa propõe exercícios que seguem o mesmo padrão da primeira atividade avaliativa e, consequentemente, as orientações de Maria. Na entrega do exercício à classe Melissa descreve que "Na última etapa, foi entregue aos alunos uma folha com um exercício seguindo o mesmo esquema dos exercícios desenvolvidos na aula" (Relatório anual - Dupla, Melissa). Em consonância, dispõe-se na figura 27 o exercício estruturado por Melissa. 


\section{EXERCÍCIO}

O esquema abaixo ilustra uma pilha em que o sentido da movimentação dos elétrons vai do zinco para o niquel.

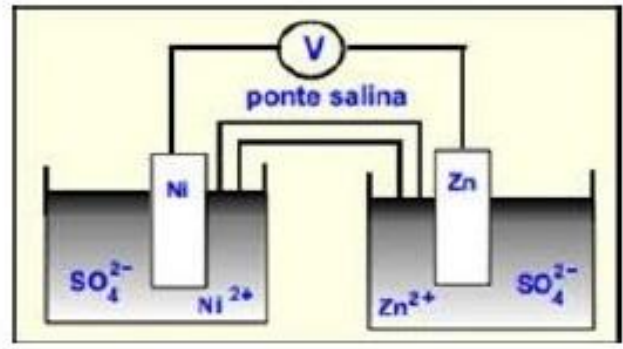

Sobre essa pilha, responda à questões:
1) Ânodo:
Cátodo:
2) Pólo positivo:
Pólo negativo:

3) Espécie que sofre oxidação:

Espécie que sofre redução:

4) Qual placa sofre corrosão?

5) Qual a placa em que se deposita sólido?

6) Equacione a semi-reação anódica:

7) Equacione a semi-reação catódica:

8) Equacione a reação global da pitha:

Figura 27. Exercício da aula de revisão.

Na proposta avaliativa de Melissa as Dimensões a serem avaliadas permearam a representação das semirreações e reações globais e a identificação do polo positivo e negativo da pilha. Além disto, o discente deveria compreender o conceito de corrosão para identificar qual placa estava sofrendo corrosão. Ao terminar de explicar os conceitos da revisão, um dos discentes demonstra preocupação com o conteúdo:

Aluno - É porque é muita coisa.

Melissa - Não olha, aqui é semi-reação...semi-reação, quando tem aquela grandona é global, só isso.

Aluno - É facinho isso aí meu.

Melissa - Ah que bom que é facinho, porque o exercício de vocês é bem isso.

Aluno - Você é inteligente ((refere-se a Melissa)) pra caramba hein. (Aula de revisão, arquivo 15, turnos 375-379).

No diálogo entre Melissa e o aluno, ganha destaque a fala "Ah que bom que é facinho, porque o exercício de vocês é bem isso", o que significa que o exercício requeria que os discentes representassem o que haviam desenvolvido em sala de aula. Entretanto, para alguns autores, quanto mais recente o aluno tiver contato com um assunto, mais complexo será seu processo de assimilação (RAMOS; MORAES, 2010). 
Essa atividade foi pensada e estruturada em virtude das dificuldades dos discentes na resolução do exercício da aula de atomística, os resultados evidenciaram que os discentes conseguiram responder pincipalmente as questões de cunho teórico. Nos dois turnos finais (378-379), infere-se que pela dinâmica da aula Melissa embute nos discentes que eles aprendem o conteúdo pelo fato de responderem a seus questionamentos, mesmo que seja pelo método de tentativa e erro. Em virtude do cenário estabelecido pelas respostas dos alunos à atividade, Melissa analisou suas aprendizagens por meio das discussões em classe, como sugere o trecho a seguir:

Os alunos tiveram uma participação significativa na discussão acerca do funcionamento das pilhas, respondendo às perguntas e apresentando questionamentos. Houve envolvimento com o texto Bateria de chumbo, momento em que eles fizeram comentários e perguntas, demonstrando interesse pelo tema. Aparentemente os conceitos envolvendo baterias foram compreendidos, conclusão possível através dos exercícios e da discussão em aula (Relatório anual - dupla, Melissa).

Os objetivos de Melissa nessa aula eram revisar os conceitos de pilhas e definir bateria. Contudo, em nenhum dos exercícios trouxe uma questão sobre os tópicos. Talvez, ao perceber essa necessidade, tenha pautado a sua avaliação em métodos não tradicionais: a participação dos alunos nas discussões promovidas em classe. Os métodos não tradicionais de compreensão da aprendizagem dos discentes aparentemente permeiam as primeiras regências da pibidiana, pois realizava indagações aos alunos sobre os conteúdos com o objetivo de analisar suas aprendizagens, entretanto, ao longo de sua prática, evidencia-se que Melissa realizava os questionamentos pelo não domínio do conteúdo reações redox, para tanto, dispõese o trecho:

É... Vamos representar isso aqui na reação então, já que vocês entenderam muito bem isso aqui? Pessoal, o zinco, o que acontece com ele? O processo de oxidar é acontecer o quê? Ele tá sofrendo oxidação, vai acontecer o que com ele? (Aula de revisão, arquivo 15, turno 189).

Talvez identificar outras formas de avaliação que não sejam fundamentadas no método quantitativo, em que os acertos ou erros nas respostas concedidas pelos discentes resultem em uma nota, o que leva geralmente o professor concluir o que o aluno aprendeu o não, revelem mais sobre a aprendizagem dos discentes. Além disto, entende-se que por mais que Melissa tenha baseado esse novo exercício em virtude de sua experiência na aula de atomística, pouco caminhou no sentido de propor questões diferentes e estratégias de ensino que possibilitassem abordar a parte representacional de modo diferente e de modo que conseguisse explorar mais a fundo as limitações dos discentes. Em suas reflexões sobre essa atividade avaliativa Melissa argumenta: 
Não ((balança a cabeça para responder)). Teve até muitos alunos, quando tava fazendo na lousa eles anotaram no caderno, e aí eles copiaram no caderno, foi engraçado porque no caderno eu pedi primeiro a de oxidação, depois a de redução, e aí a global, e aí no exercício começaram ao contrário, então vários alunos vieram mostrar " Melissa, tá certo?" E estava ao contrário, porque eles copiaram do caderno, só mudaram os metais, mas o esquema eles copiaram do caderno, não teve entendimento daquilo (Apresentação dos resultados, arquivo 21 , turno 38 ).

A percepção de Melissa que os discentes deveriam responder o que havia representado na lousa, incutiu nos mesmos que as respostas estavam nas anotações que realizaram em seus cadernos. Por outro lado, sobre essa aula compreendeu que "O público da educação EJA é composto, em sua maioria, por pessoas que já perderam o contato com os símbolos, ou nunca o tiveram; portanto são válidas outras avaliações acerca do seu conhecimento científico" (Relatório anual - dupla, Melissa). Em virtude das orientações da coordenadora, Melissa, em sua análise do conhecimento dos discentes, adotou o autor Attico Chassot (2003) sobre avaliar a alfabetização científica dos discentes da EJA. No trecho analisado tem também o Conhecimento pedagógico geral.

Em diversos momentos das aulas ministradas por Melissa e por seu par se percebe um anseio da pibidiana em aplicar os exercícios, mesmo que não houvesse tempo hábil para os alunos o resolverem. Sobre esses episódios em suas reflexões a pibidiana argumenta:

É, se fosse o caso, se não fosse, se a gente não tivesse um número contado de aula, se tivesse mais tempo, se eu visse que a aula está fluindo mais devagarinho, aí provavelmente eu deixaria, assim, não precisaria ficar naquela pressa de preciso passar mais um exercício, e tem questão também de tempo né, de deixar um tempo mais light pra eles poderem fazer, então tinha uma pressa pra gente ir pro exercício logo, se não ia dar tempo, se não fosse por causa, se a gente não precisasse dos dados, talvez não teria.

[...] se eu tivesse liberdade total pra dar aula, talvez eu tentasse fazer assim, reservar uma aula e aí eu faço a aula inteira de exercício pra gente resolver junto, porque eu acho legal e interessante a coisa de fazer exercício em sala, em grupo, porque eu acho que o aluno pensa melhor quando ele está pensando junto com outro, mas não toda aula, toda aula eu acho que come tempo, come tempo de discussão, por exemplo, a aula que a gente fez dos vídeos, que a gente precisou ficar naquela, quando que para? Para a discussão pra dar o exercício, se vai com a discussão até o final e passa o exercício em casa (Lembrança estimulada, turno 230 e 240).

Em sua fala tem-se indícios do Conhecimento Pedagógico Geral em virtude de sua gestão da classe, do tempo de aula, e de suas Decisões sobre o fazer no ensino de ciências em decorrência dos caminhos que seriam escolhidos pela pibidiana em sua aula. 
Ao analisar os exercícios da aula de revisão e a aprendizagem dos discentes, descreve:

[...] é possível dizer que os alunos se apropriaram de uma alfabetização científica a partir do momento em que eles, aparentemente, entenderam os fenômenos envolvidos na eletroquímica e suas aplicações; mesmo que esse conhecimento não seja expresso em símbolos. Até porque, é questionável a utilidade desses símbolos na vida cotidiana de um público EJA (Relatório anual dupla - Melissa).

$\mathrm{Na}$ aula de contaminação por chumbo, estruturada e implementada por Antônio, quem aplica a atividade avaliativa é Melissa:

Melissa - Deixa eu finalizar aqui rapidinho. Esse questionário que a gente trouxe aqui pra vocês, ele é um questionariozinho que vale nota.

Aluno - De novo?

Antônio - Não, a todo momento nós estamos avaliando vocês.

Melissa - Só que ele não é pra agora, eu quero que vocês...

Luiza - Na verdade, tudo que vocês fazem, a gente tá fazendo uma pesquisa tá. Então vale nota, porque assim, é uma maneira de também tá avaliando, e tá avaliando se funciona, se não funciona, tá, se...(aula de contaminação por chumbo, arquivo 16, turnos 155-159).

As atividades avaliativas na aula de sensibilização e na de logística reversa foram elaboradas por Melissa e Antônio, e tinham por objetivo incentivar a escrita dos discentes. Nesse sentido, na aula sobre logística reversa a classe foi orientada a desenvolver um pôster que englobasse os aspectos conceituais e a problemática da contaminação por chumbo. Entretanto, para chegar a essa proposta, em uma das reuniões com a coordenadora, Melissa expôs a seus pares suas dúvidas sobre 0 formato da proposta:

Melissa - Não, mas também vale a pequena, não vale a pena, se vale a pena só fazer uns três para espalhar só pela escola, não sei, eu queria a sua ((Maria)) opinião.

Maria - [...] eu concordo com o Antônio, que deixar o banner na escola é uma produção que fica pra outras turmas e até para mostrar o nosso trabalho no Pibid, porque a gente acaba fazendo um trabalho dentro da sala de aula que é um trabalho simplesmente exaustivo e que acaba não sendo visto. $E$ às vezes as pessoas vão lá e fazem um trabalhinho no dia, não estou desmerecendo, mas vai lá um dia e: "faz um cartaz aí". Aí coloca o cartaz na cidade inteira, na escola inteira e não reflete todo... (...) porque no fundo, a gente tá pegando um conhecimento e o aluno faz reflexão em cima desse conhecimento pra fazer diferentes produções e essa reflexão frente esse conhecimento que ele tá adquirindo, que ele vai trazer o aprendizado para ele [...] (Reunião para saber o andamento, arquivo 17, turno 72-73).

No diálogo acima Maria explora as possiblidades de uma atividade avaliativa, denotando o quão importante a pibidiana considerava as percepções da coordenadora em suas escolhas didáticas. Em consonância, ao avaliar a produção dos panfletos pelos discentes, Melissa argumenta: 
E esse infelizmente esse ((o desenho)) no meio no cartaz não dá pra enxergar, só que foi um grupo que assim, a produção textual dele, o que eles escreveram foi o grupo que ficou assim mais completo, porque os outros grupos ficaram meio focados né, um falou só das doenças, o outro falou só daquela coisa de descartar, apesar de não ter nenhum desenho como teve nos outros, eles escreveram tudo que precisava escrever tava ali, escreveram de uma forma poética [...] (Apresentação dos resultados arquivo 21 , turno 68).

No CoRe adaptado ao ser questionada: $O$ que você pretende que os estudantes aprendam com esta ideia?, a pibidiana aponta: "Relacionar os fenômenos de oxidação e redução com o conceito físico do funcionamento de uma pilha". Entretanto, em nenhum momento das aulas explicou qual seria essa diferença. No instrumento ao descrever que formas adotaria para avaliar a aprendizagem dos discentes, a pibidiana proporia uma "Discussão em sala de aula, lista de exercícios para serem feitos em casa e um relatório após o experimento".

Para a pibidiana os momentos finais das aulas em que ficava auxiliando os discentes na resolução dos exercícios era

[...] importante, apesar de a gente ter feito muito exercício, apesar de ter comido o tempo de explicação e tal, eu achei interessante essa coisa de eu poder sentar do lado do aluno e fazer o exercício junto com ele, porque na verdade, pelo menos que eu tinha entendido que a ideia inicial do exercício era ser justamente uma avaliação, era ver se ele tinha conseguido entender, mas eu achei que foi muito mais rico e muito mais produtivo essa coisa da gente sentar do lado deles e fazer do que eu fazer, do que eu falar tipo "Faz aí depois me entrega", eu gostei dessa oportunidade de ter sentado do lado deles. (Lembrança estimulada, arquivo 25, turno 410 ).

Melissa tinha uma percepção inicial de que a avaliação tinha por objetivo atribuir um valor à aprendizagem do discente, mas em virtude de sua participação no Pibid pôde compreender que o instrumento estruturado para avaliar o aluno tinha outro "poder", que era traduzido em enxergar como o aluno estava assimilando os conceitos que se propunha ensinar. Essa observação denota que o espaço do Pibid possibilitou à pibidiana identificar outros métodos de avaliação, e observar as Necessidades e Dificuldades de Aprendizagem dos discentes - Conhecimento da compreensão dos alunos em ciências. Outro ponto de destaque é que Melissa demonstrou ao longo de sua trajetória não compreender que existe uma diferença em entender a parte simbólica e a parte conceitual na representação química.

Por meio do delineamento desse componente, conclui-se que as atividades avaliativas adotadas por Melissa tiveram inicialmente por função diagnosticar a aprendizagem dos alunos, compor a nota atribuída pela professora supervisora e coletar dados para o subprojeto. Entretanto, a pibidiana também identificou que as atividades avaliativas poderiam ser adotadas para que o professor auxiliasse os discentes na sua aprendizagem, levando a pibidiana a compreender as limitações dos alunos. Os 
conceitos avaliados nas aulas da pibidiana foram: definição de reações redox, pilha, bateria, cátodo, ânodo, polo positivo e negativo, semi-reação e reação global, íons e eletrólito. Em virtude do exposto, acredita-se que o Pibid propiciou que Melissa conhecesse além das atividades avaliativas, e compreendesse o que era avaliar, referenciais teóricos relacionados a alfabetização científica e a CTS.

\section{Síntese do Conhecimento Docentede Melissa}

Ao analisar-se apenas as aulas ministradas por Melissa na turma da EJA se tem a imersão de seu conhecimento docente no contexto de sala de aula, disposto na tabela 16.

Tabela 16. Dados gerados no Atlas.ti - Emersão do Conhecimento Docente nas aulas ministradas por Melissa na EJA

\begin{tabular}{|c|c|c|c|c|c|c|c|c|c|}
\hline \multirow[t]{2}{*}{ Aula } & \multicolumn{8}{|c|}{ Categorias do Conhecimento Docente } & \multirow[t]{2}{*}{ Total } \\
\hline & A & B & C & 1 & 2 & 3 & 4 & 5 & \\
\hline Sensibilização (arquivo 10) & 0 & 13 & 0 & 1 & 0 & 0 & 0 & 0 & 14 \\
\hline Atomística (11) & 25 & 58 & 0 & 12 & 18 & 1 & 4 & 3 & 121 \\
\hline Pilha de moedas (arquivo12) & 0 & 1 & 0 & 0 & 0 & 0 & 0 & 0 & 1 \\
\hline Revisão (arquivo 15) & 18 & 42 & 0 & 38 & 8 & 1 & 7 & 13 & 127 \\
\hline $\begin{array}{l}\text { Contaminação por chumbo } \\
\text { (arquivo 16) }\end{array}$ & 0 & 4 & 0 & 0 & 0 & 0 & 0 & 1 & 5 \\
\hline $\begin{array}{l}\text { Logística reversa } \\
\text { (arquivo 18) }\end{array}$ & 0 & 5 & 0 & 2 & 0 & 0 & 0 & 1 & 8 \\
\hline Total & 43 & 123 & 0 & 53 & 26 & 2 & 11 & 18 & 276 \\
\hline
\end{tabular}

A - Conhecimento do Tema, B - Conhecimento Pedagógico Geral, C - Conhecimento do Contexto, 1- Orientações para o Ensino de Ciências, 2 - Conhecimento do Currículo, 3 - Conhecimento da Compreensão dos alunos em Ciências, 4 Conhecimento das Estratégias Instrucionais para o Ensino de Ciências e 5 - Conhecimento da Avaliação da Aprendizagem em Ciências

Melissa participava de modo tímido nas reuniões com as tutoras, e indícios do seu conhecimento docente emergiram principalmente nas aulas, no relatório que produziu e na lembrança estimulada.

$\mathrm{Na}$ aula de sensibilização, dispõe-se na figura 28 a integração entre 0 Conhecimento Pedagógico de Conteúdo $(B)$ e as Orientações para o Ensino de Ciências (1) em virtude da estrutura do subprojeto fundamentada na CTS e o modo como Melissa conduzia suas aulas, independente do conteúdo lecionado.

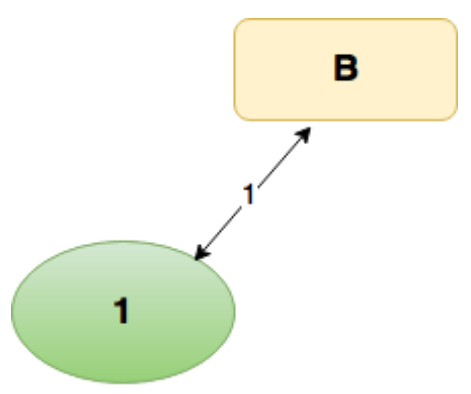

Figura 28. Mapa de integração entre os componentes do Conhecimento Docente de Melissa na aula de Sensibilização 
No preparo da aula de atomística foi a coordenadora Maria quem selecionou os conceitos a serem ensinados, refletindo diretamente nos conhecimentos de Melissa sobre o Currículo (2) e Tema (A). Entretanto, torna-se importante pontuar que apesar de Melissa conduzir os conceitos que eram objeto de ensino e apresentar a definição de reações redox nessa aula, não se pode afirmar que a pibidiana dominava o conteúdo, pois demonstrou em diversos trechos ter limitações conceituais. Essa limitação com o conteúdo levou Melissa a integrar principalmente o Conhecimento do Tema $(A)$ e do Currículo (2) ao ensinar o conceito redox na regência de atomística, pois pensava e conduzia suas aulas independentes do conteúdo. Por vezes durante as aulas a forma como a pibidiana estava conduzindo os conceitos, os discentes não estavam compreendendo. Todavia, ao refletir sobre como ensinava o conteúdo redox, inicia uma imersão no componente Decisões sobre o fazer no Ensino - Orientações para o Ensino de Ciências (1). Nessa regência as aulas foram centradas no aluno, principalmente pela insegurança da pibidiana com o conteúdo. Melissa apenas questionava os discentes sobre os conceitos de atomística e reações redox, poucos foram os episódios em que buscou conceituar o que estava ensinando. Na figura 29 tem o mapeamento da integração entre os componentes do conhecimento docente de Melissa na aula de atomística.

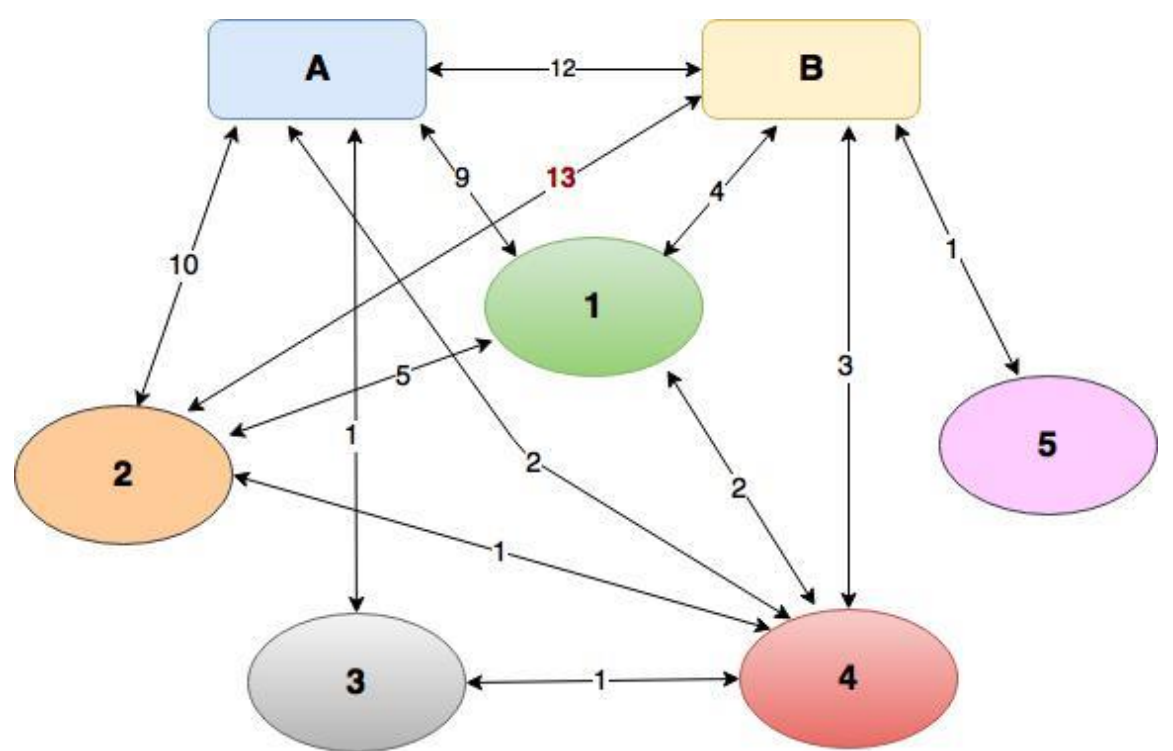

Figura 29. Mapa de integração entre os componentes do Conhecimento Docente de Melissa na aula de atomística

$\mathrm{Na}$ aula de revisão (arquivo 15) Melissa retoma os conceitos desenvolvidos em aulas anteriores. Na regência, observa-se que a pibidiana havia se dedicado a estudar os conceitos a serem ensinados, resultando em uma maior integração entre o Conhecimento do Tema (A) e as Orientações para o Ensino de Ciências (1), além disto, Melissa passou a explicar mais os conceitos, e não apenas inquerir os discentes. A 
estratégia de revisar o conteúdo e a estratégia de avaliação, bem como o conteúdo a ser avaliado foram resultado das orientações das tutoras. Na figura 30 dispõe-se a integração entre os componentes do Conhecimento Docente na aula de revisão.

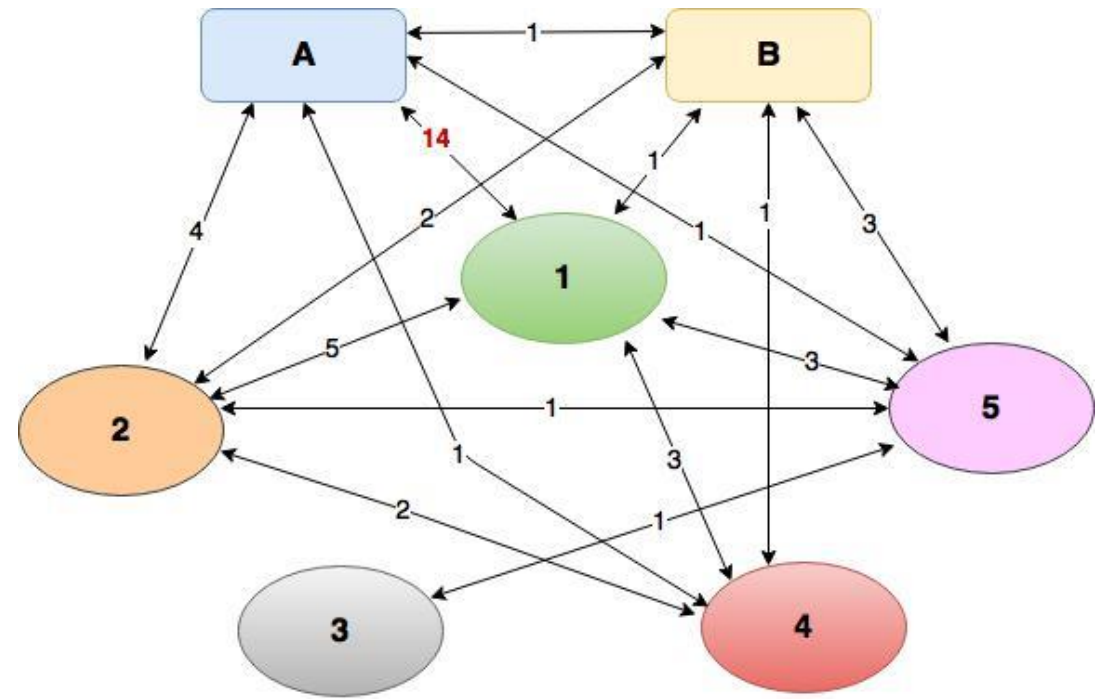

Figura 30. Mapa de integração entre os componentes do Conhecimento Docente de Melissa na aula de Revisão

$\mathrm{Na}$ aula de logística reversa Melissa propôs desenvolver o processo de reciclagem do chumbo de baterias automotivas, contudo a pibidiana não sabia o processo, o que resultou em um desconforto na classe. Durante a lembrança estimulada a pibidiana reconhece que não havia estudado o que pretendia ensinar. Nessa regência o objetivo era que os discentes aprendessem o processo de logística reversa da bateria de chumbo para integrar a avaliação proposta pelos pibidianos, que foi a produção de um cartaz no qual os discentes deveriam integrar a problemática de contaminação por chumbo. No mapa de integração (figura 31) a única conexão entre os componentes do conhecimento docente foi entre as Orientações para o Ensino de Ciências (1) e o Conhecimento da Avaliação da Aprendizagem em Ciências (5).

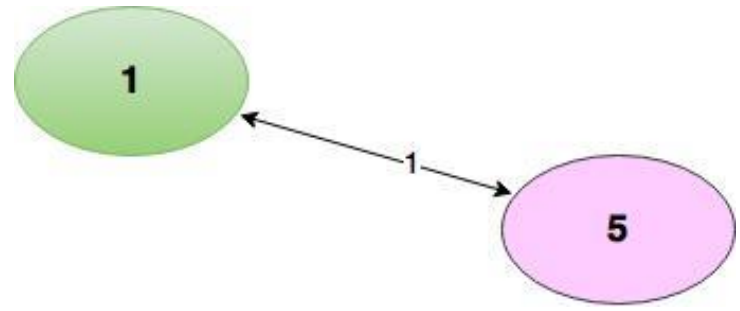

Figura 31. Mapa de integração entre os componentes do Conhecimento Docente de Melissa na aula de logística reversa

Em todas as aulas ministradas por Melissa a maior coocorrência emergiu entre os componentes Conhecimento do Tema (A) e as Orientações para o Ensino de Ciências (1), a segunda entre o Conhecimento do Currículo (2) e Conhecimento Pedagógico Geral (B). Não emergiu nas aulas da pibidiana o Conhecimento do Contexto. Em consonância apresenta-se na figura 32 o mapa de integração do 
conhecimento para à docência emergido nas aulas ministradas por Melissa na turma da EJA.

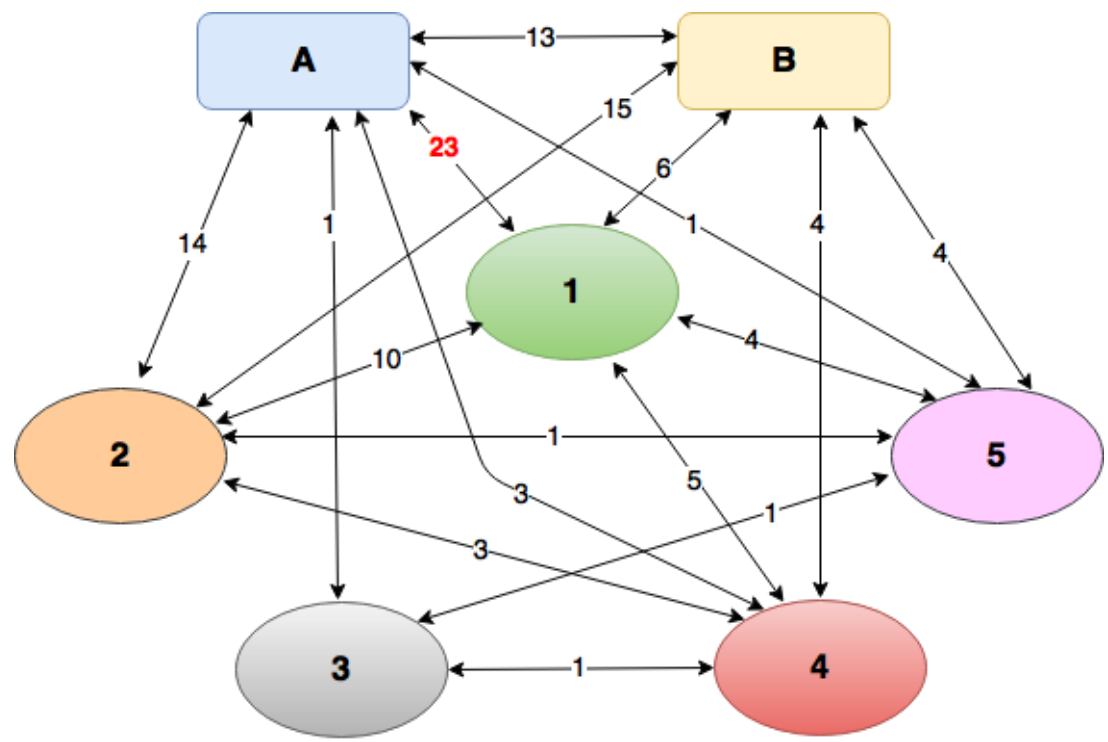

Figura 32. Mapa de integração entre os componentes do Conhecimento Docente de todas as aulas ministradas por Melissa na EJA

De modo geral, não se pode afirmar que os conhecimentos docentes mapeados nas narrativas de Melissa compõem o Conhecimento Docente de Melissa, mas inferese que começaram a ser acessados pela pibidiana a partir do conhecimento docente de suas tutoras e também pela sua prática em sala de aula, que eram reflexos dessas orientações.

\subsubsection{Percepções dos alunos da escola conveniada sobre 0 conhecimento docente de Melissa}

Melissa lecionava também na turma do $3^{\circ}$ da EJA, constituída por 13 alunos frequentes, contudo, no dia em que foi aplicado o instrumento, uma das discentes estava ausente. Sendo assim, o instrumento de percepção foi respondido por 12 alunos, uma das alunas não quis analisar o conhecimento docente de Melissa.

Inicialmente organizou-se os dados na tabela 17 de acordo com percentual de respondentes que assinalaram uma das vinte e oito subcategorias, além dos valores máximos e mínimos. 
Tabela 17. Porcentagem de respondentes que assinalaram as subcategorias e seus respectivos valores mínimos e máximos

\begin{tabular}{ccccccccc}
\hline \multirow{2}{*}{ Subcategoria } & \multicolumn{9}{c}{ Resposta assinaladas (\%) } & \multicolumn{3}{c}{ Valores } \\
\cline { 2 - 9 } & $\mathbf{0}$ & $\mathbf{1}$ & $\mathbf{2}$ & $\mathbf{3}$ & $\mathbf{4}$ & $\mathbf{5}$ & Mínimo & Máximo \\
\hline CT1 & 8,3 & 0 & 0 & 8,3 & 33,3 & 50 & 0 & 5 \\
\hline CT 2 & 0 & 0 & 8 & 33 & 17 & 42 & 2 & 5 \\
\hline CT 3 & 8 & 0 & 0 & 17 & 33 & 42 & 0 & 5 \\
\hline CT 4 & 0 & 0 & 0 & 17 & 8 & 75 & 3 & 5 \\
\hline CT 5 & 0 & 0 & 0 & 25 & 42 & 33 & 3 & 5 \\
\hline CT 6 & 0 & 0 & 8,3 & 25 & 33,3 & 33,3 & 2 & 5 \\
\hline CT 7 & 0 & 0 & 0 & 25 & 33 & 42 & 3 & 5 \\
\hline RCE 1 & 0 & 0 & 8 & 25 & 25 & 42 & 2 & 5 \\
\hline RCE 2 & 0 & 8 & 0 & 33 & 17 & 42 & 1 & 5 \\
\hline RCE 3 & 0 & 0 & 8 & 8 & 50 & 33 & 2 & 5 \\
\hline RCE 4 & 0 & 8 & 8 & 17 & 25 & 42 & 1 & 5 \\
\hline RCE 5 & 8 & 0 & 8 & 17 & 33 & 33 & 0 & 5 \\
\hline RCE 6 & 0 & 17 & 8 & 17 & 33 & 25 & 1 & 5 \\
\hline RCE 7 & 8 & 8 & 8 & 25 & 25 & 25 & 0 & 5 \\
\hline OEC 1 & 0 & 0 & 8,3 & 25 & 33,3 & 33,3 & 2 & 5 \\
\hline OEC 2 & 0 & 0 & 0 & 17 & 33 & 50 & 3 & 5 \\
\hline OEC 3 & 0 & 0 & 17 & 17 & 33 & 33 & 2 & 5 \\
\hline OEC 4 & 8 & 0 & 8 & 17 & 25 & 42 & 0 & 5 \\
\hline OEC 5 & 8 & 8 & 8 & 8 & 33 & 33 & 0 & 5 \\
\hline OEC 6 & 17 & 0 & 8 & 8 & 42 & 25 & 0 & 5 \\
\hline OEC 7 & 0 & 0 & 8 & 17 & 42 & 33 & 2 & 5 \\
\hline CCE 1 & 8 & 17 & 8 & 17 & 25 & 25 & 0 & 5 \\
\hline CCE 2 & 0 & 8 & 8 & 25 & 25 & 33 & 1 & 5 \\
\hline CCE 3 & 8 & 0 & 17 & 17 & 33 & 25 & 0 & 5 \\
\hline CCE 4 & 0 & 8 & 8 & 17 & 33 & 33 & 1 & 5 \\
\hline CCE 5 & 0 & 8 & 0 & 25 & 33 & 33 & 1 & 5 \\
\hline CCE 6 & 8 & 17 & 0 & 8 & 25 & 42 & 1 & 5 \\
\hline CCE 7 & 0 & 0 & 8 & 25 & 25 & 42 & 2 & 5 \\
\hline A & 0 & 5 & 0 & & & & 5 \\
\hline
\end{tabular}

Ao analisar-se os dados da tabela acima na subcategoria CT 1 - Meu professor sabe o conteúdo que ele está ensinando, na percepção de $50 \%$ dos discentes da EJA, Melissa sempre demonstrou saber o conteúdo, enquanto para 8\% Não me recordo/não sei. No CT 4 Meu professor selecionou conteúdos apropriados para os alunos para $75 \%$ dos discentes sempre a pibidiana selecionava de modo adequado os conceitos. Por outro lado, para $25 \%$ às vezes, e para outros $25 \%$ frequentemente, Melissa usava exemplos adequados para ensinar (RCE 1). Em relação a adoção de analogias nas aulas da pibidiana, (RCE 2) para $42 \%$ dos discentes sempre estavam presentes nas aulas de Melissa, enquanto que para outros $33 \%$ as vezes ocorria em sua prática, o que significa de modo geral que os discentes não observaram sempre que Melissa recorria a analogias em suas aulas.

Com relação à subcategoria OEC 1 Meu professor me faz compreender claramente os objetivos desse curso para $8 \%$ (raramente), $25 \%$ (às vezes), $33 \%$ (frequentemente), denotando que para $66 \%$ dos discentes Melissa nem sempre deixava claro os objetivos educacionais. Quando questionados na OEC 6 Meu professor lida 
com o contexto da nossa sala de aula adequadamente na perspectiva dos discente $17 \%$ (não me recordo/não sei), 8\% (raramente ocorreu), 8\% (às vezes) e 42\% (ocorreu frequentemente), esses valores nos levam a inferir que os discentes não tinham uma percepção homogênea sobre como Melissa lidava com a classe.

Na CCE 1 Meu professor averigua o conhecimento prévio dos estudantes antes de começar a ensinar um novo assunto para $25 \%$ sempre Melissa verificava os conhecimentos prévios, enquanto que na percepção de outros $25 \%$, frequentemente. Em contrapartida, para 8\% (Não me recordo/não sei), 17\% (nunca ocorreu na prática), $8 \%$ (raramente ocorreu) e para $17 \%$ (às vezes).

$\mathrm{Na}$ questão aberta do instrumento de percepção dois discentes compartilharam suas impressões gerais sobre Melissa. Nesse sentido, a aluna A5 argumentou que não tinha "Como não falar da professora Melissa, que além de me ajudar em uma grande aprendizagem, me ajudou a compreender mais os assuntos e a gostar mais de química, obrigada por me ajudar e me ensinar a saber mais do que imaginava sobre química (A5)". Na percepção de A5, Melissa a possibilitou compreender os conceitos químicos e a gostar da disciplina de química. O discente A6 argumentou "Bem gostei das aulas, eles explicaram muito bem na minha opinião. E sempre que tive dúvidas eles voltaram a explicar a matéria que não entendia" (A6) demonstrou em sua fala que a pibidiana retornava à explicação quando demonstrava dificuldades com o conteúdo.

Agrupou-se na tabela 18 os valores relativos a análise exploratória.

Tabela 18. Valores da média, mediana e desvio padrão de cada questão

\begin{tabular}{cccc}
\hline Questões & Média & Mediana & Desvio Padrão \\
\hline CT1 & 4,08 & 4,5 & 1,44 \\
\hline CT 2 & 3,92 & 4 & 1,08 \\
\hline CT 3 & 3,92 & 4 & 1,44 \\
\hline CT 4 & 4,58 & 5 & 0,79 \\
\hline CT 5 & 4,08 & 4 & 0,79 \\
\hline CT 6 & 3,92 & 4 & 1,00 \\
\hline CT 7 & 4,17 & 4 & 0,83 \\
\hline RCE 1 & 4,00 & 4 & 1,04 \\
\hline RCE 2 & 3,83 & 4 & 1,27 \\
\hline RCE 3 & 4,08 & 4 & 0,90 \\
\hline RCE 4 & 3,83 & 4 & 1,34 \\
\hline RCE 5 & 3,67 & 4 & 1,50 \\
\hline RCE 6 & 3,42 & 4 & 1,44 \\
\hline RCE 7 & 3,25 & 3,5 & 1,60 \\
\hline OEC 1 & 3,92 & 4 & 1,00 \\
\hline OEC 2 & 4,33 & 4,5 & 0,78 \\
\hline OEC 3 & 3,83 & 4 & 1,11 \\
\hline OEC 4 & 3,75 & 4 & 1,54 \\
\hline OEC 5 & 3,50 & 4 & 1,68 \\
\hline OEC 6 & 3,33 & 4 & 1,78 \\
\hline OEC 7 & 4,00 & 4 & 0,95 \\
\hline
\end{tabular}




\begin{tabular}{cccc}
\hline CCE 1 & 3,08 & 3,5 & 1,73 \\
\hline CCE 2 & 3,67 & 4 & 1,30 \\
\hline CCE 3 & 3,42 & 4 & 1,51 \\
\hline CCE 4 & 3,75 & 4 & 1,29 \\
\hline CCE 5 & 3,83 & 4 & 1,19 \\
\hline CCE 6 & 3,50 & 4 & 1,83 \\
\hline CCE 7 & 4,00 & 4 & 1,04 \\
\hline
\end{tabular}

Os dados da tabela acima, denotam que a média total do instrumento foi de 3,81 .

A subcategoria CT 4 Meu professor selecionou conteúdos apropriados para os alunos apresentou a maior média, 4,58 (mediana 5 e desvio padrão 0,79), em oposição na subcategoria CCE $1 \mathrm{Meu}$ professor averigua o conhecimento prévio dos estudantes antes de começar a ensinar um novo assunto tem-se a menor média 3,08 (mediana 3,5 e desvio padrão 1,73). Em relação a mediana, as subcategorias CCE 1 e RCE 7 apresentaram os menores valores, 3,5 , enquanto que CT 1 e OEC 2, os maiores valores, 4,5 .

Quando esmiuçou-se os valores relativos à dispersão, a questão CCE 6 foi a questão com maior desvio padrão, 1,83, e a OEC 2 com o menor, 0,78. Os valores acima de 1 (CT 1, 2, 3 e 6; RCE 1, 2, 4, 5, 6 e 7; OEC 1, 3, 4, 5 e 6; e CCE 1 ao 7) para o desvio indicam uma heterogeneidade nas escalas assinaladas pelos discentes, por outro lado, valores abaixo de 1 (CT 4, 5 e 7; RCE 3; OEC 2 e 7) expressam uma uniformidade entre as respostas dos alunos.

A média para cada categoria foi de 4,09 para CT, 3,72 para RCE, 3,81 para OEC e 3,61 para CCE. Em relação ao desvio padrão para cada categoria tem-se 1,06 Conhecimento do tema (CT), 1,29 Representação do conteúdo e estratégias para seu ensino (RCE), 1,29 Objetivo educacional e do contexto (OEC) e 1,40 Conhecimento das compreensões dos estudantes (CCE). Por fim, os valores da mediana para todas as categorias foram iguais a 4 .

A partir dos valores calculados emergidos para todo o instrumento e por categoria, infere-se que na percepção dos alunos Melissa tem um bom Conhecimento Docente. Contudo, a análise exploratória não possibilita concluir se as respostas assinaladas são confiáveis. Em consonância, calculou-se o alfa para verificar o grau de confiabilidade nas percepções dos alunos da EJA sobre o conhecimento docente de Melissa. Na tabela 19 dispõe-se os valores de Alfa de Cronbach separados por dimensão e pela ausência de cada categoria, além de as subcategorias que a compunha. 
Tabela 19. Alfa de Cronbach para todo o instrumento e separado por dimensão, além do alfa na ausência de cada categoria

Alpha de Cronbach na ausência da variável

\begin{tabular}{|c|c|c|c|c|c|}
\hline \multirow[b]{2}{*}{ Subcategoria } & \multirow[t]{2}{*}{ Geral } & \multicolumn{4}{|c|}{ Dimensão } \\
\hline & & CT & RCE & OEC & CCE \\
\hline CT1 & 0,95 & 0,68 & & & \\
\hline CT 2 & 0,94 & 0,69 & & & \\
\hline CT 3 & 0,95 & 0,67 & & & \\
\hline CT 4 & 0,95 & 0,78 & & & \\
\hline CT 5 & 0,95 & 0,78 & & & \\
\hline CT 6 & 0,94 & 0,74 & & & \\
\hline CT 7 & 0,95 & 0,78 & & & \\
\hline RCE 1 & 0,95 & & 0,84 & & \\
\hline RCE 2 & 0,95 & & 0,81 & & \\
\hline RCE 3 & 0,95 & & 0,82 & & \\
\hline RCE 4 & 0,95 & & 0,82 & & \\
\hline RCE 5 & 0,94 & & 0,77 & & \\
\hline RCE 6 & 0,94 & & 0,74 & & \\
\hline RCE 7 & 0,94 & & 0,75 & & \\
\hline OEC 1 & 0,95 & & & 0,76 & \\
\hline OEC 2 & 0,94 & & & 0,72 & \\
\hline OEC 3 & 0,94 & & & 0,73 & \\
\hline OEC 4 & 0,94 & & & 0,74 & \\
\hline OEC 5 & 0,95 & & & 0,70 & \\
\hline OEC 6 & 0,94 & & & 0,77 & \\
\hline OEC 7 & 0,95 & & & 0,75 & \\
\hline CCE 1 & 0,94 & & & & 0,90 \\
\hline CCE 2 & 0,94 & & & & 0,91 \\
\hline CCE 3 & 0,94 & & & & 0,91 \\
\hline CCE 4 & 0,94 & & & & 0,89 \\
\hline CCE 5 & 0,94 & & & & 0,91 \\
\hline CCE 6 & 0,94 & & & & 0,89 \\
\hline CCE 7 & 0,94 & & & & 0,89 \\
\hline $\begin{array}{c}\text { Alpha de } \\
\text { Cronbach Geral }\end{array}$ & 0,95 & 0,77 & 0,82 & 0,77 & 0,91 \\
\hline
\end{tabular}

Para as vinte e oito questões que compunham o instrumento o valor de alfa de 0,95 traduz que as respostas concedidas pela turma da EJA têm uma consistência muito boa. Como discorreu-se na análise desse instrumento para Antônio, a correlação entre as questões que compunham o instrumento como, por exemplo, CT $4 \mathrm{Meu}$ professor selecionou conteúdos apropriados para os alunos e CCE 2 Meu professor conhece as dificuldades dos alunos para aprendizagem do conteúdo específico, infere-se que possibilitou em um aumento na consistência do teste.

Os valores do alfa para cada dimensão foi de 0,77 (CT), 0,82 (RCE), 0,77 (OEC) e 0,91 (CCE). Quando o alfa foi calculado excluindo a subcategoria, poderia suscitar uma melhora ou piora do instrumento, em virtude de denotar que uma delas seria importante para a composição do instrumento. Contudo, os valores não revelam uma 
diminuição ou aumento nos valores de alfa, mas uma aproximação com o alfa $(0,95)$ para todo instrumento.

O instrumento aplicável produziu mensurações consistentes e, consequentemente, o olhar do aluno da educação básica sobre o conhecimento docente de Melissa é confiável.

\subsection{O pibidiano Mateus}

Como delineou-se no texto, os bolsistas de iniciação à docência atuavam em dupla ou trio. Mateus constituía trio com outros dois bolsistas que não comporão a análise do Conhecimento Docente.

A problemática $O$ descarte das lâmpadas fluorescentes estava fundamentada nos pressupostos da educação CTS. Segundo Mateus, o objetivo era desenvolver o conceito de contaminação por chumbo:

[...] eu falei não, eu quero falar sobre contaminação por chumbo que é algo que eu tenho muita curiosidade, eu tinha muita dúvida, e... enfim, e ela ((Maria)) chegou com essa proposta de falar sobre as lâmpadas florescentes, de eletroquímica, e foi algo muito bacana que a gente conseguiu unir (Entrevista semiestruturada Mateus, turno 44).

Mateus foi quem produziu todas as aulas, apesar de um de seus pares, Elder, lecionar algumas regências. Sobre esse aspecto, Maria concebia que "[...] Mateus era muito dedicado ao Pibid, era muito dedicado às ações, aos compromissos dele. Então, às vezes eu percebia que a Clara e o Elder ficavam um pouco à sombra do que o Mateus fazia" (Entrevista semiestruturada - Maria, turno 42). Em consonância, o pibidiano demonstrou, ao longo de sua trajetória na implementação das aulas, insatisfação com os demais membros de sua equipe por não participarem da construção das mesmas. $O$ processo de desenvolvimento e implementação das regências pelo bolsista e os documentos gerados dispõe-se em ordem cronológica na tabela 20. 
Tabela 20. Ordem cronológica de coleta de dados e seus respectivos arquivos - Mateus

Reunião geral Atividade Arquivo

Apresentação da proposta de trabalho 1

Aula experimental - Teste de chama - turma 1 3

Aula experimental - Teste de chama - turma 2 4

Reunião para saber o andamento 4.1

Reunião para saber o andamento

Aula de sensibilização

Aula estrutura atômica e definição de oxidação - turma 1

Aula estrutura atômica e definição de oxidação - turma 2

Aula de conceitos gerais de eletroquímica

Aula experimental da Gota salina e deposição do cobre - turma 2

Aula experimental da Gota salina e deposição do cobre - turma 1

Aula lúdica - Funcionamento de lâmpadas fluorescentes - turma 2 5

Aula lúdica - Funcionamento de lâmpadas fluorescentes - turma 1

Apresentação dos resultados

Reunião geral

Apresentação dos resultados e reflexão

6

7

8

8

8.1

9

10

Lembrança estimulada

10.1

11

11.1

Entrevista semiestruturada

12

Relatório individual

13

14

Ciclo de Smyth - Antes

16

Ciclo de Smyth - Depois

CoRe

A aula experimental de teste de chama foi implementada no primeiro semestre

e não compôs as regências organizadas pelo trio no segundo semestre. No quadro 21

apresenta-se a organização dos blocos de aula propostos e implementados por Mateus no segundo semestre.

Quadro 21. Blocos de aulas planejadas pelo pibidiano Mateus

\begin{tabular}{|c|c|c|}
\hline Aula & Objetivos & Atividades \\
\hline $\begin{array}{l}\text { Enquete e dinâmica das fichas } \\
\text { informativas }\end{array}$ & $\begin{array}{l}\text { Possibilitar aos alunos } \\
\text { reconhecerem os diferentes tipos de } \\
\text { lâmpadas existentes no mercado, } \\
\text { relacionando com o consumo em } \\
\text { suas residências, além de avaliar os } \\
\text { aspectos técnicos, ambientais e } \\
\text { econômicos relacionadas às } \\
\text { lâmpadas fluorescentes. Apresentar } \\
\text { a PNRS }\end{array}$ & $\begin{array}{l}\text { Aula envolvendo a } \\
\text { adoção da aplicação de } \\
\text { uma enquete e um } \\
\text { debate envolvendo } \\
\text { lâmpadas fluorescentes }\end{array}$ \\
\hline $\begin{array}{l}\text { Aula teórica: conceitos de íons } \\
\text { e estados de oxidação }\end{array}$ & $\begin{array}{l}\text { Estudar os conceitos envolvendo a } \\
\text { formação de íons e os estados de } \\
\text { oxidação das substâncias }\end{array}$ & Aula teórica e exercícios \\
\hline $\begin{array}{lll}\begin{array}{l}\text { Conceitos } \\
\text { eletroquímica }\end{array} & \text { gerais } & \text { de } \\
\end{array}$ & $\begin{array}{l}\text { Desenvolver os conceitos de } \\
\text { reações redox, semirreção e reação } \\
\text { global }\end{array}$ & $\begin{array}{l}\text { Aula teórica, permeada } \\
\text { por exercícios }\end{array}$ \\
\hline $\begin{array}{l}\text { Aula experimental da Gota } \\
\text { salina e deposição do Cobre }\end{array}$ & $\begin{array}{l}\text { Esmiuçar as concepções dos } \\
\text { alunos sobre os níveis de } \\
\text { representações macroscópico, } \\
\text { submicroscópico e o simbólico }\end{array}$ & Aula experimental \\
\hline $\begin{array}{l}\text { Aula lúdica -Funcionamento de } \\
\text { lâmpadas fluorescentes }\end{array}$ & $\begin{array}{l}\text { Compreender o funcionamento das } \\
\text { lâmpadas fluorescentes e seu } \\
\text { descarte, por meio do do } \\
\text { entrelaçamento do conceito de } \\
\text { reações redox }\end{array}$ & $\begin{array}{l}\text { Aula dinâmica, tendo } \\
\text { como pano de fundo a } \\
\text { adoção de um folder que } \\
\text { possibilitou sou uma } \\
\text { discussão sobre a } \\
\text { temática estudada }\end{array}$ \\
\hline
\end{tabular}

Capítulo 4. Resultados e Discussões 
As propostas de ensino eram apresentadas em reuniões com a coordenadora. Para o bolsista, os blocos de aulas foram desenvolvidos norteados pela questão As lâmpadas fluorescentes são uma boa opção para o uso doméstico considerando aspectos econômicos, sociais e ambientais?

Mateus integrava o subprojeto há dois anos. O planejamento de suas aulas sofriam pequenas modificações em relação a dupla Antônio e Melissa.

\subsubsection{Conhecimento Docente de Mateus}

Analisaram-se 25 documentos para identificar o possível reflexo do Pibid na construção do conhecimento docente de Mateus. O pibidiano foi o único entre os participantes do estudo que respondeu ao CoRe. O mapeamento do Conhecimento Docente, gerados no Atlas.ti (tabela 21), correspondem a 406 trechos selecionados. Em decorrência da coocorrência, teve-se um total de 583 categorias. 
Tabela 21. Relatório gerado no Atlas.ti - Conhecimento Docente de Mateus Documento

\section{Categorias do Conhecimento Docente}

$\begin{array}{llllll}\text { C } & 1 & 2 & 3 & 4 & 5\end{array}$

Reunião geral (arquivo 1)

Apresentação da proposta de trabalho (arquivo 3)

Aula experimental - Teste de chama - turma 1 (arquivo 4)

Aula experimental - Teste de chama - turma 2 (arquivo 4.1)

Aula experimental - Teste de chama - turma 1 (arquivo 4)

Reunião para saber o andamento (arquivo 5)

Reunião para saber o andamento (arquivo 6)

Aula de sensibilização (arquivo 7)

Aula estrutura atômica e definição de oxidação - turma 1 (arquivo 8)

Aula estrutura atômica e definição de oxidação - turma 2 (arquivo 8.1)

Aula de conceitos gerais de eletroquímica (arquivo 9)

Aula experimental da Gota salina e deposição do cobre - turma 2 (arquivo 10)

Aula experimental da Gota salina e deposição do cobre - turma 1 (arquivo 10.1)

Aula lúdica - Funcionamento de lâmpadas fluorescentes - turma 2 (arquivo 11)

Aula lúdica - Funcionamento de lâmpadas fluorescentes - turma 1 (arquivo 11.1)

Apresentação dos resultados (arquivo 12)

Reunião geral (arquivo 13)

Apresentação dos resultados e reflexão (arquivo 14)

Lembrança estimulada (arquivo 15)

Entrevista semiestruturada (arquivo 16)

Relatório individual (arquivo17)

Ciclo de Smyth - Antes (arquivo 18)

Ciclo de Smyth - Depois (arquivo 19)

CoRe (arquivo 20)

Trabalho de congresso

\section{Lousa}

\section{Total}

A - Conhecimento do Tema B - Conhecimento Pedagógico Geral, C - Conhecimento do Contexto, 1- Orientações para o Ensino de Ciências, 2

\begin{tabular}{cc} 
& \multicolumn{2}{c}{ Categorias } \\
\hline A & B \\
0 & 0 \\
0 & 15 \\
\hline 0 & 13 \\
0 & 16 \\
0 & 13 \\
0 & 12 \\
\hline 0 & 0 \\
0 & 41 \\
\hline 11 & 16 \\
\hline 18 & 41 \\
\hline 8 & 1 \\
\hline 4 & 1 \\
\hline 9 & 4 \\
0 & 10 \\
\hline 0 & 9 \\
\hline 0 & 7 \\
\hline 0 & 0 \\
\hline 0 & 4 \\
\hline 2 & 7 \\
\hline 0 & 18 \\
\hline 1 & 15 \\
\hline 0 & 4 \\
\hline 0 & 1 \\
0 & 3 \\
\hline 0 & 3 \\
\hline 1 & 0 \\
\hline 54 & 241 \\
\hline 0 \\
0 \\
0 \\
0 \\
0 \\
0 \\
0 \\
0 \\
0
\end{tabular}

\begin{tabular}{ccccccc}
$\mathbf{C}$ & $\mathbf{1}$ & $\mathbf{2}$ & $\mathbf{3}$ & $\mathbf{4}$ & $\mathbf{5}$ & \\
0 & 0 & 0 & 0 & 0 & 0 & 0 \\
0 & 0 & 6 & 0 & 1 & 0 & 22 \\
0 & 0 & 1 & 0 & 0 & 0 & 14 \\
0 & 0 & 0 & 0 & 0 & 0 & 16 \\
0 & 0 & 1 & 0 & 0 & 0 & 14 \\
\hline 1 & 4 & 1 & 0 & 1 & 0 & 19 \\
1 & 0 & 0 & 0 & 0 & 0 & 1 \\
0 & 18 & 0 & 0 & 0 & 0 & 59 \\
0 & 17 & 12 & 0 & 3 & 6 & 65 \\
0 & 5 & 14 & 1 & 2 & 7 & 88 \\
0 & 24 & 5 & 0 & 3 & 5 & 46 \\
\hline 0 & 13 & 3 & 0 & 4 & 2 & 27 \\
0 & 21 & 1 & 1 & 5 & 2 & 43 \\
0 & 2 & 0 & 0 & 0 & 0 & 12 \\
\hline 0 & 4 & 0 & 0 & 0 & 0 & 13 \\
\hline 1 & 6 & 0 & 1 & 1 & 2 & 18 \\
0 & 0 & 0 & 0 & 0 & 0 & 0 \\
\hline 5 & 3 & 0 & 2 & 0 & 4 & 18 \\
\hline 0 & 3 & 5 & 1 & 1 & 1 & 20 \\
\hline 0 & 7 & 2 & 0 & 2 & 0 & 29 \\
\hline 2 & 12 & 1 & 1 & 4 & 4 & 40 \\
\hline 0 & 2 & 0 & 0 & 1 & 0 & 7 \\
\hline 0 & 2 & 0 & 0 & 1 & 0 & 4 \\
0 & 0 & 0 & 2 & 1 & 3 & 9 \\
\hline 0 & 5 & 1 & 0 & 1 & 0 & 10 \\
\hline 0 & 1 & 1 & 0 & 0 & 0 & 3 \\
\hline 10 & 149 & 53 & 9 & 31 & 36 & 583 \\
\hline
\end{tabular}

(anhecimento do Currículo, 3 - Conhecimento

da Compreensão dos alunos em Ciências, 4 - Conhecimento das Estratégias Instrucionais para o Ensino de Ciências e 5 - Conhecimento da Avaliação da Aprendizagem em Ciências

Capítulo 4. Resultados e Discussões 
No primeiro documento (arquivo 1) não emerge nenhuma das categorias do conhecimento docente. Essa reunião teve por objetivo apresentar os anseios das aulas a serem elaborados e implementadas durante $\mathrm{o}$ ano pelos pibidianos. De modo semelhante, no arquivo 13 não surgiram elementos do conhecimento docente de Mateus. Os arquivos 8 e 8.1 são os documentos com maior número de componentes do conhecimento docente com os respectivos valores: 65 e 88. O Conhecimento do Contexto (C) e da Compreensão dos alunos em Ciências (3) manifesta-se timidamente no repertório de conhecimento docente de Mateus.

A coocorrência dos componentes do Conhecimento Docente foi mais expressiva entre o Conhecimento Pedagógico Geral $(B)$ e as Orientações para o Ensino de Ciências (1), reflexo, talvez, das Decisões sobre o fazer no ensino (Orientações para o Ensino de Ciências) ser influenciado pelo seu Conhecimento Pedagógico Geral.

O Conhecimento Pedagógico Geral (B) integra-se com todos os componentes do conhecimento docente, por outro lado, o Conhecimento do Contexto (C) estabelece conexão apenas com o Conhecimento Pedagógico Geral (B). Na figura 33 apresenta a integração entre os componentes do conhecimento docente de Mateus.

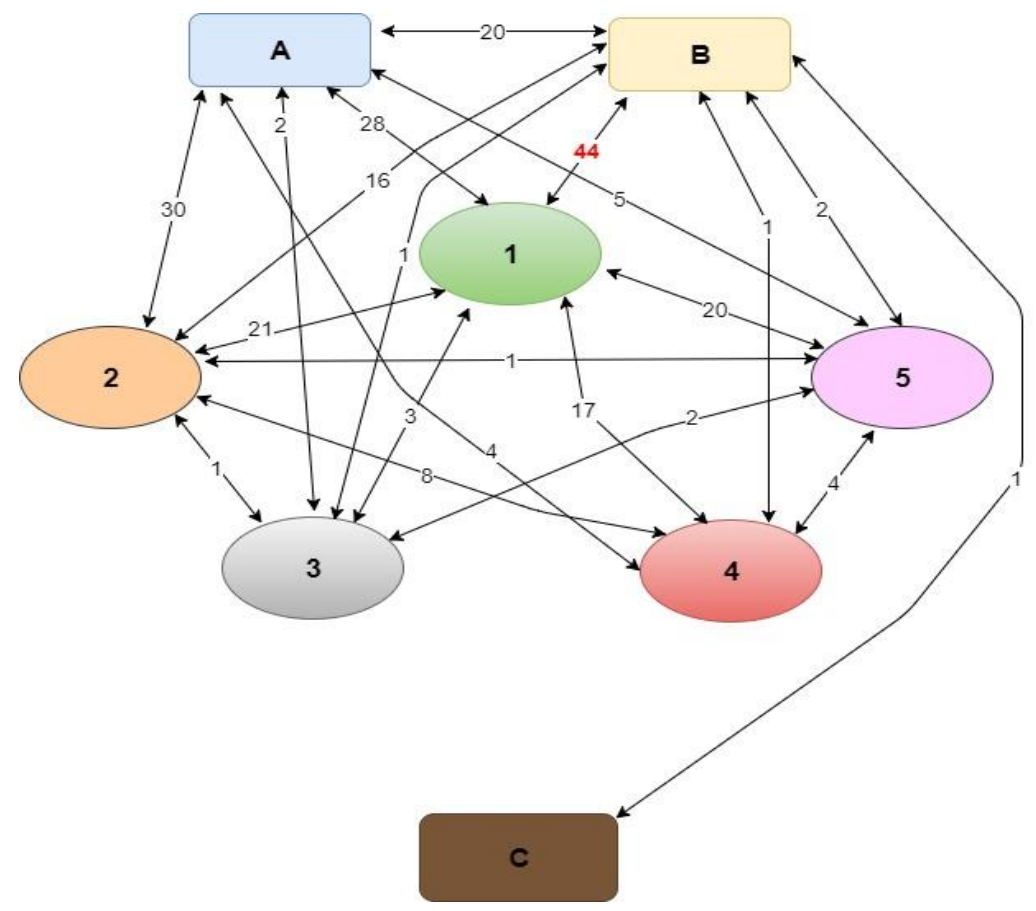

Figura 33. Coocorrência das categorias do Conhecimento Docente de Mateus ${ }^{8}$

Dispõe-se nos tópicos a seguir os contextos em que emergiam o conhecimento docente de Mateus e as suas coocorrências.

\footnotetext{
${ }^{8} \mathrm{~A}=$ Conhecimento do Tema, $\mathrm{B}=$ Conhecimento Pedagógico Geral, $\mathrm{C}=$ Conhecimento do Contexto - Orientações para o Ensino de Ciências, 2 - Conhecimento do Currículo, 3 - Conhecimento da Compreensão dos alunos em Ciências, 4 - Conhecimento das Estratégias Instrucionais para o Ensino de Ciências e 5 - Conhecimento da Avaliação da Aprendizagem em Ciências 


\section{Conhecimento do tema}

Nesse componente apresenta-se o conhecimento de Mateus sobre redox. Não emergem nesse componente as estruturas sintáticas e substantivas.

Nas reuniões em que eram apresentadas às tutoras o planejamento, o pibidiano foi direcionado por Maria a trabalhar com o conceito redox:

Maria - [...] eu acho que o ponto forte é vocês discutirem se tão falando de metais, estão falando de substâncias, sais em alguns casos, 0 estado de oxidação, porque o que vai justificar se ele é contaminante ou não, é o estado de oxidação.

Mateus - E aí vem essa parte de oxidação, de reações redox, e aí eu acho que seria interessante também, Domênica, passa mais uma, fazer os experimentos, coisas simples, por exemplo, aqueles experimentos com permanganato, potássio, que é divertido de se ver, aí o aluno fala: "Nossa, mas porque mudou de cor? Mudou de cor por causa disso?" Acho que é interessante (Apresentação da proposta de trabalho, arquivo 3, turno 48-49).

Em outro momento da reunião Mateus argumenta à Maria que para chegar a discutir com os alunos os diferentes estados de oxidação, inicialmente teria que "[...] trabalhar, não sei, oxidação, número de redução, essas coisas [...]" (Apresentação da proposta de trabalho, arquivo 3, turno 60). Apesar de ter essa percepção de currículo horizontal - Conhecimento do currículo, seu planejamento estava centrado em propriedades gerais sobre os metais, demonstrando um hiato entre o que declarou e seu planejamento, levando Maria a direcionar a discussão, como observou-se no turno 48.

Nessa reunião (arquivo 3) foram discutidos os aspectos gerais das propostas de sequências de aulas a serem implementadas por Mateus. Entretanto, a primeira aula regida posteriormente a essa reunião foi o experimento do teste de chama, que não foi apresentado pelo pibidiano na reunião com Maria. Com relação a esse episódio, Mateus, ao realizar uma retrospectiva solicitada pela coordenadora sobre o que havia implementado do planejamento, argumenta:

Mateus - Não, a gente ainda não fez nada disso, a gente, assim, a professora ela estava trabalhando modelos atômicos, e aí no fim do assunto, eu tentei relacionar, porque eu estava pensando em partir do fato, do fenômeno, fluorescência e tudo mais, tinha até feito uma apresentação no prezi, mas assim, deixei de lado.

Maria - Ah que dó gente.

Clara - Aí a gente chegou lá ela tava dando atomística.

Mateus - Aí o que eu falei? Pra gente correr que o semestre tá acabando, a gente teve a intenção de fazer um teste de chama e a gente começa a falar a parte disso, aí a gente fez o teste de chama, e atividade, essa atividade de verificação só (Reunião para saber o andamento, arquivo 5, turno 149-152). 
No diálogo acima suscita-se que não havia inicialmente uma preocupação do subprojeto em considerar o currículo que a professora supervisora estava seguindo. Por outro lado, Maria havia orientado Mateus a iniciar sua aula por uma revisão de atomística, mas essas orientações foram seguidas pelo pibidiano no segundo semestre, pois a aula de teste de chama foi a primeira e última intervenção realizada por Mateus no primeiro semestre.

No decorrer das reuniões, em que os pibidianos eram orientados por Maria, surgem indícios da influência dessa tutora sobre como Mateus deveria iniciar o ensino de reações redox. Nesse sentido, apresenta-se o diálogo:

Maria - Deixa eu mostrar uma coisa, o que a gente, se a gente for trabalhar com eletroquímica que é o segundo interesse do projeto, como a gente tá trabalhando com lâmpada é muito pertinente, a ideia seria trabalhar um pouquinho com eles a parte de íons, saber o que é um íon, perder elétrons, recebeu elétrons, seria a parte... o Mateus, talvez tenha que conversar com a Clara sobre isso aqui, seria uma lousa deles, seria uma lousa, ele ia trabalhar, seria o início vamos dizer assim [...]

Luiza - Tá, perfeito, no fundo essa questão aqui vai trabalhar a questão do conceito de íon, e a questão da própria notação, ou seja, a linguagem que o químico utiliza, e aí aqui você vai, isso usando os três níveis explicativos, então você tem uma questão que é macroscópica, uma questão que é simbólica, e uma questão que é submicroscópica, então, perfeito, aqui eu acho que é importante também ressaltar que é o conceito que o aluno tem dificuldade, e a gente tem uma diferença bem marcante em relação a esse termo elemento, que esse termo elemento pra química dentro da ciência ele tem um significado muito claro do que é eletroquímica, que é um conjunto de átomos que tem o mesmo número de prótons, que é substância, então aqui, eu acho que só falta falar de substância, então, e pontuar mesmo que o conceito de elemento químico é o conceito que é bem distinto do conceito do senso comum de elemento, porque você pode usar essa forma de elemento pra muitas coisas no senso comum, e eu acho que é bastante importante a gente pontuar, a diferenciação dos termos da ciência dos termo do senso comum (Reunião para saber o andamento, arquivo 6, turno 192-193).

As orientações das tutoras refletem diretamente na proposta de ensino conduzida por Mateus. A primeira aula ministrada pelo pibidiano envolveu o conceito de atomística e a definição de oxidação. Dispõe-se no figura 34 as lousas confeccionadas pelo pibidiano. 


\section{Números de Oxidaçáto.}

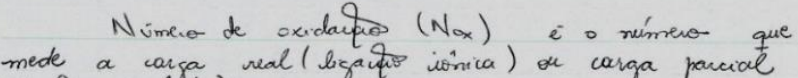

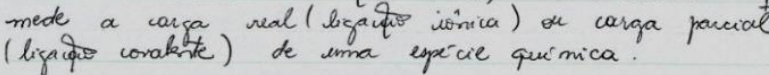

Nox em compostos ioninicos. Número que mede a canga real da espicie ExEMPLO

$$
\mathrm{C}_{2} \mathrm{~S} \rightarrow \sigma \mathrm{C}_{2} \text { cude } 2 e^{-} \text {formando- }
$$$$
\text { whin wion de coung } 2 \text { - }(\mathrm{Nox}-2 \text {. }
$$

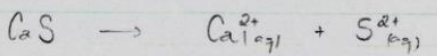

Nox en compostos coratertes.

ra moliculata. que apusenta a carga parial do àtomo

EtEMPLo:

$\mathrm{CH}_{2} \mathrm{O}$

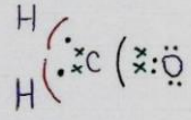

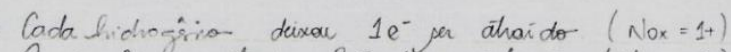

O ougino atrain $2 e^{-}$do carbono $\left(\mathrm{N}_{0} \mathrm{x}=2\right)$

0 coubono thaur $2 e^{-}$dos hidiafivos e dex

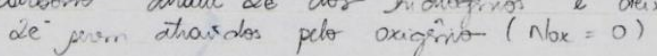

Númerss de oxidaifas usuais (regras)

possui Nox $=-1$ )

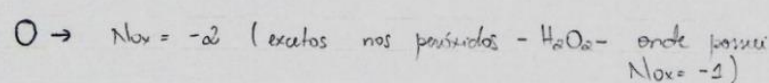

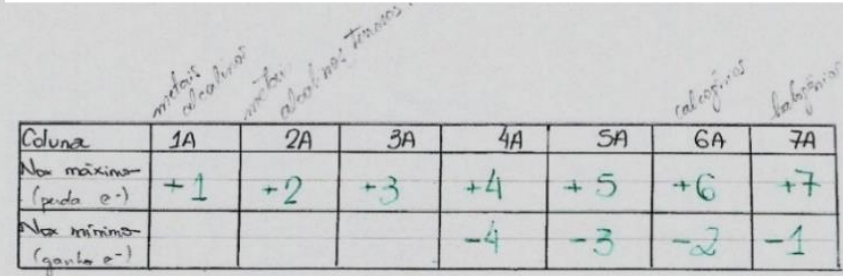

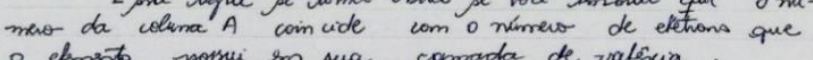

$$
\text { Cálaculo- des mineros de oxidacipos. }
$$

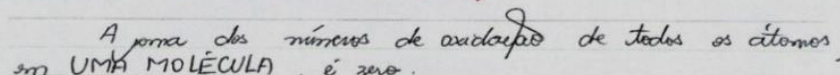

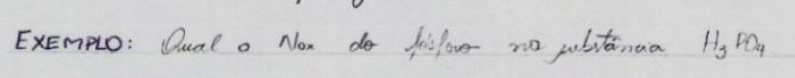

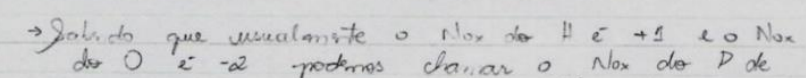
$x$ e ínailar a parra a zaro. Obsewe.

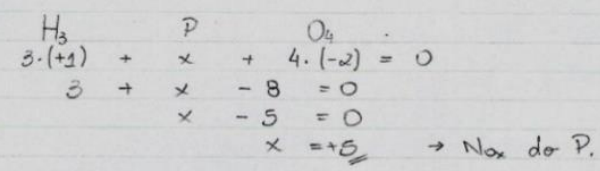

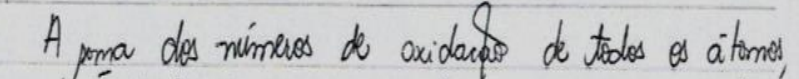
an um ION COMPOSTO, i igual à mopria carga elettica do ion.

EXEMPLOS: Ospae: $\begin{aligned} P_{2} O_{7}^{4-} \quad P_{2}^{4} & > \\ 2 x+7(-2) & =-4 \\ 2 x-14 & =-4 \\ 2 x & =10\end{aligned}$

$x=5 \rightarrow N_{x}$ do $P$.

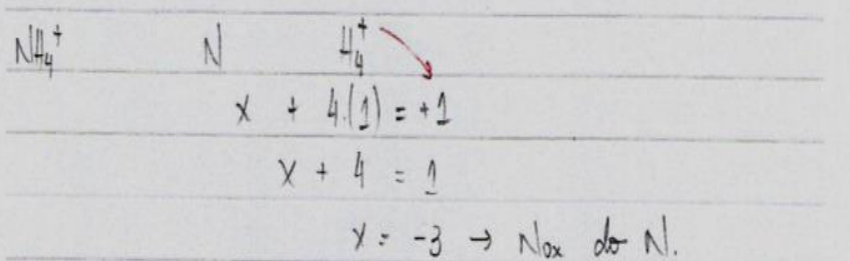

Figura 34. Lousa estruturada por Mateus para a aula de estrutura atômica e definição de oxidação 
Ao refletir sobre a organização da lousa, Mateus argumenta que a sua construção o ajuda a conduzir a aula de uma forma mais linear, e também a relembrar os caminhos que havia planejado para a condução dos conceitos que permeavam a aula, como denota a passagem:

Sim, nós fizemos esquemas do que nós, enfim, faríamos na lousa, pra gente não se perder, pra gente abranger todo conteúdo, enfim, e aí nós aplicamos essa atividade, que era justamente o que pedia era pro aluno dizer se, pro aluno responder como é que ficava, qual era a representação quando um átomo recebia, perdia, dois ou três elétrons, e em baixo também analisar a equação e poder saber dizer: "Não, recebeu dois elétrons, perdeu dois elétrons" Interessante, e o resultado foi interessante também porque praticamente não teve erro, eu não sei se é a nossa forma de trabalhar, não que não teve erro, mas eu não sei se era nossa forma de trabalhar porque era, são semelhante a essa, mas assim, né, aquela coisa de você olhar o do colega, e enfim, mas a gente ajudou também (Apresentação dos resultados, arquivo 12, turno 21).

Mateus organizou a aula sobre estrutura atômica envolvendo o conceito de perda e ganho de elétrons, para na sequência definir oxidação. Nessa regência não definiu redução. Na lembrança estimulada, ao rever essa aula, Mateus discorreu que não recordava a razão de não ter abordado a redução (Lembrança estimulada, arquivo 15). Infere-se que a insegurança com o conceito de redução tenha levado o pibidiano a desconsiderá-la:

Mateus - Depreshow ((ficar para baixo)). Não eu... eu estudei em escola pública. A nossa situação não era diferente dessa. A diferença é que a gente não saía da sala de aula. Pra se ter ideia eu nunca vi... eu fui ver é... eletroquímica no técnico, e os professores eles peçam pro... eles assim, partiam do pressuposto que você tinha aprendido isso no ensino médio, então... havia... ia pro laboratório e tudo mais. Foi difícil, depois aprender de... de novo na faculdade... só que... tem até uma... uma coisa da transposição didática porque eu aprendi de uma forma pra aplicar o... aquele conteúdo e você para assim e fala: meu Deus, eu tenho que... dar aula disso.

Elder - É porque no técnico a gente vê eletroquímica... como ligar uma pilha, por exemplo, e assim, você chegar no técnico você não vai falar como ligar uma pilha porque tem que ter uma base inteira, né.

Pesquisadora - No médio, né? Ensino médio?

Elder - No médio, isso, é.

Mateus - Isso. Então foi difícil, por conta disso. Eu tive que me preparar e ainda assim eu acho que foi pouco... (Lembrança estimulada, arquivo 15, turno 408-412).

Em outro momento Mateus relata que no ano anterior havia trabalhado em suas aulas com o conceito de orgânica, e considerou o conteúdo de eletroquímica mais difícil de aprender e ensinar (Lembrança estimulada, arquivo 15). Por outro lado, o pibidiano considerou importante desenvolver aulas sobre esse conteúdo, Capítulo 4. Resultados e Discussões 
ainda na graduação em virtude da "[...] orientação e supervisão de pessoas ((professoras)) experientes" (Lembrança estimulada, arquivo 15, turno 423).

Essa primeira regência foi implementada para duas turmas de segundo ano (arquivo 8, 8.1). Na aula ministrada na primeira turma Mateus a inicia explicando os conceitos iniciais a serem desenvolvidos e relembrando o experimento do teste de chama - Conhecimento das Estratégia Instrucionais para o Ensino de Ciências. Essa estratégia de relembrar os conceitos trabalhados no primeiro semestre também permeia suas Decisões sobre o Fazer no Ensino (Orientações para o ensino de ciências) na regência. Considerando-se que o experimento foi desenvolvido no primeiro semestre, e percebendo as dificuldades dos alunos (Conhecimento Pedagógico Geral), o pibidiano explica:

Não lembra. Eu tenho um átomo, esse daqui é como se o átomo tivesse cortado, só um pedaço do átomo, uma demonstração, eu tenho um átomo com uma área positiva e ao redor daquela área, outra área maior negativa, essa área positiva ela é chamada de núcleo, e a negativa de eletrosfera, consequentemente, no núcleo eu tenho prótons, que são essas cargas positivas e nêutrons, que são nulos, que são neutros, e na eletrosfera eu tenho elétrons que são negativos, daí no experimento que a gente fez, ocorrendo a emissão de cores, de aromas diferentes, só para retomar, basicamente a gente fornecia energia ao elétron, esse elétron pulava de uma camada superior, a camada externa, emitia luz, que seriam os fótons, e aí ele retornava para a sua camada de origem, ou seja, o fator dele mudar a cor, ele mudar a cor da chama e tudo mais, ela se dava pela absorção de energia e pela emissão de energia, quando ele emitia essa energia, ele emitia na forma de luz, ou seja, brilhava lá o bário verde, sódio amarelo? (Aula estrutura atômica e definição de oxidação, arquivo 8, turno 10).

Em outro trecho da aula para chegar ao conceito de oxidação pergunta aos discentes:

Mateus - Eu tenho um ânion, ele está negativo, então o que vai acontecer? Ele vai ganhar carga elétrica, ou seja, ele tem quantos prótons?

Alunos - 17.

Mateus - 17, ele tinha 17 elétrons, mas agora ele tem quantos? Ele ganhou carga negativa, e a quantidade vai sempre ser expressa aqui em cima.

Alunos - 18.

Mateus - Agora eu vou falar para vocês uma coisa que complementa toda essa história, é o conceito ((Mateus fica em silêncio para os alunos ficarem calmos e na sequência retoma a explicação)) de número de oxidação, número de oxidação seria o que? Seria a carga que o elemento possui naquele momento, ou seja, nesse momento aqui qual é a carga que o cloro possui? nesse daqui, a carga?

Aluno - 17. 
Mateus - Ele tem 17 prótons e 17 elétrons, eles se cancelam, e aí fica neutro, ou seja, o NOX dele é zero, nesse caso aqui, ele vai ter um NOX diferente, por que? Porque muda a quantidade, qual é a carga que ele tem? Qual é a carga que ele assume?

Alunos - Negativa.

Mateus - É negativa, a carga vai ser negativa, quanto?

Alunos - 1 .

Mateus - Vai ser menos 1 , ou seja, ele está eletricamente carregado de menos 1 (Aula estrutura atômica e definição de oxidação, arquivo 8, turno 56-66).

No episódio acima observa que Mateus entrelaça o Conhecimento do currículo (Currículo horizontal e vertical) com o conhecimento do tema e suas Orientações para o Ensino de Ciências, por causa das decisões sobre o fazer no ensino de ciências. Na aula de atomística a saliência curricular é marcada pelo conceito de Nox e oxidação.

$\mathrm{Na}$ sequência realiza um experimento demonstrativo para explicar os diferentes estados de oxidação, como denota o trecho:

Mateus - Isso é +1 . Aqui a gente tem quatro amostras, (Ininteligível 00:18:22.07), tenho sulfato de cobre, sulfato de alumínio, o alumínio (- Ininteligível 00:18:28:20), e tenho cobre metálico, e esse aqui é uma solução aquosa de sulfato de cobre 2 , qual é a diferente dos dois?

Aluno - Um está sólido e o outro [liquido].

Mateus - Um está sólido, aí esse aqui está azul e esse aqui está marrom, e por que? No caso lá do alumínio eu tenho sulfato, o sal, eu não sei se ele tem cheiro e eu tenho alumínio, deixa eu pegar aqui, eles possuem Nox diferentes, ou seja, quem disse que você vai tocar?

Aluno - Não pode?

Mateus - Não pode, você vai tocar em tudo, já pensou se fosse nitrato de prata? Sua mão ia ficar preta.

Luiza - Durante uns 6 meses mais ou menos.

Aluno - la zuar a minha mão?

Luiza- Ah claro, com certeza.

Mateus - Uma coisa que a gente pode considerar como uma das experiências da substância, o número de oxidação dela, por exemplo, quando tem um metal cobre metálico, ele tem nox zero, por que? Porque ele simplesmente é cobre 29 , esse é o número de prótons e esse é o número de elétrons, se eu tiver a solução de sulfato de cobre, eu vou ter o íon sulfato, e eu vou ter o íon cobre $2+$, e aí quantos prótons ele vai ter?

Alunos - 29.

Mateus - Ele vai ter 29 prótons e quantos elétrons?

Alunos - 27.

Aluno - O professor ((Mateus)), e para mexer nos números dos prótons, como é que é? 
Mateus - Se você mexer em números de prótons você vai estar mudando o elemento, por exemplo, naquele caso ali, eu tenho $29 \mathrm{Cu}^{2+}$ se eu por um acaso mexer isso aqui, a minha representação estaria errada, entendeu? E aí por exemplo, se eu colocar aqui para vocês. Qual elemento é esse $((27 \mathrm{Ni}))$ ? (Aula estrutura atômica e definição de oxidação, arquivo 8, turno 7083).

$\mathrm{Na}$ segunda turma do segundo ano, ao implementar a aula novamente, observa-se que o pibidiano refletiu sobre suas ações na turma anterior, e busca conduzir a aula de outra maneira. Nesse sentido, explica os conceitos desenvolvidos no experimento de teste de chama, não apenas inquerindo os discentes - Conhecimento Pedagógico Geral, mas o aproxima do tema redox Decisões sobre fazer no Ensino. Além disto, por conta da falta de tempo que teve para implementar o experimento demonstrativo na turma anterior, o pibidiano decide não aplicá-lo na segunda turma. Nessa nova oportunidade o pibidiano conduz a aula de modo a incentivar a participação dos discentes, em consonância, os discentes compartilham com o pibidiano suas dificuldades conceituais. Além disto, o pibidiano reformula a definição de oxidação:

\begin{abstract}
Uma outra coisa interessante... Falar antes de eu mostrar pra vocês. Eu vou conversar com vocês o que muda....Oh galera... Só para terminar...Nesse caso aqui galera, ele é um átomo e tá neutro ((a supervisora distribui os boletins e atrapalha o andamento da explicação de Mateus)). A gente também tem como, como posso dizer, a gente também tem como saber, o estado de oxidação de cada espécie química que existe. Isso, enfim. Como, o que seria estado de oxidação? O número de oxidação? Seria a carga parcial que o átomo assume. Nesse caso aqui, é um átomo neutro, não existe elétrons a mais, nem elétrons a menos. Qual é a carga dele? É como se eu tivesse quatro elétrons e quatro prótons todos se cancelassem. É neutro. Ele tem carga zero. E esse vai ser o estado...o número de oxidação dele, nesse caso (Aula estrutura atômica e definição de oxidação, arquivo 8.1, turno 159).
\end{abstract}

A abordagem adotada pelo pibidiano foi desenvolver o conceito de Nox por meio da carga parcial que um elemento assume ao fazer uma ligação iônica ou a carga parcial que é adquirida quando é realizada uma ligação covalente. Entretanto, em seu planejamento não apresentou a reação de redução e, consequentemente, a simultaneidade da reação redox, que na literatura é apontada como uma das problemáticas associadas ao ensino e aprendizagem de redox (NOGUEIRA; GOES; FERNANDEZ, 2017). Ainda sobre o episódio acima, talvez tenha sido mais diretivo em definir o número de oxidação justamente por ter sido direcionado por Luiza a ficar atento ao tempo da aula - Conhecimento Pedagógico Geral:

Aluno - Aquele número em cima do ferro, é o número de oxidação então?

Capítulo 4. Resultados e Discussões 
Mateus - Sim.

Luiza - Olha a hora senão vocês não vão ter tempo...

Mateus - Sim, nesse caso do ferro, a gente simplifica escrevendo dessa forma. Nesse caso do ferro é mais dois. Nesse caso aqui é um átomo neutro, nox zero. E nesse caso aqui? (Aula de conceitos gerais de eletroquímica, arquivo 8.1, turno 160-163).

Permaneceu a problemática de não apresentar a definição de redução e, consequentemente, a simultaneidade da reação redox .

Posteriormente, Mateus conduziu a regência de conceitos gerais de eletroquímica (arquivo 9) para duas turmas do segundo ano que foram unidas por conta da baixa frequência dos alunos. Essa aula foi planejada para ser desenvolvida em dois momentos. No primeiro, o pibidiano retomaria os conceitos de atomística, definição de oxidação, definição de redox, balanceamento de reações, o cálculo do Nox e eletronegatividade. A segunda etapa envolveria dois experimentos demonstrativos, um relacionado a oxidação de cobre e palha de aço em solução de sulfato de cobre e outro a fita magnésio e ácido clorídrico. Apesar de o planejamento ter sido realizado por Mateus, por sugestão da supervisora, quem iniciou a condução da aula foi o pibidiano Elder. A consequência dessa decisão foi uma aula baseada em truncamentos, na tentativa de Elder em lecionar conforme havia aprendido no cursinho. Mateus percebendo a dificuldade do pibidiano, tentou assumir a classe, mas a coordenadora chamou sua atenção:

Luiza - Está aí? Não, deixa ele ((pede para Mateus deixar o Elder)), deixa ele ((Elder)) aí, eu vou ajudando ele, ele não está aqui para aprender?

Elder - É.

Luiza - Então, manda brasa, Mateus deixa ele, os alunos sabem que ele também é aluno, tá, então, você está aqui para aprender não apavora não, tá, porque se você não aprender aqui, né, amanhã você vai fazer bobagem em outra sala então, vamos embora, não fica com medo não, eu não mordo ninguém não você já sabe, a cara é feia assim, mas foi de nascença. ((risos generalizados na sala de aula)) (Aula de conceitos gerais de eletroquímica, arquivo 9, turno 34-36).

Em outro momento a supervisora argumentou que não era importante os discentes aprenderem o Nox:

Luiza - Então, eu só dei 15 anos de aula ((risadas)). Mas não importa gente, o que importa é assim, não interessa qual é a carga como calcula entendeu? Interessa para ele que vai ser quimicozinho, não interessa para vocês, interessa mais para eles do que para vocês, né então assim, aonde que você quer chegar com esse Nox, o que qual é a ideia? É diferenciar o que tem carga do que não tem? (Aula de conceitos gerais de eletroquímica, arquivo 9, turno 102). 
O pibidiano iniciou a implementação de seu planejamento na metade do tempo inicialmente disponível. Nesse sentido, o pibidiano iniciou a sua fala:

Mateus - Isso tudo serviu e vai servir para a gente nessa aula durante as próximas aulas, justamente pelo fato, por exemplo, eu tenho o metal cobre e eu tenho uma solução cobre, ela inclusive se você quiser colocar (00:31:40) aí vocês vão ser vão ver porque o metal o cobre na forma metálica ele possui essa forma, não essa forma ((sólida - segura uma árvore de cobre)), mas essa cor, esse brilho e a solução de cobre ela é azul e por que? Isso tudo é influenciado pelo nox.

Luiza - É influenciado também por aquela aula anterior e que ela excedeu lá e quem estava na aula lembra que queimou os copinhos ficou colorido? Você estava na aula que o Mateus deu essa aula, lá atrás.

Aluno - Que o fogo ficou de cor diferente?

Luiza - Isso que o foguinho ficou de cor diferente isso mesmo.

Mateus - A grande parte dos elementos químicos eles possuem diferentes Nox, alguns possuem Nox fixos, por exemplo, eu vou encontrar o hidrogênio com Nox +1 e todas as substancias que eu encontrá-lo, exceto, nessa forma, só que aí é molecular e hidretos, aí é outra coisa, mas é fixo ele tem um Nox +1 , o oxigênio ele vai ter o Nox -2 em todas as formas, exceto nos peróxidos. Professora ((Luiza)), eu vou fazer um peróxido eu vou fazer o peróxido de hidrogênio, que seria, por exemplo, com hidrogênio ou com oxido (Aula de conceitos gerais de eletroquímica, arquivo 9, turno 107-111).

A intervenção da supervisora refletiu negativamente em todo o planejamento vislumbrado por Mateus. Em outra passagem da regência Mateus, ao retomar a palavra para levar os discentes para mediar o processo de entendimento do que havia acontecido no experimento envolvendo a fita de magnésio $(\mathrm{Mg})$ e de ácido clorídrico $(\mathrm{HCl})$, discorre:

Mateus - Nesse caso não, é como se fosse isso aí, não tem um metal, é como se fosse não, é. eu tinha um metal, esse metal passa para forma iônica... os elétrons que estavam junto com ele, serão usados por outro elemento dentro do recipiente, dentro do que se formou, dentro dos produtos dessa reação, ele vai ser usado por alguém daqui.

Aluno - Aham, aham.

Mateus - A gente pode... eu tenho ácido clorídrico se a gente dissociar é um composto iônico fica cloro negativo e o hidrogênio positivo, por que? Porque justamente quando a gente foi lá ver a tabela de nox fixos enfim, a gente vai ver que o hidrogênio ele é mais um dos compostos associado a outros elementos (Aula de conceitos gerais de eletroquímica, arquivo 9, turno 244-246).

Entretanto, tanto a supervisora como os demais pibidianos interrompem a fala de Mateus durante a regência, resultando, em conceitos desenvolvidos de modo muito superficial e não concluídos. Por conta desses truncamentos envolvendo a condução da aula de conceitos gerais de eletroquímica, como 
consequência das diversas vozes que a conduziu, confrontou-se o total de turnos com a fala de cada participante (Elder, Clara, Mateus, Luiza e alunos). Nesse sentido, tem-se a proporção entre as falas disposta no gráfico 1 :

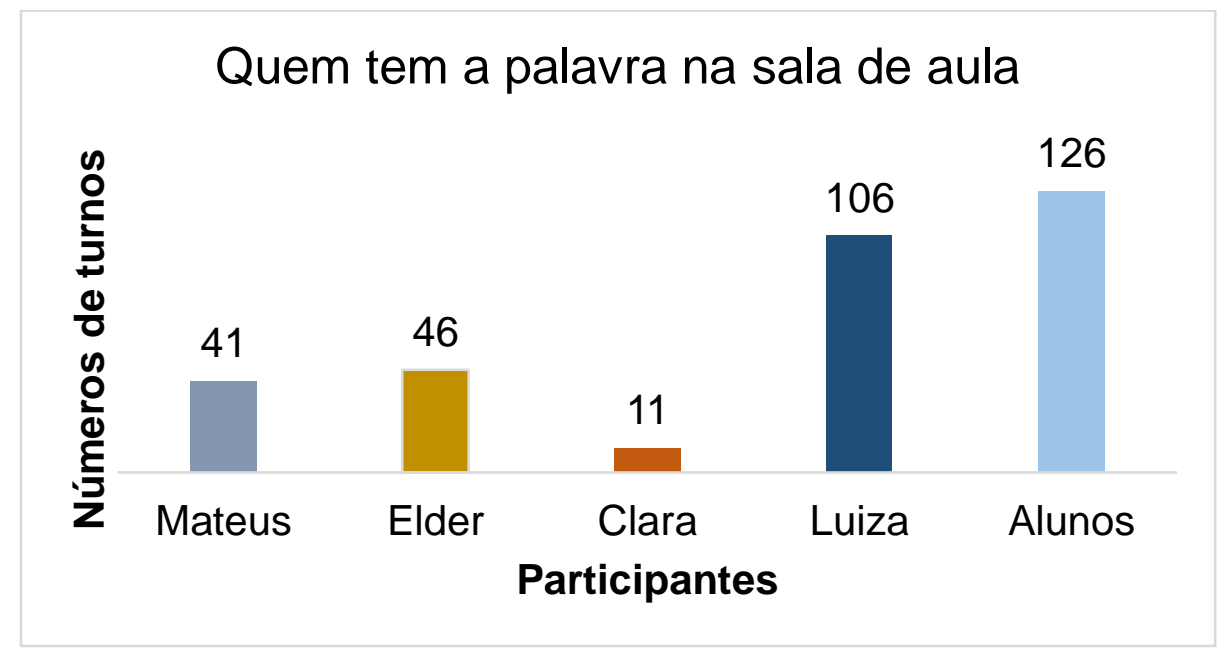

Gráfico 1. Quem tem a palavra na Aula de conceitos gerais de eletroquímica

Nessa aula contabilizou-se 330 turnos. Os discentes e a supervisora foram os participantes que mais voz tiveram nessa regência. Mateus que havia planejado a aula é o penúltimo com menor número de turnos dentre os membros do subprojeto. A descrição e os desdobramentos dessa regência não compõem a estrutura do relatório confeccionado por Mateus, talvez por seu planejamento não ter sido conduzido como havia almejado.

A terceira aula sobre o conteúdo redox, ministrada por Mateus, envolveu o experimento da gota salina e a deposição do cobre (Aula experimental da gota salina e deposição de cobre, arquivo 10 e 10.1). Nessa aula surge pela primeira vez o conceito de redução:

\footnotetext{
Mateus - Uma outra coisa que eu esqueci de falar. Vai ser importante para vocês resolverem o restante da atividade. Essas duas reações são de oxirredução, onde há transferência de elétrons. Algo que a gente já tinha visto nas últimas aulas era que quando uma espécie química, ela recebe um elétron ou elétrons, o Nox dela cai, é como se ela recebesse carga negativa, ou seja, o Nox dela diminui. Quando a espécie química, ela perde elétrons, o Nox já não aumenta, ou seja, ela perde carga negativa. É como se aumentasse a carga positiva dela. É como, não, é. E daí vem esses termos, redução e oxidação. A redução seria o ganho de elétrons pela espécie química e a oxidação, a perda, ou seja, quando o elemento reduz, o Nox dele cai. Quando o elemento oxida, o Nox dele aumenta. Isso vai ser importante para vocês responderem a atividade dois. A questão dois, da atividade um (Aula experimental da gota salina e deposição do cobre, arquivo 10 , turno 51).
}

Nesse trecho tem-se o entrelaçamento do Conhecimento do tema com os componentes Conhecimento da avaliação da aprendizagem em ciências, 
Conhecimento das estratégias instrucionais para o ensino de ciências e Conhecimento do currículo (saliência curricular).

Em outro momento do experimento da gota salina Mateus demonstrou que estava mais seguro com o conteúdo, e iniciou a explicação do experimento discorrendo sobre a formação de ferrugem na tampinha:

Mateus - Ah sim, outra coisa, galera, interessante, é que, por exemplo: "ah, bacana formou uma ferrugem na tampinha". Ok. A ferrugem já é importante ((formada)) por conta da água, da solução salina, no caso, e também do oxigênio. Outra coisa importante também é... Observem essa reação aqui, oh... Aqui a gente tem ferro metálico formando um cátion, vocês lembram da aula que a gente falou sobre cátions, ânions, que são íons. Aqui a gente tem um cátion. Qual a carga desse cátion?

Aluno - Dois mais?!

Mateus - Dois mais. E mais dois elétrons, ou seja, aqui ele tinha carga zero. Não tinha carga, era nulo. A mesma quantidade de prótons é... A quantidade de prótons é igual à quantidade de elétrons que ele tinha. E aqui? Mudou. Aqui tem carga, ou seja, ele perdeu dois elétrons para poder formar um cátion. Nesse caso, ele perdendo elétrons, ele oxida ou reduz?

Aluno - Reduz.

Mateus - Ele reduz, ou seja, se na tampinha está acontecendo um processo de corrosão, consequentemente a formação da ferrugem e o ferro oxida... O que vocês responderiam então na questão 3 ? Aí vão pensando e já vão resolvendo e já pode fazer o último bloco também. Pensa em um grupo, conversem... Aí vocês fazem para entregar.

Aluno - Agora eu posso olhar os dois? (Aula experimental da gota salina e deposição de cobre, arquivo 10, turno 88-93).

$\mathrm{Na}$ segunda vez que ministrou essa aula (arquivo 10.1) Mateus conseguiu explicar, em um dos episódios, os conceitos que os discentes estavam tendo dificuldades, como sugere os diálogos:

Aluno - Porque você ((Elder)) disse que a cada ferro...cada reação dele com oxigênio libera dois elétrons. Cada um tem dois.

Aluno - Mas ele perguntou porquê 4 ?

Aluno - Cada um tem 2.

Elder - Alguém falou certo.

Mateus - Se a gente fizer assim dessa forma, olha, se a gente considerar que essa tampinha é de Ferro metálico, ferro sólido, e que ela tá interagindo com água e com oxigênio, a gente vai produzir uma substância com essa fórmula ((vai para lousa explicar a reação)) (Aula experimental da gota salina e deposição do cobre, arquivo 10.1, turno 75-79).

No trecho acima evidencia-se a coocorrência entre as dimensões das Orientações para o Ensino de Ciências e Conhecimento da compreensão dos alunos em ciências - Dificuldade de aprendizagem. 
Ao longo de suas regências Mateus, em diversos episódios, demonstrou limitações com o conteúdo, levando Luiza a assumir as aulas. Nesse sentido, dispõe-se o turno em que a supervisora explica a simultaneidade das reações redox:

[...] Nos processos de oxirredução, sempre vai acontecer o que? Por isso chama oxirredução, sempre vai andar junto, ou seja, alguém vai receber elétron, bom, se eu vou receber elétron, alguém tem que dar esses elétrons, tá certo? Não pode receber do nada, então alguém perde elétrons pro outro receber elétrons, por isso as reações são chamadas oxirredução, tudo junto, porque ocorre oxidação e redução junto, ao mesmo tempo, alguém se oxida e alguém se reduz, beleza? Quem tem tendência a se oxidar? Os metais têm tendência a se oxidar, só que existe uma tendência maior de alguns metais, do que outros metais, vocês já ouviram falar que ouro é metal nobre? (Aula experimental da gota salina e deposição do cobre, arquivo, 10. 1, turno 118).

Em sua intervenção, Luiza explica à turma os potenciais de redução, por conta de os discentes não compreenderem como era realizada a previsão de quando um elemento sofre oxidação ou redução. Quando recorre às suas lembranças sobre a intervenção de Luiza nessa aula, Mateus reconhece que não conseguiu explicar os conceitos:

Acho que experiência, porque, por exemplo, muitos questionamentos quando o aluno tinha dúvida, tentar solucionar duvida do aluno fazer com que não fuja do assunto, não fuja da aula enfim, porque por exemplo, você está dando aula para sala toda e aí um aluno te faz um questionamento ou então ele quer saber de uma coisa, poxa, uma curiosidade e aí é uma coisa que eu... como posso dizer? Eu prezo muito e a Luiza tinha muito disso e ela ajudava a gente nisso, quando alguém fazia uma questão que a gente não conseguia responder enfim... (Lembrança estimulada, arquivo 15, turno 29).

Um das problemáticas relacionadas ao ensino de reações redox que permeou a aula de Mateus foi a ideia equivocada de que a reação de oxidação depende da presença do oxigênio para acontecer. Em consonância, tem-se o diálogo:

Luiza - Oxigênio, muito bem, então o termo oxidação lembra oxigênio, portanto é o oxigênio que fez com que oxidasse.

Mateus - Ou seja, nesse meio, ou seja, água, solução salina, principalmente oxigênio permite a formação da ferrugem, com essas informações vocês conseguem terminar essa atividade, eu vou dar exatamente dez minutos pra vocês terminarem (Aula experimental da gota salina e deposição do cobre, arquivo 10.1, turno 216-217).

Reflexões realizadas no interior do subprojeto denotam o reconhecimento de Maria de que as aulas de química implementadas pelo pibidiano não eram bem fundamentadas, quando comparadas às regências sobre a PNRS: 
Pelo que eu acompanhei o trabalho de vocês, eu acho que a gente tem de encaminhar esse trabalho aqui em termos de fazer uma publicação. Mesmo que a parte química, porque a gente teve muita limitação no desenvolvimento da parte química. Mesmo que a gente não tenha a parte química toda, bem elaborada, forte, vamos dizer assim, mas a gente deixa como ideias para se trabalhar a parte química (Reunião para avaliar o desenvolvimento do projeto pelo trio, arquivo 14, turno 209).

O conhecimento sobre reações redox de Mateus mostrou-se incipiente ao longo de sua vivência na sala de aula, por outro lado, o pibidiano demonstrou empenho em estudar o conteúdo, em virtude de suas limitações conceituais.

\section{Conhecimento pedagógico geral}

Esmiuçou-se nesse componente os conhecimentos de Mateus sobre seus alunos e sua aprendizagem, a gestão de sala de aula, o currículo e instrução, entre outros. Nesse sentido, apesar de Mateus reconhecer a importância de saber quais eram as dificuldades dos discentes com a química, não realizava o levantamento dessas limitações, estas eram reportadas pela supervisora:

[...] quando a gente, por exemplo, a gente mostra para professora supervisora o cronograma que a gente estabeleceu com as atividades que a gente pelo menos "legalizou" é... uma coisa que eu não consigo avaliar se foi positivo ou negativo, ela olha, mas diz: "eles precisam disso, disso e disso". Eu acho que ela mesmo fez, não sei, ela passa um levantamento de como a turma é, de como a turma tá (Entrevista semiestruturada, arquivo 16 , turno 58).

As aulas do pibidiano eram desenvolvidas no laboratório de química, pois para Mateus “[...] não tem como a gente trabalhar na sala de aula. Eu não gosto. Eu gosto do laboratório. Acho que ... no laboratório não tem como você dis... sabe? Ah, não copia" (Reunião para avaliar o projeto desenvolvido pelo trio, arquivo 14 , turno 267). Nesse espaço os discentes eram organizados em grupo, para que segundo o pibidiano pudessem dialogar sobre atividades propostas nas aulas. Entretanto, a partir de sua experiência em sala de aula, compreendeu que em determinados contextos a atividade em grupo não é a melhor das dinâmicas, como denota o diálogo:

Mateus - Não, ia ser bacana, porque a gente pode discutir, eles podem conversar, às vezes um tem mais vergonha que o outro mais acanhado então não consegue trocar informação. Mas na realidade não, na realidade depois isso foi algo que prejudicou a atividade.

Clara - Mas também Mateus, acho que assim, a sala de aula eles também não eram muito comportados.

Mateus - É, eu acho que seria menos pior, mas enfim, em compensação em outras atividades foi maravilhoso, por exemplo, a sensibilização e tudo mais, os experimentos, acho 
que foi muito bacana ter um espaço assim (Lembrança estimulada, arquivo 15, turno 71-73).

A vivência de Mateus no programa de iniciação à docência suscitou que o pibidiano tinha limitações com a gestão do tempo e da classe. Em suas aulas comumente ocorriam conflitos com alguns discentes, por conta das conversas paralelas, levando o pibidiano a aumentar o tom de voz como estratégia para chamar a atenção dos alunos para as aulas.

$\mathrm{Na}$ implementação das aulas Mateus e seus pares por vezes tiveram a oportunidade de ministrar a mesma aula planejada para turmas diferentes. Para o pibidiano essa dinâmica foi fundamental para readequar as regências por meio das orientações da supervisora, como denota o trecho a seguir:

Pesquisadora - O que acontecia? Tá. Vamos para esse ponto que o Mateus falou que é algo importante para ser chamado a atenção. É. Tá. No momento vocês davam aula, por exemplo, no $2^{\circ}$ ano, no segundo momento vocês iam para o $2^{\circ} \mathrm{F}$, beleza. Aí tinha esse meio tempo porque vocês primeiro davam aula num $2^{\circ}$ ano, tinha intervalo e aí ia para a outra turma. O que que mudava na percepção de vocês? Da primeira aula, intervalo que era quando ocorria esses diálogos e a Luiza chamava a atenção para a segunda aula... ela era melhor do que a primeira ou não?

Mateus - Eu acho que a falta de planejamento e trabalhar o tempo, né? Porque, por exemplo, a gente vê o que dá certo, o que precisa de mais tempo, o que a gente pode fazer de uma forma... não que a gente possa fazer de uma forma mais rápida, mas o que a gente pode avançar. Eu acho que a segunda aula sempre é melhor (Lembrança estimulada, arquivo 15, Turno 232 e 235).

Evidencia-se na trajetória do pibidiano que o Conhecimento pedagógico geral era reflexo das orientações das tutoras (Reunião para saber o andamento, arquivo 5). Isto, porque o pibidiano tinha muita limitação em manter a gestão de classe e comumente a supervisora o auxiliava. Por outro lado, por vezes a gestão de tempo das aulas geridas por Mateus era comprometida pela intervenção dos pibidianos e da supervisora.

O pibidiano, ao longo das reuniões e das aulas implementadas, emergiu conhecimentos sobre abordagens de ensino associadas a experimentação, trabalhos em grupo, situação problema, entre outros. Com relação às estratégias para avaliar a aprendizagem dos discentes, Mateus adotou métodos avaliativos associados à produção e interpretação de textos:

Mateus - Não, por exemplo, na atividade tem um pequeno texto, um pequeno enunciado que envolve os conceitos que foram estudados, e aí, por exemplo, uma ou duas questões dissertativas que peça que ele escreva sobre, reflita sobre aquilo, algo desse tipo (Apresentação da proposta de trabalho, arquivo 3 , turno 94). 
$\mathrm{Na}$ apresentação de seu planejamento para Maria e Rebeca, o pibidiano foi auxiliado principalmente na formulação das questões problemas que direcionariam a aula de sensibilização (aula das fichas, arquivo 7), como sugere o diálogo:

Rebeca - Porque os 4 grupos, supõe-se que tem integrante de todos, tem um integrante de cada texto da primeira etapa, então tem informação de todos os grupos. A primeira etapa cada um tem que focar no tema do seu grupo, ah, um vai entender bem lâmpada incandescente, o outro grupo lâmpada fluorescente, os diferentes temas, na segunda etapa, se o cara fez bem a parte dele na primeira etapa ele vai contribuir pra resolver a questão, o problema.

Maria - Ou você pode também fazer uma pergunta assim: "Olha, comparando as duas lâmpadas qual que é mais adequada pra usar em uma..." Qual que é mais adequada sobre o ponto de vista econômico e ambiental, por exemplo, pra usar numa indústria, pra usar num quarto, pra usar numa... (Reunião para saber o andamento, arquivo 5, turno 256-257).

Para essa aula de sensibilização Luiza compartilhava com Mateus algumas das possíveis dificuldades conceituais dos discentes relacionada a "[...]Então, faça a contagem de todas as lâmpadas e calcule a porcentagem, proporção eles não sabem o que é. Beleza, só pra.... Tem uns meninos que são muito bons, aquele Giovani" (Reunião para saber o andamento, arquivo 6, turno 79). Os direcionamentos das tutoras (Rebeca, Luiza e Maria) para essa aula de sensibilização estavam relacionadas também aos encaminhamentos práticos que Mateus deveria assumir na condução das aulas que estavam associadas às questões que o pibidiano deveria realizar durante as aulas para estimular a discussão em grupo e as atividades avaliativas (Reunião para saber o andamento, arquivo 6).

Comumente, nas reuniões as discussões tinham Maria como protagonista. E quando a supervisora participava das reuniões do subprojeto, os pibidianos ficavam mais observando as discussões entre as tutoras, como suscita o diálogo:

Maria - Nem com antecedência assim? Porque eu acho que 45 minutos a gente tem um material, eu considero um material bem bacana, eu acho que 45 minutos ele acaba...

Luiza - É, numa das turmas eu tenho aula dupla, a minha aula do segundo é uma aula dupla, porém, não, entendeu, pode ser que a gente consiga, mas não é uma garantia, por quê? Porque o que acontece, pra eu dar aula, eu tenho que mexer no horário, e o horário, aí assim, eu tenho que mexer no horário de outros professores.

Maria - Seria, o que eu pensei, talvez, por exemplo, o seguinte, se você tivesse aula no $1^{\circ} \mathrm{E}$ e sei lá, no $1^{\circ} \mathrm{D}$, o outro professor tem aula no mesmo dia, aí inverte (Reunião para saber o andamento, arquivo 6, turno 120-122). 
Mateus, no subprojeto, pôde compartilhar com as tutoras a sua percepção sobre as aprendizagens discentes construídas a partir das atividades implementadas:

Os pontos negativos, atividades também, enfim, passamos a parte da enquete, que eles tinham que tirar foto, usamos alguns recursos tecnológicos, e eu tinha, eu estava inclusive fazendo uma matéria que falava justamente sobre isso, e eu literalmente briguei com o professor, falei: "Professor", não, não quero isso, eu acho que não, não funcionou, e não quero, porque ele dizia: "Não, porque isso é bacana e tudo mais", assim, ele sabe, eles usam, é o cotidiano deles, tá aí, a gente simplesmente pediu pra que eles fotografassem as fotos, fotografassem as lâmpadas em casa, identificassem, lâmpada fluorescente, incandescentes, mas assim, se enviassem as lâmpadas, ou então entrassem em contato comigo pelo facebook, por e-mail, bom, recebi 4 imagens sendo 3 da mesma pessoa, das lâmpadas da sala de aula, então eu fiquei muito triste. Quanto o aspecto positivo, professora Luiza ela já disse, particularmente eu consegui muitas coisas boas e produtivas pra levar do Pibid, pra levar pra vida, experiência mesmo, e principalmente de trabalhar perto de casa, onde eu podia encontrar os alunos em supermercado (Apresentação dos resultados, arquivo 12, turno 79).

O pibidiano continuou tendo limitações com a gestão do tempo em suas regências, entretanto, em alguns episódios de suas aulas, emergiu timidamente o conhecimento desse componente. Além disto, ao reconhecer que não tinha uma boa gestão do tempo, quem sabe reflita futuramente em seu conhecimento docente (Reunião para avaliar o projeto desenvolvido pelo trio, arquivo 14).

O futuro docente, em suas ações no Pibid, não se reconhecia como um professor. Considerava-se "[...] um estagiário, um bolsista" (Lembrança estimulada, arquivo 15, turno 23). Por outro lado, os discentes da escola conveniada o reconheciam como docente (Lembrança estimulada, arquivo 15).

Para o pibidiano a reflexão seria conhecimento fundamental para a prática docente. O pibidiano compartilhou que em suas aulas carrega a influência dos professores que teve em sua prática pedagógica, pois "[...] às vezes você se perde, você não tem um referencial, aí você lembra de algum..., você tenta reproduzir a atitude de um professor, mas você fala: 'será que o aluno vai aprender dessa forma?' Muito difícil!" (Entrevista semiestruturada, arquivo 16, turno 114). O pibidiano considerou ainda que a forma como conduzia a sua regência era influenciada pelo comportamento dos alunos. Na sua percepção, os docentes da instituição que cursava a licenciatura lecionavam para alunos que estavam dispostos a aprender, enquanto na educação básica os discentes não tinham interesse, por isto considerou mais adequado adotar as estratégias de ensino de seus professores, além do mais, considerava que "[...] cada aluno tem sua dificuldade particular, em alguns conceitos, enfim, e eu gosto muito de sentar com Capitulo 4. Resultados e Discussões 
o aluno, de conversar com ele, é...e principalmente ver aonde que ele tá... é.... (Entrevista semiestruturada, arquivo 16, turno 132). Nesse sentido, para o pibidiano um bom docente deveria lecionar de modo que conseguisse estimular o apreço do discente pela disciplina que lecionava.

Infere-se que a vivência no programa de iniciação à docência e, consequentemente, na educação básica refletiu na percepção de Mateus sobre a importância de compreender o contexto de vida dos alunos e suas dificuldades de aprendizagem. Nesse sentido, apresenta-se a narrativa de Mateus que sucinta a coocorrência entre o Conhecimento Pedagógico Geral e do Contexto:

\begin{abstract}
Eu acho fundamental, eu acho fundamental às vezes até mesmo pro professor reconhecer é...que o aluno, ele possui dificuldade de aprendizagem, e existem fatores que interferem nisso né, fatores internos, externos, enfim, mas que o aluno, ele tem problemas, ele é um ser humano, às vezes é muito mais fácil você motivar um aluno, mesmo... o tempo é curto nas aulas e tudo mais, mas às vezes é muito mais fácil você motivar o aluno sobre certa temática, fazer um apanhado geral do conteúdo, sem deixar ele maçante, não aprofundando tanto, do que simplesmente você aprofundar, e o cara simplesmente não encontrar a utilidade daquilo, acho que ter um conhecimento geral e principalmente pedagógico, é fundamental e indispensável (Entrevista semiestruturada, arquivo 16, turno 146).
\end{abstract}

Para Mateus o interesse de alguns alunos da escola e a participação no Pibid influenciam no seu desejo em continuar a licenciatura, e no futuro atuar na escola pública (Relatório individual, arquivo 17, p. 5). Por outro lado, aponta que a falta de ética de outros professores despertou o desejo de desistir da docência (Entrevista semiestruturada, arquivo 16).

$\mathrm{Na}$ tabela 22 tem-se as respostas estruturadas por Mateus para a ação descrever que constituía o Ciclo reflexivo de Smyth.

Tabela 22. Resposta concedida a Ação-descrever (ciclo reflexivo) por Mateus antes e depois de assistir as regências

\begin{tabular}{|c|c|c|}
\hline Ação & Antes & Depois \\
\hline $\begin{array}{l}\text { Descrever - O que } \\
\text { faço? }\end{array}$ & $\begin{array}{l}\text { Faço uso de diferentes propostas de } \\
\text { aulas e atividade com o objetivo de que } \\
\text { os alunos possam ter um maior } \\
\text { aproveitamento do que é aplicado em } \\
\text { sala de aula. Costumo deixar que os } \\
\text { alunos troquem informações, dispondo- } \\
\text { os em grupo. }\end{array}$ & $\begin{array}{l}\text { Utilizo diferentes } \\
\text { estratégias para tentar } \\
\text { atingir a compreensão } \\
\text { dos alunos quanto aos } \\
\text { conceitos trabalhados. } \\
\text { Procuro manter o foco } \\
\text { nas aulas para impedir } \\
\text { que os objetivos não } \\
\text { sejam atingidos }\end{array}$ \\
\hline
\end{tabular}

Como se observa na reflexão acima, o pibidiano não dialoga com o conteúdo redox ao recorrer às lembranças de sua aula. Praticamente a mesma descrição é realizada após assistir aos episódios das aulas ministradas. De modo geral, a sua descrição envolve aspectos gerais de sua regência sem vincular a Capítulo 4. Resultados e Discussões 
reações redox. Talvez essa postura seja resultado de sua insegurança com o conteúdo.

Ao direcionar o olhar para a escolha profissional de Mateus pela carreira docente, esta carrega a influência de uma professora de química:

Entrevistador - É..., por que licenciatura em química?

Mateus - Eu nunca quis assim ser professor, é eu vim pra química porque eu tinha uma professora que era química, enfim, e... tanto que eu entrei no técnico por conta dela, por influência dela, e também na licenciatura, ela é minha vizinha, amiga da minha mãe, então... eu sempre tive facilidade, enfim, os conceitos, eu gostava.... Mas assim, não era o que eu que tinha assim: "Não, eu quero fazer, eu quero fazer matemática".

Entrevistador - Você queria matemática pra ser professor também?

Mateus - Também não.

Entrevistador - Pra ser matemático?!

Mateus - Só matemático. Mas aí veio a química...

Entrevistador - É...Eu sei que você falou que você não... seu objetivo não era ser professor, mas depois que você entrou na licenciatura, isso se tornou um objetivo ou continua uma não vontade de ser professor?

Mateus - É...Principalmente, porque a gente tem adversidades, que às vezes a gente pensa "Ah, eu não quero mais" Mas é algo, eu acho muito bonita a profissão, acho que tem um valor assim imenso né, é você participar da formação de um indivíduo, é algo extremamente importante, eu, assim, hoje, eu preciso ter essa experiência, eu como professor, aluno do Pibid..., depois o Pibid, eu acho que eu quero (Entrevista semiestruturada, arquivo 16, turno 9-16).

$\mathrm{Na}$ percepção do pibidiano, o profissional professor deveria formar cidadãos críticos. A sua motivação em participar do Pibid relacionava-se à oportunidade de vivenciar a futura profissão durante a graduação, além de ter a orientação de professoras experientes (Entrevista semiestrutura, arquivo 16). No contexto do Pibid, reconhece que a experiência como bolsista melhorou a forma como conduzia as aulas, pois no início de sua vivência considerava-se“[...] travado, eu era fechado, eu não conseguia falar, eu tinha medo, enfim, é... mas hoje em dia eu consigo dialogar, eu consigo gesticular, eu consigo, transmitir o que eu quero....conseguir me expressar, eu acho que é o convívio [...]" (Entrevista semiestrutura, arquivo 16, turno 32 ).

O olhar de Mateus para o seu processo de aprendizagem em sua trajetória no Pibid foi corroborado por Luiza, ao compartilhar a sua percepção sobre as aulas ministradas por Mateus:

Luiza - E eu por outro lado eu vou falar, o Mateus começou, ele fala muito baixo, ele tinha muita dificuldade de se posicionar 
perante o aluno, e ali ele falava baixo por uma questão de segurança dele que infundada porque tem conteúdo, ele tem conhecimento, mas ele tremia na hora de falar e aí a voz dele saia baixa, e aí o aluno não ouvia, e aí começava a virar tumulto né, porque aí o aluno começa a conversar com o colega porque não, aí eu falei: "Mateus, você é o dono da sala, bate o pé aí, bate o apagador na lousa, bate a régua na mesa, você é o dono da sala, você comanda essa baderna tá, se imponha, eu estou aqui, eu estou te apoiando, vai, manda brasa" E ele se lançou nessa loucura, e ele assim, foi nítido, e aí depois ele: "Ou". E aí ele se apropriou do poder entre aspas né, de que o poder do conhecimento era dele, então o conhecimento estava nele, então você que tem o conhecimento é você que tá ali, e você tem que comandar, não pode deixar o comando na mão dos outros, e isso foi, eu acho que assim, foi um ganho pra sua vida, tanto é que você ganhou em segurança, ganhou em propriedade, e eu acho que as falhas que vocês tiveram de, de repente poxa vida, não deu certo, leva a uma reflexão que faz você crescer, opa, não deu certo, olha, a gente não se preparou direito, se a gente não se a gente não se preparar direito a gente vai... (Apresentação dos resultados, arquivo 12, turno 69).

Por mais que Mateus tenha passado por diversas barreiras ao desenvolver suas propostas didáticas no contexto do Pibid, a discussão de suas aulas com os pares e o reconhecimento do que havia conseguido desenvolver na sala, bem como o que precisava ser revisto em seu planejamento impacta na sua formação, pois oportunidades como estas são escassas no processo de formação inicial de professores.

\section{Conhecimento do contexto}

Desde as primeiras reuniões no subprojeto Mateus foi orientado a buscar conhecer o contexto dos discentes para os quais lecionaria. Nesse sentido, em uma das reuniões Maria sugere que Mateus estruture um questionário sociocultural a ser aplicado aos discentes, como denota o trecho a seguir:

Maria - Sabe uma coisa que eu tô, mesma sugestão que eu fiz pro outro grupo, eu acho que talvez caberia a vocês, a Rebeca está falando de conhecer um pouco a população, os alunos que a gente vai trabalhar, vocês vão fazer questionário de levantamento sócio econômico?

Mateus - Então a gente não tinha discutido nada ainda sobre isso né.

Maria - Porque se vocês forem fazer a gente pode, ou se não fizer questionário sócio econômico, ter algum momento que vocês possam entender se os alunos sabem, ou se eles fazem a atenção da maneira como as lâmpadas são descartadas, por que eu acho que essa informação é importante, deles perguntarem em casa pro pai, pra mãe, ou até na escola, eles fazerem uma pesquisa de como é feito o descarte de lâmpadas fluorescentes, se alguém toma algum tipo de cuidado, ou então, não sei, levar a pergunta pra casa, ou se eles conseguem recordar como o pai descartou a lâmpada, se é que tem lâmpada fluorescente na cada deles, que às vezes não tem, verificar. 
Acho que essa informação é importante, porque daí a gente não pode esquecer de quais são os pressupostos CTS, o aluno tem que tá envolvido no problema, porque se não fica um problema tão geral que ah, tudo bem, é um problema do governo, não é um problema dele, o problema tem que ser dele, então ele tem que tá consciente disso, e quando ele descarta a lâmpada, joga a lâmpada na esquina, e aí vem um cara e quebra a lâmpada, e aí fica jogada no chão, é um problema dele, a região que ele tá que tá contaminando, então por isso que é importante como que ele, sempre, todos os grupos, essa é a recomendação que está sendo dada pros dois grupos que já apresentaram, tem que ser pros outros grupos também, tem que ter alguma coisa na região, na escola, no ato do aluno, no ato da família que remeta à problemática, certo? (Apresentação da proposta de trabalho, arquivo 3 , turno $85-87$ ).

Para Luiza a problemática relacionada à organização da carga horária da escola conveniada que impossibilitava que as aulas de química fossem sequenciais seria um problema sério enfrentado por Mateus quando fosse docente (Reunião para saber o andamento, arquivo 6). Entretanto, ao refletir sobre essa questão de distribuição das aulas, Mateus a internalizou como uma problemática vivenciada na escola. Por outro lado, em razão do comprometimento da equipe escolar com a comunidade, observou que era "[...] possível que o professor trabalhe de forma a colaborar com a construção da cidadania do indivíduo mesmo que os encontros sejam poucos" (Relatório anual - Mateus, p.6).

Outro aspecto relacionado ao conhecimento do contexto oportunizado pela imersão do pibidiano na escola conveniada, apesar de negativo, foi a baixa frequência dos alunos na escola, o que impactava diretamente no planejamento de Mateus, visto que por "[...] vezes, por conta de elaborar atividade, e de levar atividade, e aí não ter aluno, às vezes tem uma quantidade muito reduzida de aluno (...) E aí eu ter que virar e perguntar 'Joyce, o que eu faço?' [...]" (Apresentação dos resultados, arquivo 12, turno 66). Outra problemática que envolveu o contexto escolar foi um episódio em que uma docente foi retirar os discentes da aula de Mateus, argumentando que era a sua aula. Entretanto, posteriormente os alunos compartilharam com o pibidiano que ficaram jogando truco na sala, por sugestão da docente, como denota o diálogo:

Mateus - Engraçado que pra eles eu fiz algumas... eu fiz... uma professora, no truco, que retirou os alunos da sala...

$$
\begin{aligned}
& \text { Maria - Pra jogar truco. } \\
& \text { Mateus - Pra jogar truco. } \\
& \text { Leo - Ah, esse foi o dia. } \\
& \text { Mateus - Foi nesse dia. } \\
& \text { Leo - Ah, o dia. }
\end{aligned}
$$


Maria - Foi muito revoltante, né?

Mateus - Aí. Ah, foi no mesmo dia, é... em que os alunos estavam dispensados e mesmo assim eles ficaram. Pra terminar atividade. Eram 14, 9 ficaram (Reunião para avaliar o projeto desenvolvido pelo trio, arquivo 14, turno 173-180).

Sucintamente, Mateus emergiu seu conhecimento sobre o contexto em seus passos iniciais no Pibid. Entretanto, na sua vivência na escola conveniada foi construindo um repertório dos aspectos relacionados aos alunos e à instituição de ensino. O contexto da escola conveniada possibilitou ainda que o pibidiano experienciasse aspectos negativos associados a relações interpessoais, que por vezes permeiam o contexto profissional de professores.

\section{Orientações para o ensino de ciências}

No subprojeto em que Mateus participou, as aulas eram desenvolvidas baseadas em projetos, o que refletiu em sua orientação para o ensino de química e também no rigor acadêmico. Não obstante, tem-se um hiato que permeia as orientações de Mateus relacionadas às Decisões sobre o fazer no Ensino, pois suas regências foram marcadas por interrupções dos demais membros de sua equipe e também pela supervisora.

Inicialmente dispõe-se os objetivos do projeto e, consequentemente, das regências de Mateus, que segundo o pibidiano permeavam:

Elaborar, desenvolver e aplicar metodologias favoráveis ao ensino-aprendizagem em química a partir da temática definida pelo grupo. Introduzir no ensino de química conceitos relacionados ao ensino de eletroquímica a partir da temática do descarte das lâmpadas fluorescentes fazendo uso de metodologia CTS e tendo a PNRS como tema norteador do projeto (Relatório individual - Mateus, p.1).

No início do processo de elaboração das aulas Maria instruiu Mateus e seus pares na seleção dos conceitos que permeariam o projeto. Essas orientações iniciais foram importantes, devido ao fato de Mateus apresentar limitações em conseguir organizar os tópicos que englobariam a primeira aula de sensibilização. Em consonância, dispõe-se nos trechos a seguir as orientações de Maria ao pibidiano:

Maria - Bacana, uma sugestão gente, eu acho que vocês estão com um monte de possibilidades aí, eu acho melhor começar alinhar assim, olha, vamos fazer isso, essa coisa é bacana, mas esse momento não dá, porque de repente pode ser pra um outro momento, tudo ao mesmo tempo é muita coisa, é bacana mas, de repente, a parte de reciclagem é interessante de metais, porque recorda o problema posterior que é o descarte das lâmpadas, e como vocês disseram que tem empresas que vocês conhecem aqui em São Paulo, eu acho que isso é relevante, eu acho que uma coisa não tá longe da outra, agora, o vidro, eu 
acho que de repente a gente guarda essa carta aqui na manga, na próxima vez a gente, porque eu acho que fica muita coisa.

Maria - Até faz bastante coisa, mas a gente perde o controle Clara, porque é difícil depois, porque muita coisa, a gente vai só conseguir aplicar no segundo semestre sabia, a gente vai fazer sensibilização, algumas aulas agora, experimento, porque muito vai ficar pro segundo semestre, a gente vai fazer sensibilização, algumas aulas agora, muito vai ficar pro segundo semestre, porque junho, com essa história da copa, maio tem um monte de feriado, junho tem copa, julho é ferias, a gente vai chegar chegando mesmo em agosto, é uma pena (Apresentação da proposta de trabalho, arquivo 3, turno 98 e 100).

Em virtude das problemáticas vivenciadas no primeiro semestre envolvendo protestos, a copa do mundo, e principalmente a não organização completa do projeto por Mateus e seus pares, levam Maria a solicitar que para o segundo semestre a estrutura de todas as aulas fosse concluída antes de serem implementadas:

\begin{abstract}
Maria - [...] a gente vai conversar agora, as etapas que vocês já estão, o que vocês fizeram, pra onde a gente vai, e até lá pro dia primeiro de julho, a gente vai fechar as atividades que nós vamos realizar no semestre que vem, ou pelo menos pra fechar aquilo que nós planejamos anteriormente. $\mathrm{O}$ que isso significa? Não colocar muitas atividades, não invadir muito as aulas dela, mas deixar muitas coisas claras: "A gente precisa dessa aula, a gente precisa entrar na sala de aula e fazer isso, isso" Não importa que eu tenho que explicar pra ele o que é cátion porque a professora quer, eu posso até explicar outro dia, mas nesse dia tá programado isso, tem que acontecer isso (Reunião para saber 0 andamento, arquivo 5, turno 101).
\end{abstract}

Nessa reunião surgem os primeiros indícios do planejamento do projeto a ser desenvolvido por Mateus. Nesse sentido, primeiramente o pibidiano compartilha com os pares o que estava estruturando para a aula de sensibilização que envolvia a PNRS e o uso de lâmpadas. A dinâmica dessa regência foi inspirada na vivência do pibidiano na licenciatura em química, como denota o trecho abaixo:

\footnotetext{
Mateus - É, eu tenho uma proposta de dinâmica, que é interessante, inclusive é uma estratégia que o professor ((nome do professor extraído)) fez com a gente na sala de aula, e que eu gostei muito, é essa dinâmica, o fato a gente, de levar alguns textos pra eles, uns recortes, e aí fazer a leitura, e depois pedir que eles realizassem, que eles escrevessem, que eles elaborassem no papel questões sobre o texto, que eles elaborassem uma questão, cada um, e aí discutia, três, quatro questões, e aí fazer com que a sala no coletivo respondesse aquelas questões da melhor forma (Reunião para saber 0 andamento, arquivo 5, turno 169).
}

$\mathrm{Na}$ concepção do pibidiano, ao adotar essa estratégia incentivaria a produção coletiva entre os discentes - Conhecimento Pedagógico Geral, de modo 
a conseguir analisar o que os discentes conheciam sobre a temática das lâmpadas fluorescentes.

No decorrer da reunião Mateus apresenta a estrutura da sequência de ensino, mas Maria salienta que o pibidiano precisava ter um direcionamento melhor sobre os conceitos que iria desenvolver, pois estava propondo abordar diversos aspectos:

Maria - Mateus, eu não vi tudo, eu acho muito bom, mas eu acho que você precisa ser menos ambicioso nas aulas, porque tem muita aula, você tem muita aula, tá esquecendo, assim, a gente tem que fazer o trabalho com menos aulas, porque esse ano tá muito justo né, então não sei, mas tá bacana, pera aí vamos continuar. "As lâmpadas fluorescentes, pense o local que precisa de iluminação bem clara para todo ambiente, acesa o tempo todo. O consumo de energia deve ser bastante alto, não é? Por isso, em lugares como escolas, escritórios e hospitais, a iluminação é feita com lâmpadas fluorescentes. Elas são mais econômicas e funcionam segundo o princípio da luminescência". Se você não colocasse o que é luminescência e fosforescência, e daí você falasse assim: "Fluorescente, fala porque ela é muito usada, e fala qual que é a constituição dela, você já matava dois coelhos com uma caixa d'Água só. Entendeu? Porque falar fluorescência e fosforescência ele vai falar: "Ah tá, o que mais"?" Não vai fazer sentido pra ele, porque, se vocês colocarem junto com a ideia de lâmpada fluorescente já fala porque ela é muito usada, porque ela é clarinha, aí você coloca já a fotinha dela bem, aí tinha que ser colorido (Reunião para saber o andamento, arquivo 5, turno 190).

Nas reuniões Mateus citava que sua irmã pedagoga o auxiliava nas propostas de ensino, sugerindo que o pibidiano no início do processo de elaboração das aulas recorria a profissionais de ensino mais experientes. Por outro lado, as tutoras também influenciavam nas aulas de Mateus. Nesse sentido, sugerem que o pibidiano estruture estratégias na aula de sensibilização que estimule o aluno participar das discussões - Conhecimento pedagógico geral. Sobre esse aspecto, dispõe-se o diálogo:

Maria - Não, até que eu tenho, ah, então tá, mas o que eu vou perguntar? Porque eu vou perguntar o que? Pergunta aí qualquer coisa. Eles vão perguntar: "Quanto custa uma lâmpada?" Eu perguntaria.

Rebeca - Qual a diferença de preço, porque elas são tão diferentes de preço, a diferença de preço é absurda.

Maria - Aí, só se você fizer isso, se você fizer mais papéizinhos, e um papelzinho falar sobre preço, falar sobre, por que que você não coloca junto aqui o problema da contaminação? Aí junta pano pra manga, porque você pode fazer, ao invés de fazer só esses três aqui que vocês colocaram, quatro, coloca mais, porque vamos supor, 10 papéizinhos são 10 perguntinhas na sala, e de repente, sabe que eles podem ler alto esses papeizinhos? (Reunião para saber 0 andamento, arquivo 5, turno 205-207). 
O pibidiano sempre buscou as orientações de Maria. Em consonância, solicitou a Maria que sugerisse como poderia abordar a questão da problemática relacionada à contaminação pelo descarte inadequado de lâmpadas fluorescentes:

Mateus - Mas aí professora, essa questão, o problema da contaminação abordaria de que forma?

Maria - Porque a lâmpada, aí o que seria a ideia? Seria a ideia, presta atenção Joyce, o que seria a ideia? Já começar encaminhar 0 assunto, a conversa, praquela lâmpada que interessa, que é a priorizada (Reunião para saber o andamento, arquivo 5, turno 311-312).

Posteriormente a essa reunião, Maria descreve os aspectos que deveriam constituir o planejamento de Mateus:

Então o que eles foram orientados no final do semestre passado o que foi orientado pra eles? Que eles enxugassem, que a gente tivesse o mínimo de aulas pra com o tempo o projeto que eles estão, e que não tenha tanto prejuízo, prejuízo não é o termo, porque estávamos trabalhando da mesma maneira, mas modifica o tempo, agora, é aquilo que eu te falei, vai atrapalhar a gente? Vai... (Reunião para saber o andamento, arquivo 6, turno 3).

Em complementariedade à orientação da coordenadora, Luiza sugeri que as aulas estruturadas por Mateus necessitariam ter começo, meio e fim, pois na sua percepção:

[...] acho que a gente pode até discutir sobre isso, mas ele ((planejamento)) tem que ter começo, meio e fim, e a gente precisa que isso sirva também pra gente avaliar a aprendizagem dos alunos, porque se eles estão se formando como professores, uma das premissas que a gente espera que um bom professor tenha, é saber se aquilo que ele trabalhou com os alunos, aquilo que ele ensinou foi aprendido, então assim, que tem que ter uma avaliação dessa aprendizagem, e que obviamente eu poderia utilizar essa variação da aprendizagem até pra dar uma anotação, mais uma nota para os meus alunos (Reunião para saber o andamento, arquivo 6, turno 12).

Para a coordenadora a questão norteadora do trabalho a ser desenvolvido por Mateus estava fundamentada na PNRS, por sua relevância social, econômica e ambiental. Em consonância, a supervisora e a coordenadora orientaram Mateus a pensar sobre diversos aspectos das lâmpadas fluorescentes no momento de conduzir a discussão que envolvia o tempo de duração, custo-benefício, aspectos ambientais, mas principalmente a estabelecer relações com a PNRS Conhecimento Pedagógico Geral (Reunião para saber o andamento, arquivo 6).

No quadro 22 dispõe-se a estrutura final do planejamento, a implementação e os resultados obtidos nas aulas desenvolvidas por Mateus. 
Quadro 22. Aulas implementadas no segundo semestre e os resultados alcançados

\begin{tabular}{|c|c|c|c|}
\hline Mês & Atividades & Resultados & Comentários \\
\hline Agosto & Enquete & $\begin{array}{l}\text { Com a aplicação da enquete foi possível coletar dados } \\
\text { referentes aos hábitos que os alunos e seus familiares } \\
\text { possuem quanto ao uso e descarte de lâmpadas em geral, } \\
\text { também serviu para que os alunos pudessem reconhecer os } \\
\text { tipos de lâmpada. }\end{array}$ & $\begin{array}{l}\text { A enquete foi respondida por menos alunos que o } \\
\text { esperado o que restringiu a análise do perfil desses alunos } \\
\text { quanto ao uso das lâmpadas fluorescentes. }\end{array}$ \\
\hline Setembro & Dinâmica das fichas & $\begin{array}{l}\text { Essa etapa foi responsável pela sensibilização dos alunos } \\
\text { quanto aos benefícios e perigos oferecidos pelo uso das } \\
\text { lâmpadas fluorescentes e como resultado, a análise da } \\
\text { situação problema proposta onde consideramos as } \\
\text { reflexões debatidas em sala de aula e a abordagem social, } \\
\text { econômica e tecnológica. }\end{array}$ & $\begin{array}{l}\text { A dificuldade principal para a aplicação dessa etapa do } \\
\text { projeto foi a ausência de alunos no dia proposto para a } \\
\text { realização da aula. }\end{array}$ \\
\hline & $\begin{array}{l}\text { Aula de estrutura atômica e } \\
\text { definição de oxidação }\end{array}$ & $\begin{array}{l}\text { Os alunos tiveram um grande aproveitamento das aulas } \\
\text { sendo isso evidenciado nos acertos dos alunos que } \\
\text { ultrapassaram } 70 \% \text { do proposto nas atividades que foram } \\
\text { entregadas. }\end{array}$ & $\begin{array}{l}\text { Tivemos o objetivo de que os alunos pudessem relacionar } \\
\text { os conceitos de íons e estados de oxidação para que fosse } \\
\text { possível dar continuidade no que diz respeito aos } \\
\text { conceitos químicos relacionados a eletroquímica. }\end{array}$ \\
\hline Outubro & $\begin{array}{l}\text { Aula experimental da Gota } \\
\text { salina e deposição do cobre }\end{array}$ & $\begin{array}{l}\text { Nessa etapa, obtivemos como resultados as concepções } \\
\text { dos alunos sobre os níveis de representações } \\
\text { macroscópico, submicroscópico e o simbólico. Houve } \\
\text { dificuldade por parte dos alunos em relação ao nível } \\
\text { submicroscópico, porém, tivemos resultados positivos } \\
\text { quanto aos níveis macroscópico e simbólico. }\end{array}$ & $\begin{array}{l}\text { Os experimentos eram sobre reações de oxidação e } \\
\text { redução e durante a aula foi possível explanar esses } \\
\text { conceitos. }\end{array}$ \\
\hline Novembro & $\begin{array}{lr}\text { Aula lúdica } & - \\
\text { Funcionamento } & \text { de } \\
\text { lâmpadas fluorescentes } & \end{array}$ & $\begin{array}{l}\text { Na atividade lúdica, obtivemos como resultados um quadro } \\
\text { contendo as relações estabelecidas coletivamente por } \\
\text { grupos de alunos quanto aos processos e consequentes } \\
\text { efeitos que ocorrem no interior e no exterior das lâmpadas } \\
\text { fluorescentes e em seu descarte. }\end{array}$ & $\begin{array}{l}\text { Conseguimos mostrar aos alunos o funcionamento da } \\
\text { lâmpada fluorescente através da entrega de folders, } \\
\text { entrelaçando os conceitos de oxirredução e questões } \\
\text { sociais. Eles puderam relembrar esses conceitos os } \\
\text { correlacionando com a situação proposta nesta atividade. }\end{array}$ \\
\hline
\end{tabular}


O planejamento envolveu a participação da coordenadora, e para Mateus faltou a orientação da supervisora em sua estruturação:

Mateus - Eu acho que o ideal seria que ela participasse da, não só do planejamento, mas também nos ajudasse, não digo nem ajudar, mas participando também do planejamento das atividades...

Pesquisadora - Por que? Quem participava mais ativamente era só a coordenadora?

Mateus - Era a coordenadora e os bolsistas. E aí a gente tinha meio que uma relação com ela de apresentar... (Lembrança estimulada, arquivo 15, turno 212-214).

Por outro lado, o pibidiano reconhece que os direcionamentos dados pela supervisora ao final das aulas desenvolvidas na escola conveniada foram essenciais para as suas reformulações e reimplementações. Nas narrativas de Mateus "[...] já tinha acontecido isso com a gente no experimento do teste de chama...era primeiro uma sala, aí tinha outra aula e entre as aulas aconteceu isso. E foi interessante..." ((Mateus está relatando que entre as aulas a Luiza chamava atenção para o que estava inadequado e precisava ser reformulado para que fosse implementado na próxima turma)) (Lembrança estimulada, arquivo 15, turno 231).

$\mathrm{Na}$ entrevista semiestruturada Mateus compartilhou mais uma vez suas percepções sobre os papeis da coordenadora e supervisora, tanto na estruturação das aulas como na sua readequação, como denota o diálogo:

Mateus - É uma participação efetiva é..., desde a participação... desde a elaboração das atividades, porque assim, por exemplo, a gente tem os temas propostos, então a gente vai falar de tal coisa, a gente vai falar aquilo...mas quando por exemplo: "Não, a gente precisa entrar em sala pra gente aplicar tal atividade que a gente idealizou dessa, dessa forma..." , a gente tem um apoio da coordenadora, ela senta com a gente, mas será que dessa forma, mas será que dessa forma vai dar certo"? Mas e a análise das atividades que você já fez? Será que não tá... eu acho isso muito importante. Durante o processo de aplicação da atividade também, e após, durante a análise. Muitas vezes eu olho, mas como que eu vou extrair um resultado disso, eu consigo, mas assim, eu vejo que tem uma discrepância, um resultado ali, mas eu não consigo. $\mathrm{E}$ aí eu acho que a coordenadora me ajuda nisso..., nesses fatores.

Pesquisadora - Ela é fundamental...

Mateus - Fundamental!

Pesquisadora - No desenvolvimento de vocês enquanto pibidianos, e aí eu me refiro ao plano de aula, a ação de vocês e também no tratamento dos dados, ou seja, dos resultados que vocês tenham obtido?

Mateus - Isso.

Pesquisadora - E o papel do supervisor?

Mateus - Bom, é...bem diferente, bem diferente. A participação na elaboração eu não vejo que seja tão.. tão efetivo, porém, é... durante a aplicação da atividade é muito forte, muito forte, existem intervenções... 
Pesquisadora - Intervenções em que sentido?

Mateus - Intervenções, por exemplo, é... uma atividade que "ah, a gente idealizou que seria bacana" e a coordenadora também, os outros bolsistas, até mesmo de outros grupos, e aí a supervisora ela tem outro ponto de vista sobre aquela atividade (Entrevista semiestruturada, arquivo 16, turno 64-72).

$\mathrm{Na}$ primeira aula que implementou, o pibidiano inicialmente solicitou que os discentes respondessem a uma enquete sobre o uso de lâmpadas em suas residências. As respostas subsidiariam parte das discussões da aula Dinâmica das fichas (Aula de sensibilização, arquivo 7). Essa estratégia foi uma sugestão das tutoras nas reuniões para saber o andamento (arquivo 5 e 6). Entretanto, grande parte dos discentes não realizou a atividade. Na condução da aula Mateus conecta as Orientações para o ensino de ciências (em virtude de suas aulas serem baseadas em projeto) e o Conhecimento pedagógico geral por conduzir sua aula, em virtude de suas experiências anteriores em lecionar. Como consequência, a turma foi dividida em grupos e Mateus conseguiu conduzir a aula de modo que a gestão da classe fosse mantida - Conhecimento Pedagógico Geral. Essa regência foi a única aula que Mateus ministrou sem a interferência dos demais pibidianos e da supervisora.

Nas aulas ministradas sobre redox, em diversos episódios Mateus não esclarece as atividades a serem realizadas pelos discentes. Por exemplo, na aula experimental da gota salina (arquivo 10) Mateus não elucida o procedimento, apenas discorre à turma:

Boa noite, galera. É... Hoje a gente vai fazer dois experimentos sobre reações de oxirredução. É... Mas antes vou entregar pra vocês...((silêncio)) Antes vocês vão receber uma folha, uma folha... Uma dessa daqui por grupo. Serão duas, não é? Uma para cada experimento. E aí enquanto a gente anota as observações de uma tampinha a gente vai deixar que reaja a outra. O primeiro experimento é sobre a gota salina e segundo experimento é sobre o cobre metal. ((alunos organizam os grupos)). Como vai ficar aqui? Vai fazer um trio aqui? Uma dupla e outra dupla? ((muito barulho no momento de organizar os discentes, não demonstrar ter planejado a organização da classe)) (Aula experimental da gota salina, arquivo 10, turno 1).

Os discentes então compartilham com Mateus que não estavam compreendendo o que era para ser feito, e o pibidiano, então, argumenta:

Olha só, galera. Presta atenção. Oh, a tampinha que eu coloquei a solução é a que vocês têm que fazer nessa atividade aqui que tem esses quatro... Essa tabela com quatro bloquinhos aqui, vocês vão anotar as evidências que vocês estão observando. Se mudou de cor, enfim, nessa folha aqui a que eu pinguei. A outra, vocês vão reservar e deixar ela de canto, por favor, não mexa nela, porque qualquer movimento nela já não vai acontecer o que a gente estava esperando. $\mathrm{O}$ que é a solução salina que estavam me perguntando. A solução salina, ela é uma solução feita de ferrocianeto de potássio com fenolftaleína e cloreto de sódio. É a função de cada um. Você quer falar? (Aula experimental da gota salina, arquivo 10, turno 17). 
O pibidiano tenta orientar os discentes a examinarem as evidenciais experimentais e propor explicações para o que viriam a observar - Conhecimento das estratégias Instrucionais para o Ensino de Ciências (Aula experimental da gota salina, arquivo 10). Contudo, o planejado que Mateus havia estruturado foi alterado em decorrência das interrupções dos demais pibidianos e da supervisiona. Apesar de o pibidiano tentar persistir em seguir conduzindo a regência, como denota a passagem "Bom, galera já deu cinco minutos. Agora tem o segundo bloquinho aí de observação. Vocês vão anotar o que está acontecendo. Cada uma vai ser diferente da outra" (Aula experimental da gota salina, arquivo 10, turno 40), logo na sequência Elder interrompe a sua fala.

As Decisões sobre o fazer no ensino de Mateus foram fortemente limitadas em virtude das intervenções que ocorriam em sua aula. Nesse sentido, em diversos episódios de suas regências Mateus as encaminhava seguindo seu planejamento, mas as regências ganhavam outros direcionamentos pensados no contexto de sala de aula por Luiza e Elder, como denota o trecho:

Mateus - Ah, agora vocês fazem o terceiro bloquinho ((silêncio))

Aluno - Continua verde?

Luiza - Continua verde? Deixa eu ver?

Aluno - O meu também.

Luiza - Aqui?

Aluno - Não é um azul meio amarelado?

Aluno - Metade está azul e o outro lado está amarelo.

Aluno - Mateus, oh Mateus. Aqui não mudou nada, é normal?

Mateus - Oi?

Aluno - Tá normal. ((Ininteligível 00:16:18))

Elder - Agora, eu quero que vocês deem uma olhada na terceira questão, descendo. A pergunta... Em quais condições a ferrugem ocorre mais rapidamente? Vocês têm alguma teoria? De quais condições a ferrugem acontece mais rapidamente? (Aula experimental da gota salina e deposição de cobre, arquivo 10, turno 54-63).

$\mathrm{Na}$ sequência, Mateus solicita aos alunos observarem o experimento, mas sem sucesso, porque seus pares interrompem seus encaminhamentos. Em outro momento ao prosseguir com a aula, argumenta aos discentes que explicaria o que aconteceu no segundo experimento:

Mateus - Galera, tem alguns grupos que já fizeram a primeira atividade. Eu vou explicar a segunda atividade, quem ainda não fez presta atenção e aí depois vocês fazem tudo de uma vez só, para me entregar no final da aula. A segunda tampinha é... O que acontece... Essa segunda tampinha, a gente colocou a solução do sulfato de cobre e que cor que ficou essa solução?

Alunos - Rosa. 
Mateus - Ficou rosa, não é?

Aluno - A solução ficou rosa, não é?

Mateus - Apareceu alguma coisa rosa.

Elder - A solução... O que será que é isso? Tem que dar uma pensada. (Ininteligível 00:25:05). Pessoal, vocês querem fazer a segunda atividade? O sulfato de cobre pode ser escrito dessa maneira. A parte do sulfato, ela não vai ser importante para a nossa questão aqui. Então se pensar no cobre só como íon, o cobre dois mais, que é a solução azul do começo, ele recebe dois elétrons de algum lugar, que vocês terão que debater mais tarde, ele vira cobre sólido, cobre metálico, que é essa mancha na tampa. Cobre, cobre. ((O sinal bate os discentes saem da sala)) (Aula experimental da gota salina e deposição do cobre, arquivo 10, turno 97-102).

No trecho acima se observa que Mateus não conseguiu finalizar a aula. Na turma seguinte, ao aplicar o mesmo experimento, Mateus modificou os encaminhamentos práticos eleitos na aula anterior, dado que

[...] na primeira aula do $\mathrm{G}$ a gente, enfim, a estratégia de, dessa primeira, a questão deles anotarem não ficou... e aí a gente tinha as aulas, por exemplo, a prim... era a segunda aula e depois a quarta e a quinta. E aí nesse meio tempo, a gente teve a Luiza, ó, faz desse jeito assim, ó, porque se você der tempo, poxa, o cara vai fazer e vai sair... (Reunião para avaliar o projeto desenvolvido pelo trio, arquivo 14, turno 357).

Nessa segunda implementação da aula experimental (arquivo 10.1) Mateus a inicia exibindo um pequeno vídeo sobre o experimento da gota salina - Conhecimento das estratégias instrucionais para o ensino de ciências:

Mateus - Bom, hoje a gente vai fazer dois experimentos com vocês, um referente a gota salina e o outro a formação de cobre metálico nas tampinhas.

Luiza - Dá pra você desligar o celular, antes que eu dê um surto e jogue pela janela?

Mateus - Vocês vão fazer duplas, tem 20 pessoas, 2 pessoas, são duplas.

Aluno - Pode dupla de 6 ?

Mateus - 20.

Aluno - Vinte não são 19.

Mateus - 19.

Clara - Faz um esforcinho aí porque a atividade é pra ser entregue em duplas.

Mateus - Eu vou passar um vídeo agora, é um vídeo rápido e curto, presta atenção, é sobre a gota salina (Aula experimental da gota salina e deposição do cobre, arquivo 10.1, turno 3-11).

Nessa segunda turma para a qual aplicou o experimento, Mateus direciona os discentes em como devem proceder para a realização da prática experimental:

Mateus - O que vocês vão precisar fazer? ((os discentes não prestam atenção e Mateus voltar a falar alto)). Presta atenção, gente, pra não 
fazer errado. Na atividade, a primeira questão, ela tá pedindo o que? Ela tá pedindo pra vocês escreverem as transformações que vocês estão observando, ou seja, as evidências que vocês estão vendo, por isso vocês vão fazer em dupla ((Os pibidianos esquematizaram na lousa as reações do experimento e ilustraram uma tampinha. Talvez em virtude das dificuldades que tiveram na primeira da turma do $2^{\circ}$ ano ao implementarem a prática experimental)).

Luiza - Aviso, celulares serão retirados e jogados dentro da pia, e vai ser aberto em cima do celular a água, então eu acho bom vocês guardarem, porque eu vou passar recolhendo, tô avisando, guarda, enfia no bolso, tira esse celular da mesa, que eu vou jogar na pia.

Mateus - O que vocês vão fazer? Vocês vão anotar de início o que vocês observam na tampinha, assim que colocar, a Clara vai colocar a gota, após cinco minutos, após 15 minutos. Se vocês quiserem eu posso ficar contabilizando, ou vocês mesmo contabilizam. Então eu vejo. Oito horas agora ((22:00 horas)) (Aula experimental da gota salina e deposição do cobre, arquivo 10.1, turno 40-42).

Apesar da tentativa de Mateus em mais uma vez desenvolver o experimento por meio da investigação, logo na sequencia Elder explica o que aconteceu no experimento, tirando a atenção do discentes para as observações que deveriam realizar. Além disto, dispõe na lousa o esquema do que estava acontecendo na tampinha ao ser adicionada a solução salina (Aula experimental da gota salina e deposição do cobre, arquivo 10.1).

$\mathrm{Na}$ apresentação dos resultados do projeto Mateus, ao discorrer sobre a última aula, dispõe a narrativa:

Mateus - Foi muito bacana. A gente também das fichas, enfim as fichas levaram o trabalho, mas também as fichas a tinha uma outra ficha que não entrava no que a gente ia fazer na dinâmica das fichas, que falava sobre as composições e funcionamento das lâmpadas, e aí a gente esquematizou um folder, que a gente entregou pra eles, enfim, durante a atividade lúdica que era, solicitar ao aluno... como que era? Processos, eram os processos e os efeitos que aconteciam na lâmpada fluorescente, e o interessante é que o processo, a energia elétrica ela causa ionização do gás, e aí uma coisa vai interligando a outra como se fosse uma sequência, como se desse sequência.

Maria - Encadeamento.

Mateus - Isso, isso mesmo (Apresentação dos resultados, arquivo 12, turno 53-55).

Ao compartilhar com os pares o trabalho desenvolvido no Pibid em um encontro científico, Mateus argumenta que recebeu críticas devido a falta de conteúdos químicos. A coordenadora, Maria, argumenta com o pibidiano que a estruturação do subprojeto fundamentada na CTS tinha nuances que poderiam levar a diversas maneiras de desenvolver a prática de ensino:

Uma das maneiras que nós escolhemos que foi uma coisa que a gente já discutiu, nós optamos por começar com a parte de sensibilização e dar enfoque e esse enfoque de sensibilização e da problemática, ele clama pela química ali no decorrer [...]. Então assim, é uma... o problema, que eu acho, é que assim, as pessoas querem ver a química no primeiro momento. Né? e talvez isso seja até uma, uma coisa que 
eu tinha falado pra vocês, eu falei, olha, a gente vai apresentar na semana da química, lembra que a gente falava assim: "Ai, professora, a gente tem o que apresentar? A gente tem. $O$ que que a gente precisa falar pra pessoa que tá ouvindo? Que ainda tá incompleto o trabalho. Né? E talvez a pessoa que chegasse e batesse o olho, chegasse e falava: "Cadê a química?" Ela não tivesse percebido que era um trabalho que estava em andamento, né? E isso aconteceu com todos os grupos. E vocês ficaram muito assim, mexidos com isso. Eu não sei exatamente quais foram as pessoas que falaram isso, mas vocês eu percebi muito que ficou muito mexido. É, e talvez vocês também não tivessem percebido esse... é... essa coisa um pouco maior. Que vai chegar. E não pode ter tanta pressa, porque no fundo a gente não quer só formar o cara que sabe reconhecer íons, cátions e ânions. Porque se a gente quisesse fazer com que o cara saiba o que é cátions e ânions, a gente estaria falando de cátions e ânions desde o começo, mas não é essa a intenção. A gente quer exatamente que o cara perceba... E outra coisa, a gente quer que ele saia dali e ele vai lembrar de química quando chegar em casa? É lógico que ele lembra. Ele lembrou no ônibus, não lembrou, Mateus? Ele não saiu discutindo no ônibus? Mas ele vai lembrar também de uma outra coisa. Ele vai lembrar das lâmpadas, e talvez do problema das lâmpadas do problema das lâmpadas do que dos cátions e dos ânions. Porque a lâmpada é uma coisa que ele vai continuar vendo no cotidiano dele. $O$ cátion, os cátions e os ânions, de repente nem tanto. Então, eu, é isso que eu acho que a gente tem no nosso discurso do relatório que a gente tem que refletir um pouco. $O$ que que a gente quer formar enquanto aluno, o que a gente quer pra nossa formação, também? $E$ ́ simplesmente saber a química por si só? É a química do vestibular, é a química do Enem? A química por química só ela é, ela é bacana, ela é bonita, ela traz uma satisfação pro ego quando você consegue resolver um exercício ferrado. Mas assim, eu não sei se é suficiente pra gente (Reunião para avaliar o projeto desenvolvido pelo trio, arquivo 14, turno, 307).

Buscando propiciar a reflexão, Maria sugere que Mateus aponte em que aspectos mudaria seu planejamento caso implementasse novamente. Então, o pibidiano argumenta que mudaria os exercícios. Apesar das dificuldades de Mateus em implementar suas regências por conta das interrupções nas suas ações didáticas, ocasionadas por seus pares, o pibidiano considerou que as intervenções de Luiza foram essenciais para as suas aulas:

Então, eu acho que tem momentos que são validos, por exemplo, essa intervenção... porque a gente estava falando, tá certo que tinha o problema da indisciplina tudo, mas era um momento da aula e ela poderia deixar aquilo para fazer, ou para ter deixado ou ter feito antes ou ter deixado para fazer depois. Mas geralmente, as intervenções dela no que se refere ao que a gente está aplicando em sala de aula, são muito interessantes, são bacanas e são de suma importância (lembrança estimulada, arquivo 15, turno 59).

Para Mateus os momentos em que tinha a oportunidade de reaplicar o mesmo planejamento, as aulas eram sempre melhores - Decisões sobre o fazer no ensino, como sugerem os trechos abaixo: 
Eu acho que a falta de planejamento e trabalhar o tempo, né? Porque, por exemplo, a gente vê o que dá certo, o que precisa de mais tempo, o que a gente pode fazer de uma forma... não que a gente possa fazer de uma forma mais rápida, mas o que a gente pode avançar. Eu acho que a segunda aula sempre é melhor.

Às vezes quando a gente dava a primeira aula, aí via que ((não havia dado certo)) né? Geralmente, a gente via, não a gente tem que explicar menos, a gente tem que andar um pouco mais, conversar um pouco mais, dedicar o tempo inteiro a uma atividade. E aí na segunda aula a gente sempre reduzia em alguma coisa e dava para fazer a atividade e dava para fazer o experimento, mas eu acho que nessa, essa intervenção, realmente... (Lembrança estimulada, arquivo 15, turno 235 e 257).

No discurso do pibidiano se observa elementos do Conhecimento pedagógico geral, por conta da gestão da aula e do tempo disponível para desenvolver os conceitos objeto de ensino.

O processo de reflexão de Mateus emergiu em diversos documentos. Nesse sentido, ao refletir sobre os significados de suas ações no contexto de sala de aula e como reconstruiria algumas de suas práticas didáticas, tem-se na tabela 23 as descrições realizadas pelo pibidiano a Ação - Informar e Reconstruir que constituíam o ciclo reflexivo.

Tabela 23. Resposta concedida a Ação Informar e Reconstruir (ciclo reflexivo) por Mateus antes e depois de assistir as regências

\begin{tabular}{|c|c|c|}
\hline Acão & Antes & Depois \\
\hline $\begin{array}{l}\text { Informar - Qual o } \\
\text { significado das } \\
\text { minhas ações? }\end{array}$ & $\begin{array}{l}\text { Apresento aos alunos os conceitos } \\
\text { químicos antes de questioná-los, } \\
\text { por exemplo, quanto a a a a realizados. } \\
\text { experimentos que são rescrever } \\
\text { Faço uso da lousa para descrever } \\
\text { esquemas, desenvolver aulas } \\
\text { teóricas e até mesmo demonstrar } \\
\text { reação. }\end{array}$ & $\begin{array}{l}\text { Para atingir os objetivos do projeto, } \\
\text { a elaboração de aulas com } \\
\text { conceitos químicos que se } \\
\text { completam para que seja possível } \\
\text { chegar ao conteúdo redox. }\end{array}$ \\
\hline $\begin{array}{l}\text { Reconstruir }- \\
\text { Como posso } \\
\text { agir de forma } \\
\text { diferente? }\end{array}$ & $\begin{array}{l}\text { Algumas propostas de aulas foram } \\
\text { repensadas diversas vezes, para } \\
\text { que fosse possível que o aluno } \\
\text { assimilasse os conceitos e pudesse } \\
\text { relacioná-las com seu cotidiano. } \\
\text { Deveria ter me preparado melhor } \\
\text { para poder sanar possíveis dúvidas } \\
\text { com mais exemplos, cotidiano e } \\
\text { analogias. }\end{array}$ & $\begin{array}{l}\text { Me atentar a planejar as } \\
\text { intervenções com menos conteúdo, } \\
\text { mais organizada quanto ao tempo } \\
\text { de desenvolvimento. Me preparar } \\
\text { melhor para as aulas, buscar } \\
\text { diferentes analogias para } \\
\text { apresentar aos alunos, buscar } \\
\text { estratégias diferentes. }\end{array}$ \\
\hline
\end{tabular}

Na percepção inicial de Mateus para a Ação Informar - Antes de visualizar suas aulas, emerge a coocorrência das Orientações para o ensino de ciências e conhecimento Pedagógico Geral, por conta do pibidiano basear suas ações nas suas experiências anteriores e por suas aulas serem elaboradas por meio de projetos. Por outro lado, ao assistir suas regências emerge apenas as orientações para o ensino de ciências, pois evidencia-se que a sua descrição carrega apenas os aspectos relacionados ao subprojeto do Pibid. Por outro lado, na Ação Reconstruir o pibidiano 
reconhece que deveria ter buscado uma fundamentação conceitual sobre o conteúdo. $\mathrm{Na}$ descrição do ciclo reflexivo de Mateus se tem na Ação Reconstruir a influência do Conhecimento Pedagógico Geral sobre as Orientações para o ensino de ciências do pibidiano, em virtude de reconhecer os aspectos de seu planejamento que precisariam ser melhorados.

As Decisões sobre o fazer no Ensino de Mateus de modo semelhante a Melissa foram fortemente influenciados pelo seu Conhecimento Pedagógico Geral. Em consonância, por mais que Mateus buscasse desenvolver a aula por meio da descoberta, os fatores associados às interrupções em sua aula e a falta de gestão da classe resultou em aulas que não foram implementadas da forma como o pibidiano havia planejado. Outra inferência que se faz com relação às limitações associadas às Decisões sobre o fazer no ensino, estaria associada as dificuldades com o conteúdo redox, que o pibidiano demonstrou ter em sua trajetória. As-Crenças sobre a natureza da ciência que estruturam esse componente do PCK não emergem nas narrativas de Mateus.

\section{Conhecimento do currículo em ciências}

Seguindo o propósito de desvelar o conhecimento docente de Mateus relacionado agora aos materiais curriculares, saliência curricular e currículo horizontal e vertical, apresenta-se a reflexão de Mateus acerca da importância de Maria na etapa de seleção dos conteúdos, como denota o diálogo abaixo:

Pesquisadora - É... Quando vocês estão, eu sei que vocês trabalharam em equipe, mas aí você fala da maneira que você julgar correta. Quando você tá elaborando a sua temática, você prioriza conteúdos químicos ou não?

Mateus - Eu priorizo, eu acho fundamental, por exemplo, (ininteligível 00:17:05) fiquei até perdido, (Ininteligível 00:17:17) porque eu achei muito conteúdo, é...e aí falava sobre coisas assim, como que eu posso dizer, conteúdo muito duro, não era só sobre química, aí eu viajei, "não a gente pode fazer desse forma isso e aquilo", e aí eu fui podado até chegar no objetivo que....

Pesquisadora - Você tá querendo dizer que você tava querendo trabalhar este conteúdo de forma global?

Mateus - Eu tava levando em consideração..., eu tava reclamando pra quantidade e não a qualidade.

Pesquisadora - Ah tá a quantidade. E a quantidade (Ininteligível 00:18:08).

Mateus - Eu queria trabalhar tudo de eletroquímica, na lâmpada fluorescente.

Pesquisadora - E isso?

Mateus - E isso não....

Capítulo 4. Resultados e Discussões 
Pesquisadora - E aí vem a seleção do conteúdo com foco. E aí entra o papel da coordenadora...

Mateus - Isso (Entrevista semiestruturada, arquivo 16, turno 91-100).

De acordo com o exposto no diálogo acima, a seleção dos conteúdos que permeou as aulas implementadas por Mateus foi reflexo da orientação da coordenadora. $\mathrm{Na}$ lembrança estimulada, Mateus denota a importância de recuperar, por meio da revisão, os conceitos químicos por meio da percepção de um currículo horizontal e vertical: "E porque não relacionar, entrelaçar esse conceito com conceito de íons também, né" (Lembrança estimulada, arquivo 15, turno 78).

No quadro 23 apresenta-se a organização da aula de estrutura atômica e definição de oxidação, descrita por Mateus no relatório.

Quadro 23. Relação entre o Conhecimento do Currículo e o Conhecimento Pedagógico Geral na aula de estrutura atômica e definição de oxidação.

\begin{tabular}{|c|c|c|c|}
\hline Mês & Atividade & Resultado & Comentários \\
\hline Outubro & $\begin{array}{l}\text { Aula teórica - } \\
\text { conceitos de íons } \\
\text { e estados de } \\
\text { oxidação }\end{array}$ & $\begin{array}{l}\text { Os alunos tiveram um } \\
\text { grande aproveitamento } \\
\text { das aulas sendo isso } \\
\text { evidenciado nos acertos } \\
\text { dos alunos que } \\
\text { ultrapassaram } 70 \% \text { do } \\
\text { proposto nas atividades } \\
\text { que foram entregues. }\end{array}$ & $\begin{array}{l}\text { Tivemos o objetivo de que os } \\
\text { alunos pudessem relacionar os } \\
\text { conceitos de íons e estados de } \\
\text { oxidação para que fosse possível } \\
\text { dar continuidade no que diz } \\
\text { respeito aos conceitos químicos } \\
\text { relacionados a eletroquímica. }\end{array}$ \\
\hline
\end{tabular}

(Fonte: relatório individual - Mateus, arquivo 17, p.3)

No quadro acima a coocorrência entre esses componentes do Conhecimento Docente está relacionada principalmente aos aspectos gerais da aprendizagem dos discentes, não observasse na descrição do pibidiano possíveis limitações associadas ao ensino e aprendizagem do conteúdo de reações redox.

O conhecimento de Mateus associado aos documentos oficiais que norteiam o ensino no Estado de São Paulo e no país, não emergiu em suas narrativas. Para fundamentar suas aulas o pibidiano argumentou que adotou "Livro didático, apostila, o caderno do aluno do Estado de São Paulo, a gente retirou bastante coisa de lá. A gente frisou bastante coisa da apostila (Entrevista semiestruturada, arquivo 16, turno 52).

Nas regências, a saliência curricular foi marcada pelo conceito de Nox e de oxidação. Para o pibidiano a importância do Nox repousava na sua percepção de que "[...] tal número de oxidação permite que o elemento possa se combinar com o outro, enfim, ganhar propriedades que sejam diferentes de que se ele combinasse com outro elemento" (Lembrança estimulada, arquivo 15, turno 298).

Infere-se que Mateus foi tendo a percepção do currículo horizontal e vertical por meio das orientações de Maria. Por outro lado, buscou em seu planejamento vislumbrar diversas práticas experimentais que poderia adotar em suas aulas. 
De modo geral, concebe-se que Mateus iniciou o processo de identificar quais eram os conceitos fundamentais para ensinar redox e os materiais curriculares no contexto do Pibid. Talvez suas limitações com o conceito de redox tenham refletido na sua escolha por desenvolver o conceito de oxidação e Nox, deixando em segundo plano a definição de redução.

\section{Conhecimento da compreensão dos alunos em ciências}

Os aspectos associados aos conhecimentos que o professor deveria vislumbrar no processo de elaboração e aplicação das aulas, não emergem de modo sólido no repertório de conhecimento docente de Mateus. Nesse sentido, o entendimento do pibidiano acerca das limitações dos discentes associadas a oxirredução emergem somente nas suas narrativas após a finalização de suas aulas e no CoRe.

No CoRe, ao responder as questões 4 e 5, Mateus pontua as dificuldades dos discentes. Nessa perspectiva, no quadro 24 dispõe-se a descrição realizada pelo pibidiano para essas duas questões que compunham o CoRe.

Quadro 24. Respostas concedidas por Mateus as questões 4 e 5 do CoRe.

\begin{tabular}{|c|c|c|c|}
\hline \multirow[b]{2}{*}{ Questões } & \multicolumn{3}{|c|}{ Ideias centrais vinculadas a esse conteúdo } \\
\hline & Definição & Conceitos & exemplos \\
\hline $\begin{array}{l}\text { 4. Quais são as } \\
\text { dificuldades } \\
\text { limitações ligadas ao } \\
\text { ensino desta ideia? }\end{array}$ & $\begin{array}{ll}\text { Dificuldade } & \text { de } \\
\text { encontrar o } & n^{\circ} \\
\text { de oxidação } & \text { de } \\
\text { espécies } & \\
\text { químicas } & \end{array}$ & $\begin{array}{l}\text { Dificuldade de identificar } \\
\text { a quantidade de elétrons } \\
\text { ganhos e perdidos }\end{array}$ & $\begin{array}{l}\text { A não relação dos } \\
\text { conceitos químicos } \\
\text { com remplos } \\
\text { cotidianos vividos por } \\
\text { eles mesmos }\end{array}$ \\
\hline $\begin{array}{l}\text { 5.Que conhecimento } \\
\text { sobre o pensamento } \\
\text { dos estudantes tem } \\
\text { influência no seu } \\
\text { ensino sobre está } \\
\text { ideia? }\end{array}$ & $-\cdots$ & $\begin{array}{l}\text { O que eles sabem sobre } \\
\text { reações químicas, } \\
\text { ligações químicas e } \\
\text { fundamentação } \\
\text { matemática }\end{array}$ & $\begin{array}{l}\text { O fato de acharem o } \\
\text { fenômeno, como de } \\
\text { oxidação (corrosão) } \\
\text { sem importância ou } \\
\text { sem aplicação, pelo } \\
\text { fato de não } \\
\text { conhecerem. }\end{array}$ \\
\hline
\end{tabular}

$\mathrm{Na}$ percepção do pibidiano, as limitações associadas ao ensino de redox estavam pautadas na dificuldade do discente em identificar o número de oxidação, a espécie química que se reduzia ou se oxidava. Com relação aos conceitos químicos que poderiam influenciar na aprendizagem do conteúdo redox, Mateus considera as reações químicas, ligações químicas e conceitos fundamentais de matemática.

No processo de elaboração da proposta de ensino, Mateus foi orientado por Maria a preencher o CoRe para o planejamento da aula de sensibilização. Ao discorrer sobre o que havia descrito nesse instrumento, argumenta que não havia compreendido a quarta pergunta, como denota o diálogo:

Mateus - Aí essa cinco ((quis dizer a pergunta quatro)) foi um erro, ficou grifado.

Maria - Então a 4, a 4, "Quais são as dificuldades e as limitações conectados ao ensino dessa ideia? ". Aí eu acho que vocês já sabem um pouco dessas dificuldades, se vocês forem trabalhar com metas, e 
aí tem a parte de reação redox, essa é uma problemática, talvez assim, não esteja muito claro pra vocês, e não vão preencher agora, porque são vocês que tem que preencher, eu acho que vai surgir essa informação, vocês vão começar a perceber, mas eu acho que vocês já sabem, vocês não sabem que sabem (Apresentação da proposta de trabalho, arquivo 3, turno 73-74).

$\mathrm{Na}$ narrativa de Maria, a coordenadora parte do pressuposto que o pibidiano vislumbrava as limitações associadas ao ensino de redox. Entretanto, Mateus não as conhecia. Logo, nas regências, Mateus não se atentou às dificuldades dos discentes com o conteúdo redox, e por vezes ignorou as dúvidas dos alunos levando-o a considerar respostas equivocadas conceitualmente de alunos. Nesse sentido, apresenta-se o diálogo:

Mateus - O nox cai, e quando ela perde carga negativa, o nox aumenta, ou seja, ela fica positiva, ou então metálico, enfim. Um conceito que vai ser importante pra essa aula e principalmente pra resolução dos exercícios vai ser esse, que quando essa espécie química ela recebe o elétron, ou seja, o nox dela, o número de oxidação, o estado de oxidação diminui, quer dizer que ela reduz, ela sofre redução, e quando ela perde esses elétrons, ou o elétron, ela fica positiva, ou o nox dela aumenta, e ela oxida

Aluno - O que seria oxidar?

Aluno - Enferruja.

Mateus - Exatamente. Vocês vão ver, exatamente, a gente vai começar com o experimento da gota salina, vocês já separaram em duplas (Aula experimental da gota e deposição do cobre, arquivo 10.1, turno 29-32).

O trecho acima sugere que Mateus desconhecia que uma das principais limitações conceituais de redox seria o aluno compreender equivocadamente que toda reação de oxidação resultaria na formação de ferrugem.

$\mathrm{Na}$ estruturação da aula de atomística e definição de oxidação, apesar de inicialmente Mateus não vislumbrar a necessidade de revisar esses conceitos, posteriormente à sua vivência no Pibid, o pibidiano inicia a sua percepção sobre as necessidades dos discentes:

[...] Aí nós tivemos uma aula teórica que era uma necessidade de, que eu queria falar sobre oxidação, redução, reações de oxirredução sem que os alunos tivessem conhecimento do que é íons, os estados de oxidação, enfim, número de oxidação, então, eu até esqueci de colocar, eu esqueci de pegar em casa na realidade, pra gente colocar as lousas que foram feitas pra essas aulas (Apresentação dos resultados, arquivo 12, turno 19).

Esse trecho é um dos poucos que Mateus se atenta às necessidades prévias dos discentes antes de ensinar um conteúdo. Talvez essa percepção reflita futuramente na composição do seu repertório de conhecimento docente. 
A vivência no programa de iniciação científica possibilitou que Mateus começasse a refletir sobre as dificuldades dos discentes, apesar de essas não terem feito parte de seu planejamento. Com relação a essas limitações, dispõe-se o diálogo:

Mateus - Bom... ((longo período de silêncio)) Eu acho que principalmente o fato de eu não ter a certeza se eles compreenderam o que ganha o que perde elétrons, porque, por exemplo, está uma confusão ali, por exemplo, o elemento perdeu carga negativa, não espera aí, o elemento ganhou carga negativa então, ele fica negativo, o fato de ter ganhado quer dizer que ele... e dá essa confusão e aí...

Pesquisador - Essa questão de sinais, né.

Mateus - Dá uma insegurança de você... por exemplo, partir disso, mas acho que é melhor ainda assim por conta da representação, porque é o que ele está vendo, você representa o átomo, o átomo e o íon e aí o cara vê lá, poxa, mas aqui tem esse sinal, aqui tem isso, tem aquilo (lembrança estimulada, arquivo 15, turno 80-82).

Mateus - Isso. Então foi difícil, por conta disso. Eu tive que me preparar e ainda assim eu acho que foi pouco...

Pesquisadora - Mas é... você estudava praticamente que nível do ensino médio ou superior?

Mateus - Não, eu estudava por livro de ensino médio. Eu estudei pelo... é... como é o nome? Martha Reis, que foi o que usava, tinha o Feltre, tinha o... enfim, tinha outros livros...

Pesquisadora - Mas você teve a percepção ou não de era também necessário dar uma... estudar pelo livro superior ou por que... só estudar pelo livro de ensino médio?

Mateus - Eu... é porque, eu pensei: pôxa, o livro de ensino médio é feito... né, o público alvo são os alunos, então eu falei não, é melhor me restringir só aos de ensino médio. Eu até folheava o caderno enfim, da faculdade, do técnico, mas eu... pra falar a verdade, pra fazer as lousas eu usei do ensino médio. E pra mim foi... não foi fácil não. Foi muito difícil. Eu estudei muito (Lembrança estimulada, arquivo 15, turno 412-416).

Nos turnos acima tem-se o Conhecimento de estratégias instrucionais, Conhecimento da avaliação e Conhecimento da compreensão dos alunos em ciências.

Para Mateus as dificuldades dos discentes em compreenderem os conceitos envolvidos no experimento de decomposição do cobre foi reflexo da falta de tempo disponibilizado para a resolução das questões durante a aula, pois para o pibidiano "[...] A parte que eu acho, a parte da gota salina... é, gota salina. É... eles conseguiram responder melhor. Aí na parte da deposição do cobre não, acho que por conta do tempo, não sei” (Reunião para avaliar o projeto desenvolvido pelo trio, arquivo 14, turno 345). Contudo, para Maria, Mateus e seus pares deveriam ser mais cautelosos na avaliação dos discentes, devido as suas dificuldades e por conta do contexto no qual lecionaram, pois "[...] vocês estão explicando oxirredução, e uma condição específica da oxirredução, um experimento específico pra alunos de escola pública e noturna. Então 
acho que a gente tem que olhar tudo isso daqui com um olhar [...]" (Reunião para avaliar o projeto desenvolvido pelo trio, arquivo 14, turno 352).

Nesse componente do PCK Mateus demonstrou, inicialmente, desconhecer as limitações dos discentes com o conteúdo redox, as concepções equivocadas e suas necessidades. As necessidades dos discentes foram possíveis de serem percebidas pelo pibidiano, por conta das orientações de suas tutoras, principalmente de Maria. Algumas das concepções equivocadas sobre reações redox foram acessadas, por outro lado, outras (oxidação resulta na formação de ferrugem, a oxidação ocorre somente na presença de oxigênio, entre outras) estavam internalizadas no próprio repertório do pibidiano. A motivação e interesse dos discentes não emergem na estrutura do Conhecimento da compreensão dos alunos em ciências.

\section{Conhecimento das estratégias instrucionais para o ensino de ciências}

Nas aulas de reações redox, as principais estratégias de ensino adotadas por Mateus em sua regência foram: exposição teórica do conteúdo (giz e lousa), revisão de conteúdo, experimentos, resolução de exercícios, exibição de vídeos experimentais e trabalho em grupo. Não mapeou nos documentos evidências de analogias adotadas por Mateus.

$\mathrm{Na}$ primeira aula de química que ministrou, Mateus lecionou uma revisão de conceitos de atomística e oxidação (arquivo 8 e 8.1). Na primeira turma (arquivo 8) o pibidiano foi orientado por Luiza a realizar "[...] uma coisinha boba que eu faço com ele, que eu já fiz, que vocês, quando eu pego o cobre, que a gente tem ali o cobre metálico, e eu tenho o sulfato de cobre" (Reunião para saber o andamento, arquivo 6, turno 201). Em consonância com a orientação de Luiza, Mateus implementou o experimento demonstrativo nessa primeira aula.

$\mathrm{Na}$ reunião com as tutoras Mateus apresentou a estrutura de uma aula experimental que comporia a segunda regência. A supervisora, ao analisar o roteiro, sugere ao pibidiano desenvolver por meio de uma abordagem investigativa 0 experimento que havia planejado, como denota o trecho:

Luiza - É, então eu compartilhei, o Antônio compartilhou com vocês, não compartilhou? O Antônio copiou dois vídeos, um da Sociedade Brasileira de Química, um que é da Rita Estwart que dá algumas dicas de como... bem pra o professor como trabalhar em sala de aula determinadas questões, visando o experimento investigativo, né, também, que eu acho que é uma das coisas que a gente tem que se preocupar, então não fazer uma experiência pela experiência, mas que aquilo tem que sair alguma coisa, e aí assim, até depois eu conversei com o carioca, só deixando vocês a par, de um experimento lá, como que ele poderia transformar aquele experimento em investigativo? Então eu falei assim: olha, por exemplo, se você coloca aqui em vez de dar a montagem já pronta pros alunos, que vai acender a lâmpada que é uma pilha, o que você não faz? Bota pra eles montarem com o 
papelzinho seco, não vai acontecer nada, tá, observe o que aconteceu, faz uma pergunta, aí molha o papelzinho na água, o que aconteceu? Aconteceu alguma coisa? Mudou alguma coisa? Molha o papelzinho na água com sal, mudou alguma coisa? O que você consegue concluir disso? Então você vai levando o aluno a pensar, e a refletir no caminho daquilo que você quer, que é que ele compreenda que pra haver corrente elétrica é necessário a presença de íons (Reunião para saber 0 andamento, arquivo 6, turno 14).

Considerando a orientação da supervisora, Mateus reestruturou o roteiro de modo que o possibilitasse direcionar os encaminhamentos práticos por meio da investigação. Dispõe-se o roteiro final na figura 35.

\section{Experimento Reações de oxirredução - Gota salina}

1. Observe as transformações que ocorrem no experimento e complete a tabela abaixo com suas anotações:

\begin{tabular}{|l|l|l|l|}
\hline Início & 5 minutos & 10 minutos & 15 minutos \\
\hline & & & \\
\hline
\end{tabular}

2. Sabendo que ao final ocorrerá a corrosão da tampinha, o ferro contido nela se oxidará ou se reduzirá? Sabe-se que a corrosão é um processo oxidativo.

3. O experimento realizado tem como objetivo mostrar a corrosão da tampinha (formação de ferrugem) metálica espontaneamente. Em qyaus condições a ferrugem ocorre mais rapidamente?

(a)

\section{Experimento Reações de oxirredução - Deposição de cobre}

1. Foi possivel observar no experimento a formação de cobre metálico após adicionarmos uma gota da solução de solução de $\mathrm{CuSO}_{4}$ a tampa metálica de ferro.

a) Houve transformação química decorrente da interação a tampinha metálica e a solução de $\mathrm{CuSO}_{4}$ ? Cite evidências que comprovam esta ideia.

b) Nesse caso os íons $\mathrm{Cu}^{2+}$ da solução sofrem oxidação ou redução? Justifique sua questão propondo uma equação química que representa essa semirreação.

c) Faça um desenho que representa os ions na solução de $\mathrm{CuSO}_{4} \mathrm{e}$ os átoms de cobre metálico formados na placa. Apresente as semelhanças e diferenças entre essas duas espécies.

Figura 35. Roteiro da aula experimental da gota salina (a) e deposição de cobre (b)

(Fonte: Relatório individual - Mateus, p.32).

A aula experimental da gota salina foi aplicada para as duas turmas do segundo ano. Na primeira sala o pibidiano inicialmente orientou os discentes a observarem os fenômenos e proporem explicações. Contudo, a supervisora sugeriu que Elder prosseguisse na condução da aula, o que interrompeu as Decisões para o Ensino de Ciências de Mateus e, consequentemente, a sua estratégia de ensino baseada na 
experimentação investigativa (Aula experimental da gota salina, arquivo 10). O pibidiano reconheceu que as aulas não ocorreram como havia planejado:

\begin{abstract}
Mateus - Aí as aulas experimentais, foram duas, uma deu certo, quer dizer, parte de uma deu certo, mas a gente não conseguiu que os alunos fizessem as atividades que foram propostas, essa que deu certo, que a gente conseguiu mostrar pra eles os experimentos, demonstrativamente, foi, eu não lembro quais, era... Enfim, não vou lembrar agora, mas enfim, a gente não conseguiu, era justamente pra cobrar do aluno, de representação, macroscópico, microscópico, e a gente enfim, não que não teve tempo, mas a gente não planejou o nosso tempo pra que eles pudessem responder as atividades da melhor forma, enfim, e eu digo que a mesma coisa aconteceu na atividade, só que na outra atividade a gente mudou de uma aula para outra porque a gente começava, depois pra outra, a gente mudou, e aí na outra turma deu certo, que era os dois experimentos, uma com a deposição de cobre, e a outra a gota salina.
\end{abstract}

Luiza - A ponte salina e a gota salina.

Mateus - E aí foi muito interessante porque ali a gente conseguiu solicitar dos alunos os níveis de representação, a gente conseguiu cobrar o fato de oxidação, se o ferro oxidou, se reduziu, o que aconteceu, e principalmente quanto ao macroscópico...observação dele, porque era aquilo que eu estava vendo.

Maria - As evidências.

Mateus - Exatamente, foi muito interessante, foi muito produtivo, muito mesmo (Apresentação dos resultados, arquivo 12, turno 26-30).

Mateus, em sua reflexão, analisou o que não havia dado certo nas aulas experimentais, entretanto, na percepção da supervisora, na aula experimental da gota salina, o pibidiano havia conseguido conduzir a aula da forma como havia planejado.

De modo geral, Mateus, no contexto do programa de iniciação à docência, teve a possibilidade de experimentar em suas aulas as estratégias de ensino a saber: experimento demonstrativo e investigativo, vídeo, situações-problemas e aulas desenvolvidas com lousa e giz. Deduz-se que a estratégia investigativa e demonstrativa foi eleita por Mateus em suas regências, em virtude da orientação principalmente da supervisora. O conhecimento do tema incipiente e as interrupções de outros pibidianos e da supervisora na implementação das aulas influenciaram negativamente no desenvolvimento desse componente do PCK, por Mateus não conseguir conduzir as aulas.

\title{
5. Conhecimento da avaliação da aprendizagem em ciências
}

Os conhecimentos de Mateus relacionados aos métodos de avaliação e o que avaliar em suas aulas estavam associados a dois objetivos principais: o primeiro, coletar dados para o subprojeto, e o segundo, compor a nota do bimestre da professora supervisora. 
As atividades avaliativas adotadas por Mateus ao longo das aulas foram constituídas por questões que levaram os discentes a reproduzirem suas explicações. Além disto, Mateus sempre argumentava aos discentes "[...] que a professora Luiza vai considerar, então eu só peço que vocês façam com o mínimo de comprometimento, o mínimo, simplesmente fazer silêncio já nos ajuda demais [...]" (Aula lúdica funcionamento de lâmpadas fluorescentes, arquivo 11.1, turno 18).

De modo semelhante aos outros pibidianos, Mateus propos exercícios de fixação, uma orientação de Maria. Na figura 36 apresenta um dos exercícios que compuseram a sequência de ensino de Mateus.

1. Complete as tabelas abaixo, indicando o que se forma quando as espécies químicas recebem ou perdem elétrons e o estado de oxidação da espécie em cada caso.

\begin{tabular}{|c|l|l|}
\hline Espécie química & Recebe 1 $\mathrm{e}^{-}$ & Estado de oxidação \\
\hline $\mathrm{H}$ & & \\
\hline $\mathrm{F}$ & & \\
\hline $\mathrm{Co}^{3+}$ & & \\
\hline Espécie quimica & Recebe 2 $\mathrm{e}^{-}$ & Estado de oxidação \\
\hline $\mathrm{S}$ & & \\
\hline $\mathrm{Au}^{3+}$ & & \\
\hline $\mathrm{Hg}^{2+}$ & & \\
\hline Espécie química & Recebe 3 e & Estado de oxidação \\
\hline $\mathrm{P}$ & & \\
\hline $\mathrm{N}$ & & \\
\hline $\mathrm{Al}^{3+}$ & & \\
\hline $\mathrm{Br}^{3+}$ & & \\
\hline
\end{tabular}

\begin{tabular}{|c|l|l|}
\hline Espécie química & Perde 1 $\mathrm{e}^{-}$ & Estado de oxidação \\
\hline $\mathrm{H}$ & & \\
\hline $\mathrm{Li}$ & & \\
\hline $\mathrm{Ti}^{2+}$ & & \\
\hline $\mathrm{Cu}^{+}$ & & \\
\hline Espécie quimica & Perde 2 $\mathrm{e}^{-}$ & Estado de oxidação \\
\hline $\mathrm{Se}^{2+}$ & & \\
\hline $\mathrm{Sb}^{2+}$ & & \\
\hline $\mathrm{Ti}^{+}$ & & \\
\hline Espécie quimica & Perde 3 $\mathrm{e}^{-}$ & Estado de oxidação \\
\hline $\mathrm{Al}$ & & \\
\hline $\mathrm{Fe}$ & & \\
\hline
\end{tabular}

2. Complete com a quantidade de elétrons que falta como os exemplos abaixo:

$$
\begin{aligned}
& \mathrm{Cu}(\mathrm{s}) \rightarrow \mathrm{Cu}^{2+}{ }_{(\mathrm{aq})}+2 \mathrm{e}^{-} \\
& \mathrm{I}_{2}+2 \mathrm{e}^{-} \rightarrow 2 \mathrm{I}^{-}
\end{aligned}
$$
(a) $\mathrm{H}_{2} \rightarrow 2 \mathrm{H}^{+}$(aq) +
(d) $\mathrm{Br} 2++\ldots 2 \mathrm{Br}_{\text {(aq) }}$
(b) $\mathrm{Ag}_{(\text {aq) }}^{+}+\longrightarrow \mathrm{Ag}_{(\mathrm{s})}$
(e) $\mathrm{Mg}^{2+}{ }_{(\mathrm{aq})}+\ldots \rightarrow \mathrm{Mg}_{(\mathrm{s})}$
(c) $\mathrm{Zn}^{2+}{ }_{\text {(aq) }}^{+}+\rightarrow \mathrm{Zn}_{(\mathrm{s})}$
(f) $\mathrm{Al}^{3+}{ }_{(\mathrm{aq})}+$

Figura 36. Exercício proposto na aula de estrutura atômica e definição de oxidação

No contexto de sala de aula o pibidiano ao aplicar o exercício diálogo com a classe:

Mateus - Eu vou fazer o exemplo da 1 e um exemplo da 2. Eu vou fazer dois exemplos, eu vou fazer do exercício $1 . .$. na primeira coluna eu tenho o flúor e aí na segunda coluna está pedindo para você fazer a representação dele quando ele recebe um elétron e depois indicar o 
estado de oxidação dele, o número de oxidação que ele assume nessa representação, quando o flúor recebe um elétron, como que isso fica?

Aluno - Negativo.

Mateus - Ele fica negativo, como que ele fica então?

Aluno - Menos 1

Mateus - Flúor menos 1, ou só menos? E qual é o número de oxidação que ele assume?

Aluno - Menos 1.

Mateus - Menos 1, é isso. Na segunda coluna, por exemplo, o lítio, aí no caso ele perde um elétron, como que fica quando o lítio perde um elétron?

Aluno - Ele fica positivo.

Mateus - Ele fica positivo, então fica Li positivo, ou 1, e qual é o número de oxidação que ele assume?

Aluno - Mais 1.

Mateus - Mais 1, por que? Por que o número de oxidação é a carga. No exercício 2 eu peço para vocês completarem o número de elétrons que falta na reação, aí eu tenho dois exemplos, vamos discutir os dois exemplos, nesse caso aqui (- Ininteligível 00:29:53.04), nesse caso aqui, no exercício 2 nós vamos acrescentar a quantidade de elétrons que falta, ou seja... (Aula de estrutura atômica e definição de oxidação, arquivo 8, turno 97-107).

Do modo como o exercício foi estruturado, o aluno poderia conceber que a reação de oxidação configuraria tanto como a perda quanto como o ganho de elétrons, em virtude o conceito de redução não ter sido ensinado na aula pelo pibidiano. Para o pibidiano o exercício "[...] era simples, era básica, era fácil e era simplesmente reconhecer e informar o número de oxidações, acho que sim" (Lembrança estimulada, arquivo 15, turno 89). Considerando-se ainda esse exercício, Mateus propõe que os discentes resolvam questões associadas ao número de oxidação e de quantidade de elétrons perdidos e ganhos em uma reação redox - Dimensões sobre a aprendizagem ciências para avaliar. $\mathrm{Na}$ análise dessa atividade avaliativa Mateus descreve em seu relatório que os discentes acertaram mais de $70 \%$ do exercício, sugerindo uma estratégia de avaliação de caráter mais certificativo (Relatório individual, Mateus).

$\mathrm{Na}$ segunda turma ao ser aplicado esse mesmo exercício, Mateus explica a atividade, e não simplesmente argumenta que irá resolver duas questões do exercício - Decisões sobre o fazer no ensino (Orientações para o Ensino de Ciências). Nesse sentido, tem-se o diálogo abaixo:

Mateus - Bom, vamos lá. Oh, presta atenção. No exercício 1 tá pedindo pra vocês completarem a tabela indicando se o elemento... indicando a representação que o elemento vai ficar quando ele recebe um elétron, dois elétrons ou três elétrons. Então, na primeira coluna, é o recebimento de elétron, quero que vocês se atentem a isso.

Aluno - Tá escrito! 
Mateus - Na segunda coluna é o quando o elemento perde aquela quantidade de elétrons.

Aluno - Oxidação.

Mateus - Por exemplo, o lítio. O lítio ele perdeu um elétron. Presta atenção.

Elder - Essa é a primeira coluna e essa é a segunda.

Mateus - Por exemplo, o segundo exercício da segunda coluna. $O$ segundo item da segunda coluna. A gente tem o lítio. Quando o lítio perde um elétron, como que ele fica?

Aluno - Eu não sei quanto o lítio tem.

Mateus - Tá escrito ai.

Aluno - Não, a gente tem que olhar na tabela.

Mateus - Mas olha gente. Uma coisa interessante que vocês podem fazer é isso: eu tenho o lítio, ele perdeu um elétron. Ele perde.... ((muito barulho na turma)) (Aula de conceitos gerais de eletroquímica, arquivo 8.1, turno 171-181).

No experimento da gota salina o pibidiano, ao orientar os discentes a responderem as questões, discorre:

Mateus - Ele reduz, ou seja, se na tampinha está acontecendo um processo de corrosão, consequentemente a formação da ferrugem e o ferro oxida... O que vocês responderiam então na questão 3 ? Aí vão pensando e já vão resolvendo e já pode fazer o último bloco também. Pensa em um grupo, conversem... Aí vocês fazem para entregar (Aula experimental da gota salina e deposição do cobre, arquivo 10, turno 92). Envolve (cat. A, 1 e 5).

Revela-se no trecho acima que Mateus vislumbrava que nos exercícios os discentes deveriam reproduzir o que explicava nas aulas. A mesma dinâmica permeou a condução do exercício proposto na aula de deposição do cobre:

Mateus - A gente fez o experimento da gota salina, aí eu coloquei essa reação aqui na lousa, logo em seguida essa daqui representando a perda de dois elétrons do átomo, do Ferro, aliás metálico, formando um cátion... porque ele perdeu dois elétrons. Eu também falei na outra aula que a espécie que recebe elétrons ela reduz, e a que perde elétrons, ela oxida. Nesse caso aqui a gente pode dizer que aconteceu com o Ferro? (Aula experimental da gota salina e deposição do cobre, arquivo 10.1, turno 202).

Permeando-se ainda o contexto do experimento da gota salina, Mateus argumenta, durante a aula, que os discentes precisavam prestar atenção em sua explicação para conseguirem responder a questão três:

Mateus - Já deu já. O Elder tava explicando que esse interage com o oxigênio atmosférico e também o da água, o que acontece aqui... se o Ferro perdeu elétrons, o oxigênio na reação redox por ter interagido com o Ferro, ele vai ganhar elétrons, ou seja, ele vai reduzir, tem inclusive uma questão que pergunta justamente isso, então eu preciso que vocês prestem atenção. Já passou dez minutos? (Aula experimental da gota salina e deposição do cobre, arquivo 10.1, turno 99). 
O objetivo nessa aula do experimento da gota salina e deposição do cobre (arquivo 10, 10.1), segundo Mateus, era "[...] solicitar dos alunos os níveis de representação, a gente conseguiu cobrar o fato de oxidação, se o ferro oxidou, se reduziu, o que aconteceu, e principalmente quanto ao macroscópica... observação dele, porque era aquilo que eu estava vendo" (Apresentação dos resultados, arquivo 12, turno 28). Entretanto, nas narrativas de Mateus não vislumbrou-se que o pibidiano tenha englobado em seu discurso os três níveis representacionais da química, apesar de o mesmo argumentar que o tenha desenvolvido.

Posteriormente à implementação da aula experimental da gota salina e deposição do cobre, Mateus reconhece um equívoco conceitual dos discentes que considerou ser reflexo de sua explicação:

Mateus - $\mathrm{Na}$, na nossa, assim, falando de modo geral, em nossa explicação houve um equívoco que todos responderam que sim. Sabe? Necessariamente pra ocorrer a.... Não que não seja. Não seja, mas pra ocorrer a ferrugem é preciso ter sal e solução salina.

Maria - É, não necessariamente.

Mateus - E tava na nossa lousa (Reunião para avaliar o projeto desenvolvido pelo trio, arquivo 14, turno 372-374).

Nesse diálogo tem-se o entrelaçamento do Conhecimento da compreensão dos alunos em ciências e da avaliação.

No quadro 25 dispõe-se os métodos de avaliação e as dimensões a serem avaliadas sobre reações redox descritos por Mateus para as questões 1, 2 e 8 do CoRe.

Quadro 25. Repostas concedidas por Mateus as questões 1, 2 e 8 do CoRe

\begin{tabular}{|c|c|c|c|}
\hline \multirow{2}{*}{ Questões } & \multicolumn{3}{|c|}{ Ideias centrais vinculadas a esse conteúdo } \\
\hline & Definição & Conceitos & Exemplos \\
\hline $\begin{array}{l}\text { 1. O que você pretende } \\
\text { que os estudantes } \\
\text { aprendam com esta } \\
\text { ideia? }\end{array}$ & $\begin{array}{l}\text { O que ocorre nos } \\
\text { processos de oxidação } \\
\text { e redução nos } \\
\text { diferentes níveis } \\
\text { representacionais }\end{array}$ & $\begin{array}{l}\text { Reconhecer o que é } \\
\text { ganho e perda de } \\
\text { elétrons pelas } \\
\text { espécies químicas }\end{array}$ & $\begin{array}{l}\text { Reconhecer em } \\
\text { seu dia a dia a } \\
\text { ocorrência } \\
\text { desse } \\
\text { processo. }\end{array}$ \\
\hline $\begin{array}{l}\text { 2. Por que é importante } \\
\text { para os estudantes } \\
\text { saberem esta ideia? }\end{array}$ & $\begin{array}{l}\text { Para que ele tenha } \\
\text { maneiras de entender } \\
\text { e interpretar os } \\
\text { processos de oxidação } \\
\text { e redução }\end{array}$ & -------- & ---------------- \\
\hline \begin{tabular}{lrr} 
8. Que & \multicolumn{2}{r}{ maneiras } \\
específicas você utiliza \\
para avaliar \\
compreensão a \\
confusão dos alunos \\
sobre esta ideia?
\end{tabular} & $\begin{array}{l}\text { Aplicação da mesma } \\
\text { atividade após } 0 \\
\text { desenvolvimento das } \\
\text { outras atividades }\end{array}$ & $\begin{array}{l}\text { Exercícios de fixação } \\
\text { em sala de aula }\end{array}$ & $\begin{array}{l}\text { Anotação das } \\
\text { observações } \\
\text { dos alunos } \\
\text { referentes a } \\
\text { aula } \\
\text { experimental }\end{array}$ \\
\hline
\end{tabular}

Infere-se que as estruturas dos métodos de avaliação foram resultantes das orientações de Maria associadas ao Conhecimento Pedagógico Geral de Mateus. O pibidiano descreve que os três níveis representacionais da química permeariam seus 
exercícios e que os discentes deveriam ainda compreender quem perde e ganha elétrons - Conhecimento da compreensão dos alunos em ciências.

Compreende-se a partir das narrativas de Mateus ao longo de sua trajetória no Pibid que as atividades avaliativas tinham a função de compor a nota das avaliações bimestrais da professora supervisora e dados para o subprojeto. Contudo, mesmo que incipientemente, Mateus vislumbrou outras possibilidades associadas à avaliação. Nessa direção, o pibidiano propôs timidamente atividades que levassem os discentes a refletirem, entretanto, as conduziu de modo que os discentes reproduzissem o que havia explicado.

\section{Síntese do Conhecimento Docente de Mateus}

Esmiuçando-se apenas as aulas ministradas por Mateus nas turmas do segundo ano, mapeou-se a imersão de seu conhecimento docente no contexto de sala de aula. Nesses documentos selecionou-se 217 turnos, mas por conta da sobreposição entre as categorias do conhecimento docente obteve-se 353 itens classificados. Na tabela 24 dispõe-se os dados gerados no Atlas.ti.

Tabela 24. Dados gerados no Atlas.ti - Emersão do Conhecimento Docente nas aulas ministradas por Mateus nas turmas de segundo ano

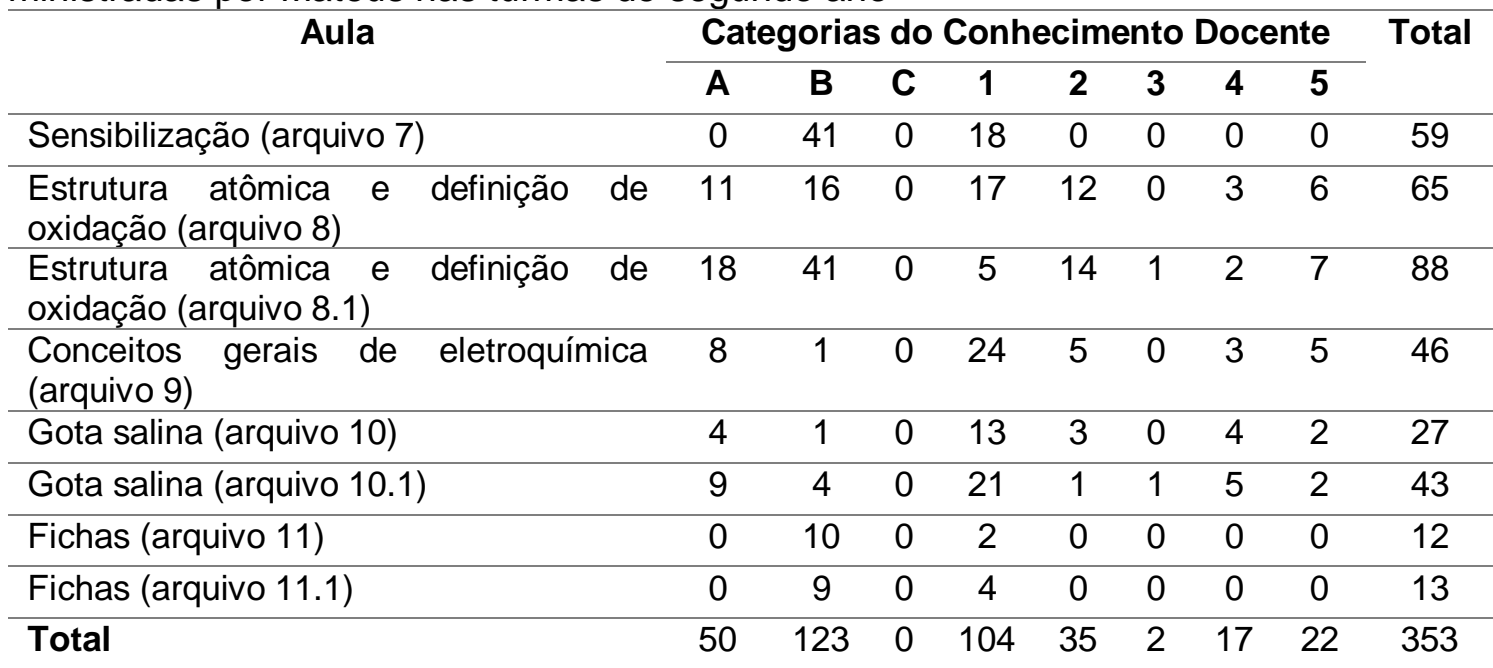

A - Conhecimento do Tema, B - Conhecimento Pedagógico Geral, C - Conhecimento do Contexto, 1- Orientações para o Ensino de Ciências, 2 - Conhecimento do Currículo, 3 - Conhecimento da Compreensão dos alunos em Ciências, 4 Conhecimento das Estratégias Instrucionais para o Ensino de Ciências e 5 - Conhecimento da Avaliação da Aprendizagem em Ciências

$\mathrm{Na}$ aula de sensibilização Mateus inicia por meio da proposição de situações problemas associadas ao descarte das lâmpadas fluorescentes e a PNRS. Nessa atividade os discentes foram divididos em grupos para que discutissem entre si e propusessem uma solução. Na sequência, compartilharam com a classe as soluções. A estrutura dessa aula foi baseada em uma dinâmica adotada por um docente de Mateus, mas readequada de acordo com as orientações das tutoras. Na figura 37 dispõe-se a congruência entre o Conhecimento Pedagógico Geral (B) e as Orientações para o 
Ensino de Ciências (1). Essa harmonia talvez seja reflexo da estrutura do subprojeto, e por Mateus conduzir suas aulas independente do conteúdo.

\section{B}

Figura 37. Mapa de integração entre os componentes do Conhecimento Docente de Mateus na aula de Sensibilização

$\mathrm{Na}$ segunda aula ministrada Mateus realizou uma revisão de conceitos de atomística para na sequência definir oxidação. Nessa regência o pibidiano não definiu redução, devido a sua insegurança conceitual. Na figura 38 tem-se o mapeamento do conhecimento docente emergido na primeira turma (mapa a) e na segunda turma (mapa b).
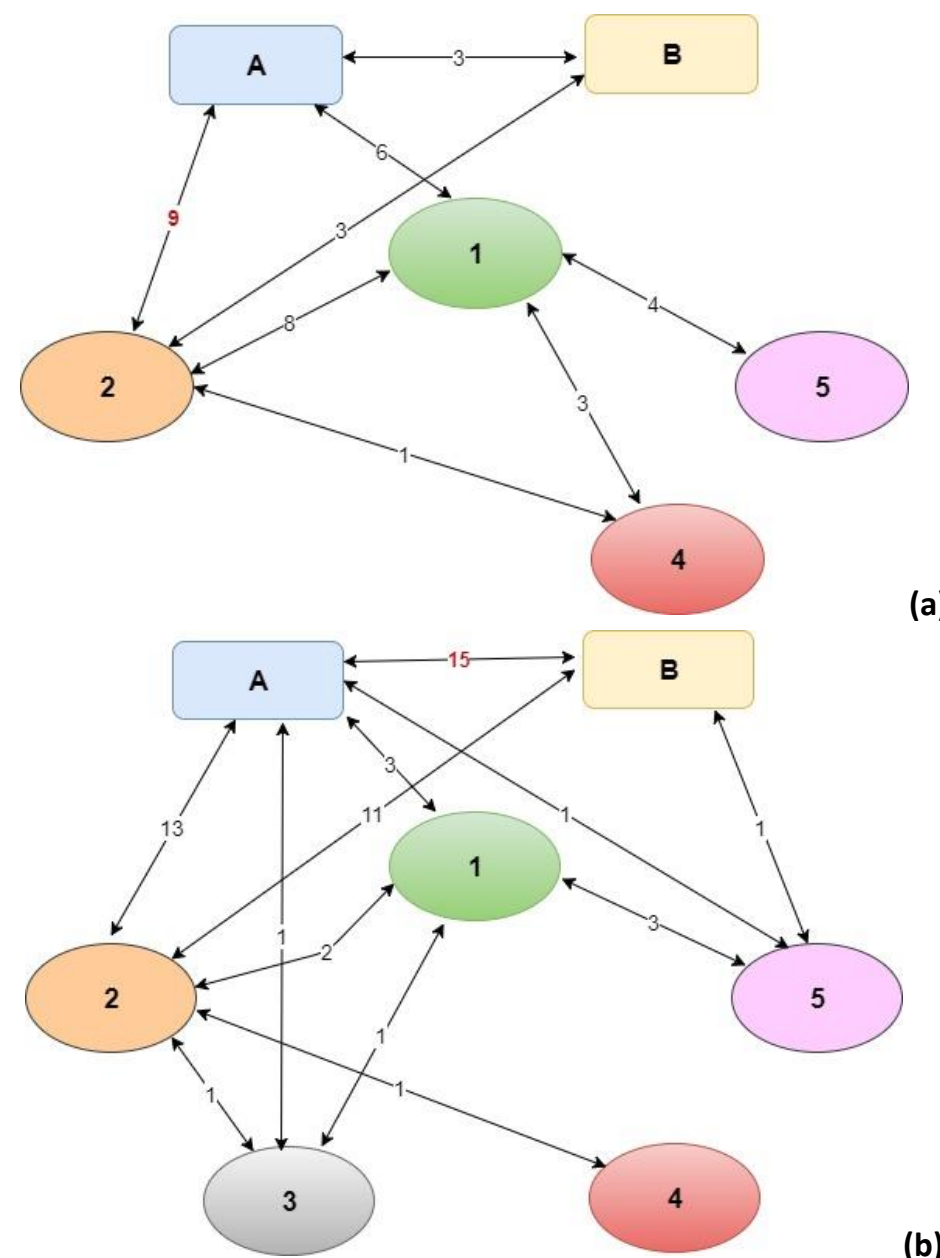

(b)

Figura 38. Mapa de integração entre os componentes do Conhecimento Docente de Mateus na aula de Estrutura atômica e definição de oxidação a. (arquivo 8) e b.

(arquivo 8.1)

Na primeira turma (mapa a) a maior integração ocorreu entre o Conhecimento do Currículo e Conhecimento do Tema, por conta da relação entre o currículo horizontal Capítulo 4. Resultados e Discussões 
e vertical, e da saliência curricular, marcadas respectivamente pelo conceito de atomística, Nox e o conceito de oxidação (arquivo 8).

$\mathrm{Na}$ segunda aula (mapa b) as conexões entre os componentes do Conhecimento Docente aumentam em relação à aula na primeira classe do segundo ano (mapa a), sugerindo-se que Mateus refletiu sobre a aula e a readequou para ser reaplicada. Outra diferença das aulas aplicadas na turma a e na turma $b$ permeia a emersão da conexão entre o Conhecimento da avaliação da aprendizagem em ciências com os componentes Conhecimento do Tema e Conhecimento Pedagógico Geral. No mapa b, observa-se que Mateus acessa o componente Conhecimento da compreensão dos alunos em ciências.

Nessas aulas a e b (arquivo 8 e 8.1) o Conhecimento Pedagógico Geral (B) influência nas Orientações para o ensino de ciências - Decisões sobre o fazer no ensino de Mateus.

A regência de conceitos gerais de eletroquímica foi marcada por interrupções dos pibidianos e da supervisora. O pibidiano Mateus teve pequenas oportunidades para conduzir a regência como havia planejado, resultando em um conhecimento docente incipiente no contexto de sala de aula. Apesar das problemáticas vivenciadas nos episódios finais da aula Mateus, realizou um fechamento conceitual explicando o que havia ocorrido no experimento da árvore de cobre, o que refletiu no acesso ao Conhecimento Docente, descritos no diagrama disposto na figura 39.

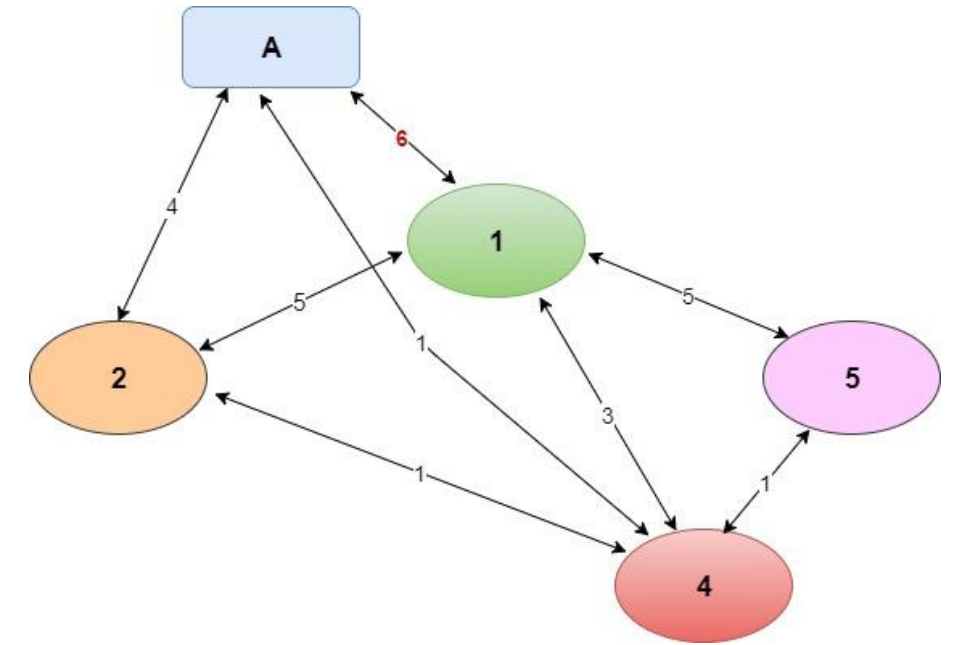

Figura 39. Mapa de integração entre os componentes do Conhecimento Docente de Mateus na aula de conceitos gerais de eletroquímica

$\mathrm{Na}$ aula experimental da gota salina e deposição de cobre o Conhecimento do Contexto (C) não emergiu em nenhuma das duas turmas para a quais o pibidiano ministrou as regências. Na figura 40 apresenta-se o mapa de integração dos componentes de conhecimento docente de Mateus emergidos na turma a (mapa a) e na turma b (mapa b). O pibidiano fundamentou a estruturação dessa aulas por meio da 
abordagem investigativa. Entretanto, devido as interrupções e a sugestão de Luiza para Elder conduzir a aula, o Conhecimento docente de Mateus foi incipiente. Na primeira turma (mapa a) e na segunda turma (mapa b) a integração foi mais significativa entre 0 Conhecimento do Tema (A) e Conhecimento do currículo (2).

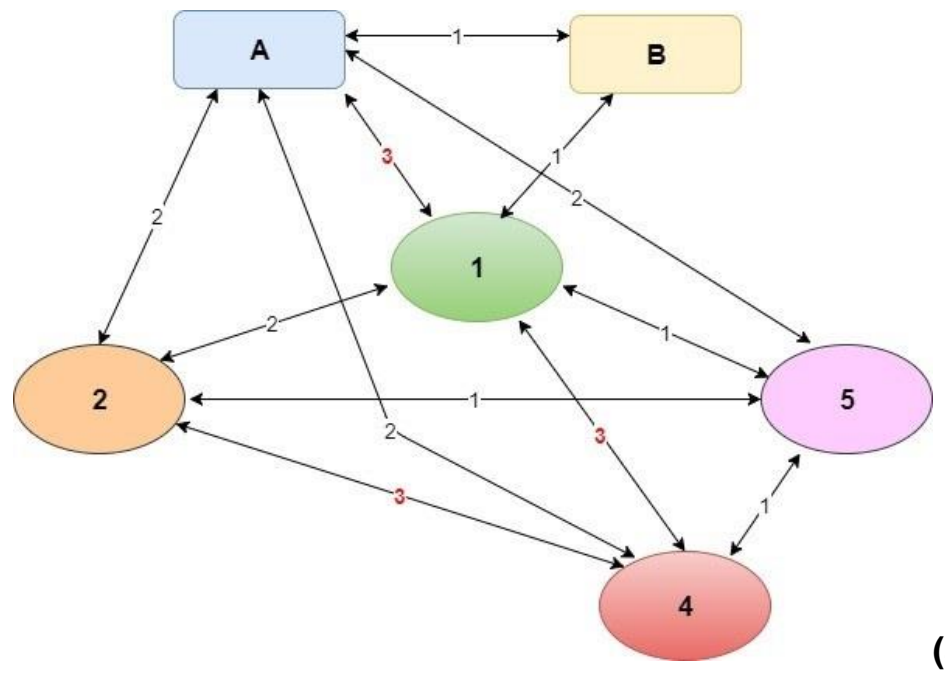

(a)

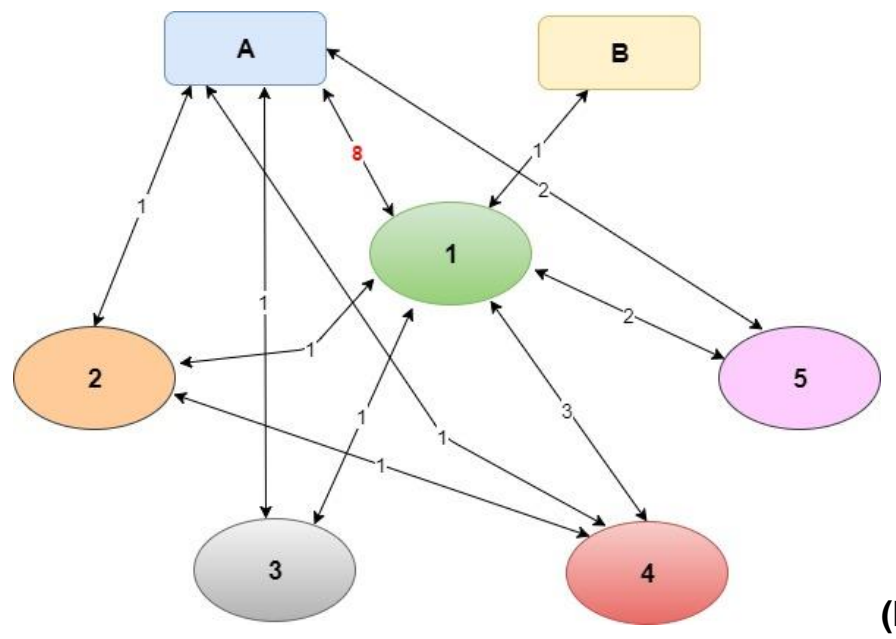

(b)

Figura 40. Mapa de integração entre os componentes do Conhecimento Docente de Mateus na aula gota salina e deposição de cobre a. (arquivo 10) e b. (arquivo 10.1)

A última regência ministrada por Mateus envolveu um jogo sobre 0 funcionamento das lâmpadas fluorescentes. Essa atividade resultou em um quadro constituído pelas relações construídas coletivamente pelo grupo de alunos. A aula foi estruturada e fundamentada no ensino desenvolvido por meio de projetos, e a sua condução foi influenciada pelo Conhecimento Pedagógico geral do pibidiano. Observase que no mapa da aula b há uma maior integração entre o Conhecimento Pedagógico Geral (B) e as orientações para o ensino de ciências (1) do que no mapa da aula a. 
(a)
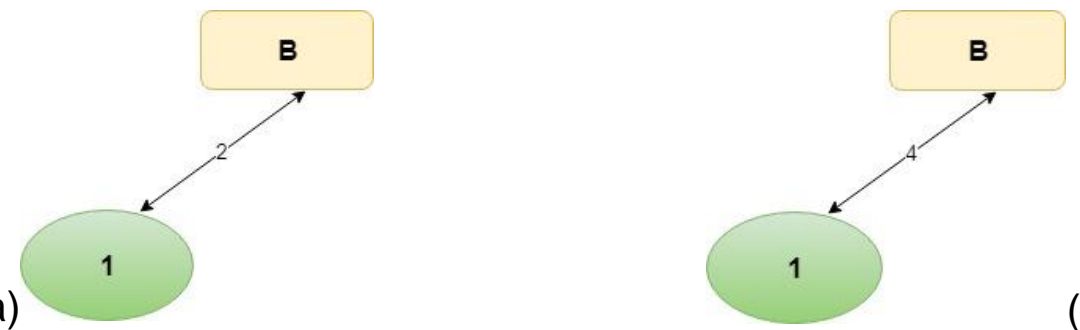

(b)

Figura 41. Mapa de integração entre os componentes do Conhecimento Docentede Mateus na aula lúdica a. (arquivo 11) e b. (arquivo 11.1)

Em síntese, o conhecimento docente de Mateus começou a manifestar-se timidamente ao longo de sua trajetória no Pibid, reflexo de suas limitações conceituais com redox e por não conduzir as aulas como havia planejado, por conta de Elder e Luiza assumirem a condução das aulas. A vivência no programa de iniciação à docência permitiu que Mateus começasse a vislumbrar as dificuldades do discentes com oxirredução, a conectar os conteúdos químicos - currículo horizontal e vertical, a buscar formas de conduzir as aulas considerando o conteúdo específico, entre outros. O acesso de Mateus a esses conhecimentos foi possível pela orientação das tutoras, pela prática em sala de aula e pela análise dos resultados obtidos na implementação de cada regência.

Nas aulas ministradas por Mateus a coocorrência mais expressiva ocorreu entre o Conhecimento do Tema (A), o Conhecimento Pedagógico Geral (B), Orientações para o Ensino de Ciências (1) e Conhecimento pedagógico geral (B). De modo semelhante a Melissa, no mapa de integração de Mateus, não emergiu o Conhecimento do Contexto. $\mathrm{Na}$ figura 42 o mapa de integração do conhecimento para à docência emergido nas aulas ministradas por Mateus nas turmas de segundo ano.

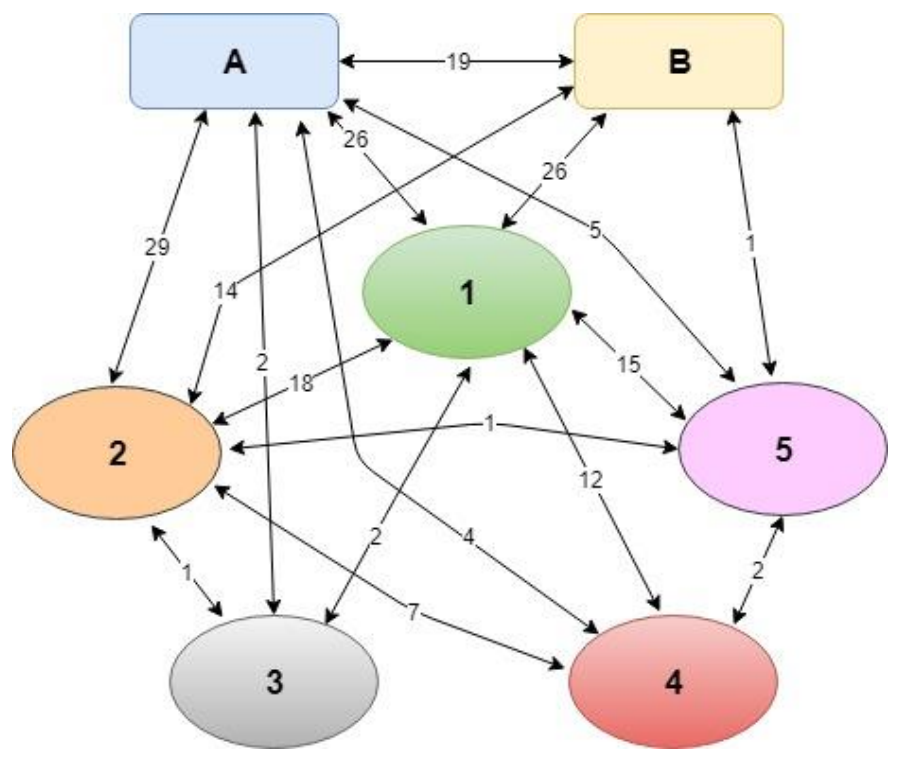

Figura 42. Mapa de integração entre os componentes do Conhecimento Docentede todas as aulas ministradas por Mateus nas turmas de segundo ano 
Os conhecimentos docentes mapeados nos documentos que estrutura 0 diagrama apresentado na figura 42 apresenta muita fragilidade, e infere-se que os conhecimentos emergidos nas narrativas de Mateus foram fortemente influenciados pela orientação das tutoras e pela implementação das aulas pelo pibidiano.

\subsubsection{Percepções dos alunos da escola conveniada sobre 0 conhecimento docente Mateus}

Mateus desenvolveu suas atividades em duas turmas do $2^{\circ}$ ano do Ensino Médio regular. As classes unidas tinham em média 15 alunos frequentes, denotando-se que essa foi a população que respondeu ao instrumento.

Agrupou-se na tabela 25 os dados segundo o percentual de participantes que assinalaram as subcategorias que constituíam o instrumento, além de os valores mínimos e máximos.

Tabela 25. Porcentagem de respondentes que assinalaram as subcategorias, que compunha cada categoria, e seus respectivos valores mínimos e máximos

\begin{tabular}{|c|c|c|c|c|c|c|c|c|}
\hline \multirow{2}{*}{ Categoria } & \multicolumn{6}{|c|}{ Resposta assinaladas (\%) } & \multicolumn{2}{|c|}{ Valores } \\
\hline & 0 & 1 & 2 & 3 & 4 & 5 & Mínimo & Máximo \\
\hline CT1 & 0 & 0 & 0 & 20 & 0 & 80 & 3 & 5 \\
\hline CT 2 & 0 & 6,66 & 0 & 20 & 60 & 13,33 & 1 & 5 \\
\hline CT 3 & 0 & 0 & 0 & 13,33 & 66,66 & 20 & 3 & 5 \\
\hline CT 4 & 0 & 0 & 6,66 & 13,33 & 6,66 & 73,33 & 2 & 5 \\
\hline CT 5 & 0 & 0 & 6,66 & 6,66 & 40 & 46,66 & 2 & 5 \\
\hline CT 6 & 6,66 & 0 & 6,66 & 33,33 & 20 & 33,33 & 0 & 5 \\
\hline CT 7 & 0 & 0 & 6,66 & 6,66 & 53,33 & 33,33 & 2 & 5 \\
\hline RCE 1 & 0 & 0 & 0 & 20 & 13,33 & 66,66 & 3 & 5 \\
\hline RCE 2 & 0 & 40 & 0 & 33,33 & 6,66 & 20 & 1 & 5 \\
\hline RCE 3 & 0 & 13,33 & 0 & 13,33 & 0 & 73,33 & 1 & 5 \\
\hline RCE 4 & 0 & 6,66 & 0 & 6,66 & 6,66 & 80 & 1 & 5 \\
\hline RCE 5 & 0 & 6,66 & 6,66 & 26,66 & 26,66 & 33,33 & 1 & 5 \\
\hline RCE 6 & 0 & 6,66 & 6,66 & 33,33 & 13,33 & 40 & 1 & 5 \\
\hline RCE 7 & 0 & 13,33 & 66,66 & 6,66 & 6,66 & 6,66 & 1 & 5 \\
\hline OEC 1 & 0 & 0 & 6,66 & 6,66 & 26,66 & 60 & 2 & 5 \\
\hline OEC 2 & 0 & 0 & 6,66 & 33,33 & 33,33 & 26,66 & 2 & 5 \\
\hline OEC 3 & 0 & 0 & 0 & 13,33 & 33,33 & 53,33 & 3 & 5 \\
\hline OEC 4 & 0 & 0 & 6,66 & 26,66 & 33,33 & 33,33 & 2 & 5 \\
\hline OEC 5 & 0 & 0 & 6,66 & 26,66 & 26,66 & 40 & 2 & 5 \\
\hline OEC 6 & 0 & 0 & 13,33 & 6,66 & 26,66 & 53,33 & 2 & 5 \\
\hline OEC 7 & 0 & 0 & 6,66 & 6,66 & 13,33 & 73,33 & 2 & 5 \\
\hline CCE 1 & 20 & 6,66 & 13,33 & 26,66 & 20 & 13,33 & 0 & 5 \\
\hline CCE 2 & 6,66 & 0 & 6,66 & 53,33 & 13,33 & 20 & 0 & 5 \\
\hline CCE 3 & 0 & 0 & 20 & 26,66 & 26,66 & 26,66 & 2 & 5 \\
\hline CCE 4 & 6,66 & 0 & 13,33 & 33,33 & 20 & 26,66 & 0 & 5 \\
\hline CCE 5 & 0 & 0 & 6,66 & 20 & 6,66 & 66,66 & 2 & 5 \\
\hline CCE 6 & 0 & 0 & 0 & 13,33 & 40 & 46,66 & 3 & 5 \\
\hline CCE 7 & 0 & 0 & 6,66 & 13,33 & 6,66 & 73,33 & 2 & 5 \\
\hline
\end{tabular}

Em consonância com os dados da tabela 25 , quando os discentes foram questionados CT 1 Meu professor sabe o conteúdo que ele está ensinando, para $80 \%$ da classe Mateus sempre exprimiu dominar o conteúdo que ensinava. Talvez por 
entenderem que o pibidiano dominava o conteúdo. Quando questionados CT $3 \mathrm{Meu}$ professor sabe como as teorias ou princípios do conteúdo específico foram desenvolvidos, para $66,66 \%$ frequentemente o pibidiano sinalizava os conhecer. Com relação ao uso de analogias (RCE 2), 40\% dos discentes assinalaram a escala 1 (Se nunca ocorreu na prática de ensino), o que significa que não reconheciam a adoção dessa estratégia, por outro lado, para $66,66 \%$ dos respondentes, o pibidiano trazia exemplos (RCE 1) que facilitavam a sua aprendizagem.

$\mathrm{Na}$ OEC 2 Meu professor interage adequadamente com os alunos e proporciona um bom ambiente de convívio, a classe não teve uma percepção hegemônica, pois, 6,66 (raramente ocorreu), 33,33\% (às vezes), 33,33\% (frequentemente) e para apenas $26,66 \%$ (sempre) Mateus conseguia implementar um bom ambiente para 0 desenvolvimento interpessoal. No entanto, para $70 \%$ dos alunos sempre o pibidiano promovia um ensino dinâmico e ativo (OEC 7).

$\mathrm{Na}$ percepção dos discentes sobre o conhecimento da compreensão dos estudantes para $13,33 \%$ sempre Mateus verificava os seus conhecimentos prévios (CT 1). Com relação a avaliação, para $73,33 \%$ sempre Os testes do meu professor me ajudam a compreender a situação do aprendizado (CCE 7), enquanto para os demais $6,66 \%$ (raramente), 13,33\% (às vezes) e 6,66\% (frequentemente). Para 66,66\% dos discentes o pibidiano adotava diferentes abordagens de ensino para verificar a sua aprendizagem (CCE 5).

Apresenta-se na tabela 26 os resultados da análise exploratória.

Tabela 26. Valores da média, mediana e desvio padrão para cada subcategoria

\begin{tabular}{cccc}
\hline Questões & Média & Mediana & Desvio Padrão \\
\hline CT1 & 4,6 & 5 & 0,83 \\
\hline CT 2 & 3,73 & 4 & 0,96 \\
CT 3 & 4,06 & 4 & 0,59 \\
\hline CT 4 & 4,46 & 5 & 0,99 \\
\hline CT 5 & 4,26 & 4 & 0,88 \\
\hline CT 6 & 3,6 & 4 & 1,40 \\
\hline CT 7 & 4,13 & 4 & 0,83 \\
\hline RCE 1 & 4,46 & 5 & 0,83 \\
\hline RCE 2 & 2,66 & 3 & 1,59 \\
\hline RCE 3 & 4,2 & 5 & 1,47 \\
\hline RCE 4 & 4,53 & 5 & 1,12 \\
\hline RCE 5 & 3,73 & 4 & 1,32 \\
\hline RCE 6 & 3,73 & 4 & 1,46 \\
\hline RCE 7 & 3,65 & 2 & 0,91 \\
\hline OEC 1 & 4,4 & 5 & 0,94 \\
\hline OEC 2 & 3,8 & 4 & 0,73 \\
\hline OEC 3 & 4,4 & 5 & 0,96 \\
\hline OEC 4 & 3,93 & 4 & 1 \\
\hline OEC 5 & 4 & 4 & 1,08 \\
\hline OEC 6 & 4,2 & 5 & 1,72 \\
\hline OEC 7 & 4,53 & 5 & \\
\hline CCE 1 & 2,6 & 3 & \\
\hline
\end{tabular}

Capítulo 4. Resultados e Discussões 


\begin{tabular}{lccc}
\hline CCE 2 & 3,26 & 3 & 1,28 \\
\hline CCE 3 & 3,6 & 4 & 1,12 \\
\hline CCE 4 & 3,4 & 3 & 1,40 \\
\hline CCE 5 & 4,33 & 5 & 1,04 \\
\hline CCE 6 & 4,33 & 4 & 0,72 \\
\hline CCE 7 & 4,46 & 5 & 0,99 \\
\hline
\end{tabular}

As questões com maior média $(4,53)$ foram a RCE 4 Meu professor oferece oportunidade para eu expressar meus pontos de vista durante a aula e OEC 7 Meurofessor acredita ou valoriza um ensino que seja ativo e dinâmico.

Ao examinar-se os valores da mediana, a categoria com menor valor foi a $\mathrm{RCE}$ $7 \mathrm{Meu}$ professor usa mídias ou tecnologias para expressar os conceitos. Para essa mesma questão tem-se o desvio padrão de 1,46 denotando que os discentes assinalaram diferentes escalas, denotando que tinham uma percepção heterogênea sobre os aspectos que permeavam o uso de mídia e novas tecnologias pela pibidiano.

A CT 3 Meu professor sabe como as teorias ou princípios do conteúdo específico foram desenvolvidos foi a subcategoria com menor desvio padrão suscitando que os discentes do ensino médio tinham uma percepção homogênea sobre esse conhecimento docente de Mateus. Por outro lado, na CCE 1 Meu professor averigua o conhecimento prévio dos estudantes antes de começar a ensinar um novo assunto temse o maior desvio padrão 1,72, o que refletiu nos discentes assinalarem todas as seis escalas. Salienta-se que essa foi a única questão em os estudantes marcaram todas as escalas. Na sequência, dispõe-se as percepções dos discentes sobre as regências de Mateus:

\footnotetext{
Mateus é um ótimo professor (Q3).

Aprendi sim foi legal (Q5).

Sim, pois acho que ele as vezes não compreende o aluno (Q6).

$O$ prof. Mateus, sabe lidar com os alunos para que eles prestem atenção na explicação (Q9).

Sim, pelo jeito dele (Mateus) se comunicar com os alunos parece ser um pouco ignorante (Q12).

Para mim as aulas dele são muito compreensíveis, mas infelizmente houve algumas dificuldades por falta de respeito vindo de alguns alunos, mas me agrada seu modo de dar aulas (Q13).
}

Organizou-se na tabela 27 os valores relacionados a Alfa de Cronbach calculados para todo o instrumento por dimensão e na ausência de cada subcategoria. 
Tabela 27. Alfa de Cronbach para todo o instrumento e separado por dimensão, além do alfa na ausência de cada categoria

\begin{tabular}{|c|c|c|c|c|c|}
\hline \multirow[t]{3}{*}{ Questão } & \multicolumn{5}{|c|}{ Alfa de Cronbach na ausência da variável } \\
\hline & \multirow[t]{2}{*}{ Geral } & \multicolumn{4}{|c|}{ Dimensão } \\
\hline & & CT & RCE & OEC & CCE \\
\hline CT1 & 0,95 & 0,82 & & & \\
\hline CT 2 & 0,95 & 0,79 & & & \\
\hline CT 3 & 0,95 & 0,82 & & & \\
\hline CT 4 & 0,95 & 0,83 & & & \\
\hline CT 5 & 0,95 & 0,81 & & & \\
\hline CT 6 & 0,95 & 0,88 & & & \\
\hline CT 7 & 0,95 & 0,82 & & & \\
\hline RCE 1 & 0,95 & & 0,83 & & \\
\hline RCE 2 & 0,95 & & 0,84 & & \\
\hline RCE 3 & 0,95 & & 0,82 & & \\
\hline RCE 4 & 0,95 & & 0,81 & & \\
\hline RCE 5 & 0.94 & & 0,78 & & \\
\hline RCE 6 & 0,95 & & 0,77 & & \\
\hline RCE 7 & 0,95 & & 0,85 & & \\
\hline OEC 1 & 0,95 & & & 0,88 & \\
\hline OEC 2 & 0,95 & & & 0,87 & \\
\hline OEC 3 & 0,95 & & & 0,88 & \\
\hline OEC 4 & 0,95 & & & 0,89 & \\
\hline OEC 5 & 0,95 & & & 0,87 & \\
\hline OEC 6 & 0,95 & & & 0,90 & \\
\hline OEC 7 & 0,95 & & & 0,86 & \\
\hline CCE 1 & 0,95 & & & & 0,77 \\
\hline CCE 2 & 0,95 & & & & 0,77 \\
\hline CCE 3 & 0,95 & & & & 0,72 \\
\hline CCE 4 & 0,95 & & & & 0,70 \\
\hline CCE 5 & 0,95 & & & & 0,76 \\
\hline CCE 6 & 0,95 & & & & 0,72 \\
\hline CCE 7 & 0,95 & & & & 0,78 \\
\hline Cronbach Geral & 0,95 & 0,85 & 0,84 & 0,90 & 0,77 \\
\hline
\end{tabular}

O alfa para todo instrumento foi 0,95 , incutindo que as respostas concedidas pelos discentes do $2^{\circ}$ ano do ensino médio resultaram em uma boa consistência para o instrumento, denotando-se que o instrumento também apresentou valores confiáveis no contexto no qual Mateus ministrou suas regências.

As dimensões Conhecimento do tema (CT), Representação do conteúdo e estratégias para seu ensino (RCE), Objetivo educacional e do contexto (OEC) e Conhecimento das compreensões dos estudantes (CCE) apresentaram os respectivos valores de alfa 0,85, 0,84, 0,90 e 0,77. Como se pode observar, todas as categorias apresentaram uma diminuição no valor do alfa em relação ao valor encontrado para todo o instrumento, mas ainda acima do 0,6 e abaixo de 1. A categoria CCE apresentou o menor valor em comparação as demais dimensões. Ao excluir-se subcategoria a subcategoria, considerando-se as 28 questões não se observou uma priora no instrumento, ou seja, uma diminuição ou aumento significativo nos valores de alfa, ficando esses próximos ao alfa geral $(0,95)$. 
Conclui-se que o instrumento aplicável produziu mensurações consistentes acerca da percepção do aluno da escola sede sobre o conhecimento docente de Mateus.

\section{4. As tutoras - Maria e Luiza}

Nesse item desvelara-se os possíveis impactos do Pibid na formação das tutoras Maria e Luiza e a imersão dos componentes do Conhecimento Docente em suas narrativas. Nesse sentido, na apreciação dos documentos inventariados mapeou-se no Atlas.ti os episódios que evidenciassem as orientações relacionadas as categorias do conhecimento docente e outras categorias emergentes associadas a importância do Pibid para a formação da coordenadora e supervisora. Inicialmente, dispõe-se os conhecimentos docentes das tutoras emergidos nas orientações no contexto de sala de aula e na entrevista semiestrutura. Na sequência, apresenta-se os impactos do Pibid para as suas formações, de modo a envolver suas percepções sobre a importância desse programa para a formação de futuros professores.

O mapeamento dos componentes do conhecimento docente se justifica para compreender-se os direcionamentos nas orientações dos pibidianos priorizados pela coordenadora e supervisora, e que refletiram na construção do conhecimento docente dos pibidianos.

\subsubsection{Componentes do conhecimento docente}

Para análise dos indícios do conhecimento docente de Maria analisou-se 20 documentos, enquanto na análise realizada para Luiza mapeou-se 24 documentos. Valde destacar, que analisou-se os indícios do conhecimento docente, pois não foi realizado a coleta de dados, com as tutoras ministrando aulas envolvendo o conteúdo de reações redox, mas em reuniões em que ocorriam as orientações aos pibidiano.Os documentos analisados serão apresentados no item em que discute-se o impacto do Pibid na formação das tutoras. Na tabela 28 apresenta-se o mapeamento dos documentos no Atlas.ti.

Tabela 28. Relatório gerado no Atlas.ti - Categorias do Conhecimento Docentedas tutoras

\begin{tabular}{cccccccccc}
\hline & \multicolumn{8}{c}{ Categorias do Conhecimento Docente } & Total \\
\cline { 2 - 11 } Tutora & A & B & $\mathbf{C}$ & $\mathbf{1}$ & $\mathbf{2}$ & $\mathbf{3}$ & $\mathbf{4}$ & $\mathbf{5}$ & T \\
\hline Maria & 15 & 285 & 35 & 159 & 32 & 19 & 29 & 28 & 602 \\
\hline Luiza & 69 & 249 & 39 & 62 & 66 & 12 & 35 & 0 & 532 \\
\hline
\end{tabular}

Não esmiuçou-se o conhecimento docente das tutoras como procedeu-se na análise realizada para os pibidiano.

\section{Coordenadora Maria}


Os indícios das categorias do Conhecimento Docente emergiram timidamente nas narrativas de Maria, o que não significa que não tenham influenciado no conhecimento para a docência dos licenciandos.

$\mathrm{Na}$ entrevista semiestruturada, Maria discorre que no final do colegial, antigo ensino médio, prestou vestibular para química e história, mas optou por cursar o bacharelado em química, sob influência de sua professora Verônica:

E me decidi pela química, aí fui fazer em Ribeirão Preto, na USP. Terminei a graduação, fui convidada por essa mesma professora para substituí-la, porque ela foi candidata a vereadora na cidade e era funcionária pública, e você não pode ser candidata assumindo a função pública, tem que se afastar. E aí eu fui dar aula na escola em que eu estudei, no lugar da professora que me inspirou. E eu acho que me inspirou mais ainda. Antes disso, antes, não, eu acho que depois disso eu fui convidada para trabalhar numa empresa, na verdade, eu mandei o currículo, fui selecionada e comecei a trabalhar na empresa, no laboratório que fazia rotina de verificação dos reagentes que chegavam, do produto. Era um laboratório que controlava a rotina da empresa. Trabalhei 3 meses e quando foi para fazer a minha efetivação, eu pedi demissão, porque eu vi que não era aquilo, aquela rotina não combinava comigo, eu não gostava. Aí eu dei aula então por 3 meses, trabalhei por 3 meses e resolvi voltar para fazer o mestrado. Eu fiz o mestrado na área da eletroquímica, na química inorgânica, especificamente eletroquímica, eletrocatálise. Depois fiz o doutorado na área da físico-química, mas aí eu já sabia que eu queria me formar para assumir a atividade docente, tinha interesse de ir para a sala de aula (Entrevista semiestruturada - Maria, turno 4).

Maria retornou para a escola onde havia concluído o colegial ao finalizar a graduação. A coordenadora atuou ainda um período na indústria, mas percebeu que não desejava seguir carreira nesse setor. Então, voltou a estudar, cursando o mestrado e depois o doutorado. Mas, o seu desejo era retornar para a sala de aula. E assim o fez, depois de um período volta para docência, atuando na educação básica e no ensino superior.

Os passos iniciais de Maria no Pibid foram iniciados ao auxiliar outro docente na função de coordenador de subprojeto, na sequência, com a abertura de um novo edital pela Capes "[...] submeti um projeto. É um projeto com dois coordenadores, eu e o professor João. O meu projeto, a parte que cabe a mim está muito associado à Política Nacional de Resíduos Sólidos e à Educação CTS" (Entrevista semiestruturada - Maria, turno 12).

No processo de orientação dos pibidianos e na estrutura do subprojeto evidencia -se que Maria segue as Orientações para o Ensino de Ciências baseada em projetos. Ancorando as aulas na CTS, a coordenadora acreditava que essa abordagem sustentaria o desenvolvimento das regências por temáticas. Não se identificou nas narrativas de Maria as Crenças sobre a natureza da ciência. 
Ao relembrar o processo de organização das aulas e das orientações, argumenta:

[...] Inicialmente, no começo do ano, as reuniões normalmente são com o grupo todo, inclusive com os supervisores e com os (00:09:32 ininteligível) pibidianos, para definir qual seria o resíduo que cada grupo iria trabalhar. A partir dali, sabendo qual é o resíduo, e esse resíduo tem que ser pensado também em função dos alunos que irão desenvolver o projeto, alunos das escolas, e da escola. Porque, atendendo os pressupostos da Educação CTS, aquela problemática tem que ser vivenciada pelo aluno, tem que fazer parte do meio dele. Então pensar no resíduo significa pensar em qual escola a gente vai estar trabalhando, em qual público, se é público (00:10:09 ininteligível) ou público regular, por exemplo. Então as reuniões iniciais, no começo do ano têm esse perfil. Posteriormente a isso, nós sempre temos algumas reuniões no começo, para trabalhar referenciais: para ler artigos, para a discussão de artigos. E esses referenciais, normalmente, dão subsídios para as ações que serão implementadas no decorrer do ano. Então reuniões mais amplas, a gente tem como objetivo discutir coisas que são de interesse de todos os grupos. A partir do momento que já está definido o resíduo que vai ser trabalhado, as estratégias em si: sensibilização, qual o conceito de química que vai ser desenvolvido, qual a atividade laboratorial que vai ser montada, conceitos teóricos, esta parte já fica com reuniões individuais (...) Então aí a gente passa para as reuniões individuais. Essas reuniões individuais, às vezes acontecem entre a maioria das vezes, coordenadores pibidianos, em alguns momentos acontecem entre coordenador e supervisor pibidianos [...] (Entrevista semiestruturadaMaria, turno 16).

Na percepção da coordenadora, para o desenvolvimento do planejamento era essencial que os pibidianos conhecessem os alunos antes de iniciarem a estruturação das aulas. Outra influência eram os referenciais teóricos e o próprio conhecimento dos bolsistas de iniciação à docência (Entrevista semiestruturada - Maria). Nessas reuniões emergem os conhecimentos relacionados ao currículo, a avaliação e conhecimento pedagógico geral.

O conhecimento do contexto de Maria se associava principalmente a uma possível contaminação de chumbo que envolvia o bairro onde a escola conveniada estava sediada. Em um dos encontros Maria solicitou que os pibidianos aplicassem um questionário socioeconômico e cultural para conhecerem a origem dos discentes da escola sede.

Nas reuniões finais mapeou-se direcionamentos de Maria aos pibidianos acerca do conhecimento sobre compreensão dos alunos em ciências com o conteúdo redox, como exemplo, em uma reunião com Melissa e Antônio. Maria os questiona se em algum momento a dupla leu materiais sobre as dificuldades dos discentes com a parte representacional da química:

Maria - E vocês chegaram a ler alguma coisa a respeito disso, por que o aluno tem tanta dificuldade de fazer a parte simbólica? 
Melissa - Não.

Maria - Acho que pode ser uma pergunta que a gente pode procurar, né (Reunião com a dupla - Melissa e Antônio, arquivo 16, turno 51-53).

De modo semelhante orientou o grupo de Mateus a analisar as possíveis limitações conceituais dos discentes e, consequentemente, a "[...] gente vai discutir os resultados, que a gente vai fazer uma reflexão sobre a aprendizagem, sobre as dificuldades que os alunos apresentaram. É... aí a gente busca os nossos referenciais [...]" (Apresentação dos resultados e reflexão, arquivo 14, turno 21).

Com relação ao conhecimento do currículo - Currículo horizontal e vertical, Maria orientou os pibidianos a revisarem os conceitos de atomística, e o reflexo dessa orientação se manifesta na estrutura da aula de conceitos de atomística desenvolvidas pelos pibidianos (Mateus, Antônio e Melissa).

A coordenadora orientava os pibidianos a revisar os conceitos desenvolvidos em aulas anteriores e a realizar experimentos demonstrativos - Estratégias instrucionais para o ensino de Ciências. Ao orientar Antônio no desenvolvimento de uma das aulas sobre redox, Maria direciona o pibidiano em como poderia proceder na implementação da aula - Decisões sobre o fazer no ensino:

[...] fala assim: "Olha, porque mudou de cor" toda aquela investigação né "Ah professor, é porque o cobre que era zero perdeu elétron e foi pra cobre 2+ mudou de cor, e aqui o zinco, aí tem uma parte da história que a gente não vai contar direito pra eles né, que é o potencial né, potenciais de redução, por que se não também não vai adiantar o negócio, então ele percebe que a reação acontece, só que o que ele não percebe aqui (...) A ideia de vocês era partir pra um experimento, que iria causar muito incomodo aos alunos, porque eles não iam conseguir explicar um montão de coisa, e a partir daí ir desenvolvendo o conhecimento. Então vocês iam tirar eles da situação de conforto, de conhecer todo o sistema, e mostrar que eles não estavam sabendo por que aquela coisa funcionava, e ir construindo o conhecimento. Pelo que nós estamos alinhavando aqui, a gente tá indo agora no sentido da gente tá construindo esse conhecimento e cada aula a gente tá agregando coisinhas né, a esse conhecimento, porque antes a gente já tinha feito o contrário, a gente tinha partido pra uma situação de desconforto (Reunião para saber o andamento - Antônio e Melissa, arquivo 12, turno 399).

No trecho acima tem-se indícios que Maria entrelaça os componentes Orientações para o ensino de Ciências, do Tema e do Currículo.

A coordenadora orientava os pibidianos a organizarem os discentes para desenvolverem as atividades em conjunto, por inferir que estes tinham limitações relacionadas a escrita, a leitura e com os conceitos químicos.

Com relação aos conhecimentos docentes sobre avaliação do conteúdo químico, Maria tem uma percepção mais certificativa, por outro lado, nas atividades que envolviam a aprendizagem dos alunos associadas a PNRS vislumbrava mais o processo cognitivo de criação. 
Um dos aspectos importantes associados ao desenvolvimento dos componentes do PCK é a reflexão sobre a prática. Sobre esse aspecto Maria conduzia as suas tutorias de modo a levarem os pibidianos a refletirem sobre os resultados obtidos com o desenvolvimento das aulas. Nesse sentido, ao orientar os pibidianos na estrutura do relatório anual, emergem elementos associados ao Conhecimento Pedagógico Geral Alunos e aprendizagem, Orientações para o ensino de ciências e Conhecimento da Avaliação da aprendizagem em ciências, como sucinta o trecho:

[...] a gente vai pensar um pouquinho porque o nosso aluno errou, a gente vai fazer a reflexão de como nós atuamos, cada intervenção que nós fizemos, essas intervenções merecem ser repensadas, a gente vai discutir um pouco os resultados em função de referenciais teóricos, referenciais da política nacional, referenciais de CTS, de elaborações de questões, de eletroquímica. Então esse segundo questionário, esse segundo relatório, é um relatório de trabalho né, vai ser feito em dupla, e porque eu separei? Antigamente entregava todo mundo junto e cada um fazia o seu individual, eu acho que essa etapa aqui das discussões ela acaba sendo mais produtiva se a gente fizer na dupla e ir conversando, porque vão surgir dúvidas, a gente vai ter dificuldade de explicar, ou então de fazer considerações a respeito do que a gente tem, vai demorar mais pra gente pesquisar, apesar que vocês têm bastante referencial que vocês colocaram. Entendeu como vai ser? (Reunião com a dupla - Melissa e Antônio, arquivo 16, turno 1).

A coordenadora, ao recorrer às suas memórias quando aprendeu o conteúdo redox, argumenta que a sua aproximação com esse conceito ocorreu na graduação, mas a sua dedicação a essa área da química foi proporcionada pelo curso de mestrado e doutorado. Entretanto, considerou que

[...] o estudo ou o ensino da situação redox e das condições das reações redox, eu acho que só foi acontecer mesmo quando eu comecei a dar aula, tanto no ensino médio quanto para a universidade. Porque ali que você senta e pensa em estratégias. Porque uma coisa é você estudar para compreender o conceito e outra coisa é você estudar para você encontrar uma estratégia de ensinar aquele conceito. Então eu acho que foi quando eu me tornei professora é que eu comecei a pensar nas estratégias de ensino. O conteúdo mesmo eu tive contato na graduação, quiçá no ensino médio, mas eu não me lembro o que eu aprendi no ensino médio (Entrevista semiestruturada, arquivo 16, turno 10).

Pela narrativa de Maria, infere-se que nas disciplinas que ministra busca englobar diversas estratégias para ensinar oxirredução. Vislumbra-se que se tornou docente quando passou a refletir sobre como ensinar um conceito.

\section{A supervisora Luiza}

Luiza graduou-se em química na Universidade de São Paulo. A supervisora tem mestrado em ensino de ciências. Atuou na educação básica e no ensino superior. Seu ingresso no Pibid ocorreu por intermédio da coordenadora pedagógica da escola sede. 
Bom, na verdade a professora Maria entrou em contato com a coordenadora da escola ((nome da escola suprimido)) que na época era Zilda e que eles estavam precisando de uma escola pro projeto pois eles já tinham trabalhado com outra escola mas não sei o que tinha acontecido com a coordenadora ou a diretora lá, não queriam mais o projeto lá e aí a Zilda falou, ah não, nós temos professora que vai gostar e tudo (...) eu recebi os alunos do Pibid na escola, eu antes disso não conhecia o projeto, mas eu achei interessante, nós fizemos atividades diferenciadas, né, então, no meu entender o projeto foi muito bom para os alunos até porque nós como professores de química temos uma dificuldade adicional que é o uso do laboratório (Entrevista semiestrutura - Luiza, turno 2).

No início de sua participação no Pibid a supervisora demonstrou preocupação com o conteúdo químico que iria constituir as aulas, e quais eram os objetivos pensados pelos pibidianos para cada regência - Conhecimento do tema e Conhecimento Pedagógico Geral. Em outro processo de orientação da supervisora aos pibidianos emerge o Conhecimento Pedagógico Geral e do Contexto:

[...] quando eu conversei com eles, era que assim, eu acho que todo conteúdo de química e todo assunto desde que seja química ele é muito bem-vindo, certo, e como a gente não consegue, de maneira alguma com duas aulas por semana, isso eu falei pra eles desde 0 começo, cumprir todo conteúdo, tá, então, só que ele, todo conteúdo, o conteúdo que eu falo é, o conteúdo ele é um conteúdo atitudinal, procedimental e curricular, tá certo, tem conceito, tem habilidades, competências, acho que a gente pode até discutir sobre isso, mas ele tem que ter começo, meio e fim, e a gente precisa que isso sirva também pra gente avaliar a aprendizagem dos alunos, porque se eles estão se formando como professores, uma das premissas que a gente espera que um bom professor tenha, é saber se aquilo que ele trabalhou com os alunos, aquilo que ele ensinou foi aprendido [...] (Reunião para saber o andamento -Grupo do Mateus, arquivo 6, turno 12).

A realidade da escola conveniada sempre esteve presente nas falas de Luiza nas reuniões com os pibidianos, o que os possibilitava compreender esse Contexto que envolvia a instituição de ensino, a origem de seus alunos, bem como em conhecer o bairro onde estava sediada a escola. Em conformidade, a supervisora discorre aos pibidianos que componentes do corpo docente da escola sede eram "[...] resistentes, e os professores daqui a grande maioria dos professores dessa escola são efetivos [...]" (Reunião para saber o andamento -Grupo do Mateus, arquivo 6, turno 10), além de as dificuldades conceituais. Para a supervisora a questão relacionada a organização dos horários na escola, apesar de ser uma dificuldade, era uma realidade que os pibidianos teriam que vivenciar (Reunião para saber o andamento -Grupo do Mateus, arquivo 6).

Os pibidianos, ao apresentarem as propostas das aulas experimentais nas reuniões do subprojeto a supervisora, foram orientados a reestruturarem os roteiros para que desenvolvessem os experimentos por meio da investigação. Nesse sentido, apresenta-se o trecho: 
[...] então não fazer uma experiência pela experiência, mas que aquilo tem que sair alguma coisa, e aí assim, até depois eu conversei com o Antônio, só deixando vocês a par, de um experimento lá, como que ele poderia transformar aquele experimento em investigativo. Então eu falei assim: olha, por exemplo, se você coloca aqui em vez de dar a montagem já pronta pros alunos, que vai acender a lâmpada que é uma pilha, o que você não faz? Bota pra eles montaram com o papelzinho seco, não vai acontecer nada, tá, observe o que aconteceu, faz uma pergunta, aí molha o papelzinho na água, o que aconteceu? Aconteceu alguma coisa? Mudou alguma coisa? Molha o papelzinho na água com sal, mudou alguma coisa? O que você consegue concluir disso? Então você vai levando o aluno a pensar, e a refletir no caminho daquilo que você quer, que é que ele compreenda que pra haver corrente elétrica é necessário a presença de íons [...] (Reunião para saber o andamento -Grupo do Mateus, arquivo 6, turno 14).

Em outro momento da reunião Luiza chama a atenção de Mateus, dizendo que para desenvolver os conceitos de oxirredução deveria revisar os conceitos de atomística - Currículo horizontal e vertical (Reunião para saber o andamento -Grupo do Mateus, arquivo 6).

A supervisora sempre direcionava os pibidianos a vislumbrarem a organizar da classe em grupo e a pensar no tempo necessário ao desenvolvimento das aulas Conhecimento Pedagógico Geral. Para Luiza a organização dos discentes em grupo era importante para que os grupos que tivessem afinidade fossem separados, assim evitaria o “[...] desgaste também, tá, porque sempre tem aquele que ninguém quer ficar com ele, porque é burro ou chato ou não sei o que, tá, e tem aquelas panelas que a gente sabe que se a gente não desmanchar, no fim a gente tem uma discussão inócua [...]" (Reunião para saber o andamento - Antônio e Melissa, arquivo 9, turno 38).

Outro aspecto associado aos indícios desse conhecimento base estava no direcionamento que seria eleito pelos pibidianos na implementação de suas aulas, pois para Luiza a sua "[...] preocupação aqui é em relação a essa discussão porque a tendência do aluno é ter muita opinião, ele tem muitas opiniões, mas sem embasamento, então, eu acho que tem que ficar claro que eles tem que ler, e eu acho que a pergunta deveria ser outra [...]" (Reunião para saber o andamento -Grupo do Mateus, arquivo 6, turno 93). Sugeri, então, que os pibidianos desenvolvessem questões mais direcionadas, e que para serem respondidas necessitassem de embasamento teórico proporcionado na aula do pibidiano Mateus por enquetes.

Nos diálogos das reuniões com os pibidianos, Luiza buscou descrever a importância das aulas desenvolvidas englobarem os três níveis representacionais da química, pois considerada que o nível macro, micro e simbólico faziam a química ser a disciplina mais difícil. Além disto, a tutora questionava os bolsistas de iniciação à docência sobre os propósitos de cada aula - Orientações para o ensino de ciências. 
Nas orientações para o ensino de ciências, mais especificamente - Decisões sobre o fazer no ensino, Luiza orienta Mateus:

[...] você pode voltar nessa mesma folhinha aí, aí você faz sei lá, por exemplo, você pode fazer dois desses quadrinhos com eles, remanejar aí e fazer, entendeu dois quadrinhos, outros eles fazem pra entregar depois, e você também faz esses exercícinhos (sic) alguns pra ele entender, aí assim, no fundo você já chegou na oxidação, na redução, vocês só dá nominho pros bois depois, entendeu? Tá, e aí no fundo você já chega na questão de semi-reação, que é um conceito complicado, mas você chega nele pelo uso (Reunião para saber o andamento -Grupo do Mateus, arquivo 6, turno 219).

A proposta de trabalhar com a contaminação pelo descarte inadequado de bateria automotiva pelo grupo de Antônio e Melissa, por possivelmente impactar a região da escola conveniada seria "[...] achismo né, precisaria fazer uma investigação certa a respeito disso, mas pode ter uma relação pode, porque não?" (Reunião para saber o andamento - Antônio e Melissa, arquivo 9, turno 94). Apesar dos direcionamentos de Luiza, os pibidianos não pesquisaram em fontes oficiais dados que corroborassem com a percepção do grupo que a região da escola sede era impactada pela contaminação por chumbo.

A supervisora, em suas orientações, demonstrou inquietações relacionadas à aprendizagem dos discentes da escola conveniada, pois o seu objetivo era que "[...] o aluno do médio aprende alguma coisa, pra ele não tem aquele discurso vazio de ter uma opinião sem conhecimento, opinião todo mundo tem, tem que ter opinião com conhecimento" (Reunião para saber o andamento - Antônio e Melissa, arquivo 9, turno 48).

Em estudos dedicados a compreender as dificuldades e limitações associadas ao ensino e aprendizagem da oxirredução se discute que a maioria dos docentes não desenvolve esse conceito durante o ano letivo, por considerarem difícil. De modo semelhante, Luiza compartilha que nunca trabalhou com reações redox no ensino médio (Reunião para saber o andamento - Antônio e Melissa, arquivo 9). Por outro lado, a tutora apresenta uma das dificuldades associadas ao ensino de redox em decorrência de uma "[...] convenção dos físicos, em 1900 e nada, tá, a corrente ela está no sentido inverso do caminho do elétron, certo, isso aí dá nó na cabecinha de químico, quem dirá na de ((alunos)) [...]" (Reunião para saber o andamento - Antônio e Melissa, arquivo 9, turno 419).

Antônio tinha crenças sobre a natureza da ciência que a partir do experimento poderia comprovar os conceitos químicos que ensinava. Como consequência, Luiza inicia um diálogo com o pibidiano:

Antônio - Saber assim, a química existe pra isso ((pra explicar o que tá sendo observado)). 
Luiza - Então, mas se a gente ficar nessa de pra que, esse utilitarismo da química, você matou a nossa ciência. Então assim, porque, porque, faz te dá à ciência, então a ciência tem essa forma de encontrar, essa linguagem, faz parte da ciência entendeu?

Maria - Então Antônio, é a mesma coisa, porque você vive?

Antônio - Porque eu vivo?

Luiza - Faz parte, faz parte, entendeu. Então assim, não dá pra gente ficar nesse utilitarismo, tudo tem que ter utilidade, pra quê? Não entra nessa pilha, não entra, entendeu? Porque isso faz parte dessa ciência química (Reunião para saber o andamento - Antônio e Melissa, arquivo 9, turno 328-332).

Sobre esse aspecto, Chassot (2014) no livro Para Que(m) é útil o ensino? argumenta

[...] que não cabe um conhecimento químico desencarnado, como se a Química fosse pura (acepção boa e maravilhosa, como costuma, às vezes ser pintada) e neutra. A transmissão desses conhecimentos dever ser encharcada na realidade, e isso não significa o reducionismo que virou o modismo Química do cotidiano (às vezes, apenas de utilitarismo) [...] (CHASSOT, 2014, p. 146).

Os indícos do conhecimentos docentes de Luiza manifestam-se, principalmente, nas aulas implementadas pelos pibidianos, e estes estavam relacionados ao Conhecimento do Tema, do Currículo e Conhecimento Pedagógico Geral, bem como com as Orientações para o Ensino de Ciências - Decisões sobre o fazer no ensino. Nesse contexto de sala de aula, Luiza, por vezes, queria direcionar os encaminhamentos práticos das regências dos pibidianos. Em outros, auxiliou os bolsistas em momentos que tinham limitações conceituais e com a gestão de classe. $\mathrm{Na}$ implementação das aulas, a supervisora entrelaçava o conteúdo redox com outros conceitos - Currículo horizontal e vertical (Conhecimento do currículo).

Nas aulas, Luiza, observa as dificuldades dos discentes e orienta os pibidianos a realizarem certas Decisões sobre o fazer no ensino. Nesse sentido, tem-se os diálogos:

Luiza - Eu acho que ele precisar ver a reação antes de representar, ele não sabe o que vai acontecer.

Mateus - Vocês prestem atenção, porque o visual, e depois eu quero que vocês representem também...

Luiza - Tá, mas tira um pouquinho da solução só para eles verem como que era a solução antes e depois. Ah, tá, tá, tem então, tá bom, pega um outro béquer e bota um pouquinho só para eles compararem depois, isso, isso, beleza. Não, eu entendi, perfeito, está ótimo, está ótimo (Aula de conceitos gerais de eletroquímica - grupo do Mateus, arquivo 9, turno 169, 170 e 228).

Com relação aos indícios do conhecimento pedagógico geral e ao modo como percebia o desenvolvimento da docência, Luiza constrói a narrativa: 
É aquilo que ele quer que o aluno saiba, o que ele passa é diferente, o professor não devia passar nada, tá, porque se a gente passa é assim, dou um passe nele meu filho dou um passe, né, volta naquele conceito de que eu grudo a minha cabeça aqui passando conhecimento para ele, não passa, ele constrói o conhecimento dele a partir do arcabouçou que ele tem dentro do cérebro dele e ai gente tem também vários pesquisadores, desde Piaget que vai falar de como esse processe se dá no cérebro, e aí tem outra coisa que, por exemplo, que se fala em pedagogia é isso, usar uma linguagem de pedagogia é isso, que é chamado de cognição que é o aprendizado. Então assim, quando o aluno pensa sobre aquilo que ele aprendeu que ele realmente aprende... (Aula de conceitos gerais de eletroquímica - grupo do Mateus, arquivo 330).

Uma das problemáticas vivenciadas pelos licenciandos e compartilhada pela vivência de Luiza sobre o contexto escolar, envolvia a frequência reduzida de alunos regularmente matriculados, o que levava a supervisora a orientar os pibidianos a revisarem os conceitos desenvolvidos em aulas anteriores, pois havia aluno "[...] que não estava na aula passada, então essas pessoas que não estavam aula passada, não sabem o que é oxidação, não sabem o que é redução, você falou em potencial de redução, vocês entenderam esse potencial de redução? Porque eu olhei pra cara de vocês e vi um monte de cara de 'ué'?" (Aula experimental pilha de moedas - Antônio e Melissa, arquivo 12, turno 25).

A tutora Luiza demonstrou conhecer materiais curriculares (livros didáticos, experimentos, textos didáticos, entre outros) e os documentos oficiais que norteavam o ensino no Brasil e no estado de São Paulo. O indício desse conhecimento docente permeou os encontros realizados com os pibidianos. A supervisora compartilhou ainda nesses encontros alguns dos problemas estruturais do laboratório de química:

Certo, dois, não tem porta de emergência, qualquer laboratório tem que ter duas portas, não tem, certo, nós só temos essa porta de entrada e saída, terceiro, não tem chuveiro e lava olhos, ok, tá, eu sei tudo que tem que ter, infelizmente não depende de mim, ok, o que nós temos aqui já é um milagre. $O$ dia que eu conseguir, eu terei, certo, o dia que eu conseguir eu vou colocar tudo isso, porque peço, peço, peço, quem sabe, antes de eu aposentar eu consigo colocar (Aula de contaminação por chumbo - Antônio e Melissa, arquivo16, turno 82).

Parte das orientações de Luiza se referia, principalmente, aos anseios do subprojeto. Nesse sentido, ao compartilhar suas narrativas sobre o processo de orientação dos pibidianos, argumenta:

A temática do projeto era a questão do programa nacional de resíduos sólidos, do PNRS e a questão envolvendo isso implica na questão da logística reversa e tal, então a gente teve grupo que quis investigar o descarte de lâmpadas, ou grupo quis descarte de pilhas e baterias, enfim, então o tema da investigação, os alunos já tinham, né, quer dizer, bom eu vou investigar a questão do descarte das lâmpadas. A minha atuação junto a eles foi muito mais, ok, mas, e o que nós vamos trabalhar de química disso, quais são os conteúdos, quais são os conceitos da química que nós vamos trabalhar a partir desse tema 
gerador, né, então na verdade a gente trabalhou com uma estratégia de ter um problema gerador, quer dizer, uma situação problema e a partir dessa situação problema, extrair os conceitos que eram inerentes àquele tema, né? Então, sei lá, com a questão das lâmpadas, a gente foi investigar do que que era composta, como funcionava e a questão da própria incandescência, luminescência, da diferencial dos fenômenos, né, a ionização do gás e aí pra compreender isso você tem que compreender o modelo atômico, a questão das camadas, dos elétrons, então a gente foi entrando, né, quer dizer, nessa (Entrevista semiestruturada - Luiza, turno 8).

Na percepção de Luiza, para que o Pibid impactasse positivamente na formação do pibidiano era fundamental que o supervisor tivesse um bom conhecimento em química e em pedagogia, pois assim poderia o auxiliar na reestruturação das aulas, na seleção das estratégias de ensino, e entre outros aspectos do conhecimento docente (Entrevista semiestruturada - Luiza). Em conformidade, apresenta-se a narrativa:

\begin{abstract}
Eu acho que assim, nesse aspecto eu, de uma maneira geral eu acho que o Pibid ajuda a formar esse futuro professor ou não, quando eu digo ou não, é, ou ajuda ele a perceber que não é esse o caminho que ele quer tomar na vida, socorro eu não quero dar aula nunca mais, tá? Mas efetivamente, alunos que estão no primeiro semestre da graduação, trazem muitas deficiências de conteúdos do ensino médio que a gente espera que sejam sanadas no superior, né, na graduação e são os que mais tem dificuldade em atuação junto com os estudantes, né? Então quando você pega um aluno da graduação que já está no terceiro semestre, ele já passou pela química básica, ele já tem uma noção de inorgânica, ele já tem mais conhecimento da química em si. Um aluno que acabou de entrar na graduação, ele não sabe, infelizmente ele não sabe o conteúdo, e ele, eu acho que a premissa inicial para alguém iniciar, é saber o que ele vai ensinar, saber o conteúdo, então eu não posso ensinar algo que eu não sei, né, e isso, em muitos momentos foi o que acabou acontecendo, né, o aluno não sabia, e eu não via muito compromisso nessa questão de aprofundar naquele conteúdo, e se aprofundar naqueles conceitos fundamentais (Entrevista semiestruturada - Luiza, turno 26).
\end{abstract}

Para a supervisora o pibidiano deveria ter um bom conhecimento do tema, pois para lecionar "[...] tem que estar muito bem preparado, né? (...) Ele trabalha em grupo, ele troca com seus pares, ele tem essa possibilidade de uma construção conjunta" (Entrevista semiestruturada - Luiza, turno 32).

Para Luiza o desconhecimento da realidade da escola estadual pelo docente universitário era um problema limitante para desenvolvimento do subprojeto na escola conveniada. A supervisora considerou que o Pibid despertou timidamente 0 desenvolvimento do conhecimento para a docência dos pibidianos (Entrevista semiestruturada - Luiza).

\title{
4.4.2. Os impactos do Pibid na formação continuada Coordenadora Maria
}


$\mathrm{Na}$ apreciação dos dados constituídos de 20 documentos, mapeou-se no Atlas.ti os episódios que evidenciassem os impactos do Pibid na formação de Maria. Foram agrupados um total de 98 turnos nas categorias emergentes que vislumbram os impactos do Pibid na formação de Maria. As categorias emergentes são:

- Conhecer a escola pública - relaciona-se com o conhecimento da coordenadora acerca da realidade da escola pública oportunizado pela sua participação no Pibid.

- Dificuldades - engloba as dificuldades vivenciadas por Maria na sua trajetória no Pibid e que emergem em suas narrativas como problemas.

- Mediação - permeiam os episódios que a coordenadora compartilha os processos de mediação entre os componentes do subprojeto associados a diversos aspectos, entre eles, relações interpessoais, formação de grupo, seleção de conteúdo, escolha de estratégias de ensino, entre outros.

- Orientação - referem-se aos episódios em que a coordenadora discorre especificamente sobre o processo de orientação no Pibid.

- Reflexão sobre a prática - permeiam as narrativas que Maria reconhece que sua participação no programa de iniciação à docência propiciou a sua reflexão sobre a prática.

$\mathrm{Na}$ tabela 29 dispõe-se o resultado da análise gerada no Atlas.ti, que englobaram as categorias descritas acima. 
Tabela 29. Relatório gerado no Atlas.ti - A importância do Pibid na formação da coordenadora Maria

\section{Impactos na formação da coordenadora}

Documentos

Conhecer a
escola pública
0
Dificuldades Mediação Orientação

Reunião geral (arquivo 1)

Reunião geral (arquivo 2)

Apresentação da proposta de trabalho - Grupo do Mateus (arquivo 3)

Apresentação da proposta de trabalho - Antônio e Melissa (arquivo 3.1)

Reunião para saber o andamento - Grupo do Mateus (arquivo 4)

Reunião para saber o andamento - Antônio e Melissa (arquivo 5 )

Reunião geral (arquivo 6)

Reunião para saber o andamento - Grupo do Mateus (arquivo 7)

Reunião para saber o andamento - Antônio e Melissa (arquivo 8)

Reunião para saber o andamento - Grupo do Mateus (arquivo 9)

Reunião para saber o andamento - Antônio e Melissa (arquivo 9.1)

Reunião para saber o andamento - Antônio e Melissa (arquivo 10)

Reunião para saber o andamento - Grupo do Mateus (arquivo 11)

Reunião para saber o andamento - Antônio e Melissa (arquivo 12)

Reunião para saber o andamento - Grupo do Mateus (arquivo 13)

Reunião para avaliar no desenvolvimento do projeto em 2014 - Antônio

$\begin{array}{ll}0 & 0 \\ 0 & 0 \\ 0 & 0 \\ 0 & 0 \\ 0 & 0 \\ 0 & 0 \\ 0 & 0 \\ 0 & 0 \\ 0 & 2 \\ 0 & 0 \\ 0 & 3 \\ 0 & 0 \\ 0 & 0 \\ 0 & 0 \\ 0 & 0 \\ 0 & 0\end{array}$

3

e Melissa (arquivo 14)

Apresentação dos resultados - Melissa e Antônio (arquivo 15)

Apresentação dos resultados - Grupo do Mateus (arquivo 15.1)

Discussão geral sobre os objetivos do subprojeto e que foram alcançados

no ano de 2014 (15.2)

Entrevista semiestruturada - Maria

0
1
3

0
0
0

prática

\begin{tabular}{cccc}
3 & 0 & 0 & 3 \\
0 & 0 & 0 & 0 \\
0 & 0 & 0 & 0 \\
0 & 0 & 0 & 0 \\
31 & 0 & 0 & 31 \\
0 & 0 & 0 & 0 \\
8 & 0 & 0 & 8 \\
\hline 3 & 0 & 0 & 3 \\
0 & 0 & 0 & 2 \\
0 & 0 & 0 & 0 \\
4 & 0 & 0 & 7 \\
\hline 5 & 0 & 0 & 5 \\
0 & 0 & 0 & 0 \\
0 & 0 & 0 & 0 \\
\hline 6 & 0 & 0 & 6 \\
\hline 2 & 0 & 0 & 2
\end{tabular}

0

0
0
11

0
0
0

11

$\begin{array}{cc}0 & 0 \\ 1 & 2 \\ 1 & 15\end{array}$

6

10

4

2

1


Nas narrativas de Maria emergem aspectos relacionados à importância do Pibid para a coordenadora Conhecer a realidade da escola pública. Nessa categoria agruparamse 6 turnos. A autora Silva (2015) analisa as marcas deixadas pelo programa de iniciação à docência na formação de coordenadores da área de física. Estas, se relacionam, principalmente, ao conhecimento da realidade da escola básica. Sobre esse aspecto emerge a passagem de Maria:

Ele favorece muito. Ele me faz repensar a minha prática docente, não a todo momento, porque às vezes eu não penso nela a todo momento, mas ele contribui nas minhas reflexões. Porque participar do Pibid dá oportunidade de compartilhar realidades diferentes. Eu tenho a oportunidade de compartilhar uma realidade da escola pública, uma realidade dos professores da escola pública. Falando em professores nesse setor escola pública, instituição, faculdade e a educação básica, é um universo interessante o conhecimento que o professor tem, 0 supervisor, a forma como ele trabalha com os alunos, a forma como ele trabalha com os pibidianos e o que a sala de aula lá da escola estadual está fazendo com os professores, que é um pouco assustador para mim, enquanto docente aqui no Instituto Federal. Porque a minha realidade, hoje olhando a realidade das escolas que eu coordeno e a realidade do Instituto Federal, eu me sinto muito privilegiada (...). Eu percebo alunos se esforçando, eu vejo o esforço dos meus alunos para tentar aprender, para trilhar esse caminho do conhecimento. E a realidade que eu tenho, quando eu vou lá para a escola estadual, pelo menos as que a gente participa, é um professor muito desmotivado, é um professor que entra na sala de aula e até a própria maneira como ele conversa com os alunos, às vezes me deixa um pouco, eu não digo constrangida, mas...(Entrevista semiestruturada - Maria, turno 46).

No trecho acima tem-se elementos da categoria reflexão sobre a prática, pois a coordenadora compartilha que a vivência no programa de iniciação à docência a levou a refletir sobre as suas aulas no ensino superior e no ensino médio. Em outro momento da entrevista a coordenadora argumenta que o Pibid é uma política pública que faz a diferença na formação de professores e, principalmente, na educação pública brasileira. Essa percepção reflete no seu repertório de conhecimento da realidade da educação básica:

Olha, se realmente a gente quer mudar o cenário da educação no Brasil, se isso for realmente uma vontade política, porque nossa é, não tenho dúvida, a gente só está indo para a sala de aula, a gente só continua na sala de aula porque a gente confia que a gente pode mudar, que a gente pode fazer a diferença. Então eu não tenho dúvida que os professores querem mudar. Eu quero mudar, você quer mudar e quem participa do Pibid quer mudar. Então precisa a vontade política, a vontade de mudar a educação, de tornar a educação boa no Brasil tem que ser política. E o Pibid é um programa institucional que faz a diferença (Entrevista semiestruturada - Maria, turno 60).

Os processos relacionados ao gerenciamento dos participantes no Pibid eram uma das principais Dificuldades vivenciados pela coordenadora:

A questão de gerenciar pessoas. Então eu considero que isso tem uma... porque você tem um grupo de alunos e às vezes nesse grupo você trabalha com um grupo maior, de doze pessoas, depois tem grupos menores, então tem que ter uma boa integração entre o grupo maior, tem 
que ter uma boa integração também entre as pessoas que estão participando do grupo pequeno (...). E tem também a parte dos supervisores, não é? Porque às vezes o grupo está bem, entre os pibidianos, com a coordenação está indo tranquilo, mas às vezes a supervisora está num momento um pouco mais difícil da carreira profissional, ou da vida particular dela e tem algumas atitudes que causam um pouco de ruído entre o grupo. Então eu acho que administrar todo esse contexto talvez seja um desafio grande imposto pelo Pibid (Entrevista semiestruturada - Maria, turno 20).

No discurso da coordenadora tem-se elementos dos processos de Mediação que realizava por conta das relações interpessoais. Nessa categoria se agrupou um total de 77 turnos. Na entrevista semiestruturada também emergem aspectos relacionados à Orientação de Maria na estruturação das aulas, e também limitações associadas ao processo:

Seria se a disponibilidade de tempo é uma problemática na administração do Pibid. Eu não sei se é uma problemática, mas é um fato que precisa ser observado com atenção. Então você realmente precisa ter um momento da sua semana, e você é pago para isso, que é dedicado ao Pibid. Então como a gente gerencia isso? Eu tenho uma tarde que é presencial. Então eu estou à tarde atendendo aos alunos e as nossas reuniões são fixas. Então semanalmente, duas vezes na semana tem reunião. Ou eu converso com todo mundo junto ou eu converso com todos os grupos semanalmente. Só que o Pibid também impõe um trabalho fora das reuniões: o trabalho de preparo de atividades, de pesquisa, de leitura. E parte desse material, desse trabalho é feito à distância. Então o aluno produz, compartilha com o supervisor e com o coordenador e com os demais integrantes do grupo e ali a gente faz uma construção. Normalmente, a gente fecha a construção que foi feita durante a semana na reunião. Então é a reunião em que a gente bate o martelo e fecha o que vai ser trabalhado. Mas, realmente precisa ter uma dedicação, porque é muito gente...(Entrevista semiestruturada - Maria, turno 22).

Para Maria escolher o Pibid significou abdicar da família e da vida social (Entrevista semiestruturada - Maria). Outra Dificuldade vivenciada no contexto do programa de iniciação à docência era a orientação dos discentes, pois:

[...] Normalmente, eles são de semestres iniciais: primeiro, segundo ou terceiro semestre. Porque eles já chegam na graduação e ficam sabendo do programa pelo rádio peão, não só rádio peão, mas o coordenador informa que existe o programa, os próprios alunos discutem o que acontece no Pibid. Então quem chega aqui na instituição tem interesse em participar do Pibid. $O$ fato de eles entrarem no Pibid com uma bagagem acadêmica ainda pequena, porque está no segundo semestre ou até no primeiro semestre, coloca alguns desafios para eles e até para a coordenação também do Pibid. Por quê? Até um ano atrás, eles estavam na sala de aula, tendo aula e agora eles são as pessoas que vão coordenar uma ação com esses alunos. Então é uma mudança muito grande [...] (Entrevista semiestruturada, turno 30).

Apesar de a literatura apontar que o Pibid tem sido fundamental para a formação inicial de professores, por estreitar os laços entre a escola da educação básica e o ensino superior, a coordenadora compartilha que nos últimos dois anos o programa sofreu duros 
cortes, mas que por conta da unidade entre os participantes houve uma organização de vários setores sociais para que o Pibid não fosse extinto, pois:

[...] ele atinge a escola, os alunos, os pais dos alunos, porque eles acompanham os trabalhos que são realizados, não somente os professores que participam do Pibid, mas os outros professores da escola, os diretores. Aqui na instituição, os nossos alunos, os pibidianos, os professores que trabalham com formação de professores, então foi uma rede muito grande. Então, se nós quisermos realmente mudar ou melhorar o ensino no Brasil, o Pibid não pode morrer. Porque o Pibid é a garantia ou uma porta que a gente tem para melhorar a formação do nosso professor. É óbvio que eu também acho que o Projeto Pibid, o Programa precisa estar sempre sendo supervisionado em como está sendo conduzido, mas isso é uma coisa que é intrínseca a qualquer programa que é colocado, que precisa ser supervisionado, isso é uma coisa natural. Porque essa experiência que o professor tem de ir para a sala de aula, que o aluno tem de ir para a sala de aula, de ter essa convivência com o supervisor, com a coordenação, com os alunos, isso é um diferencial na formação dele. Ele não seria o mesmo professor se ele não tivesse passado pelo Pibid (Entrevista semiestruturada, turno 66).

As relações interpessoais no contexto do subprojeto, por vezes, emergiram como uma Mediação, e ao realizar uma Reflexão sobre a prática, Maria, no final das atividades desenvolvidas pelos pibidianos, argumenta que todos os participantes deveriam buscar aceitar mais uns aos outros:

Eu professora Maria, eu coordenadora do Pibid Maria, eu tenho pontos positivos e pontos negativos, paciência, é assim que nós somos, a professora Luiza enquanto supervisora ela tem pontos positivos e pontos negativos, entendeu? E a gente tem que se aceitar, todo mundo aqui, a parte forte e a parte, não é fraca, é aquela parte assim que a gente, poxa vida, eu sou assim, entendeu? E aí a gente traz uma outra coisa pro Pibid que esse ano a gente teve a sorte, vamos dizer assim, de contornar, que Pibid não é só estudar química, Pibid é trabalhar em grupo, e isso não é fácil, às vezes é muito mais fácil dar físico-química, do que fazer essa relação interpessoal que vai do princípio também, da gente se você aceitar gente, sabe, uma coisa que eu gostaria da gente começasse a pensar da gente se aceitar, eu me aceito enquanto professora que, é o meu perfil, não é que eu vou ser sempre assim, tá na minha genética, eu vou falar: "Vamos fazer, o nosso caminho é esse, e vamos, que vamos, temos que cumprir" Entendeu? Por outro lado, eu também tenho que aceitar que eu tenho as minhas deficiências, eu tenho que aceitar, e eu tenho que aceitar as deficiências do meu colega aqui, do meu colega (Discussão geral dos resultados, arquivo 19 , turno 65 ).

De modo geral Maria vislumbra que a inserção de licenciandos no Pibid possibilita que desenvolvam conhecimentos para atuarem na sala de aula, pois "[...] ele é destinado a ir para a sala de aula, para fazer uma intervenção com os alunos, ele tem que se preparar. Então são muitos fatores que vão contribuir para o crescimento desse pibidiano. São suportes que ele tem do supervisor, do coordenador" (Entrevista semiestruturada - Maria, turno 56).

Outra Dificuldade era na organização dos grupos. Parte dos licenciandos eram alunos recém ingressantes na graduação, enquanto outros estavam na metade do curso. 
Buscando contornar essas particularidades, Maria estrutura as equipes de modo a manter um equilíbrio, como denota o trecho:

Elder estava junto com a Melissa ((quis dizer que eram alunos do primeiro ano da licenciatura)). Então, para esses alunos que são ingressantes, que são os mais novinhos, eu percebo que a dificuldade é maior, porque eles não tiveram nada da parte de didática, eles não tiveram nada das disciplinas da licenciatura, então eles estão bastante perdidos. O que fazer? Agora, os alunos que estão um pouquinho mais avançados ficam um pouco mais fácil o trabalho. Então as dificuldades são menores. De toda forma, a inserção em um projeto que tem uma temática específica, que tem rumos específicos, que sai um pouco daquele trivial da sala de aula, isso causa um certo desconforto para eles no começo. Eles precisam ir se familiarizando. Então isso causa uma insegurança (Entrevista semiestruturada - Maria, turno 42).

Os aspectos relacionados à Reflexão sobre a prática de Maria foram influenciados ainda pelo processo de construção da sequência de ensino em conjunto com os pibidianos, proporcionando uma troca entre os pares em virtude dessas experiências. Maria argumenta ainda que:

Porque às vezes na sala de aula, se você tem quarenta alunos, quarenta e cinco alunos, mesmo na graduação, às vezes você não consegue sentar do lado e discutir por que o aluno está errando, por que está certo, por que está errado, ou tirar uma dúvida mais personalizada. E o Pibid permite isso, eu vou conversando com o aluno ((pibidiano)). A gente discute, ele coloca uma ideia, eu coloco outra ideia, o supervisor outra ideia e a gente chega num consenso. Então essa construção, eu acho que é enriquecedora e eu levo para a sala de aula (Entrevista semiestruturada Maria, turno 52).

Segundo a coordenadora o Pibid tem contribuído para que o professor supervisor se sinta valorizado como um profissional, em virtude da forma como a sociedade brasileira vislumbra a profissão docente. Nessa perspectiva, para Maria a supervisora "[...] passa a se sentir importante, porque ela está orientando um aluno da licenciatura, está mostrando como é a escola. Por mais que por vezes a realidade seja dura. E também tem experiências positivas, escreve trabalhos para congresso" (Entrevista semiestruturada - Maria, turno 87).

Resumidamente, a principal marca deixada pelo programa de iniciação à docência para a formação de Maria foi possibilitar a essa docente de uma instituição de ensino federal mediar as relações entre os participantes do subprojeto. As orientações de Maria estavam mais direcionadas na estruturação das aulas, na sua implementação e na confecção dos relatórios finais.

\section{A supervisora Luiza}

Mapeou-se 24 documentos para verificar os impactos do Pibid na formação de Luiza por meio de cinco categorias emergentes, descritas abaixo: 
- Co-formadora - refere-se a episódios em que a supervisora se reconhece como co-formadora dos pibidianos.

- Cooperação dos pibidianos na prática docente da supervisora - engloba as narrativas em que a supervisora vislumbra a importância dos pibidianos no desenvolvimento de suas aulas.

- Ensinar os pibidianos - permeia a percepção da supervisora que uma de suas funções no Pibid era ensinar os bolsistas de iniciação à docência.

- Mediar a inserção do pibidiano na escola - engloba os discursos de Luiza associados aos processos de mediação que promoveu para contribuir na adaptação dos pibidianos na escola sede.

- Pesquisa - relaciona-se às narrativas da supervisora que vislumbram as atividades desenvolvidas pelos pibidianos como destinadas a pesquisa.

Agrupou-se na tabela 30 o resultado de tabulação dos documentos gerados no Atlas.ti por meio das categorias emergentes que denotam as marcas deixadas pelo programa de iniciação à docência na formação da supervisora. 
Tabela 30. Relatório gerado no Atlas.ti - A importância do Pibid na formação da supervisora Luiza Documentos

Impactos na formação da supervisora

\begin{tabular}{|c|c|c|c|c|c|c|}
\hline & \multirow[b]{2}{*}{ Co-formadora } & & & & & \\
\hline & & $\begin{array}{c}\text { Cooperação dos } \\
\text { pibidianos na prática } \\
\text { docente da supervisora }\end{array}$ & $\begin{array}{l}\text { Ensinar } \\
\text { os } \\
\text { pibidianos }\end{array}$ & $\begin{array}{c}\text { Mediar a inserção } \\
\text { do pibidiano na } \\
\text { escola }\end{array}$ & Pesquisa & Total \\
\hline Reunião geral (arquivo 1) & 0 & 0 & 0 & 0 & 0 & 0 \\
\hline Aula experimental teste de chama - Grupo do Mateus (arquivo 2) & 0 & 0 & 0 & 0 & 0 & 0 \\
\hline Aula experimental teste de chama - Grupo do Mateus (arquivo_2.11) & 0 & 0 & 0 & 0 & 0 & 0 \\
\hline Aula de sensibilização - Grupo do Mateus (arquivo 3) & 0 & 0 & 0 & 0 & 0 & 0 \\
\hline Reunião geral (arquivo 4) & 0 & 3 & 0 & 0 & 0 & 3 \\
\hline Reunião para saber o andamento - Melissa e Antônio (arquivo 5) & 0 & 0 & 0 & 0 & 0 & 0 \\
\hline Aula de atomística - Antônio e Melissa (arquivo 6) & 0 & 0 & 10 & 2 & 0 & 12 \\
\hline Aula Pilha de moedas - Antônio e Melissa (arquivo 7) & 0 & 0 & 4 & 0 & 0 & 4 \\
\hline $\begin{array}{l}\text { Aula estrutura atômica e definição de oxidação - turma 1- Grupo do } \\
\text { Mateus (arquivo 8) }\end{array}$ & 0 & 0 & 0 & 0 & 0 & 0 \\
\hline $\begin{array}{l}\text { Aula estrutura atômica e definição de oxidação - turma } 2 \text { - Grupo do } \\
\text { Mateus (arquivo 8.1) }\end{array}$ & 0 & 0 & 0 & 1 & 0 & 1 \\
\hline Aula Pilha de Daniell - Antônio e Melissa (arquivo 9) & 0 & 0 & 10 & 1 & 0 & 11 \\
\hline Reunião para saber o andamento - Melissa e Antônio (arquivo 10) & 0 & 0 & 0 & 0 & 0 & 0 \\
\hline Aula de revisão - Antônio e Melissa (arquivo 11) & 0 & 0 & 1 & 0 & 0 & 1 \\
\hline Aula de contaminação por chumbo - Antônio e Melissa (arquivo 12) & 0 & 1 & 0 & 0 & 1 & 2 \\
\hline $\begin{array}{l}\text { Aula de conceitos gerais de eletroquímica - Grupo do Mateus (arquivo } \\
\text { 13) }\end{array}$ & 0 & 1 & 15 & 0 & 0 & 16 \\
\hline $\begin{array}{l}\text { Aula experimental da Gota salina e deposição do cobre - turma } 2 \text { - } \\
\text { Grupo do Mateus (arquivo 14) }\end{array}$ & 0 & 0 & 3 & 1 & 0 & 4 \\
\hline $\begin{array}{l}\text { Aula experimental da Gota salina e deposição do cobre - turma } 1 \text { - } \\
\text { Grupo do Mateus (arquivo 14.1) }\end{array}$ & 0 & 0 & 1 & 0 & 0 & 1 \\
\hline $\begin{array}{l}\text { Aula lúdica - Funcionamento de lâmpadas fluorescentes - turma } 2 \text { - } \\
\text { Grupo do Mateus (arquivo 15) }\end{array}$ & 0 & 0 & 0 & 0 & 0 & 0 \\
\hline $\begin{array}{l}\text { Aula lúdica - Funcionamento de lâmpadas fluorescentes - turma } 1 \\
\text { (arquivo 15.1) }\end{array}$ & 0 & 0 & 0 & 1 & 0 & 1 \\
\hline Apresentação dos resultados - Mateus (arquivo 16) & 0 & 0 & 2 & 0 & 0 & 2 \\
\hline Apresentação dos resultados - Antônio e Melissa (arquivo 17) & 0 & 0 & 0 & 0 & 0 & 0 \\
\hline $\begin{array}{l}\text { Discussão geral sobre os objetivos do subprojeto e que foram } \\
\text { alcançados no ano de } 2014 \text { (arquivo 18) }\end{array}$ & 0 & 1 & 0 & 0 & 0 & 1 \\
\hline Relatório anual da supervisora & 0 & 0 & 0 & 0 & 0 & 0 \\
\hline Entrevista semiestruturada & 3 & 2 & 4 & 0 & 0 & 9 \\
\hline Total & 3 & 8 & 50 & 6 & 1 & 68 \\
\hline
\end{tabular}

Capítulo 4. Resultados e Discussões 
Os estudos que analisam as marcas deixadas pelo Pibid na formação continuada dos supervisores denotam que esses docentes atuam como co-formadores dos pibidianos. Suas práticas didáticas são modificadas com a adoção de novas estratégias pelo contato com os futuros professores, e se aproximam da acadêmica ao participarem de congressos. Na análise das possíveis contribuições do Pibid na formação de Luiza, essas e outras marcas emergiram. Com relação à percepção que Luiza se considerava co-formadora dos pibidianos, temos o trecho:

Então, eu acho que o supervisor, o papel do supervisor é o que eu desempenhei mesmo, quer dizer, é ajudar na formação desses alunos, é intervir quando for importante e necessário, né, mas eu acho que dentro do subprojeto tem que ser levado em consideração o contexto aonde isso vai ser aplicado, então aonde isso vai ser aplicado? [...] (Entrevista semiestruturada - Luiza, turno 114).

No mapeamento do conhecimento docente de Luiza emergiu, principalmente, no contexto de aplicação das aulas pelos pibidianos, o que em alguns episódios se revelou como uma problemática para os bolsistas de iniciação à docência, pois a aula acabava sendo direcionada para os seus Ensinamentos, ou seja, a supervisora entendia que um de seus papeis na formação dos pibidianos era ensiná-los. Essa percepção de Luiza de que teria a função de ensinar os pibidianos foi o impacto que mais emergiu em nossa análise, tendo um total de 50 turnos agrupados nesse descritor. Em consonância, dispomos os trechos:

Luiza - Sem dúvida, porém a principal função da ponte salina, primeiro é fechar o circuito tá, e segundo é o que você tá falando, equilibrar as cargas, mas como é que se equilibram, né, que você vai explicar agora.

Luiza - Não, gente, ele é aluno, ele tá aprendendo, então, eu tô aqui ligada porque ele tá ensinando vocês, eu tô ensinando ele (Aula pilha - Antônio e Melissa, arquivo 12, turno 62 e 65).

Luiza - Então, manda brasa, Mateus deixa ele, os alunos sabem que ele também é aluno, tá, então, você está aqui para aprender não apavora não, tá, porque se você não aprender aqui, né, amanhã você vai fazer bobagem em outra sala então, vamos embora, não fica com medo não, eu não mordo ninguém não você já sabe, a cara é feia assim, mas foi de nascença (Conceitos gerais de eletroquímica Grupo do Mateus, arquivo 9, turno 36).

A supervisora mediava a inserção dos bolsistas de iniciação à docência na escola estabelecendo a comunicação com outros docentes, e também na sala de aula ao solicitar que os discentes cooperassem com as aulas desenvolvidas pelos pibidianos. Por vezes, solicitou que professores de outras áreas liberassem suas regências para que os pibidianos continuassem ministrando seus planejamentos.

A vivência dos pibidianos na escola conveniada possibilitou que Luiza propusesse aulas no laboratório - Cooperação dos pibidianos na prática docente da supervisora, pois

Capítulo 4. Resultados e Discussões 
[...] é complicado você ir pra um laboratório às vezes com 40 alunos, e além disso é complicado porque você tem que separar o material, esse material tem que ser lavado previamente, arrumado previamente, depois da aula depois tem que arrumar, guardar esse material, e a gente não tem nenhum tipo de ajuda (...) E a gente já ganha tão pouco, você ficar ainda trabalhando de graça pro governo fica complicado, né? Então o Pibid proporcionou atividades práticas no laboratório, experimentos investigativos [...] (entrevista semiestruturada - Luiza, turno 2).

Para Luiza uma das problemáticas relacionadas à formação de professores está ligada às instituições de ensino da educação básica onde concluíram o ensino médio, pois ao observar a prática docente de um dos bolsistas de iniciação à docência, afirma que:

Eu ia dizer, porque esse tipo de escola eles têm uma característica, tá, esse tipo de escola é escola bitoleba, tá, então, eles não deram o conceito real para ele, eles deram a bitola as regras práticas e aí ele vai na base da bitolinha a vida inteira, tá, mas o conceito mesmo tem ' $n$ ' artigos lá falando sobre a educação, alias a minha tese era para ser sobre isso não deixaram que um nome muito grande, né. (Conceitos gerais de eletroquímica - Grupo do Mateus, arquivo 9, turno 96).

Revela-se, ainda, nas narrativas de Luiza que a supervisora vislumbrava que deveria ensinar os pibidianos. Nessa perspectiva, ao assumir as aulas, direcionava suas falas aos pibidianos ao invés de explicar os conceitos aos alunos da escola conveniada. Talvez por ser mestre em Ensino de Ciências e uma boa formação, sentia-se formadora dos pibidianos

Outro impacto do Pibid mapeado na literatura aponta que os professores da educação básica passaram a participar de congressos e investigações associadas às análises das atividades desenvolvidas no subprojeto que integram. Nessa perceptiva, Luiza argumentou aos discentes que "[...] tudo que vocês fazem, a gente tá fazendo uma pesquisa tá. Então vale nota, porque assim, é uma maneira de também tá avaliando, e tá avaliando se funciona, se não funciona, tá, se..." (Aula de contaminação por chumbo - Antônio e Luiza, arquivo 12, turno 159).

De modo geral o Pibid contribuiu para que Luiza se considerasse co-formadora dos pibidianos, que os pibidianos a auxiliassem no desenvolvimento de práticas experimentais e mediassem a inserção dos bolsistas de iniciação à docência na escola sede. Entretanto, uma das problemáticas foi a supervisora assimilar que tinha a função de Ensinar os pibidianos nos contextos de sala de aula por os considerar alunos e não distingui-los dos educandos da educação básica para os quais lecionava.

Essa postura trouxe alguns constrangimentos aos pibidianos, estes revelados em diversos trechos de suas falas. 


\section{CAPÍTULO 5. CONCLUSÕES}

Na revisão de literatura sobre o Pibid evidenciou-se que o programa de iniciação à docência, vem constituindo-se como um terceiro espaço de formação. As investigações catalogadas dedicam-se, principalmente, a analisar as marcas deixadas pelo programa na formação dos pibidianos, relacionadas às oportunidades de vivência do espaço profissional ainda na formação, de participar de eventos científicos, de discussões sobre referenciais teóricos e reflexões sobre suas práticas pedagógicas, entre outros. Em relação aos supervisores, o Pibid oportunizou que os professores da educação básica atuassem como co-formadores dos licenciandos. Apenas um dos estudos apontou os impactos do Pibid na formação do coordenador de área, focando no seu conhecimento do contexto da escola da educação básica.

Com relação ao mapeamento das limitações associadas ao tema redox nos eventos nacionais e internacionais, as principais limitações identificadas foram a não compreensão da simultaneidade das reações redox, da diferenciação entre pilha e eletrólise e transpor os conceitos redox para outros temas. Para o desenvolvimento desse tema, a principal estratégia adotada foi a experimentação.

Nesta pesquisa investigou-se o Conhecimento Pedagógico de Conteúdo e a Base de Conhecimentos emergidos pelos bolsistas durante suas vivências no programa de iniciação à docência. Em consonância, os caminhos trilhados envolviam responder as questões de pesquisa:

- Quais foram os conhecimentos docentes acessados pelos futuros professores de química durante suas trajetórias como bolsistas?

- Qual a influência das orientações da supervisora e da coordenadora na construção dos conhecimentos docentes dos bolsistas?

- O Pibid tem impactado na formação continuada da supervisora e coordenadora?

- O Pibid vem constituindo-se um terceiro espaço de formação inicial?

Para responder essas questões de pesquisa buscou-se desvelar 0 conhecimento docente de três pibidianos em momentos distintos de formação na licenciatura, associando-o a essas questões.

O pibidiano Mateus estava no segundo ano, Melissa no primeiro e Antônio, entre o terceiro e quarto ano da licenciatura. As análises realizadas nos dados coletados tiveram como foco emergir e analisar a contribuição do Pibid na formação desses futuros professores e, consequentemente, na construção do Conhecimento Docente.

Em consonância, Antônio buscou em suas ações didáticas na escola conveniada seguir as orientações das tutoras, principalmente de Maria, por outro lado, suas aulas 
eram influenciadas também pelos conhecimentos aprendidos na licenciatura em química. Nas reuniões o pibidiano discutiu com Maria cada etapa das aulas elaboradas e implementadas. Antônio pôde vislumbrar e discutir as dificuldades relacionadas ao ensino do conteúdo redox, bem como compreender a relação entre o currículo horizontal e vertical possibilitado pela orientação de Luiza e Maria. No início de suas ações as atividades avaliativas tinham por objetivo compor a nota da professora supervisora e dados a serem analisados no subprojeto. O pibidiano Antônio demonstrou ter conhecimento do tema redox, e buscou desenvolvê-lo levando em consideração a turma na qual ministrava suas aulas.

As principais abordagens de ensino adotada nas aulas de Antônio foram a CTS e a atividade experimental investigativa e demonstrativa. A abordagem CTS era reflexo da orientação da coordenadora e da estrutura do subprojeto. Entretanto, as aulas experimentais eram implementadas com a função de comprovar a teoria. A classe era sempre organizada em grupos, pois para Antônio essa dinâmica possibilitava a discussão do conteúdo e contribuia no desenvolvimento das atividades propostas.

Durante suas regências o pibidiano teve limitações em orientar a classe para o desenvolvimento de algumas tarefas, como quais seriam os procedimentos a serem seguidos na aula experimental, além de não organizar o tempo disponível para que o conteúdo fosse lecionado de modo organizado, o que aconteceu em diversas aulas. $\mathrm{Na}$ visão de Antônio, a principal dificuldade enfrentada em suas regências foi a baixa frequência dos alunos, apesar de considerar que o número de alunos facilitava a sua prática de ensino.

Para propor as aulas envolvendo a contaminação de chumbo, o principal argumento usado pelo grupo do subprojeto era que a região na qual a escola estava localizada sofria, possivelmente, com esse tipo de contaminação pelo descarte inadequado de baterias automotivas. Em decorrência dessa temática, Antônio foi orientado pelas tutoras a pesquisar sobre a comunidade na qual a escola estava sediada, e a origem de seus discentes. Em muitos momentos Antônio demonstrou ter um bom relacionamento com os funcionários do setor administrativo e com os professores, que em muitas ocasiões contribuíram para a sua ação didática.

Os indícios do Conhecimento do Contexto foram acessados por Antônio durante a sua trajetória como pibidiano, mas principalmente incorporados em seus discursos, em virtude do conhecimento da supervisora sobre o contexto em que viviam seus alunos, da escola e do bairro em que a escola estava sediada, e que foi compartilhado com Antônio nas reuniões.

As Orientações para o ensino de ciências nas aulas de Antônio englobaram as orientações: Rigor Acadêmico, Ciência baseada em projetos, Investigação e Didática. Conclusões 
Rigor acadêmico, pois buscou trabalhar com práticas experimentais com o objetivo de comprovar os conceitos científicos desenvolvidos. As aulas foram desenvolvidas por meio de projetos, uma direção natural a ser seguida pelo pibidiano, pois era a orientação do subprojeto do qual participava. Nesse projeto em específico, seus bolsistas, procuraram envolver uma gama de atividades que os alunos da escola conveniada desenvolviam. Antônio estruturou uma aula experimental por meio da atividade investigativa, e apesar de apresentar dificuldades em conduzí-la, tentou seguir a orientação da supervisora para o ensino de seus discentes, levando-o a caracterizar a sua orientação como didática, pois sua aula era centrada na figura do professor. As orientações de Antônio foram influenciadas pelas exigências do programa no qual está inserido, e também por suas crenças pessoais sobre a natureza da ciência.

Durante a elaboração da sequência de ensino, Antônio não levou em consideração os documentos oficiais (PCN e Currículo do Estado de São Paulo). Apesar de estar inserido num projeto que tem certas diretrizes, o pibidiano preparou seu material didático, além de escolher alguns referenciais para nortear em sua confecção. Infere-se que o conhecimento sobre o conteúdo possibilitou que Antônio relacionasse os conceitos trabalhados em classe em diferentes momentos, entretanto, seu Conhecimento do currículo de ciências (horizontal e vertical) e os currículos oficiais foram reflexo dos conhecimentos de suas tutoras.

O licenciando não demonstrou, inicialmente, compreender as limitações dos discentes com reações redox (Conhecimento da compreensão dos alunos em ciências), entretanto, em sua trajetória no Pibid as acessou. Para motivar seus alunos a aprender, evidenciava suas compreensões sobre o que estava sendo ensinado, pois via a motivação como um anseio individual e coletivo nos discentes da EJA.

Muitas das escolhas avaliativas (Conhecimento da avaliação da aprendizagem em ciências) de Antônio, apesar de serem de sua autoria, eram solicitações das tutoras. As avalições eram implementadas, tendo três propósitos: coletar dados para o subprojeto; analisar a aprendizagem dos alunos; e compor a nota dos bimestres da supervisora.

Antônio demonstrou ter um conhecimento rico sobre estratégias instrucionais que foram adotadas em suas regências, resultando em aulas que envolveram a experimentação investigativa/demonstrativa, a leitura de textos, o trabalho em grupo, a revisão do conteúdo, a explicação e discussão dos conteúdos, entre outros. A experimentação investigativa foi uma orientação da supervisora durante uma reunião em que buscou orientar o pibidiano de como deveria encaminhar a aula (Reunião para saber o desenvolvimento, arquivo 9). 
A trajetória de Antônio no Pibid, evidenciou que o pibidiano pode iniciar a construção do conhecimento docente, principalmente, das limitações associadas ao ensino redox, do contexto e do currículo. Entretanto, a estruturação do subprojeto tendo como temática central a PNRS, não possibilitou que Antônio tivesse autonomia para lecionar. Nesse sentido, em alguns episódios o pibidiano demonstrou descontentamento ao ter que aplicar atividades avaliativas, para compor dados para o subprojeto. Inferese que a produção de trabalhos para congressos, não priorizando autonomina dos pibidiano e o seu desenvolvimento como futuro professor, parece desviar o projeto de seu principal objetivo que é a formação de professores.

Outra participante da pesquisa, Melissa, em seus passos iniciais no Pibid, observava e pouco participava dos diálogos entre as tutoras e os outros pibidianos nas reuniões. Para o planejamento das aulas, Melissa sempre recorria à orientação de Maria para definir o que seria ensinado e como deveria ensinar. Nesse sentido, observa-se a influência da tutora no conhecimento de Melissa sobre o Currículo (saliência curricular e currículo horizontal/vertical) nas orientações para o ensino de ciências, no conhecimento da avalição da aprendizagem em ciências, entre outros. Em sua vivência no contexto de sala de aula, a pibidiana demonstrou um conhecimento incipiente sobre o conteúdo reações redox. Para ensinar nas primeiras aulas recorreu ao caderno da licenciatura, mas ao compreender que para ensinar era preciso conhecer mais o conteúdo, buscou a orientação da ex-coordenadora Rebeca, que por sua vez lhe aconselhou a estudar por livros didáticos da educação básica. As estratégias adotadas no ensino do conteúdo redox, como a revisão, foram escolhas das supervisoras, assim como as propostas avaliativas. Em uma das regências Melissa implementou uma proposta de avaliação de modo diferente das orientações da coordenadora e supervisora. Nesse sentido, ao invés de aplicar o instrumento, foi resolvendo-o em conjunto com os discentes.

Ao iniciar suas aulas na EJA, Melissa não tinha compreensão a respeito das dificuldades de seus alunos sobre reações redox e outras limitações. Estas foram sendo acessadas pela pibidiana a cada aula. Além disto, a pibidiana revelou ter um conhecimento incipiente do contexto.

As escolhas de Melissa para conduzir as aulas eram reflexos de sua vivência na educação básica e na curta vida na licenciatura. Contudo, pela sua participação no programa, ao ministrar aulas sobre reações redox, existiram alguns episódios em que, ao perceber que o modo que estava conduzindo sua aula - por meio de indagações sobre o conteúdo específico - não permitia que os discentes conseguissem acompanhar, fez com que modificasse suas ações didáticas. Infere-se que essa mudança foi o início da construção de suas Decisões sobre o fazer no Ensino. 
O terceiro participante do estudo foi Mateus. O conhecimento sobre reações redox de Mateus se mostrou incipiente ao longo de sua vivência na sala de aula. Entretanto, em virtude de sua participação no Pibid se empenhou em estudar o conteúdo para superar suas limitações conceituais.

O pibidiano Mateus demonstrou ter um bom Conhecimento Pedagógico Geral relacionado às estratégias de ensino e aos métodos de avaliação dissociados do conceito redox. Por outro lado, apresentou limitações em reger o tempo, a classe e vislumbrar as dificuldades de aprendizagem dos discentes.

O conhecimento do contexto de Mateus emergiu, timidamente, nos seus passos iniciais no programa de iniciação à docência. Nas primeiras reuniões com as tutoras foi orientado por Maria a desenvolver e aplicar um questionário socioeconômico e cultural para identificar a origem dos alunos da escola conveniada, propiciando que Mateus conhecesse um pouco de seus discentes. A imersão de Mateus no contexto escolar possibilitou que ele vislumbrasse problemáticas relacionadas à organização da carga horaria e à baixa frequência dos alunos.

As orientações para o ensino de Mateus eram reflexo da estrutura do subprojeto do Pibid baseada em projetos. A condução das aulas de redox foi influenciada pelo Conhecimento Pedagógico Geral de Mateus, por conta de suas dificuldades na gestão da sala de aula, e por encaminhar suas regências independentemente do conteúdo.

Infere-se que Mateus vislumbrou os conceitos fundamentais para ensinar redox e os materiais curriculares por sua participação no Pibid. Talvez suas limitações com o conceito redox tenham refletido em sua escolha por desenvolver o conceito de oxidação e Nox, ignorando a definição de redução.

As limitações dos discentes com o conceito redox foram acessadas por Mateus no processo de análise dos exercícios. Nas reuniões Maria orientava o pibidiano a observar as necessidades dos discentes. No desenvolvimento do conceito redox Mateus emergiu uma concepção alternativa sobre redox ao explicar que a oxidação resultava na formação de ferrugem, e que a oxidação ocorre somente na presença de oxigênio, entre outras.

As narrativas de Mateus no contexto do programa de iniciação à docência revelaram que o pibidiano teve a possibilidade de propor e implementar várias estratégias de ensino. A adoção da prática investigativa e de alguns experimentos demonstrativos em suas aulas foram reflexo da orientação de Luiza e Maria.

Compreende-se que as atividades avaliativas propostas por Mateus tinham a função de compor a nota das avaliações bimestrais da professora supervisora e dados para o subprojeto. Entretanto, no decorrer do desenvolvimento de sua sequência de 
ensino, Mateus passou a sugerir atividades avaliativas que propiciassem a reflexão dos discentes.

Dos três pibidianos analisados, percebe-se um maior ganho nos conhecimentos docentes de Antônio, que era também o licenciando mais avançado no programa de iniciação à docência e Licenciatura. Antônio possuía um melhor conhecimento do tema redox e, assim, pôde apresentar uma melhor articulação com os demais conhecimentos docentes. Os outros dois licenciandos apresentavam falhas importantes de conhecimento de conteúdo e tinham de se ancorar nos demais conhecimentos na sala de aula, fragilizando bastante suas ações didáticas e suas possibilidades de desenvolver os conhecimentos base. Esse resultado trouxe indícios de que a inserção do licenciando no programa de iniciação à docência deveria ser analisada considerandose o contexto escolar, o conteúdo a ser ensinado, entre outros aspectos. Nesse sentido, estudos apontam que licenciandos onde os conhecimentos do conteúdo estivessem mais consolidados, tem um desenvolvimento do conhecimento docente mais significativo. Esses indícios foram condizentes com a postura de diversos autores que consideram o conhecimento do conteúdo externo ao PCK (GROSSMAN, 1990; MAGNUSSON; KRAJCIK; BORKO, 1999).

Ao mensurar o conhecimento docente dos pibidianos a partir do olhar dos alunos da educação básica, o instrumento de percepção revelou que os estudantes apreciaram a ação dos mesmos, pois perceberam a capacidade e o compromisso em cada atividade desenvolvida. Os valores encontrados para o Alfa de Cronbach suscitam que o instrumento aplicado produziu mensurações confiáveis. Os discentes consideraram que os pibidianos têm conhecimentos docentes sobre o conhecimento do tema, do contexto, da compreensão dos alunos, métodos de avaliação, entre outros. Os discentes não perceberam as fragilidades apontadas na análise qualitativa para o Conhecimento Docente dos participantes da pesquisa.

Evidenciou-se que para a formação da coordenadora o programa de iniciação à docência possibilitou que Maria refletisse sobre a sua prática, conhecesse a realidade da educação básica e, principalmente, mediasse os processos envolvidos no desenvolvimento do subprojeto. Com relação à supervisora, observou-se que a partir de sua inserção no Pibid ela se percebeu como co-formadora dos licenciandos e observou que suas aulas foram modificadas, devido a cooperação dos Pibidianos no desenvolvimento de suas regências.

Entretanto, a postura, por vezes, pouco adequada da supervisora em alguns episódios chamando a atenção dos pibidianos em frente aos alunos da educação básica, sugere a necessidade de os supervisores estarem mais atentos ao modo como 
exercem suas funções no Pibid e, consequentemente, sobre os objetivos do programa de iniciação à docência.

Conclui-se queo Pibid contribuiu para o processo de construção do conhecimento docente de Mateus, Antônio e Melissa ao oportunizar que esses futuros professores fossem inseridos no contexto da educação básica tendo a orientação de professores experientes, e experienciassem o futuro ambiente de trabalho ainda na formação inicial e por um tempo mais prolongado, se comparado ao estágio supervisionado. Pela descrição realizada para a construção e início do acesso aos conhecimentos para a docência pelos pibidianos, infere-se que que o Pibid vem se constituindo como um terceiro espaço de formação, por seguir uma dinâmica de formação que se distancia do estágio supervisionado e das fronteiras da universidade ao propiciar o entrelaçamento do pibidiano com a educação básica. Além do reflexo nos pibidianos, o programa deixou marcas na coordenadora e na supervisora, que por vez passaram a refletir mais sobre suas ações didáticas, e se sentiram valorizadas pela participação na formação de professores e na aproximação com a universidade, bem como na participação em congressos, além de adquirirem conhecimentos novos relacionados à realidade da escola pública.

De modo geral, o Pibid, como uma política jovem, vem propiciando o aperfeiçoamento e valorização da carreira docente, que pela primeira vez subsidiou de maneira sólida a formação de professores, para além das fronteiras da universidade e do estágio supervisionado. Nesse sentido, o Pibid tem se constituído como um terceiro espaço de formação, possibilitando que o coordenador atue como um mediador na transição do espaço de formação (IES) e atuação (Escola da Educação Básica), o supervisor, seja um co-formador dos licenciandos e o futuro professor, vivencie o ambiente profissional ainda na graduação, por meio da implementação de aulas, da vivência com alunos, professores, gestores, entre outros. Contudo, não se pode ter uma visão ingênua de que o programa de iniciação à docência resolveria problemas historicamente presentes na formação de professores em nosso país. Entretanto, tratase, sem dúvida, de um programa que caminhou na direção de valorização do professor e de seu processo de profissionalização.

Apesar dos impactos positivos do programa para a formação inicial e continuada de professores, o Pibid vem sofrendo duras perdas nos últimos anos. No início de 2016 o governo anunciou o corte de 45.000 bolsas pela portaria $n 046 / 2016$, em decorrência da crise política e econômica instaurada no país. Em ofício, a Capes sinalizou ainda que os participantes do programa que completassem 24 meses seriam desligados de suas funções. Posteriormente, a portaria citada foi revogada, em virtude de uma mobilização de um movimento conhecido "Fica Pibid", que conseguiu revogar a portaria. Todavia, Conclusões 
acredita-se que o programa sofra mais cortes nos próximos anos. Uma situação não desejada em virtude dos impactos relevantes do Pibid para a profissão docente.

O \#ficaPibid está intimamente ligado a um desejo infindável de possibilitar a valorização docente em nosso país. 


\section{REFERÊNCIAS}

AFONSO, A. F. Os professores da escola de educação básica e suas contribuições na formação dos bolsistas de iniciação à docência da área de química. 2013. $161 \mathrm{f}$. Tese (Doutorado) apresentada à Universidade Federal de São Carlos, 2013.

AFONSO, A.F.; MARQUES, R.N.; MARQUES, C.M.P. Considerações iniciais sobre a interação professor-licenciando atuantes no PIBID/UFSCar do curso de Química. In: XVI Encontro Nacional de Ensino de Química (XVI ENEQ) e X Encontro de Educação química da Bahia (X Eduqui). Anais...Salvador: ENEQ, p.1, 2012.

AFONSO, A.F.; MARTINS, G.G.; SILVA, M.J.; GOMES, B.L.; MARQUES, R.N.; MARQUES, C.M.P. A Importância do Professor da Educação Básica na formação do licenciando de Química. In: 34ํReunião Anual da Sociedade Brasileira de Química. Atas...Florianópolis: RASBQ, p.1, 2011.

AFONSO, A.F.; SILVA, M.J.; MARQUES, R.N.; MARQUES, C.M.P. PIBID e Estágio supervisionado: implicações na formação inicial de licenciandos do curso de química da UFSCar. In: VI Encontro Paulista de Ensino de Química. Anais...São Carlos: EPPEQ, p.50, 2011.

AGUIAR, C. A. C.; SOBREIRA, H. A.; SILVA, R. M. G. Projeto Tecnologias digitais na formação de professores apresenta: reações de óxido-redução. In: XIII Encontro Paulista de Ensino de Química. Anais...Campinas: EPPEQ, 2006, p.1.

AHTEE, M.; ASUNTA, T.; PALM, H. Student Teachers Problems in teaching electrolysis with a key demonstration. Chemistry Education: Research and Practice in Europe. v.3, n.3, p. 317-326, 2002.

ALEIXO, A. A.; LEÃO, M. B. C.; SOUZA, F. N. FlexQuest: potencializando a WebQuest no Ensino de Química. R. Faced, Salvador, v.14, p.119-133, 2008.

ALMEIDA, J. S. Currículos da Escola Normal Paulista (1846-1920): Revendo uma Trajetória. R. bras. Est. Pedag., Brasília, v. 76, p.665-689, 1995.

ALMEIDA, M. G. O.; SABINO, J. D.; PEREIRA, M. F.; ANDRADE, A. M. C.; SOUZA, A. M. A. Reação redox e diabetes: uma abordagem experimental e interdisciplinar. In: $37^{\circ}$ Reunião Anual da Sociedade Brasileira de Química. Anais...Natal: RASBQ, 2014, p.1.

ALMEIDA, P. C. A.; BIAJONE, J. Saberes docentes e formação inicial de professores: implicações e desafios para as propostas de formação. Educação e Pesquisa, v. 33, n.2, p.281-295, 2007.

ALMEIDA, V.C. Percursos formativos, profissionais e as práticas dos docentes coordenadores do Programa Institucional de Bolsa DE INICIAÇÃO À DOCÊNCIA - PIBID. 2015. 107 f. Dissertação (Mestrado) Universidade Federal de Viçosa, 2015.

ARANTES, F. J. F. Formação de professores nas licenciaturas do instituto federal goiano: políticas, currículos e docentes. 2013. 141f. Dissertação (Mestrado) Universidade Federal de Goiás, Campus Catalão, Departamento de Educação, 2013.

ARAÚJO, J. C. S. Docência e ética: da dimensão interativa entre sujeitos ao envolvimento sócio institucional. In: ROMANOWISKI, J.P.; MARTINS, R.D.O.; JUNQUEIRA, S.R. (Orgs.). Conhecimento local e conhecimento universal: práticas sociais, aulas, saberes e políticas. Curitiba: Champagnat, 2004.

ARAÚJO, U. F.; PUIG, J. M.; ARANTES, A. A. (Org.). Educação em valores: pontos e contrapontos. São Paulo: Summus, 2007. p.168.

AZEVEDO, F. A Cultura Brasileira. Parte 3. A Transmissão da Cultura. 4. Ed., São Paulo: Melhoramentos; Brasília: INL, 1976. 
AZEVEDO, F. A Cultura Brasileira. Parte 3. A transmissão da Cultura. 7. Ed., São Paulo: Editora da Universidade de São Paulo, 2010.

AZEVEDO, M. C. P. S. Ensino por Investigação: Problematizando as Atividades em Sala de Aula. In: Ensino de Ciências: Únindo a Pesquisa e a Prática. São Paulo: Thomson, Cap. 2, p. 19-34, 2004.

BARDIN, L. Análise de conteúdo. São Paulo: Edições 70, 2011.

BARRETO, B. S. J.; BATISTA, C. H.; COUTINHO, R. S.; SOUSA, N. O.; SANTOS, L. D.; CRUZ, M. C. P. Concepções dos alunos sobre célula galvânica e célula eletrolítica após experimentação para o ensino de eletroquímica. In: XVII Encontro Nacional de Ensino de Química. Anais...Ouro Preto: ENEQ, 2014, p.1503-1513.

BARROS, H. I. C.; BRAGA, D. M. Dificuldades de aprendizagem em eletroquímica: investigação de três questões de vestibulares da UFMG. In: 24ํㅜ Reunião Anual da Sociedade Brasileira de Química. Atas...Poços de Calda: RASBQ, 2001, p.1.

BARROS, H. L. C.; SILVA, P. S.; RIBEIRO, P. E. A. Ensino de Eletroquímica: Relação entre os Aspectos Representacional e Fenomenológico. In: 26ํㅜ Reunião Anual da Sociedade Brasileira de Química. Anais...Poços de Caldas: RASBQ, p.1, 2003.

BARROSO, M.T.; KERMEN. Classificação de tarefas previstas em roteiros de aulas práticas. Uma forma de perceber a concepção de um experimento didático.. In: $37^{\circ}$ Reunião Anual da Sociedade Brasileira de Química. Anais...Natal: RASBQ, 2014, p.1.

BARROSO, M.T.; KERMEN. Comparação dos modos de ação de duas professoras em aulas sobre pilhas eletroquímicas. In: XVII Encontro Nacional de Ensino de Química. Anais...Ouro Preto: ENEQ, 2014, p.3784-3792.

BASTOS, M. H. C. A instrução pública e o ensino mútuo no Brasil: uma história pouco conhecida (1808-1827). Revista História da Educação, v.1, n.1, p.115-133, 1997.

BELTRAME, A. C. F.; PROENÇA, A. O.; MACHADO, T. A. M.; STEVANATO, A.; FERREIRA, F. C. Avaliando a importância do PIBID para estudantes de Licenciatura em Química da UTFPR - Campus Londrina. In: 39 Reunião Anual da Sociedade Brasileira de Química. Anais...Goiânia: RASQ, 2016, 1.

BENIGNO, A. P. A; OLIVEIRA, P. C. C.; FRANCISCO JUNIOR, W. E. Experimentos como estratégia de aprendizagem de processos de oxidação-redução: uma análise da linguagem química. In: XVI Encontro Nacional de Ensino de Química (XVI ENEQ) e X Encontro de Educação química da Bahia (X Eduqui). Atas...Salvador: ENEQ, p.1, 2012.

BERNAL, I.; VALBUENA, E. Estructura sustantiva y sintáctica del conocimiento biológico. Anais I Congreso Nacional de Investigación en Enseñanza de la Biología. VI Encuentro Nacional de Investigación en Enseñanza de la Biología y la Educación Ambiental. Bio-grafías, escritos sobre la biología y su enseñanza, p. 297- 310, 2011.

BIANCHINI, T. B.; ZULIANI, S. R. Q. A. Utilizando a Metodologia Investigativa para diminuir as distâncias entre os alunos e a Eletroquímica. In: XV Encontro Nacional de Ensino de Química. Atas...Brasília: ENEQ, 2010, p.1-12.

BLACKER, D.; ENDICOTT, J. Psychometric properties: concepts of reliability and validity. Handbook of psychiatric measures. Washington, p.7-14, 2002.

BLAND, J. M.; ALTMAN, D. G. Cronbach's alpha. British Medical Journal, p.314-572. 1997.

BOCANEGRA, C. H.; GAZOLA, R. J. C. O uso da eletroquímica em um experimento investigativo: relato de uma atividade de ensino. In: VI Encontro Paulista de Ensino de Química. Anais...São Carlos: EPPEQ, p.1-6, 2011.

BOGDAN, R. S.; BIKEN, S. Investigação qualitativa em educação: uma introdução à teoria e aos métodos. 12.ed. Porto: Porto, 2003 
BORGES, M. C.; AQUINO, O. F.; PUENTES, R. V. Formação de professores no Brasil: história, políticas e perspectiva. Revista HISTEDBR On-Line, Campinas, n.42, p.94-112, 2011.

BOTTI, M.; MEZZAROBA, C. Relação entre as experiências anteriores e a escolha do curso na formação profissional em Educação Física. Revista da Educação Física/UEM, Maringá, v.18, p. 213-216, 2007.

BOUNI, J. P.; EL HAGE, S.; OLFA, S.I; MOHAMED, S. Analysis of electrochemical cells processes simulations. students' points of view. In: C. Bruguière, $A$. Tiberghien \& P. Clément (Eds.), E-Book Eletronic Proceedings of the ESERA 2011 Conference: Science learning and Citizenship. $1^{\circ}$ ed. Lyon, France: European Science Education Research Association. ISBN: 978-9963-700-448, 2011, p.13-19.

BRAGA, M. M.; MIRANDA-PINTO, C. B; CARDEAL, Z. L. Perfil socioeconômico dos alunos, repetência e evasão no curso de química da UFMG. Química Nova, v.20, p.438, 1997.

BRASIL. Lei $n^{\circ}$ 12.305. de 2 de agosto de 2010. Politica Nacional dos Resíduos Sólidos PNSR.

Disponível em:<http://www.planalto.gov.br/ccivil_03/_ato2007-2010/2010/lei/l12305.htm>. Acesso em: 04/12/2014.

BRASIL. Lei no. 9.394, de 20 de dezembro de 1996. Estabelece as Diretrizes e Bases da Educação Nacional. Diário Oficial da União, de 23 de dezembro de 1996.

BRASIL. MINISTÉRIO DA EDUCAÇÃO. Educação de jovens e adultos: proposta curricular para o $1^{\circ}$ segmento do ensino fundamental. São Paulo: Ação Educativa; Brasília: MEC, 1997. [Coordenação e texto final: Vera Maria Masagão Ribeiro]

BRASIL. Orientações Curriculares para o Ensino Médio: Ciências da Natureza, Matemática e suas Tecnologias. (2006). Disponível em: $<$ http://portal.mec.gov.br/seb/arquivos/pdf/book_volume_02_internet.pdf>. Acesso em:05/03/2015.

BRASIL. Resolução CNE 02/2015, de $1^{\circ}$ de Julho de 2015. Define as Diretrizes Curriculares Nacionais para a formação inicial em nível superior (cursos de licenciatura, cursos de formação pedagógica para graduados e cursos de segunda licenciatura) e para a formação continuada. Diário da União, Brasília, 2 de Julho de 2015. Seção 1, p.8-12. Disponível em: < http://pronacampo.mec.gov.br/images/pdf/res_cne_cp_02_03072015.pdf>. Acesso em 16/09/2016.

BRASIL. Resolução CNE/CP 2, de 19 de fevereiro de 2002. Institui a duração e a carga horária dos cursos de licenciatura, de graduação plena, de formação de professores da Educação Básica em nível superior. Diário Oficial da União, Brasília, 4 de março de 2002. Seção 1, p. 9. Disponível em: < http://portal.mec.gov.br/cne/arquivos/pdf/CP022002.pdf>. Acesso em 15/12/2014.

BRASIL. Resolução CNE/CP1, de 18 de fevereiro de 2002. Institui Diretrizes Curriculares Nacionais, para a formação de professores de Educação Básica, em nível superior, curso de licenciatura, de graduação plena. Diário Oficial da União, Brasília, 9 de abril de 2002. Seção 1, p.31. Disponível em: $\quad<$ http://portal.mec.gov.br/cne/arquivos/pdf/009.pdf>. Acesso em:08/06/2015.

BUCAT, R. Pedagogical content knowledge as a way forward: Applied research in chemistry education Chemistry Education: Research and Practice, v.5, n. 3, p.215-228, 2004.

BUTY, C.; TIBERGHIEN, A.; LE MARECHAL, J. F. Learning hyphoteses and an associated tool to design and to analyse teaching-learning sequences. International Journal of Science Education, v. 26, n.5, p.579-604, 2004. 
CAMARGO, C. P.; SILVA, C. S.; OLIVEIRA, O. M. M. F. Iniciação à docência em Química e os saberes necessários à prática educativa: reflexões iniciais pautadas na Pedagogia da Autonomia. In: IX Encontro Nacional de Pesquisa em Educação em Ciências. Anais... Águas de Lindóia: ENPEC, p.1-8, 2013.

CAMPOS, T.C.; OKUBO, T.C.A.Q.; ROSA, M.I.F.P.; PINTO NETO, P.C. Dois Currículos e o mesmo PIBID: reflexão de um bolsista sobre as potencialidades na formação inicia. In: VI Encontro Paulista de Ensino de Química. Anais...Santo André: EPPEQ, p.1-2, 2013.

CANAN, S. R. PIBID: promoção e valorização da formação docente no âmbito da Política Nacional de Formação de Professores. Revista Brasileira de Pesquisa sobre a Formação de Professores, v.4, n.6, p.23-43, 2012.

CARAMEL, N. J. C.; PACCA, J. L. A. Concepções alternativas em eletroquímica e circulação da corrente elétrica. Caderno Brasileiro de Ensino de Física, v.28, n.1, p.7-26, 2011.

CARDOSO, T. F. L. As aulas régias no Brasil. In: STEPHANOU, M.; BASTOS, M. H. C. (Orgs.). Histórias e memórias da educação no Brasil, vol. I: séculos XVIXVIII. Petrópolis, RJ: Vozes, p. 179-191, 2004.

CARMO, H. M. S. As contribuições dos subprojetos do PIBID-UESC para a constituição dos saberes docentes na formação inicial de professores de ciências. 2015. 131 f. Dissertação (Mestrado) - Programa de Pós-Graduação em Educação em Ciências da Universidade Estadual de Santa Cruz, 2015.

CARVALHO, A. M. P. Uma metodologia de pesquisa para estudar os processos de ensino e aprendizagem em salas de aula. In: A pesquisa em ensino de ciências no Brasil e suas metodologias. ljuí: Ed. Unijuí, p.13-48, 2006.

CARVALHO, A. M. P.; GIL-PÉREZ, D.; Formação de professores de Ciências: tendências e inovações, Cortez: São Paulo, 2006.

CARVALHO, Â.P.; RIBEIRO, R.C.S. As contribuições do PIBID Química à formação docente segundo Professores Supervisores. In: XVII Encontro Nacional de Ensino de Química. Anais...Ouro Preto: ENEQ, p.1-11, 2014.

CARVALHO, L. P.; SOBREIRA, H. A.; AGUIAR, C. A. C.; SILVA, R. M. G. Sobre o ensino de reações de óxido-redução. In: 29 Reunião Anual da Sociedade Brasileira de Química. Atas...Águas de Lindóia: RASBQ, p.1, 2006.

CÁSSIO, F.L.; CORDEIRO, D.S; CORIO, P.; FERNANDEZ, C. O protagonismo subestimado dos íons nas transformações químicas em solução por livros didáticos e estudantes de química. Revista Electrónica de Enseñanza de las Ciencias, vol. 11, n. 3, p.595-619, 2012.

CASTANHA, A.P.1827-2007: 180 anos da primeira lei brasileira sobre a escola primária. Simpósio de Educação: Formação de professores no contexto da pedagogia histórico-crítica/XIX Semana de Educação: 35 anos do curso de pedagogia/Campus $\quad$ Cascável. $2007 . \quad$ Disponível em: <http://www.unioeste.br/cursos/cascavel/pedagogia/eventos/2007/trabalhos.ht $\mathrm{ml}$. Acesso em: 27/09/2014.

CASTRO, P. M. A. O PIBID química da UFABC e os reflexos nos conhecimentos docentes de seus graduandos. 2016. 186 f. Dissertação (Mestrado) apresentada ao Programa de Pós-Graduação em Ensino, História e Filosofia das Ciências e Matemática da Universidade Federal do ABC, 2016.

CHASSOT, A. Para Que(m) é Útil o Ensino? 3. Ed., ljuí: Editora Unijuí, 2014.

CHUEIRI, M. S. F. Concepções sobre a Avaliação Escolar. Estudos em Avaliação Educacional, v.19, n.39, p.49-64, 2008.

COORDENAÇÃO DE APERFEIÇOAMENTO DE PESSOAL DE NÍVEL SUPERIOR CAPES. Portaria № 46, DE 11 de abril de 2016. Disponível em: <https://www.capes.gov.br/images/stories/download/legislacao/15042016Portaria-46-Regulamento-PIBID-completa.pdf>. Acesso em 20/10/2016.

COORDENAÇÃO DE APERFEIÇOAMENTO DE PESSOAL DE NÍVEL SUPERIORCAPES. Portaria № 096, de 18 de julho de 2013. Disponível em: 
$<$ https://www.capes.gov.br/images/stories/download/legislacao/Portaria_096_ 18jul13_AprovaRegulamentoPIBID.pdf >. Acesso em: 20/09/2016.

COORDENAÇÃO DE APERFEIÇOAMENTO DE PESSOAL DE NÍVEL SUPERIORCAPES. Programa Institucional de Bolsas de Iniciação à Docência (PIBID). Disponível em: <http://www.capes.gov.br/educacao-basica/capespibid>. Acesso em 30/01/2014.

COORDENAÇÃO DE APERFEIÇOAMENTO DE PESSOAL DE NÍVEL SUPERIORCAPES. EDITAL IFSP/PRE/DGD N060/2014. Disponível em:< http://webcache.googleusercontent.com/search?q=cache:s9VjtAnIMqlJ:www.if sp.edu.br/index.php/arquivos/category/304-bolsas-

pibid.html\%3Fdownload\%3D9260\%253Aedital-aluno-bolsistas-

pibid $+\& c d=1 \& \mathrm{hl}=\mathrm{pt}-\mathrm{BR} \& \mathrm{ct}=\mathrm{clnk} \& \mathrm{gl}=\mathrm{br}>$. Acesso em: 30/01/2014

COORDENAÇÃO DE APERFEIÇOAMENTO DE PESSOAL DE NÍVEL SUPERIORCAPES. Portaria $\mathbf{N}^{\circ}$ 72, de 9 de abril de 2010. Disponível em:< https://www.capes.gov.br/images/stories/download/diversos/Portaria72_PIBID .pdf>. Acesso em: 25/02/2015.

COORDENAÇÃO DE APERFEIÇOAMENTO DE PESSOAL DE NÍVEL SUPERIORCAPES. Diretoria de formação de professores da educação básica (DEB) - Relatório de gestão do PIBID, Brasília, 2013. Disponível em: < https://www.capes.gov.br/images/stories/download/bolsas/1892014-relatorioPIBID.pdf >. Acesso em: 17/06/2015.

CÔRREA, K. R. C.; BATISTA, L. A. PIBID em prática: relato de experiências sob o olhar das supervisoras na escola. In: V SIMFOP- Simpósio sobre formação de professores. Anais... Tubarão: SIMFOF, 2013.

CRESWELL, J.W.; PLANO CLARK, V.L. Pesquisa de métodos mistos. 2.ed. Porto Alegre: Penso, 2013.

CRONBACH, J. L. My current thoughts on coefficient alpha and successor procedures. Educational and Psychological Measurement, v.64, n.3, p.1-36, 2004.

CRONBACH, L. J.; SHAVELSON, R. J. My current thoughts on coefficient alpha and successor procedures. Educational and Psychological Measurement, v.64, n.3, p.391-418, 2004.

CRUZ, Â. C.; SANDRIN, D.; ALMEIDA, L. E.; ANDRAD, D. Eletroquímica: uma abordagem experimental em nível do ensino médio. In: XIII Encontro Nacional de Ensino de Química. Anais...Campinas: ENEQ, 2006, p.1.

CUNHA, A. M.; TUNES, E.; SILVA, R. R. Evasão do curso de química da Universidade de Brasília: a interpretação do aluno evadido. Química Nova, v.24, n.1, p.262280, 2001.

CZEKSTER, H. C.; AGOSTINHO, S. M. L.; MAXIMIANO, F. A. Avaliação de um estudo de caso no ensino de eletroquímica. In: 34ํำ Reunião Anual da Sociedade Brasileira de Química. Anais...Florianópolis: RASBQ, p.1, 2011.

DANTAS, L. K. Iniciação à docência na UFMT: Contribuições do PIBID na formação de professores de química. 2013. 198 f. Dissertação (Mestrado) - Universidade Federal do Mato Grosso, Instituto de Educação, Programa de Pós-Graduação em Educação, Cuiabá, 2013.

DANTAS, L. K.; SOARES, E. C.; MELLO, I. C. Iniciação à Docência em Química na UFMT: O Pibid incentivando a Formação pela Pesquisa. In: XVIII Encontro Nacional de Ensino de Química. Anais...Florianópolis: ENEQ, p.1-8, 2016.

DANTAS, L.K.; MELLO, I.C. O subprojeto de química/PIBID-UFMT: uma reflexão sobre as necessidades formativas e a crise na educação. In: XVI Encontro Nacional de Ensino de Química (XVI ENEQ) e X Encontro de Educação química da Bahia (X Eduqui). Anais...Salvador: ENEQ, p.1-9, 2012.

DE JONG, O., TREAGUST, D. The teaching and learning of electrochemistry. In: J. K. GILBERT, O; DE JONG, R.; JUSTI, D.F.; TREAGUST; J. H. VAN DRIEL, EDS., Chemical Education: towards research-based practice, Dordrecht: Kluwer, p.317-337, 2002. 
DEIMLING, N. N. M. Programa institucional de bolsa de iniciação à docência: contribuições, limites e desafios para a formação docente. 2014. 307 f. Tese (Doutorado) apresentada ao Programa de Pós-Graduação em Educação da Universidade Federal de São Carlos, 2014.

DIAS, D.A.D.; SILVA, N.S.; MATTOS, C.G.V. A importância do PIBID de Química da UFMG para a formação inicial e continuada e para as escolas envolvidas. In: XVII Encontro Nacional de Ensino de Química. Anais...Ouro Preto: ENEQ, p.19, 2014

DIEHL, A. A. Pesquisa em ciências sociais aplicadas: métodos e técnicas. São Paulo: Prentice Hall, 2004.

DUARTE, F.C.T.; BOTELHO, M.L.S.T.; QUADROS, A.L. O professor supervisor do PIBID Química: que atenção tem recebido esse ator? In: XVII Encontro Nacional de Ensino de Química. Anais...Ouro Preto: ENEQ, p.1-8, 2014.

DUARTE, R. Entrevistas em pesquisas qualitativas. Educar em Revista, Curitiba, v.24, p.213-225, 2004.

ECHEVERRÍA, A. R.; MELLO, I. GAUCHE, R. Em Educação Química no Brasil: memórias, políticas e tendências; Rosa, M.I.P.; Rossi, A.V., eds.; Editora Átomo: Campinas, 2008.

EKIZ, B.; KUTUCU, E. S.; AKKUS, H.; BOZ, YEZDAN. Pre-service chemistry teachers' understanding of electrolytic cells. In: C. Bruguière, A. Tiberghien \& P. Clément (Eds.), E-Book Eletronic Proceedings of the ESERA 2011 Conference: Science learning and Citizenship. $1^{\circ}$ ed. Lyon, France: European Science Education Research Association. ISBN: 978-9963-700-44-8, 2011, p.51-54.

ELIAS, P. G. Indícios do conhecimento pedagógico do conteúdo de licenciandos em química durante o estágio supervisionado. 2011, 204 f. Dissertação (Mestrado em Ensino de Ciências) - Instituto de Física, Instituto de Química, Instituto de Biociências, Faculdade de Educação, Universidade de São Paulo, São Paulo.

ENNIS, C. Knowledge and beliefs underlying curricular expertise. Quest, Champaign, v.46, n.2, p.164-75, 1994.

FADIGAS, J. C. A importância do Programa Institucional de Bolsas de Iniciação à Docência para a formação inicial de professores de química no Recôncavo da Bahia. Em: 36으 Reunião Anual da Sociedade Brasileira de Química. Anais...Águas de Lindóia: RASBQ, 1, 2013.

FALCÃO, D; GILBERT, J. K. Método da lembrança estimulada: uma ferramenta de investigação sobre aprendizagens em museus de ciências. Histórias, Ciências e Saúde- Manguinhos, Rio de Janeiro, v. 12 (suplemento), p. 91 $115,2005$.

FARIAS, I. M. S.; JARDILINO, J. R. L.; SILVESTRE, M. A. Aprender a ser professor: aportes de pesquisa sobre o PIBID. Jundiaí, Paco Editorial: 2015.

FELÍCIO, H. M. S. O PIBID como "terceiro espaço" de formação inicial de professores. Rev. Diálogo Educ., Curitiba, v. 14, n. 42, p. 415-434, 2014.

FERNANDES, N.C.; MENDONÇA, P.C.C.; GOMES, A.O. Influências do PIBID na formação dos estudantes de Química da Universidade Federal de Ouro Preto. Em: VIII Encontro Nacional de Pesquisa em Ensino de Ciências. Anais...Campinas: ENPEC, p.1-12, 2011.

FERNANDEZ, C. PCK - Conhecimento Pedagógico do Conteúdo: perspectivas e possibilidades para a formação de professores. In: VIII Encontro Nacional de Pesquisa em Educação em Ciências, 2011, Campinas. Atas do VIII Encontro Nacional de Pesquisa em Educação em Ciências. Rio de Janeiro: UFRJ, v.1, p.1-12, 2011.

FERNANDEZ, C. Knowledge base for teaching and Pedagogical Content Knowledge (PCK): some useful models and implications for teachers'training. Problems of Education in the Twenty First Century, v.60, p.79-100, 2014a. 
FERNANDEZ, C. A base de conhecimentos para o ensino e o Conhecimento Pedagógico do Conteúdo (PCK) de professores de Química. Tese de Livre Docência. Departamento de Química Fundamental do Instituto de Química da Universidade de São Paulo. 331p., 2014b

FERNANDEZ, C. Revisitando a base de conhecimentos e o conhecimento pedagógico do conteúdo (PCK) de professores de ciências. Revista Ensaio, v.17, n.2, p.500-528, 2015.

FERNANDEZ, C.; GOES, L. F. Conhecimento pedagógico do conteúdo: estado da arte no ensino de ciências e matemática. In: Andoni Garritz; Silvio Fernando Daza Rosales; María Gabriela Lorenzo. (Org.). Conocimiento Didáctico del Contenido. Una perspectiva Iberoamericana. 1ed.Saarbrücken, Alemania: Editorial Académica Española, v.1, p.65-99, 2014.

FERNÁNDEZ, I.; GIL, D.; CARRASCOSA, J.; CACHAPUZ, A.; PRAIA, J. Visiones deformadas de la ciencia transmitidas por la enseñanza. Enseñanza de las ciencias, v.20, n.3, p.477-488, 2002.

FERREIRA, M.A.; LIMA, A.B.; KELTE FILHO, I.; TAKATA, N.H.; CHAGAS, N.V. Avaliação do Projeto PIBID nos Colégios de Guarapuava: um olhar de professores e bolsistas. p.1, 2012.

FONTES, A. M.; LOURENÇO, M. F. P.; MESSEDER, J. C. A representação experimental da pilha de Daniell nos livros didáticos: um erro questionado. In: XVI Encontro Nacional de Ensino de Química (XVI ENEQ) e X Encontro de Educação Química da Bahia (X Eduqui). Atas...Salvador: ENEQ, p.1-10, 2012.

FRANCISCO JÚNIOR, W. E.; ZIBETTI, M. L.T. PIBID - Novos ou velhos espaços formativos? Perspectiva para a formação docente em Rondônia e no Brasil. São Carlos: Pedro \& João Editores, 2011.

FREIRE, J. B. Educação de corpo inteiro: teoria e pratica da educação física. São Paulo: Scipione, 1997.

FREIRE, L. I. F.; FERNANDEZ, C. A base de conhecimentos dos professores, a reflexão e o desenvolvimento profissional: um estudo de caso a partir da escrita de diários de aula por estagiários de professores de Química. Revista Brasileira de Estudos Pedagógicos RBEP-INEP, v.96, p.359-379, 2015.

FREIRE, L. I. F.; FERNANDEZ, C. Professores novatos de química e o desenvolvimento do PCK de oxirredução: influências da formação inicial. Educación Química, v.25, n.3, p.312-324, 2014.

FREIRE, M. S.; SILVA JÚNIOR, C. N. S.; SILVA, M. G. L. Dificuldades de aprendizagem no ensino de eletroquímica segundo licenciandos de química. In: VIII Encontro Nacional de Pesquisa em Ensino de Ciências. Anais...Campinas: ENPEC, p.112, 2011.

FREIRE, P. Pedagogia da autonomia: saberes necessários à prática educativa. 20 ed. São Paulo: Paz e Terra, 1996.

FREITAS, A.L.P.; RODRIGUES, S. G. A avaliação da confiabilidade de questionários: uma análise utilizando o coeficiente alfa de Cronbach. In: XII Simpósio de Engenharia de Produção (SIMPEP). Anais...Bauru: SIMPEP, p.1-13, 2005.

FREITAS, L. A. B.; GOMES, R.; MOURA, A. L.; ALMEIDA, M. Â. V. Parceria bolsista PIBID e professora do Ensino Médio: A História da Química como facilitadora na aprendizagem de eletroquímica. In: XVI Encontro Nacional de Ensino de Química (XVI ENEQ) e X Encontro de Educação Química da Bahia (X Eduqui). Atas...Salvador: ENEQ, p.1-8, 2012.

GARCEZ, A.; DUARTE, R.; EISENBERG, Z. Produção e análise de vídeogravações em pesquisas qualitativas. Educação e Pesquisa, v.37, n.2, p.249-262, 2011.

GARNETT, P. J.; TREAGUST D. F. Conceptual difficulties experienced by senior high school students of electrochemistry: electric circuits and oxidationreduction equations. Journal of Research in Science Teaching. v.29, n.2, p.12142, $1992 b$. 
GARNETT, P. J.; TREAGUST D. F. Implications of research on students understanding of electrochemistry for improving science curricula and classroom practice. International Journal of Science Education, v.12, n.2, p.147-156, 1999.

GARNETT, P. J.; TREAGUST D. F..Conceptual difficulties experienced by senior high school students of electrochemistry: electrochemical (galvanic) and electrolytic cells. Journal of Research in Science Teaching. v.29, n.10, p.10799, 1992a.

GATTI, B. A. Formação de professores no Brasil: características e problemas. Educ. Soc., Campinas, v.31, n.113, p.1355-1379, 2010.

GATTI, B. A.; BARRETO, E. S. S. Professores: aspectos de sua profissionalização, formação e valorização social. Brasília, DF: UNESCO, 2009. (Relatório de pesquisa)

GATTI, B. A.; NUNES, M. M. R. (Org.). Formação de professores para o ensino fundamental: estudo de currículos das licenciaturas em Pedagogia, Língua Português, Matemática e Ciências Biológicas. Textos FCC, São Paulo, v.29, p. 155, 2009.

GAUCHE, R.; SILVA, R. R.; BAPTISTA, J. A.; SANTOS, W. L. P.; MÓL, G. S.; MACHADO, P. F. L. Formação de professores de química: concepções e proposições. Revista Química Nova na Escola, n.27, p.26-29, 2008.

GAUTHIER, C; MARTINEAU, S.; DESBIENS, J.; MALO, A.; SIMARD, D. Por uma teoria da pedagogia: pesquisas contemporâneas sobre o saber. Unijui: 3. Ed. da UNIJUI, p.480, 1998.

GIL PÉREZ, D.; MONTORO, I. F.; ALÍS, J.C.; CACHAPUZ, A.; PRAIA, J. Para uma imagem não deformada do trabalho científico. Ciência e Educação, v.7, n.2, p.125-153, 2001.

GIL-PÉREZ, D.; VILCHES, A.; FERREIRA-GAUCHÍA, C. (2008). Overcoming the Oblivion of Technology in Physics Education. Disponível em: < https://web.phys.ksu.edu/icpe/publications/teach2/Gil-perez.pdf >. Acesso em: 10/09/2015.

GIROTTO JÚNIOR, G. Análise do conhecimento pedagógico do conteúdo de professores de Química a partir da perspectiva do educando. 2015. $245 f$. Tese (Doutorado) apresentada ao Instituto de Física, Instituto de Química, Instituto de Biociências e à Faculdade de Educação, Universidade de São Paulo.

GIROTTO JÚNIOR, G. De licenciando a professor de Química: um olhar sobre o desenvolvimento do Conhecimento Pedagógico do Conteúdo. 2012. 160f. Dissertação (Mestrado) apresentada ao Instituto de Física, Instituto de Química, Instituto de Biociências e à Faculdade de Educação, Universidade de São Paulo.

GIROTTO JÚNIOR, G.; FERNANDEZ, C. Following early career Chemistry teachers: the development of Pedagogical Content Knowledge from pre-service to a professional teacher. Problems of Education in the Twenty First Century, v.55, p.57-73, 2013.

GOES, L. F. Conhecimento Pedagógico do Conteúdo: Estado da Arte no Campo da Educação e no Ensino de Química. 2014. 155f. Dissertação (Mestrado) apresentada ao Instituto de Física, Instituto de Química, Instituto de Biociências e à Faculdade de Educação, Universidade de São Paulo.

GOES, L. F.; FERNANDEZ, C. Using CoRes for capturing pedagogical content knowledge of redox reactions. In: J. Lavonen, K. Juuti, J. Lampiselkä, A. Uitto \& K. Hahl. (Org.). E-Book Electronic Proceedings of the ESERA 2015 Conference. In: J. Lavonen, K. Juuti, J. Lampiselkä, A. Uitto \& K. Hahl (Eds.), Electronic Proceedings of the ESERA 2015 Conference. Science education research: Engaging learners for a sustainable future. $1^{\circ}$ ed. Helsinki, Finland: University of Helsinki. ISBN 978-951-51-1541-6, 2015, p.2163-2173. 
GOES, L. F.; LEAL, S. H.; CORIO, P.; FERNANDEZ, C. Aspectos do Conhecimento Pedagógico do Conteúdo de Química Verde em professores universitários de Química. Educación Química, v. 24, p.113-123, 2013.

GOES, L. F.; VAIROLETTE, L.; ALBUQUERQUE, G. Z. C.; BLOISI, G. D.; FERNANDEZ, C.; AGOSTINHO, S. M. L. Reflexos de um curso de formação contínua em Eletroquímica em um grupo de professores do Ensino Médio. In: 39ํReunião Anual da Sociedade Brasileira de Química. Anais...Goiânia: RASQ, 2016, 1.

GOES, L. F.; VAIROLETTE; FERNANDEZ, C.; AGOSTINHO, S. M. L. Concepções e dificuldades de um grupo de professores de química sobre conceitos fundamentais de eletroquímica. In: XVIII Encontro Nacional de Ensino de Química. Anais...Florianópolis: ENEQ, 2016, 1-12.

GOMES, G. S.; FREITAS, K. C. S.; LIMA, A. A.; SILVA, S. A.; SOUZA, S. R. Utilização de um biossensor para dosagem de triglicerídeos em caldos industrializados utilizados na culinária brasileira como ferramenta didática para o ensino de eletroquímica. In: XVII Encontro Nacional de Ensino de Química. Anais...Ouro Preto: ENEQ, 2014, p.1607-1618.

GOMES, J. N.; PEREIRA, L. L. S. As concepções sobre pilhas no âmbito de um curso técnico em química em Goiás. In: XVII Encontro Nacional de Ensino de Química. Anais...Ouro Preto: ENEQ, 2014, p.385-794

GOMES, W. S. B.; GOMES, F. O PIBID na formação dos bolsistas de Licenciatura em Química do IFG - Campus Uruaçu. In: XVIII Encontro Nacional de Ensino de Química. Anais...Florianópolis: ENEQ, p.1-11, 2016.

GROSSMAN, P. L. The making of a teacher: teacher knowledge and teacher education. New York: Teachers College Press, 1990.

GROSSMAN, P. L; WILSON, S. M.; SHULMAN, L. Teachers of substance: subject matter knowledge for teaching. In: Reynolds, M.C. (Ed.): Knowledge Base for the Beginning Teacher. Oxford: Pergamon Press, 1989.

HAIR, A. Análise multivariada de dados. 5. Ed. Porto Alegre: Bookman, 2005.

HAYES, B. E. Measuring Customer Satisfaction: Survey design, use, and statistical analysis methods. Milwaukee, Wisconsin: ASQC Quality Press, 1998.

HEIDE, A.; STILBORN, L. Guia do professor para a internet: completo e fácil. Tradução de Edson Furmankiewz. 2. ed. Porto Alegre: Artes Médicas, 2000.

HERBER, J.; SEVERO FILHO, W. A.; PINO, J. C. D. Avaliação do Pibid/SubprojetoQuímica a partir da análise das atividades desenvolvidas nas escolas parceiras nos anos de 2014 e 2015. In: XVIII Encontro Nacional de Ensino de Química. Anais....Florianópolis: ENEQ, p.1-11, 2016.

HERBER, J.; SEVERO FILHO, W.A.; ROHLFES, A.L.B.; BACCAR, N.M.; DEL PINO, J.C. O subprojeto Pibid/Química da Universidade de Santa Cruz do Sul - RS. Em: 38ำ Reunião Anual da Sociedade Brasileira de Química. Anais...Águas de Lindóia: RASBQ, 1, 2015.

HILSDORF, M.L.S. História da educação brasileira: Leituras. São Paulo: Thomson Learning Edições, 2006.

HOFFMANN, J. Avaliação Mediadora: uma prática em construção da pré-escola à universidade. Porto Alegre: Mediação, 2009.

HUDLE, P. A.; WHITE, M. D.; ROGERS, F. Using a teaching model to correct known misconceptions in electrochemistry. Journal of Chemical Education. v.77, n.1, p.104-110, 2000.

IGNE, M. C. I.; JUNIOR, J. C. L; HADDAD, E. B; CAMPANERUT, F. Z.; VALLECA, R. F. E; FALJONI-ALARIO, A. Investigando as Concepções Alternativas dos Estudantes sobre Eletroquímica. In: XIII Encontro Nacional de Ensino de Química. Anais...Campinas: ENEQ, 2006, p.1-8.

JANG, S. J.; GUAN, S. Y.; HSIEH, H. F. Developing an instrument for assessing college students' perceptions of teachers' pedagogical content knowledge. Procedia Social and Behavioral ciences, v.1, n.1, p.596-606, 2009. 
KLÜBER, Tiago Emanuel. Atlas/ti como instrumento de análise em pesquisa qualitativa de abordagem fenomenológica. ETD - Educ. tem. digit., Campinas, SP, v. 16, n. 1, p.5-23, jan./abr. 2014.

KOTHZ, J. C.; TREICHEL JUNIOR, P. M. Química geral 1 e reações químicas. Tradução técnica Flávio Maron Vichi. São Paulo: Pioneira Thomson Learning, 2005.

KRUS, D. J.; HELMSTADTER, G. C. The problem of negative reliabilities. Educational and Psychological Measurement. v.53, p.643-650. 1993.

LANDIS, J. R.; KOCH, G. G., The measurement of observer agreement for categorical data. Biometrics, v.33, p.159-174, 1977.

LEAL, S. H. B. S.; NOVAIS, R. M.; FERNANDEZ, C. Conhecimento Pedagógico do Conteúdo de Estrutura da Matéria de uma Professora de Química Experiente em aulas de Química Geral. Ciência \& Educação, v.21, p.725-742, 2015.

LEONTITSIS, A.; PAGGE, J. A simulation approach on Cronbach's alpha statistical significance. Mathematics and Computers in Simulation. v.73, p.336-340. 2007.

LIBÂNEO, J. C. Didática. Cortez Editora: São Paulo, Coleção Magistério $2^{\circ}$ Grau Série Formando Professor, 1994.

LIJNSE, P. L. La recherche-developpement: une voie vers une structure didactique de la physique empiriquement fondee. Didaskalia, v.3, p.93-108, 1994.

LIJNSE, P. L.; KLAASSEN, K. Didactical structures as an outcome of research on teaching learning sequences? International Journal of Science Education, v.26 n.5, p.537-554, 2004.

LIMA, J. C.; TEIXEIRA JÚNIOR, J. G. Análise das dificuldades conceituais dos alunos do Ensino Médio sobre o conteúdo de Eletroquímica. In: XVII Encontro Nacional de Ensino de Química. Anais...Ouro Preto: ENEQ, 2014, p.3720.

LIMA, J.P.M.; ANDRADE, D.; SUSSUCHI, M.; Contribuições do PIBID/química/UFS/São Cristóvão na formação inicial de professores de química. In: VI Encontro Paulista de Ensino de Química. Anais...Santo André: EPPEQ, p.1-4, 2013.

LIMA, S. P. Os paradigmas atuais da formação docente: olhares sobre o PIBID. 2015. 198 f. Dissertação (Mestrado) apresentada ao Programa de Pós-Graduação em Educação da Universidade Federal de Rondônia, 2015.

LIMA, V. A.; AGOSTINHO, S. M. L.; MARCONDES, M. E. R. Reflexão de um grupo de professores sobre o Ensino de Eletroquímica em um Curso de Formação Continuada. In: 27ํㅡㄹ Reunião Anual da Sociedade Brasileira de Química. Atas...Salvador: RASBQ, p.1, 2004.

LIMA, V. A.; AKAHOSHI, L. H.; MARCONDES, M. E. R. Análise de mapas conceituais elaborados por professores de química para o ensino de eletroquímica. In: v Encontro Nacional de Pesquisa em Educação em Ciências. Anais...Bauru: ENPEC, p.1-10, 2005.

LIMA, V. A.; MARCONDES, M. E. R. Atividades experimentais no ensino de química. Reflexões de um grupo de professores a partir do tema eletroquímica. Enseñanza de las Ciencias, v. extra, p.1-4, 2005.

LIMA, V.A. A formação inicial de professores de Química no Tocantins: colaboração Universidade e escola. In: $34^{\circ}$ Reunião Anual da Sociedade Brasileira de Química. Atas...Florianópolis: RASBQ, p.1, 2011.

LÔBO, S. F. O trabalho experimental no ensino de química. Química Nova, v.35, n.2, p.430-434, 2012.

LOCATELLI, S. W.; ARROIO A. Estratégia metavisual no auxílio a reconhecer submicroscopicamente diferenças de tamanho (átomo/cátion) numa interação eletroquímica. In: XVII Encontro Nacional de ensino de química. Anais...Ouro Preto: ENEQ, 2014, p.959.

LOIZOS, P. Vídeo, filme e fotografias como documentos de pesquisa. In: BAUER, M. W.; GASKELL, G. (Orgs.). Pesquisa qualitativa com texto, imagem e som. 2 ed. Petrópolis: Vozes, p.137-155, 2008. 
LONGHIN, S. R.; ZANON, C. R. R.; SOUZA, J. T.; PEREIRA, M. C. Estágio Supervisionado e PIBID: Ações e Reflexões. In: XVIII Encontro Nacional de Ensino de Química. Anais...Florianópolis: ENEQ, p.1, 2016.

LOPES, E. M. T.; FARIA FILHO, L. M.; VEIGA, C.G. (orgs.). 500 anos de educação no Brasil. 5 ed. Belo Horizonte: Autêntica, 2011, p.43-251.

LOUGHRAN, J., MULHALL, P.; BERRY, A. In search of pedagogical content knowledge in science: developing ways of articulating and documenting professional practice. Journal of Research in Science Teaching, v.41, n.4, p.370-391, 2004.

LUDKE, M.; ANDRÉ, M. E. D. A. Pesquisa em educação: abordagens qualitativas. São Paulo, Editora Pedagógica e Universitária, 1986.

MACHADO, J.L.; BANDEIRA, J.N.C.; FAZOLO, M.; GUEDES, N.A.; FERNANDES, K.S.; CARVALHO, T.M.; ASSIS, J.; PROFETI, D.; MIGLIO, H.S.; VOGEL, M.; VOGEL, A.J.Z.; PATROCÍNIO, M. G.C.T. Reflexões de licenciandos no âmbito do subprojeto PIBIDUFES-Quimica-Alegre direcionados a formação inicial docente. In: XVII Encontro Nacional de Ensino de Química. Anais...Ouro Preto: ENEQ, p.1, 2014.

MACIEL, J. A; SANTOS, A. L.; NÓBREGA, D. S. Eletroforca: A eletroquímica trabalhada em um contexto lúdico. In: XVII Encontro Nacional de ensino de química. Anais...Ouro Preto: ENEQ, 2014, p.5279.

MAGNUSSON, S.; KRAJCIK, L.; BORKO, H. Nature, sources and development of pedagogical content knowledge. In: GESS-NEWSOME, J.; LEDERMAN, N.G. (Eds.). Examining pedagogical content knowledge: the construct and its implications for science education. Dordrecht, The Netherlands: Kluwer Academics, p. 95-132, 1999.

MAIA, J. O.; SANJUAN M. E. C.; SANTO, C. V.; SILVA, A. F. A.; WARTHA, E. J. Maresia: Uma proposta para o ensino de eletroquímica. In: XIV Encontro Nacional de ensino de química. Anais...Curitiba: ENEQ, 2008, p.1-9.

MAIA, J. O.; SEGRE, N.; SCATIGNO, A.C.; STELLA, M. B. Experimento sobre a Influência do pH na Corrosão do Ferro. Quím. nova esc., v.37, n.1, p. 71-75, 2014.

MALDANER, O. A. A Formação Inicial e Continuada de Professores de Química Professores /Pesquisadores. ljuí: Editora Unijuí, 2003.

MALDANER, O. A. A pesquisa como perspectiva de formação continuada do professor de química. Química Nova, v.22, n.78, p.289-292, 1999.

MALHOTRA, N. Pesquisa de marketing: uma orientação aplicada. 6. ed. Porto Alegre: Bookman, 2011. 768p.

MANACORDA, M. A. História da Educação: da antiguidade aos nossos dias. Tradução Gaetano Lo Mônaco; revisão técnica da tradução e revisão geral Paolo Nosella, 13. Ed., São Paulo: Cortez, 2010.

MANZINI, E. J. A entrevista na pesquisa social. Didática, v.26/27, p.149-158, 1991.

MANZINI, E. J. Considerações sobre a elaboração de roteiro para entrevista semiestruturada. In: Maria Cristina Marquezine, Maria Amélia Almeida, Sadao Omote (Orgs.). Colóquios sobre pesquisa em educação especial. Londrina: Eduel, 2003, p.11-25.

MARTINS, A.C.; LOURENÇO, V.D.; MARQUES, C.M.P.; ZANON, D.A.V. Olhares sobre a iniciação à docência e ao ensino de Ciências: depoimentos de licenciandos em Química. In: XVI Encontro Nacional de Ensino de Química (XVI ENEQ) e X Encontro de Educação química da Bahia (X Eduqui). Anais...Salvador: ENEQ, p.1, 2012.

MARTINS, D. J. S. As repercussões do Programa Institucional de Bolsa de Iniciação à Docência do Instituto Federal de Educação Ciência e Tecnologia do Sertão Pernambucano para a formação inicial do docente. 2016. 101 f. Centro Universitário Univates Programa de Pós-Graduação Stricto Sensu Mestrado em Ensino, 2016. 
MARTINS, T. D.; OLIVEIRA, A. J.; RODRIGUES, L. L.; SANTOS, I. M.; MASSENA, E. $P$. Memoriais: percursos formativos que se constituem a partir da iniciação à docência no PIBID. In: XVI Encontro Nacional de Ensino de Química (XVI ENEQ) e $X$ Encontro de Educação química da Bahia (X Eduqui). Anais...Salvador: ENEQ, p.1, 2012.

MASSENA, E. P. Avaliando a produção científica em torno do PIBID: tendências, relevâncias e silenciamentos. In: IX Encontro Nacional de Pesquisa em Educação em Ciências. Anais... Águas de Lindóia: ENPEC, p.1-8, 2013.

MASSON, N. C.; TAKATA, N. H.; RODRIGUES, P. R. P.; AGOSTINHO, S. M. L. Avaliação dos conceitos relacionados às reações de oxidação-redução utilizando mapas conceituais. In: 25ํㅡㄹ Reunião Anual da Sociedade Brasileira de Química. Anais...Poços de Caldas: RASBQ, p.1, 2002.

MATOS, A. B.S.; CUSTÓDIO, C. C.; PEREIRA, T.; MARQUES, B. V.; VERDELONE, I.; Lencastre, K. PIBID - a influência do projeto na formação de docentes em um curso EAD. In: XVI Encontro Nacional de Ensino de Química (XVI ENEQ) e X Encontro de Educação química da Bahia (X Eduqui). Anais...Salvador: ENEQ, p.1, 2012.

MATOS, L.A.C.; CHAGAS, N.V.; TAKATA, N.H. A contribuição das atividades do projeto PIBID na formação do licenciando em Química. In: 34ํ Reunião Anual da Sociedade Brasileira de Química. Atas...Florianópolis: RASBQ, p.1, 2011.

MATOS, D. C. V. S. Estágio supervisionado x pibid: duas faces da mesma moeda? Revista (Con)textos Língusticos, v. 9, n.14, p.93-105, 2015.

MELLO, G. N. de. Formação inicial de professores para a educação básica: uma (re) visão radical. Revista Iberoamericana de educación, OEl, n.25, p.1-16, 2001.

MELO, A. M. O.; SANTOS, M. G.; SANTOS, W. C. A influência da realidade escolar sobre a forma de atuação dos bolsistas do PIBID: Um estudo realizado no subprojeto da Licenciatura em Química do IFBA de Vitória da Conquista - BA. In: XVIII Encontro Nacional de Ensino de Química. Anais...Florianópolis: ENEQ, p.1, 2016.

MELO, B. M. N.; SOUSA, E.C.; CINTRA, E. P. Análises estatística e pedagógica de itens envolvendo conceitos de eletroquímica do ENEM (2009 a 2013). In: 38응 Reunião Anual da Sociedade Brasileira de Química. Anais...Águas de Lindóia: RASBQ, 2015, 1.

MENDES, A. M. V.; BATINGA, V. T. S.; CAMPOS, A. F. Análise de uma atividade experimental envolvendo o uso de um inibidor químico em alimentos: uma abordagem com alunos da rede pública de ensino na cidade de Recife-PE. In: XVII Encontro Nacional de Ensino de Química. Anais...Ouro Preto: ENEQ, p.4239-4245, 2014

MENDONÇA, A. W. P. A. A gênese de uma profissão fragmentada. Revista Brasileira de História da Educação, v.15, p.31-52, 2007.

MENDONÇA, A. W. P. A. Reforma Pombalina dos estudos secundários e seu impacto no processo de profissionalização do professor. EDUCAÇÃO (UFSM), Santa Maria, v.30, n2, p.27-42, 2005.

MENEZES, B.A.T.; FARIA, N.C.A.; SILVA, R.A.B.; ARAÚJO, S.; PINHO, GABRIELA S. A.; SILVA, V.D. PIBID: Uma maneira de quebrar os paradigmas da sociedade perante o profissional da área da educação. In: XVI Encontro Nacional de Ensino de Química (XVI ENEQ) e X Encontro de Educação química da Bahia (X Eduqui). Anais...Salvador: ENEQ, p.1, 2012.

MESQUITA, N. A. S.; SOARES, M. H. F. B. Aspectos históricos dos cursos de licenciatura e química no Brasil nas décadas de 1930 a 1980. Química Nova, v.34, n.1, p.165-174, 2011.

MESQUITA, N. A. S.; SOARES, M. H. F. B. Relações entre concepções epistemológicas e perfil profissional presentes em projetos pedagógicos de cursos de licenciatura em química do estado de Goiás. Química Nova na Escola, v.31, n.2, p.123-131, 2009. 
MIRALLES, M.V.; MONTIEL, G.; ODETTI, H. Analisis de las dificultades en el aprendizaje autogestionado de un tema. Enseñanza de las Ciencias, v. extra, 2009, p.1861-1867.

MIZUKAMI, M.G. Aprendizagem da docência: algumas contribuições de L. S. Shulman. Revista Educação, v.29, n.2, p.1-11, 2004.

MONTENEGRO, V. L S.; FERNANDEZ, C. Processo reflexivo e desenvolvimento do conhecimento pedagógico do conteúdo numa intervenção formativa com professores de química. Revista Ensaio, v.17, n.1, p.251-275, 2015.

MONTENEGRO, V. L. S. Processo reflexivo e o desenvolvimento do Conhecimento Pedagógico do Conteúdo: análise a partir de uma intervenção na formação contínua de professores de química. 2011. 270f. Dissertação (Mestrado) apresentada ao Instituto de Física, Instituto de Química, Instituto de Biociências e à Faculdade de Educação, Universidade de São Paulo.

MORAES, R. Uma experiência de pesquisa coletiva: introdução à análise de conteúdo. In GRILLO, M.C.; MEDEIROS, M.F. (Org). A construção do conhecimento e sua mediação metodológica. Porto Alegre: EDIPUCRS, 1999, p.45-63.

MORAES, R.; RAMOS, M. G.; GALIAZZI, M. C. (1999). O processo de fazer ciência para a reconstrução do conhecimento em Química: a linguagem na sala de aula com pesquisa. Disponível em: < http://www.sbq.org.br/30ra/Workshop\%20PUC\%20URG.pdf>. Acesso em: 17/09/2015.

MOURA, A. L.; MATA, M. M. S.; CUSTÓDIO, A. C.; CORREIA, J. K.; SOUZA, F. R.; SILVA, L.A. Experimentação no Ensino de Eletroquímica: Pilha e Eletrolise. In: XVII Encontro Nacional de Ensino de Química. Anais...Ouro Preto: ENEQ, 2014, p.4324.

NAKANISHI, Y.Y.; ALTARUGIO, M.H. Reflexão sobre a prática: as experiências de uma professora de ciências na supervisão do PIBID. In: VI Encontro Paulista de Ensino de Química. Anais...São Carlos: EPPEQ, p.131-136, 2011.

NASCIMENTO, M. G. S.; MELO, N. M. C. O.; REGIANI, A. M. Usando pilhas e baterias, instrumentos facilitadores de aprendizagem para o ensino médio. In: XVII Encontro Nacional de Ensino de Química. Anais...Ouro Preto: ENEQ, 2014, p.3283-3292.

NASCIMENTO, R. L. O ensino de química na modalidade Educação de Jovens e Adultos e o cotidiano como estratégia de ensino/aprendizagem. 2012. 32 f. Monografia (Licenciatura em Química) - Setor de Ciências Exatas, Faculdade Integrada da Grande Fortaleza, Peabiru, 2012. Disponível em: < http://www.nead.fgf.edu.br/novo/material/monografias_quimica/rosimar_luca_ do_nascimento.pdf >. Acesso em: 25 de janeiro de 2016.

NASCIMENTO, V. R.; ALVES, S. D. B.; SANTOS, D. G.; NUNES, S. M. T. Análise da importância do PIBID na formação de professores de química. In: XVI Encontro Nacional de Ensino de Química (XVI ENEQ) e X Encontro de Educação química da Bahia (X Eduqui). Anais...Salvador: ENEQ, p.1, 2012.

NOGUEIRA, K. S. C.; GOES, L. F.; FERNANDEZ, C. As limitações de ensinoaprendizagem associadas ao conteúdo redox nos eventos brasileiros. Ensenanza de Las Ciencias, v. Extra, p. 4197-4202, 2017.

NOVAIS, R. M.; FERNANDEZ, C. A gestão da sala de aula de um professor do Ensino Superior. Campo Abierto, v.33, p.141-165, 2014.

NOVAIS, R. M.; LEAL, S. B. S.; FERNANDEZ, C. O uso de vídeo gravações na pesquisa qualitativa em ensino de Química: um relato de experiência. In: VI EPPEQ Encontro Paulista de Pesquisa em Ensino de Química, Caderno de Resumos do VI EPPEQ -Encontro Paulista de Pesquisa em Ensino de Química. São Carlos: Universidade de São Paulo, v.1, p.1, 2011.

NOVAIS, R. M.; VAIROLETTE, L.; AGOSTINHO, S. M.; FERNANDEZ, C. Concepções de professores de Química da Educação Básica sobre "radicais livres" e 
“antioxidantes". In: $37^{\circ}$ Reunião Anual da Sociedade Brasileira de Química. Anais...Natal: RASBQ, 2014, p.1.

NÓVOA, A. Profissão professor. Porto, Portugal: Porto Editora, 1995.

NÓVOA, A.. Os professores e a sua formação. São Paulo: Dom Quixote, 1992.

NUNES, C. T. S.; DIAS, A. A. S. L.; GAMA, A. J.; SANTOS, J. L.; SILVA, J. C.; SILVA, E. L. O ensino de Eletroquímica: desenvolvimento, aplicação e validação de uma Sequência de Ensino Aprendizagem. In: IX Encontro Nacional de Pesquisa em Educação em Ciências. Anais... Águas de Lindóia: ENPEC, 2013, p.1-8.

OBARA, C. E.; PASSOS, M. M.; BROIETTI, F. C. D.; STANZANI, E. L. Contribuições do PIBID para a aprendizagem docente. In: XVIII Encontro Nacional de Ensino de Química. Anais...Florianópolis: ENEQ, p.1-11, 2016.

OGUDE, A. N.; BRADLEY, J. D. Ionic conduction and electrical neutrality in operating electrochemical cells. Journal of Chemical Education. v.71, n.1, p. 29-34, 1994.

OLIVEIRA JÚNIOR, M. M. Flashes das disciplinas de formação inicial no repertório profissional de licenciandos em química. 2011, 194 f. Dissertação (Mestrado em Ensino de Ciências) - Instituto de Física, Instituto de Química, Instituto de Biociências, Faculdade de Educação, Universidade de São Paulo, São Paulo, 2012.

OLIVEIRA, C.V.; SIQUEIRA, B.I.; SUART, R.C. Contribuições do PIBID para a formação inicial docente: investigando os materiais produzidos por licenciadas de química. In: XVII Encontro Nacional de Ensino de Química. Anais...Ouro Preto: ENEQ, p.1, 2014.

OLIVEIRA, N.T.C.; SILVA, F.T.; VIEIRA, M.B.; AMARAL, E.M.R. Contribuição de atividades do PIBID/QUÍMICA na formação de futuros professores de química. In: $34^{\circ}$ Reunião Anual da Sociedade Brasileira de Química. Atas...Florianópolis: RASBQ, p.1, 2011.

OLIVEIRA, R.S.A. P.; TORRES, B. B. Conceitos alternativos sobre radicais livres em pós-graduandos e professores de Ensino Médio de escolas públicas. In: X Encontro Nacional de Pesquisa em Ensino de Ciências. Anais... Águas de Lindóia: ENPEC, 2015, 1-8.

ÖZKAYA, A. R. Conceptual Difficulties Experienced by Prospective Teachers in Electrochemistry: Half-Cell Potential, Cell Potential, and Electrochemical Equilibrium in Galvanic Cells. Journal of Chemical Education, v.79, n.6, p.735-738, 2002.

ÖZKAYA, A. R.; UCE, M.; SAHIN, M. Prospective teachers' conceptual understanding of electrochemistry: galvanic and electrolytic cells. University Chemistry Education, v.7, p.1-12, 2003.

PAGANINI, T. I. O.; GOMES, K. A.; PONZONI, A. C. I. Impacto do sub-projeto PIBID Química UFRuralRJ na escolha profissional dos graduandos e graduados participantes do projeto. In: 38으 Reunião Anual da Sociedade Brasileira de Química. Anais...Águas de Lindóia: RASBQ, 1, 2015.

PARÂMETROS CURRÍCULARES NACIONAIS - PCN (Ensino Médio). Disponível em: $<$ http://portal.mec.gov.br/seb/arquivos/pdf/ciencian.pdf>. Acesso em:07/03/2017.

PARK, S. H.; OLIVER, J. S. Revisiting the conceptualization of Pedagogical Content Knowledge: PCK as a Conceptual Tool to Understand Teachers as Professionals. Research in Science Education, v.38, n.3, p.261-284, 2008a.

PARK, S.; CHEN, Y. C. Mapping out the integration of the components of pedagogical content knowledge (PCK): examples from high school biology classrooms. Journal of Research in Science Teaching, v.49, n.7, p.922-941, 2012.

PARK, S.; OLIVER, J. S. National Board Certification (NBC) as a catalyst for teachers' learning about teaching: The effects of the NBC process on candidate Teachers' 
PCK development. Journal of Research in Science Teaching, v.45, n.7, p.812-834, 2008b.

PASSOS, C.G.; SALGADO, T.D.M. Interação Universidade-Escola: conquistas e perspectivas do Subprojeto PIBID/Química da UFRGS. In: XVII Encontro Nacional de Ensino de Química. Anais...Ouro Preto: ENEQ, p.1-8, 2014.

PEREIRA, A. A. B. "Eletroquímica: um grande choque" - webquest para construção de conhecimento de química no ensino médio. (Dissertação de mestrado). $128 \mathrm{f}$. Campo Grande-MS; Instituto de Física da Universidade Federal de Mato Grosso do Sul, 2014.

PEREIRA, C.L.N.; ADAMS, F.W.; SANTOS, D.G.; NUNES, S.M.T. Os bolsistas PIBID na elaboração de suas aulas. In: XVI Encontro Nacional de Ensino de Química (XVI ENEQ) e X Encontro de Educação química da Bahia (X Eduqui). Anais...Salvador: ENEQ, p.1, 2012.

PEREIRA, J. E. D. As licenciaturas e as novas políticas educacionais para a formação docente. Educ. Soc. v.20, n.68, p.109-125, 1999.

PEREIRA, J. E. D. Formação de professores: pesquisas, representações e poder. Belo Horizonte: Autêntica, 2000.

PEREIRA, P. G. E. M.; FERNANDEZ, C. Indícios do Modelo Integrativo no desenvolvimento do PCK em licenciandos em Química durante o estágio supervisionado. Revista de Educación en Ciencias, v.14, n.2, 74-78, 2013.

PERRENOUD, P. A prática reflexiva no ofício do professor: Profissionalização e Razão Pedagógica. Porto Alegre: Artmed, 2002.

PERRENOUD, P. Avaliação: da excelência à regulação das aprendizagens. Porto Alegre: Artmed, 2007.

PIANA, C. F. B.; MACHADO, A. A.; SELAU, L. P. R. Estatística básica: versão preliminar. Pelotas. (2009). Disponível em: < http://minerva.ufpel.edu.br/ markus.stein/Apostila_EB.pdf>. Acesso em: 05/09/2015.

PIMENTA, S. G. (org). Saberes pedagógicos e atividade docente. 8. Ed. São Paulo: Cortez, 2012. p. 248.

PIMENTA, S. G.; LIMA, M. S. L. L. O estágio e docência. São Paulo: Cortez, 2004.

PINHO, G.S.A. A interface entre três saberes: educação, química e psicologia - PIBID no Instituto Federal DO Rio de Janeiro (IFRJ). In: XVI Encontro Nacional de Ensino de Química (XVI ENEQ) e X Encontro de Educação química da Bahia (X Eduqui). Anais...Salvador: ENEQ, p.1-8, 2012.

PINTO, M.F.S.; ANDRADE, D.; LIMA, J.P.M. PIBID e formação inicial de professores: o olhar dos bolsistas do PIBID/química da UFS/São Cristóvão sobre as atividades desenvolvidas. In: XVII Encontro Nacional de Ensino de Química. Anais...Ouro Preto: ENEQ, p.1-10, 2014.

PITANGA, Â. F.; OLIVEIRA, E. C. Radicais livres e antioxidantes: Atividade investigativa sobre reações de oxirredução em compostos orgânicos. In: 32ํReunião Anual da Sociedade Brasileira de Química. Atas...Fortaleza: RASBQ, p.1, 2009.

PRADO, J.V.; SILVA JÚNIOR, A.J. Júnior. A Formação de professores e a Educação como escolha (ou não) para os bolsistas do PIBID-UESB campus de ItapetingaBa. In: XVII Encontro Nacional de Ensino de Química. Anais...Ouro Preto: ENEQ, p.1, 2014.

PRIMI, R.; MUNHOZ, A. M. H.; BIGHETTI, C. A.; DI NUCCI, E. P.; PELLEGRINI, M. C. K.; MOGGI, M. A. Desenvolvimento de um inventário de levantamento das dificuldades da decisão profissional. Psicologia: Reflexão e Crítica, v.13, n.3, p.451-463, 2000.

RAMOS, E. A.; PEREIRA, J. A.; LOPES, S. A.; PINHEIRO, P. C. Ensinando eletroquímica: o que os alunos querem saber? In: XV Encontro Nacional de Ensino de Química. Atas...Brasília: ENEQ, 2010, p.1.

RIZZATTI, I.M.; SOUSA, E.S.; MEDEIROS, I.J.S.; LIMA, E.F. O PIBID como ferramenta complementar na formação dos acadêmicos de licenciatura em química da 
Universidade Estadual de Roraima. In: XVII Encontro Nacional de Ensino de Química. Anais...Ouro Preto: ENEQ, p.1-8, 2014.

ROCHA, M. A. G.; LIMA, M. C. P.; PINHO, G. S.A. A contribuição do PIBIDQuímica/IFRJ-Campus Duque de Caxias na formação continuada do professor supervisor. In: XVIII Encontro Nacional de Ensino de Química. Anais...Florianópolis: ENEQ, p.1, 2016.

ROLLNICK, M.; BENNETT, J.; RHEMTULA, M.; DHARSEY, N.; NDLOVU, T. The Place of Subject Matter Knowledge in Pedagogical Content Knowledge: A case study of South African teachers teaching the amount of substance and chemical equilibrium. International Journal of Science Education, v.30, n.10, p.13651387, 2008.

ROLLNICK, M.; MAVHUNGA, E. PCK of teaching electrochemistry in chemistry teachers: A case in Johannesburg, Gauteng Province, South Africa. Educ. quím., v.25, n.3, p.354-362, 2014.

ROSA, C. W.; ROSA, A. B. Discutindo as concepções epistemológicas a partir da metodologia utilizada no laboratório didático de Física. Revista Iberoamericana de Educación / Revista Ibero-americana de Educação, n. 52/6, p.1-10, 2010.

ROSA, D. L. A sistematização dos saberes docentes na formação inicial de professores de química na Universidade Federal do Espírito Santo. 2016. 123 f. Dissertação (Mestrado) apresentada ao Programa de Pós-Graduação em Ensino na Educação Básica do Centro Universitário Norte do Espírito Santo da Universidade Federal do Espírito Santo, 2016.

ROSA, D. L.; MENDES, A. N. F.; LOCATELLI, A. B. A constituição da identidade docente e a epistemologia da prática na formação inicial de professores de Química participantes do PIBID. In: XVIII Encontro Nacional de Ensino de Química. Anais...Florianópolis: ENEQ, p.1-11, 2016.

RAMOS, D. C. P.; ARAÚJO, R. S.; SANTANA, R. O. A internet como fonte de análise para o pibid e a formação inicial docente. Revista de Pesquisa Interdisciplinar, Cajazeiras, v. 1, Ed. Especial, p.63-72, 2016.

ROZO, E. F. G. Las prácticas de laboratorio en la formación inicial de profesores de ciencias. Una aproximación al análisis epistemológico y didáctico para el caso de la bioquímica. 2012. 256f. Tesis de Maestría. Universidad Pedagógica Nacional.

RUTHVEN, K.; LABORDE, C.; LEACH, J.; TIBERGHIEN, A. Design tools in didactical reasearch: instrumenting the epistemological and cognitive aspects of the design of teaching sequences. Educational Researcher, v.38, n.5, p.329-342, 2009.

SÁ, C. S.; MOREIRA, B. C. T.; BELLAS, R. R. D.; VARJÃO, T. A. Constituição de identidades docentes em atividades do Pibid. In: XVII Encontro Nacional de Ensino de Química. Anais...Ouro Preto: ENEQ, p.1-10, 2014.

SÁ, C. S.; SANTOS, W.L.P. Motivação para a carreira docente e construção de identidades: o papel dos pesquisadores em ensino de química. Quim. Nova, v. 39, n.1, p.104-111, 2016.

SALAZAR, S. F. El conocimiento pedagógico del contenido como categoría de estudio de La formación docente. Actualidades investigativas en educación, v.5, n.2, 2005.

SALES, M. G. P. Investigando o conhecimento pedagógico do conteúdo sobre "soluções" de uma professora de Química. 2010. 253 f. Dissertação (Mestrado) apresentada ao Instituto de Física, ao Instituto de Química, ao Instituto de Biociências e à Faculdade de Educação da Universidade de São Paulo, São Paulo.

SANDRI, V.; TERRAZZAN, E. A. Caracterização de Práticas de Supervisão Docente desenvolvidas por Bolsistas Supervisores participantes do PIBID. In: IX 
Encontro Nacional de Pesquisa em Educação em Ciências. Anais... Águas de Lindóia: ENPEC, p.1-8, 2013.

SANGER, M. J.; GREENBOWE, T. J. An analysis of college chemistry textbooks as sources of misconceptions and errors in electrochemistry. Journal of Chemical Education, v.76, n.6, p.853-860, 1999.

SANGER, M. J.; GREENBOWE, T. J. Common student misconceptions in electrochemistry: Galvanic, electrolytic, and concentration cells. Journal of Research in Science Teaching, v. 34, 4, p.377-398, 1997a.

SANGER, M. J.; GREENBOWE, T. J. Students' misconceptions in electrochemistry: Current flow in electrolyte solutions and the salt bridge. Journal of Chemical Education, v.74, p.819-823, 1997b.

SANJUAN, M. E. C.; DOS SANTOS, C. V.; MAIA, J. O.; DA SILVA, A. F. A.; WARTHA, E. J. Maresia: Uma Proposta para o Ensino de Eletroquímica. Química Nova na Escola, v.31, n.3, p.190-197, 2009.

SANTOS, A. C. S. Complexidade e formação de professores de química. In: I Encontro brasileiro de estudos da complexidade. Anais...Curitiba: I EBEC, 2005.

SANTOS, A.; ADORNI, D.S.; SILVA JÚNIOR, A.J. A contribuição do PIBID para a formação do licenciando em Química: reflexões de um bolsista. In: XVII Encontro Nacional de Ensino de Química. Anais...Ouro Preto: ENEQ, p.4417, 2014.

SANTOS, A.O.; LORENZO, J.G.F. A importância do PIBID na formação continuada de licenciandos em química do IFPB, Campus João Pesso. In: 34ํReunião Anual da Sociedade Brasileira de Química. Atas...Florianópolis: RASBQ, p.1, 2011.

SANTOS, I. G. S.; LEÃO, M. B. C. A construção de FlexQuests sobre Eletroquímica por professores da educação básica. In: VIII Encontro Nacional de Pesquisa em Ensino de Ciências. Anais...Campinas: ENPEC, p.1-12, 2011.

SANTOS, I. G. S.; LEÃO, M. B. C. A FlexQuest como estratégia de ensino no contexto da Eletroquímica voltada para a Educação Básica. In: XVI Encontro Nacional de Ensino de Química (XVI ENEQ) e X Encontro de Educação Química da Bahia (X Eduqui). Atas...Salvador: ENEQ, p.1-12, 2012.

SANTOS, L. M. C. Um estudo sobre os impactos das ações do PIBID nos cursos de licenciatura em química da UFS e do IFS. 2016. 116 f. Dissertação (Mestrado) apresentada à banca examinadora do Programa de Pós-Graduação em Ensino de Ciências e Matemática na Universidade Federal de Sergipe, 2016.

SANTOS, N. P; FILGUEIRAS, C. A. O primeiro curso regular de química no Brasil. Química Nova, v.34, n.2, p.361-366, 2011.

SANTOS, N. S.; COSTA, F. J.; CHAVES, A. C. L. Efeitos positivos da utilização de recursos multimídia no processo ensino-aprendizagem de radicais livres e antioxidantes no Ensino Médio. In: IX Encontro Nacional de Pesquisa em Educação em Ciências. Anais... Águas de Lindóia: ENPEC, 2013, p.1-8.

SANTOS, V.C.; ARROIO, A. Contribuições do PIBID de Química da USP - São Paulo na formação do licenciando em Química para a prática docente e para o trabalho em grupo. In: VI Encontro Paulista de Ensino de Química. Anais...Santo André: EPPEQ, p.1-2, 2013.

SÃO PAULO. CONSELHO ESTADUAL DE EDUCAÇÃO. Deliberação CEE N 78/08. Publicado no DOE em 04/12/08 Seção I Página 25. Disponível em: <http://www.profdomingos.com.br/estadual_deliberacao_cee_78_2008.html>. Acesso em: 23/10/2014.

SÃO PAULO. CONSELHO ESTADUAL DE EDUCAÇÃO. Deliberação CEE № 111/12. Publicado no DOE em 03/02/2012 - Seção I - Página 46. Disponível em: <http://webcache.googleusercontent.com/search?q=cache:k4NK9LqgNeYJ:di sciplinas.stoa.usp.br/mod/resource/view.php\%3Fid\%3D72053+\&cd=1\&hl=ptBR\&ct=clnk\&gl=br>. Acesso em: 23/10/2014. 
SAVIANI, D. Formação de professores: aspectos históricos e teóricos do problema no contexto brasileiro. Revista Brasileira de Educação, v.14, n.40, 2009.

SAVIANI, D. História da formação docente no Brasil: três momentos decisivos. Revista Educação (UFSM), v.30, n.2, 2005.

SCHNETZLER, R. P. A pesquisa em ensino de química no brasil: conquistas e perspectivas. Quim. Nova, v.25, Supl.1, p.14-24, 2002.

SCHWAB, J. Structure of the disciplines: meanings and significances. In: FORD, G. W.; PUGNO, L. The Structure of Knowledge and the curriculum. Chicago: Rand McNally, 1964.

SENA, C. M. Interação universidade-escola e formação continuada de professores: percepções dos supervisores do PIBID de química da PUCRS. 2015. 138 f. Dissertação (Mestrado) apresentada ao Programa de PósGraduação em Educação em Ciências e Matemática, da Pontifícia Universidade Católica do Rio Grande do Sul, 2015.

SEVERINO, A. J. Metodologia do trabalho científico. 24 ed. rev. e atual. São Paulo: Cortez, 2016.

SERRANO, G. P. Investigación cualitativa. Retos e interrogantes.4 ed. Madrid: Editorial La Muralla, 2007.

SILVA, M. S. O Programa de Bolsas de Iniciação à Docência (PIBID) e a carreira docente em Ciências Biológicas. Trabalho de Conclusão de Curso (TCC), Universidade Federal do Rio Grande do Sul, 2012.

SHENTON, A. K. Strategies for ensuring trustworthiness in qualitative research projects. Education for Information, v. 22, p.63-75, 2004.

SHIGUNOV NETO, A.; MACIEL, L. S. B. O ensino jesuítico no período colonial brasileiro: algumas discussões. Educar em Revista, n.31, p.169-189, 2008.

SHULMAN, L. Knowledge and teaching: foundations of the new reform. Harvard Educational Review, v.57, n.1, p.1-22, 1987.

SHULMAN, L. Those who understand: Knowledge growth in teaching. Educational Researcher, v.15, n.2, p.4-14, 1986.

SHULMAN. L. S. Professing the liberal arts. In: ORILL (Ed.). Education and democracy: Reimagining liberal learning in America. New York: The College Entrance Examination Board, 1997. In: SHULMAN, L.S. Teaching as community property. Essays on higher education. San Francisco: Jossey-Bass, 2004, p. 12-31.

SILVA JÚNIOR, A. J.; PRADO, J. V. A Formação de professores de Química e Biologia e a Educação como escolha (ou não) para os bolsistas do PIBID-UESB campus de Itapetinga-BA. In: X Encontro Nacional de Pesquisa em Ensino de Ciências. Anais... Águas de Lindóia: ENPEC, p.1-8, 2015.

SILVA, A. A.; MARTINS, R. A.; TEIXEIRA JÚNIOR, J. G. Uma Análise das Dificuldades Conceituais de Alunos do Ensino Médio sobre Processos de Oxirredução. In: XVII Encontro Nacional de Ensino de Química. Anais...Ouro Preto: ENEQ, 2014, p.1369-1377.

SILVA, A. L.; MOGNHOL, T. D.; KAUARK, F. S.; COMARÚ, M. W. Construção de um professor de química crítico-reflexivo e Pesquisadora através da formação continuada: Possibilidades do Pibid. In: XVIII Encontro Nacional de Ensino de Química. Anais...Florianópolis: ENEQ, p.1-10, 2016.

SILVA, A. N. Um professor de Química e dois contextos escolares: o conhecimento pedagógico do conteúdo em ação. 2012. 161f. Dissertação (Mestrado) apresentada ao Instituto de Física, Instituto de Química, Instituto de Biociências e à Faculdade de Educação, Universidade de São Paulo.

SILVA, C. S. B. Curso de Pedagogia no Brasil: história e identidade. 2. Ed. Campinas: Autores Associados, 2003.

SILVA, E. T. Ciência, leitura e escola. In: ALMEIDA, M. J. P. M. de; SILVA, H. C. da. (Orgs.). Linguagens, Leituras e ensino de ciências. Campinas, SP: Mercado das Letras: ALB, 1998. Capítulo 7, p. 121 - 130. 
SILVA, F. C.; RIBEIRO, R. C.; CHAVES, A. C. L. Radicais livres e antioxidantes: concepções e expectativas dos professores do ensino médio. In: VII Encontro Nacional de Pesquisa em Educação em Ciências. Anais...Florianópolis: ENPEC, p.1-12, 2009.

SILVA, G. G. Significações do PIBID à formação para a docência na percepção de licenciandos em Ciências da Natureza/Química do IF-SC/SJ. 2015. 136 f. Dissertação (mestrado) apresentada ao Programa de Pós-Graduação em Educação Científica e Tecnológica, da Universidade Federal de Santa Catarina, para a obtenção do grau de Mestre na área de Ensino de Ciências.

SILVA, G.A.L.; CORREA, M.A.; SILVA, G.E.B.; SAMPAIO, M.E.C.; SILVA FILHO, L.C.R.; BRANCO, M.A.; PINHO, G.S.A. A atuação no PIBID e o impacto na formação dos licenciandos em Química - IFRJ. In: 35 Reunião Anual da Sociedade Brasileira de Química. Anais...Águas de Lindóia: RASBQ, 1, 2012.

SILVA, H. M. N.; FERNANDES, A. C.; SOUZA, J. P. I. Uso de Dinâmicas CTS no Ensino de Eletroquímica: Um Estudo de Caso. In: $37^{\circ}$ Reunião Anual da Sociedade Brasileira de Química. Anais...Natal: RASBQ, 2014, p.1.

SILVA, H. M. N.; SILVA, A. C.; SOUZA, J. P. I. A Intervenção Didática Dialógica como Proposta Motivacional no Ensino de Eletroquímica. In: XVII Encontro Nacional de Ensino de Química. Anais...Ouro Preto: ENEQ, 2014, p.3607.

SILVA, L. F. Coordenadores de área do PIBID: um olhar sobre o desenvolvimento profissional. 2015. 154 f. Dissertação de mestrado, Instituto de Física, Instituto de Química, Instituto de Biociências e Faculdade de Educação - Programa de Pós-Graduação Interunidades em Ensino de Ciências, Universidade de São Paulo, São Paulo, 2015.

SILVA, L. M. I.; PINHEIRO, F.; FELÍCIO, C. M. Percepções dos bolsistas PIBID Licenciandos em Química do IF Goiano campus Morrinhos frente aos possíveis impactos do programa. In: XVIII Encontro Nacional de Ensino de Química. Anais...Florianópolis: ENEQ, p.1, 2016.

SILVA, M. R. E.; CINTRA, E. P. Experimentação e Simulações: Contribuições para o Ensino e Aprendizagem das Reações Redox. REEC. Revista Electrónica de Enseñanza de las Ciencias, v. extra, p.1153-1159, 2013.

SILVA, M. S. Contribuições do PIBID/QUÍMICA UEM para o desenvolvimento dos saberes necessários à prática do professor de química. 2016. $129 \mathrm{f}$. Dissertação (Mestrado) apresentada ao Programa de Pós-Graduação em Educação para Ciências e Matemática da Universidade Estadual de Maringá, 2016.

SILVA, M.S.; SILVEIRA, M.P.; KIOURANIS, N.M.M. Contribuições do Subprojeto PIBID Química UEM na formação inicial de professores: uma análise dos diários dos bolsistas. In: XVII Encontro Nacional de Ensino de Química. Anais...Ouro Preto: ENEQ, p., 2014.

SILVA, P. R.; LOPES, J. G. Proposta de um jogo pedagógico para o ensino de eletroquímica. In: XVI Encontro Nacional de Ensino de Química (XVI ENEQ) e X Encontro de Educação Química da Bahia (X Eduqui). Atas...Salvador: ENEQ, p.1, 2012.

SILVA, S. F.; PRADO, J. V.; JESUS, F. W. A. Relato de experiência: contribuições do PIBID no processo ensino-aprendizagem da disciplina Química e na formação inicial de professores. In: XVIII Encontro Nacional de Ensino de Química. Anais....Florianópolis: ENEQ, p.1, 2016.

SILVEIRA, N. J.; SANTOS, R. G.; ALVES, É. C. R. F.; ALVES, B. H. P.; COSTA, M. A.; FARIA, D. M. A contribuição do PIBID na perspectiva dos professores supervisores de Química para a unidade escolar e para sua própria formação. In: XVIII Encontro Nacional de Ensino de Química. Anais...Florianópolis: ENEQ, p.1, 2016.

SIQUEIRA, M.; MASSENA, E. P.; BRITO, L. D. Contribuições do PIBID à construção da identidade e de saberes docentes de futuros professores de ciências. In: IX 
Encontro Nacional de Pesquisa em Educação em Ciências. Anais... Águas de Lindóia: ENPEC, p.1-8, 2013.

SKEIKA, T. et al. O conteúdo de oxidação e redução na visão dos Bolsistas do Pibid de Química. In: XVII Encontro Nacional de Ensino de Química. Anais...Ouro Preto: ENEQ, p.3942, 2014.

SMYTH, J. Una pedagogía crítica de la práctica en el aula. Revista de Educación, v.294, p.275-300, 1991.

SOARES, A. B.; MÜNCHEN, S.; ADAIME, M. B. O desbotamento do jeans como possibilidade de abordagem de reações de oxirredução. In: XVII Encontro Nacional de Ensino de Química. Anais...Ouro Preto: ENEQ, p.1607-1618, 2014.

SORDI, Mara Regina L. de. Alternativas propositivas no campo da avaliação: por que não? In: CASTANHO, Sérgio; CASTANHO, Maria Eugênia (orgs.). Temas e textos em metodologia do Ensino Superior. Campinas, SP: Papirus, 2001.

SOUDANI, M., SIVADE, A., CROS, D., MÉDIMAGH, M.S. Transferring knowledge from the classroom to the real world: redox concepts. School Science Review, v.82, n.298, p.65-72, 2000.

SOUZA, C.T.; SANTOS, L.B.; LEITE, J.L.; NUNES, F.J.; MACHADO, G.G.; FREIRE, D.; SANTOS, B. O PIBID e a prática pedagógica do professor de química: entre a sala de aula e as oficinas didáticas. In: $37^{\circ}$ Reunião Anual da Sociedade Brasileira de Química. Anais....Natal: RASBQ, p.1, 2014.

SOUZA, N. S.; REIS, E. M.; LINHARES, M. P. Ensino de química no proeja: integrando o espaço virtual de aprendizagem às ações de sala de aula. In: VII Encontro Nacional de Pesquisa em Educação em Ciências. Anais...Florianópolis: ENPEC, p.1-12, 2009.

STADLER, Z.; BARBOSA, L. M.V. O discurso do professor e a linguagem dos livros didáticos na construção do conhecimento em química. Disponível em:<www.diaadiaeducacao.pr.gov.br/portals/pde/arquivos/971-4.pdts. Acesso em: 06/02/2017.

STANZANI, E. L. O papel do pibid na formação inicial de professores de química na Universidade Estadual de Londrina. 2012. 88 f. Dissertação (Mestrado) Programa de Pós-Graduação em Ensino de Ciências e Educação Matemática da Universidade Estadual de Londrina, 2012.

STREINER, D. L. Being inconsistent about consistency: when coefficient alpha does and doesn't matter. Journal of Personality Assessment, v.80, p.217-222. 2003.

TACOSHI, M. M. A.; FERNANDEZ, C. Knowledge of Assessment: an Important Component in the PCK of Chemistry Teachers. Problems of Education in the Twenty First Century, v.62, p.124-147, 2014.

TANURI, L. M. História da formação de professores. Revista Brasileira de Educação, v.14, p.61-88, 2000.

TARDIF, M. Saberes docentes e formação profissional. 11.ed. Petrópolis: Vozes, 2010.

TARTUCE, G. L. B. P.; NUNESO, M. M. R.; ALMEIDA, P. C. A. Alunos do ensino médio e atratividade da carreira docente no Brasil. Cadernos de Pesquisa, v.40, n.140, p.445-477, 2010.

TEIXEIRA JÚNIOR, J. G. Contribuições do PIBID para a formação de professores de química. 2014. $182 \mathrm{f}$. Tese (Doutorado) apresentada ao Programa de PósGraduação em Química, do Instituto de Química, da Universidade Federal de Uberlândia, 2014.

TEIXEIRA, N. S.; COLLET, L. S. F. C.; GODINHO, M.; ALCÂNTARA, P. H. N.; JUNIOR, P. M. Projeto do Curso de Formação de Professores da Educação Básica: Curso Superior de Licenciatura em Química. São Paulo, 2008.

TERRAZAN, E. A.; DUTRA, E. F.; WINCH, P. G.; SILVA, A. A. Configurações curriculares em cursos de licenciatura e formação identitária de professores.

Rev. Diálogo Educ., v. 8, n. 23, p. 71-90, 2008. 
TESTI, B. M. Estudo avaliativo do Programa Institucional de Bolsas de Iniciação à Docência (PIBID) na formação de professores de química na UNESP. 2015. 204 f. Dissertação (Mestrado) Universidade Estadual Paulista "Júlio de Mesquita Filho", Faculdade de Ciências e Letras (campus de Araraquara), 2015.

TIBERGHIEN, A.; VINCE, J.; GAIDIOZ, P. Case of a teaching sequence on mechanics. International Journal of Science Education, v.31, n.17, p.2275-2314, 2009.

TOBALDINI, B. G. Os saberes docentes na formação de professores: o caso do programa institucional de bolsa de iniciação à docência (PIBID) subprojeto química/UFPR - 2010/2012. 2013. 265 f. Dissertação (Mestrado) apresentada ao Programa de Pós-Graduação Educação em Ciências e em Matemática, Linha de Ensino e Aprendizagem de Ciências, Setor de Ciências Exatas, da Universidade Federal do Paraná, 2013.

TORRALBO, D.; FALJONI-ALARIO, A. Contextualização no ensino de química: óxidoredução abordando temas de saúde. In: II Encontro Paulista de Ensino de Química. Anais... Araraquara: E, p.47, 2005.

TRIBUNAL DE CONTAS DA UNIÃO (2013). Relatório. Disponível em: < http://portal3.tcu.gov.br/portal/page/portal/TCU/comunidades/contas/contas_g overno/Contas2012/docs/RELATORIO-MIN-JJ-2013-5-23.pdf>. Acesso em 08/09/2014.

TRIVIÑOS, A. N. S. Introdução à pesquisa em ciências sociais: a pesquisa qualitativa em educação. São Paulo: Atlas, 1987.

UNIVERSIDADE DE SÃO PAULO. Normas históricas - Decreto n. 6.283 de 25 de janeiro de 1934. Disponível em:< http://www.leginf.usp.br/?historica=decreton-o-6-283-de-25-de-janeiro-de-1934>. Acesso em: 25/03/2015.

VALBUENA, E. El Conocimiento Didáctico del Contenido Biológico. Estudio de las concepciones disciplinares y didácticas de futuros docentes de la Universidad Pedagógica Nacional (Colombia). 2007. 663f. Tesis para optar al título de Doctor en Didáctica de las Ciencias Experimentales. Universidad Complutense de Madrid.

VALENCIA, R.; HURTADO, J.; BENAVIDES, J; MUÑOZ, L. COnstrucción de los modelos sobre la electroquímicay su enseñanza. Enseñanza de las Ciencias, v. extra, p.3565-3600, 2013.

VALLE, I. R. A era da profissionalização: formação e socialização profissional do corpo docente de 1a a 4a série. Florianópolis: Cidade Futura. p.273, 2003.

VAN DRIEL, J. H.; DE JONG, O. Investigating the Development of Preservice Teachers' Pedagogical Content Knowledge. Paper presented at the Annual Meeting of the National Association for Research in Science Teaching, St Louis, MO. p.1-39. 2001.

VAN DRIEL, J. H.; VERLOOP, N.; DE VOS, W. Developing science teachers' pedagogical content knowledge. Journal of Research in Science Teaching, v.35, n.6, p.673-695, 1998.

VELOSO, T. C. M. A.; ALMEIDA, E. P. Evasão nos cursos de graduação da Universidade Federal de Mato Grosso, campus universitário de Cuiabá: um processo de exclusão. In: 24aㅡ reunião anual da associação nacional de pósgraduação e pesquisa em educação (ANPED), Anais...Caxambu: 2001.

VIDAL, Diana Gonçalves. 0 exercício disciplinado do olhar: livros, leituras e práticas de formação docente no Instituto de Educação do Distrito Federal (1932-1937). Bragança Paulista: EDUSF, 2001.

VIEIRA, S. Como elaborar questionários. São Paulo: Atlas, 2009.

VILLELA, H. O. S. O mestre-escola e a professora. In: LOPES, E.; FARIA FILHO, L.; VEIGA, Cyntia (org.). 500 anos de educação no Brasil. 2. Ed. Belo Horizonte/MG: Autêntica, p.95-134, 2000.

VOGEL, M.; REZENDE, D. de B. Comparação entre Árvores máximas de Similitude de termos evocados por alunos participantes do PIBID-QUíMICA e não- 
participantes. In: 38ํㅡㄹ Reunião Anual da Sociedade Brasileira de Química. Anais...Águas de Lindóia: RASBQ, 1, 2015.

WALLON, H. A evolução psicológica da criança. São Paulo: Martins Fontes, 2007.

WILSON, S.; SHULMAN, L. S.; RICHERT, A. E. 150 ways of knowing: Representations of knowledge in teaching. In: CALDERHEAD, J. (Ed.). Exploring teachers' thinking. Grã-Bretanha: Cassell Educational Limited, p. 104-124, 1987.

YILMAZ, A.; BAYRAKÇEKEN, S. Determining of the prospective teachers' understadings of electrochemistry. Procedia - Social and Behavioral Sciences, v.174, p.2831-2838, 2015.

YIN, R.K. Estudo de caso: planejamento e métodos. Tradução Ana Thorell; revista técnica Cláudio Damacena. 4. Ed. Porto Alegre; Bookman, 2010.

ZEICHNER, K. Repensando as conexões entre a formação na universidade e as experiências de campo na formação de professores em faculdades e universidade. Educação, v. 35, n. 3, p. 479-504, maio/ago. 2010.

ZITTEL, R.; MILARÉ, T.; FREIRE, L. I. F. Ensino de Eletroquímica: algumas dificuldades de estudantes. In: 34ำ Reunião Anual da Sociedade Brasileira de Química. Atas....Florianópolis: RASBQ, p.1, 2011. 


\section{APÊNDICES}

\section{Apêndice 1 - Termo de consentimento livre e esclarecido}

Universidade de São Paulo - Instituto de Química

\section{Termo de consentimento livre e esclarecido}

Eu, concordo em participar, como voluntário, do projeto de pesquisa intitulado "Reflexos do PIBID na prática pedagógica de licenciandos em química", que tem como Pesquisadora responsável a mestranda Keysy Solange Costa Nogueira do Programa de Pós-Graduação Interunidades em Ensino de Ciências da Universidade de São Paulo, orientada por Carmen Fernandez, que podem ser contatadas pelo e-mail carmen@usp.br ou pelo telefone (11) 3091-9619. O presente trabalho tem por objetivos gerais: analisar e documentar o processo de construção do Conhecimento Pedagógico do Conteúdo de professores em formação participantes do PIBID (Iniciação à Docência) acerca do tema "reações redox".

Para tanto, a minha participação consistirá em conceder uma entrevista semiestruturada sobre minha trajetória como aluno do PIBID, que será gravada em áudio e vídeo e transcrita pela Pesquisadora.

Compreendo que este estudo possui finalidade de pesquisa e que os dados obtidos serão divulgados seguindo as diretrizes éticas da pesquisa ${ }^{9}$. De acordo com as finalidades expostas AUTORIZO à Pesquisadora, exclusivamente para fins acadêmicos e científicos, a utilização total ou parcial dessas transcrições em suas atividades de pesquisa.

e-mail:

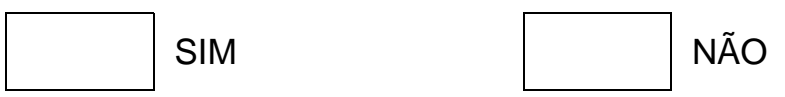

Desejo receber uma cópia desse termo por e-mail:

Assinatura

Local e data

${ }^{9}$ COMITÊ DE ÉTICA NA PESQUISA DA FEUSP - http://www3.fe.usp.br/pgrad - acesso 02/02/2014 


\section{Apêndice 2 - Roteiro de entrevista semiestruturada - Pibidianos}

Entrevistado (a):

1. Qual a sua nacionalidade?

2. Qual a sua naturalidade?

3. Em que ano ingressou na licenciatura em química? Qual era a sua idade ao ingressar?

4. Por que a licenciatura em química? Você sempre quis ser professor? Qual o interesse em ensinar?

5. Você já atuou em sala de aula antes do Pibid?

6. O que motivou você a participar do Pibid?

7. Estar no Pibid contribuiu com a sua graduação? De que maneira?

8. Quais são as suas funções enquanto pibidiano?

9. Como ocorre a escolha do tema das aulas?

10. Como são elaboradas as aulas que você ministra como bolsista do Pibid?

a. Você tem o hábito de recorrer a que materiais: livros, artigos, entre outros?

b. Você faz o levantamento dos conhecimentos prévios dos alunos?

c. Qual o papel do professor supervisor e coordenador neste processo?

d. Você prioriza os conteúdos químicos nesse processo de elaboração?

11. Que tipo de estratégias você utiliza durante a sua regência na escola conveniada?

12. Como você avalia o nível de exigência do Pibid?

13. Que habilidades você considera inerentes à prática docente? Essas habilidades estão sendo melhor estruturadas pela sua participação no Pibid?

14. O que você pibidiano faz em sala de aula para ajudar os seus alunos a aprenderem?

15. O que seria um bom professor? Que conhecimentos são necessários para ser um bom professor?

16. Quais são os fatores motivacionais vivenciados no Pibid, que o levam a querer exercer a docência?

17. Quais são as principais dificuldades vivenciadas no desenvolvimento de suas práticas de ensino na escola conveniada?

18. Ao participar do Pibid, a realidade da escola e do professor supervisor se apresentou como esperada?

19. Que eventos acadêmicos você participou, apresentando trabalhos desenvolvidos como bolsista do Pibid? Quais foram os trabalhos apresentados?

20. Quais são as suas perspectivas futuras em relação a sua carreira como docente? Para você, qual a contribuição do Pibid para a sua formação como professor?

21. Você teria alguma sugestão a fazer em relação ao desenvolvimento do subprojeto Pibidquímica?

Eu,

concordo em participar, como voluntário, do projeto de pesquisa intitulado "A transformação do conteúdo reações redox em sequências didáticas produzidas por alunos do Pibid: do currículo à sala de aula.", que tem como Pesquisadora responsável a mestranda Keysy Solange Costa Nogueira do Programa de Pós-Graduação Interunidades em Ensino de Ciências da Universidade de São Paulo, orientada por Carmen Fernandez, que podem ser contatadas pelo e-mail carmen@usp.br ou pelo telefone 11 3091-9619. O presente trabalho tem por objetivos gerais: analisar e documentar o processo de construção do Conhecimento Pedagógico do Conteúdo de professores em formação participantes do Pibid (Iniciação à Docência) acerca do tema "reações redox".

Para tanto, a minha participação consistirá em conceder uma entrevista semiestruturada sobre minha trajetória como aluno do Pibid, que será gravada em áudio e vídeo e transcrita pela Pesquisadora.

Compreendo que este estudo possui finalidade de pesquisa e que os dados obtidos serão divulgados seguindo as diretrizes éticas da pesquisa ${ }^{10}$. De acordo com as finalidades expostas AUTORIZO à Pesquisadora, exclusivamente para fins acadêmicos e científicos, a utilização total ou parcial dessas transcrições em suas atividades de pesquisa.

Assinatura

Local e data

100OMITÊ DE ÉTICA NA PESQUISA DA FEUSP - http://www3.fe.usp.br/pgrad - acesso $02 / 02 / 2014$ 


\section{Apêndice 3 - Roteiro de entrevista semiestruturada - coordenadora}

Nome:

Formação:

Docência na universidade:

Disciplina que leciona:

Curso em que ministra aulas:

Função que exerce no Pibid:

1. Relate sobre a sua escolha profissional.

2. Qual a sua formação no ensino redox?

3. Você recorda em que momento ensinou esse conteúdo pela primeira vez?

4. Qual a sua motivação em participar do Pibid? Qual a sua função neste programa?

5. No subprojeto ocorrem encontros com os pibidianos. Como você os organiza? Qual a importância e os objetivos desses encontros?

6. Os pibidianos compartilhavam as aulas estruturadas com as tutoras por e-mail, contudo durante as reuniões ficou perceptivo que o planejamento não era lido pelas tutoras o que dificulta o diálogo com os pibidianos. Você teve essa mesma percepção?

7. Durante as reuniões com os pibidianos, que lecionariam o conteúdo redox, você os orientou a começar por uma revisão sobre atomística. Por quê? É dessa forma que você aborda esse conteúdo quando o ensina?

8. Você consegue reconhecer a influência das disciplinas pedagógicas de sua graduação nas suas orientações aos pibidianos?

9. Ao lembrar de Antônio, Melissa e Mateus, quais foram as evoluções dos pibidianos ao seu ver? Você conseguiria realizar uma descrição sobre cada um deles?

10. Quais as principais dificuldades enfrentadas ao orientar esses pibidianos?

11. Como você aprecia o processo de elaboração das aulas por cada pibidiano (Melissa, Antônio e Mateus)?

12. Em que nível de desenvolvimento profissional você avalia que estava Mateus, Antônio e Melissa, em virtude de suas participações no Pibid?

13. Em uma entrevista realizada com Antônio, o pibidiano avaliou que não teve autonomia para elaborar suas aulas. Qual a sua percepção sobre esta afirmativa?

14. Você acredita que influenciou os pibidianos (Antônio, Mateus e Melissa) em que aspectos didáticos?

15. Como você avaliaria o conhecimento dos pibidianos em relação ao conteúdo redox, no início do planejamento das aulas, durante a sua implementação e após o fechamento do projeto? Você observou alguma limitação?

16. O que os pibidianos carregam em sua formação, promovido pelo Pibid que difere da graduação?

17. De que forma o Pibid tem possibilitado sua formação continuada?

18. Quais foram os maiores desafios enquanto coordenadora? 


\section{Apêndice 4 - Roteiro de entrevista semiestruturada - supervisora}

Nome:

Formação:

Docência na universidade:

Disciplina que leciona:

Docência na educação básica:

Função que exerce no Pibid:

Curso em que ministra aulas:

1. Relate sobre a sua escolha profissional.

2. Qual a sua motivação em participar do Pibid?

3. Qual a sua formação no conteúdo redox?

4. Você recorda em que momento ensinou esse conteúdo pela primeira vez?

5. Qual a sua função dentro do programa institucional?

6. Durante as reuniões com os pibidianos que iniciaram a lecionar o conteúdo, você compartilha com a coordenadora que os pibidianos deveriam começar suas aulas por uma revisão sobre atomística? É dessa forma que você aborda esse conteúdo quando o ensina?

7. As disciplinas de didática que teve em sua graduação a influenciou na tutoria dos pibidianos?

8. Ao lembrar de Antônio, Melissa e Mateus, quais foram as evoluções dos pibidianos em relação às suas ações como futuros professores? Você conseguiria realizar uma descrição de cada um deles?

9. Quais as principais dificuldades enfrentadas nas orientações desses pibidianos?

10. Como você aprecia o processo de elaboração das aulas por cada pibidiano (Melissa, Antônio e Mateus)?

11. Em que nível de desenvolvimento profissional você avalia que estavam Mateus, Antônio e Melissa, em virtude de suas participações no Pibid?

12. Em uma entrevista realizada com Antônio e Melissa, os pibidianos ao reverem suas aulas gravadas, comentaram que no Pibid eles não tiveram chance de errar durante a implementação de suas aulas, pois a supervisora sempre estava atenta, e chamava a sua atenção na frente dos alunos, e considerava que deveria fazer isso quando estivessem discutindo os resultados das aulas. Qual a sua percepção sobre esta afirmativa?

13. Durante algumas aulas de Melissa e Antônio, você costumava perguntar conceitos como, por exemplo, como Antônio poderia afirmar que uma solução estava conduzindo corrente elétrica, e também a função da ponte salina. Como você avalia essas intervenções?

14. Em uma aula Melissa demonstrou limitações em exemplificar uma semi-reação de redução e solicitou a sua ajuda. Gostaria que comentasse esse episódio.

15. Em relação a Mateus, você sempre o elogiava. Quais as diferenças formativas, que você observava nesse pibidiano, que não notava em Melissa e Antônio?

16. Como você avaliaria Mateus, Melissa e Antônio, como futuros docentes?

17. Você acredita que influenciou os pibidianos (Antônio, Mateus e Melissa) em que aspectos didáticos?

18. O que os pibidianos carregam em sua formação, promovido pelo Pibid que difere da graduação?

19. De que forma o Pibid tem possibilidade sua formação continuada?

20. Quais foram os maiores desafios enquanto supervisora?

21. Em que aspectos o subprojeto poderia mudar na sua percepção? 


\section{Apêndice 5 - Questionário socioeconômico e cultural Instituto de Química da Universidade de São Paulo}

\section{Questionário Socioeconômico e cultural}

Este questionário sociocultural tem por objetivo único coletar dados socioeconômico e cultural dos alunos da licenciatura em química do IFSP-SP, participantes do Pibid (Iniciação à Docência). As informações coletadas são sigilosas, serão tratadas coletivamente, para comporem o trabalho intitulado "A transformação do conteúdo reações redox em sequências didáticas produzidas por alunos do Pibid: do currículo à sala de aula”.

\section{Antes de responder, leia atentamente as instruções abaixo:}

- Analisar com atenção cada item.

- Optar por apenas uma resposta.

- Não deixar respostas em branco.

1. Qual é o nível de escolaridade de seu pai?

\begin{tabular}{|l|l|}
\hline a. Analfabeto & b. Primeiro grau incompleto \\
\hline c. Primeiro grau completo. & d. Segundo grau \\
\hline e. Superior & f. Não sei \\
\hline
\end{tabular}

2. Qual é o nível de escolaridade de sua mãe?

\begin{tabular}{|l|l|}
\hline a. Analfabeta & b. Primeiro grau incompleto \\
\hline c. Primeiro grau completo. & d. Segundo grau \\
\hline e. Superior & f. Não sei \\
\hline
\end{tabular}

3. Qual o seu sexo?
a. Feminino
b. Masculino

4. Qual a sua faixa etária?

\begin{tabular}{|l|l|}
\hline a. De 16 a 20 anos & b. De 29 a 32 anos \\
\hline c. De 21 a 24 anos & d. De 33 a 36 anos \\
\hline e. De 25 a 28 anos & f. Mais de 36 \\
\hline
\end{tabular}

5. Qual o seu estado civil?
a. Solteiro
b. Divorciado
c. Viúvo
d. Casado
e. Outro

6. Você exerce alguma atividade remunerada?
a. Não.
b. Sim, em tempo parcial (até 30 horas semanais).
c. Sim, em tempo integral (mais de 30
d. Sim, mas trata-se de trabalho eventual. horas semanais).

7. Qual a sua participação na renda familiar?

a. Não trabalha e recebe ajuda financeira da família.

b. Trabalha e recebe ajuda financeira da família.

c. Trabalha e não recebe ajuda financeira da família.

d. Trabalha e contribui parcialmente para o sustento da família.

e. Trabalha e é responsável pelo sustento da família.

8. Em que colégio/escola você concluiu o ensino médio?

9. Você fez algum curso técnico?
a. Sim. Qual?
b. Não

10. Como você considera seu conhecimento em Língua Espanhola?

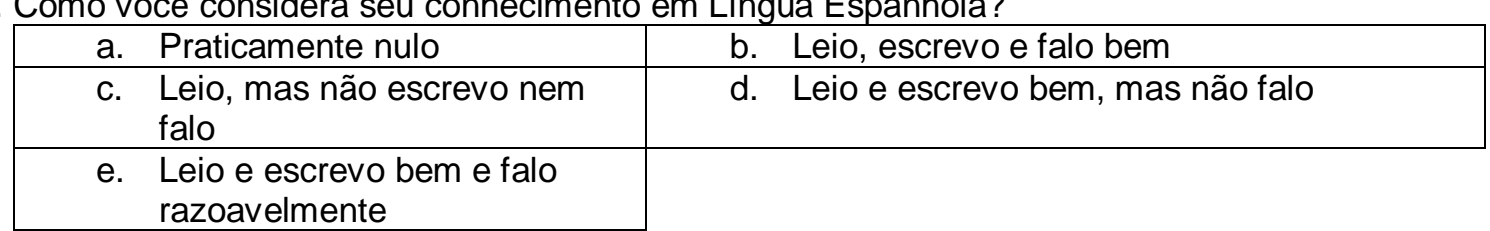

11. Como você considera seu conhecimento em Língua Inglesa?
a. Praticamente nulo.
b. Leio, escrevo e falo bem. 

c. Leio, mas não escrevo nem falo.
d. Leio e escrevo bem, mas não falo.
e. Leio e escrevo bem e falo
razoavelmente.

12. Há quanto tempo você concluiu o ensino médio?
a. Entre 6 meses e 1 ano.
c. Entre 2 e 3 anos.
b. Entre 1 e 2 anos.
e. Entre 4 e 5 anos.
d. Entre 3 e 4 anos.
f. Há mais de 5 anos.

13. Como você se preparou para o vestibular?
a. Apenas estudei durante $03^{\circ}$ ano regular.
b. Fiz cursinho.
c. Estudei sem o auxílio de professores.
d. Não estudei

14. Quantos vestibulares, você prestou, para entrar na licenciatura em química?

\begin{tabular}{|c|c|}
\hline Um & Dois \\
\hline Três & Mais de três \\
\hline
\end{tabular}

15. Você já fez outro curso superior?
a. Não.
b. Sim. Em qual instituição de ensino?

16. Como você se considera com relação ao curso em que está cursando?
a. Absolutamente decidido.
b. Com alguma dúvida.
c. Totalmente indeciso.

17. Qual dos fatores seguintes mais influenciou na sua opção de curso?

\begin{tabular}{|ll|l|}
\hline $\begin{array}{l}\text { a. Área de atuação profissional } \\
\text { de meus pais. }\end{array}$ & b. Professor(es) que tive. \\
\hline c. & Amigo(s). & d. A relação candidato/vaga no vestibular \\
\hline e. & Perspectiva profissional. & f. Outro. \\
\hline
\end{tabular}

18. Em que bairro ou local você mora?

19. Quanto tempo leva para chegar à instituição de ensino? Qual(ais) o(s) meio(s) de transporte utiliza?

20. Quantas horas por dia você dedica aos estudos?

21. Existe microcomputador em sua casa?
a. Sim e eu o utilizo bastante.
b. Sim, mas eu pouco utilizo.
c. Sim, mas eu nunca o utilizo.
d. Não, mas eu utilizo microcomputador fora do meu ambiente doméstico.

22. Caso utilize microcomputador, você tem predominantemente acessado a Internet a partir de que equipamento?
a. O disponibilizado pela instituição onde estudo.
b. Daquele disponível na minha residência.
c. Daquele colocado à disposição em outro local.

23. Qual o meio de comunicação que você costuma acessar para se manter atualizado?
a. Revista.
b. Jornais.
c. Televisão.
d. Internet.
e. Rádio. 


\title{
ANEXO
}

\section{ANEXO 1 - Instrumento de percepção do Conhecimento Docente}

\author{
Universidade de São Paulo - Instituto de Química
}

\section{Termo de consentimento livre e esclarecido}

Eu, , concordo em participar, como voluntário, do projeto de pesquisa intitulado "A transformação do conteúdo reações redox em sequências didáticas produzidas por alunos do Pibid: do currículo à sala de aula", que tem como Pesquisadoraa responsável a mestranda Keysy Solange Costa Nogueira do Grupo Pequim - Pesquisa em Ensino de Química, orientado e co-orientado, respectivamente, por Carmen Fernandez e Elaine Pavini Cintra, que podem ser contactadas pelo telefone (11) 3091-9619 ou keysynogueira@gmail.com.

Minha participação consistirá em preencher um instrumento diagnóstico composto por um conjunto de afirmativas que deverão ser avaliadas utilizando as opções de uma escala Likert, que indica o meu nível de concordância com as afirmações.

Compreendo que este estudo possui finalidade de pesquisa e que os dados obtidos serão divulgados seguindo as diretrizes éticas da pesquisa ${ }^{11}$. Sendo assim, AUTORIZO a Pesquisadora, exclusivamente para fins acadêmicos e científicos, a utilização total ou parcial de minhas respostas nesse instrumento diagnóstico em suas atividades de pesquisa.

Assinatura:

e-mail:

Local e data

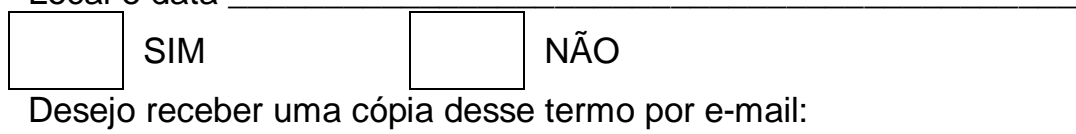

Este teste tem como objetivo reconhecer e registrar algumas percepções dos estudantes do ensino médio sobre a atuação dos alunos do Pibid (subprojeto química), no ano de 2014.

Analise as afirmações que se seguem e use a escala abaixo para manifestar as suas opiniões a respeito delas, considerando o pibidiano (a) durante a implementação de suas aulas neste ano:

\begin{tabular}{|l|c|}
\hline 0 & Não me recordo / Não sei \\
\hline 1 & Se nunca ocorreu na prática de ensino \\
\hline 2 & Se ocorreu raramente na prática de ensino \\
\hline 3 & Se ocorreu às vezes na prática de ensino \\
\hline 4 & Se ocorreu frequentemente na prática de ensino \\
\hline 5 & Se sempre ocorreu na prática de ensino \\
\hline
\end{tabular}

Marque uma das colunas numeradas que corresponde à sua percepção sobre a afirmação feita. Caso queira fazer algum comentário sobre as afirmativas, utilize o verso e identifique com a letra e o número a qual item se refere o comentário.

\begin{tabular}{|c|c|c|c|c|c|c|}
\hline a) Conhecimento do tema (CT) & $\mathbf{0}$ & 1 & & 3 & 4 & 5 \\
\hline a.1) Meu professor sabe o conteúdo que ele está ensinando. & & & & & & \\
\hline a.2) Meu professor explica claramente o conteúdo específico. & & & & & & \\
\hline $\begin{array}{l}\text { a.3) Meu professor sabe como as teorias ou princípios do conteúdo específico } \\
\text { foram desenvolvidos. }\end{array}$ & & & & & & \\
\hline a.4) Meu professor selecionou conteúdos apropriados para os alunos. & & & & & & \\
\hline $\begin{array}{l}\text { a.5) Meu professor sabe as respostas para as perguntas que lhe fazem sobre } \\
\text { o conteúdo. }\end{array}$ & & & & & & \\
\hline a.6) Meu professor explica o impacto desse conteúdo na sociedade. & & & & & & \\
\hline $\begin{array}{l}\text { a.7) Meu professor conhece toda estrutura e os objetivos do Conteúdo } \\
\text { Específico. }\end{array}$ & & & & & & \\
\hline b) Representação do conteúdo e estratégias para seu ensino (RCE) & 0 & 1 & 2 & 3 & 4 & 5 \\
\hline
\end{tabular}

${ }^{111}$ COMITÊ DE ÉTICA NA PESQUISA DA FEUSP - http://www3.fe.usp.br/pgrad - acesso 25/02/2014. 
b.1) Meu professor usa exemplos adequados para explicar os conceitos relacionados a um conteúdo específico.

b.2) Meu professor usa analogias familiares para explicar os conceitos relacionados ao conteúdo específico.

b.3) Meu professor utiliza métodos de ensino que me motivam a manter o interesse pelo conteúdo.

b.4) Meu professor oferece oportunidade para eu expressar meus pontos de vista durante a aula.

b.5) Meu professor usa as manifestações dos alunos para ajudar a explicar os principais conceitos.

b.6) Meu professor usa uma variedade de abordagens de ensino para transformar o conteúdo específico em uma forma de conhecimento compreensível para os alunos.

b.7) Meu professor usa mídias ou tecnologias para expressar os conceitos.

c) Objetivo educacional e do contexto (OEC)
c.1) Meu professor me faz compreender claramente os objetivos desse curso.

c.2) Meu professor interage adequadamente com os alunos e proporciona um bom ambiente de convívio.

c.3) Meu professor presta atenção na reação dos alunos durante a aula e ajusta sua atitude de ensino.

c.4) Meu professor cria na sala de aula circunstâncias para promover meu interesse pela aprendizagem.

c.5) Meu professor prepara materiais didáticos adicionais para as aulas.

c.6) Meu professor lida com o contexto da nossa sala de aula adequadamente.

c.7) Meu professor acredita ou valoriza um ensino que seja ativo e dinâmico.

d) Conhecimento das compreensões dos estudantes (CCE)

d.1) Meu professor averigua o conhecimento prévio dos estudantes antes de começar a ensinar um novo assunto.

d.2) Meu professor conhece as dificuldades dos alunos para a aprendizagem do conteúdo específico.

d.3) As questões do meu professor avaliam minha compreensão sobre um tópico.

d.4) Os métodos de avaliação utilizados pelo meu professor avaliam minha compreensão sobre o conteúdo.

d.5) Meu professor usa diferentes abordagens (questões, discussões, etc.) para saber se eu compreendi adequadamente um tópico.

d.6) As escolhas metodológicas do meu professor facilitam minha compreensão sobre o conteúdo.

d.7) Os testes do meu professor me ajudam a compreender a situação do aprendizado.

Durante o estabelecimento das aulas do pibidiano (a) houve alguma dificuldade de aprendizagem? Ou se você deseja fazer algum comentário, por favor, utilize esse espaço. 